Anna Wylegała

\title{
Displaced Memories
}

Remembering and Forgetting in Post-War Poland and Ukraine

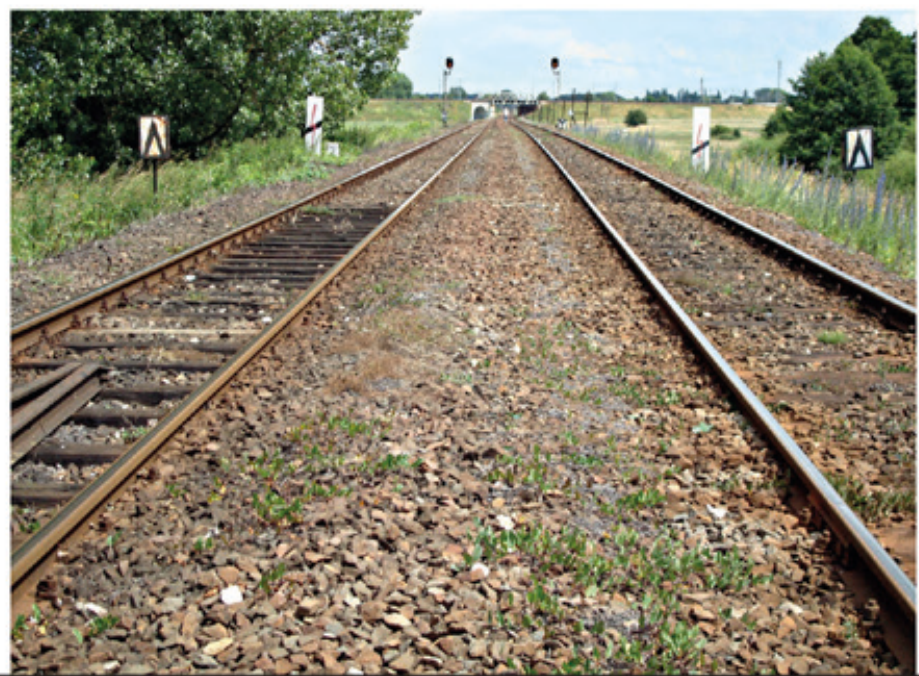




\section{Anna Wylegała}

\section{Displaced Memories}

The book is a comparative case study of collective memory in two small communities situated on two Central-European borderlands. Despite different pre-war histories, Ukrainian Zhovkva (before 1939 Polish Zołkiew) and Polish Krzyż (before 1945 German Kreuz) were to share a common fate of many European localities, destroyed and rebuilt in a completely new shape. As a result of war, and post-war ethnic cleansing and displacement, they lost almost all of their pre-war inhabitants and were repopulated by new people. Based on more than 150 oral history interviews, the book describes the process of reconstruction of social microcosm, involving the reader in a journey through the lives of real people entangled in the dramatic historical events of the $20^{\text {th }}$ century.

\section{The Author}

Anna Wylegała is Assistant Professor at the Institute of Philosophy and Sociology, Polish Academy of Sciences, Warsaw. Sociologist by training, she works at the intersection of sociology of culture, history and anthropology, with a special focus on memory in Poland and Ukraine. 
Displaced Memories 


\title{
GESCHICHTE - ERINNERUNG - POLITIK STUDIES IN HISTORY, MEMORY AND POLITICS
}

Herausgegeben von / Edited by Anna Wolff-Powęska \& Piotr Forecki

\author{
Bd./Vol. 26
}

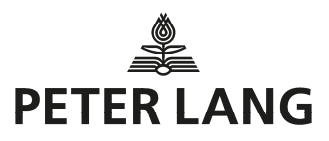




\section{Anna Wylegała}

\section{Displaced Memories}

Remembering and Forgetting in Post-War Poland and Ukraine

Translated by Simon Lewis, Copyedited by Klara Naszkowska 


\title{
Bibliographic Information published by the Deutsche Nationalbibliothek
}

The Deutsche Nationalbibliothek lists this publication in the Deutsche Nationalbibliografie; detailed bibliographic data is available in the internet at http://dnb.d-nb.de.

\section{Library of Congress Cataloging-in-Publication Data}

A CIP catalog record for this book has been applied for at the Library of Congress.

The Publication is funded by Ministry of Science and Higher Education of the Republic of Poland as a part of the National Programme for the Development of the Humanities. This publication reflects the views only of the authors, and the Ministry cannot be held responsible for any use which may be made of the information contained therein.

Cover image: @ Katarzyna Madoń-Mitzner

\author{
ISSN 2191-3528 \\ ISBN 978-3-631-67871-8 (Print) \\ E-ISBN 978-3-653-07004-0 (E-PDF) \\ E-ISBN 978-3-631-71244-3 (EPUB) \\ E-ISBN 978-3-631-71245-0 (MOBI) \\ DOI 10.3726/b15815 \\ (C) Peter Lang $\mathrm{GmbH}$ \\ Internationaler Verlag der Wissenschaften \\ Berlin 2019 \\ All rights reserved. \\ Peter Lang -Berlin · Bern · Bruxelles · New York · \\ Oxford $\cdot$ Warszawa $\cdot$ Wien \\ All parts of this publication are protected by copyright. Any \\ utilisation outside the strict limits of the copyright law, without \\ the permission of the publisher, is forbidden and liable to \\ prosecution. This applies in particular to reproductions, \\ translations, microfilming, and storage and processing in \\ electronic retrieval systems. \\ This publication has been peer reviewed. \\ www.peterlang.com
}




\section{Note on Translation, Transliteration and Names}

This book is a translation, but that does not make it simply a product of a Polish monograph being translated into English and revised to accommodate the customs and expectations of an Anglophone readership. The Polish book was written in 2013 and published in 2014, on the basis of research conducted much earlier, between 2008 and 2011. The people interviewed spoke in their own languages: Polish in Poland, and usually Ukrainian but also Russian and Polish in Ukraine. Thus, some quotes were translated into Polish first, and then retranslated into English. The respondents spoke about their own lifeworlds, which also meant that their experiences had to be translated into the analytical language of scholarship. When I started to prepare my Polish book for translation into English, it transpired that it was necessary to write a completely new introduction, as well as to make numerous minor changes to the main text: some details would have been of little interest to a non-Polish reader, whereas other things needed to be expanded and explained more explicitly.

Importantly, although I continue to pay attention to the memory politics and symbolic spaces of both Krzyż and Zhovkva (and, of course, in Poland and Ukraine more generally), this book analyses the social reality of these two localities as I encountered them at the time of my fieldwork. Whilst I note more recent changes in the footnotes, the analysis of the interviews does not take later developments into consideration: such an updating would entail, de facto, a whole new round of interviews. This book is thus about Polish and Ukrainian memory before 2014, before the Euromaidan protests and the Russian annexation of Crimea. Whereas the dynamics of memory in Krzyż are fairly stable, interviewees in Zhovkva today would probably voice very different opinions, above all anti-Russian and anti-Soviet ones. However, I prefer not to speculate.

In proper nouns and in the references, I transliterate from Russian and Ukrainian in accordance with the Library of Congress system, simplified so as to facilitate reading (e.g. omitting ligatures and soft signs). Towns are referred to using their current names, i.e. "Zhovkva" and "Krzyż," when the analysis concerns the present day; however, they are also referred to as "Żółkiew" and "Kreuz" when discussing historical matters (before 1939 for the former, before 1945 for the latter). The same principle is applied to other localities whose countries, and therefore also names, changed. 



\section{Acknowledgements}

The publication of the English version of this book provides a pleasant opportunity to thank people.

This book would never have come into existence without the interviewees, old and young - people who agreed to devote their time to me and share their experiences, including very difficult and painful ones. The majority of individuals from the oldest generation have now passed away. I hope they would be pleased that their stories are being made accessible to a wider readership, and that the new readers may perceive a universal dimension in Polish-Ukrainian-GermanJewish experiences of resettlement.

The fieldwork and writing that went into this work would have been impossible without the generous support of numerous institutions. A fellowship at the University of Toronto provided an opportunity to consult literature that was difficult to access in Poland. Research grants from the Polish Centre for Holocaust Research of the Institute of Philosophy and Sociology of the Polish Academy of Sciences, Geschichtswerkstatt Europa and the National Science Centre allowed me to conduct the fieldwork. The Centre for Urban History of East Central Europe in Lviv awarded me a yearlong fellowship and hosted me during all of my trips to Ukraine. The final version of the manuscript, which served as the basis for the English translation, was completed during my fellowship at the Imre Kertész Kolleg in Jena. The translation itself was supported by a grant from the Polish Ministry of Science and Higher Education.

I would also like to thank all of the people who conducted and recorded the interviews analyzed here, whether as part of the project conducted by the KARTA Centre, their own individual research, or at my request: Dominik Czapigo, Piotr Filipkowski, Jarosław Pałka, Myroslava Keryk, Tetiana Rodnienkova and my mother, Teresa Wylegała, who was like a guardian angel to the research carried out in Krzyż. Successive versions of individual chapters were read and commented on by Halyna Bodnar, Piotr Filipkowski, Tomasz Molenda, Justyna Straczuk, Joanna Wawrzyniak, Joanna Konieczna-Sałamatin, Olga Linkiewicz and Grzegorz Motyka. I am also grateful to the examiners of my doctoral dissertation, Professor Kaja Kaźmierska and Professor Elżbieta Tarkowska, as well as numerous anonymous reviewers of those parts of the text that were published earlier as stand-alone articles. 
The English version of this text would have been much less accomplished if it were not for the work of the translator, Simon Lewis, to whom I am grateful for his insightful comments and unending patience.

I would also like to acknowledge my teachers, thanks to whom I became the scholar I am: Małgorzata Melchior, for many years of academic patronage, her unconditional support and careful supervision of the difficult process of turning ideas into text; Yaroslav Hrytsak, for his inspiration, and for always being someone I could rely on; and Ola Hnatiuk, for the very beginnings, a long time ago.

And special thanks go to my husband, as always, for everything. 


\section{Contents}

Introduction ………………………………………………………………... 13

Beginnings: Questions, Inspirations, Objectives ........................................ 13

Theories: Memory, Politics and Forgetting .................................................. 19

In the Field: Methods and Methodology ........................................................ 27

1 Dramatis personae: History and Memory ……………................... 37

Roots (up to 1939) ………………………….............................................. 37

War and Other Misfortunes (1938-1945) .................................................... 43

Brave New World (1945-1953) ..................................................................... 48

The Post-war Culture of (Non-)Remembrance (1953-1989/1991) ........... 56

After the Fall of Communism: New Beginnings? (1989/1991-present) ....... 66

2 Resettlement and the First Phase of Adaptation ....................... 79

The Journey: Autobiographical Memory and its Transmission ................. 79

Fear, Violence, Poverty: After Arrival ............................................................ 90

Yearning, Temporariness, Alienation ........................................................... 100

3 The Creation of a New Community and Social Integration ...... 113

Relations with the Authorities and the New Political System .................... 113

To Build Everything Anew, or the Social Wild West ................................... 125

The Long-term Consequences of Post-war Divisions: Integration

Processes Among the Younger Generations ................................................. 133

4 Resettlement and Identity ................................................................... 147

Returning Home - the Last Stage of the Psychological Integration

Process 
People Make a Place a Home: "Who would I return to?" 148

The Former Homeland as an Element of Identity: "It's good that we know these things."

The Lost Homeland and Crippled Identity: "A person is always attached to their homeland."

No Need for Homeland: "Why would we go there?" 153

The Old Homeland in the Consciousness of the Younger Generations .... 154 Gains and Losses - Who Came Through Migration Successfully?

\section{Remembering the Absent: Germans and German} Heritage in Krzyż

Settlers vs. Germans: Memories of the Oldest Generation .......................... 163

Before our Grandparents: Memory Among the Younger Generations ..... 172

The Germans Today: Castaways, Tourists, Litigants? .................................... 176

Around Material Heritage ............................................................................. 187

German Heritage and Identity ....................................................................... 194

\section{Remembering the Absent: Jews and Jewish Heritage} in Zhovkva

Life and Death Among Neighbors .................................................................. 201

Hearsay: What do the Resettlers Know about Zhovkva's Jews? ................. 209

Family (Non-)Memory: The Next Generations ............................................. 214

Foreign Heritage .................................................................................................. 222

Survivors, Ghosts, Visitors .......................................................................... 230

\section{Remembering the Absent: Poles and Polish Heritage} in Zhovkva

Once upon a Time in Poland ................................................................... 237

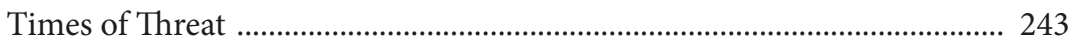

Emigration, Expulsion, Marginalization ......................................................... 251 


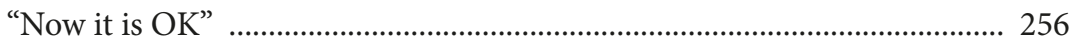

Material and Symbolic Heritage ....................................................................... 261

8 Between Heroes and Traitors: The UPA and the Soviets

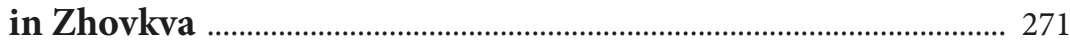

Bandits or Heroes? Troubled Autobiographical Memories ......................... 271

Pride and Prejudice: Ukrainian Nationalists in Collective Memory ......... 275

"Liberators" and Liberators - or Two Types of Soviets ................................. 285

Stalinism, Stabilization, Veterans: Memories of Soviet Zhovkva ............... 291

Heroes and Traitors: Summary ........................................................................ 297

9 A Land Without Heroes: Problems of the Memory Canon in Krzyż ................................................................................... 301

Good Russians and Bad Russians: Autobiographical Memory ................... 301

The Soviets in the Memories of the Younger Generations ........................... 308

Krzyż and Zhovkva: A Comparison of Heroic Canons ................................ 311

Postscriptum: Symbolic Space ............................................................... 315

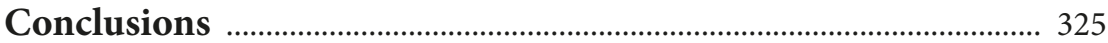

Memories of Resettlement ........................................................................... 326

Memories of Absent Others ............................................................................. 327

Memories of Heroes ................................................................................ 329

Between Memory and Forgetting ……………………………………….... 330

Memories of the Past and Collective Identity ................................................ 332

Biographical Index of Respondents .................................................... 337

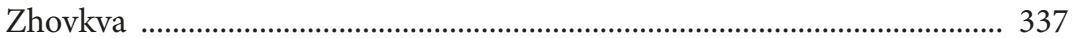

Krzyż ……….......................................................................................... 344 
Bibliography

Index

373 


\section{Introduction}

\section{Beginnings: Questions, Inspirations, Objectives}

On the outer wall of my family home in Krzyż - the German town of Kreuz (Ostbahn) before 1945 - it is possible to discern a Cyrillic inscription scraped onto one of the red bricks: "Zubov." It was only when I became interested in the history of the town that I realized that this graffiti was probably carved by a Red Army soldier in the winter of 1945, when the Soviets "liberated" Kreuz on the way to their victorious advance on Berlin. I do not know who Zubov was; I have no way of finding out whether he met the previous owners of my home. But it was this inscription that kept returning to my mind as I wrote this book, a work devoted in most part to the memory of the Others who vanished from their (now our) homes: Germans from the Polish "Recovered Territories" [pl. Ziemie Odzyskane], and Poles and Jews from Western Ukraine.

This book, however, was initially supposed to be about something completely different. The research that I embarked on in 2007 was focused on collective memory in Ukrainian Galicia, a region I already knew, having spent time studying at the University of Lviv. I chose to look at the town of Zhovkva, situated between Lviv and the Polish border. I had been there for the first time in 2000. A further visit - a study trip with students from Lviv - gave me the idea that a town with such a complicated history would be interesting to study in terms of its "ordinary" inhabitants and their relationship with the past. After I started my doctoral studies, Zhovkva became the standout candidate for a case study. A multi-ethnic and multi-confessional locality before the Second World War, with Jewish, Polish and Ukrainian inhabitants, after 1945 it became a town of uprooted people. At the same time, because of the relatively good state of repair of the town's material heritage, history here was tangible and close up; thus, the question of how present-day inhabitants relate to the past almost asked itself. I carried out my first pilot interviews, whilst still not having a coherent research concept, in Zhovkva in 2008.

It was at this time that I started working with the Oral History project at the Warsaw-based KARTA Centre, the most important non-university research institute in Poland dealing with the contemporary history of the country and of the broader East-Central European region, with a focus on individual people. ${ }^{1}$

1 http://karta.org.pl/, last accessed 13.12.2018. 
The first project I carried out independently was a documentation of testimonies in my hometown, Krzyż; a town that was brought under Polish administration after 1945, where it is still possible to find traces of its German past. In the course of three years that I spent collecting personal biographies of the town's oldest residents, ${ }^{2}$ I started to notice that I was comparing Krzyż and Zhovkva in my thoughts with increasing frequency; that the testimonies from the two places had remarkable parallels; and that I was asking about very similar things. Thus, seemingly by accident, the concept of a comparative analysis between two postmigratory towns was born. ${ }^{3}$

Although the pre-war histories and starting points for post-war transformations in the two towns were different, the existence of a tertium comparationis was indisputable: the contemporary faces of both towns are the products of wartime and post-war mass expulsions and other forms of mass population transfer. Both towns lost most of their residents as a result of the Second World War; both towns were repopulated by various, sometimes conflicting, groups of settlers; both towns emerged from the war in a different country with altered state borders; and finally, both towns experienced post-war life in non-democratic political systems that imposed a new, ethnically monolithic collective identity Polish and Ukrainian, respectively. The testimonies of residents from Krzyż and Zhovkva, superficially so different, rapidly began to come together in a fascinating mosaic of similar experiences and similar memories.

The testimonies also strengthened my conviction that, despite the passing of time, the consequences of mass population transfer are still to be felt in Poland and other European countries. Resettled people not only lose the physical, material foundations of their existence; they are also threatened by a loss of identity, their functioning in society changes, and society itself changes significantly when it is uprooted and transported. Both Poland and Ukraine in the post-war era were countries where a substantial part of the population were faced with the necessity of rebuilding their lives from scratch, in a new place, and in a new political, cultural and material reality. Their situation was not made any easier by the

2 Cf. https://audiohistoria.pl/zbiory/16-krzyz-kreuz-w-xx-wieku-polska-i-niemieckapamiec-p, last accessed 13.12.2018.

3 Post-migratory communities are those that, as a result of mass population transfer (in the Polish and Ukrainian contexts) were rebuilt and reconstituted by settlers and migrants, with a minor role played by the (remaining) autochthonous population, see: Wojciech Łukowski, Społeczne tworzenie ojczyzn. Studium tożsamości mieszkańców Mazur (Warszawa: Scholar, 2002); Zdzisław Mach, Niechciane miasta. Migracja $i$ tożsamość społeczna (Kraków: Universitas, 1998). 
lingering traumas of war or the oppressive political system, which was focused on building a "brave new world" rather than mourning the loss of the old. The experiences of resettled persons appear fundamental to an understanding of how history is interpreted in both countries, how national identity is constructed, how communities position themselves in relation to the past, and also their attitudes to neighboring countries. These experiences also influence the structure and strength of social bonds at various levels, from the cohesiveness of local communities, to the building of essential tenets of civic responsibility in modern societies. This influence is not limited to the individuals who were personally resettled; it also, indirectly, concerns successive generations.

On a broader scale, the post-war outcome in the area usually known as Central or East-Central Europe was the result of two major historical events: the Second World War as a total war, and the ethnic cleansings and genocides that began during the Stalinist Terror of the 1930s and continued in different forms until some years after the end of the war. The specific character of this region is poignantly conveyed by the title of Timothy Snyder's book Bloodlands: Europe Between Hitler and Stalin. ${ }^{4}$ Enormous bloodshed and two totalitarianisms these are the reasons behind the demographic, political and economic situation of East-Central Europe in the second half of the twentieth century. Considering questions of identity and collective memory, however, it is vital to add a third factor, one that followed directly from those first two: mass population transfers on an unprecedented scale. Another book title can serve as an apt metaphor for the resonance of this theme: Der Verlust [Loss], authored by the German journalist Thomas Urban in 2004 in the wake of Polish-German debates concerning the Centre Against Expulsions. ${ }^{5}$ The book's introduction features a one-and-ahalf page summary of all of the European nationalities that were subjected to

4 Timothy Snyder, Bloodlands: Europe Between Hitler and Stalin (New York: Basic Books, 2010).

5 Thomas Urban, Der Verlust. Die Vertreibung der Deutschen und Polen im 20. Jahrhundert (München: C.H. Beck Verlag, 2004). The Centre Against Expulsions (German, Zentrum gegen Vertreibungen) was an initiative of the German Union of Expellees, a political organization that brings together individuals who were deported from the formerly German territories that were transferred to Poland and Czechoslovakia, as well as their descendants. The Centre was supposed to commemorate the expulsions of Germans and other ethnic groups during and after the Second World War. In Poland, the idea of the planned documentation center caused controversy, because of fears that it could relativize German responsibility for war crimes and lead to claims of equality between German victims and other victims of resettlement. The Centre has still not been built. 
deportation, flight or other forms of forced migration in the years 1939-1956; the list includes all of the ethnicities that lived in the interwar Polish state. After 1945, both Poland and Ukraine became republics with completely new borders. Poland was "shifted" westwards, losing the eastern provinces known informally as Kresy Wschodnie [Eastern Borderlands], ${ }^{6}$ gaining territories to the north and west that had previously been part of Germany. ${ }^{7}$ The Germans in these areas either escaped or were deported. A similar plight met the Poles who had lived in the former eastern provinces, which became part of the Soviet Union; they departed under various degrees of duress during a series of "repatriation" waves. ${ }^{8}$ Soviet Ukraine was expanded by three southeastern Voivodeships of interwar Poland; as Poles left these territories, Ukrainians and Russians from eastern Ukraine and other Soviet Republics arrived in Galicia, as did ethnic minority Ukrainians deported from the south-western provinces of the new Polish state. ${ }^{9}$

6 The concept of Eastern Borderlands has many different connotations in Polish, but it is most commonly used as a neutral term to denote the pre-war provinces that Poland lost as a result of the war and the post-war settlement. On the memory of the Eastern Borderlands and the use of the term, see: Małgorzata Głowacka-Grajper, Transmisja pamięci. Działacze "sfery pamięci" i przekaz o Kresach Wschodnich we współczesnej Polsce (Warszawa: Wydawnictwa Uniwersytetu Warszawskiego, 2017). On the ideological disputes over the idea of Kresy, see: Tomasz Zarycki, Ideologies of Eastness in Central and Eastern Europe (New York: Routledge, 2014).

7 On the post-war border shifts and mass population transfers in Poland and Ukraine, see: Pertti Ahonen, Gustavo Corni, Jan Kochanowski, Reiner Schulze, Tamar Stark and Barbara Stelzl-Marx, People on the Move. Forced Population Movements in Europe in the Second World War and its Aftermath (Oxford-New York: Berg Publishers, 2008); Grzegorz Hryciuk, Małgorzata Ruchniewicz, Bożena Szaynok and Andrzej Żbikowski, Wysiedlenia, wypędzenia i ucieczki 1930-1959. Atlas ziem Polski (Warszawa: Demart, 2008).

8 The resettlement of Poles from the former eastern provinces, and of Germans from the post-war western and northern regions of Poland, have been discussed in a range of studies, e.g. the documentary collections: Stanisław Ciesielski, ed., Przesiedlenie ludności polskiej z Kresów Wschodnich do Polski: 1944-1947 (Warszawa: Neriton, 1999); Włodzimierz Borodziej and Hans Lemberg, Niemcy w Polsce 1945-1950. Wybór dokumentów, Vol. 1 (Warszawa: Neriton, 2000). The resettlement of the Polish Ukrainians in 1944-47 is discussed in: Orest Subtelny, "Expulsion, Resettlement, Civil Strife: The Fate of Poland's Ukrainians, 1944-1947," in: Redrawing Nations. Ethnic Cleansing in East-Central Europe, 1944-1948, ed. Philipp Ther and Ana Siljak (Lanham: Rowman \& Littlefield Publishers, 2008), pp. 155-172.

9 On post-war migration to Galicia, see: Tarik Cyril Amar, The Paradox of Ukrainian Lviv. A Borderland City between Stalinists, Nazis, and Nationalists (Ithaca and London: Cornell University Press, 2015). 
Thus, East-Central Europe of the second half of the twentieth century was not only the Europe of murdered bodies, but also of resettled persons. It was a Europe of lost friends and family, but also of lost homes and homelands. At its core, this book is about this fundamental loss and its consequences.

However, this book is not a history of resettlement and deportation; it is about the ways in which population transfer was experienced by concrete individuals, how they remember those ordeals today, and how the fact of resettlement influences successive generations of residents in contemporary Zhovkva and Krzyż. It is therefore a study of personal experience, local memory, and identity, not a reconstruction of history on the micro scale. ${ }^{10}$ Maurice Halbwachs long ago proposed the notion that collective (social) memory is distinct from history; for him, history was an objective picture of what happened, whereas memory was a source of tradition that could vary as long as different social groups existed. Elsewhere, Halbwachs opposed "living history," or in other words collective (social) memory, to academic history. ${ }^{11}$ Polish historian Robert Traba, an expert in the culture of the German-Polish borderlands, argues that the essential difference between history and memory lies in the role the latter plays in group identity. As he puts it: "Cultural memory, that is, the recollections that contribute to the creation of meaning and identity, always carry with them the danger of being forgotten, erased, or of concealing that which would cast doubt on individual and collective identity: most often, guilt." ${ }^{12}$ Another historian, Jay Winter, wrote, "History is memory seen through and criticized with the aid of documents [...]. Memory is history seen through affect." ${ }^{13}$ Thus, memory belongs to a completely different order to history; memory is non-normative and its objectives are distinct to those of history, as are the expectations placed on it. Memory is that

10 At the same time, I am indebted to many studies that do employ a microhistorical approach, especially in the context of the Polish-German and Polish-Ukrainian borderlands, e.g.: Shimon Redlich, Together and Apart in Brzezany: Poles, Jews, and Ukrainians, 1919-1945 (Bloomington: Indiana University Press, 2002); Andrzej Sakson and Robert Traba, Przeszłość zapamiętana. Narracje z pogranicza: materiały pomocnicze do analizy polsko-niemieckich stosunków narodowościowych na przykładzie warmińskiej wsi Purda Wielka (Olsztyn: Stowarzyszenie Wspólnota Kulturowa “Borussia," 2007).

11 Maurice Halbwachs, On Collective Memory (Chicago: The University of Chicago Press, 1992).

12 Robert Traba, Historia - przestrzeń dialogu (Warszawa: ISP PAN, 2006), p. 34.

13 Jay Winter, “The Performance of the Past: Memory, History, Identity, in: Performing the Past: Memory, History, and Identity in Modern Europe, ed. Karin Tilmans, Frank van Vree and Jay Winter (Amsterdam: Amsterdam University Press, 2010), p. 12. 
which transforms history into individual experience; or in other words, it turns the past into a material from which identities are constructed. ${ }^{14}$ On the other hand, the pursuit of history is itself an act of remembrance. ${ }^{15} \mathrm{~A}$ hard opposition between history and memory is ultimately useless: perhaps it is better to understand both processes as different modes of remembering in culture. The past is not something given; rather, it must always be constantly reconstructed and represented. ${ }^{16}$ "Professional" history written by academics is undoubtedly distinct from the memory of "ordinary" individuals, but they also remain in a dynamic relationship of interdependence as cultural methods of facing the past. A consequence of accepting the equal status of history and memory is the unconditional rejection of a research methodology that aims to show the chasm between what people remember and what "really happened." Memory is a research object in and of itself.

What, then, did I wish to find out from the residents of Krzyż and Zhovkva? At the most fundamental level: what they remembered, what they had forgotten or suppressed, and why. More specific questions were divided into three groups. The first category concerned the resettlement and its direct and indirect consequences. I was interested in how respondents interpreted questions of guilt, punishment and responsibility, as well as their personal evaluations of the benefits and losses of resettlement. I considered it important to understand the dynamics of how these processes took root in different generations: whether a new, internally cohesive community was successfully created which identified with the new post-war place; and also the extent to which the pre-war history of the town was recognized by residents as "their own." I tried to interpret the extent to which the older generation still felt attached to their former places of residence, and whether this question had any significance at all for young people. The second group of questions concerned the memory of the previous residents of the town: the vanished "Others." Was this a troublesome memory; was it screened off, or associated with a specific set of problems? Did it in any way affect attitudes towards present-day Poles, Jews and Germans? The third group of questions revolved around the transmission of memory. Did accounts

14 Cf. David Lowenthal, The Past is a Foreign Country (London: Cambridge University Press, 1985).

15 Cf. Jay Winter, Remembering War: The Great War between Memory and History in the Twentieth Century (New Haven: Yale University Press, 2006).

16 Cf. Astrid Erll, "Cultural Memory Studies: An Introduction," in: Cultural Memory Studies. An International and Interdisciplinary Handbook, ed. Astrid Erll and Ansgar Niinning (Berlin-New York: De Gruyter, 2008), pp. 1-18. 
of the past play a role in family life? If so, in what ways did the younger generations modify the contents of the experiences of the older generation? If not, why was there no intergenerational transmission of memory? How large was the influence of other factors that affect collective memory, such as official memory, neighbors' accounts, or group representations? These three groups of questions were posed with the contextual background in mind: i.e. local policies of commemoration and identity construction in both Krzyż and Zhovkva. I was interested in how official commemorative policy operated in both towns, whether it approached the pre-war cultural heritage of the towns, and what the relationship was between private and official memory.

\section{Theories: Memory, Politics and Forgetting}

But what exactly do I mean when I declare that I am studying memory? Theoretical treatments are so abundant, sophisticated and diverse that it is impossible to provide a comprehensive summary of memory studies, a discipline that emerged relatively recently. ${ }^{17}$ Nonetheless, this book employs terms that have specific histories and conventions of usage, so it is important for the sake of clarity that the main ones are explained. The theoretical axis around which my analysis spins is the relationship between individual and collective memory. Collective memory is defined as the sum of cultural narratives about the past, including both knowledge about and judgment of history, that are potentially available to the average citizen (not just the intellectual elites). In my understanding it forms a kind of cultural "background" that includes mediated (i.e. not personal, first-hand) experience, which is essential to the construction and consolidation of group identity.

Maurice Halbwachs, one of the "founding fathers" of the discipline, argued that all individual memory is immersed in, and formed under the influence of, "social frames" of memory. Individual memory functions in particular (sometimes multiple) networks of referentiality; this is why we cannot separate it from the collective dimension or analyze it without situating it in the context of remembering groups. Social frames of memory carry out a very important

17 This does not mean that no such attempts have been made on the basis of particular studies, see: e.g. Jeffrey Olick and Joyce Robbins, "Social Memory Studies: From 'Collective Memory' to the Historical Sociology of Mnemonic Practices," Annual Review of Sociology, Vol. 24, No. 1 (1998), pp. 105-140; and on Polish scholarship on memory, see: Kornelia Kończal and Joanna Wawrzyniak, "Provincializing memory studies: Polish approaches in the past and present," Memory Studies, first published 25.01.2017, https://doi.org/10.1177/1750698016688238, last accessed 15.02.2019. 
function, in that they create a sense of continuity within a community. For Halbwachs, it is nearly impossible to cleanse individual memory of the influence of social framing and thereby to access a pure, undistorted experience. ${ }^{18}$ My research repeatedly confirms this observation: biographical memory is never based solely on individual experience, because each person uses models provided by culture to interpret his or her own experience. There is also an influence in the other direction: individual experiences, if they concern a significant portion of members of a community or are important enough to constitute part of its identity, over time become part of the collective memory. Needless to say, as in every aspect of collective identity, it is the elites who most easily make the cultural "background" their own, i.e. in Central European conditions - the intelligentsia. ${ }^{19}$ Nonetheless it remains an important fact that, although the elites have a closer relationship with the dominant narratives of collective memory, they never gain exclusive access to it.

Influential scholars in the German humanities also discuss the internal tension between collective and individual memory. Jan Assmann, who coined the term "cultural memory," defines it as follows: "Cultural memory refers to one of the exterior dimensions of human memory [...] the contents of this memory, the ways in which they are organized, and the length of time they last are for the most part not a matter of internal storage or control but of the external conditions imposed by society and cultural contexts." ${ }^{20}$ Assmann distinguishes four areas of memory: mimetic memory (modes of action, which we learn through repetition); memory of things (objects, material culture); communicative memory (language and communication); and cultural memory (transmission of meanings). Communicative memory - that is, memories of the recent past as preserved by the closest generations - plays a special role in the interactions between individual and collective remembrance. Like Halbwachs, Assmann argues that there are no pure forms of memory: every individual recollection is a reconstruction of the past immersed in a social and cultural context.

Both Assmann and other scholars who have expanded on his theories make it clear that the two types of collective memory - communicative and cultural can only be distinguished at the level of theory. As Harald Welzer writes, in

18 Halbwachs, On Collective Memory.

19 For a definition of the intelligentsia, see: Maciej Janowski, Birth of the Intelligentsia 1750-1831, Vol. 1 (Frankfurt am Main: Peter Lang Edition, 2014), especially Jerzy Jedlicki, "Introduction" in this volume.

20 Jan Assmann, Cultural Memory and Early Civilization: Writing, Remembrance and Political Imagination (Cambridge: Cambridge University Press, 2011), p. 5. 
the social practices of individuals and groups, these two forms of memory are tightly interwoven. ${ }^{21}$ The narratives of communicative memory can enter cultural memory through concrete practices of cultural transmission; they can be preserved, or otherwise, they are lost together with the memories of individuals. Communicative memory can also influence the content of cultural memory; for example, it can remove certain elements. Autobiographical memory is formed as a result of a constant interaction between people's internal autonomy as individuals and external influences of which they are often unaware. What distinguishes the autobiographical memory of a given individual from the memories of everyone else is precisely the history of that individual's communication with others.

Another German scholar, Astrid Erll, argues that "cultural memory" can serve as an "umbrella term" that covers various related meanings employed by researchers in different disciplines, such as: "social memory" (a point of departure for studies in the social sciences), "material memory" or "communicative memory" (objects of interest in studies of literature and media) and "mental" or "cognitive memory" (the field of research in psychology and cognitive science). ${ }^{22}$ Erll points out that the concept of "collective" or "cultural memory" is ultimately a figurative metaphor, whereby the mental act of remembering (a cognitive process that takes place in individual minds) is metaphorically transferred to the realm of culture.

Collective memory can also be understood as a communicative and ritualistic framework that gives biographical memory a collective dimension. ${ }^{23}$ It thus supplies "keys" through which individual experiences can be interpreted, creating a symbolic and cultural medium for the group in which one functions. This is precisely why in many of the testimonies analyzed here, the boundary between what someone personally experienced and what he or she only heard from others is often blurred. Asymmetry between biographical and collective memory - which arises when significant personal experiences do not become absorbed into collective memory - can lead to serious disturbances of identity, as well as marginalization and exclusion. Autobiographical memory, based on personal experience, is also sometimes described as "primary" memory, in

21 See Harald Welzer, "Communicative Memory", in: Cultural Memory Studies: An International and Interdisciplinary Handbook, ed. Astrid Erll and Ansgar Nünning (Berlin/New York: de Gruyter, 2008), pp. 285-300.

22 Erll, "Cultural Memory Studies."

23 Kaja Kaźmierska, Biography and Memory. The Generational Experience of the Shoah Survivors (Boston: Academic Studies Press, 2012), p. 57. 
contradistinction to the "secondary memory" of derivative "knowledge about" events, ${ }^{24}$ as well as "postmemory," i.e. memory passed down to successive generations. ${ }^{25}$

Whilst the concept of collective memory is methodologically attractive, it does have its critics. One of the most interesting alternatives to the theory of collective memory is provided by Jay Winter, who argues: "If the term 'collective memory' has any meaning at all, it is the process through which different collectives, from groups of two to groups in their thousands, engage in acts of remembrance together. ${ }^{26}$ For Winter there is no such thing as the memory of a state or nation; at most, there are memories held by people who are connected to the other people by virtue of belonging to the same group. If there are no remembering individuals - for example if they lose interest in a particular aspect of history, pass away, or physically relocate - the remembering collective also vanishes. This is, according to Winter, what Halbwachs had in mind when he wrote about memory disappearing when the social frames of memory disappear. Rather than "collective memory," therefore, Winter proposes that we think in terms of "collective remembrance." The essential questions for such an approach concern the intentions of individuals who are publicly active in spheres related to the past, i.e. those involved in the "work of memory." Collective memory becomes only a metaphorical term, which in reality denotes a "set of practices of collective remembrance." What matters, then, is not what people think about the past, but how they act. Winter's critique of the term "collective memory" allows us to consider memory as a social phenomenon that is changing, procedural, constantly renegotiated, and always situated in the here and now.

An important question that follows from Winter's critique is the distinction between collective and official memory. By official memory I mean the vision of the past constructed and transmitted by authorities through the available means of symbolic enforcement: education (curriculums and textbooks), various forms of public commemoration (museums, a monopoly on shaping symbolic space, the organization of holidays and anniversaries, etc.), and the media. The form of official memory that most frequently features in this study is the memory propagated by the state; nonetheless, it is worth noting that there are

24 Dominick LaCapra, History and Memory after Auschwitz (Chicago: Cornell University Press, 1998).

25 Marianne Hirsch, Family Frames. Photography, Narrative and Postmemory (Cambridge: Harvard University Press, 1997).

26 Winter, Remembering War, p. 4. 
also official memories whose carriers are groups other than (smaller than) the state. In any situation where a social group creates a structure of power, they may also advance an official memory. A good example is the official memory of tightly knit ethnic minority groups, which have their own means of education and information distribution, such as the Polish minority in Ukraine and the Ukrainian minority in Poland. Official memory maintains various relationships of interdependence with biographical and collective memory. In a democratic society, collective memory is a foundation for official memory, whilst official memory can convey aspects of collective memory to individual memories. The less democratic a society is, and the more its governance relies on a ruling ideology, the more collective and official memory are out of joint. For example, Polish memory of the resettlement from the pre-war eastern territories was only inscribed into official memory after $1989 .{ }^{27}$

Thus, collective memory is inextricably entwined with group identity: a common memory turns a group into a remembering collective. Lech M. Nijakowski provides a useful description of remembering collectives as

aggregates of individuals (not necessarily groups) that are connected by a specific biographical experience, not always of a traumatic nature, as well as their descendants who inherit family frames of memory. Remembering collectives are made distinct from each other not just by the different "objective" histories of their members [...], but also through the individual perspectives of their members $[\ldots]$ and the emotions that are associated with those perspectives. ${ }^{28}$

Membership of a remembering collective does not have to be based on a familial transmission of memories that are constitutive for a given group; it can also be gained by means other than inheritance. Group memory does not only form a specific sensitivity to historical events that comprise that particular collective identity; it can also influence how people evaluate other elements of social memory. Group memory can define both large collectives (e.g. Red Army veterans in Ukraine) and small, localized groups (e.g. particular groups of settlers in Krzyż and Zhovkva). It can be integrated into collective and official memory, as has happened, for example, with the memory of settlers from the former Eastern Borderlands in Poland, or members of the group can undertake efforts to make it so. Particular remembering collectives in a given community can be in conflict

\section{See: Głowacka-Grajper, Transmisja pamięci.}

28 Lech M. Nijakowski, Domeny symboliczne. Konflikty narodowe i etniczne w wymiarze symbolicznym (Warszawa: Scholar, 2006), pp. 32-33. 
with each other; but in this case, it is less likely that their narratives will enter collective and official memory.

Group memory is a particularly fertile foundation on which social practices of remembrance can develop; it is therefore the point at which memory understood as a potential repository of culture transforms into actual activity - a "historical remembrance" in Winter's terms..$^{29}$ Nonetheless, if memory is not turned into action, this does not mean that it does not exist; the reasons behind such passivity (or invisibility) can be various, from weak internalization of the narratives of collective memory to limitations resulting from diverse factors. Collective memory is often too weakly connected to personal experience to mobilize people into getting involved in practices of remembrance; autobiographical memory is too particular for such an outcome. This is precisely why remembering collectives are the most influential actors on this stage.

Another concept that is as important as memory for the purposes of this book is forgetting. The centrality of forgetting for collective identity was captured by Ernest Renan at the end of the nineteenth century, who argued that a nation is a collective that remembers together, and even more importantly, forgets in unison. ${ }^{30}$ Forgetting - also referred to as non-memory or selective remembering - is the second face of memory. Aleida Assmann states that memory and forgetting are inseparable parts of the same whole, together forming cultural memory. ${ }^{31}$ Paul Ricœur, who adapts the theories of Sigmund Freud, transfers psychoanalytical concepts from the individual to the collective, such as: repression; remembering, repeating and working through; excess of memory; and work of memory. ${ }^{32}$ In Ricœur's understanding, societies struggle with similar problems to individuals: driven by anxieties about the integrity of their identities, they forget about certain elements of their past, only to later work through them arduously and to struggle with the returning effects of memories banished to the unconscious. The philosopher introduces a key distinction between active and passive forgetting: active forgetting is a conscious and purposeful action, intended to erase a feature of memory in order to preserve the symbolic and material good of the group; passive forgetting, on the other hand, is the

29 Winter, Remembering War, p. 9.

30 Ernest Renan, "What is a Nation?," in: Nation and Narration, ed. Homi Bhabha (London: Routledge, 1990), pp. 8-22.

31 Aleida Assmann, "Canon and Archive," in: Cultural Memory Studies: An International and Interdisciplinary Handbook, ed. Astrid Erll and Ansgar Nünning (Berlin/ New York: de Gruyter, 2008), pp. 97-108.

32 Paul Ricœur, Memory, History, Forgetting (Chicago: University of Chicago Press, 2004). 
usually unconscious avoidance of memories sensed to be problematic, difficult, or dangerous.

References to Ricœur's ideas can be found in a broad range of empirical and theoretical studies. For a study based on analysis of personal interviews, an important consideration noted by Kaja Kaźmierska with reference to Fritz Schütze is that at the level of oral narration, "fading out of awareness" acts as the equivalent of passive forgetting. ${ }^{33}$ Marek Ziółkowski writes about the strong relationship of identity not only with forgetting, but also with what he calls "painful memory" (in relation e.g. to political and inter-ethnic conflicts). He argues that events that become part of collective non-memory are initially diminished and banished to the subconscious (passive forgetting), before they disappear from public discourse and cease to be a basis for collective action (active forgetting) ${ }^{34}$ Analyzing the memory of the Holocaust, Michael Bernard-Donals divides memory into Aristotelian anamnesis - recollection of persistently returning narratives that are uncomfortable or previously repressed - and mneme: rational, deliberately constructed stories about the past, or cultural memory. ${ }^{35}$ Anamnesis constantly interferes with mneme, trying to impose elements that have been erased from cultural memory. According to Bernard-Donals, these two dimensions of memory can be interpreted both in individuals (in which case anamnesis refers to difficult memories for the person) and in entire societies (in which case the repressed memories are those that have been erased from mneme by the collective as a whole). He argues that the Holocaust is a classic event that pertains to anamnesis.

When analyzing collective forgetting, it is important to consider why and how memory is suppressed. A community forgets certain facts, either actively or passively, in order to protect its group identity and moral integrity. That which is uncomfortable and unsafe, which might lead to some members of the collective ceasing to positively identify with the group, is erased. A second reason is more closely connected to the mechanisms by which individual and collective memory function. The loss of memory is a result of the disappearance of the

33 Kaźmierska, Biography and Memory. Kaźmierska discusses the notion of "fading out" at greater depth in her earlier text: Kaja Kaźmierska, "Wywiad narracyjny - technika i pojęcie analityczne," in: Biografia a tożsamość narodowa, ed. Marek Czyżewski, Andrzej Piotrowski and Alicja Rokuszewska-Pawełek (Łódź: Wydawnictwo Uniwersytetu Łódzkiego, 1996), pp. 35-45.

34 Cf. Marek Ziółkowski, "Pamięć i zapominanie: trupy w szafie polskiej zbiorowej pamięci," Kultura i Społeczeństwo, Vol. 3/4 (2001), pp. 3-22.

35 Michael F. Bernard-Donals, Forgetful Memory: Representation and Remembrance in the Wake of the Holocaust (Albany: SUNY Press, 2009). 
social frames of memory; when they are removed, memory is also lost, first at the collective level, and then at the individual. Halbwachs argued that if certain memories fail to resurface, it is not because they are too old and gradually faded, but because they were previously part of a conceptual system that no longer exists. ${ }^{36}$ Jan Assmann makes a similar argument: when communication is interrupted or frames of memory disappear, forgetting ensues. ${ }^{37}$ The ideas voiced by both theorists are crucial for a study such as this one, which has been conducted in places where the previously existing frames of memory have completely vanished in the course of a single generation, or at least have been very substantially modified.

Another essential question in this context is the extent to which the social process of forgetting is reversible. As several scholars have shown, biographical memory can be altered under the influence of collective memory: individuals not only forget certain facts from their own lives, but also "re-remember" those that appeared forgotten forever. ${ }^{38}$ Can the same be said of collective memory? It appears that forgetting is a matter of a degree, and is more or less irrevocable. Aleida Assmann, using the same terms as Ricœur but giving them a completely different meaning, draws a distinction between active and passive forgetting: ${ }^{39}$ active forgetting removes an event from memory permanently and is irreversible; passive forgetting, on the other hand, happens through lack of attention rather than active choice, and can therefore be undone. In the scheme proposed by Assmann, collective forgetting (both active and passive) are complemented by active and passive remembering. Within a society, specific institutions - schools, civil offices and museums - are involved in active remembering. Active remembering constructs a canon of memory, whereas passive remembering happens in the realm of archival memory. Assmann illustrates this co-dependence by means of the suggestive metaphor of a museum, which has a display and storage. The display is accessible at any time, and is similar to active remembering. The storage is the archival memory, which is more difficult to access, but which can potentially be moved to the display hall. Processes of passive forgetting are often, in essence, passive remembering. The memory is not lost; it is merely temporarily out of use.

36 Halbwachs, On Collective Memory.

37 Assmann, Cultural Memory, p. 23.

38 Alicja Rokuszewska-Pawełek, Chaos i przymus. Trajektorie wojenne Polaków - analiza biograficzna (Łódź: Wydawnictwo Uniwersytetu Łódzkiego, 2002).

39 Assmann, "Canon and Archive." 


\section{In the Field: Methods and Methodology}

The method used in the present study essentially comprises three strands: a specific local community, memory seen through the prism of autobiography, and analysis of family memory through different generations. I decided to research social memory in small towns because I believe that the questions at the heart of this project are better answered from a lesser distance, rather than from a macro perspective; moreover, small-scale research facilitates deeper analysis. Of course, the findings of this study cannot be extrapolated to the greater whole of Polish and Ukrainian societies. Nonetheless, they do give an indirect perspective on the bigger picture by means of the typicality of the towns under consideration. Autobiography is a key word for this project because it is precisely through personal narratives that I examine how social worlds are reflected in the accounts of my interviewees. ${ }^{40}$ Especially in the case of older respondents, it would be impossible to understand their views and memories without a holistic consideration of their lives. As Norman Denzin argues in his essay reinterpreting the autobiographical method in sociology, "human behavior must be studied and understood from the perspective of the people under consideration." ${ }^{41}$ If subjectivity is thus taken seriously, the categories of truth and falsehood become inadequate. The concepts of authenticity and inauthenticity, or "emotional authenticity" as the well-known oral historian Alessandro Portelli put it, become more appropriate. ${ }^{42}$

40 My basic inspiration was the biographical method, a classic school in Polish sociology that draws on the work of William Thomas and Florian Znaniecki: their The Polish Peasant in Europe and America (Chicago: Chicago University Press, 1918). Among the more recent sociological studies that employ autobiography as a key concept, the following have particularly inspired me: Barbara Engelking, Zagłada $i$ pamięć. Doświadczenia Holocaustu i jego konsekwencje opisane na podstawie relacji autobiograficznych (Warszawa: IFiS PAN, 2001); Małgorzata Melchior, Zagłada a tożsamość. Polscy Żydzi ocaleni “na aryjskich papierach." Analiza doświadczenia biograficznego (Warszawa: IFiS PAN, 2004); Kaja Kaźmierska, Doświadczenia wojenne Polaków a kształtowanie tożsamości etnicznej. Analiza narracji kresowych (Warszawa: IFiS PAN, 1999).

41 Norman Denzin, "Reinterpretacja metody biograficznej w socjologii: znaczenie a metoda w analizie biograficznej," in: Metoda biograficzna w socjologii, ed. Jan Włodarek and Marek Ziółkowski (Warszawa-Poznań: Państwowe Wydawnictwo Naukowe, 1990), p. 53.

42 Alessandro Portelli, "Philosophy and the Fact: Subjectivity and Narrative Form in Autobiography and Oral History," in: The Battle of Valle Giulia: Oral History and the Art of Dialogue (Madison: University of Wisconsin Press, 1997), pp. 79-90. 
Moreover, memory that is constructed socially - through family, neighborhoods, and localities - is always connected to identity (both individual and group), and is thus impossible to study without reference to biography. Even if the respondent's autobiographical narrative does not supply clues as to how one can place their views in a particular interpretive frame, as often happens with younger people, delving into the history of their family - and thus into constructed biography - completely changes the situation. Research into the intergenerational transmission of memory, especially studies of Holocaust survivors, ${ }^{43}$ shows the extent to which narratives distributed within the family can be used to understand the mechanisms of memory and forgetting.

At the fieldwork stage of this project, I treated generation as a working category - I was trying to carry out interviews with at least one member of each generation within a family, starting with the oldest. Only when I started analyzing the material did it transpire that a more nuanced division of respondents into different generations was needed. Besides respondents' age, their shared historical experiences were also essential (although they did not necessarily lead to a feeling of community), as was their participation during their childhood and youth in the same memory culture (i.e. the overall mechanisms by which perspectives on the past were formed, including family, society, and official memory).$^{44}$ Considering the enormous variety in age among my interviewees

43 Cf. Karoline Tschuggnall and Harald Welzer, "Rewriting Memories: Family Recollections of the National Socialist Past in Germany," Culture Psychology, Vol. 8 (2002), pp. 130-145; Lena Inowlocki, "Grandmothers, Mothers and Daughters. Intergenerational Transmission in Displaced Families in Three Jewish Communities," International Yearbook of Oral History and Life Stories, Vol. 2 (1993), pp. 139-154; Daniel Bertaux and Paul Thompson, eds., Between Generations. Family Models, Myths and Memories (New Brunswick: Transaction Publishers, 2005); Gabriele Rosenthal, The Holocaust in Three Generations. Families of Victims and Perpetrators of the Nazi Regime (Opladen-Farmington Hills: Barbara Budrich Publishers, 2010).

44 Historical experience is a key concept in many studies of generation, see: Thomas C. Wolfe, "Past as Present, Myth or History? Discourses of Time and the Great Patriotic War," in: The Politics of Memory in Postwar Europe, ed. Richard Ned Lebow, Wulf Kansteiner and Claudio Fogu (Durham-London, Duke University Press, 2006), pp. 249-283; Piotr T. Kwiatkowski, "Wprowadzenie. Doświadczenie II wojny światowej w badaniach socjologicznych," in: Między codziennością a wielką historią. Druga wojna światowa w pamięci zbiorowej społeczeństwa polskiego, ed. Piotr T. Kwiatkowski, Lech M. Nijakowski, Barbara Szacka and Andrzej Szpociński (Warszawa: Scholar, 2010), pp. 12-54; Howard Schuman and Jacqueline Scott, "Generations and Collective Memories," American Sociological Review, Vol. 54, No. 3 (1989), pp. 359-381. 
(who were born between 1914 and 1992) I decided to sort them into four generations (codified in respondents' identity ciphers as A, B, C and D, respectively). The first (born before 1936) was the "Witness Generation:" the biographical memory of these individuals covers the entirety, or at least a large part of the Second World War, and often the pre-war period as well. War and its consequences were formative experiences for them. They underwent resettlement and experienced the building of a new post-war society as fully conscious adults or teens.

The second generation (born between 1936 and 1954) was the "Generation of Living Memory:"45 their memories were formed in the period immediately following the war, above all through direct transmission. These individuals experienced the war and resettlement as children (and often were unable to distinguish what they remembered themselves from what they were told by older people), or were born in the early post-war years and grew up hearing stories about the war and were formed in social conditions directly affected by it. ${ }^{46}$ The third, "Thaw Generation" (born 1955-1975) was made up of people born during the Thaw period, with a significant temporal distance from the end of the war; their memories were fully codified, formed by family memories crystallized by a specific time lag, and also especially by the official memory of the Polish People's Republic and the USSR. The last generation, the "Grandchildren's Generation" (born 1976-1992), were respondents whose socialization occurred in part or in whole after the fall of communism. Because of their young age, they have limited access to memories of personal experiences of the war.

Because I was interested above all in the memories of "ordinary" people, i.e. vernacular memory, the decision to carry out personal interviews and (partially participant) observation was an obvious one. As Mirosława Grabowska argues, the interview is the only possible research tool in situations where the questions

45 Polish sociologist Nina Assorodobraj's idea of "living history" provided the inspiration for this concept, see: Nina Assorodobraj, “'Żywa historia.' Świadomość historyczna: symptomy i propozycje badawcze," Studia Socjologiczne, Vol. 2, No. 9 (1963), pp. 4-28.

46 Dorothee Wierling identifies a "war children generation," corresponding rather well with my generation $\mathrm{B}$ : she describes them as people whose childhood happened during the war; who grew up without their fathers, who had been conscripted to the army; and who were too young to get involved in any political activities before 1945, see: Dorothee Wierling, "Generations as Narrative Communities. Some Private Sources of Public Memory in Postwar Germany," in: Histories of the Aftermath. The Legacies of the Second World War in Europe, ed. Frank Biess and Robert G. Moeller (New YorkOxford: Berghahn Books, 2010), pp. 102-120. 
being posed are complex or can be understood by scholar and subject in different ways. ${ }^{47}$ In such situations, this subjective understanding becomes the object of inquiry - and there is no method other than conversation by which to access it. I employed two types of interviews: narrative (autobiographical, oral history) interviews with older individuals (generation A and older interviewees from B) and thematic interviews with elements of biographical questioning with younger respondents (younger people from the generation $\mathrm{B}$, as well as $\mathrm{C}$ and $\mathrm{D}$ ). In sociology, narrative interviews can be both a research method and a method of analysis: for me, they were primarily a tool for gathering empirical material. ${ }^{48}$ The essence of this technique is that the narrative reflects personal experiences: the interviewee tells his/her story, creating his/her own narrative, and only after s/he has finished does the interviewer pose additional questions.

In practice, ideal narrative interviews happen rarely: often, the respondent does not have the narrative competence to construct their story (and this is not necessarily related to their level of education). The researcher's prompts notwithstanding, respondents insist on concrete questions or start to relate their most important life experiences right away (in the case of older interviewees, this is most often the war), omitting their childhood. ${ }^{49}$ In such situations, I was compelled to pose questions that were in any case asked in every interview, not least because I was interested in respondents' views on themes and events that were not necessarily directly related to their life experience. Additionally, interviews with older respondents almost always had a therapeutic dimension. Many people were telling their stories about painful experiences for the first time, and all of them found it difficult to articulate their wartime memories. Such conversations necessitated a particular empathy towards the respondents, and sensitivity to

47 Mirosława Grabowska, "Wywiad w badaniu zjawisk 'trudnych.' Przypadek polskiej religijności," in: Poza granicami socjologii ankietowej, ed. Antoni Sułek, Kazimierz Nowak and Anna Wyka (Warszawa: UW, IS, PTS, 1989), pp. 141-166.

48 Cf. Kaźmierska, "Wywiad narracyjny."

49 This type of autobiographical narrative is observed fairly frequently among respondents who were born before the war, see: Ewa Nowicka, "Wojna jako element opowieści biograficznej greckich repatriantów z Polski," in: Pamięć zbiorowa jako czynnik integracji iźródło konfliktów, ed. Andrzej Szpociński (Warszawa: Scholar, 2009), pp. 73-124. On the problems involved in soliciting a "good" autobiographical narrative, see: Gabriele Rosenthal, "Rekonstrukcja historii życia. Wybrane zasady generowania opowieści w wywiadach biograficzno-narracyjnych," in: Metoda biograficzna w socjologii, ed. Jan Włodarek and Marek Ziółkowski (Warszawa-Poznań: Państwowe Wydawnictwo Naukowe, 1990), pp. 97-112. 
their needs. ${ }^{50}$ Interviews with younger people were more rigidly structured and were conducted according to previously prepared interview blueprints (which differed somewhat in the two localities).

Research in Zhovkva was carried out in 2008-2010, while fieldwork in Krzyż was carried out between 2009 and 2011. During my stays in both towns, besides conducting interviews, I tried to observe local commemorative practices: I attended ceremonies connected to important historical events (e.g. in Ukraine, Victory Day on 9 May and Independence Day on 23 August, and in Poland, Constitution Day on 3 May and Independence Day on 11 November); I also visited cemeteries and other sites of memory, museum exhibitions (in Zhovkva) and commemorative displays in schools (in Krzyż). In both places, I favored non-probability-sampling (purposive sampling). ${ }^{51}$ I recruited my first interviewees on the principle that they had to have lived in the town before the late 1940s: it was crucial that their experience encompassed the momentous period of the resettlements, the change of statehood, and the building of a new society. The first interviewees suggested contacts to other people, and I thus followed this classic "snowball" method of gathering interviewees, trying to collect respondents whilst maintaining proportionality of the different groups of residents who created the new Krzyż and Zhovkva after 1945. When I deviated from this principle on a few occasions and spoke to people who settled in the town after 1950, I did so because of the exceptionality of their experience or because of the difficulty of reaching individuals who fit my criterion. I carried out interviews until a point of saturation was achieved; or in other words, until I was convinced that further respondents would not bring any new contents to the already accumulated material..$^{52}$

50 Questions surrounding the therapeutic dimension of interviews and of the accompanying difficulties, have been discussed in a large corpus of literature, see: Juliet Corbin and Janice M. Morse, "The unstructured Interactive Interview: Issues of Reciprocity and Risks when Dealing with Sensitive Topics," Qualitative Inquiry, Vol. 9, No. 3, (2003), pp. 335-354.

51 On purposive sample and methods of achieving point of saturation in the sample, see: Daniel Bertaux, "From the Life-History Approach to the Transformation of Sociological Practice," in: Biography and Society, ed. Daniel Bertaux (London-Beverly Hills: Sage Publications, 1981), pp. 19-28.

52 Daniel Bertaux calls this type of obtained representativeness - in opposition to statistical representativeness that appears at the morphological level (superficial description) - representativeness at the sociological level (in socio-cultural relations), see: Bertaux, "From the Life-History Approach." 
Conducting fieldwork in both towns, I used interviews that I myself had carried out and, to a lesser extent, those recorded by others. In Krzyz this was connected to the simultaneous progress of the Karta Centre's documentation project; in Zhovkva, the Geschichtswerkstatt Europa was conducting a project financed by the EVZ Foundation. This multi-pronged amassment of empirical material made the body of available sources very large. In Krzyż, over 100 interviews were recorded; in Zhovkva, there were more than 90 (in both towns, nearly half of the conversations were with people born before the war). My initial plan was to collect about 15 interviews for each generation in both towns, or about 60 for each town, as well as supplementary expert interviews (with individuals who were important for the transmission of memory in the local community: representatives of the local authorities, teachers, culture professionals, etc.). However, gathering interviews with members of all the generations in a family turned out to be a difficult task. In many situations, a promising start with the eldest representative did not lead to further interviews with descendants: respondents did not have children or grandchildren, or the younger generations lived outside Zhovkva or Krzyż, or I simply had difficulties in establishing contact with them. On some occasions, the younger members refused to answer questions; older individuals also sometimes declined to participate. The final selection of material was the product of compromises: sometimes, I kept a conversation for my sample even if it had no generational continuation, or I kept a fairly average interview with an older person because his/her children or grandchildren gave an enlightening response. In the end, 82 interviews from Krzyż were kept for the sample ( 7 full generational sets/families, 17 partial sets, and 8 expert interviews) and 75 from Zhovkva (7 full generational sets/families, 13 partial ones, and 10 expert interviews).

In both towns, fieldwork had its own specificity. In Krzyż, progress was influenced by the fact that I myself come from there. In some situations, my connection to the town made work easier; in others, it was a limiting factor. Gathering materials and observing social life was certainly made simpler by my familiarity with local conditions. In this small community, I knew without any additional effort which employees in culture or administration had a real influence on local memory policy, which teachers conducted an extracurricular course on regional history, and who collected German memorabilia. Similarly, respondents were often better disposed towards being interviewed by me, because they already knew me or members of my family. This factor of being an insider, however, did come with a price, and in other situations was a hindrance. For instance, it happened that during interviews, respondents treated certain questions only 
briefly or omitted them altogether, judging them to be obvious; they assumed there was no need to talk about them if I knew about them already. ${ }^{53}$

Carrying out research in Zhovkva was much more complicated. Difficulties arose above all from being in a foreign country: from the outset, the fact that my interviewees and I (usually) came from different cultures and linguistic environments created barriers. ${ }^{54}$ Another problematic issue was the fact that I, as a Pole, was conducting fieldwork in Galicia - as a result of the difficult history of Polish-Ukrainian relations in this region, my background often affected the relationship between my respondents and myself. Above all, I received frequent refusals - roughly one in five interview requests was turned down, mostly by older individuals who had been resettled from Poland or had lived in Zhovkva since before the war; they had no desire to tell someone from Poland about their painful experiences from the past, which were perpetrated by Poles. A second group who fairly frequently declined interview requests were Ukrainians and Russians who had originally come from the East; this was most likely due to a general suspicion of foreigners, as well as a fear of recounting experiences from the war and immediate post-war years, for a variety of reasons. ${ }^{55} \mathrm{~A}$ number of individuals who I knew to have been active "builders of the new system"

53 On the limitations of being an "insider researcher," see: Marta Kurkowska-Budzan, Antykomunistyczne podziemie zbrojne na Białostocczyźnie. Analiza wspótczesnej symbolizacji przeszłości (Kraków: Tow. Wydawnicze "Historia Iagellonica," 2009), p. 98; Jennifer Platt, "On Interviewing One's Peers," The British Journal of Sociology, Vol. 32, No. 1 (1981), pp. 75-91; Maxine Baca Zinn, "Insider Field Research in Minority Communities," in: Contemporary Field Research: Perspectives and Formulations, ed. Robert M. Emerson (Long Grove: Waveland Pr Inc., 2001), pp. 159-166.

54 On conducting fieldwork in a country other than one's own, and the possible modifying effects of the researcher's nationality on biographical narratives, see: Gabriele Rosenthal and Dan Bar-On, "A biographical case study of a victimizer's daughter," Journal of Narrative and Life History, Vol. 2, No. 2 (1992), pp. 105-127; Anna Wylegała, "Badacz z Polski na Ukrainie: problemy metodologiczne," Przegląd Socjologii Jakościowej, Vol. 9, No. 4 (2013), pp. 140-151.

55 One of my interviewees (born in central Ukraine) told me that she considered for a long time whether to agree to the interview, because she had been afraid of coming into contact with foreigners since the time of the war, when she was deported to Germany as a forced labourer. Her reluctance to voice her experiences from those times was not groundless. After the war had ended, thousands of Soviet forced labourers in Germany who returned to their homes were deported to the camps in Siberia. Those who avoided this fate were afraid to talk about their wartime histories for the rest their lives. See: Marta Dyczok, The Grand Alliance and Ukrainian Refugees (New York: Palgrave Macmillan, 2000); Gelinada Grinchenko, "The Ostarbeiter of Nazi Germany in Soviet 
also refused to grant interviews - here, it was probably an anxiety about their connections to the previous regime, rather than anything to do with my nationality, that played a key role. One respondent, a former serviceman and functionary of the security services originally from central Ukraine, explained his refusal to be interviewed by stating that he had not lived in Zhovkva during the war, had no knowledge of Polish-Ukrainian relations at that time, and never had any conflicts with Poles. The logic of this explanation speaks volumes about how I might have been perceived: despite my efforts to convince people that I was not only researching Polish-Ukrainian conflicts, some residents of Zhovkva assumed a priori that, as a Pole, I could only be interested in this topic. Another, more fundamental issue was that my nationality could have prompted respondents to modify their narratives, more or less consciously. ${ }^{56}$

A few words of explanation are needed on how the collected materials were used. Because of the methodological foundations of the analysis, I decided to directly quote my interviewees, to give them a voice, as often as possible. All names are anonymized, not because of a desire to de-individualize them, but in order to protect their privacy. Working with materials gathered in such small communities, the simple method of substituting names with initials would have been insufficient. ${ }^{57}$ Thus, respondents are assigned identity ciphers, and their short biographies are given at the end of the book, ordered according to generational sets (i.e. families), for easy reference between quotes in the text and the speaker's biographical context..$^{58}$ Anonymization was carried out with a broad scope: not only are interviewees' names hidden, but the names of people they are talking about have also been removed (in exceptional cases where names are supplied, justification is provided in the text); biographical details that would make it easy

and Post-Soviet Ukrainian Historical Memory," Canadian Slavonic Papers (SeptemberDecember 2012), pp. 401-426.

56 This is a question that can only be discussed in relation to specific interviews and their historical contexts. For this reason, I develop it in later sections of the book, see: e.g. footnote 313 in Chapter 8: "Between Heroes and Traitors: the UPA and the Soviets in Zhovkva."

57 On the limitations of mechanical anonymization in research on "sensitive" issues, see: Ralph Larossa, Linda A. Bennett and Richard J. Gelles, "Ethical Dilemmas in Qualitative Family Research," Journal of Marriage and Family, Vol. 43, No. 2 (1981), pp. 303-313.

$58 \mathrm{Z}$ or K indicates Zhovkva or Krzyż, respectively; number - the number of the generational set/family; the capital letter is the generation, and $\mathrm{f} / \mathrm{m}$ - the person's gender. $\mathrm{Z1Af}$ is thus a female interviewee in Zhovkva from the oldest generation, and Z1Bf is her daughter. 
to identify individuals have also been held back. However, local toponyms from the areas surrounding Krzyż and Zhovkva have not been anonymized, as to do so would be to lose a substantial amount of local expressivity in the study. The biographical notes contain information about respondents' professional and/or social activities only in cases where such details are directly related to their views (e.g. museum director or school headmaster). In order to protect the anonymity of interviewees, I did on several occasions (in cases where I was analyzing issues that were particularly delicate and potentially conflictual for the community) have to refrain from directly quoting an individual, instead paraphrasing their response in general terms (and omitting their identity cipher).

The qualitative interview, and especially the biographical interview, is by nature not just a process of extracting information, but also an interpretive and interactive event. ${ }^{59}$ In my fieldwork, this event always entailed an act of trust giving. This is why the preservation of the integrity of the interviews and of the anonymity of the interviewees was so important to me. For the same reason, working on the text of this book was more than a scholarly challenge: because of the themes involved, it was also a constant imbrication in other people's traumas, losses and disinheritances. Maintaining an emotional distance from such matters turned out to be impossible and, in the context of the methodological foundations of the work, inappropriate. Also, because the inscription "Zubov" is still visible on my house, I glimpse at it every time I walk through the door. I still do not know who lived here before 1945. For this reason, the book that resulted is not only a scholarly analysis; it is also - for me, above all - a record of a personal journey towards understanding a certain reality and a particular set of people, who are close to me for a range of reasons. I hope that this intimacy is not a weakness, but a strength.

59 Piotr Filipkowski, "Historia mówiona i wojna," in: Wojna. Doświadczenie i zapis nowe źródła, problemy, metody badawcze, ed. Sławomir Buryła and Paweł Rodak (Kraków: Universitas, 2006), p. 15. 



\section{Dramatis personae: History and Memory}

\section{Roots (up to 1939)}

In order to write about identity and memory in any place, we need firstly to outline its history. I will therefore attempt to briefly sketch of the histories of the two towns, using scholarly works as well as statements of my interviewees. Before the Second World War, both Zhovkva and Krzyż were towns with very distinct identities, with their own specific dynamics that had, and continue to have, a substantial impact on the identity of the locality and its inhabitants. ${ }^{60}$ In the case of Zhovkva it was an identity of a historically multicultural town; for Krzyż, it was an identity of a modern, energetic society that had emerged thanks to the presence of a railroad: the quintessence of nineteenth-century progress.

Zhovkva was founded (as Żółkiew) at the end of the sixteenth century by Stanisław Żółkiewski, the Field Crown Hetman (i.e. the highest-ranking military commander) of the Polish-Lithuanian Commonwealth. It was designed as an ideal Renaissance-era town: Paweł Szczęśliwy [Paul the Happy], a prominent architect of Italian origin, was commissioned to design the castle complex, the town walls and the Collegiate Church of St. Lawrence, the most important buildings in Żółkiewski’s vision. Żółkiew was granted town privileges in 1603, and from this time it enjoyed rapid advancement in both the economic and the cultural spheres, reaching a zenith in the second half of the seventeenth century. At this time, Żółkiew was the favorite residence of King Jan III Sobieski and his wife Marie. The Ukrainian national hero Bohdan Khmelnytsky is also connected to Żółkiew ${ }^{61}$ - according to local lore, he was born in the town or its surroundings and spent part of his childhood there. Whether or not this is true, it is beyond doubt that the Cossack hetman stationed his troops in Żółkiew twice

60 I present the histories of Krzyż and Zhovkva on the basis of scholarly histories and document publications, as well as oral and written accounts preserved in archives, and statements made by present-day citizens of both towns during the fieldwork (archival materials were found in the Oral History Archive and Eastern Archive of the History Meeting House and KARTA Centre, Warsaw; the Archive of the Jewish Historical Institute, Warsaw; and the Visual History Archive).

61 Bohdan Khmelnytsky (1595-1657) - Polish-Lithuanian nobleman, Hetman of the Zaporozhian Host, leader of the Cossack Uprising against the Polish-Lithuanian Commonwealth in the years 1648-1654; Khmelnytsky is considered a national hero in Ukraine, a historical figure who fought for Ukrainian statehood. 
during the Cossack-Polish War (1648-1657), leading to considerable damage. In the second half of the seventeenth century, a series of impressive buildings were erected, which remain the principal landmarks of the town to this day: the Roman Catholic Church of St. Lawrence, the Orthodox Church and monastery of the Basilians, the walled Renaissance synagogue, the Dominican church and monastery, and the arcaded townhouses surrounding the market square.

At this time, Żółkiew was already a multinational and multi-confessional town. Żółkiewski had founded it on the site of an old Ukrainian village called Winniki (Vynnyky), so it is hardly surprising that Orthodox (and later, Greek Catholic) Ruthenians comprised a significant part of the town's population. Roman Catholic Poles arrived together with Żółkiewski, and since the town became an important trading hub, Armenian, German and Jewish merchants soon followed. Whereas Armenians assimilated with the Polish majority relatively quickly due to the absence of a confessional barrier, the Jews remained an autonomous and closed community right up to the twentieth century. Zhovkva's synagogue is still one of Ukraine's largest buildings despite wartime damage, testifying to the significance and size of the town's historical Jewish community.

In the eighteenth century, a period of relative decline ensued, as Żółkiew was conquered and plundered by Polish, Cossack, Swedish, Saxon and Russian armies. In 1772, after the first Partition of the Polish-Lithuanian Commonwealth, Źókkiew the town became part of the Habsburg monarchy, along with the rest of the region of present Lwów (now Lviv, which started to be named Lemberg). The Habsburg period in Żółkiew, particularly the second half of the nineteenth century, was above all a time of competing nationalisms: Polish and Ruthenian (Ukrainian). ${ }^{62}$ For the Ruthenian national movement this involved a conflict between opposing visions of nationhood: the so-called Muscophile branch, which held that Ruthenians were members of the Russian ethnos, and the Ukrainophile branch, which believed that they were a fully separate collective. ${ }^{63}$ At the same time, the Ruthenians were keen students of Polish nationalism, although the Poles rarely took notice. An indirect consequence was that the Ukrainophile vision eventually held sway throughout Habsburg Galicia, with Żółkiew conforming to the pattern. As a result, residents of the town were active participants in the Polish-Ukrainian conflict over Galicia after the First World

62 See: Timothy Snyder, The Reconstruction of Nations. Poland, Ukraine, Lithuania, Belarus, 1569-1999 (Yale: Yale University Press, 2003).

63 On competing visions of Ukrainian-ness in nineteenth-century Galicia, see: Danuta Sosnowska, Inna Galicja (Warszawa: Elipsa, 2009). 
War. The Great War itself did not leave substantial physical damage in Żółkiew, although the retreating Russian army burned down the already damaged castle in 1915. In November 1918, a Ukrainian administration took control of the town, and many Ukrainians joined the ranks of the Sich Riflemen and (later) the Ukrainian Galician Army - military organizations that fought for Ukrainian independence against both the Bolsheviks and Poles. Until spring 1919, Żółkiew was a field of battle between Polish and Ukrainian armies. The conflict ended in May 1919, when Poles gained control of the town.

In the inter-war period, the contestation between Polish and Ukrainian nationalisms in Źółkiew lost none of its intensity, but its form changed. Ukrainians engaged in activities that the Polish authorities allowed. Ukrainian social organizations were active, such as the most wide-spread and influential Prosvita [Enlightenment], and the associations Zoria [Star], Besida [Dialogue], Sojuz Ukrainok [the Union of Ukrainian Women] and Sokil [Falcon]; Ukrainian co-operatives also developed. The center of cultural and religious life was the monastery and church of the Basilians, as well as the Ukrainian printing house. For a time, there was also the local branch of the all-Ukrainian Scout Organization, Plast, until it was outlawed by the Polish authorities in 1930 and became an underground organization. These events coincided with the emergence in Żółkiew and its surroundings of illegal OUN groupings [Orhanizatsia Ukrayinskykh Natsionalistiv, or the Organization of Ukrainian Nationalists], which attracted an ever-increasing number of young Ukrainians. Poles, meanwhile, found themselves in a rather comfortable situation between the wars their nationalism had yielded a nation state, and they were the group holding the reins of power. There were, at this time, three schools in Żókiew that taught in Polish, a Polish-language middle school, and a college for teachers run by Felician nuns. In contrast, there was only one Ukrainian school - in the district of Winniki, a part of the town that had previously been a Ukrainian village. There was also a Jewish finishing school for girls and a fully-fledged Jewish school of the Tarbut network. ${ }^{64}$

The results of the national census of 1931 (in which there was no data about nationality, only mother tongue and religious affiliation) show that of the 18,070 people living in the towns in the Źółkiew district (i.e. the 11,000 residents of Żółkiew itself, as well as neighboring Kulików (Kulykiv) and Mosty Wielkie (Velyki Mosty)), $68.6 \%$ regarded Polish as their mother tongue, with

64 Tarbut was a network of secular, Hebrew-language and Zionist schools in inter-war Poland and other countries of the region. 
7.1\%, declaring Ukrainian and $13.8 \%$ Yiddish. $27.3 \%$ of respondents considered themselves to be Roman Catholics, with $37.8 \%$ Greek Catholics and $34.4 \%$ of the Jewish faith.$^{65}$ Meanwhile, the Ukrainian historian and geographer Volodymyr Kubiiovych, who edited the monumental Encyclopedia of Ukrainian Studies, estimated that in September 1939 there were 4,270 Jews, 3,500 Poles and 3,100 Ukrainians among the 11,100 residents of Żółkiew. ${ }^{66}$ Gerszon Taffet, author of the book entitled The Extermination of Zhovkva's Jewry, believed there were around 4,500 Jewish residents in the town on the eve of war. ${ }^{67}$ The question of which of these estimates is the most precise is moot, given that many individual identities certainly did not fit into these clearly delineated ethnic categories. It is difficult to draw conclusions about ethnonational identity from the census categories of mother tongue and religion, especially when it comes to, say, Polish-speaking Jews or Polish-speaking Greek Catholics. ${ }^{68}$ Nonetheless, it can be concluded from each of the estimates that Jews formed the most numerous ethno-confessional group in Żółkiew; Poles and Ukrainians comprised roughly a third of the population each, although it can be assumed that the Ukrainians were slightly less numerous than the Poles, and certainly weaker. The more pertinent question concerns the relations between the groups.

As Yaroslav Hrytsak argues, multiculturalism did not exist in Galicia during this period in the normative sense, i.e. there was no peaceful coexistence of different cultures in one place without the domination of any single group. ${ }^{69}$

65 "Drugi powszechny spis ludności z dn. 9.XII.1931 r. Mieszkania i gospodarstwa domowe, ludność, stosunki zawodowe. Województwo lwowskie bez miasta Lwowa," Statystyka Polski - Główny Urząd Statystyczny, Series C, Vol. 68 (Warszawa: 1938), pp. 32-38.

66 Andrii Turchyn, “Administratyvno-statystychnyi ohliad 1880-1979." In: Zhovkivshchyna. Istoryko-memuarnyi zbirnyk Vol. 2, ed. Yaroslav Kalika (ZhovkvaLviv-Baltimore: Instytut Krypiakevycha NAN Ukrainy, 1995), p. 94.

67 Gerszon Taffet, Zagłada Żydów żółkiewskich (Łódź: Centralna Żydowska Komisja Historyczna, 1946).

68 The census itself was not free of controversy. Already in the inter-war period, criticisms were raised against the methods of data collection, and it was argued that state authorities had intentionally inflated the number of Polish-speakers on many occasions, see: Grzegorz Siudut, "Pochodzenie wyznaniowo-narodowościowe ludności Małopolski Wschodniej i Lwowa wedle spisu ludności z 1931 r., in: Lwów. Miasto - społeczeństwo - kultura, Vol. 2, ed. Henryk Żaliński and Kazimierz Karolczak (Kraków: Wydawnictwo Naukowe WSP, 1998), pp. 261-280; Piotr Trojański, "Liczba, rozmieszczenie oraz struktura wewnętrzna ludności wyznania mojżeszowego," in: Lwów. Miasto - społeczeństwo - kultura, Vol. 2 (1998), pp. 243-260.

69 Yaroslav Hrytsak, "Strasti po Lvovu," Krytyka, Vol. 7/8 (2002), pp. 2-7. 
Poles, Ukrainians and Jews lived in the same town, Żółkiew, but to all intents and purposes they lived separately, with the dominant group, the Poles, setting the tone. Cultural, social and religious practices were formed in more or less closed and parallel ethnonational communities. They came into contact mostly during conflicts of collective interest. The Poles treated the Ukrainian national movement as a fabrication dreamed up by a clique of intellectuals and an act of indecency on the part of the previously docile Ruthenians. The Ukrainians, on the other hand, felt discriminated against as an ethnic minority. Both groups knew little about the Jews who co-inhabited their town and the changes that were occurring within their community, such as the development of Zionist and communist ideas. Whereas Polish-Ukrainian marriages were not rare, JewishChristian ones practically never occurred. The fact that there were three football teams in Żółkiew serves as a poignant illustration of the ethnonational division of communities in the town: Polish "Lubicz," Jewish "Noria" and Ukrainian "Strila." This national segregation that was characteristic of Galicia had significant consequences for the residents of Zhovkva during and after the Second World War.

Krzyż, like Zhovkva, was founded on the site of a much older village. In 1701, a major local landowner and the future governor [starosta generalny] of the province of Wielkopolska, Jan Kazimierz Sapieha, founded the village of Olędry Sapieżyńskie on the site of today's Krzyż, based on the specific legal principles for the settlement of Olędrzy, i.e. peasants usually from Friesian or Netherlandish backgrounds and often of Mennonite faith, who were permitted to set up free villages in pre-defined regions of the Polish-Lithuanian Commonwealth. The first settlers in Olędry Sapieżyńskie were probably Dutch, and in time Germans and Poles joined them, although the community became Germanized relatively quickly (the treaty for the granting of land towards the construction of an Eastern Railway in 1848 contains exclusively German surnames). During the period of the Partitions of Poland (1772-1918), the German name of the village came into common use, which identified two separate parts: Drage-Lukatz and BuschLukatz. A major development was the decision, made in the 1840s, to construct a Prussian Eastern Railway to connect Berlin with Bromberg (Polish: Bydgoszcz) and Königsberg (now Kaliningrad, Russia).

The railway colony that sprung up around the new train station began to develop quickly and dynamically. Drage-Lukatz and Busch-Lukatz were formally unified into the district of Lukatz-Kreuz. Residential complexes were built around the station for employees of the rail company, postal workers and civil servants, and the fact of being a railway junction made Kreuz an important communications and trade hub. The fortuitous location (in addition to the railway, 
the town was also near a major loading port on the River Netze (Polish: Noteć)) was conducive to industrial development - Kreuz was home to a starch factory, a syrups factory and a sawmill, amongst other businesses. The construction of an Evangelical church was completed in 1882, and a few years later the first school building appeared on the grounds of the new parish. It was nonetheless the railroad that defined the atmosphere of the town; trains departed from Kreuz in five directions: Berlin, Stettin (Szczecin), Posen (Poznań), Bromberg (Bydgoszcz) and Deutsche Krone (Wałcz). For the comfort of travelers, Kreuz offered several restaurants and wine taverns, a hotel, and a cinema.

Kreuz also had ambitions to become a town where people lived well. In 1915 the municipality acquired a nearby lake, named Kaisersee in honor of Kaiser Wilhelm. A park and recreational area was created across five hectares of land surrounding the lake, featuring tennis courts, sports fields and a dance floor; a yacht pier, swimming pool and trampoline were also built. The picturesque landscapes and easy accessibility helped the villages surrounding Kreuz (especially Busch-Lukatz and Neu-Beelitz, which were located on the water) to become resort destinations for summer tourists.

The Kreuz district was inhabited almost exclusively by Germans - the last pre-war census counted 4,922 residents in the town and several hundred more in the surrounding villages, of which only nine individuals declared Polish nationality. ${ }^{70}$ There were also a few Jewish families in Kreuz, who were completely assimilated. Some Germanized Polish surnames can be found in local newspapers, photographs and tombstones that have survived from the period, but these are the only traces of the historical Polish presence in today's Krzyż. Nonetheless, Kreuz always had very close contact with Poles. The closest Polish "neighbor" was the older village of Drawsko, which was originally larger than Kreuz. Before the First World War, Germans from Kreuz and Poles from Drawsko ran businesses together, served side by side in the military, and sent their children to the same schools. The gaining of independence by Poland in 1918 changed the situation dramatically. During the Wielkopolska Uprisings of $1918-1919,{ }^{71}$ fierce battles were fought over Polish villages on the opposite bank of the Netze, and Kreuz served as a base of operations for German units fighting

70 See: Tomasz Molenda, “Zmiany ludnościowe w Krzyżu Wielkopolskim i okolicy w latach 1945-1950," unpublished MA dissertation (Poznań, 2008), pp. 14-15.

71 The Wielkopolska Uprising was an armed insurgency by Poles in the Province of Posen in 1918 and 1919, against the German Reich and aimed at joining the lands of the former Prussian partition to the newly formed Polish state. It is one of the very few Polish national uprisings to have ended in success. 
against the Polish insurgents. After 1919, the new German-Polish border ran two kilometers to the east of Kreuz, along the River Netze. The border changes had a major effect on the economic situation of the municipality of Kreuz, which lost a part of its market in the newly Polish territories; some of the rail connections were also suspended. Nonetheless, contacts with Poles from the other side of the Netze remained fairly strong. Poles from surrounding villages frequently visited the town: they came to do their shopping or to visit the hairdresser, and many people still owned land on the German side of the river, as did Germans on the Polish side.

\section{War and Other Misfortunes (1938-1945)}

The Second World War was not only experienced completely differently in Kreuz and Zhovkva; it started at very different times. In Kreuz, the outbreak of war was the culmination of political developments over several years in the 1930s: the creeping militarization and ideologization of everyday life, the obligation to join the Hitler-jugend and Bund Deutscher Mädel for children and young people, the pressure to sign up for the party and paramilitary organizations among adults. In 1938, the Jews "disappeared" from Kreuz. In the course of one night, all families of Jewish background were deported from the town, most likely to one of the concentration camps that were being constructed around Germany. Their property - houses, craft workshops, and trading premises (the local department store belonged to a Jewish merchant) - was confiscated by the state. War broke out formally in the town on September 1, 1939, when the border crossings were dismantled at the bridge over the Netze on the road leading to Drawsko. The majority of Germans perceived this event as a return to things as they should be: they saw the Polish state's two-decade existence as a temporary nuisance. Soon afterwards, German homes in Kreuz acquired Polish forced laborers from nearby areas that had until recently been on the Polish side of the river. Poles worked in practically every German household, in trade, and above all in agriculture, where they substituted for the German men who had been mobilized for the front. They received varied treatment: some were subjected to very harsh conditions, but in other cases, Poles became something close to family members for the Germans. Kreuz also became the site of a camp for Prisoners of War (PoWs,) located next to the starch factory; American, French and Soviet prisoners were interned there.

The period up to 1944 was relatively calm for Kreuz: other than food shortages, for its residents the war started "for real" only when the German army started to lose. In 1943, people displaced from German cities bombed by the Allies 
started to arrive in Kreuz. Information that the Red Army was approaching the town began to reach its residents in the autumn of 1944, alongside reports of the Soviet treatment of German civilians. The village of Glasshütte, just a few kilometers from Kreuz, was converted into a transit camp for German escapees from the East. Between December 1944 and January 1945, the majority of the town's residents fled: some of them left of their own initiative, while the authorities evacuated others in organized transports. Of those who did not manage to board the last evacuation train on January 26, 1945, many tried to escape Kreuz by foot or private transport but were killed by the Red Army, which had already arrived in the region. Kreuz was taken or "liberated" in the official language used up to 1989 - by the $5^{\text {th }}$ Shock Army (part of the $1^{\text {st }}$ Belarusian Front) on January 28, 1945.

For Kreuz, "liberation" meant the greatest defeat in the town's history. Kreuz had not suffered during the bombardments, and there had been no heavy fighting over the town. Like many other localities on the territories conquered by the Soviets, it was destroyed by the Red Army after its military takeover. Soviet soldiers peppered the tower of the Catholic Church with bullets, and burned down half of the buildings in the market square - the former Hitlerplatz - as well as an entire row of townhouses on the main street, just for fun. Overall, over $50 \%$ of the town was destroyed. The fate of German residents, who, for diverse reasons, had not left, was worse than that of the buildings; they were primarily elderly people and farmers. Dozens of people were murdered and women were raped in broad daylight. The handful of German communists who had escaped from a nearby concentration camp and arrived in Kreuz to greet the Red Army as liberators were accorded the same treatment as all other Germans.

For the residents of Żółkiew, the war lasted incomparably longer and was a much more complex historical reality. The Red Army entered the town on September 21, 1939. Local communists greeted the new masters at a hastily assembled triumphal entry gate, but were accorded hardly any attention. The reorganization of all spheres of public life according to the Soviet model began immediately. Factories, craft enterprises and shops were nationalized, and agricultural land around the town was seized with a fanfare of propaganda from the gentry, the church and wealthier villagers. The schools were converted into Soviet institutions, with ten years of teaching in the Ukrainian school and eight years in Yiddish in the Jewish one. "Political work" on the residents of Zhovkva also began: dozens of party and Komsomol (political youth organization in the Soviet Union) activists arrived in order to conduct interviews, meetings and lectures with obligatory attendance for all residents; Soviet-trained teachers were also brought in for the schools. 
Arrests began soon after the Soviet takeover, with deportations to Siberia starting in 1940. Historian Jan T. Gross writes about a young communist activist from Zhovkva who recounted during an interview, recorded in 1980 in Tel Aviv, that the Soviets began to study official files in the local district archives; they wanted to know each individual history. ${ }^{72}$ Poles who in the pre-war period had worked as civil servants, teachers, forestry workers and military settlers, as well as Poles, Jews and Ukrainians, who were simply relatively wealthy, were persecuted. The NKVD (Narodnyy Komissariat Vnutrennikh Del) also interrogated and arrested former members of the Organization of Ukrainian Nationalists (OUN). Many people disappeared without a trace, and town residents could only assume that they had fallen victim to Soviet terror. ${ }^{73}$

The zenith of the terror in Zhovkva was in June 1941, during the Soviet retreat in the face of Nazi advancement: the NKVD carried out a mass murder of the prisoners held in the castle tower. ${ }^{74}$ According to the residents' recollections, tractors with running engines were deployed under the tower, so as to drown out the screams of the victims. On June 28, 1941, when the German forces occupied Zhovkva, more than 50 murdered bodies were found in the courtyard of the prison. The majority of the victims who could be identified were Ukrainians active in the independence movement or otherwise standing up to Soviet power. The funeral that was arranged for the victims transformed into a Ukrainian patriotic rally. In the context of the declaration of a pro-Nazi Ukrainian state by Yaroslav Stetsko in Lviv on June 30, 1941, Zhovkva also made gestures of support for the Germans. The main town gate was adorned with the slogans "Heil Hitler!" and "Long live our leader Stepan Bandera!" hanging next to each side by side. Nonetheless, the pro-German enthusiasm among Zhovkva Ukrainians was premature. The Stetsko government was promptly arrested and imprisoned, and the Germans refrained from any form of cooperation with the Ukrainian nationalists for most of the war.

72 Cf. Jan T. Gross, Revolution from Abroad. The Soviet Conquest of Poland's Western Ukraine and Western Belorussia (Princeton: Princeton University Press, 1998), p. 51.

73 In the 1990s, the remains of several dozen corpses were discovered in the ground under of the Basilian church; it was established that they belonged to men, women and children. Initial examinations suggested that these people died during the Soviet occupation, but these findings were never confirmed. The investigation was never finished, and the remains were buried in the town cemetery.

74 For an overview of the Soviet killings of the prisoners in June 1941, see: Oleh Romaniv and Inna Fedushchak, eds., Zakhidnioukrainska trahediia 1941 (LvivNew York: Naukove Tovarystvo im. Shevchenka, 2002). 
Although the Polish and Ukrainian populations of Zhovkva lived under difficult conditions during the German occupation - the most acute problem was the threat of deportation for forced labor ${ }^{75}$ - the gravest experience of occupation was reserved for the Jews. ${ }^{76}$ In the very first days after taking over the town, the Germans set fire to the synagogue and murdered a delegation of Jews who had come out to greet them. They introduced discriminatory policies that were common to all of the occupied lands: Jews were forced to wear badges with yellow stars, they were expropriated and thrown out of their own homes, and forced to labor under oppressive conditions. In March 1942, the first mass expulsions took place, with 700 people transported to the death camp in Bełżec. ${ }^{77}$ In November of the same year, 2,500 Jews were taken to Bełżec. The construction of a closed ghetto followed, and surviving Jews from the nearby shtetls of Kulykiv and Velyki Mosty were made to resettle there alongside those from Zhovkva. On March 15, 1943, several dozen young Jewish men from Zhovkva were sent to the Janowski concentration camp in Lviv. ${ }^{78}$ Ten days later, the "Liquidation Operation" took place: divisions of the SS, Schutzpolizei and Ukrainian auxiliary police surrounded the ghetto, rounded up all of the Jews they could find on St. Dominic's Square, and transported them in trucks to a forest approximately $3 \mathrm{~km}$ from the town, known among inhabitants as "Borek" (literally, "the thicket.") There, they shot the Jews and buried them in pre-dug mass graves. Those who

75 It is believed that around 400,000 people were deported from Galicia to work as forced laborers, see: David R. Marples, Stalinism in Ukraine in the 1940s (New York: Palgrave Macmillan, 1993), p. 59.

76 No study exists analyzing the Holocaust in Zhovkva. The most comprehensive history of the Holocaust in Galicia remains the book by German historian Dieter Pohl: Dieter Pohl, Nationalsozialistische Judenverfolgung in Ostgalizien 1941-1944: Organisation und Durchfihrung eines staatlichen Massenverbrechens (Munich: R. Oldenbourg Verlag, 1997). A multi-perspectival study of the Holocaust in Ukraine is available in the edited volume: Ray Brandon and Wendy Lower, eds., The Shoah in Ukraine. History, Testimony and Memorialization (Bloomington and Indianapolis: Indiana University Press, 2008).

77 I have adopted this timeline of events during the Holocaust in Zhovkva in whole from: Taffet, Zagłada Żydów żółkiewskich.

78 The Janowski camp in Lviv was a German concentration camp located near the Lviv ghetto. To begin with (in autumn 1941) it functioned mainly as a labor camp for Jewish prisoners; later, political prisoners and Soviet PoWs were also brought there. From the spring of 1942 it also functioned as a transit camp for Jews being transported to the death camp in Bełżec. It was destroyed in November 1943 after a mass murder of its prisoners. It is estimated thar approximately 200,000 people were killed in total during the war at this site. 
managed to survive the liquidation of the ghetto were murdered in the "Final Operation" of 6 April.

In Zhovkva, only 74 individuals of Jewish descent survived the Holocaust, out of a pre-war population of 4,500. Most of them hid in refuges in the town and surrounding areas, helped by local Christians; a few survived in labor camps, including the Janowski camp. Both Ukrainians and Poles sheltered Jews; likewise, both Ukrainians and Poles handed Jews over to the Nazis. After the liberation of the town by the Red Army on July 24, 1944, a number of Jews were murdered by local residents.

After the Soviets had re-conquered Zhovkva, only a small group of Poles remained of the town's pre-war residents, alongside the Ukrainians, who now formed a clear majority, and the handful of Jews who had survived. ${ }^{79}$ The German occupation had resulted in an escalation of the Polish-Ukrainian conflict that had simmered for decades previously, with local units of the Ukrainian Insurgent Army [Ukrainska Povstanska Armiia, UPA] playing an active role. ${ }^{80}$ Poles in Zhovkva itself felt relatively secure, yet murders of Poles by the UPA were taking place in the surrounding areas in broad daylight, with support from local Ukrainian civilians; sometimes, entire villages were razed. For this reason, many Polish families had evacuated the town towards the end of the German occupation. Most of them treated their departure as a temporary journey to the west, but none returned to Zhovkva permanently.

Those Poles who refused to leave the ("perennially") "Ukrainian" lands were a secondary enemy for the UPA. The more important battles were being fought on other fronts. After an initial period of collaboration with the Germans, the UPA fought against both the Germans and the Soviets, enjoying the majority support

79 According to the book Zhovkivshchyna. Istorychnyi narys, approximately 1,700 people lived in the town as of the autumn of 1944, see: Mykola Lytvyn, ed. Zhovkivshchyna. Istorychnyi narys, Vol. 1 (Zhovkva-Lviv-Baltimore: Instytut Krypiakevycha NAN Ukrainy, 1994), p. 240.

80 The most comprehensive and also objective studies on this topic are the works of the Polish historian Grzegorz Motyka. E.g.: Grzegorz Motyka, Od rzezi wołyńskiej do akcji "Wisła." Konflikt polsko-ukraiński 1943-1947 (Kraków: Wydawnictwo Literackie, 2011). In Ukraine, one of the few scholars considering this theme with scholarly objectivity is Ihor Iliushyn, see e.g.: Ihor Iliushyn, Ukraiinska Povstanska Armiia i Armiia Kraiova. Protystoiania v Zakhidnii Ukraiini (1939-1945 rr.) (Kyiv: Vydavnychyi Dim "Kyievo-Mohylianska Akademiia," 2009). On the collaboration of local Ukrainian civilians in the murders, see: Jared McBride, "Peasants into Perpetrators: The OUNUPA and the Ethnic Cleansing of Volhynia, 1943-1944," Slavic Review, Vol. 75, No. 3, (Fall 2016), pp. 630-654. 
of local Ukrainians. ${ }^{81}$ After the Soviets had taken Zhovkva, the insurgents carried out a successful assassination of an NKVD major. In the autumn of 1944 the areas surrounding Zhovkva were the scene of a heated battle between Ukrainian nationalists and the Soviet military.

\section{Brave New World (1945-1953)}

Thus, the turning point for both towns was their "liberation" by the Red Army (Zhovkva in July 1944, Kreuz in January 1945). Although it was not immediately obvious to residents at the time, this moment was the beginning of a completely new chapter in their histories. Relative to the pre-war period, everything was subject to change in a short period: the states to which the towns belonged, the political and economic systems, and above all, the composition of residents. If in Zhovkva the first Soviet occupation had given a taste of radical change and the town lost its pre-war residents gradually, in waves, in Kreuz the transformation was substantially more rapid and violent.

After the Red Army had been through Kreuz, there remained in the empty, burned out town a Soviet military headquarters and a handful of traumatized Germans. Before the first Polish railway workers arrived in February 1945, tasked with reviving the rail connections and restoring the hydroelectric power station that provided the town's electricity, a wave of lootings went through Kreuz. Residents of surrounding Polish villages, often former forced laborers who had worked in the area, emptied the town of everything of any value; household equipment, clothes, fittings for shops and workshops, even tiles from dismantled stoves. Some of these people settled in newly renamed Krzyż, occupying the best and least destroyed buildings in the town; they set up a close-knit group of former "neighbors," who experienced the fewest difficulties in adapting to the changed circumstances and therefore had a relatively easy start to their new lives in a new place. Soon after the looters and the railwaymen, the first "pioneers" from central

81 At this time there were already some individuals among the Ukrainians who were sceptical of the UPA. If they voiced their views, however, they were likely to be killed by the insurgents as traitors. The most tragic known example of such a death was the 1943 murder of the parents of a man originally from Zhovkva, now living in Poland, with whom I conducted an interview (on condition of anonymity). His father was Ukrainian and his mother Polish (she was heavily pregnant at the time of the incident), and they were shot to death as they rode on a horse-drawn carriage during a village wedding ceremony. Their children survived because they were sitting on the floor of the carriage. 
Poland arrived, i.e. settlers moving to the so-called Recovered Territories as part of the repopulation operation organized by the Polish authorities; the idea behind this move was to consolidate the Polish presence and thereby "prove" the Polishness of these formerly German lands.

The "Centrals" arrived having been tempted by promises of German houses and homesteads being available for takeover. In central regions of Poland, which had been significantly damaged during the war, the promises made by the communist authorities fell on fertile pastures, especially in rural communities that were impoverished and overpopulated; people left for "the West" in search of a new life, and just as often as a matter of sheer survival. The settlement operation was directed by the State Repatriation Office [Państwowy Urząd Repatriacyjny, PUR] ${ }^{82}$ which was tasked with providing assistance to Poles returning from Germany and to those resettling from the former eastern territories of the prewar Polish Republic. Whilst the former - of whom there were only a few dozen families in Krzyż - really were returning home in a sense, the situation among "repatriates" 83 from the eastern territories was completely different. In theory, "repatriation" was voluntary everywhere in the former eastern lands, however in practice the Soviet authorities applied various forms of duress in an attempt to rid communist Lithuania, Belarus and Ukraine of Poles. In Ukraine, an additional complication was the threat from the Ukrainian nationalist underground, or simply from Ukrainian civilians, as was the case in Volhynia. Many families chose to relocate out of fear, of the Ukrainians rather than the Soviets.

A significant number of Poles did, however, leave "voluntarily:" faced with a choice between staying in the Soviet Union or leaving for the new Polish state, they chose the latter with a heavy heart. Because Krzyż was easily accessible for

82 The State Repatriation Office [PUR] was a Polish state department founded as a result of a decree by the Polish Committee of National Liberation [Polski Komitet Wyzwolenia Narodowego, PKWN] in October 1944. Its initial remit was to supervise the resettlement of Poles from the eastern territories that were ceded to the USSR as a result of the post-war settlement formalized at the Yalta and Potsdam Conferences. Later, its sphere of responsibilities was expanded to include all migration to and within the Polish state.

83 The word "repatriates" [repatrianci] has been common in both scholarly and everyday usage in Poland, meaning people who "returned" to Poland from the former eastern territories that were ceded to the USSR after the war. I employ it in this book in quotations throughout, to acknowledge its ideological colouring. On the problems associated with the term, see: Małgorzata Głowacka-Grajper, "Społeczna i indywidualna kontynuacja pamięci ojczyzn kresowych,” in: Pamięć utraconych ojczyzn, ed. Ewa Nowicka and Aleksandra Bilewicz (Warszawa: Wydawnictwa Uniwersytetu Warszawskiego, 2012), pp. 155-182. 
the trains that transported migrants, the first "repatriates" arrived on May 9, 1945; this transport brought 513 people. ${ }^{84}$ Trains most frequently brought people from the former Tarnopol, Stanisławów and Nowogródek voivodships; by the end of 1945 there were 2,433 "repatriates" living in Krzyż (a further 663 persons were classified as "resettlers" [przesiedleńcy], which meant that they came from the part of pre-war Poland that remained in the state borders after 1945). ${ }^{85}$

The "repatriates" often arrived in Krzyż to discover a somewhat surprising situation: between the front shifting westwards and the arrival of the first transports from the former Polish Eastern Borderlands, several hundred Germans had arrived back in the town (sources state that 670 Germans lived in the area as of May 1945). ${ }^{86}$ Since the main wave of Polish settlers had not yet arrived in Krzyż, many of the Germans had managed to set up home in the houses they originally owned, while others stayed with friends and acquaintances or simply started to live in unoccupied premises. All of them were of the belief that after the passing of the Red Army, the town would remain within the borders of the future German state. Their return to the by-then Polish Krzyż ended in misfortune for the majority. The Polish civilian administration and Soviet military command treated Germans as a source of free labor and drove them into conditions of slavery, and refused the men the right to immigrate to Germany. Germans were treated with disdain and - like the Poles in wartime Kreuz - they were forced to wear badges with the letter "N" [pl. Niemiec - a German] on their shoulder; they were stripped of their property and humiliated at every opportunity. There were still cases of rapes against German women as well as murders, although less frequently than in the weeks immediately following the arrival of the Red Army; in most cases, the perpetrators of these deeds were Soviet soldiers.

Many "repatriate" families were allocated houses or apartments that were inhabited by Germans. For weeks or even months on end, Poles who themselves had just been resettled from their own houses lived together with Germans who were waiting for a transport to the West. Relations between the two sides were varied: it happened that Poles were hostile to the Germans, but it was also possible that the two cohabiting families recognized the misfortunes suffered by the other side.

None of the population groups who were in Krzyż at this time had particularly easy lives: neither the "autochthonous" residents, nor the "Centrals," nor the

84 Molenda, “Zmiany ludnościowe," p. 90.

85 Molenda, “Zmiany ludnościowe," p. 97.

86 Molenda, “Zmiany ludnościowe," p. 65. 
"repatriates." Relations with the Red Army were particularly tense, as the military administration governed in Krzyż as over a conquered enemy territory. Whilst the majority of the Soviet military headquarters in the formerly German territories of Poland were liquidated in July 1945, they remained active in places with major railway connections for much longer, including Krzyż. Many transports from Berlin to Poland went through the station at Krzyż, as did trains to the USSR carrying war trophies obtained in Germany by Soviet soldiers. Krzyż itself was treated by the Soviets as a war trophy of sorts: equipment from the town's factories and sawmill, destroyed in the winter of 1945, was dismantled and carried off to the East; Soviet soldiers even took apart a section of the railway. An atmosphere of war therefore remained for a long time after the formal cessation of hostilities. There was a police curfew in place, and people - especially women, and German women most of all - were afraid to be alone at home.

The situation normalized only after a Polish civilian administration took over the governance of the town. This event coincided with the end of the first phase of the creation of a new society in Polish Krzyż. In 1946 the expulsion operation against Germans was coming to an end; the last transport carrying Germans left Krzyż in October of that year. Deportation was often carried out in a violent manner: Germans were given a few hours to pack their belongings, whilst some had their meager property confiscated on their way to the station. One German family remained in Krzyż, as well as a few elderly Germans and a small number of individuals who married Poles either during or after the war. In 1947, a group of Lemkos deported from Ukraine arrived in Krzyż, ${ }^{87}$ settling in the villages furthest away from the town itself, Kuźnica Żelichowska and Przesieki. As the first wave of settlers consolidated their presence in Krzyż, another influx of economic migrants from various regions of Poland started to arrive, looking for work in

87 Lemkos are an ethnic group that lived until 1947 on the borderland of what is now Poland, Ukraine and Slovakia. In 1947, the Polish communist government deported most of the Lemkos (ca. 140,000 civilians) living in South-east of Poland to the western and northern parts of the country. The operation was called "Vistula" and was part of the wider operation aimed at destroying the UPA in Poland. However, most historians today argue that its goal was also to assimilate the deported Lemkos and Ukrainians. For an overview of the "Vistula" Operation see: Motyka, Od rzezi wotyńskiej; Marek Jasiak, "Overcoming Ukrainian Resistance: The Deportation of Ukrainians within Poland in 1947," in: Redrawing Nations: Ethnic Cleansing in East-Central Europe, 1944-1948, ed. Philipp Ther and Ana Siljak (Lanham, Md.: Rowman \& Littlefield, 2001), pp. 173-194. 
the increasing stabilized town. Life thus continued to unfold, in a new town with new residents.

If the first post-war years were tough for the residents of Krzyż, in Zhovkva they were truly hellish. The Soviets declared the draft to be compulsory in Galicia in the autumn of 1944, and 700,000 men from the region were called up to the Red Army. ${ }^{88}$ After the conquest of Zhovkva, the Soviet authorities set about re-introducing Soviet ways in all spheres of life. In addition to a return to the political and economic mechanisms that were in place in the years 19391941, this entailed dealing with ideological enemies. The first to be identified and arrested were real or suspected Nazi collaborators: members of the Ukrainian auxiliary police and Volksdeutche. One of the Volksdeutsche detained by the Soviets had hidden 17 Jews during the German occupation; such cases show that some of the arrests were unjustified according to the Soviets' own criteria. ${ }^{89}$ Shocked by the way things were developing, almost all of the Jewish survivors (of which there were only a handful in the town itself) and the majority of Poles left for Poland before the end of the official "repatriation" period ended, i.e. by 1947. In their place - sometimes in the most literal sense of occupying their homes came Ukrainians deported from southwestern Poland in the years 1944-1946. Some of them, especially in the latter stages of the population transfers, arrived in Zhovkva directly, usually with little property to their name; the majority, however, came through eastern Ukraine, where the Soviet authorities had initially sent all transports. Due to prevailing conditions of famine and forced membership in collective farms, Ukrainians deserted their designated new places of residence en masse, escaping to the western part of the country with the intention of returning home. When they reached Galicia, it transpired that the border with Poland was already closed. Thus, many resettlers remained in the border regions, including Zhovkva region. Because of their status as illegal fugitives from

88 Cf. Marples, Stalinism in Ukraine, p. 59.

89 This story is recounted in the memoir of one of the Jews saved by the person in question. The author was a teenage girl at the time. The original diary (written in Polish) is held in the Holocaust Memorial Museum, and it was published in 2017 by the Polish Centre for Holocaust Research of the Institute of Philosophy and Sociology, Polish Academy of Sciences: Clara Kramer, Tyleśmy już przeszli. Dziennik pisany w bunkrze (Żółkiew 1942-1944) (Warszawa: Stowarzyszenie Centrum Badań nad Zagładą, 2017). A video testimony by Klara Schwarz (now Clara Kramer) is available in the archive of the Shoah Foundation Institute under catalogue number 37123. 
collective farms, these resettlers could not rely on any state financial support, and were socially marginalized for a long time. ${ }^{90}$

A second group that gradually filled the gaps left by the Jews and Poles was the stratum of teachers, librarians, skilled workers and party functionaries chosen to head village councils and collective farms. This group of new arrivals was not great in number, but it was very specific in its composition: most of these people were born or at least grew up in the Soviet Union, they had been educated in the Soviet mould, but they also often had personal experience of Stalinist Terror or the Holodomor (i.e. the Great Famine of 1932-1933 in Soviet Ukraine), events that were incomparably harsher than the experiences of Galicians during the short Soviet occupation of 1939-1941. Moreover the demographic structure of the region was altered by the fact that Soviet military units were permanently stationed in Zhovkva and the neighboring village of Volia Vysots'ka, tasked with guarding the western border of the USSR. Not many of these servicemen had moved to Zhovkva voluntarily; the majority had been sent to Galicia as part of Soviet modernization policy in the newly acquired territories. Many of these soldiers had been afraid to go to western Ukraine, with its reputation as a hotbed of ethnic nationalism. Officially, this modernization project was designed to facilitate economic advancement and industrialization, but in practice the Soviet authorities wanted to ensure control over this unruly territory with the help of people loyal to the system. ${ }^{91}$

The task of the "Easterners" [Ukr. skhidniaky] - as they were called in Zhovkva and as I will call them in this book for ease of reference - was to engage the local population in the building of communism. Their efforts were met with fierce

90 The transfer of Ukrainians from Poland to the Ukrainian SSR (1944-1946) has recently been studied in some detail by Ukrainian historians, such as Volodymyr Kitsak, Tamara Hontar, Stepan Makarchuk and others. Nonetheless, research on the social adaptation of resettlers and the effects of deportation on their identity are still scarce. One of the few available studies is by Halyna Bodnar, who uses an oral history approach, see: Halyna Bodnar, “'Tam bulo dobre i tut ye nepokhano zhyty:' osoblyvosti istorychnoi pamiati ukraintsiv, pereselenykh iz Polshchi," in: Ukraina-Polshcha: istorychna spadshchyna $i$ suspilna svidomist, Vol 2: Deportatsii 1944-1951 (Lviv: Instytut Ukrainoznavstva im. Krypiakevycha, 2007), pp. 20-36; Subtelny, "Expulsion, Resettlement, Civil Strife."

91 On the social and political effects of the Soviet modernization project in Ukraine, see e.g. Martin Åberg, "Paradox of Change: Soviet Modernization and Ethno-Linguistic Differentiation in Lviv, 1945-1989," Harvard Ukrainian Studies, Vol. 24: Lviv. A City in the Crosscurrents of Cultures, ed. John Czaplicka (2002), pp. 285-302; Yaroslav Bilinsky, The Second Soviet Republic: The Ukraine after World War II (New Brunswick: Rutgers University Press, 1964); Amar, The Paradox of Ukrainian Lviv. 
resistance from the Ukrainian nationalist underground. A bloody and attritional battle was fought in Zhovkva and surroundings until the beginning of the 1950s between the Ukrainian Insurgent Army and the Soviet government; the local population was frequently drawn into this conflict, sometimes against its will. The Ukrainian partisans, who were mostly active in the villages, attacked Red Army units, the Soviet police and the NKVD; they executed Soviet civil servants and other representatives of power. They also killed settlers from the East, whom they saw as agents sent by the authorities: victims included teachers, collective farm directors, and workers. Their deaths were supposed to frighten off new settlers and to show them that they were not welcome. The best-known UPA operation was the shooting of Ilia Dovhanyk, a communist from the Zhovkva region, whom the Soviets turned into a "martyr of the revolution."92

The terror conducted by the UPA also affected locals - individuals who, for various reasons, supported the new regime or simply had no means of resisting it. In 1947, the UPA hanged two collective farm workers in Zhovkva. In 1948 they burned down an entire collective farm that had been established in the town. The following year, in the nearby village of Mokrotyn, they shot dead a seventy-yearold man whose son was working with the Soviet police, and in the neighboring village of Nova Skvariava, they hanged a woman suspected of working with the security services. Sentences passed by the UPA on "traitors to the Ukrainian cause" resulted in fear becoming widespread among civilians, no less so than the fear they felt at the equivalent actions of the NKVD. The most violent action by the UPA was the burning of the village club in Vynnyky, a suburb of Zhovkva, where the Soviet authorities showed propaganda films. Several children were killed in the fire.

The Soviets replied to terror with terror. Insurgent units were hunted down to the last man, and hideouts destroyed. Those who were captured alive were tortured for information, sentenced to long terms of hard labor, and sent to the camps. ${ }^{93}$ It was common practice to display the mutilated bodies of captured and killed combatants in front of the Zhovkva prison: the families would then be able

92 It is not exactly clear who killed Dovhanyk. Communists claim to this day that it was the UPA, while a clear majority of my interviewees (including people who were critical of the UPA) were of the opinion that the Soviets themselves had shot their own comrade: in order to gain a highly ranked martyr for their cause, and to blacken the reputation of the UPA.

93 Ukrainians deported from Zhovkva during this period started to return after the death of Stalin in 1953; the final amnesty for political prisoners of this category was granted in 1965, the twentieth anniversary of the end of the year, see: Amir Weiner, Making Sense of War. The Second World War and the Fate of the Bolshevik Revolution (Princeton: Princeton University Press, 2001), p. 233. 
to identify the bodies (and made to suffer the consequences of their kinship), and town residents would be deterred from taking up resistance. Relatives were sent to Siberia together with captured fighters; sometimes, if they managed to escape before deportation, they would all flee to the forest, reinforcing the partisan detachments in turn; the cycle of resistance and repression thus continued..$^{94}$ The Soviet authorities also punished people who provided assistance to the UPA, which was a fairly significant portion of the population. Often, the charge of "helping the insurgents" served as a mere pretext for expelling people whom the Soviets considered suspicious, i.e. Kulaks. ${ }^{95}$ The Soviets' struggle against the UPA and the deportation of "enemies of the people" continued in the Zhovkva region until the mid-1950s, when state policy was made less brutal in the aftermath of Stalin's death. That is also when the first rehabilitated Gulag prisoners and expellees started to return - if, of course, they had survived. During the Soviet Thaw, laws concerning registration and settlement in towns were relaxed, and a wave of economic migrants arrived in Zhovkva from surrounding villages.

Neither in Krzyż nor in Zhovkva was the construction of a "brave new world" an easy task. This was in part because the new, post-war residents of both towns had arrived with their own specific experiential baggage, which could not help but affect their adaptation to a new place: their attitudes to the people who had lived there previously, as well as to the material culture they found and the new socio-political order. Interestingly, the majority of these residents can be understood through the prism of their collective biographies - although, of course, the sum total of individual stories does not fit into any kind of overall scheme. Both towns in the post-war period had groups of "voluntary returnees:" Poles from the eastern provinces in the case of Krzyż and Ukrainians from Poland in Zhovkva. Old "neighbors" were also present in both towns: in Krzyż, locals from the other side of the border at the River Noteć, and in Zhovkva, economic migrants from the Galician villages and smaller towns. Finally, both towns were

94 One of the most thorough studies of Soviet deportations from western Ukrainian in the years 1944-1953 is the book by Tamara Vronska: Upokorennia strakhom: simeine zaruchnytstvo u karalnii praktytsi radianskoii vlady (1917-1953) (Kyiv: Tempora, 2013).

95 The Soviet authorities used a wider definition of the "Kulak" in Western Ukraine after the war than they did in other Soviet republics. Here, a Kulak was not just a person who owned more than 10 ha of land, but anyone who was opposed to collectivization, was against the Soviet order as such, or was recognized by the Soviets as a nationalist, see: Marples, Stanilism in Ukraine. 
the destinations of "pioneers" traveling to the Wild West: eastern Ukrainians in Zhovkva and Poles from central regions in Krzyż. All of these groups had to come to terms with their new lives, and with the post-war culture of (non-) remembrance.

\section{The Post-war Culture of (Non-)Remembrance (1953-1989/1991)}

In the new Zhovkva and Krzyz the authorities were faced with a difficult task: they had to legitimize the presence of the new residents in the town, which of course was a component of the wider problem of justifying the Polishness of the "Recovered Territories" and the Ukrainianness of formerly Polish Galicia. In both towns, the task was connected to the targeted, top-down construction of memory.

Zhovkva was replete with material traces of the past, and it was difficult to completely marginalize the town's history. The authorities therefore approached it selectively. In general, Soviet-Ukrainian version of the heroic canon included only these figures from the pre-1939 period, who did not challenge the idea of the Ukrainian-Russian unity.96 The early history was framed in terms of the development of Ukrainian culture, especially folk culture, whilst the Polish presence in the region was treated as a centuries-long foreign occupation. Events that could confirm the town's Ukrainian roots were especially emphasized, for example the supposed birth and upbringing of Bohdan Khmelnytsky in the locality. PolishUkrainian relations were rendered as a class war: the Polish lord [pan] and the Jesuit had oppressed the Ukrainian peasant and worker. The Soviet ideologists treated the historical presence of other ethnic groups as an ethnographic supplement bearing witness to the tolerance of the historical (and also, indirectly, the present-day) population of Zhovkva. In relation to the inter-war period, the activities of the communist underground were given primacy (although, in reality, they were marginal compared to the OUN): this narrative was designed to "prove" the long-term striving of the residents of Zhovkva and Galicia to be "united" with Soviet Ukraine and the "fraternal" Russian nation. ${ }^{97}$ The year 1939 was represented as the crowning moment of success of these efforts: the town

96 See: Zbigniew Wojnowski, The Near Abroad: Socialist Eastern Europe and Soviet Patriotism in Ukraine, 1956-1985 (Toronto: Toronto University Press, 2017), pp. 165-168.

97 On post-war Soviet memory policy in the area, see: Serhy Yekelchyk, Stalin's Empire of Memory. Russian-Ukrainian Relations in the Soviet Historical Imagination (TorontoBuffalo-London: Toronto University Press, 2004); Iulia Kysla, "Konstruiuvaniia 
had thrown off the shackles of bourgeois Polish rule and joyfully embarked on the construction of a socially just community in union with their kin from Soviet Ukraine. However, this lustrous process had been stopped in its tracks by the German invasion.

The Second World War, known as the Great Patriotic War in the USSR, became the dominant historical myth both in Zhovkva and throughout the Soviet Union, where efforts to construct a coherent pan-Soviet identity and memory before 1941 had been unsuccessful. The situation changed after the victory in 1945, an event that pushed even the October Revolution into the shadows. ${ }^{98}$ The construction of a foundation myth entailed the universalization and selective deployment of narratives that fit the ideological mould. These included the heroic resistance of the civilian population, and the liberation of Zhovkva by the Red Army. In turn, UPA insurgents and all other supporters of the Ukrainian independence movement were made into unequivocal villains, as "UkrainianGerman bourgeois nationalists" who collaborated with the Nazis and used bandit methods to fight against Soviet power. People deported to Germany for forced labor were also condemned as collaborators. ${ }^{99}$ Besides a binary division into heroes and villains, the official memory of Zhovkva was also characterized by its silences. The centuries-long presence of Poles was eradicated from the history of the town, along with their influence in forming its spiritual and material culture; their role was limited to that of occupants oppressing the autochthonous Ukrainian population. Their disappearance from the post-war town was also shrouded in mystery. The wartime years were cleansed of any accounts of the repressions that were carried out against various groups of residents during the first Soviet occupation, such as the murder of prisoners in June 1941 and the deportations to Siberia that carried on into the post-war period.

The most significant forgotten tragedy was, however, the Holocaust. In a town where nearly half the pre-war population was Jewish, the authorities simply pretended that these people had never existed. After the end of the war, not a single memorial plaque was placed to commemorate the Zhovkva Jews. The destroyed

ukrainskoi istorychnoi pamiati w URSR vprodovzh stalinskoho periodu (1930-ti-1950-ti rr.)," Mizhkulturnyi dialog, Vol. 1: Identychnist (2009), pp. 221-244.

98 Cf. Vladyslav Hrynevych, "Mit viiny ta viina mitiv," Krytyka, Vol. 5, No.91, (2005), pp. 2-8. The construction of a new Soviet identity was under way already during the war, as shown in: Karel Berkhoff, Motherland in Danger (Cambridge MA: Harvard University Press, 2013).

99 On the fate of Ukrainians who returned to the USSR from the West, see: Dyczok, The Grand Alliance. 
synagogue was sealed off and served as a storage house for the entire post-war period, first for salt and later for various industrial products. The Jewish cemetery, which had been partially destroyed by the Germans (headstones had been used to pave the road to Lviv), was converted into a market place in the 1960s, and all traces of the space's original function had been removed. Schools did not teach about the local Jews, guidebooks did not mention them, and popular scientific works on the history of Zhovkva omitted them entirely. This silence was in tune with a broader Soviet policy, under which Jews were at most commemorated as "Soviet civilians murdered by the Nazis." A separate category of Jewish victims of the Holocaust could not be admitted, as such a move would reduce the significance of Soviet victims of the war, which would threaten the myth of the USSR as both the main victor of the war and the principal victim. ${ }^{100}$ The Holocaust did feature in Soviet historiography, but only as a historical event fully removed from Soviet wartime reality: its symbols were the camps in Auschwitz and Majdanek, both in Poland and both liberated by the Red Army. Eastern European Jews, including those of Zhovkva, were thus robbed of their memory. ${ }^{101}$

The official version of history was reflected in public space. Whilst Jewish victimhood was erased, it was far from the only form of forgetting. Plaques and crosses commemorating the people murdered by the NKVD in the town prison in 1941 were removed from the cemetery and market square. Polish monuments to Jan Sobieski and Stanisław Żółkiewski, as well as many other traces of pre-war Polish culture and religious symbols (such as the figure of Mary in front of the castle) were dismantled. A giant statue of Lenin replaced Sobieski's statue. Soon, other Soviet monuments and symbols of memory were erected: for example, the town cemetery was furnished with a special area for Red Army soldiers who died

100 Cf. Anataolii Podolskyi, "Ukraiinske suspilstvo i pamiat pro holokost: sproba analizu deiakykh aspektiv," Holokost $i$ suchasnist. Studii w Ukriini i sviti, Vol. 1, No. 5, (2009), pp. 47-59; John-Paul Himka, "The Reception of the Holocaust in Postcommunist Ukraine," in: Bringing the Dark Past to Light: The Reception of the Holocaust in Postcommunist Europe, ed. Joanna Michlic and John-Paul Himka (Lincoln \& London: University of Nebraska Press, 2013), pp. 627-661; Tarik Cyril Amar, "A Disturbed Silence. Discourse on the Holocaust in the Soviet West as an Anti-Site of Memory," in: The Holocaust in the East. Local perpetrators and Soviet Responses, ed. Michael David-Fox, Peter Holquist and Alexander M. Martin (Pitsburgh: University of Pitsburgh Press, 2014), pp. 158-184.

101 Cf. Timothy Snyder, "Holocaust: The Ignored Reality," The New York Review of Books 56, No. 12 (16 July 2009), http://www.nybooks.com/articles/2009/07/16/holocaustthe-ignored-reality/, last accessed 15.02.2019. 
whilst liberating Zhovkva. The central site for Soviet ceremonies of all kinds, of which Victory Day (9 May) had pride of place, was the so-called Eternal Flame: an expressive sculptural composition representing a soldier dying for the Fatherland, placed opposite the eighteenth-century wooden church of the Holy Trinity.

The town's new elites and local authorities acted as guardians of the official version of events. New arrivals from eastern Ukraine led the line: Party members, civil servants, teachers and the so-called technical intelligentsia. They took up residence in the best houses and apartments (which had usually belonged to murdered Jews or deported Poles and Ukrainians), occupied positions of power, and set the tone for community life. With their privileged positions came responsibilities as protectors of the new order: during religious holidays, teachers from the East would ensure that children did not attend church, and Komsomol activists had to prove that they were making progress in "political work" with the local population. The residents of Zhovkva's barracks, in which more than 10,000 soldiers and officers were stationed at any time, were assigned a special role as guardians. Many of the officers had arrived with their families, and a Russian-language school had been established for the children. The Komsomol and the organization of Pioneers (i.e. scouts) facilitated the indoctrination of the young generation, but the school played the most important role, often inciting conflicts between generations in its efforts to create a new Soviet citizen.

Official memory was thus sustained by state authorities: the Party, the Komsomol, the school, places of work, as well as the Orthodox Church of the Moscow Patriarchate, which after the forced "union" of the Orthodox and Greek Catholic Churches in 1946 had become the only legal religious institution in Zhovkva, taking over the building of the Basilian church. As everywhere in western Ukraine, local memories of the war were formed in two distinct streams: official memory on the one hand, and private, family-based memories that were not always voiced and were difficult to situate, but nonetheless created alternative heroes and anti-heroes. An important role in the preservation of this alternative memory in Zhovkva was played by the underground Greek Catholic Church, which continued to operate until Perestroika. The last Roman Catholic Church in Zhovkva was closed shortly after the war, after the last priest had left the town, following in the footsteps of his Polish parishioners.

As a symbolic sealing of the new face of Zhovkva, the town's name was changed in 1952. It was renamed Nesterov in honor of a Russian pilot who had crash-landed and died in Volia Vysotska, a village near Zhovkva, while executing a complicated maneuver during the First World War. 
Whilst the past was handled selectively in Zhovkva, in Krzyż it was fully discarded. The town had become Polish, thereby returning to its "roots," and the task facing its residents was the construction of socialism in the "Recovered Territories." Remembering the German past was not a component of this project, and in any case, the official narrative had it that the German presence in the region's history was only a thin layer superimposed on a Slavic base. If the past was evoked, both in Krzyż and in the wider region, it was the very distant time of the Piast dynasty, ${ }^{102}$ which could be called Polish with few complications. The typical temporal axis drawn by a state ideologist for the "Recovered Territories" in this period would have had a large gap in the middle: the Piast era in the distant, murky middle ages; then nothing for a long six centuries; then triumphant liberation by the Red Army and return to the Polish womb. ${ }^{103}$ This middle hiatus was given some color by patches of autochthonous Polish folk culture and struggles for cultural autonomy - primarily in Upper Silesia, Warmia and Masuria. The town of Krzyż, however, did not quite fit into this scheme. Finding a Piast-era past in a town founded as a German railway settlement in the middle of the nineteenth century was not easy. The surrounding villages, which had been founded by Dutch and German Protestants, were equally bad candidates as evidence of the region's age-old Polishness. For this reason, the authorities in Krzyż concentrated not on the risky business of "proving" the town's Polishness, but on broadly screening out the memory of the German past.

The operation of "de-Germanization" (also sometimes known as "re-Polonization") was carried out in Krzyż in accordance with patterns that were applied to the entire stretch of the "Recovered Territories." 104 There were

102 The Piast dynasty ruled in Poland in the Middle Ages, from the mid-ninth century until 1370. In the early period of their rule, the borders of the Polish state coincided in many ways with the Poland that emerged after 1945, including a large part of Silesia and Pomerania (i.e. the lands that post-war Poland gained from Germany). In communist propaganda (as well as in Polish political thought of the interwar period) the fact that these "Recovered Territories" had been part of the Piast kingdom was the principal justification of their "perennial" Polishness.

103 On the construction of memory by local authorities in this region, see: Zenon Romanow, "Pamięć historyczna mieszkańców Ziem Zachodnich i Północnych w latach 1945-89 na przykładzie Pomorza Zachodniego," in: Ziemie Odzyskane 19452005. 60 lat w granicach państwa polskiego, ed. Andrzej Sakson (Poznań: Instytut Zachodni, 2006), pp. 201-218.

104 Cf. Bernadetta Nitschke, "Repolonizacja czy polonizacja? Polityka władz polskich wobec byłych kresów wschodnich III Rzeszy”, in: Polacy-Niemcy-Pogranicze, ed. Grzegorz Wyder and Tomasz Nodzyński (Zielona Góra: Oficyna Wyd. Uniwersytetu Zielonogórskiego, 2006), pp. 275-290. Beata Halicka has also recently published an 
two planes to this process: the human and the material. The re-Polonization of the urban and rural landscape consisted in the removal of German-language inscriptions from public spaces and the Polish renaming of places. German monuments and memorials were also removed, especially those commemorating Wehrmacht soldiers who had died in the First World War and historical figures whom the Poles would associate with anti-Polish activities during the Partition period. In Krzyż itself, two monuments to Wehrmacht servicemen were destroyed. "The fight against Germanness" also involved the reconstruction or refurbishment of buildings whose appearance was considered typically German: red-brick houses and timber-framed buildings were thus plastered over, "Polish-style" wooden porches were added to houses, and neo-Gothic reliefs were removed.

The two churches in Krzyż were stylistically converted: the Roman Catholic one had its choir seating and chancel repositioned, and all the furnishings changed; the Protestant church was completely revamped (e.g. the balconies typical of Evangelical churches were dismantled, and the cockerel-shaped wind vane, considered German in style, was removed), ${ }^{105}$ and then it was re-consecrated as Catholic. Churches in the neighboring villages met similar fates: Lubcz, Kuźnica Żelichowska and Huta Szklana. The eighteenth-century church in Huta Szklana (Glasshütte before the war), a valuable example of wattle and daub architecture, was so thoroughly transformed by the villagers, new arrivals from the East, that it was completely unrecognizable from the original. A lot of these alterations were made spontaneously, without prior planning. The Polish settlers had no

excellent work on the cultural and social changes of this period in the "Recovered Territories:" Beata Halicka, Polski Dziki Zachód. Przymusowe migracje i kulturowe oswajanie Nadodrza 1945-1948 (Kraków: Universitas, 2015). The Polonization of the "Recovered Territories" is also analyzed in: Hugo Service, Germans to Poles. Communism, Nationalism and Ethnic Cleansing after the Second World War (Cambridge: Cambridge University Press, 2013). Another example of the work studying cultural polonization of the German city is: Gregor Thum, Uprooted: How Breslau Became Wrockaw during the Century of Expulsion (Princeton and Oxford: Princeton University Press, 2011).

105 Andrzej Brencz examines examples of similar activities in other towns of this region, in his: "Oswajanie niemieckiego dziedzictwa kulturowego. $Z$ badań etnologicznych na Środkowym Nadodrzu," in: Wokół niemieckiego dziedzictwa kulturowego na Ziemiach Pómnocnych i Zachodnich, ed. Zbigniew Mazur (Poznań: Instytut Zachodni, 1997), pp. 191-216. On the Polonization of Silesia, see: Andriy Demshuk, "Reinscribing Schlesien as Śląsk: Memory and Mythology in a Postwar German-Polish Borderland," History and Memory, Vol. 24, No. 1, (2012), pp. 47-53. 
attachment to the German heritage sites; instead, they wanted their places of worship to resemble the churches they had left behind in the East. Sometimes the "familiarization" of a given building or site turned out to be impossible; sources from this period attest, for example, to "repatriates" from the East wandering from one German village to another because the houses they found seemed to them excessively "lordly and rich." 106 On the other hand, settlers succeeded in making the cultural space look more like "home" by placing wayside crosses and shrines. The areas surrounding Krzyż were dotted with several such artifacts; one of them, on the road leading into the village of Lubcz Mały, funded by one of my interviewees, bore the inscription "Mother of God, bless us on this recovered Polish land."

De-Germanization sometimes bordered on absurdity. The authorities went on the hunt for German inscriptions on towels, ashtrays and tiles; a precedent was set by the punishment in 1947 of the Voivodeship office in Olsztyn for retaining the words "frei" and "besetzt" ("free"/"occupied") on their lavatory doors. ${ }^{107}$ That these efforts were largely unsuccessful - and that residents were guided often by practical common sense rather than ideology - is shown by the fact that many households in Krzyż use German items to this day. Such practices were often pragmatic in nature: it was, after all, difficult to dispose of German kitchenware if you had none of your own.

It was not only space that was Polonized; people were, too. One of the steps of the "re-Polonization operation" was the forced alteration of the spelling of names deemed too German. Very often - also in Krzyz - this affected people who had nothing to do with German culture or identity. If it was not only the name that was in doubt, but the individual personally, then that individual could be sent to "Polonization classes." ${ }^{108}$ In areas with a relatively large number of so-called native residents, educational summer camps and regular classes were organized; in Krzyż, Polish language lessons for autochthonous residents took place in the House of Culture.

All of these activities were, needless to say, backed up by propaganda. Like in Galicia, the new post-war authorities in the "Recovered Territories" created

106 Cf. Zbigniew Czarnuch, "Oswajanie krajobrazu. Polscy osadnicy w dorzeczu dolnej Warty," in: Wokół niemieckiego dziedzictwa kulturowego na Ziemiach Pótnocnych i Zachodnich, ed. Zbigniew Mazur (Poznań: Instytut Zachodni, 1997), pp. 169-190.

107 Cf. Nitschke, "Repolonizacja czy polonizacja?"

108 This process begun after the formal end of the verification operation, after which only people who could prove their Polish ethnicity were permitted to stay. 
a pantheon of heroes and villains. ${ }^{109}$ The heroes included, above all, the Red Army (and the Polish People's Army), which had "liberated" the eastern territories of the Third Reich. Soldiers killed during the war were usually buried in town cemeteries, or simply in the center of the village or town; these hastily arranged tombstones were often the first non-German memorials in the locality. This was the case in Krzyż: Polish and Soviet soldiers were buried in the middle of the market square, and a plaque commemorating their deeds was placed on the former German memorial stone honoring Wehrmacht soldiers active in the First World War. Later, the graves were transferred to the communal cemetery, but the plaque that was added in the 1960s mentions only Polish soldiers. ${ }^{110}$ The monument functioned for some time as a "Freedom Memorial,"111 but it was later dismantled (the middle of the market square was incorporated into a section of the freeway).

Another set of heroes, who had no statues dedicated to them but were equally lionized by propaganda, were the migrant "pioneers;" this group was also much closer to the average Pole in Krzyz than wartime soldiers. Socialist propaganda portrayed these resettlers as competent and brave individuals who, spurred by patriotism, arrived in the "Recovered Territories" to help these "perennially Polish" regions to flourish; despite hardships, they had dedicated themselves to People's Poland. ${ }^{112}$ The archetypal "pioneer" was a native of central Poland

109 On the formation of the heroic canon for educational purposes, see: Marta Brodala, "Propaganda dla najmłodszych w latach 1948-1956. Instrument stalinowskiego wychowania," in: Przebudować człowieka. Komunistyczne wysiłki zmiany mentalności, ed. Marta Brodala, Anna Lisiecka and Tadeusz Ruzikowski (Warszawa: Trio, 2001), pp. 123-179. More broadly on the communist-era politics of memory surrounding the Second World War, see: Bartosz Korzeniowski, "World War II in the Politics of Memory of the Polish People's Republic 1944-1970," in: World War II and Two Occupations. Dilemmas of Polish Memory, ed. Anna Wolff-Powęska and Piotr Forecki (Frankfurt am Main: Peter Lang, 2016), pp. 61-80.

110 The remains of the Soviet soldiers were exhumed and transferred to the military cemetery in nearby Piła (the regional capital in the years 1975-1998).

111 "Freedom Memorial" is the caption found on a postcard of Krzyż produced in 1948 by a company called J. Grablis (one of a series); the image is a low-quality reprint of a pre-war German postcard. In all of the landscapes depicted in the series, elements have been visibly retouched: all German inscriptions have been removed from signs, street names, etc., and replaced with Polish-language toponyms.

112 Cf. Maria Tomczak, "Obraz osadników w prasie i publicystyce polskiej," in: Ziemie Odzyskane 1945-2005. 60 lat w granicach państwa polskiego, ed. Andrzej Sakson (Poznań: Instytut Zachodni, 2006), pp. 45-58. 
and a worker or peasant, who was devoted to the socialist project. If he (in the symbolic paradigm, he was usually male) had arrived from the pre-war eastern regions, his official image included no indication of why he had to leave those territories. ${ }^{113}$ The pioneer was therefore the ideal man of work, with no sentimental attachment to the family home left behind in the East, and no difficulty in adapting to the new conditions.

The primary villain of post-war propaganda was the German revisionist. For obvious reasons, there was no need to stoke the flames of anti-German sentiment in Poland after the war, but in the "Recovered Territories" the authorities made additional efforts to create a threat of German revanchism. The irrational fear of Germans that they manufactured through propaganda, education and popular culture had a specific and clear function: the pioneer would be grateful to his socialist homeland for the opportunity to resettle in the newly acquired territories, but would also link the safety of his new home and existence to unconditional support for the Polish regime, which was fighting the external enemy on his behalf.

This situation changed somewhat in the 1970s, after the Polish People's Republic and the German Democratic Republic (GDR) had established diplomatic relations. From this time, the official discourse in Poland operated with two images of Germany: a positive one for the GDR, which had previously been duped by its leaders but was now back on the righteous road to socialism; and a negative one for the revisionist-capitalist Federal Republic, which was constantly laying claim to Wrocław, Gdańsk and Szczecin. ${ }^{114}$ Besides a modification in the official narrative, the transformation of Polish-German relations entailed another important change for the residents of Krzyż: the border with the GDR was opened, and former residents of Kreuz were able to travel to the now-Polish town. This was an unprecedented phenomenon, which sets Krzyż apart from Zhovkva. In the 1970s, visits by East Germans were a common phenomenon in Krzyż, and led to intensive contact at the individual level between residents past and present.

113 This observation applies to the early post-war years. In later decades, the censorship of biographies of people from the former eastern borderlands abated considerably; an iconic example is the classic film All Friends Here [Sami swoi, 1967, dir. by Sylwester Chęciński], which tells the story of two feuding families, both resettled in the "Recovered Territories" from eastern regions after the war.

114 Cf. Andrzej Sakson, "Niemcy w świadomości społecznej Polaków," in: Polacy wobec Niemców. Z dziejów kultury politycznej Polski 1945-1989, ed. Anna Wolff-Powęska (Poznań: Instytut Zachodni, 1993), pp. 408-429. 
The individual opening up of contacts did not, however, lead to any substantial change in the official memory policy concerning the region's German past. It was still forbidden to memorialize the German period of the "Recovered Territories." In Krzyż, both the German origins of the town and the fate of the Germans who had lived there before the war were suppressed. The experiences of settlers from the East were also subject to erasure: it was possible to discuss in private their wartime experiences (including the period of Soviet occupation) and the territories they had left behind; but in public, it was impossible.

The inculcation of a unitary vision of the past was above all the task of schooling, as was the case in Zhovkva. The new Polish school in Krzyż could not measure up to the Russian one in terms of the scale of its indoctrination, but its education model was still radically different to pre-war norms. ${ }^{115}$ It was officially secular, and its aim was to produce citizens devoted to the socialist state who would not be overly curious about the past. Unlike the school in Zhovkva, however, the success of these objectives depended to a significant extent on the ideological convictions of individual teachers; the teachers, meanwhile, had a range of legally operating allies if their aims were relatively seditious. The most important was, without doubt, the Catholic Church, which - in addition to its religious function - was in Krzyż the largest and most prominent social structure other than the state. It was, of its very nature, interested in the cultivation of an alternative form of memory. The most valuable religious artifact in the local parish church was a heraldic flag transported from Drohobycz, a formerly Polish town in Galicia transferred to Ukraine after the war. After the practical liquidation of the scouts' movement in Stalinist times, ${ }^{116}$ the Polish Scouting and Guiding Association (Związek Harcerstwa Polskiego, ZHP) became a major pillar in local efforts to educate youth independently of the state's ideological missives; especially at the local level, the organization maintained a substantial level of autonomy.

The state was, of course, not only concerned with the opinions of the youth, although it did direct the majority of its efforts towards this segment of the population. Adults were also the target of propaganda: in workplaces, through special

115 Cf. Krzysztof Kosiński, O nowa mentalność. Życie codzienne w szkołach 1945-56 (Warszawa: Trio, 2002).

116 From the very beginning of communist rule, the authorities made numerous efforts to influence the activities of the Polish Scouting and Guiding Association and to co-opt its power structures. Thus, in 1950 it was merged with the Union of Polish Youth (i.e. the equivalent of the Soviet Komsomol). The Polish Scouting and Guiding Association was reactivated as a separate organization during the Thaw of 1956. 
meetings (e.g. to encourage people to join collective farms or co-operatives), ${ }^{117}$ and in the obligatory celebration of state holidays such as Labor Day (1 May), Victory Day (9 May), and Independence Day (22 July). ${ }^{118}$ Nonetheless, the ideological pressure in socialist Krzyż paled in comparison to Soviet Nesterov (Zhovkva).

\section{After the Fall of Communism: New Beginnings? (1989/1991-present)}

The fall of state socialism meant, in both Krzyż and Zhovkva, a radical political and economic transformation, the opening of borders - a very significant fact for borderland towns - and the return of hitherto suppressed memories. The taboo on previously hushed up experiences of individuals and groups was lifted almost overnight, and people could publicly question the dominant versions of history. Unlike in previous decades, the situations in Krzyż and Zhovkva developed in completely different ways.

Up to 2009 the events in Krzyż can be described under the overarching theme of "public silence." In the first two post-socialist decades, only two memorials were installed in the town. The first was in 1995, in the market square - a busy space crisscrossed by trucks and other vehicles on weekdays, a venue for processions and public events on holidays. A boulder was placed in front of the

117 Collective farms [Państwowe Gospodarstwo Rolne, PGR] were created in Poland from 1949 on the Soviet model. In the present-day administrative region of Krzyż, one PGR was formed: in a village somewhat distant from the town itself called Żelichowo (at the time located in the administrative district of Kuźnica Żelichowska); its residents were mostly repatriates from Ukraine. The agricultural co-operative was in operation for a short time only in Huta Szklana. The post-war collectivization of agriculture in Poland has been discussed in a rich body of scholarly literature; see: Tomasz Skonieczny, Postawy chłopów wobec koncepcji i poczynań PPR (PZPR) w początkowej fazie kolektywizacji polskiego rolnictwa (1948-1949) (Słupsk: Akademia Pomorska w Słupsku, 2009); Antoni Kura, Aparat bezpieczeństwa i wymiar sprawiedliwości wobec kolektywizacji wsi polskiej 1948-1956 (Warszawa: IPN, 2006); and numerous other studies that focus on specific regions.

118 The National Day of the Rebirth of Poland [Narodowe Święto Odrodzenia Polski] was celebrated on 22 July during communist times, on the anniversary of the declaration of the manifesto of the Soviet-sponsored Polish Committee of National Liberation [Polski Komitet Wyzwolenia Narodowego, PKWN] in 1944. Since 1989, Independence Day has been celebrated on 11 November, the anniversary of the declaration of Polish independence in 1918. 
town hall, on the initiative of the town council, with a plaque bearing the inscription "On the $50^{\text {th }}$ anniversary of the Return of the Krzyż Lands to Poland" (at the time, two history teachers of the elder generation were members of the council; the idea was theirs). In 2005, in a small park in front of the secondary school, a similar, smaller rock memorial was installed in honor of Pope John Paul II. Not a single memorial was placed to commemorate the Poles who had been transported from the East, nor to the Germans who had been deported from Krzyż; no commemorative sign whatsoever mentioned the town's German past. Indeed, traces of the German past were physically removed: in 2008, a major portion of the derelict German cemetery was razed to the ground. This cemetery had bordered with the (new post-war) Polish one, separated by a wall, and had become completely covered by a forest that grew over it. The area was annexed to the Polish cemetery, and is used to this day as a burial site.

Moreover, in the years 1989-2016 only one street name was changed - the main thoroughfare previously named after the Polish Stalinist leader Bolesław Bierut (1892-1956) was dedicated to the Polish Armed Forces (ulica Wojska Polskiego). Nonetheless there remained streets in Krzyż named after communists such as Julian Marchlewski and Karol Świerczewski; these were given more "neutral" names only in the nationwide decommunization wave of 2017. ${ }^{119}$ Meanwhile, Polish national history remained the dominant memory paradigm. The biggest public celebration in the town is Constitution Day, 3 May, perhaps because the celebrations coincide with a religious holiday, a national fest of the Virgin Mary (during which processions take place from church to church). In 2008, as usual, the main ceremony took place in front of the monument in the market square. The guard of honor by the memorial rock was conducted by four schoolboys dressed in the military uniform of the Wielkopolska Insurgents, ${ }^{120}$

119 Julian Marchlewski (1866-1925): activist of the workers' movement, communist, opponent of the independence of the interwar Polish republic; in 1920, on the recommendation of Lenin, was appointed the head of the Provisional Revolutionary Committee of Poland in Białystok. Karol Świerczewski (nom de guerre "Walter;" 18971947): Polish serviceman, general of the Red Army and the Polish Armed Forces, member of the Polish Workers' Party; was killed fighting against the UPA in the Bieszczady mountains. Marchlewski Street became Western Street (ulica Zachodnia); Świerczewski Street was renamed after Józef Wybicki (1747-1822), a Polish writer and politician, and the author of the words of the Polish national anthem. The residents of the town proposed the new names.

120 For the Wielkopolska Uprising, see: footnote 71 in Chapter 1: "Dramatis personae: History and Memory." 
and the culmination of the event was the collective singing of the patriotic song Rota [The Oath], an early twentieth century piece composed in protest against Prussian rule. At the same time, the speech delivered by the chairman of the town council was largely devoid of any references to the past - he spoke of development opportunities within the European Union and the prospects for cooperation with Germany.

Thus, whereas one would expect a process of "reimmersion" into history in the aftermath of systemic transformation, the first two decades were characterized by the opposite process: on the one hand, an absence of public interest in the formerly censored elements of the past (including both Poles' "own" history, understood as the experiences of specific groups of people, and the ethnically "other" past of the Germans who had lived there previously); on the other hand, the ideology of the fallen regime was conserved to a great extent, with the monument to the "Polishness" of Krzyż in the town square the exemplary expression of this mnemonic continuity. The historical vision of the town's present-day authorities is also on display in the "History" section of the municipality's official website $^{121}$ as well as the historical sketches published in the town's regular information bulletins. The website text gives a detailed outline of the foundation and development of the town as a railway junction, but without mentioning even one word about it being a German settlement called Kreuz (Ostbahn), rather than Krzyż Wielkopolski; the year 1945 is described euphemistically as "a difficult time," and the Red Army's conquest of Kreuz in 1945 is referred to as a "liberation." Neither the deportation of German residents nor the reasons for the emergence of a Polish town are mentioned. A similar history is presented in a 2010 special issue of the town council's information bulletin, Wieści gminne, published to mark the 300th anniversary of the founding of the village of Huta Szklana; the years of war are summarized in a single sentence, "a new division of Europe ensues in 1945, and Huta Szklana, alongside the other lands of western Poland, is joined to its ancient homeland." ${ }^{22}$

Nonetheless, an analysis of unofficial, informal initiatives in Krzyż shows a somewhat different picture. Towards the end of the 1990s, a small brochure on the history of the village of Łokacz Mały (before 1945 Busch-Lukatz) appeared, thanks to the efforts of a local history enthusiast. Here, the German past is not emphasized, but it is not openly negated: the history of the settlements before

$121 \mathrm{http}: / /$ www.krzyz.pl/historia-1.html, last accessed 19.12.2018.

122 Huta Szklana. Jubileuszowy biuletyn $z$ okazji 300-lecia istnienia wsi (Krzyż: Urząd Miejski w Krzyżu, August 2010), p. 4. 
1945 is presented without reference to ethnonational categories, as the story of the Olędrzy, the lord Sapieha who founded the village, and the railwaymen who develop the station and town as a whole. A substantial portion of the book is devoted to the individual biographies of the oldest residents of Łokacz, describing their experiences before arriving in Krzyż and in the first years after resettlement. In 2005, on the initiative of the same individual in conjunction with a local cycling club, and in cooperation with the local forestry authority and the town council, a cycle path named in honor of Hans Paasche was opened on the outskirts of the Drawa National Park just north of Krzyż. Hans Paasche was the owner of a nowvanished manor called Waldfrieden, located a few dozen kilometers to the north of Kreuz (the place's post-war Polish name is Zacisze). He was a locally renowned pacifist who, in 1920, was shot dead by German soldiers stationed in Wiesenthal (now Przesieki). Alongside the construction of the bike path, the organizers of this initiative distributed information leaflets about Hans Paasche in the material promoting the new route. The cycle path is used, for example, for regular outings by the local scouts' association, which also pays close attention to the story of Paasche; they even use pre-war German maps of the area to plan their trips, and set assignments involving searching for traces of German monuments and buildings. Besides such initiatives with a social benefit, there are individuals and interest groups who collect local German artifacts: postage stamps, newspapers, decorations and other everyday items (porcelain, cutlery, bottles, hangers, etc.). Moreover, in Huta Szklana, the owners of an organic farm have revived local German methods of dairy production, selling cheeses made using old German recipes; the most popular is called "Kreuzer," and pictures of pre-war dairies in Glasshütte are on display on the shop walls. All of these activities combine to reveal a cultural tendency that aims to (re)discover the area's German heritage, though of course on a small scale relative to the official Polonocentrism. The bestknown example in Poland of an organization promoting the complex heritage of the "Recovered Territories" is the "Borussia" cultural association in Olsztyn. ${ }^{123}$

Another important part of the new mnemonic landscape in Krzyż are the activities of the KARTA Centre, a non-governmental institution that documents and publicizes history, in the years 2008-2012; in turn, the reception of these efforts in the town shows that KARTA effectively responded to the needs of residents. Before the research project of which this book is a product had been

123 On "Borussia" and similar initiatives, see: Robert Traba, Kraina tysiąca granic. Szkice o historii i pamięci (Olsztyn: Borussia, 2003). 
conceived, I was part of a pilot project that collected oral testimonies among the oldest residents of Krzyż. A follow-up project involved, inter alia, educational activities: we carried out workshops for secondary school students, organized a meeting for residents to present some of the gathered testimonies, and published a brochure entitled From Kreuz to Krzyz: Polish and German residents of Krzyż in the Twentieth Century [Od Kreuz do Krzyża: losy polskich i niemieckich mieszkańców Krzyża w XX wieku.] A website was also launched, where it was possible to access fragments of oral history interviews, as well as archival photographs. ${ }^{124}$ For a short time, therefore, I was not only an observer, but also a practitioner of local memory in Krzyż. The response to the activities of KARTA easily exceeded our expectations. The project presentation in the town cultural center attracted enough people to fill the hall, including the mayor, the chairman of the town council and the heads of all the schools. Through the municipal library, over 100 copies of the brochure From Kreuz to Krzyż were distributed to local residents. At its peak, the website was visited by several dozen people a day, most of them from Krzyż itself.

It would be possible to diagnose of the state of commemoration in Krzyż as "public forgetting, private fascination," if it were not for events that took place in 2009 and 2010. In 2009, burials began to take place in the part of the municipal cemetery that had been converted from the old German graveyard. As graves were dug, the remains of people buried in the same spots before the war were found. A scandal broke out in Krzyż: residents objected to laying their loved ones to rest in plots where other corpses already lay. The matter was brought to the town authorities, and a heated discussion broke out on the pages of the local newspaper Tygodnik Notecki. Many people only then discovered that the cemetery had been expanded on the site of the pre-war German burial ground. Public pressure led the authorities to conduct reburials, in consultation with the Protestant Church based in Poznan, and a modest memorial to the Germans formerly buried there was erected in spring 2010. A black granite plaque bears the bilingual dedication. It stated in Polish: Pamięci zmarlych tej ziemi [In Memory of the Dead of this Land]; in German: Ruhe sanft in eurer Gruft [Rest in Peace in your Graves]. A similar memorial inscription was put up on the wall of the cemetery chapel. At roughly the same time, the town council of Krzyż instigated the publication of an album of old postcards from Kreuz. The 85-page book is entitled Krzyż Wielkopolski: A History Written in Postcards [Krzyż Wielkopolski: historia

124 The website stopped working due to the technical problems of its administrator, the KARTA Centre, in 2017. 
pocztówka pisana], and features more than one hundred German images of the town and surroundings. The subtitles to the images provide information about the postcards, always featuring the old German name of the building or place next to the present-day Polish one. However, the book's introduction somewhat dampens the impression of an opening up to the past on the part of local officialdom. A text that could have been written in communist times tells readers that: "in 1772 - during the first Partition of Poland - these lands were conquered by the Prussians, but the area remained largely inhabited by Poles, who were mostly farmers;" "[in the interwar period] Krzyż unfortunately did not return to Polish territory;" "the town was liberated after intense fighting on January 27, 1945." ${ }^{225}$ For someone with no knowledge of the region's history, it may be difficult to understand why the pictures on these postcards have German text at all.

Meanwhile, Polish-German contacts flourished in Krzyż at several levels. At the beginning of the 1990s, Germans who had previously lived in Kreuz started to travel to the town, the second such wave in recent decades. This time, it was people from former West Germany who came, i.e. those who had been previously labeled by communist-era propaganda as threatening revisionists. In the new political situation, the Polish residents of Krzyż perceived these tourists differently to the East Germans who had visited 20-30 years previously. The Germans also had different preconceptions of Poland and Poles, and behaved differently to their compatriots from the GDR; in many cases, their self-confidence led the locals to feel threatened. Fear of the Germans reached a zenith during the campaigning period before the European Union membership referendum in 2003, when conservative and populist parties stirred anxiety in western regions of Poland by arguing that Germans would try and reclaim pre-war homes and plots of land by legal means. However, campaigning ended, Poland joined the EU, and no Germans arrived. As time passed, their visits became increasingly rare; at present, the majority of Germans who travel through the region are ordinary tourists with no sentimental attachment to the area. Many agrotourism companies cater to Germans, with promotional material printed primarily in German. Partnerships are also developing at the level of educational and cultural institutions. The secondary school in Krzyż has for several years arranged exchanges through the EU's "Comenius" program, and the Polish Scouting and Guiding Association organized a joint scouting camp for young Poles from Krzyż and scouts from Germany in 2007. Informal contacts have also played

125 Bronisław Sudnik, ed., Krzyż Wielkopolski - historia pocztówkq pisana (Piła: Wydawnictwo Media, 2010), p. 7. 
a role. Krzyż is located just $100 \mathrm{~km}$ from the border, with good transport links to Germany, and many families in the 1990s subsisted by means of (more or less legal) cross-border trade. Many residents of Krzyż also work, whether permanently or seasonally, in Germany.

At first glance, the situation in Zhovkva after 1991 looks to have been the exact opposite. Whereas the post-transformation years were fairly calm in Krzyż, Zhovkva was mired in conflicts over the meaning of the past. In order to understand these disputes, it is necessary to consider nationwide debates about the past in Ukraine. ${ }^{126}$ The official vision of the country's history had begun to change during Perestroika, and radical alterations were introduced after Ukraine gained independence in 1991. The Soviet memory narrative was gradually discredited, although not without difficulty, and a new, national history gained primacy. A new state requires new heroes, and in addition to the Cossacks and the leaders of medieval Kievan Rus', the UPA was elevated to the status of collective hero. Meanwhile, a dominant tendency in Ukrainian historiography promoted a victimhood narrative, whereby Russia and the Soviet Union had oppressed the Ukrainian people for centuries. However, the new paradigm was not accepted by all Ukrainians, the biggest controversies arising in the eastern regions of the country, where the UPA was seen as a criminal organization that collaborated with the Nazis, and the Red Army remembered as genuine liberators. Nevertheless, the proponents of UPA mythology made significant gains, succeeding in instating their version of events into school textbooks. ${ }^{127}$ Disputes about the UPA are ongoing - many observers argue that this problem divides Ukrainian society more than any other. Debates also cause divisions within the nationalist camp, which struggles to come to terms with issues such as the massacres of Poles in Volhynia (1943-44) or collaboration with the Nazis (both

126 This is such a large topic that there is neither room for detailed analysis here, nor are there many scholarly works that consider it in its totality. Older publications remain the best complex analyses, see: David R. Marples, Heroes and Villains. Creating National History in Contemporary Ukraine (Budapest-New York: CEU Press, New York 2008); Tomasz Stryjek, Jakiej przeszłości potrzebuje przyszłość? Interpretacje dziejów narodowych w historiografii i debacie publicznej na Ukrainie 1991-2004 (Warszawa: ISP PAN, Rytm, 2007). One of the most recent overviews is: Georgiy Kasianov, "History, Politics and Memory (Ukraine 1990s-2000s)," in: Memory and Change in Europe. Eastern Perspectives, ed. Małgorzata Pakier and Joanna Wawrzyniak (New York-Oxford: Berhahn Books, 2016), pp. 193-211.

127 Many analyses of Ukrainian histories have been published. See works by scholars including Viktoria Sereda, Nancy Popson and Leonid Zashkilniak. 
military collaboration by the SS Galizien division and civilian participation in the auxiliary police, including collaboration in the Holocaust). ${ }^{128}$ The controversy of the theme also affects pragmatic questions: it was only in 2015, as part of the decommunization laws passed that year, that the UPA's soldiers were officially recognized as "fighters for Ukrainian independence," thus gaining a status alongside Red Army veterans and a range of benefits and privileges that, often, meant a substantial economic benefit for the individuals concerned. ${ }^{129}$ It should also be noted that, for all the dominance of nationalist memory in Ukraine, there are many different narratives that coexist, even in the western regions; these are often mutually contradictory. The Soviet commemorative canon was not completely dismantled, as can be seen in statues that are still standing in Galician towns and in the fact that in Galicia - unlike in, say, Estonia - there were no acts of vandalism after 1991 against Soviet-era monuments; usually only Lenin monuments were toppled in isolated cases. ${ }^{130}$ This changed after the Euromaidan

128 For an example of the discussions thereof, see a volume published in 2010 that compiles topical essays written by various opinion-makers: Tarik C. Amar, Ihor Balynskyi and Yaroslav Hrytsak, eds., Strasti za Banderoiu (Kyiv: Hrani-T, 2010). An interesting analysis of the memories of members of the SS Galizien division and the politics of memory in Ukraine is: Olesya Khromeychuk, "Undetermined" Ukrainians. Post-War Narratives of the Waffen SS "Galicia” Division (Oxford-BernBerlin-Bruxelles-Frankfurt am Main-New York, New York-Wien: Peter Lang, 2013). Also see: Grzegorz Rossoliński-Liebe, "Debating, obfuscating and disciplining the Holocaust: post-Soviet historical discourses on the OUN-UPA and other nationalist movements," East European Jewish Affairs, Vol. 3, No. 42, (2012), pp. 199-241.

129 Former president Viktor Yushchenko made attempts to change this situation during his tenure (2005-2010); in 2005, he invited UPA veterans and former Red Army soldiers to a joint ceremony commemorating the end of the Second World War, whilst one of his last acts in 2010 was the granting of the title of "Hero of Ukraine" to Stepan Bandera. In April 2010, a Donetsk court overturned this decision. Radical changes were only introduced after the overthrow of the presidency of Viktor Yanukovych and the Euromaidan. For consistent analysis of the Yushchenko's politics of memory, see: Per Anders Rudling, "Memories of 'Holodomor' and National Socialism in Ukrainian Political Culture," in: Rekonstruktion des Nationalmythos? Frankreich, Deutschland und die Ukraine im Vergleich, ed. Yves Bizeul (Göttingen: Vandenhoeck \& Ruprecht Unipress, 2013), pp. 227-258. On the decommunization laws, see: John-Paul Himka, Legislating Historical Truth: Ukraine's Laws of 9 April 2015, https://www.academia. edu/12056628/Legislating_Historical_Truth_Ukraines_Laws_of_9_April_2015, last accessed 15.02.2019.

130 Cf. Andrij Portnow, “'Wielka Wojna Ojczyźniana’ w polityce pamięci Białorusi, Mołdawii i Ukrainy,” Res Publica Nowa, Vol. 7 (2009), pp. 24-35. 
revolution of 2014, when Soviet monuments were dismantled en masse across Ukraine. ${ }^{131}$

How does Zhovkva fit into this national context? After 1991, the official representation of the town's past was completely changed: the "Soviet" interpretation that had dominated until then was rendered "incorrect," and a national memory took its place. The mnemonic paradigm shift can be seen above all in the symbolic furnishing of public space: Zhovkva became a symbolic domain ${ }^{132}$ in which nationally minded Ukrainians, for whom the OUN and UPA were model patriots, gained supremacy. From the beginning of the 1990s, several new monuments were erected. The most prominent are the monument-shrine to the victims of the NKVD massacre in 1941, placed in front of the town hall, the statue of the OUN leader Yevhen Konovalets (on the spot where the monument to Piotr Nesterov had previously stood), and the monument to the victims of the Great Famine of 1932-1933. Graves of the Sich Riflemen were renovated in the town cemetery, and commemorative plaques were installed to those victims of Stalinist Terror in Zhovkva whose bodies were never found and to the human remains discovered in the crypt of the Basilian church.

Besides the three memorials connected to the Holocaust (to which I shall return below), only three of the new monuments do not have an anti-Soviet thrust: the statue of Mary in front of the castle, the "family monument" (which features as woman and man leaning over a child) and the monument to soldiers who died in Afghanistan, which appeared in 2000. All of the memorials were installed with the active participation of local residents, some on their initiative. Zhovkva's community engagement is also visible in a range of other projects: in 1990 the Svitlo kultury [Light of Culture] association, which restored old buildings in Zhovkva, was founded; then, a community museum was opened (although it closed after a few years); and in 2007 the local Tourist Information Centre was established. The naming of streets was revised in many instances: streets dedicated to communists such as Kirov and Dovhanyk disappeared, alongside those commemorating Russian authors and artists, such as Lermontov and Pushkin. They were replaced by streets named after the Warriors of the UPA, Stepan Bandera,

131 Cf. Tadeusz Olszański, Wielka dekomunizacja. Ukraińska polityka historyczna czasu wojny (Warszawa: Ośrodek Studiów Wschodnich, 2017).

132 Lech M. Nijakowski developed the concept of the symbolic domain - understood as a space in which a given group realizes its historical policy - in his book Domeny symboliczne. 
Yevhen Konovalets, the Sich Riflemen, Oleksa Hasyn (UPA commander in the "Western" district), and other nationalists.

The fall of state socialism also enabled a religious revival, which had important consequences for the culture of remembrance in Zhovkva. Greek Catholics in the town had started to demand that the Orthodox Church return the Basilian church to them in the late 1980s. A heated dispute broke out between the faithful and clergy of the two confessions, with exchanges not only confined to words: for example, Greek Catholics chained themselves to the church door, and an Orthodox priest attempted to sneak out some of the relics of a saint. Eventually the Basilians returned to the church and monastery, and the Orthodox hierarchy commissioned a new, enormous temple on the edge of the town on the road to Lviv. Alongside the Orthodox Church of the Moscow Patriarchate in Zhovkva, there is also a small church of the autocephalous branch of the Orthodox faith, ${ }^{133}$ located in the former chapel of the Felician convent next to St. Lazar's Hospital, while Greek Catholic services are conducted in three other churches. The Basilians have great cultural authority in Zhovkva, being associated with patriotic virtues. They symbolize the pre-war tradition of Ukrainian culture and the post-war resistance to the imposition of communism. They therefore act as patrons to many local events that commemorate the past. However, relations with the Orthodox Church of the Moscow Patriarchate remain strained, although this has been true of all of the confessions in Zhovkva - none of them retains friendly relations with the Moscow branch.

Social divisions in Zhovkva quickly spread to the linguistic, national and political spheres, although the boundaries between them were often difficult to identify. ${ }^{134}$ On one side of the barricades were nationally-minded Ukrainians who supported the Ukrainian cultural and linguistic rebirth as well as a nationalist approach to memory; on the other side were ethnic Russians and Russianspeaking Ukrainians who preferred Soviet models of identity and culture to the Ukrainian national ones. The former accused the latter of disloyalty to the Ukrainian state; the latter reciprocated with charges of national chauvinism. Language was the issue that caused particularly heated clashes: the first group argued that the Russian-speakers were purposefully demonstrating a lack of

133 At the time of the writing of this book, three separate branches of the Orthodox Church operated in Ukraine: the Moscow Patriarchate, the Kyiv Patriarchate, and the Autocephalous Church.

134 On the linguistic divisions in Ukraine at this time, see: Lada Bilaniuk, Contested Tongues: Language Politics and Cultural Correction in Ukraine (Itaca \& London: Cornell University Press, 2005). 
respect for Ukrainian; the second group countered by accusing the Ukrainianspeaking majority of denying them their right to use their minority language in public. Open conflicts sometimes broke out - partly facilitated by the closure of the military garrison in Zhovkva.

The Roman Catholic Church was reopened in Zhovkva shortly after the fall of communism; Polish conservation officers have continually refurbished it with financial backing from the Polish state. The Roman Catholic congregation is small in number, and mass is celebrated once a week. Most of the faithful here are Ukrainians, with a relatively low number of ethnic Poles. Services are held partly in Polish and partly in Ukrainian. Despite the existence of a Polish community in Zhovkva, no commemorative plaque to the Poles who lived in the town has appeared since 1991: neither to those who contributed to the culture of the town historically, nor to the victims of Soviet repressions or UPA atrocities. The only Polish memorial is a cross in the town cemetery commemorating Polish soldiers who died in war against the Soviets in 1920; it was placed in the interwar period and renovated after 1991 on the initiative of the Polish community. The local museum, situated in the castle, presents the town's history through the prism of its architecture - the castle, churches of different Christian denominations, synagogue and other building reveal different layers of the past. Characteristically for western Ukraine (and also for western Poland), the texts in the display avoid any reference to the ethnicity of the people who designed and built these artifacts. Stories about Ukrainian heroes: Bohdan Khmelnytsky (born in Zhovkva) and Ivan Mazepa (who visited the town) are the principal additions to the architectural descriptions. Meanwhile, a temporary exhibition from 2010 departed from this nationalizing paradigm. It presented several dozen photographic portraits of historical residents of Zhovkva (most of them Ukrainians and Poles), based on a collection of glass plates made by the town's last Polish photographer, Emil Domański. The exhibition attracted a great deal of interest from the local population, especially those whose families had roots in the locality; according to the curator, museum visitors spent a long time studying the photographs and looking for their relatives and acquaintances. Another of the museum's initiatives is highly reminiscent of the book of old postcards published in Krzyż: in 2010, a calendar featuring Polish images of Zhovkva townscapes was issued, with bilingual inscriptions in Polish and Ukrainian. However, similarly to the case of the Krzyż album, the publication contains no information as to why the Poles and Jews who created much of the material culture featured in the images are no longer present in the town.

Finally, memory about the town's Jews is also largely absent. In theory, in contrast to the (non-)commemoration of the Poles, we cannot say that there have 
been no public memory projects in Zhovkva whatsoever. In the early 1990s, a symbolic grave in memory of the Jews who died here during the liquidation of the Zhovkva ghetto (1943) was placed in the town cemetery. The inscription reads:

Here are buried the remains of Jewish residents of Zhovkva, the victims of the genocide carried out by Nazi Germany, shot to death during the liquidation of the ghetto on 25 March 1943. Your integrity, rectitude and virtue remain in our hearts. In eternal memory. We ask for prayers. From the residents of Zhovkva.

Nonetheless, although the plaque purported to be "from the residents of Zhovkva," in reality it was the result of individual efforts by the town's last living Holocaust survivor. The second Holocaust memorial in the locality was also created independently of the town authorities, with funding from former residents of Zhovkva now living in Israel. Situated approximately $2 \mathrm{~km}$ outside the town at a site of wartime mass executions, the large memorial was erected towards the end of the 1990s and bears the bilingual (Ukrainian-Yiddish) inscription: "In Blessed Memory of the 3,500 Victims of the Zhovkva Ghetto. 25.03.1943" in Ukrainian; and "In Blessed Memory of the 3,500 Victims of the Zhovkva Ghetto. May their Souls be United by the Bonds of Life" in Yiddish. When the monument was unveiled, numerous members of the Jewish diaspora, as well as representatives of the local authorities and Zhovkva residents attended the ceremony. At present, after the death of the town's last Holocaust survivor in 1999, the memorial stands neglected and has been vandalized several times: for example, the decorative bronze elements were removed by thieves. The Zhovkva synagogue is in no better state. After the fall of communism, restoration works were started (the building is owned by the state), but only after 2001, thanks to the support of the World Monuments Fund's Jewish Heritage Programme, the synagogue received a new copper roof. The restoration is still in progress in 2018. A site of Jewish memory that was until very recently completely removed from the symbolic space of Zhovkva is the ohel (ornate burial house) of Aleksander Sender Schor, local rabbi and Talmudist (died 1737), built by his descendants on the former site of the Jewish cemetery, which now functions as a marketplace. The building is closed with a padlock. A piece of paper hung in the window tells readers, in Hebrew only, that the key is kept in a house nearby.

Thus, whilst there is no shortage of memorials representing diverse memories and narratives in Zhovkva, their prominence and state of repair are very different. Newly erected monuments to heroes of the Ukrainian underground stand alongside memorials to murdered Jews and religious sites of memory. With the exception of the Lenin statue that was pulled down before the official collapse of the USSR, all but one (the Nesterov statue) of the Soviet monuments 
are still standing: the figure of the soldier-liberator and the designated segment for Red Army soldiers in the municipal cemetery, and the monument to the heroes of the "Great Patriotic War." Flowers are occasionally laid at the feet of these memorials (especially on Victory Day, 9 May), but in general it is difficult to conclude that anyone is maintaining them regularly: the graves are overgrown and the monuments neglected.

Like in Krzyż, the opening of borders gave Zhovkva opportunities to increase contacts with Poland. Many Poles traveling to see Lviv visit the town, and in high season at least one coach full of Polish tourists stops by daily. Information material sold in the Tourist Centre is printed primarily in Polish and Ukrainian, and local guides are mostly conversant in Polish. Zhovkva is also visited by actual former residents and their descendants, although less frequently than Krzyż. Jewish tour groups also visit the town and leave a lasting impression in the memories of locals due to the characteristic religious clothing worn by some; however, in the course of my visits I did not come across any such groups. There are, however, no Polish-Ukrainian cooperation projects aimed at the wider population. Zhovkva has an official twin town in Poland, museums run joint projects, but there are no school exchanges or contacts between local NGOs. Economic networks are significantly more developed. Zhovkva being just $30 \mathrm{~km}$ from the Polish border, many residents trade with Poland, not necessarily legally. Many Ukrainians in Zhovkva - as well as almost all of the Poles - work in Poland, on either a permanent or a seasonal basis.

Zhovkva had its origin name restored in $1992 .{ }^{135}$

135 After the publication of the Polish version of this book, the state of commemoration in Zhovkva changed somewhat. In 2013, a group of local activists took part in a project financed by the Ministry of Foreign Affairs and the American Jewish Committee, and carried out by the Ukrainian Centre for Holocaust Studies in Kyiv: "Preserving and Memorializing the Holocaust Mass Graves of Eastern Europe." Two books about the history of Zhovkva's Jewry, aimed at a wider audience, were published as a result of this project. Moreover, in 2017 a memorial plaque was unveiled on the site of the former Jewish cemetery, now a marketplace. Three information boards about the castle, synagogue and Basilian church were produced, as well as a fourth one about the Holocaust in Zhovkva. There is no space here for a detailed analysis of these new forms of memory, but the very fact of their emergence is significant, as is the fact that teachers and young people from Zhovkva schools took part in their creation. 


\section{Resettlement and the First Phase of Adaptation $^{136}$}

\section{The Journey: Autobiographical Memory and its Transmission}

One of the most important factors that affected the adaptation of the new inhabitants of Krzyż and Zhovkva to their surroundings was the extent to which their migration was voluntary or forced. ${ }^{137}$ Forced migrants differed from voluntary ones not just in terms of access to various resources, but also in their mindsets when they arrived at their new places of residence. The more forced the migration, the more negatively inclined people are to their new surroundings; the more free will was exercised in the decision to leave one's old home, the greater the readiness to accept a new one. This first categorization shows from the outset that many different aspects of the adaptation process, ${ }^{138}$ which will be discussed in the following two chapters, affected different groups of residents in different ways.

The first such element that occupies divergent places in the accounts of different groups of respondents is resettlement itself - an experience that was constitutive for two groups of forced migrants: "repatriates" from the former eastern provinces of interwar Poland, and Ukrainians resettled from eastern Poland to Ukraine. Their stories share a common theme of highly emotive remembrance of

136 An earlier version of this chapter was previously published as an article: "Społeczna pamięć przesiedlenia: studium porównawcze na przykładzie dwóch powojennych społeczności lokalnych Polski i Ukrainy," Studia Socjologiczne, Vol. 2 (2013), pp. 149-172.

137 Zdzisław Mach observed this rule in his book Niechciane miasta.

138 I use the term "adaptation" in this chapter and subsequent ones in the most broad and general sense. I understand adaptation as the process whereby an individual or group adjusts to new life conditions. In instances that call for a more specific concept of the kind of adjustment, I use adjectival inflections such as "cultural adaptation," etc. Because I am more interested in subjective memory of adaptation than in objective processes, I consciously refrain from elaborate references to existing literature on adaptation as a subject of inquiry (which in any case, as with memory, represents something of a conceptual chaos rather than established and accepted conventions); see: Aleksandra Grzymała-Kazłowska, “'Integracja' - próba rekonstrukcji pojęcia," in: Problemy integracji imigrantów. Koncepcje, badania, polityki, ed. Aleksandra Grzymała-Kazłowska and Sławomir Łodziński (Warszawa: Wydawnictwo Uniwersytetu Warszawskiego, 2008), pp. 29-50. 
the journey: each of the interviewees described it as a long, arduous experience that was made difficult by the poor sanitary conditions and lack of food.

We set off for Ukraine. It was 1946, towards the end of February or the beginning of March. It was very cold. They gave us all two carts each, two for each family, so that we could get in them, and we got in them. [...] At that time there was no railway station in Berezhany, there was a siding about two or three kilometers away. That was where we arrived, a whole trainload of people, with animals if some had taken them, with small children, with everything, horses, the livestock. [...] I was still a small boy then, but I remember how my mother wrapped me in a shawl, because it was very cold, there was such a wind, such terrible weather $(\mathrm{Z} 15 \mathrm{Am})$.

We sang "Go to Sleep Jesus" [a Christmas carrol "Lulajże Jezuniu"] in the cattle cars at Lubań Śląski. [...] We learned at Lubań that my father’s family was living in Legnica. There was nothing to eat, nor, well... there was water to drink, but no food. Frozen potatoes and onions on Christmas Eve, because we had nothing when we arrived from Russia, you know, we had no clothes and we were cheerful. That was real life, there was no relaxing here (K24Am).

The accounts of Poles who traveled from the eastern territories are also abundant in tales of the makeshift organization of everyday life, forced by the circumstance of several weeks spent traveling by rail: they cooked under the open sky during stopovers and gathered food supplies in diverse ways. The Polish interviews differ from the Ukrainian ones in that they contain, as a rule, elaborate accounts of the journey to Krzyż. Such stories were told in almost every interview, with certain variations; they differ only in the narrative competence of the respondent and the level of emotional involvement. In Ukrainian accounts, there were a number of longer narratives, but usually the process of deportation was told in a more restrained way:

What was it like? Well they gave us carts, and in Lubaczów there was a train, and we got on the train... They took us to the train in the carts, packed us into the train, and we went. We stopped at... how far was it from Rava [Ruska], not far, about $30 \mathrm{~km}$. We stopped, my father was already here, and he kind of came out to get us, and we stayed here (Z4Af).

This laconicism is easy to understand when we take into account that most Ukrainian resettlers from Poland traveled to Zhovkva over a distance of $100 \mathrm{~km}$ at most; the Poles traveling in the other direction had several hundred kilometers to cover before arriving in the new western territories. The objectively greater distance is conducive to a more elaborate narration in the Polish interviews: longer, more detailed, and with more different threads. Many of these threads do not feature at all in the Ukrainian interviews. There are several explanations to this observation: first, the journey undertaken by the 
Polish "repatriates" was not only longer, but was richer in various incidents and adventures. Also, awareness of the great distance led to a keener appreciation of the liminality of their situation and a greater sense of threat. The overwhelming sense of pity at abandoning their homes ("we lost everything, everything we had, the entire livelihood of my father and mother" (K2Af)) was made worse for the Krzyż "repatriates" by the fact that Poles in central Poland, whom they encountered during stopovers, treated them with disdain:

A few curious types came over and asked "where, where are you going? Where are you going?" "Well, they're repatriating us, because over there it will be Ukraine now." "You're lying, you're going to hunt for German fortunes. Throw them under the wheels, under the wheels!" That is how they talked to us. It was a terrible experience, because it's not enough that you've lost your house [...] now it turns out that you're traveling in search of a gold rush (K35Af).

A further factor that differentiates Polish accounts from Ukrainian ones is the social formation of narrative models, which are distinct in each language and culture and which form a basic grounding for remembrance. ${ }^{139}$ In Poland, a societal working through of the memory of resettlement was to an extent carried out as a result of the easing of state censorship from the 1970s onwards; this fact has an observable effect on the accounts of Poles resettled from the East, which is absent in the Ukrainian testimonies. It was at this time that the classic film All Friends Here [Sami swoi, dir. by Sylwester Chęciński, 1967] was released, introducing an account of the resettlement to official discourse in comedic form. Although the film's plot concentrates on the lives of "repatriates" only after their arrival in the "Recovered Territories," it was significant that a certain taboo was broken. Unlike in Ukraine, where the ideological regime was part of everyday life until the late 1980s, the Polish "Little Stabilization" 140 allowed at least a partial release of memories about resettlement. This explains why accounts of Krzyż residents resettled from the East sometimes contain elements of humor, indicating that years of

139 Harald Welzer is one of the scholars who have commented on the construction of narrative through culture and the influence of social communication on individual autobiographical memory, see: Welzer, "Communicative Memory;" Harald Welzer, Das kommunikative Gedächtnis: Eine Theorie der Erinnerung (München: $\mathrm{CH}$ Beck, 2002), pp. 171-192.

140 The "Little Stabilization" [Mała Stabilizacja] is the name given to a short-lived period of liberalization of the political system during the first years of Władysław Gomułka’s tenure as Party Secretary (the late 1950s and early 1960s). The term originates from a play by Tadeusz Różewicz, entitled Witnesses, or Our Little Stabilization [Świadkowie, albo nasza mała stabilizacja, 1964]. 
"working through" have enabled a certain emotional distance to be gained from past traumatic experiences; for example, they told stories about chasing after departing trains.

The fact that some of the Krzyż interviews contained direct references to All Friends Here shows the extent to which autobiographical memory is formed not just by individual experience, but also through interaction with other social agents and under the influence of factors such as the media. As one of the respondents said:

And then they transported us across, just like that, in those cattle cars of course. Three... three weeks we spent traveling to the west. Like in... like the Karguls and Pawlaks [the main characters of Sami swoi] in the film, that was how we went, with those cows (K4Af).

In order to describe their own individual experiences, narrators reach for images memorized from the film; it can only be assumed that in some ways, the image from the film acquires in their memories the status of something that was actually lived through. Similar mechanisms of memory have been discussed on several occasions in the scholarly literature. Thus, Christopher R. Browning, in his analysis of the testimonies of Holocaust survivors, discusses ways in which so-called later accounts of the Holocaust included themes that witnesses had borrowed from other testimonies, popular iconography, and other sources - for example, fear of gas being emitted from showers instead of water, or recollections of shootings above mass graves. ${ }^{141}$ Harald Welzer et al., in turn, write about the phenomenon of Germans of the "Günter Grass generation" inscribing events from the film The Bridge [Die Brücke, dir. by Bernhard Wicki, 1959] into their autobiographical memory; in the film, set in the closing days of the Second World War, a division of young army recruits desperately defends a bridge that has little strategic significance. Welzer et al. call this phenomenon a "source amnesia." 142 As David Lowenthal has rightly noted, the mechanisms of memory convert macro-scale history into individual remembrance, and the experiences of others into personal recollection; the more often such a memory is verbalized, the more it becomes one's "own." 143

141 Christopher R. Browning, Collected Memories. Holocaust History and Postwar Testimony (Madison: University of Wisconsin Press, 2004).

142 Harald Welzer, Sabine Moller and Karoline Tschuggnall, "Opa war kein Nazi:" Nationalsozialismus und Holocaust im Familiengedächtnis (Frankfurt am Main: Taschenbuch Verlag, 2002).

143 Lowenthal, The Past is a Foreign Country. 
Accounts of resettlement are usually accompanied by retrospective evaluation and reflection on the themes of guilt and responsibility. Among Ukrainian resettlers, the assessment tends to depend on whether they left Poland in the first population transfer operation (which was de facto still voluntary) or the second (which was fully forced). People who departed in 1944-1945 spoke of a relative voluntariness of their decision, noting only that the reality of the move did not correspond to the propaganda ("It was meant to be voluntary, and it wasn't forced. [...] It was just that they lied to us. We arrived at the station in Odessa, and what did we find... Some marshes, a couple horses, two cows, and that was it" [Z13Am]). Later resettlers, however, claimed that they were coerced into moving to Ukraine, and more frequently complained of the brutality of the resettlement operation itself. ${ }^{144}$

The most important thing was that the Poles forced us to leave. First they said we should leave, and there was a Soviet commission organized for us. But people didn't go, because how were they supposed to leave what they had, their households, and go who knows where. [...] Later, when they started killing people, that was the worst, and people had to leave (Z6Am).

Both groups blame the Poles and the Soviets in similar measure for the loss of their homes. For a large portion of people, the fault does not lie directly with either of these sides, and is not an essential category for the experience of deportation. Their testimonies are characterized by the use of impersonal constructions. Also, on several occasions, interviewees were unable to select vocabulary appropriate to what they had experienced; they either did not have the words, or still struggled to sufficiently understand what had happened so as to describe it properly, e.g.: "They resettled us. [When was it, still during the war?] In 1945. When the war finished, because Poland was what it was then... I don't know how to describe it. Things happened, and [people] left" (Z4Af). The formulation "voluntary forced resettlement" appears in many accounts, suggesting helplessness of memory against the extremity of experience, and defenselessness of memory that is not equipped with suitable social frames to provide concepts and terminology.

The Poles spoke more of a voluntary "repatriation operation," although they also frequently underlined the illusoriness of the free choice being exercised. Among the factors that diminished the voluntariness were: the threat of new political persecutions; the threat from the Ukrainians; and simple patriotism

144 Halyna Bodnar notes a similar split in the evaluation of the resettlement experience in her research on adaptation among people transferred to Ukraine from Poland: Bodnar, "Tam bulo dobre." 
which demanded that they go to the territory that would now be Poland. This last factor in particular is completely absent from Ukrainian accounts. It is clear that the fact of having lived in the interwar Polish republic, in their own state, had a significant influence on the formation of civic and patriotic values among the migrating Poles. The Ukrainians had had no such experience, and the idea of "Great [i.e. reunited] Ukraine" was for them a much bigger abstraction than the new Polish state was for the Poles coming from the East.

The eastern lands of Poland were annexed to the USSR and we were given a choice signing up for Soviet citizenship or leaving. Of course, we didn't even have to think about it - we chose the second option. [...] Of course on the one hand it was a pity, it was difficult, we were being evicted from our homelands - and we were evicted, it wasn't a deal, it might have been a deal on paper, but people were deported. [...] So were we supposed to sign up as Russian citizens, even though we were Poles? (K17Am).

Besides patriotic sentiment, people also remembered coercion - whether direct or indirect. Words such as "order," "evacuation," "deportation" feature in the interviews. Nonetheless, such statements are much less common, and in most cases a political context lies in the background. In addition, the very common use of the expression "repatriation" suggests that post-war propaganda had a substantial effect; this was the phrase coined by official memory to describe the resettlement operation from the "Eastern Borderlands" to the "Recovered Territories."

A common feature among the Polish interviewees is a conviction that the Russians were responsible for the loss of their homelands. The names used by them varied: from the "Russkies" (i.e. Ruscy, a mild pejorative distinct from the neutral Rosjanie, Russians) and "Soviets," to the "Reds" or "communists." Sometimes, a fellow group of perpetrators is named: the Ukrainians, in cases where interviewees moved from Ukraine; more politically aware respondents named the Allies, who had "sold" Poland. Interestingly, unlike in Ukraine, there were no instances of an inability to verbally place oneself as an individual in the wider context of resettlement as a macro-scale political process - even among the least educated interviewees originally from rural areas. It is clear that in Poland, the many years of active memory work related to this specific historical experience - in the family, in local communities, and later (especially after 1989) in wider public discourse - have enabled resettlers to come to terms with their plight. Polish respondents had no difficulties in clearly assessing and articulating the events they had lived through, because they had done so many times previously. Ukrainian interviewees, on the other hand, had had no such opportunity, 
and they came across in comparison as people who were lost and helpless with regard to their own unprocessed traumas.

Details are what is most readily lost in the intergenerational transmission of memory. This was especially visible in the interviews from Zhovkva, where I only heard a detailed account of the resettlement process from younger respondents a handful of times. Much more frequent were generalized statements, encapsulating in a few sentences what the respondent wanted or was able to say about the experiences of their parents or grandparents.

Well, what I know about Granny's history is that she was, what do you call it, a participant of that "Operation Vistula,"145 that's all I know. And that she lived in Poland to start with, and then they moved her over here. And Granny told me that when they arrived here, they chose this house because it had windows. [...] What else is there to say? (Z4Dm).

In Krzyż, more young people gave detailed accounts of the resettlements, and their ability and willingness to do so was directly correlated to the declared intensiveness of the preservation of memory within the family and a general interest in history. Piotr T. Kwiatkowski has described such dependence on the basis of qualitative data. ${ }^{146}$ In these extended stretches of interviews about the resettlement process, powerful themes from the tales of grandparents recur, such as the tough sanitary conditions or the lack of food in the "cattle cars;" Welzer et al. have coined the term "topoi of memory" to describe such ideas that traverse intergenerational narratives. ${ }^{147}$

[Granny] always used to tell us about how they were transported, in what conditions. She always said that they were transported in those, in these wagons for animals, that there was one hole that served as a toilet. There were lots of people in the wagon and it was incredibly stuffy (K29Df).

Both in Krzyż and in Zhovkva, the accounts of resettlement told by younger people contain echoes of the voices of the older generation, although it is the theme of coercion that dominates - suggesting that this trope served as a basis

145 In Ukraine it is common in informal discourse to use the name "Operation Vistula" for all of the resettlements of Ukrainians to Poland between 1944 and 1947. However, "Operation Vistula" was the name of a specific resettlement operation carried out by the authorities of the Polish People's Republic in 1947.

146 Piotr T. Kwiatkowski, "The Second World War in the Memory of Centemporary Polish society," in: Memory and Change in Europe. Eastern Perspectives, ed. Małgorzata Pakier and Joanna Wawrzyniak (New York-Oxford: Berhahn Books, 2016), pp. 231-245.

147 Welzer, Moller and Tschuggnall, "Opa war kein Nazi." 
for the creation of family memory, due to its potency and its simple division of roles into "our own" and "other." In the younger people's renditions, coercion is usually direct; indirect coercion is mentioned more in the accounts of Krzyż residents with roots in today's Ukraine, as a fear of the Ukrainians, and also in interviews in Zhovkva where families preserved a narrative of antagonistic relations between Poles and Ukrainians during the war. Interestingly, some respondents in Ukraine understood the resettlement process as a political act of population exchange between Poland and Ukraine (or Poland and the USSR).

You of course know fully well that this whole resettlement business began in September 1944, when an agreement was signed between Bolshevik Poland and the Soviet Union that they would exchange populations in accordance with the borders that were in force then. And this process was supposed to take place on an exclusively voluntary basis, or in other words, those who wanted to return to Ukraine could go, and people who wanted to go over there, could go over there (Z33Bm).

Such an explanation of the reasons behind the resettlement did not appear even once in the interviews with residents of Krzyż. It seems that the deportation of Polish Ukrainians, as a second component of the resettlement process, simply has no place in their memories. Several reasons lie behind this fact. Krzyż residents who arrived from what is now Ukraine did not usually meet Ukrainian resettlers; they did not witness the Ukrainians' arrival in their former hometowns. Also, schools and media discourse in the Polish People's Republic omitted this question entirely, while after 1989, the issue did not become a topic of public discussion, unlike the later "Operation Vistula" of 1947. Instead of explanations that refer to official inter-state agreements, younger residents of Krzyż focused on the difficult choices faced by their parents. Such statements were most common among more introspective interviewees, those with a general interest in history, and people who grew up with a strong family tradition of memory preservation.

They felt Polish, it was difficult for them to leave. Mother says to this day that she opens her eyes at night, then closes them, and, she says, she sees the streets of [her hometown], she walks in those streets. [Were they forced to leave...?] Well the situation forced them to go to Poland, because after all, staying in a place that isn't your home country, is not an option for someone who has any kind of patriotic feeling... [...] That was the decision, even though it was painful, though it ruined their lives, because they were leaving everything and going into the unknown. The decision was to go to Poland (K2Bm).

Compared to older respondents, younger residents of Krzyż and Zhovkva appear more inclined towards categorical statements and naming of specific perpetrators. It is possible that this observation is a consequence of the structure of the interviews themselves: in conversations with the older generation, 
narrative description of the individual experience predominates, or in other words - borrowing terms proposed by Fritz Schütze ${ }^{148}$ - the interviewees supplied purely narrative segments, sometimes completely void of any theoretical consideration. Conversations with younger people were primarily comprised of argumentative units and elaborate theoretical consideration on short narrative segments. Another factor could be the greater feeling of security among younger respondents - neither in Zhovkva nor in Krzyż does the younger generation feel the sort of fear that might have prevented their parents and grandparents from directly naming perpetrators. Interviewees in both towns considered the Soviets to have been at fault for the plight of their families ("I don't remember exactly, I can't tell you in any detail, but I remember that it was the Soviet authorities that did it, not the Polish side" [Z4Dm]). At the same time, there was a reluctance to blame specific individuals for the resettlements; instead, greater political processes were responsible. In other words, laying blame on the Soviets did not mean that respondents held a distaste for individual Russians from the past, and even less so in the present. Having a temporal distance enables younger people to emotionally detach themselves from the assessment of the past, at least partially.

I know from what my great-grandmother told me that they don't really blame anyone in particular. What happened had to happen. But they are filled with pretense towards he government of that time, precisely because of this resettlement, they were afraid in these parts, afraid to move people here, and they were forced to live here, afraid that the Germans would come back and evict the population that lived here now, wanting to take back their land (K29Df).

I think that ordinary people weren't to blame for this resettlement. Because ordinary people lived side by side in peace, the different communities got on well, building relationships, and there were even marriages between the two groups, so ordinary people were not to blame. It was politics, it seems to me, it was the politics of Stalin and Hitler (Z18Bf).

In both towns, there was a contingent within the younger cohort who had little or no idea what the resettlements actually were. In Zhovkva this group was a little larger than in Krzyż; most such individuals were from the fourth generation, with a smaller number from the third. There were no instances of such lack

148 Fritz Schütze, Biography Analysis on the Empirical Base of the Autobiographical Narratives: How to Analyse Autobiographical Narrative Interviews, Part II, INVITE Biographical Counselling in Rehabilitative Vocational Training. Further Educational Curriculum. EU Leonardo da Vinci Programme (14 May 2018) http://www.zsm. ovgu.de/zsm_media/Das+Zentrum/Forschungsprojekte/INVITE/B2_1-p-140.pdf, last accessed 18.02.2019. 
of knowledge among the second generation, who were born shortly after the war. Respondents most often knew in general terms where their older relatives came from, but could not explain how and why they had arrived in Krzyż or Zhovkva; also, they could not repeat any family histories or anecdotes, and were unable to relate the fate of their family to the broader context of historical processes. It was also evident that they were simply uninterested in such issues.

My father came, he actually came from Kalush, that's somewhere in Ukraine. As to how he came here, well I think, that he, you know, emigrated to Poland (K15Cf).

Oh, I don't know, my mother was resettled too, my father was born in Poland, in the Chełm area or something like that. Then they came here, in like, I don't know, maybe it was the fifties or the sixties (Z17Cf). ${ }^{149}$

In other instances, respondents did not know which part of the generalized "East" their grandparents had come from, but they were able to reproduce family stories from everyday life, both before resettlement and during the migration itself.

[Where did your grandparents come from, Ukraine or Belarus?] You know, I don't even really know... [So why did they come here from Ukraine or Belarus?] How was it...? It was after the war and those resettlements happened, and they left everything over there, their house and farmstead. They owned a forest there, Granny told me, they also had a meadow and they came to Poland. I'm not sure whether it was from Ukraine or Belarus (K33Df).

Such statements are striking because of their ahistoricity - the fates of the grandparents are suspended for these speakers in a kind of timeless realm, and resettlement is not given any residual meaning. From the present-day perspective of these young people, it is something completely incomprehensible - "some kind of emigration," or "those resettlements." It appears that in both towns, such views on the resettlements were voiced by people with an insignificant interest in other aspects of family history, and also in history more generally. Perhaps it should simply be assumed that in any society and in any socio-political conditions, there would be a certain percentage of the population who are indifferent to the past - whether that means family, local or national history. Perhaps (especially in Zhovkva) the loss of interest in one's roots can be attributed to difficult material circumstances and political insecurity. Elżbieta Tarkowska refers to such temporal outlook as a "presentist orientation,"150 while Maria Lewicka argues in her analysis of attitudes towards the past that individual psychological

149 In reality, the interviewee's father moved to Zhovkva in 1947.

150 Elżbieta Tarkowska, Czas w życiu Polaków (Warszawa: IFiS PAN, 2005). 
traits can determine an absence of historical interest. ${ }^{151}$ At the same time it holds true that forgetting within a family, which is the organically closest sphere of influence on individual identity, precedes forgetting in all the other spheres. As Piotr Kwiatkowski argues, family memory is intimately connected with collective (social) memory; if memories cease to be preserved in the family - for a variety of possible reasons, from force of circumstance to intentional suppression - then they will also disappear from society at large. ${ }^{152}$

Meanwhile, memory processes were very different among people who migrated voluntarily, whether "pioneers" - i.e. those who arrived in Krzyż from central Poland, and people who came to Zhovkva from eastern regions of Ukraine and other areas of the USSR - or "neighbors," i.e. people who came from neighboring villages in both towns. If in the memories of people who were resettled, the journey plays a central role in their remembrance of the ordeal, individuals who migrated of their own accord place much less emphasis on this aspect in their testimonies. Although it happened that voluntary migrants underwent longer journeys to their new homes than "repatriates," and sometimes suffered equally bad or worse conditions of transport, they were frequently surprised that I should ask about the journey: it had not registered as an important or constitutive event, rather like an average act of moving house. In the second generation there were no received memories at all about the trip to Krzyż or Zhovkva. Accounts of the parents' or grandparents' arrival lack drama; they are matter-offact statements that often explicitly emphasize that there was nothing out of the ordinary in the experiences of the older generation.

We came to Krzyż in 1945, because granddad found a restaurant here, and he had worked in a restaurant. He had his own restaurant somewhere near Kraków - that is where I come from, from Kraków. He heard about this restaurant in Krzyż, that he could open it here, and that was when my whole family on my father's side came here (K25Bf).

The memory of voluntary migrants (and their families) convincingly shows the importance of the decision to move being at least partially one's own. A forced journey, being the final element in a sequence of violence, becomes embedded in the memory of deported individuals as yet another traumatic

151 Maria Lewicka, "Place attachment, place identity, and place memory: Restoring the forgotten city past," Journal of Environmental Psychology, Vol. 28, No. 3, (2008), pp. 209-231.

152 Kwiatkowski, “The Second World War.” 
experience that must be worked through. For voluntary migrants, the experiential baggage was already a little lighter at the stage when they moved to the new place.

\section{Fear, Violence, Poverty: After Arrival}

Whilst the strength of memories about the migration itself was differentiated above all by the extent to which the move was forced, the first period after arrival is remembered by all of the resettlers in both towns as an intense event. Some of these stories even took on an apocalyptic resonance, despite the amount of time that had lapsed. The reality with which the migrants were faced at their places of arrival was horrifying, in particular because scenes were still filled with traces of wartime violence.

What did I find in Zhovkva? The first thing I noticed, my first impression, was fear. My husband was waiting for me at the station, and next to it was a big park, which seemed so dark to me then, and next to the police building lay three dead bodies. That sight just made me shiver, it really shook me up. It was just... I said I was going home, that I was going back, I said I don't want to be here, there are murders happening here! (Z24Af).

The first moment I arrived in Krzyż [...] One of them [Russians] was drunk and he started to shoot, like he wanted to kill us. I remember the first words I heard in Russian: "Ochen horoshaia dochenka!" ["Very nice daughter!"] Someone from down below, one of those officers, was shouting that "a nice daughter" was coming. I was walking in front, and my mother behind me. And he was saying they shouldn't shoot because of the "nice daughter." We went down those stairs, and of course, right in front of my eyes, they shot that Russian (K23Bf).

For the new Polish arrivals, the town of Krzyż was not only unsafe because of the ongoing situation of war, it was also painfully foreign - and for that reason it seemed all the more oppressive and threatening. The migrants from the eastern territories and others who were not from Wielkopolska found both the space, saturated as it was with German influence, and the people to be foreign: often, the first encounters with human beings other than the staff of the railway were with Germans. Both the townscape and the German locals, who were negatively disposed towards the Polish settlers, made the newly arriving migrants feel even more insecure.

My father went to the town here in Krzyż, and I went to have a look around. [...] A German woman was in the window, and when she saw me, she shouted: "Polnische Schweinerei!" ["Polish scum!"] That's how she welcomed me here - because there were some Germans left here. I'm not surprised they reacted like that, because the 
deportations of Germans had already started - you know what that was like - but it was still an unpleasant experience. "My first time in Krzyż," I thought to myself. "What a nice welcome" (K17Am).

In the Zhovkva testimonies, on the other hand, a sense of foreignness was not a major thread of memories about the initial period; there are also no stories about contact with Poles. This is easy to explain, because the largest group of new residents of Zhovkva - Ukrainians resettled from Poland - did not overlap with the Poles who left the town. Moreover, the urban landscape of Zhovkva may have seemed different to some (especially those who arrived from Soviet Ukraine and Russia), but in such cases it was usually welcomed as a pleasant surprise.

Another feature that is specific to the interviews in Krzyzi is a sense of relief that was felt after arrival, often mixed in perplexing ways with feelings of fear, insecurity and nostalgia. ${ }^{153}$ Such contradictory emotions were experienced primarily by migrants from the East who had left regions affected by Polish-Ukrainian conflict; on the one hand, they felt all of the anxieties of other resettlers, and on the other, they were happy that the troubles of the recent past were now behind them. ${ }^{154}$

Once we were here in Poland, we had finally arrived, and we slept so soundly that we couldn't get up [laughter], we didn't need to eat, we didn't need... [...] Here we had peace, quiet, and over there it was such a tough life, that we never thought we would survive it, but somehow God helped (K20Af).

It might appear that there would be no shortage of Ukrainians resettled from Poland who would similarly breathe a sigh of relief upon arriving in a new place after their difficult wartime experiences. However, the Zhovkva testimonies contain no such statements. Perhaps the Ukrainian migrants found it hard to sleep soundly in unfamiliar Polish and Jewish homes. The more likely reason, however, is that the first post-war years in Zhovkva were so arduous and insecure, in

153 In his study of the post-war period, Frank Biess argues that the three dominant emotions were fear, hope and resentment, see: Frank Biess, "Feelings in the Aftermath. Towards a History of Postwar Emotions," in: Histories of the Aftermath. The Legacies of the Second World War in Europe, ed. Frank Biess and Robert G. Moeller (New YorkOxford: Bergham Books, 2010), pp. 30-48.

154 The emotional state of this group of respondents can be compared to what Hanna Malewska-Peyre, in relation to ordinary migrants, calls the "emigrant's honeymoon period:" this is a period when positive emotions dominate in the perception of the new place, partly triggered by a comparison of the new home country with the old one, see: Hanna Malewska-Peyre, "Ja wśród swoich i obcych," in: Tożsamość a odmienność kulturowa, ed. Paweł Boski, Maria Jarymowicz and Hanna MalewskaPeyre (Warszawa: Instytut Psychologii PAN, 1992), pp. 15-70. 
comparison to Krzyż, that they did not register in my respondents' memories as qualitatively very different from the war period.

A theme that is indisputably common to both towns is the strenuous, piecemeal construction of a new life upon arrival, above all in its most elementary and everyday dimensions. Many people spoke about the difficulties they experienced in finding a house or apartment, having to wander from homestead to homestead, and sitting in the station for weeks whilst waiting for help that had been promised by the state. Another recurring theme is unwillingness to live in someone else's house ${ }^{155}$ - these people who had just been expelled from their own homes were now being offered to settle in properties that lay empty (or were about to be emptied) after similar evictions.

We came here, to Zhovkva, and how much time did we spend at the station, on the platform? Three weeks. And they sent us here and there, here and there, on wild goose chases. We went to Dobrosyn [a village near Zhovkva], and in Dobrosyn the people had been deported to Siberia, and only some young girls were left. They were crying, walking around this house that we were supposed to get... I said, "I don't want this house, it's full of tears" (Z18Af).

In Krzyż, when we arrived [...] we didn't have a place to live, because in these houses here there were still some German women who lived in them. And they sent us to school [...] When J. [respondent's sister] and I were a little older, we used to ask our father why he chose such a shack to live in [...] And he would always say: "there were German women living everywhere with their kids, and I wasn't going to evict them” (K32Bf).

Everyday problems were severest for forced migrants, who had been torn away from their home territory and were now at the mercy of new authorities; the state, however, was often barely interested in the fate of these new arrivals. Even today their testimonies contain tones of embitterment and a feeling that they were deceived and abandoned by the state.

This West was made out to be some kind of Mecca, like it was something new, that everything would be waiting for us here. That's what they used to say, that those [eastern] territories were given away, but that these "Recovered Territories," as they called them then, would be compensation. And some kind of paradise was supposed to await us here. But it was no paradise! There were houses, there were apartments - but we had to do everything ourselves. There was no one here waiting for us with open arms (K17Am).

At the same time, complaints about lack of assistance from the state were also heard from a number of Poles who moved to Krzyż from central Poland and Wielkopolska, under the centrally organized scheme for migration to the 
"Recovered Territories." Tempted by the promises of the poster campaign, when they arrived they had to go to considerable lengths to ensure their own survival, and then spent years repaying state loans. One interviewee bitterly underlined that "we didn't get anything for free here" (K27Af). Between the lines of such statements, it is possible to discern a conviction that these resettlers were duped, and also that other groups of migrants - in this case those resettled from the prewar eastern provinces, who did not have to pay the local authorities to obtain land in the "Recovered Territories" - received a better deal. Interestingly, however, such a conviction of being "the biggest victims" is shared among practically all of the different groups of settlers in both Zhovkva and Krzyż, irrespective of their objective situation. Whereas the Poles from central regions complained about material difficulties, those from the eastern regions of pre-war Poland believed that "Poles from Poland" (i.e. from within the post-war borders) had adapted most easily to life in the new town - above all because they unscrupulously commandeered German property that had been earmarked for the eastern Poles. In Zhovkva, on the other hand, mutual incriminations were forthcoming most often between Ukrainians born in the town or its surroundings (the "neighbors,") and those deported from Poland. The former argued that whilst they had huddled in ruined houses after the war, the new arrivals always received accommodation from the state.

Ukrainians did not go there [to houses abandoned by Poles]. Firstly, no one invited them, and secondly, they wouldn't have had any business there. I mean Ukrainians as in people born here. Because those who arrived from Poland, they always found [a house] one way or another (Z36Af).

Meanwhile among younger respondents, stories about the difficulties experienced in the first phase of adaptation featured rarely as fully fledged topoi of memory. Interviewees born in the 1940s and early 1950s (the second generation) did speak about post-war poverty, but treated it as something obvious and characteristic of that period, rarely making connections with the fact of migration. The few testimonies that did link material difficulty with resettlement were given exclusively by the children ${ }^{156}$ of forced migrants - reinforcing the additional

156 Children in general were much more vulnerable to the postwar poverty and insecurity, see: Heide Fehrenbach, "War Orphans and Postfascist Families: Kinsship and Belonging after 1945," in: Histories of the Aftermath. The Legacies of the Second World War in Europe, ed. Frank Biess and Robert G. Moeller (New York-Oxford: Berghahn Books, 2010), pp. 175-195. 
strain of this type of migration. Most probably, these families did indeed suffer more in comparison to others.

We had to start everything from scratch. Over there we had something, a house from our parents at least. But here, we had to build everything all over again. And it was tough for sure: children, everything. It was very tough; I remember that alright, we were poor, just poor (K20Cf).

You know, it's not as if the people who came here were poor and had nothing. The people who came here were landowners, who had everything, everything. And they came here and they had to work for others. They went to work as laborers. You know how hard that was? [...] And in that whirlwind after the war, they were also... There wasn't much to eat (Z18Bf).

Similarly to the memory of the resettlement process itself, memories about the first phase of adaptation are richer and more abundant in the Krzyż testimonies. Two themes that stand out are looting and the town's poor state of repair; ${ }^{157}$ both issues are perceived by respondents as key factors that made settling into the new place difficult. ${ }^{158}$ The perpetrators of looting were identified unanimously as residents of the villages surrounding Krzyż. Poles resettled from the East were particularly vociferous in their criticism of this specific post-war form of "enterprise:"

Drawsko [a Polish village on the other side of the Noteć river] did well for itself, they did well for themselves. I remember, there are some people who are still around, they took away the property of Germans, they took those beautiful German embroidered sheets, and they would wash them and hang them out to dry. But now they're gone, those linens, as if they never existed [i.e. the speaker suspects that people did not take proper care of them]. They were beautiful German embroidered sheets, you know? And now they're gone. It was a long time ago. They had nothing then, and they have nothing now (K31Af).

Interestingly, younger respondents spoke of post-war looting with an even greater sorrow than the older people, irrespective of their family background. If the older generation's accounts centered on their own personal grievances, younger residents displayed a more civic attitude to the issue: they treated the phenomenon as something that diminished the present-day potential of Krzyż and impoverished the town. Accounts by people with an active interest in the

157 On looting in Poland during and immediately after the Second World War, see: Marcin Zaremba, "Gorączka szabru," Zagłada Żydów, Vol. 5 (2009), pp. 193-220.

158 On looting in the "Recovered Territories," see: Halicka, Polski Dziki Zachód, pp. 199202; Service, Germans to Poles, pp. 88-89. 
German history of Krzyż are characterized by a particular grief, and sometimes also sarcasm; for instance, one such person told me in an unrecorded interview that he had always wondered which houses in Drawsko were still hiding the German clocks and porcelain stolen from Krzyż, which the Polish "village folk" were still unable to appreciate.

Not many people admitted to taking part in looting - as a rule, the Krzyż residents who had lived in the region before the war insisted that everyone had looted, but that their own family did not participate. ${ }^{159}$ The few who openly admitted to plundering goods always placed their statements in a specific context, pointing to the carnivalesque atmosphere of the post-war period, in which the boundaries of the permissible were significantly extended. Theft of German property is conveyed in these testimonies as the frivolous indulgence of youths who have unexpectedly encountered freedom; such actions, it is implied, should not be judged seriously, according to any standards of moral responsibility.

When he [a German from Krzyż, for whom this interviewee had worked] left, I started to look for a bicycle, we found some gramophones and things, various things, there were lots of us, scoundrels. At that time we took whatever we could find, and I had about fifteen bikes in the attic. Then someone tipped off the Russians and they came by. They took all of the bikes (K11Am).

The carnivalesque slackening of moral norms and suspension of reality between the old and new worlds are poignantly conveyed by the testimony of a man who arrived in Krzyż as a twenty-year old, to work on the redevelopment of the railways. Post-war Krzyż appears in his account as a kind of Polish Wild West, in which diverse characters interact, and where local residents strive to acquire as much gain from the situation as possible. ${ }^{160}$ The man still remembers this time with a sense of reverie, although this sentiment is also mixed with a certain embarrassment:

In 1945 there were more bars than anything else in Krzyż. There were five or six of them. Because all of those looters came from Warsaw or wherever, and the first thing they did

159 This is a fairly typical narrative strategy for events that are now seen as amoral or are simply not accepted; the speaker can recall the event without taking personal responsibility, see: Aleida Assmann, Der lange Schatten der Vergangenheit. Erinnerungskultur und Geschichtspolitik (München: CH Beck, 2006), pp. 169-182.

160 Julita Makaro has written about many institutions, often of dubious repute, that characterized the typical townscape in the "Recovered Territories," for the example of Gubin, see: Julita Makaro, Gubin - miasto graniczne. Studium socjologiczne (Wrocław: Wydawnictwo Uniwersytetu Wrocławskiego, 2007). 
was... There was even a hotel here, so they could have a rest. [...] And they spent a day acclimatizing and went on further to plunder, and later they came back here and went their separate ways. [...] You could get anything here. Dollars, girls, food, and a place to sleep. [...] And they all drank, both the Russians and the Poles (K2Am).

The carnivalization of life in Krzyż was sometimes amusing, but on the everyday level it was certainly also a burden, because it strengthened the sense of insecurity and being under threat. People lived on a minefield - both in a figurative sense and literally. After its destruction by the Soviets, the town was on a slow road to recovery, and the necessity of contributing to the rebuilding process was an additional strain for many residents. ${ }^{161}$ However, the post-war reconstruction of Krzyż also features in many accounts as a patriotic deed, which released the best emotions and energy in people and cemented a new sense of community.

When we arrived, we had to do everything from scratch. Above all - I remember for example that we, the scouts, signed up to remove debris [...], the bricks had to be transported to a square somewhere, and we were told that those bricks would go towards the reconstruction of Warsaw. There was this great goal: all of society was building its capital city. ${ }^{162}$ Later it turned out that these bricks were going to [the village of] Drawsko, and to all kinds of other places for other building projects, and the whole communal effort was wasted. [...] But obviously, people didn't complain, because all of that was necessary (K17Am).

The theme of sincere post-war enthusiasm is also present in interviews with younger people, especially in families that preserve a tradition of telling stories about wartime and post-war experiences. The following statement, for example, shows the genuine pride of a son towards his father's commitment to rebuilding the town of Krzyz:

In 1945, when Krzyż found itself on the Polish side, we gained independence here as the "Recovered Territories," and they started to launch rail connections. [...] There were

161 Statistical data gives a good idea of the scale of destruction in the "Recovered Territories." As Czesław Osękowski shows, post-war destruction affected $97 \%$ of the railway rolling stock, $70 \%$ of river bridges, $63 \%$ of the railway lines, and $27.5 \%$ of agricultural estates, see: Czesław Osękowski, Społeczeństwo Polski Zachodniej $i$ Północnej w latach 1945-56 (Zielona Góra: Wyższa Szkoła Pedagogiczna im. Tadeusza Kotarbińskiego, 1994).

162 "The Whole Nation is Building its Capital City" ["Cały naród buduje swoją stolicę"] was one of the propaganda slogans of the early post-war years in Poland, emphasizing the contribution of all Poles to the reconstruction of Warsaw after its destruction by the Germans. This phrase is still visible on a building from that era in the center of Warsaw. 
announcements in Poznan, my dad told me, that they needed people to work on the railways. He was 18 years old then, in 1945. He got on a train and went. Those were the times when he was practically one of the first, although he wasn't the most important person. He had no idea about railways (K2Bm).

Despite their awareness that lofty ideals often were not matched by reality, both of the above respondents expressed the idea that participating in the reconstruction of the town was a formative and bonding experience (or, for the second-generation interviewees, the received memory of this deed had a similar value); it contributed both to personal identity and to the creation of bonds between the new residents of Krzyż. Such statements are abundant in the Krzyż testimonies. It is striking that people in Krzyż saw participation in reconstruction as a positive experience, whereas Zhovkva had no such opportunity. In Krzyż, memories about the difficulties of the first phase of post-war adaptation are offset by a joy at building a new homeland - both the new regional home in western Poland, and the greater ideological home of the nation, for which bricks from the debris in Krzyż would be sent to Warsaw. Even when the brick turned out to have been "wasted" and those bricks went to Drawsko, the effort itself strengthened a feeling of community among the new Krzyż residents and allowed people to experience their own agency, at least at the local level. The new people of Zhovkva, meanwhile could not benefit from an equivalent endeavor. The town of Zhovkva did not suffer as much during the war, which was of course a positive circumstance. But it did mean that the lack of a formative phase of reconstruction was another lost opportunity for the building of social bonds. Whereas in Krzyż in the first post-war period, people were united in their hope for a new reality (not necessarily in a political dimension), in Zhovkva the totalitarian regime consigned the community to enforced passivity from the very beginning. ${ }^{163}$

In both towns, the first phase of adaptation was accompanied by a sense of threat. ${ }^{164}$ This was connected above all to the militarization of everyday life and

163 Zdzisław Mach identifies the necessity and possibility of independently organizing social life as one of the conditions of successful migration, see: Mach, Niechciane miasta.

164 The existing literature points to the feeling of being under threat (including by the presence of and behavior of Soviet soldiers) as one of the most significant factors that destabilized resettled persons in the "Recovered Territories" in the first years after the war, see: Janusz Chumiński, "Czynniki destabilizujące proces osadnictwa we Wrocławiu (1945-1949)," in: Studia nad procesami integracji i dezintegracji społeczności Śląska, ed. Władysław Misiak (Wrocław: Wydawnictwo Uniwersytetu Wrocławskiego, 1993), pp. 55-78. 
the organization of social space - in the immediate post-war period, the Red Army was in charge in both places, and this fact was tangible on an everyday basis. Residents of Krzyż and Zhovkva recall shootouts, brawls and bust-ups being caused by Red Army soldiers. Memories about the first weeks and months in both towns are distinguished by an extreme sense of insecurity, including in one's own house. Respondents recalled that they were constantly afraid of being attacked: by Banderites, ${ }^{165}$ Ukrainians, Moskals, Red Army soldiers or simply ordinary bandits. ${ }^{166}$

The worst thing was, when it started to get dark, I was scared. My husband and I, we were scared, and we blacked out the windows. [What were you afraid of?] That the Germans would come and murder us right here. I was scared, honest to God. I kept listening out to see if it was quiet. The nights were almost sleepless, because we were so afraid. [...] And [we were afraid of] criminals too, there were various people from the East, and maybe they were even worse than the Germans (K27Af).

I still remember how people walked around our house. They had these long cloaks, these bloody enormous coats. Their hands and arms were completely covered up. There, where we have our garden now, just before the forest, that's where they would come out of the forest, and they would walk around our garden. [...] And we would straight away sit still, closed up inside, and that was it. [So you were afraid of them?] Well yes, for sure. Because who knows who those people were and what they were up to $(\mathrm{Z} 12 \mathrm{Bf})$.

Both fragments illustrate not only a constant state of fear, but also mutual distrust - different settlers were mindful of each other, often not even wanting to find out who really was walking in their garden. These perceptions of new neighbors signal the extent to which mutual prejudice was prevalent; this was one of the greatest obstacles to the building of social bonds in the new community. In the majority of interviews, everyone but the most narrowly understood

165 In this and similar contexts, residents of both towns use the word Banderites to refer not just to supporters of Stepan Bandera (who, at the point in question here, had long left Ukraine and had little real direct influence in the country), but more generally to all of the diverse underground movements of Ukrainian nationalists.

166 Marcin Zaremba argues that fear of attacks by criminals was one of the most common emotions in Poland in the immediate post-war period. There was a particularly heightened tension in the "Recovered Territories" and in places with a large concentration of Red Army personnel in important transport hubs - such as, for example, Krzyż. It was also common in the "Recovered Territories" for different groups of settlers to be mutually suspicious of each other, such as "repatriates" from the East and other Poles, see: Marcin Zaremba, Wielka Trwoga. Polska 1944-1947. Ludowa reakcja na kryzys (Warszawa: Znak, 2012), pp. 157, 316, 330. 
in-group was seen as a potential enemy in the initial period. Stories about fear of diverse "bandits" are mixed with feelings of alienation and loneliness, of a need for self-reliance; in time, the constant sensation of surrounding enmity could result in withdrawal and conscious self-alienation:

Different things were going on here. [...] You don't know... I can't tell you ... It was a time when they were closing the Greek Catholic churches and turning them all into Orthodox ones. They didn't want them... Different things were happening here. People were so angry. The Banderites were everywhere. There were... there were the Red Epaulettes ${ }^{167}$ the Red Army, and... It was awful. But I'm telling you, we didn't understand anything, didn't see anything, nothing... (Z16Af).

The universal feeling of fear affected all the new arrivals equally, including those who belonged to the privileged social layers, of whom others were most afraid such as the Soviet "pioneers" in Zhovkva. Whereas autochthonous locals and Ukrainians resettled from Poland trembled before the ruthless "party" officials and "political" comrades, the wives of the communist functionaries traveled to work in fear, convinced that they were always being watched by the local population.

I trembled every night when I was on duty. Because there would always be some Russian chairman in one of the villages or in a different district, and he was bound to be tracked down, and we were bound to receive a corpse in the end. There were such cases. I don't remember anything else about those incidents. The Banderites were active, but what kind of Banderites? They would capture people, track them down, kill them, and later bring us a dead body (Z26Af).

Despite the enormous objective differences in the experiences of Ukrainian resettlers and the wives of party dignitaries, there are striking similarities in their inability to place themselves in the new reality. The woman cited above stated with a disarming sincerity that she had, and still has, no idea why whole villages around Zhovkva had been emptied out after the war: "That was my job I worked in the hospital. I only did good to people, and I am totally incompetent when it comes to those other issues" (Z26Af).

Although various groups of Zhovkva residents were similarly afraid of unspecified things and people, declaring an ostentatious disinterest in the threats that were encircling their houses, the reasons behind their attitude were different. This characteristic detachment from reality has its roots not in real lack

167 The respondent probably means the functionaries of the NKVD, who were informally called the "Red Epaulettes" [krasnopogonniki] because of the decoration of their uniforms. 
of knowledge, but in a deep-seated conviction that this is the only strategy that will provide protection from further repressions. The ignorance of the women representing officialdom shows that they lived in a completely different world to the Ukrainian resettlers, not knowing how the locals lived and died - often at the hands of their own husbands. Such statements prove that the integration of Soviet newcomers with the rest of Zhovkva society was superficial at best, notwithstanding their heated assurances that, with time, they had grown to enjoy living in Zhovkva in peace and prosperity.

A final significant difference between the testimonies in Krzyż and Zhovkva is that the latter contain no elements of humor. Residents of Krzyż today are capable of talking about the post-war carnival with certain ironic distance, if they did not suffer a grave personal loss during this time.

We went to this town, this German town. What would it look like? [...] There was someone shouting: "Hey! Washing powder, there is washing soda!" "Where?!" And he says: "Over there by the church." [...] We hadn't seen washing powder for ages. It was tough, everything was dirty, because we had traveled for about ten days. And we go in, and there is whole courtyard covered in feathers: "What on earth? Where is the powder?," we shout. "In the feathers! You have to look for it!" So we completely covered ourselves in feathers and dug around in there. It turned out that the soldiers who were leaving had unstitched German bedding to look for hidden treasures [laughter]. And the whole courtyard was covered in feathers. And we, repatriates had feathers all over us as we looked for soap! We searched, and we had paper bags, and we collected feathers on our bodies and soda and soap in the bags. We did find some treasures though! (K17Af).

Such stories are practically unthinkable in the Zhovkva context. The difference in respondents' emotional distance towards the events they describe is striking. People in Krzyż remember moments of danger in the past tense, not only in terms of grammar, but also in their emotional attitudes. Zhovkva residents to this day speak in hushed tones when recalling people walking around in their gardens, and humor is the last thing they would associate with the reality of the 1940s.

\section{Yearning, Temporariness, Alienation}

In his book Unwanted Towns [Niechciane miasta], Zdzisław Mach compares migration to a rite of passage and, adopting and modifying the classic theory of Arnold van Gennep, distinguishes three phases of the migration process: separation (exclusion stage), liminality (marginal stage) and aggregation (incorporation stage). ${ }^{168}$ The first period of adaptation for the migrants in Krzyż and

168 Cf. Mach, Niechciane miasta. 
Zhovkva - especially for forced migrants - was a liminal phase, a time of transition, in which individual subjectivities were suspended; they had not severed their ties with the old home, but were yet to create a bond with the new one. For the vast majority of respondents, the most important emotion associated with this period was a feeling of longing. Interviewees remembered that for a considerable amount of time, they lived with what they had left behind. Although the feeling of yearning was universal for all settlers in both towns, different groups of settlers in fact longed for different things. Poles from the eastern territories spoke above all about their native town or village and the area they saw as their "small homeland," and also about the specific regional Polish identity that they could not take with them to the West. Ukrainians resettled from Poland missed their homes, understood as their own pieces of land that had belonged in the family for generations - together with the surrounding neighborhood, these homesteads comprised the "native land." Eastern migrants in Zhovkva spoke relatively little about their feelings of yearning. When related themes cropped up in their testimonies, they spoke less of their former houses and places of residence than about a certain type of social and political bond. No one missed the stern totalitarian system of the Soviet 1930s, but several people recalled a certain nostalgia for the Soviet culture of "equality" and "cosmopolitanism." Such statements were especially prominent in the accounts of individuals whose relations with the local population later became strained.

The whole time the children were small, I felt a real yearning for home. [...] Our people over there are better, there's no Nazism over there. When my son-in-law learned that I am a Pole, and that we have Polish roots, he said to my daughter: "I would never have married you if I had known you were Polish" - that's what he said. And I laughed and said: "Well it would have been a great loss" [laughter] [...] At home that would have never happened. We had different ethnicities living together. [Was it difficult for you to get accustomed to the life in Zhovkva?] Yes, very, very difficult. Every part of me was splitting inside, every part of me wanted to go home (Z10Af).

Whilst forced migrants described their nostalgia in more acute terms, there were also instances of people who moved voluntarily - at least in theory - speaking with longing about their old homes. This is illustrated by the accounts of a mother and son, whose family came from the area surrounding Warsaw, which was in ruins after the uprising, ${ }^{169}$ to Krzyz in search of better living conditions. The transgenerational dialogue also allows a comparison between the memory of

169 The Warsaw Uprising was an armed insurgency against the German occupation, led by the Polish Underground State, which began on August 1, 1944. In its aftermath, the Polish capital city was largely destroyed (in districts where fighting was most intense, 
a woman who experienced resettlement as an adult, and a man who left his first home as a young boy. The nostalgia of the mother is despairing and filled with agony, whereas that of the son is more akin to a mild nostalgia that mythologizes the native territory as an Arcadian land of childhood innocence. The mother is riven by a desire to return; the son is satisfied with reminiscence.

How many tears I shed, how much health I lost, because of the fact that I had to come here. Here, everything was foreign, everything was wild, everything was so empty, and I couldn't cope with it. It was like, we arrived at this house and, dear Lord, it was a complete ruin... (K27Af).

I remember that I missed home, even as a small boy... I remember the stream, the alley of willows, that big forest we used to go to. And under the hill, I used to play there as a child and I remembered that quite often. And how we sang "Warsaw my Warsaw" ["Warszawo, ty moja Warszawo"], quite often, and how it made me feel comfortable inside; I sang that song a lot as a child, about that Warsaw of ours (K27Bm).

Of course there were also respondents who did not recall feeling any sense of yearning for their former places of abode in the immediate post-war years. However, among the several dozen interviews in both towns, these were only a handful of individuals. These respondents came from different groups of settlers; absence of nostalgia was therefore not correlated with a migrant group. Level of education was also not a factor. It appears that the decisive trait was rather a certain type of sensitivity and ability to construct a deep emotional bond with one's place of residence. Respondents who claimed that they never missed home were more prone than others to commenting on material conditions, and they perceived resettlement exclusively using the pragmatic categories of social and economic gain and loss.

[You didn't miss home?] No, no, why should I? [Well you said that you had your own field and...] Yes I said that, but what would we have done there? Work in the kolkhoz? Never in my life! I used to work in Mir [a town in today's Belarus] in a bakery, but never in a kolkhoz. My mother did, she worked there, because what else was there for her? But my brother also refused to go. He was in the military, he came back, and we left straight away, as soon as he came back from the army. What were we going to do in the kolkhoz? (K33Af).

A second dominant emotion that yet more strongly underlines the liminality of the first phase of adaptation is a feeling of temporariness, of impermanence. ${ }^{170}$

up to $90 \%$ of buildings were ruined). Approximately 200,000 peple died, and many thousands of Polish survivors left the city permanently after the event.

170 Cf. Głowacka-Grajper, Transmisja pamięci, pp. 189-190. 
This is partly an extension of yearning for the home that had been left behind, whereby people were inclined to believe in a quick return home and to resist accepting the changes that had affected their lives. Another factor that contributed to this feeling was a belief that the post-war political reality was not final, and that the state borders would revert to their pre-war alignments. Almost all of the forced migrants (and a significant part of the voluntary settlers, with the notable exception of the Poles from nearby western regions in Krzyż) claimed that they were convinced for many months - sometimes even years - that they would not remain in Krzyż or Zhovkva permanently. ${ }^{171}$

To begin with - after all, no one knew anything about what would happen to us, who would come, whether we were in Russia or whether it would be Poland. [...] People always said in 1945 that "Anders ${ }^{172}$ would arrive on his white horse and we would all go back to Lwów." Everyone from the East had this hope [...], that this whole history of Europe, those wars, all of that would somehow change, and the Russians would leave, and those lands over there would return to us (K3Af).

What were people's attitudes then? That we would "stay here for another year, we won't stay long." [Did you think you would go back?] Yes, we believed we would return home. [...] It was the politics of that time that the they [the Poles] would come back to reclaim their houses, that they would somehow punish people, those owners. There was a fear around. I chose not to take this building, I told you about that Polish woman. [...] I bought it in the end, officially, all above board, and now I am not afraid of anyone here (Z33Am).

As the second quote shows, the feeling of temporariness was often combined with a fear of the return of previous homeowners. ${ }^{173}$ Although the authorities

171 There was a specific group of respondents whose sense of instability and temporariness was heightened by a fear of being forced to go back. These were just a few individuals whose lives in their old homes had been especially difficult and arduous. These interviewees were also affected by rumours of the imminent downfall of the post-war order, but unlike the majority of others, they did not look forward to this eventuality.

172 Władysław Anders was a Polish military commander and politician, who during the Second World War led the Polish Second Corps and was the Commander-in-Chief of the Polish Armed Forces in the West. He lived in exile after the war. In the first post-war period, many people believed that he would work with the Allied forces and Polish divisions that had remained in western countries to regain the eastern provinces that had been ceded to the Soviet Union.

173 Many publications, by both historians and sociologists, show that temporariness was a common experience among "repatriates" from the East (see the works by Andrzej Sakson, Andrzej Brencz, Czesław Osękowski, Wojciech Łukowski, Zdzisław Mach and Beata Halicka). Research on other deported people confirms that this was a universal 
used various means to persuade settlers that there was no such threat in reality, people were still afraid. Many people therefore tried to "legalize" and "ensure" their ownership of the homes they had occupied, by gathering appropriate documents or by simply buying the property without the mediation of the state.

My father was so precautious that as soon as he moved here, we lived here for a bit, and he made arrangements to buy the whole house [...]. And it's paid up, in the ownership deeds, everything is organized in such a way that the Germans can't come back (K15Bf).

It was not only the individuals who migrated who felt longing for the old; successive generations, who were born in Krzyż or Zhovkva, were also affected by these emotions. For members of the second generation and a part of the third, the sense of impermanence became one of the most important and intense memories from their childhood, often shaping the life of the entire family; it was an oppressive post-memory. Almost all respondents now in their sixties and seventies mentioned the ever-present sense of insecurity and their parents' constant mental harking back to a distant home. The ubiquity of a long-time inability to part with an old life suggests the strength of these emotions. People who were born in the new place spoke about a yearning that sometimes abated somewhat, but never vanished entirely. There was a recurring theme in the interviews of living in suitcases and being always ready to move back:

When my parents arrived, they said that the buildings were all empty and everything was closed up. We had everything, furniture, crockery, but my parents said that none of this was ours, that we couldn't just move into someone else's house, maybe we'll go home in two weeks or so. Maybe things will normalize and they will tell us that we can go home. It wasn't like we had arrived and we were going to live here forever (K26Bf).

I know that my grandmother, my mother's mother, was also moved here from Poland, and she used to say that they always thought that they would go back there. That she didn't even bring many things with her, that her mother had stayed behind, saying that "you'll come back here." They thought it was temporary, that they would still go back, and be home again (Z6Cf).

The sense of temporariness affected all aspects of life, disrupting it in a variety of ways. The suffering of parents are often stretched to grotesque proportions in the memories of descendants - one person remembered a large suitcase that belonged to their grandmother and was never put away in the attic, while

feeling throughout this part of Europe, see Alexandra Wangler's work on the Lemkos deported to North-West of Poland in 1947: Alexandra Wangler, Rethinking History, Reframing Identity. Memory, Generations, and the Dynamics of National Identity in Poland (Wiesbaden: Springer VS, 2012). 
another recalled that their grandfather missed out on a place in the local cemetery because the family refused to believe that he would not find his final resting place in his former hometown in eastern Poland, and failed to make the proper arrangements.

The sense of temporariness that resulted from anxiety about the Germans returning is also carried into the memories of the younger generations. Whilst they insist that they themselves have no fear of former inhabitants coming to claim their properties, they remember well the anxiety that their parents' generation suffered in their childhood. Interestingly, even the youngest generation, of people born after 1989, spoke about this feeling: "They were afraid when they moved here that the Germans would come back and push out the people who had moved into these territories, trying to reclaim their land and their houses" (K29Df). A fear of the Germans is also still alive, to an extent, in the younger generations, although it is usually expressed as a mediated emotion - neighbors and friends are afraid of a German invasion, but we ourselves take this fear with a pinch of salt.

[Were your parents afraid of the Germans coming back?] I think everyone thought about this. And not only in my parents' generation, because even in my generation, when we started to build our house, I met people who told me "you know, I would never build a house on this side of the Noteć [river]" (K30Cf).

It is worth noting that statements about insecurity, especially connected to the potential return of former landlords, were found much more frequently in the Krzyż interviews than in Zhovkva. The second and third generations of new residents in Zhovkva remember the fears of their parents from their own childhood, but these sentiments have a smaller bearing on their daily lives and consciousness. Not one person suggested that their parents, let alone the speakers themselves, were afraid of the Poles returning and repossessing their homes. An important factor here is the effect of propaganda fed to the first generation of people born in the "Recovered Territories" and "timelessly Ukrainian Galicia." In Krzyż, as everywhere else in the formerly German areas of Poland, the authorities intended both to persuade people of the Polishness of the territories in which they were settling, and to maintain a state of tension by constantly emphasizing the threat of German revanchism. ${ }^{174}$ Even if people did not take these messages

174 Cf. Jakub Tyszkiewicz, "Communist Propaganda in the German Provinces Ceded to Poland," in: 1945: A Break with the Past. A History of Central European Countries at the End of World War Two, ed. Zdenko Cepic (Ljubljana: Institute of Contemporary History, 2008), pp. 91-100. 
at face value, they must have nonetheless been affected by them at some level, especially if they were children at the time. ${ }^{175}$ In Zhovkva, state propaganda had a diametrically opposite objective - the authorities were also keen to emphasize the historical Ukrainianness of the area, but because of the doctrine of socialist friendship between nations, Polish revanchism was never used as a tool of persuasion. The Soviet state, after all, had much more effective means of control.

The feeling of insecurity and instability also contributed to a reluctance to invest in the inherited space. If such attitudes were less common in Zhovkva, because of the relative absence of anxiety about the return of the Poles, in Krzyz they were almost ubiquitous. Spacious German houses were only partially used, refurbishment was not carried out for years after the war, and farming premises and machinery were also allowed to deteriorate. Characteristically, it was the younger respondents who tended to observe this tendency the most, and especially those who had no roots in the East; the first generation either did not remember these events or did not want to remember.

There was a big influx of people from the East. It was about 1946 that they all came. Maybe they were more scared than the rest of us that they could be driven out at some point. [...] For a certain time, about 12 or 15 or even 20 years, there was no proper investment in the farms. No one was really investing. There were even cases, I know, when a roof started to need repairing, and it wasn't repaired. Some houses just collapsed by themselves. [...] Because after all, we were here, but nobody knew how long we would be staying $(\mathrm{K} 37 \mathrm{Bm})$.

It appears that temporal distance allows younger respondents to more calmly and objectively assess the processes by which the new residents of Krzyż gradually set roots in the town. In their statements, understanding and empathy for the fears of their parents and grandparents is mixed with a certain regret at the damage that was done as a result of this behavior.

Another factor that made adaptation difficult for many settlers was the foreignness of the geographical surroundings, the economic conditions, material culture, and climate. ${ }^{176}$ Resettlers did not only have to deal with the

175 For the ideologization of education and schooling in the Stalinist period, see: Kosiński, O nową mentalność.

176 Andrzej Brencz has written on this issue, using the collective category of "cultural landscape" [krajobraz kulturowy], see: Brencz, "Oswajanie niemieckiego dziedzictwa kulturowego." Beata Halicka employs the term "cultural familiarization" [kulturowe oswajanie]. Similar findings in the context of comparative reserch on Polish and German resettlers were proposed by the German historian Philipp Ther, in: Philipp Ther, "The Integration of Expellees in Germany and Poland after World War II: A Historical Reassessment," Slavic Review, Vol. 55 (1996), pp. 779-805. 
straightforward issue of arranging their material lives in the new place; they also, above all, had to go through a process of cultural adaptation, understood as a holistic process of changing one's symbolic universum. ${ }^{177}$ Krzyż residents originally from the East were affected most of all; Poles from central regions more rarely. Issues of cultural and geographic difference do not feature in the testimonies of Ukrainians resettled from Poland to Zhovkva; in their case, the change was objectively small, with a move of a few dozen kilometers meaning essentially the same climate, architectural styles and agrarian organization. There was no such problem, for similar reasons, for the Poles who came to Krzyz from the neighboring areas. Soviet pioneers, on the other hand, had been prepared for the worst, with stories of "wild Banderaville" and awful living conditions in western Ukraine influencing their expectations. Thus, if the conditions they found in Zhovkva were surprising, it was often a positive surprise, and feelings of foreignness were less prominent. For the embittered and mournful eastern Poles in Krzyż, the German cultural and geographic landscape was a hostile and foreign environment, which demanded additional effort in order to feel at home there. Many individuals, especially those who never again saw their ancestral homes, tended to idealize their native lands at the expense of the new, "foreign" reality in which they had to live after the war. In the East, the land was more fertile, the architecture was more attractive and even the air was cleaner:

We had no brick-walled houses, for example; we had wooden ones. They were beautiful houses, really beautiful, and they all had a red roof. [...] And here we had arrived, and everything was made of this brick, bricks everywhere, and we couldn't get used to it. [...] It was somehow damp everywhere, or maybe it wasn't damp, but the air was so different, it was wet. We had better, drier air over there (K19Af).

Sometimes, the encounter with a different material culture had a positive effect. Some interviewees, especially among those who came from less privileged rural backgrounds, emphasized the civilizational superiority of the new town and praised German furnishings and technology. ${ }^{178}$ These same characteristics of "new" houses could arouse different emotions in different groups of settlers, as well as mixed reactions from individuals.

177 I use the concepts of cultural adaptation and symbolic universum in the meanings proposed by Józef Niżnik, see: Józef Niżnik, Symbole a adaptacja kulturowa (Warszawa: Centralny Ośrodek Metodyki Upowszechniania Kultury, 1985).

178 Zbigniew Czarnuch has analyzed the issue of civilizational difference and its various effects on the adaptation of settlers to new conditions in: Czarnuch, "Oswajanie krajobrazu." 
In the East we had those clay huts, and very few people had brick walls. Even more popular were those low, wooden houses. But here we found these big, pretty houses, strong ones. It was certainly a difference, my God! [...] The furniture was different, it was so rich. They even had sofas, and those beds, and elegant mattresses, everything. There was a big difference, a huge difference. The culture was different. German culture was much better (K21Af).

For the "repatriates" for whom migration did not entail a radical change for the worse in material terms (as was the case, for example, with people who moved from a town in former eastern Poland to a small village near Krzyż), the objective civilizational differences between the old and new places were undeniable. Living conditions in Krzyż itself were better than in the small towns of former eastern Poland, whilst German villages were completely different from the rural areas people had left behind. Nonetheless, this forced civilizational advancement was, for the most part, imposed and unwanted, and for this reason, people often declined to take advantage - especially those from rural backgrounds. ${ }^{179}$ The majority of farmers from eastern villages struggled to feel at home in German homesteads, because they were used to a different way of working the land. Wasteful attitudes towards German farm machinery had their roots not only in the sense of impermanence among "repatriates," but also often in a simple lack of knowledge about how to use it. The oldest interviewees spoke about their encounters with "civilizational advancement" reluctantly; people from the younger generation were much more willing to raise this issue, especially the children of migrants from nearby Wielkopolska. The children of eastern Poles, however, never spoke on this topic, as if they were ashamed of the incompetence of their parents. Statements by the descendants of settlers from Wielkopolska contain a distinct tone of superiority and pride that, unlike others, their own parents would have known what to do with German equipment.

There were some funny situations. When I was working on various local censuses, I would visit the homes of various newcomers, and they didn't always have, so to say, orderliness like in Poznań [laughter]. ${ }^{180}$ Hens were laying eggs in pianos, and other such pearls. [...] For example, newcomers would just leave farm machinery standing in the

179 On this topic see also: Andrzej Sakson, "Procesy integracji i dezintegracji społecznej na Ziemiach Zachodnich i Północnych Polski po 1945 roku," in: Pomorze - trudna ojczyzna? Kształtowanie się nowej tożsamości 1945-1995, ed. Andrzej Sakson (Poznań: Instytut Zachodni, 1996), pp. 131-154.

180 According to stereotype, people from Poznań and Wielkopolska more generally are believed to be fastidious and orderly, or pedantic - or in the negative version of this image, miserly. 
field. After finishing the tilling, they would leave a plough for the whole winter on the spot where they finished using it. [...] It was funny, if you're used to something different. Now they have learned a bit more, it's different now, subtler, they've got to grips with that new [culture], it's been a few years after all (K1Bf).

Another aspect of migration that made post-war integration difficult - both in Zhovkva and Krzyż - was the change of environment from a rural to an urban setting or vice versa. In both cases, moving from a village to a town was more common; this entailed a dual process of change. On the one hand, because of the minimal presence or - in the case of Krzyż - complete absence of the town's former inhabitants, both places underwent a radical re-ruralization. Urban lifestyles simply disappeared, and the visual landscapes of the towns were transformed - humorous stories about chickens being reared on balconies and pigsties being installed in laundry rooms were not just myths. On the other hand, even the little remaining urbanism, such as the buildings themselves, demanded that new arrivals from villages adapt their ways to fit the new setting. Both levels of this two-directional process - individual and social (urbanistic) - are powerfully illustrated by the following statements of two Krzyż residents, who arrived respectively from near Lwów (now western Ukraine) and Bełchatów (central Poland).

To begin with, I was ashamed to buy bread, because I came from a farm, and I thought: would I buy bread on the farm? I was embarrassed that someone might see me. Later we started to buy bread and I got used to it (K20Af).

I lived just like in a village. My husband was sick, and his pension was small. So I had rams, five rams, pigs, the lot. There were unused fields on the side [of the house] facing the countryside, but in the town centre I wouldn't have been able to keep animals like that. In the laundry room I made a kind of pigsty, for the chickens and pigs. And that's how we lived (K36Af).

Interestingly, Ukrainians who moved from Poland to Zhovkva did not talk a great deal about problems adapting to an urban style, although this group above all would have been the main driver of sustained changes in the cultural practices of Zhovkva. Ukrainians from Poland, however, very rarely settled in the town center: the most prestigious properties in streets lined with villas were reserved for Soviet incomers, but they themselves, if given a choice, often preferred to look for a house in the suburbs and to lead a rural life as before.

Movement from a larger town to a smaller one was less common, but is also worth consideration. I met people in both Zhovkva and Krzyż who had had lived in much bigger urban settings before 1945, such as Lwów (Lviv), Kołomyja (now Kolomyia in western Ukraine), Łódź and Poznań. Moving to a small town was 
for such individuals a step down and felt like a reduction of their social status. Many of them felt deceived, because the authorities had presented the end goal of their journey as a town comparable to the place they were leaving.

I was very disappointed when we came here. On arrival, my father didn't say anything to us, he looked around, and there was just nothing here. A small town, with one main street. But we had come to feed ourselves, what could we do? There was no other choice. So we had to make the journey - to the place where we had been sent (K2Af).

My father said: "Oh that Zhovkva, it's a big town, they have trams!" When we arrived, we saw all these buildings that were falling apart, ruined by the war. It was awful! (Z9Af).

People who had no choice in where to go and expected few favors from the Soviet authorities - such as representatives of the Ukrainian intelligentsia returning from Siberian exile - were no less embittered when they arrived in Zhovkva. The feelings of alienation and loss, as well as a certain "superiority" over the "rural" surroundings, were in fact carried on into the second generation.

We felt foreign here, to a certain extent. [...] My parents were from Lviv after all... I remember I had a friend who used to say that my parents and aunt were so different. They were so.... well, upper class. In their hats... They had come from Lviv in their gloves and all that... They were more bourgeois than the people here in Zhovkva (Z41Bf).

In addition to changing the appearances and cultures of the towns, both directions of migration entailed serious consequences for processes of individual adaptation to the new reality. It is a truism that the more the new place resembles the old home, the easier the process of adaptation becomes. Thus, whether it was an undesired social advancement resulting from a move to a larger town, or an equally unwanted reduction in status associated with moving from a city to a provincial town, the change itself acted as a barrier. In both situations, settlers had to acquire a completely new set of skills that were indispensable to daily living. Whether the challenge was to buy groceries at an "urban" marketplace, or to learn something typically rural such as rearing animals or growing one's own vegetables, it was an additional strain and effort, which had to be faced alongside all of the other difficulties of post-migratory life. Migration thus turned out to be a challenge in yet another way, through a need for social and cultural adaptation; it certainly did not mean simply moving in space.

Around the middle of the 1950s, when the political situation had stabilized somewhat, groups of forced migrants in Krzyż and Zhovkva made their first journeys to their former home regions. They traveled with diverse intentions and emotions: some wanted to visit relatives who had remained behind; others 
went to scout the possibility of going back; others simply wanted to see their houses. Regardless of the reasons behind the visit, all of the travelers discovered that the possibility of returning home was an illusion, and their impressions of their "old homeland" were abysmal. Nothing was the same as before: the people had changed, the space had changed, and the dominant customs and social relations had changed.

I went to Poland, to my relatives, but my relatives were no longer there - they had died. So I went to see my nephews ... [What year was this in? How long ago was it, roughly?] I don't remember any more, all of our children were still small... My sister was married to a Pole and arranged for a visa [invitation], and we went, spent a week here, nothing more, we had a look at the place and came running back. [...] They were afraid to speak our own language [po nashomu] we spoke to them in Ukrainian, but they were afraid, they spoke Ukrainian in whispers, otherwise it was all Polish. [...] [And who lives in your old house?] Our former neighbor, in the house was our neighbor, he was in Germany before. My uncle and nephews were supposed to sell it and send me the money, but... Then the house was taken apart and that was it... My sister said to me: "Come, come to the church," but imagine what they had done to this church... The services were in Polish, and everyone was staring at us... ${ }^{181}$ They were giving us such nasty looks! And we left the church, we got out of there straight away, we got out, because people were acting like we were God knows what. And we left that place. I couldn't stand it, I said: "Let's get out of here, back to the kids," and that was it, we left $(\mathrm{Z} 18 \mathrm{Am} / \mathrm{Z} 18 \mathrm{Af})$.

With the passing of time, the places that resettlers had left behind had changed beyond recognition; their former homes were now foreign and often even hostile. This was especially true for the formerly eastern Poles from what became western Ukraine, whom locals were not very keen to greet. Sometimes, other than shreds of physical matter, there was nothing at all in these landscapes that reminded one of home. Such journeys made to native lands in the first decade or two of post-war life convinced resettlers that the changes they had lived through were now irreversible. The transformation and foreignness of their "old homes" strengthened their conviction that there was nothing left to return to. This

181 Before 1945 the church in this locality was a Greek Catholic church. After the resettlement of most of the local Ukrainian population to the Ukrainian SSR in 1944-46 and the arrival of significant numbers of Polish Roman Catholics, the parish was probably transferred to the Catholic Church. This is why the speaker was surprised to find mass being celebrated according to the Latin rite when they visited in the 1950s or 1960s and (in large part or in whole, if the visit occurred after 1962) in the Polish language. 
revelation was extremely difficult and painful, but it was also a necessary step towards closing one phase of migration and embarking on a new one. Referring once again to Mach and van Gennep, the liminal phase of transition was finally over, and it became possible to move on to the final, definitive phase; it became possible, potentially, to successfully integrate into the new social reality. 


\section{The Creation of a New Community and Social Integration}

\section{Relations with the Authorities and the New Political System}

The post-war residents of Zhovkva and Krzyż were confronted not only with a new material and cultural reality, but also with a political and social one. This meant, above all, that they had to adapt to a new political system. Attitudes to the communist authorities were most clearly expressed in conversations with Poles who migrated to Krzyż from the pre-war eastern provinces; they were quick to notice that the political reality of the new Poland would have much in common with the Soviet system they had escaped. Many of them had sensed this danger before they arrived, but had hoped that the communist regime in nominally their "own" country would be somehow different. Their illusions were dispersed once they arrived in the "Recovered Territories." Apparently the "repatriated" eastern Poles, who had experienced Soviet occupation in 1939-41, were better prepared for the realities of communist Poland than others - the only surprise they experienced was positive, when life under this regime later turned out to be less brutal than the Soviet system. People who came to Krzyż from central and western areas of Poland remembered their reactions to the political change as a time of disorientation and insecurity; they were afraid of political persecution. All of the interviewees in Krzyż perceived the communist authorities as a foreign imposition. They reconciled themselves to the idea of life under a communist regime because they had no other choice, but they were certainly not enthusiastic about it.

The one voice of approval came from a party veteran, a communist since before the war, who was an active party functionary in Krzyż after 1945. For him, the installation of a communist government was an integral part of the process of post-war reconstruction and an effective mechanism for the introduction of social order in the insecure territories of the new Polish West.

The director of the secondary school, D., became the new municipal [secretary], and we took hold of the reins of the town, and of the railways, and we kept close control. [...] Someone had to do it. We couldn't let it all go to ruin, because we would have all dropped like flies. If nothing had been done here, the Germans could have returned (K28Am).

This respondent's chaotic and disconnected narrative about the construction of a new system - he was quite heavily ill at the time of the interview - was comprised 
in large part of propaganda staples: the challenges of life as a "pioneer" in the new lands; the feeling of ideological obligation; and the imperative of defending the "Recovered Territories" from enemies on all sides, whether internal ideological foes or the external threat of German revanchism. There was little reflection on his personal experiences, which were subordinated to the dictates of the ideological front. ${ }^{182}$ This stand-alone narrative is important because it serves as a mirror against which all of the other Krzyż testimonies are reflected, showing the reverse image of other people's memories.

Interestingly, no such accounts were found in Zhovkva, despite the fact that there were quite a few representatives of state power among the respondents. The fact of living in a communist country rarely featured as a separate theme in these interviews. This is presumably a consequence of the fact that for migrants who moved from eastern Ukraine or Russia to Zhovkva (who formed the bulk of the party activists), there was no real change in situation: they moved from Soviet communism to Soviet communism, and their own political identities were often so obvious that they hardly warranted explicit commentary. Rather, the opposite was true: the political system they knew from their former homes was the most familiar part of their lives in Zhovkva; it facilitated their adaptation to their new place of residence. "Old" residents of Zhovkva and Ukrainians resettled from Poland certainly felt more of a change, yet they appear to have experienced the political upheaval less acutely than the people of Krzyż. For the Poles in Krzyż, the new Poland signified a loss of a genuinely sovereign state. For the Ukrainians in Zhovkva, the Soviet regime was yet another occupation - even if it was more brutal than the previous one.

The new system was more than a set of ideological principles. For people in both Krzyż and Zhovkva, the everyday "face" of the new authorities was what mattered most. While the difficulty for residents of Krzyz was to accept the very fact of a change in political system, for people in Zhovkva, the greatest problem was the distribution of power: one group, migrants from eastern Ukraine and Russia, held all the cards. The "Easterners" in Zhovkva took up the majority of positions of power - their dominance was visible in the police, the military, the town and raion ${ }^{183}$ party committees, and all of the largest companies and

182 Ewa Nowicka has written about the specific characteristics of narrative biographies by political activists, on the example of interviews with members of the Communist Party of Greece, see: Nowicka, "Wojna jako element opowieści."

183 Raion was (and is still in most post-Soviet states) an administrative unit usually two levels lower than the level of the union republic (the union republic was divided into oblasts and oblast was divided into raions). 
public services. ${ }^{184}$ Autochthonous locals and Ukrainians resettled from Poland speak about this fact in bitter tones to this day, but also emphasize that there was nothing they could do to rebel against the situation.

Ukrainians after the war were in those... non-management positions. The management positions were taken by, well, I mean jobs like secretaries of the district [raion] committee [of the Communist Party], directors of the executive committee, commanders of the police, these were taken by people who liberated our lands "liberators" who were sent by the state institutions - you know which ones. [...] Their aim was to bring Soviet government to these western regions. [...] And if locals tried to take control, to take up any important jobs... Well, you know, Ivan ${ }^{185}$ would come along, and that was that! He was the boss and you had to do what he said. The law was the law. [Well the law is one thing, but people had opinions, didn't they?] Sure, anyone could have an opinion about the situation, but if you said anything anywhere - they would pay you a visit in the evening and you'd end up dead or in Siberia (Z15Am).

The political privilege enjoyed by people sent from the East also meant economic benefits. The Easterners in Zhovkva lived in the best town houses, had larger incomes, and had better access to scarce goods and services. Whilst other groups in Zhovkva accepted the Easterners' political privileges with a certain resignation, the material advantages inflamed tensions.

Loads of Russkies came over here, they were all these party types, and they took up the best houses... [...] And if you were a party type, a Russki, then you had a right to get an apartment quicker, you could do all sorts of things, but if not... [...] They made this distinction, that if you were in the party, like in our factory, because I worked, we worked, and we had specific quotas that meant we were always working, and we had a break that was long enough to quickly eat something and then go back to work. But those communists, they would play cards, sit around, and they had small quotas and they got paid a lot (Z8Af).

All of the interviewees in Zhovkva shared a conviction that being on the side of the authorities was worthwhile in economic terms. Younger respondents also saw the long-term effects of the Easterners' material privilege. They frequently

184 Tarik Cyril Amar makes a similar point about Lviv, in: Amar, The Paradox of Ukrainian Lviv, pp. 185-220. William Risch writes about the natives of Western Ukraine being underrepresented in all political bodies of the oblast, raion and city, see: William Jay Risch, The Ukrainian West. Culture and the Fate of Empire in Soviet Lviv (CambridgeLondon: Harvard University Press, 2011), pp. 53-81.

185 Ivan (one of the most popular Russian names) means here simply a person of Russian nationality. 
noted that the state of inequality continued until after 1991 - those who previously had power were able to smoothly accommodate themselves to the new circumstances and secure their futures.

They just raked in the money. Look at who owns the shops now: the [former] first secretary of the district committee owns the market, the one near the synagogue, that one belongs to the first secretary. W. owns the sawmill, but where did he get that money from? (Z27Bm).

Such statements show that the genuinely existing social divisions from the first post-war years, which were based on place of origin and/or political outlook, continued to have significance in the minds of most Zhovkva residents of the oldest and middle generations. The Easterners themselves were also aware of their position relative to others. They admitted that people from their group occupied the most privileged positions in the community, although in many cases, they considered this situation to have been perfectly natural, seeing no reason to repent.

Yes, the directors of the factories were [...] mostly from either eastern Ukraine or Russia. That is true. [You mean Ukrainians weren't allowed to take up these positions? The local ones, I mean?] I don't know if they weren't allowed or not, maybe they just weren't educated. Here in western Ukraine, people weren't very educated (Z10Af).

Easterners who were not directly connected to the state apparatus, and who were often critical of Soviet power (e.g. because they had been victims of Stalinist terror), considered the local division of power unfair and admitted that the locals had every reason to be ill disposed towards them. Nonetheless, their statements often contained a sense of helplessness - what could they have done in this situation?

They called us Moskals, "the Moskals have arrived." I tell you, the local population didn't really want the Moskals here. Some people from the KGB and the police, they treated the locals badly. They hadn't done anything bad, but they still treated them badly. People from the East were in all the important positions everywhere, and that was also wrong (Z11Af).

Respondents in Krzyż did not have a feeling that any particular group of residents was politically more privileged in the post-war years. People who were politically involved in building the new regime (as opposed to physically rebuilding Poland) were a small minority among the interviewees; political officials who worked in Krzyż tended not to stay there in the long term. The only statements about inequalities between different migrant groups were related to the worse situation among Poles from the pre-war eastern provinces and central regions, 
who were cut off from their homelands; these differences, however, did not affect anyone's relationship with state power. ${ }^{186}$

Residents of both Krzyż and Zhovkva perceived the post-war state to be an oppressive force against ordinary individuals. People who were politically suspect were persecuted fiercely, that is, above all, individuals with the "wrong" past, such as former members of Ukrainian nationalist organizations or the Polish Home Army. ${ }^{187}$ Residents of both towns who had been involved in resistance movements during the war were painstakingly harassed, including in cases where the accusations were leveled at relatives rather than the victims themselves. Interviewees recalled their ordeals with a hardly diminished dread.

My sister, she was in the resistance [the UPA] [...] And there was this guy K., from the KGB. My God, he would summon me to their office, to the KGB, every week. And he would say: "where is your sister? Where? You must know." And I would tell him that we didn't know where my sister was... [...] "Who do you know? Who was that? Who was there?" I would say to him: "I don't remember anyone, no-one talked to me, I was still little." He would bang his fists on the table and scream at me like a madman (Z3Af).

When they [the Security Department, Urzad Bezpieczeństwa, UB] let me out [after an interrogation], I was terrified, I still feel it now. They were here once, all over the place. They wore these white coats, because that's what they wore in the UB. [...] When I saw [someone] in a white coat, it didn't even have to be someone from the secret police, I got such shudders (K16Af).

The fear felt by people with "bad" pasts was thus similar in Krzyż and Zhovkva. There was however a difference between the towns in that in Krzyż, the situation normalized relatively quickly, as shown by the complete absence of accounts of such fear in the interviews with the younger generation, who were born after

186 Philipp Ther provides statistics that show an over-representation of people from central Poland in the institutions of state power, in particular the police - the Civic Militia [Milicja Obywatelska] and secret police - the Security Department [Urzad Bezpieczeństwa,] as well as their economic privilege, see: Ther, "The Integration of Expellees." Tomasz Molenda has shown that a similar situation prevailed in the Krzyż area (a majority of the post-war heads of the villages [soltysi] came from surrounding villages), see: Molenda, “Zmiany ludnościowe," p. 90.

187 The Home Army [Armia Krajowa] was the military of the Polish Underground State during the Second World War. It was founded in 1939 as the Union of Armed Struggle [Związek Walki Zbrojnej] and transformed into the Home Army in 1942. It was dissolved in 1945. After the war, many former members settled in the "Recovered Territories" in the hope that the communist authorities would not persecute them in the new surroundings. 
the war (with one exception, discussed below). In Zhovkva, on the other hand, almost all of the respondents from the second generation and many from the third remembered both their own anxieties and those of their parents, as well as concrete acts of repression.

They didn't want to register us. I even remember, there was this lady at my dad's workplace, M., one of the Russian liberators, and she could even talk about my sick dad in terms like: "Not much of a doctor is he?" She spoke Russian. Yes, I think they [the speaker's parents] felt that oppression, they got through it somehow, but... I don't know. I think that they had a hard time, because dad had already suffered under the Stalinist [repressions] (Z41Bf).

Besides people with "suspicious" pasts, the few remaining representatives of ethnic minority groups were also victims of state violence: Poles in Zhovkva, and Germans - real or imagined - in Krzyż. People from these families remembered the anxiety that reigned in their households about letting out the truth of their difference - and the potential consequences of such a slip. State policies made it perfectly clear that the results of such carelessness could be tragic. The fear of informers is a recurring theme in the interviews, especially with speakers who were children at the time.

The younger children were taught that, firstly, you weren't allowed to talk on the street about things that had been discussed at home. On holidays, if we shared Christmas wafers or Easter eggs, ${ }^{188}$ we had to black out the windows with blankets, so that no-one could see from outside, so that no-one could hear, so no-one could snitch on us (Z28Bf).

My father-in-law was going to his son's christening [...] and the UB came long and took him away to Piła [the district capital]. Then they took his shoes away and let him out on foot, and he couldn't attend his own son's christening. We had UB officers around here, they're mostly dead now, otherwise I would... I'm telling you, they persecuted my father-in-law. The UB was here in Żelichowo [a village near Krzyż] too, and they listened out for everything under your windows, checking what we were saying, what was going on. Checking if people weren't teaching their kids German (husband of respondent K39Bf).

The situation in the "Recovered Territories" was such that it was not only "real" Germans who were afraid of state harassment. Anyone who was suspected of having links with "Germanness" could fall victim, for example, people with

188 In Polish Catholic tradition, special wafers are shared between family and friends at Christmas time, and eggs are painted and taken to the church for blessing at Easter. 
"German-sounding" names. ${ }^{189}$ One of the interviewees, who changed her surname to a "more Polish" one, said: "I was forced to do this by the authorities. [...] I know that's what happened, although my parents resisted for a bit, but everyone was agreeing to these things, so there was nothing doing" (K34Bf). Such situations show how deeply the state interfered at this time in the life of the individual, and how painful this interference could be: in addition to physical persecution, people were deprived of a right to their own identities and forced to rupture their symbolic bonds with parts of their family history.

In Zhovkva, resettlers from Poland were a potentially suspect group - in part because of their relatives living abroad. A clue as to the scale of fear experienced by people is visible in the fact that the oldest respondents were still afraid to talk about their attitudes to Soviet power. We can discern from half-uttered words and unfinished statements that the often explicitly declared disengagement from political issues was, in fact, a product of fear. Only the children broke the silence of the parents.

Later, when they came here, life wasn't sweet over here either, because of course, the regime that was in power then, it wielded horrific means of control over people. They had to know literally everything about you, from A to Z. That's why my parents, when they came here, were subjected to a certain level of discipline. They were always being listened to and interrogated by the KGB (Z33Bm).

The most important characteristic of memory about post-war relations with the authorities is that everyone felt fear: people who had a reason to be afraid, and those who believed they had no guilt, were equally vulnerable to the sensation of insecurity. In both towns, the situation can be conceived of as a permanent "threat of potential guilt," which was fully detached from any real guilt or absence thereof. Especially in Zhovkva, recollections of the first post-war years were above all memories of fear, and of a latent threat that seemed to practically hang in the air. After nocturnal arrests, adults came to work to find that colleagues had gone missing, and children noted that classmates had disappeared ("then we came to school the next day, and so many kids had gone, five kids. And we were afraid to ask out loud where they were, what had happened to them" [Z28Bf]). In Krzyż, repressions were less severe, but there were enough minor infringements for the overall situation to become unsafe. In the fragment cited below, there is a striking sense that the new authorities were not only making life difficult for

189 Forcing people to change "German-sounding" names was a common practice in the "Recovered Territories." In Silesia, 200,000 people had already changed their names by 1947 , see: Nitschke, "Repolonizacja czy polonizacja?" 
people directly, but also pitting them against each other, exploiting mutual animosities as a means of internal control.

Those first years in Krzyż were very tough, because they were supposedly building communism, but there were people who were hostile towards the system. [...] Someone came to our house and saw that my dad had a [picture of] Piłsudski ${ }^{190}$ on horseback, and of course he was called out to the party office, he had to explain the Piłsudski. [...] There was an unfriendliness developing then between people, people would sniff around each other's houses, just in case, God forbid, they had a radio. If someone heard that you had a radio, you weren't allowed to have a radio, they would come and start listening in, snitching on you (K35Af).

And once again, despite the essential similarity, there is a fundamental difference between the situations in Krzyż and Zhovkva: the fear felt by people in the Ukrainian town did not disappear after the first post-war years; it weakened, but it remained an inseparable component of life in the Soviet Union right until the fall of the regime. This is shown by interviews with younger respondents: even those who were born in the 1960s and 1970s remembered instances of their parents behaving strangely, in ways they did not then understand. They remembered both their parents' fear and their own anxiety.

For instance, more or less until 1985 or so in Lviv and Galicia, it was dangerous to display any real private culture. That meant that anything fancy or different, like gloves with fingers, serviettes with crowns, or a dinner set with forks and knives [at the lunch table]. [...] It was just that if the wrong person saw that, if they informed on you, there was a real possibility you would end up in Siberia. [...] [That was the situation right up to the 1980s?] [...] Maybe those same repressions weren't happening any more, not like people remembered from back then, but in any case, things were happening. I remember very well, for example, that when my grandparents laid the table nicely, with napkins, with decorations, with knives and forks, they always locked the door with the key (Z1Cf).

People born in Krzyż after the war sometimes recalled their parents' fears, but these memories concerned a distant reality so remote for them that it was often a source of amusement or perplexity, not something to be treated seriously. Postwar generations could feel uncomfortable in socialist Krzyż, but they were never threatened by the system.

190 Józef Piłsudski (1867-1935), Polish politician, an independence activist and member of the military, one of the creators of the revival of the Polish state after 1918. After 1945 he was considered a "bourgeois reactionary" by official historiography, while in the mass consciousness he remained a symbol of patriotism (and anticommunism). 
My dad, when we lived here in Łokacz [a village near Krzyż], he would listen to Radio Free Europe, and it had to be quiet, he was so afraid. "Because of the NKVD [i.e. the Soviet, not Polish, secret police,]" we would laugh. And he would reply: "You have no idea about the NKVD, a black car will come, arrest me, and take me to prison." And he was really afraid of this, always. The doors had to be locked, the windows closed, to make sure that, God forbid, no-one was listening in (K20Cf).

Fear of the authorities also had a significant influence on relations between different groups of residents. In Krzyż this phenomenon was fairly marginal, and its effects were most visible in the very first months, when people did not know anything about each other, although this was also a factor that acted as an obstacle to social integration. Zhovkva, however, was a real "society of whisperers"191 in miniature: people were afraid of each other, did not talk about their wartime pasts, and did not strike up neighborly or friendly relationships for a long time. Resettlers were afraid of locals, locals were suspicious of the new arrivals, and everyone feared the migrants from the East (who, in turn, were afraid of the local "bourgeois-fascist nationalists.") People who had already had negative experiences of Soviet repression, i.e. those who had been deported or released from camps or prisons, were especially careful.

Back then, in Stalinist times, no one asked who you were or where you came from. [...] At school, [...] we were a class of 14 people. I sat with a girl [...] who had been deported, she came from Iavoriv [a town in western Ukraine], and she only recently told me her history. [...] No one in school asked, because the children had been taught not to ask questions about where others were from. She came to my house a lot, we were good friends, but no one asked anything (Z29Af).

It is especially surprising that even resettlers, some of whom had practically been neighbors before their deportation, were distrustful of each other. In Krzyż, whilst there were sometimes prejudices within the group of "repatriates," especially between people who had arrived from what are now Belarus and Ukraine, everyone knew where everyone else came from and what they had been through during the war. The Poles from the East had a distinct feeling of being different to the settlers from central and western regions of Poland, and they were able to converge around a certain group solidarity: an awareness of a shared fate and shared loss created a deep bond between them, which remained strong for many years after the war. Ukrainian resettlers had no such bond between them, and

191 Orlando Figes coins the term "society of whisperers" to describe Stalinist Russia, in: Orlando Figes, Whisperers: Private Life in Stalin's Russia (New York: Metropolitan Books, 2008). 
their solidarity was limited to families who came from the same village; everyone else, even those who had likewise been deported, was treated with distrust. Many people said that they had only recently discovered that neighbors or work colleagues had also been resettled. When mutual distrust is so profound and long lasting, it is difficult speak of any real social integration. Elementary social bonds were eventually created, but by force of circumstance, and these bonds remained somewhat superficial. Mutual distrust also contributed substantially to the fragmentary nature of local memory. ${ }^{192}$

The authorities did not only monitor relations between people; their ambitions extended to exercising complete control over all aspects of social life. This was especially felt in the sphere of religion, from which the state felt a need to protect its citizens. In this regard, residents of both Krzyż and Zhovkva perceived state policies as yet another form of oppression. Like in other spheres, the difference between Krzyż and Zhovkva was in the scale and severity of interference. In Krzyż, an unsuccessful attempt by so-called patriot priests ${ }^{193}$ to take over a local village church ended in fiasco and a compromise by the authorities; no further attempts of this nature were made.

They were supposed to close the church in Huta Szklana [village near Krzyż]. But how many people came, my God! There was shouting and screaming, and they didn't let them close it. Some other priest was supposed to come, maybe some kind of communist or something. The authorities apparently wanted to close it, but they didn't. They would have had to fight with people (K20Af).

In Zhovkva, the sphere of institutionalized religion was entirely domesticated by the state. The Roman Catholic Church was closed down and the Greek Catholic church was forcibly converted to Orthodoxy. The faithful in Zhovkva tried to resist, but their efforts only provoked the state to escalate its repressions. The prewar residents of Zhovkva remembered these events unequivocally - in their testimonies, the town's new pastors were "KGB agents" ("They just called themselves "Orthodox," but they were all Chekists... The whole KGB, the district directors and even more senior people than that, they grew beards, and [pretended to be

192 I make this argument in further detail in later chapters, on the memory of Others.

193 "Patriot priests" was the name given to a group of Catholic clergy in socialist Poland who supported the regime and the systemic changes in the country after 1944 . They were most active in the years 1949-1956, and the movement's formal representation took the form of the Committee of Priests [Komisja Księży] which was part of the official veterans' organization called Union of Fighters for Freedom and Democracy [Związek Bojowników o Wolność i Demokrację, ZBoWiD.] 
priests]" [Z2Am]). An underground Greek Catholic church acted as a new form of resistance, lasting right until the collapse of the USSR. ${ }^{194}$ Its significance for the functioning of a new community was double-edged. On the one hand, people who congregated around illegal practices gained a certain autonomy in acting against the oppressive state, which could facilitate the formation of a new social solidarity based on their opposition identity. On the other hand, the danger associated with illegal worship intensified people's distrust of others and increased their guardedness in relations with people from various backgrounds. The Zhovkva testimonies paint a picture rife with secondary divisions and judgmental relations between residents. Rather than uniting, community members were divided between those who "conformed" and practiced in the official church, and those who remained "resolute" and refused to step inside the compromised institution. The divide was strengthened by the tendency for underground worshippers to be mainly comprised of "old" locals of Zhovkva and the surrounding villages, whereas the majority of resettlers (and the few Easterners who were practicing believers) attended the Orthodox Church. A minority of the latter group, especially people originally from the region around Chełm (in today's eastern Poland) were already Orthodox anyway; others had accepted the change, or did not consider it particularly important, such as the following speaker:

There was an Orthodox church, because they had closed the [Greek] Catholic Church in 1947. [...] [And did your family attend the Orthodox Church service?] Yes, we attended the church, and we still go there now. [But back then, when you started going to the Orthodox Church, did you not feel that it was somehow different from the Greek Catholic one?] No. We prayed, we prayed in our own way, no one said anything different. The Lord's Prayer is the same after all, right? (Z16Af).

Despite the formal approval with which the Orthodox Church operated, people in Zhovkva remembered religious practice as a sphere of life in which the state constantly interfered; it often appeared as a pretext for harassing citizens. Both older and younger respondents had clear memories of their teachers, who were obliged to record the names of pupils who attended religious services, and to try and prevent children from going on carol-singing expeditions. Teachers from the East stated in their interviews that they had to act this way; otherwise

194 For exhaustive studies on the underground Greek Catholic Church in Ukraine, see: Bohdan R. Bociurkiw, The Ukrainian Greek Catholic Church and the Soviet State (1939-1950) (Edmonton-Toronto: Canadian Institute of Ukrainian Studies Press, 1996); Serge Keleher, Passion and Resurrection - The Greek Catholic Church in Soviet Ukraine, 1939-1989 (Lviv: Stauropegion, 1993). 
they would have lost their jobs. Teachers who were locals from Zhovkva and surrounding villages said that they tried to fulfill their duties in such a way as to do minimal harm to children and their parents. Their testimonies contain a hint of conspiracy, and a certain satisfaction at having deceived their communist colleagues. This is essentially the only instance in which pressure from the authorities pushed residents of the town to build any kind of internal solidarity; however, even in this case, only a part of the community was implicated, and people even kept up their guards against local children.

I have this, you know, problem with my throat. And often, when we went out to catch those children singing festive songs, I would go... [loud clearing of throat]. The next day, the children at school would come to me and say: "Mrs. I., you gave us a signal, and we escaped" [laughter]. I was afraid of some of the children though, some of the classes, and in some classes I would say: "What are you talking about, I just have a problem with my throat." But with some of them you could be open (Z1Af).

Compared to the situation in Zhovkva, the atmosphere in Krzyż was idyllic. The oldest respondents recalled that party members and people who held prominent positions were pressurized not to go to church, at least not too ostentatiously. Nonetheless, the vast majority of interviewees agreed that, whilst the state would have preferred to see the churches empty, no one was prevented from worshipping ("Although there were different organizations and party secretaries, I never had a situation where someone said to me 'you're not allowed to go to the church' or 'your children [shouldn't be going to church]'" [K3Af]).

The example of the state's treatment of religious practices clearly shows the most substantial differences in the starting positions from which new communities were formed in the two towns. The most important difference was the scale of repression: whilst in Krzyż there was just one failed attempt by loyalist priests to take over the church, in Zhovkva one could be sentenced to a long exile in Siberia for illegal worship. In Zhovkva, the paralyzing fear that affected everyone made it impossible for them to achieve any real integration, while in Krzyż people came together in resistance against the state. The privileged position of one group in Zhovkva, related to their close identification with state power, aggravated the already existing divisions in society and strengthened mistrust; the absence of a similar phenomenon in Krzyż meant that state power was considered something foreign, located outside the community; even party secretaries could be "our people" ("All those secretaries were so.... We all knew each other, and I don't know why they did all that recording" [K3Af]). A final important question concerns social authority. In both towns in the post-war period, there was a complete loss of authority, caused by migration and the necessity of 
reconstituting social bonds on the one hand, and the hostile state's appropriation of all the key social institutions on the other. In this context, the legally existing Roman Catholic Church in Krzyż played an extremely important role - as it did everywhere in Poland; it was the only institution that had not been taken over by the state. In Soviet Zhovkva, the regime worked hard to make sure that no such authorities could emerge, and in doing so it deprived the population of a very important tool in the process of social integration.

\section{To Build Everything Anew, or the Social Wild West}

One of the interviewees gave the following answer to a question about social life in the early post-war years: "What do you mean? Everyone was new here! No one knew anything. [There weren't many local people?] There weren't any. Take our street - not a single local, not one. We were all from somewhere else" (Z19Af). This short statement provides a perfect inroad to the following analysis of how post-war social integration is remembered by residents of Krzyż and Zhovkva. ${ }^{195}$ This section of the book considers the social dimension of integration, or in other words the issue of how and to what extent a new community was formed in both places. The individual dimension of integration, i.e. the topic of identity transformation among migrants, is the subject of the next chapter. ${ }^{196}$

Besides the objective material and cultural differences, and difficult relations with the state in the new political system, a third substantial challenge the resettlers faced was the fact that they had to build relations from scratch with other migrants. Both towns after the war were agglomerations of diverse groups. Aside from the few locals who remained in Zhovkva, everyone was foreign to

195 By social integration I mean the process whose end objective is the creation of a harmonious and cohesive social whole by previously disparate and disconnected elements (both groups and individuals), by mutual recognition and adaptation. My understanding of this concept is close to that from the book: Mirosława Marody and Anna Giza-Poleszczuk, Przemiany więzi społecznej (Warszawa: Scholar, 2004). The most general and widely accepted definition of social integration is the following: "Social integration refers, in the first instance, to the extent and intensity of the interlinkages among the constituent parts of social unit," see: Richard Münch, "Social integration," in: International Encyclopedia of the Social and Behavioral Sciences, Vol. 11, ed. Neil Smelser and Paul Baltes (Amsterdam \& New York: Elsevier, 2001), p. 7591. In this particular case, the social unit is the local community.

196 Czesław Osękowski has also insisted on the necessity of distinguishing these two dimensions of integration (the social and the individual) in the context of the "Recovered Territories," see: Osękowski, Społeczeństwo Polski Zachodniej i Pótnocnej. 
their new places of residence; however, this "foreignness" was a matter of degree, and the different levels of otherness created a peculiar and at times unclear situation. The majority of studies on social integration in the Polish "Recovered Territories" emphasize the inadequacy of classical theories of assimilation and integration as tools of analysis in this particular context: the absence of a receiving community and the fact that a new society was built from nothing make this case exceptional. In Krzyż the situation was yet more specific, because the town's proximity to the pre-war border meant that some of the new residents, the "neighbors from across the river," were de facto almost locals.

In Zhovkva, the settlers from nearby villages were in similar circumstances. These two groups of settlers had a very specific status: although they were both "nearly" locals, this "nearly" meant very different things. The Poles from across the river in Krzyz formed a group of migrants who could easily adapt to the German heritage of the town: they had the appropriate cultural competences and social and political potential for fast adaptation. At the same time, they did not take up the role of local "hosts" in Krzyz - they were settlers like everyone else, just perhaps "better equipped" for the role; their dislike of German culture in post-war conditions was surely a major factor in their reluctance to become "locals." Migrants from nearby villages in Zhovkva, meanwhile, took up the functions of "locals" fairly quickly, treating the town as their own; the very few "real" locals who remained in the town perceived them, against the background of alien hordes arriving from both East and West, as allies - rural and backward, perhaps, but allies nonetheless. Because of these nuances, the status of the group of "neighbors" was ambiguous in both towns: sometimes they had a "superior" status to other migrants as hosts, and at other times they were settlers like the others, with the same rights and difficulties. It appears that this dual role had a negative effect on their social integration; it was conducive to the strengthening of mutual stereotypes.

In both towns, the first prominent demarcation line was the divide between "repatriates" on the one hand, and locals and "neighbors" on the other. ${ }^{197}$ Negative experiences are predominant in the testimonies of "repatriates:" above all, they

197 Interesting analogies comparable to the process of constructing relations between locals and settlers in Poland and Ukraine are provided by studies that focus on the integration of eastern Germans in West Germany after the war, see: Rainer Schulze, "Growing Discontent: Relations between Native and Refugee Population in a Rural District in Western Germany after the Second World War," in: West Germany under Construction. Politics, Society and Culture in the Adenauer Era, ed. Robert G. Moeller (Ann Arbor: University of Michigan Press, 1997), pp. 53-72. 
complained of a lack of assistance and of basic everyday sympathy. Instances in which locals who were relatively well off refused to offer a helping hand remain to this day a painful memory.

[They treated us] like dogs. My sister-in-law had a seven-month-old baby when she arrived here, she had no milk, she had nothing. [...] When we came to Drawsko, we walked for three kilometers on foot, I remember how I went with her, and they whistled at us like we were dogs. "Go away, go away, go! There's no milk for you here." That kind of thing, it stays with you; we didn't forget that (K31Af).

An equally strong memory is the lack of understanding and empathy shown by the locals, alongside the accusation that the "repatriates" had come to Krzyż/Zhovkva in order to make a quick buck by taking German/Polish property. It was hurtful to the resettlers that locals judged them to have purely material motivations, oblivious to the tragedy of their recent ordeals; moreover, difficulties were aggravated when they were treated like foreigners by their own compatriots. Another painful memory for the "repatriates" was the feeling of inferiority relative to the others, due to their less favorable material circumstances. Both the eastern Poles in Krzyż and the Ukrainians resettled from Poland in Zhovkva formed a specific economic sub-class in their new places of residence. Not only were they poorer in absolute terms than migrants from Wielkopolska or central Ukraine; crucially, they also could not benefit from assistance provided by relatives living in the vicinity. Their material poverty, cultural differences, and the fact that the majority of "repatriates" came from rural backgrounds prompted many locals to label them as "bumpkins" [pl. wsioki] ("They laughed at us, that we came laden with paper bags. [...] We were always worse than them" [K2Af]) ${ }^{198}$ Respondents who experienced resettlement as at least young adults were able to analyze their emotions at the time, and to consider rational justifications for the behavior of the locals. Speakers who were children in that period continued to hold feelings of resentment, and recollections of their childhood, a time when the lack of basic food supplies was a symbol of their poverty, evoked very negative emotions.

The second day in school $[\ldots]$ we stood on opposite sides of the corridor along the walls - on one side the foreigners like me [the interviewee was born in Germany into a Polish family that emigrated to Germany in the late 1920s and in 1945 re-emigrated to Poland], and those from the East, and on the other side the kids from Drawsko and

198 For an analysis of the problem of the economic marginalization of Ukrainian migrants, see: Volodymyr Kitsak, "Rozselennia ukraintsiv Polshchi v URSR (1944-47). Pereselennia ikh iz pivdennykh ta skhidnykh oblastei v Zakhidnu Ukrainu," Moloda Natsia, Vol. 1 (2000), pp. 96-122. 
Wieleń [villages in the vicinity of Krzyż] [...] They're standing there along the wall, each of them holding a chunk of white bread stuffed with sausage, eating. As for us, standing on the other side with no breakfast, because you couldn't buy bread in those days, not everyone had money, let alone sausages of course - where were we supposed to get them? We looked across at them as they ate. I remember that to this day... I came home, I told my parents, and my mother said: "Son, where am I supposed to get breakfast for you?" [cries] (K25Bm).

There was a family of [locals] living near us, they were rich. They had two girls, like my sister and I, the same age. And we used to run over to them to play. But we were poor then. They had white bread. Our mother would cook us flatbreads [palanychky], ${ }^{199}$ she fed us as best she could. And L. over there, she would sometimes give us a couple of slices of bread, and we would eat it... [voice trembling] (Z12Bf).

Tellingly, the only people to remember relations between "repatriates" and locals as positive were... the locals. In their testimonies there is no hint of dislike of the "repatriates" or of any belief that they had arrived in Krzyż/Zhovkva with material gain in mind. The locals constructed narratives of spontaneously helping their new neighbors, sometimes coloring their stories with a somewhat magnanimous and condescending commentary about the ways in which the "repatriates" were actually different to them ("We helped them in everything, we gave them everything, everything... But they had lived differently over there, they were differently educated. They were different..." [Z2Am]). The theme of objective differences between the "repatriates" and other settlers is present in the interviews from both towns, but in very differently forms. In Zhovkva, assessments of the other groups lack specifics and are typically vague, limited to a simple statement of an opinion (though a very certain one) that the others were "different." It would be difficult to gain any insights from these testimonies as to how exactly Ukrainians from Poland were different to Ukrainians who had lived in or near Zhovkva before the war. On the one hand, this could be because there really were only minor differences between these two groups of Ukrainians - the exception being the minority of resettlers from the Chelm region in Poland who were Orthodox Christians. Another factor could be that no image of a settler from Poland solidified in Ukrainian social memory: no staple figure was created by mass culture, the way that the "repatriate" from the eastern Kresy was turned into a cultural phenomenon in Poland. Residents of Zhovkva looked at each other through labels that magnified difference, but the social imaginary did

199 Palanychky [in Ukrainian; the Polish equivalent is podpłomyki] are a simple flatbread, usually made without yeast, which can be made without an enclosed oven. 
not provide any specific features of the resettlers' alterity to give the topos any substance.

In Krzyż, the situation was different. Above all, the objective difference between the Poles from the pre-war eastern provinces and the other settlers were genuinely significant. Additionally, collective narratives about resettlement created, with time, specific images of the "repatriated" eastern Pole and the "settler from the centre" (for example, the aforementioned film All Friends Here), which also influenced the autobiographical memories of the people in Krzyż. ${ }^{200}$ Individual memories are imbricated in the social memory of the collective in which one lives; collective memory frames autobiographical memory, allowing people to interpret their own lived experience. It is precisely a function of these rich social frames of memory that interviews in Krzyż contained many extensive accounts of the differences between Poles from the East and other regions. Even after many years, these opinions were replete with mutual prejudices, which were strongest between people from the former eastern provinces and from Wielkopolska. Besides emotional accusations of inhumanness and lack of empathy, some of the Easterners talked in depth about the specific character of people from Wielkopolska: as miserly, hard-headed, and practical. Most often these traits aroused dislike on the part of the eastern Poles, although sometimes they were impressed (by "Poznanian orderliness,") and others told stories with a large helping of humor. Respondents originally from Poznań, on the other hand, were convinced of the civilizational inferiority of the settlers from the East, believing them to be backward, careless and lazy. They struggled to understand differences in everyday customs, and were perplexed by the Easterners' attachment to traditional rural architecture and agricultural methods, as well as their inability and/or unwillingness to use the existing equipment of the German houses.

They [Poles from the East] were different to us, and I think they were perhaps a little backward as well. I remember that when we arrived here, they didn't know what a washing line was, like how we hung up our clothes to dry on a line, with clothespin. They would just throw their clothes on a blackcurrant bush to dry, and trample them in cold water. But they learned that all here, they learned it (K22Af).

Such opinions about the "impurity" of the Easterners and the condescending satisfaction of the locals when they "became civilized" must have provoked deep indignation in the "repatriates." Fuel was added to the fire by the fact that Poles from central regions and Wielkopolska often thought of the Easterners, who were

200 Cf. Tomczak, "Obraz osadników w prasie." 
mostly very proud of their Polish identity, as essentially second-class members of the nation. Their pity was aroused not just by the "repatriates" material poverty or civilizational difference, but also their different accents and vocabulary - their dialect was frequently mistaken for Ukrainian. This theme was sometimes raised jokingly; whilst speakers added straight away that there were no conflicts, these assertions were tinted with a conviction of their own superiority.

There was an old lady [from the East], she's dead now. [...] And this lady could speak Polish well if she wanted to, but if she didn't want to, she would go off babbling in Ukrainian, and I couldn't understand anything, not a word. I nodded my head, but I didn't actually understand any of that Ukrainian. And her daughter, it's been so many years since the war and she still hasn't learned to speak Polish properly! (K23Af).

After noting the linguistic difference of the eastern Poles, it was only a small step to then discount their Polishness more generally. Statements to this effect were usually made indirectly, through layers of phraseological padding of which speakers were perhaps unaware; when asked, they categorically denied that they could ever doubt the Polishness of the migrants from the East.

Here we were all Poles, not from the other side of the [river] Bug, there weren't any of them here. Everyone here was Polish. [But those people from the other side of the Bug - weren't they also Poles?] Yes of course they were. It's just a way of speaking. Mrs. S. [a teacher] came from over there after all. I don't know what to call it... You know, they always had a different accent, they spoke completely differently, so that's what people said: that they had come from the other side of the Bug (K25Bf).

One of the consequences of these mutual prejudices was that initially, the groups kept very much to themselves. This peculiar social segregation was visible in both groups, "repatriates" and "locals," which remained more or less closed to people from outside for a long time. Significantly, people in Krzyż remembered this phase as a time of "internal" consolidation, without hostility to others people who had arrived from the same regions were spending time together and inviting each other to weddings and baptisms, thereby compensating for the absence of extended families that had been left behind ("On Sundays we went to visit friends and acquaintances. [...] To other people with whom we came here" $[\mathrm{K} 26 \mathrm{Bf}]){ }^{201}$ In Zhovkva this memory took on a slightly different form.

201 As existing scholarship and my observations from Krzyż and Zhovkva both show, social divisions in rural areas were much stronger and longer lasting than in urban environments. This is well illustrated by the case of a village near Krzyż, where train loads of "repatriate" Poles from the same village in former eastern Poland had settled together. Here, it was only in the third generation that mixed marriages between 
Because of distrust within the settler groups, the prejudices held by locals did not strengthen the bonds of solidarity among "repatriates" to a similar extent as in Krzyż. There was a more intensive process of keeping others out, rather than building ties within the group, for example among the youth: "Once a young man started courting our daughter and others started shouting: What's this? Going out with a settler? Haven't you got your own girls?" [Z3Af]. This was a kind of negative consolidation based on isolation, rather than community construction.

A completely separate issue is the question of how relations between the "Easterners" in Zhovkva on the one hand, and locals and/or Ukrainian resettlers on the other, were remembered. Although objective differences between these groups of residents were no less significant than those between Poles from Wielkopolska and the pre-war East in Krzyż, the Zhovkva interviews differ in that they contain no humorous elements. This may be a reflection of the fear that people had felt several decades previously, or perhaps it is the result of a stilllingering animosity. Where laughter does feature in accounts of this period, it is bitter, as if the speaker was unsure whether crying may not have been a more appropriate emotion.

They got married [in a church], so we went to have a look at what it was like... [laughter]. Just to have a look. After the part where they kissed the icon, they all started drinking champagne. She worked in the cafe here near the church, and he was a brigadier. At that time there wasn't yet so much pressure to join the party. And we just watched them drinking champagne... (Z2Am).

Zhovkva residents who came from Galicia remembered their relations with the Easterners as above all cautious; they may not have been outwardly kind towards them, but out of fear of the possible consequences of conflict, they tried to maintain at least cordial relations with them. At the same time, they emphasized the borders of their familiarity and largely kept to themselves.

If a girl was seeing a Russian, then people would mock her, saying... you know... But if ever a big conflict were to arise, there had to be no conflict. Like, between the Easterner teachers there were no conflicts. Everyone thought whatever they thought, in their heads, but they wouldn't say it out loud, no... People didn't talk, because they were afraid of saying what they really thought. [...] We were a bit careful towards them, so as not to say anything out of order... We wouldn't be hostile to them, no (Z1Af).

eastern and local Poles started to occur. The integration of migrants in large towns proceeded much faster. There were fewer social constraints and more possibilities: if someone wanted to be rid of the label of an "eastern bumpkin," a large city in Galicia or in the "Recovered Territories" was the ideal place to do so. 
The only people who spoke of positive encounters with the Easterners were locals who, because of their own positions in the community, had entered the privileged group and become part of the apparatus of power. As beneficiaries of systemic change, they no longer remembered any conflicts or difficulties with the migrants from the East, who were part of their own professional and social circles.

We would all get together and have fun together, and no one ever felt any distance. What did it matter if you worked for the police? For example, the wife of the police chief worked with her [the speaker's wife] together in the school, they worked in the same school. Then the wife of that KGB employee, what's her name, who lives in Rava [RavaRuska, a town near the Polish border] now? She also worked there. And we weren't afraid of anyone, and no one was afraid of them (Z20Am).

Such relationships with locals were the main reason why the majority of the Easterners continue to have positive memories to this day of the social aspect of their first years in Zhovkva. The Easterners tend to remember kind people, a generous environment, and warm neighborly relations.

Hospitable people, generous. [...] There was a lady who worked as a cleaner at the factory. We didn't even have a bowl for doing our laundry, we didn't have that... that sieve for cabbage. She brought them to us, and looked after our son, once he was born. I would be called out to the middle school or to the high school if someone was sick, and I would substitute $[\ldots]$ and she looked after my son. And I have to say that people were very kind to me, the other teachers too (Z11Af).

Perhaps it really was the case that the Easterners were lucky, and they met the most generous souls among the Ukrainians and Poles, who had no qualms with them and actively offered to help their "brother Moskals." It does nonetheless seem more likely that the majority of Easterners lived in a kind of ghetto composed of people from their own circles, as well as locals who aspired to join their ranks. The rest of the population tended to treat them well, but this was usually a calculated act of pragmatism or a result of fear, rather than genuine benevolence. Such a conclusion is supported by the fact that the testimonies of Easterners did occasionally contain accounts of hostile relations, but these were to be found exclusively in interviews with people who entered into marital relations with locals; in other words, these were the individuals who definitely had frequent, intensive contact with the autochthonous population.

I arrived, and they didn't call me anything other than Moskal, as if I was a Moskal. But what have I got to do with the Moskals? [laughter] I always laughed, because my mother-in-law always called me Moskal, and my daughter's husband's mother called me her "Little Jew" [Zhydivochka], because I had curly hair (Z10Af). 
Many Easterners also claimed that the place of origin of their neighbors and colleagues had no significance to them. Perhaps this was a sign of the Soviet Union's cosmopolitanism, but it can also be interpreted as a form of shortsightedness, as well as a lingering disinterest in the situation of other resident groups. It was easy to have no concern for the town's social stratification when one was sitting pretty at the top.

\section{The Long-term Consequences of Post-war Divisions: Integration Processes Among the Younger Generations}

The post-war divisions did not affect just the oldest generation. Respondents who were born after the war, that is, people for whom Krzyż/Zhovkva was the only social reality they knew, also remembered mutual prejudices. In this generation as well, there was a strong memory of prejudices held between "repatriates" and settlers whom the forced migrants considered to be "locals" (in Krzyż, those from central and western Poland, and in Zhovkva, Poles and Ukrainians from Galicia). People whose childhood fell in the immediate post-war period generally talked about their own experiences; meanwhile, younger respondents who were born in the second half of the 1950s and the 1960s discussed the relations they had observed between their parents and others, or the stories they had heard from them.

People here didn't accept us too willingly, because they said we were Poles. My mother told me on several occasions that she had even been brought to tears. [...] They mocked us, because of some words and phrases that were similar to Polish. We had lived with Poles before, and they laughed at us that we were "bloody Poles." They always called us resettl... reshittlers [peresrantsi], saying that we had been resettled, we were foreign, Poles. "What are you doing here, go back to your Poland," they would say (Z18Bf).

Here they [the speaker's parents] were called Ukrainians, because we had lived with Ukrainians after all, and we had some mannerisms in our speech that were more Ukrainian, needless to say. Before they adapted, before they [learned to speak] Polish correctly, that was another problem (K20Cf).

Significantly, it was only the children of resettlers who remembered conflict, similar to the situation among the oldest generation. The children of "locals" had no recollection of treating the "repatriates" differently to anyone else. They spoke at length about the differences that they felt even in their own generation - mostly in linguistic usage - and about their awareness of the divergent experiences that different groups had had during the war; but their testimonies tended to verge towards stories about helping the resettlers and how the speakers 
themselves and their parents had been involved in the construction of a harmonious environment of social solidarity. Interestingly, in accounts of relations with their classmates in school, these respondents remembered themselves in the role of generous guides, who helped the "repatriate" children to learn the ropes of the correct "Polish" customs that were acceptable in the new Poland.

The teachers taught us that you couldn't just tease them. That maybe they talked a bit differently or something, but you weren't allowed to tease them for it, you had to help. So that they started speaking properly as soon as possible (K1Bf).

The exact opposite image was often to be found in the recollections of people whose families had moved from the East - memories of being ostracized at school, discriminated against by teachers, and facing up to a widespread absence of openness and a lack of understanding that the families of forced migrants had lost everything they had previously accumulated in life, as well as their homelands.

Some of the teachers treated us, kids from the East, worse. [...] Worse than that, I still remember, I'm not sure why [...] there was this incident, where [a student] had turned 18 and was called to pick up his ID card. This guy went to the office, and on the card it said he was born in the USSR - well, we all had that written. [...] And he objected that he wasn't born in the USSR, that he wouldn't accept this ID. And they harassed him, they really had a go at him, it was pretty unpleasant, though I don't know the details (K26Bf).

The resentful voices of the children of eastern Poles may be a reflection of the actual behavior of their classmates and teachers, but they could equally be part of their emotional reaction to the trauma of resettlement. The children of locals rarely noticed the delicate nuances of their schoolmates' emotional baggage, because their socialization within the family environment had not equipped them with the appropriate tools for such empathy; it did not instill in them a strong enough sensitivity towards difficult experiences. For their part, the children of resettlers were hypersensitive towards any instances of being treated as different, as this was a way for them to process the loss their parents had experienced and to deal with the taboos and silences that weighed on them in the public sphere. In this situation, it was easy for them to assign negative attitudes to the fairly neutral behavior of others. In the case of the young man who railed against the inscription on his ID card, the teachers who tried to persuade him to accept the document may well have been trying to protect him from serious trouble with the authorities, rather than act out of spite.

Whereas in Krzyż the division between "repatriates" and locals remained significant in the middle generation, in Zhovkva the most prominent fissures were between the "Easterners" and the rest of the population - both locals and 
Ukrainians resettled from Poland. The overall picture that can be discerned from speaking to residents in their forties, fifties and sixties (at the time of the interviews) is one of tense relations, or at best of mutual indifference; the groups remained strictly separated from each other. This is well illustrated by a statement made by a woman whose parents were resettlers, who spontaneously described her relations with her peers from Easterner families as positive - but when asked to elaborate on this opinion, she revealed that these relations were good because they were superficial. The speaker, in other words, did not maintain contact with anyone from this group ("Personally, no. It just so happened that I didn't make any friends like that" [Z6Cf]). Others spoke outwardly about segregation and animosity; these statements contained echoes of the post-war mistrust towards Soviet "liberators." They were ill-disposed towards their peers from the ruling castes and tried not to enter any kind of relations with them. If this turned out to be impossible, they maintained their distance and remained cautious, and even applied this principle to children from primary school. Parents remembered the terror of the post-war years too strongly to not try to inculcate a sense of caution in their children.

In my class there was this girl, Y., who was the daughter of a judge. [And how was she treated by the class?] How? Well the Russkies were what they were, we were careful with them. And this one, she was always "friendly" [said through gritted teeth]... We didn't really understand it, but in spite of everything we were afraid of offending her in some way, or her father. When your father is a judge... we didn't trust people like that, there were rumors that they had been sent here as spies $(\mathrm{Z} 5 \mathrm{Cm})$.

The children and grandchildren of the Easterners appear to have lived in a completely separate world to their local contemporaries, with those worlds rarely overlapping. Local social life was configured in such a way that the borders between the groups were fairly impermeable. One of the most important separating mechanisms was at the level of school education: as noted previously, there were two institutions, a Ukrainian-language ("ordinary") school and a Russian-language one (the "Russian" school). The children of Easterners attended, needless to say, the latter, and the rivalry between the two institutions such as in sport or academic competitions - was fierce and not always gentlemanly. Unwritten social rules strengthened the segregation: fraternizing with the enemy was strongly frowned upon, and a young woman who agreed to go on a date with a soldier would immediately be vilified as having loose morals.

The barracks, the gendarmerie, the soldiers - girls who were friendly with them were, well, let's say, a certain category of girls. I was brought up in such a way that I could never belong to that category of girls. I had no contact with [the soldiers]. As for military 
families - my parents had no contacts like that, none at all. They all studied at the Russian school, they had their own circles (Z1Bf).

The division formed by institutional means and social norms was consolidated by fear on the one hand, and by dislike and jealousy on the other; the Easterners had special access to scarce goods, as the locals were well aware. Military personnel and many of the civilian Easterners had advantageous positions in the shady makeup of Soviet society: they could buy goods in special stores, and in ordinary shops they could obtain supplies under the counter; they also had more opportunities to travel. Understandably, such special entitlements made other residents of Zhovkva bitter. One of the younger interviewees remembered access to chewing gum as the defining symbol of segregation: "You have to understand, chewing gum was something only the 'whites' could have" (Z1Cf). In the recollections of locals, the children of Easterners also behaved in a way that betrayed their position. They were not only better off materially, politically more privileged and potentially more secure; they also - perhaps above all - made sure the other people of Zhovkva knew it.

Those people didn't try to learn our language, they didn't try to integrate in any way, they were absolutely convinced that if they spoke Russian, everyone else should understand them, although they didn't make an effort to understand others... [...] Their superiority was visible on absolutely all levels, and only a very small group of people tried to integrate, I mean to try to talk to their neighbors and so on. But the thing was, they didn't need to try to get to know their neighbors. They lived in special apartment blocks that were built for them, and they only socialized in their own circles (Z1Cf).

Like their parents, the majority of children from Easterner families did not remember any difficulties in their relationships with their peers. None of them remembered shopping in special stores or other signs of their privilege. They did attend the Russian-language school, sure, but so did many other children from different backgrounds - including some children whom one might least expect. One of the interviewees argued for the equality that reigned in his school by citing the example of a Ukrainian boy whose parents had been active in the UPA; the family had returned from exile and sent their son to the Russian-language school because he spoke no Ukrainian.

And he graduated with us, this friend of ours. [...] No one made any fuss, you know, whether you were a Ukrainian or whatever... My God... It was a very good school, a Russian school, it was called the Russian School no. 2. We lived together perfectly well $(\mathrm{Z} 38 \mathrm{Cm})$.

The sense of comfort and harmony with which the children of the Easterners lived was rarely troubled; perhaps even less frequently than the bliss of their 
parents. Statements about peaceful coexistence and mutual tolerance abound in these interviews. One testimony contrasts with this general picture, however; the speaker was from the family of a serviceman and a Ukrainian resettled from Poland. The woman bitterly recalled the lack of acceptance among the local Ukrainians, the abuse she received as a child, and the sadness and regret she still felt.

We're the second generation now, but they still call us Moskals, they don't call us Ukrainians. [...] And how I suffered in school! [...] I come home [from school] and I say: "Mother, listen, I was at this girl's house, and her mother said, 'that Moskal is here again." I ask, "why did she call me that, what's that all about? Do they hate me so much, or do we have this name somewhere, or what is it?" And my granny told me "no, it's because your father is a Russian," and she burst out laughing - she found this hilarious, you know. [...] And I went out with her brother for five years, but they didn't agree for him to marry me, because I was a Moskal (Z16Bf).

Similarly to the oldest generation, the exceptional case of a person who remembers strained relations between locals and Easterners was an individual who had close contact with the other group - as if the only guarantee of decent relations between the groups was their superficiality. Both interviewees, the older woman (Z10Af) and the younger one, complained about the rejection with which they were met when they wanted to cross the divide (or in the case of the older woman, once they had already crossed the divide). It would appear that this rejection later affects their perceptions of relations with locals for the rest of their lives: pre-existing scars amplify neighborly conflicts, tensions and misunderstandings. Tellingly, the younger woman was born to a mixed family, but not to a mixed marriage between a Russian and a local Ukrainian; her mother was a Ukrainian from Poland. If we consider the biographies of the interviewees in Zhovkva, it is striking that this type of marriage happened much more frequently than marriages between locals and migrants, with marriages between locals and Easterners especially rare in the oldest generation. It would appear that Easterners and resettlers were to an extent united by their common ostracism by the locals, as the following quote shows.

[Our] street was inhabited almost entirely by resettlers, they lived in practically every house, and we, people of the same age, we stuck together. And there were also people from eastern Ukraine, because there had been a famine in eastern Ukraine, and many people came here from there. And we were close to them as well. I mean, we were friendlier within our own group, but we had good contacts with them as well, because they had had a tough time and so had we. You see, they understood us and we understood them well (Z18Bf). 
The density of accounts of conflict in interviews with the second and third generations in Zhovkva, and the fading of animosity in the same generational groups in Krzyż, show that in these societies, the processes of social integration developed in two different directions. In Krzyż, divisions gradually vanished. In the increasingly revitalized town, there were more and more factors that united residents rather than divided them; a sense of community was evolving. The most important elements, described in detail in many testimonies by people who were children in the post-war years, were school, sport and the scouting movement. School brought people together through its universality and relatively low level of ideologizing, at least in the first years after the war, when pre-war textbooks and curriculums were still in use, pre-war teachers taught in the classrooms, and religion was still a compulsory subject. ${ }^{202}$

Scouting and sport were important because they were voluntary. As Zdzisław Mach argues, the ability to actively organize social life and feel one's own influence is an essential factor that determines the success or otherwise of the third phase of migration, the phase of aggregation. Even during the times when state interference in the structure and activities of the Polish Scouting and Guiding Association was at its greatest, young people in Krzyż treated the scouting movement as something they themselves helped to form, as a sphere of autonomous action; they were fairly effective in resisting the state's efforts to appropriate and discipline the organization. The Catholic Church played an even more significant role in facilitating social integration. I described earlier the example of people uniting to defend their local parish from the advances of "patriot priests." Equally important, however, was the status of the church as the only legally operating institution that retained its authority and autonomy after the war. ${ }^{203}$ Young people treated forms of activity within the church, such as altar service, as a substitute for an independent and patriotic social movement.

202 Authors such as Czesław Osękowski and Julia Makaro have written about school and sport (in the sense of supporting a team) as factors that were conducive to the integration of people born in the "Recovered Territories," see: Osękowski, Społeczeństwo Polski; Makaro, Gubin.

203 Marcin Zaremba has noted this exceptional position of the church in post-war Polish society, in his "Trauma wielkiej wojny. Psychospołeczne konsekwencje II wojny światowej," Kultura i Społeczeństwo, No. 2 (2008), pp. 3-42. For more information regarding the Catholic Church in communist Poland, e.g. about state-church relations and the role of the church in shaping public resistance against the regime, see: Brian Porter-Szucs, Faith and Fatherland. Catholicism, Modernity, and Poland (Oxford: Oxford University Press, 2011). 
Mixed marriages could be a substantial step in the integration process, and were already fairly common among the generation of people born in the 1930s, who entered adulthood in the "Recovered Territories." Accounts of such relations were usually full of warmth and humor: interviewees told various amusing anecdotes about cultural differences and minor difficulties in adapting to each other's ways at the level of everyday life. Although respondents who entered such marriages remembered initial difficulties, narratives of gradual accommodation were predominant; with the passage of time, the cultural differences no longer had any significance.

The best illustration of how things became normalized is that I married a woman from Poznań. Me, from Lwów, and her, from Poznan. And I remember that when we went to say our vows, the priest said: "Whoa, you're from completely different ends of the country! Lwów and Poznań, fancy that!" [...] Of course, the differences gradually faded. Today no one goes about saying that someone is from Poznań, they just say that we're all from Krzyż (K17Am).

For children born to such couples, the different backgrounds of their parents were perceptible only in minor trifles, such as culinary habits. No interview contained references to significant differences between their parents' mentalities or identities, and no one remembered any conflicts resulting from such differences.

Once we were a little bit older, those differences had already faded; at most, they liked different foods - say, Poznań-style potatoes as opposed to more eastern dishes. As for me, I didn't notice anything at all, I didn't see any differences related to my parents being brought up in different ways or in different places (K2Cf).

The younger the respondents, the more likely they were to declare that, although they were aware of their own family's history, the family backgrounds of other people had no meaning for them. I heard many firm opinions from interviewees that people simply did not talk about such issues, or that they had no idea where their friends' families had come from - not because it was a secret or taboo, but because it was simply unimportant. ${ }^{204}$ "No, we don't [talk about] where our grandparents came from. We were never very interested in that kind of thing.

204 For comparison, another study that shows the disappearance of distinctions between groups in the third generation in another post-migration community is: Werner Hollz, "Traces of German-Czech History in Biographical Interviews at the Border: Construction of Identities and the Year 1938 in Bärenstein-Vejprty," in: Living (with) Borders. Identity Discourses on East-West borders in Europe, ed. Ulrike H. Meinhof (Aldershot: Ashgate, 2002), pp. 95-118. 
I have no idea why friends would need to know where my granny is from, it wouldn't change anything (K25Df)."

In Zhovkva, things were different. In the high-pressure times of the 1940s and 1950s, there were no social mechanisms that could acts as a positive catalyst for social integration, unlike in Krzyż - such as common schooling, a united church or grassroots social movements. The schools in Stalinist Zhovkva were an instrument of oppression, and they also divided the children into a privileged and a subjugated group. The division was reinforced by spatial segregation (in the case of military families, who lived in a special district of the town) and material distinctions that were related to the distribution of goods. The available forms of social engagement, such as the Pioneer scouting organization, were completely subordinated to the state and therefore did not play an integrative role; the same could be said of the Orthodox Church. In the first generation of settlers, there were relatively few mixed marriages; crossing boundaries between groups was still too big a taboo. The few instances of mixed marriages among the interviewees could be counted on the fingers of one hand. Moreover, characteristically, respondents felt somehow obliged to explain or even justify their choice, whereas for the respondents in Krzyż there was nothing unnatural about marrying across the divide.

Lots of people here married like that. Lots, because after the war, you know... There are people who, for example, hated them: "Oh you Moskal!" This and that. These types, you know them... We had lived here and there, and we didn't really care, as long as a person had a good heart. And that is how we still live. He [the speaker's husband, a Russian] never interfered with anybody, he never got involved in politics, he never argued with anyone (Z16Af).

If in Krzyż the most serious problems for mixed marriages were to do with what to serve for a festive meal, in Zhovkva they could be of greater consequence because they raised essential questions, like national identity and one's view of the past. Many respondents made it clear that potentially controversial topics were not discussed at home - not because they were unimportant, but rather in order to protect the fragile unity of the family. Still, deep-lying mutual prejudices and irreconcilable differences in political or other opinions made themselves known in banal, everyday situations.

In terms of confrontations, I remember my dad, because he comes from near Volia Vysotska near Zhovkva, and there were lots of Bandera supporters in his family, Banderites. [...] So sometimes my dad would, you know - when generations argue they will reach for all the available arguments. There's no holding back when the situation gets emotional. [...] So they were arguing about something, and she [the speaker's Russian grandmother] called him a Banderite, saying "because of people like you I've suffered all 
my life, always running away," and he answered back, calling her a "vagabond," and so it went on. But on the whole we didn't talk about that (Z43Cf).

Of course, there were also stories of family harmony. Most commonly, however, these were furnished with ironic commentary or facial gestures that strongly suggested a different subtext: that we talk to each other because we have to, but in reality everyone knows we are different.

My son is married, and my daughter-in-law, K.'s [the speaker's granddaughter's] mother, her grandfather was sent to the camps, he was even in the Halychyna Division [SS Galizien, a German military division during the war], and then he was with the Banderites. And yes, we talk to him [laughter] (Z20Am).

The absence of social factors facilitating integration did not prevent it totally, but certainly slowed down the integration. Whereas in Krzyż, differences began to diminish in the second generation and had completely disappeared by the third and fourth generations, in Zhovkva the differences continued to divide people. Their pertinence is shown by the fact that the 1990s in Zhovkva did not bring openness towards the various identities and group memories that had been hitherto suppressed, but the opposite: the return of open conflicts on two fronts: religion and politics. The dispute between the Greek Catholics, who demanded the return of the Basilian church and monastery, and the Orthodox, who had occupied it since Soviet times, is remembered in Zhovkva as two separate narratives with no overlap. The two camps blame each other and are to this day unwilling to compromise. The Orthodox feel disparaged by the hostility of the Greek Catholics, which they consider to have been undeserved. Especially in conversations with older people, there comes across a conviction that the Greek Catholic Church is a forgery dreamed up by local nationalists.

There used to be one church, the Orthodox one, and everyone went to the same church, and everything was fine. I didn't even know there was such a thing as a Greek Catholic Church. But once Ukraine became independent, how they started to fight, the Orthodox and the Greek Catholics, provoking each other all the time...! They drove them out of that church, there were services being carried out outside the church doors, it was an absolute nightmare! (Z10Af).

The Greek Catholics answer with accusations to the effect that the Orthodox made the return of the church unnecessarily difficult, tried to steal valuable relics, and even betrayed their nation by preventing Orthodox believers from being "true" Ukrainians. They considered the Orthodox Church in Zhovkva to be nothing more than a Moscow agent, and Russian dominion over the local parishes was a particular thorn in their side ("We never went to Russia to install the Kyiv patriarchate there, so why should we have a Moscow patriarchate? [...] 
As my grandmother used to say, Moscow needs to shove its nose in everyone else's business" [Z19Bf]). Both narratives contributed to the reactivation of divisions that had begun to fade by the end of the 1980s. These divisions reverberate in Zhovkva society with the echoes of old prejudices, and they pit people against other who had apparently nearly forgotten who arrived from where in the 1940s and why. Meanwhile, each side is convinced of their own moral correctness, as well as the wrongness of the other.

When that war began, that division into different churches, there was, for example, an old lady, 87 years old, she's dead now, and she was like family to us. And when that storm started to brew, she just turned her back on us. We became enemies, we didn't even say hello to each other for ten years, even though she had looked after me as a child, but she wouldn't talk to me because I was a traitor. [...] All the Orthodox were enemies to her, we were all Moskals (Z20Bm).

A simple example: it's the Easter procession, the Way of the Cross. The whole town is taking part: the Polish Church, the Autocephalous Church, the Greek Catholic Church, all of these confessions are out on the streets. But Comrade H. - the priest from the Russian Orthodox Church - he doesn't even open the church doors. He doesn't go out with the people. [...] [And who goes to that church?] Well there are a couple of idiots who do. There's no other word for it (Z29Bm).

Interestingly, the religious conflict also became a platform on which new prejudices grew, as a result of the convergence of old wounds and new power divides. Since "Moskals" and "idiots" attended the Orthodox Church, everyone else who adhered to Orthodox religious practice must also have had a similar status. The new division of power in the town and the political fall from grace of the old elite, together with the religious conflict, led to the emergence of new social stigmas. In this situation, resettlers were especially prone to feeling victimized, believing that they were yet again being unfairly discriminated against.

People now say: "you resettlers, you go to the Russian Church because you're not real patriots." [...] If you have a look at our church, the Orthodox one, the Russian one, it's only laborers who go there. No one from management. The dentist, all the doctors, they all go to the Catholic Church, even if their father was Orthodox. ${ }^{205}$ [They go to the Greek Catholics?] Yes, for example, my wife's sister has started going to them as well, she converted from the Orthodox Church to the Catholic one. She says: "everyone goes there, I'm the only one here..." So it's about her career and all that. You can't be a manager and go to the Orthodox Church (Z5Bm).

205 When this particular interviewee uses word "Catholic," he of course means Greek Catholic - this is a fairly common language practice in Zhovkva. 
The religious conflict acted as a prelude to extreme tensions with a political basis, whose zenith occurred during the referendum on Ukrainian independence in 1991. This conflict was, effectively, the second act of the same drama, with the same cast: on one side, the Zhovkva residents who had arrived from the East; on the other side, "real," Galician Ukrainians; and the resettlers caught in the middle, although on this occasion they took the side of the locals in much greater numbers. The axis around which the conflict turned was the issue of language, although conflicting regimes continued to play a similar role: Easterners felt unjustly persecuted and discriminated against, and the locals perceived the installment of Ukrainian as the state language to be rightful revenge for years of oppression against their own native tongue. ${ }^{206}$

They're still as stubborn as goats can be. Whereas Moskals turn up, they always bring their own people and let them rule...! So pack your bags and be off with you if you don't like it here. [But no one has left?] No, no one, what would they do over there? They're not fools after all, quite the opposite. They try and come here and make a life of it. [...] They live in Ukraine but they're Russian, and they want Russian to be the [official] language as well, because they refuse to speak Ukrainian (Z19Af).

Against the background of this conflict, the position taken by Zhovkva's Poles is especially interesting. Despite their unwavering anti-Soviet stance, during the Ukrainian "national rebirth" they were firmly on the side of the Easterners. Perhaps they were expressing a simple solidarity between two minorities, of which one had suddenly lost its dominant position and the other was unsure what its fate might be under the new regime; perhaps they were driven by a fear that the reawakening of western Ukrainian nationalism under the sign of Stepan Bandera would not necessarily be a positive change for them. A middle-aged Polish woman remembered Ukrainian nationalism in the early 1990s as "wild," virulent, and uncompromising. She said that she had been afraid of

206 The issue of language and nationality in Ukraine in the 1990s is explored, among others, in: Ian Bremmer, "The politics of ethnicity: Russians in the new Ukraine," Europe-Asia Studies, No. 46(2) (1994), pp. 261-283; more information concerning the relationship between language and identity in Ukraine, with a particular focus on Russians' responses, can be found in: Roman Solchanyk, "Russians in Ukraine: Problems and Prospects," in: Cultures and Nations of Central and Eastern Europe. Essays in Honor of Roman Szporluk, ed. Zvi Gitelman, Lubomyr Hajda, John-Paul Himka and Roman Solchanyk (Cambridge: Harvard University Press, 2001), pp. 539-554; Taras Kuzio, Robert. S. Kravchuk, Paul D' Amieri, eds., State and Institution Building in Ukraine (London: Palgrave Macmillan, 1999). 
her own husband, a Ukrainian from near Zhovkva, who told her that if he had known of her Polish roots before their marriage, he would never have tied the knot with her.

Accounts of these religious and political conflicts differ in their temperature. Memories of confessional disputes remain heated to this day, arousing strong emotions even among people who are generally detached from politics. Political and linguistic issues, on the other hand, which returned as an echo in the period of the Orange Revolution of 2004, retain a potential for conflict only among the most "fanatical" representatives of both camps, to borrow a word used by the above interviewee. The majority of people in Zhovkva believed that the flames of conflict were gradually dying down, and that the present-day situation was free of problems.

However, interviews with people from the fourth generation showed that social integration had taken place in Zhovkva. Whereas they did remember the conflicts of the 1990s, they thought of them as something from the past that could only interest older people. These recent disputes had no relevance to them.

I think that's an issue for older people mainly. Once in a while I hear that this person is from that church, and that person is from a different one, and someone else used to be a communist. Sometimes, though not very often, you might hear that someone is a Jew, another person a Russian, a Pole, and so on. Ukrainians can blurt stuff like that sometimes. But for there to be openly hostile relations, no... (Z47Cf).

The youngest generation's openness to the future of their town in both Krzyż and Zhovkva, and their backing away from historical prejudices, can be seen as a sign of a very positive development - that social integration has been completed, and that the young people pay no attention to personal origins because everyone is simply local. Even if some respondents still harbored the divisions from 60 years previously, these are merely examples of unsuccessful psychological integration, which occur everywhere. Nonetheless, a comparison of the development of the integration process in the two towns prompts us to retain certain reservations. If society in Krzyż appears to have overcome its fractures to such an extent that problems seem unlikely to occur, the same cannot be said of Zhovkva.

Paradoxically, although the differences between certain groups of migrants were objectively greater in Krzyż than among most of the new residents of Zhovkva, they turned out to be easier to navigate, because these differences primarily concerned everyday habits, which were easier to change. In Zhovkva, the contrasts related to fundamental issues: national identity, political identity, one's vision of the state, and the past - especially questions about who was a perpetrator and who a victim. It was the categorical weight of these differences that led 
to their return as soon as systemic transformation was embarked upon after the fall of the USSR. In Krzyż there were no divisions that could return. It remains an open question - especially in the climate of political uncertainty in today's Ukraine - whether the return of these resentments was the last one, or whether they might recur as an echo in the future. 



\section{Resettlement and Identity}

\section{Returning Home - the Last Stage of the Psychological Integration Process}

It is difficult to grasp the exact moment in a migrant's narrative when they have become fully integrated into the new place of residence. The description of this process is always intense, saturated, and many-sided. But the respondents' testimonies were usually concerned with the social aspect of integration (the creation of a new community with new social bonds), rather than the psychological dimension. ${ }^{207}$ While the first visits to the "former homeland" acted as a coda for the first phase of integration - above all, in the material and everyday aspects the later phase of social adaptation essentially has no temporal boundaries. Change is clearly visible at its peak, during the conflictual stage, but then gradually loses its sharpness, eventually disappearing completely from the section of the narrative about more recent times. We could see this as evidence of the successful completion of psychological integration; but at the same time, it may be possible to discern a resignation and surrender to the impossibility of changing a reality over which one has no influence, especially among older respondents. It is the former scenario that is observable in the majority of the autobiographical narratives of my respondents. Interestingly, whilst it was the first post-war visits to former homes that functioned as a closing coda, later visits after the fall of communism played a dual role. On the one hand, they allowed people to reprise a question that had ostensibly been put to one side, the question of their relationship to their former homeland; on the other hand, these visits were an opportunity to finally gain closure on this aspect of their biography. Reflected against the broader biographies of the interviewees, these trips also had a substantial effect on their narratives. Based on the type of experience, and also taking into account individuals' prior attitudes to their new and old homelands, we can distinguish several different types of narrative about these journeys as acts of returning to

207 The mutual dependence of these two levels is posited both by classical theories of interethnic relations (e.g. theories of assimilation by Robert Park and Milton M. Gordon), and by numerous studies on the psychological aspects of the integration of migrants, particularly in western Europe and the USA, see: Janusz Mucha, Stosunki etniczne we współczesnej myśli socjologicznej (Warszawa: PWN, 2006); Paweł Boski, Maria Jarymowicz, Hanna Malewska-Peyre, eds., Tożsamość a odmienność kulturowa (Warszawa: Instytut Psychologii UW, 1992). 
a former home. Juxtaposed with the statements of younger people, they form a certain typology of relations between resettlement and identity.

\section{People Make a Place a Home: "Who would I return to?"}

The first type of narrative is characteristic of respondents who yearned more for the people they had left behind than for the places. When, after the fall of communism, they could finally visit their native territory without any difficulties, it turned out that their homes were gone, because the people who comprised and created that homeliness were no longer there: neighbors had departed, relatives had become estranged, and younger generations had changed their identities.

To begin with, everyone wanted [to make the journey]. I also went home, a few times, to... to L. [...] It was alright I suppose, but what was left for us there...? They are all settled there, their children are Poles now. They're not Ukrainian any more. My younger sister married a Pole, and they've become completely polonized. [...] The children, the girls, are also Polish. There's nothing that can be done about it. Let them be Poles, as long as they live in friendship and accord with Ukrainians (Z3Af).

In this testimony, the speaker's disappointment and regret at the polonization of her former homeland and its residents turns into an acceptance of the situation and a recognition of the irreversibility of the changes - both in other people and in her own self. Such statements were observed almost exclusively in interviews with Ukrainians who were resettled from Poland. Their children and grandchildren sometimes recalled traveling to Poland with their parents and/or grandparents, but stated that they did not maintain contact with their cross-border relatives. Like the oldest generation, they perceived the former homeland of their forebears through the prism of people - and since nothing connected them to those people any longer, the lost homeland had no significance for them.

Well we are bit further removed from them now. Otherwise we would correspond with them, we would call and maintain friendly relations. But I can't say that we have any real contact with them. They are proper Poles now, through and through... They don't even try to speak Ukrainian. And to be honest, those children and grandchildren of theirs... They're just not really our relatives any more, all of that is slowly disappearing (Z6Df).

A mirror image of this type of narrative can be seen in the accounts of respondents who never visited their former homes, because they believed they had no one to return to ("Who would I return to? Especially after my children were born here and went to school here. Why would I go back?” [Z32Af]). Above all, in Zhovkva it was migrants from the East, and occasionally Ukrainians resettled 
from Poland, who made similar statements and never went "home;" the eastern Poles in Krzyż, in contrast, never spoke in this manner. It is clear from the above statements that these people have no "old homeland" - the only home they have is in Zhovkva, where their family lives.

\section{The Former Homeland as an Element of Identity: "It's good that we know these things."}

The second type of narrative appears in conversations with individuals who made the journey to their old homes not out of nostalgia, but in order to achieve a harmonious conclusion to their personal biographies. Compared to others, their return trips appear as the most consciously experienced, and the most similar in function to what Kaja Kaźmierska calls a "biographical coda" that gives symbolic closure. ${ }^{208}$ Respondents were effectively tying up matters that, due to the necessity of post-war resettlement, had become permanently and painfully unfinished: visiting the graves of loved ones, or revisiting places where their houses had stood and where they had played as children. This group was comprised mostly of people resettled from the former eastern provinces to Krzyż, and to a lesser extent, of Ukrainians resettled to Zhovkva from Poland. Whilst it cannot be said that these people felt no yearning for their native territories, this feeling was usually a calm nostalgia that had been worked through, rather than a deep-seated and painful longing. A substantial role in this attitude is played by a conviction that their lives had been a success - these respondents did not have a feeling that resettlement had been a cause of individual failure, and so they could transform the memories of their former homes into a positive element of their identities. They often traveled back to these regions with children and grandchildren, wanting to show them their family roots, and also thereby passing on their family memory to successive generations. None of the interviewees said so directly, but it was apparent that the presence of the younger generations on these trips had been very important to them - as providers of emotional support in the moment of confrontation with their own pasts, and also means of closing a phase in their biographies.

I went there recently with my children, to the village, to the banks of the S. river and the bridge, which is still there to this day. Our house is gone, but the house of the Pole whom my sister married is still there. My brother, who was born in 1938, he's younger than me, said: "When the war was over in 1945, I went to hide in the cellar in Aunt H. and Aunt J's house. Is that cellar still there, do you think?" A family lives in that house now, they

208 Kaźmierska, Biography and Memory. 
resettled some Hutsuls into it. ${ }^{209}$ And he [the new owner] says: "the cellar is there, have a look, I'll show you" (Z15Am).

It is extremely interesting and instructive to compare this statement with the speaker's daughter's impressions of the same journey. Her statement perfectly illustrates the process whereby individual experience, which is still alive as part of autobiographical memory, becomes transformed into family memory, which carries a significantly lighter emotional load.

We went to my father's home territories, twice. I was surprised that it was just a few small houses, and then my father and his brother began to tell us about how "this is where we hid, and they were shooting from over there..." They even showed us the cellar where they took shelter then. It was just like in their stories, even when we went in there, my sister, my aunt, we all went in that building, and it was as if our hearts started to beat differently because we were seeing this place. [...] We went to the grave where lots of [people from] our family are buried, and dad and his brother told us that this was our family. So those memories, they really are... Objectively it's good that they are there and it's good that we know these things, but with time they are disappearing... (Z15Cf).

It is noteworthy that consciousness and acceptance of the process of change is observable in both statements. Both father and daughter understand that a gradual weakening of their connection to the old homeland is a natural and de facto positive development, because it allows them to put down roots in the new place. Another statement, by a woman from Krzyż whose family originally hailed from the eastern borderlands, brilliantly complements this intergenerational dialogue:

I am really interested in where my grandparents came from and how they lived there all those years ago. Because I, for example, if I had moved somewhere very far away, I would want to go back, to go and see who lives there now, to see what the place I lived in before looks like now (K9Df).

This interviewee had never visited the birthplace of her grandparents, and for obvious reasons, did not feel any nostalgia for it, but declared that she understood the longing of her grandparents' generation, and that she would like to visit the territory one day. Nonetheless, she perceived any such journey in terms of an interesting possibility, rather than an undertaking hat was indispensable to the maintenance of her identity.

209 The Hutsuls are an ethno-cultural group of Rusyn highlanders, one of three subgroups alongside the Boykos and Lemkos. Since the Hutsuls have historically lived in the eastern part of the Carpathian Mountains, it is in fact unlikely that members of this group were resettled after the war to the region being discussed by this respondent (Lublin region). He may mean that Poles who were resettled after 1945 from majority-Hutsul territories inherited the house. 
Sometimes, only the younger members of a family accomplished symbolic closure of the biography of a resettled person. This happened when resettlement was a trauma that not only burdened the migrants who experienced it first hand, but also affected their children and grandchildren, who felt the consequences for years to come. In such cases, the descendants of resettled persons treated their visits to the former home territory as a duty towards their parents or grandparents, who could not make the journey themselves, or sometimes as a kind of reckoning with previous wrongs or moral reparation.

My grandma lived in Sverdlovsk, Sverdlovsk in Russia, that's a long way, isn't it? I went there two years ago, not for very long... My family didn't go there because it was too far. But I went, and I felt just this nostalgia, or what would you call it... I saw everything, now I knew what it was all like. Grandma was put in prison, granddad too. Granddad was given four years, and grandma two years. ${ }^{210}[\ldots]$ She [grandma] didn't tell us much about it, but I later found documents in the archive $(\mathrm{Z} 38 \mathrm{Cm})$.

Significantly, this speaker was the only respondent from an eastern background in Zhovkva who considered a return to his grandparents' native territory to be an important deed. It appears that homelands left behind in eastern Ukraine and Russia were the least loved and pined for. This may be because a Soviet childhood in Stalinist times provided a weak basis for a myth of lost childhood innocence; alternatively/additionally, it may be because these migrants' journeys to Zhovkva were more voluntary than the resettlements of those who were deported from or to Poland.

\section{The Lost Homeland and Crippled Identity: "A person is always attached to their homeland."}

The third type of return narrative concerns trips to the former home territory that were very painful experiences. Respondents who suffered as a result of their visits had never completely come to terms with the loss of their old homes, and never really put down roots in their new places of residence. Migration was for them a debacle, above all at the level of individual identity. Even if they did adapt - sometimes very successfully - to the new geographical and cultural setting, the phase of identity assimilation was never completed. Having been torn by longing and a sense of alienation for decades, these individuals traveled back to their "homes" whenever they got a chance; they made the journey in a fit of

210 The grandparents of this speaker, ethnic Russians, were victims of the Stalinist Terror, most probably in the 1930 s. 
vain hope, believing that the trip would help them to gain reckoning with their yearning. In their accounts of return, embitterment and disappointment are the dominant tones; sometimes the pain of loss is even endured all over again - this time irreversibly.

I went there, I went to D., to a little church. The Ukrainians had burned down the church, there is nothing there, they just put up a cross there. The church was burned down. It's gone. And so I was in Volhynia and my God, I was looking around, I was devastated, I want to cry, I wanted to cry. [...] Where our house used to be, our farm, and also where we lived, where our Ukrainian neighbors used to live, those large manors - it's all gone without a trace. I looked for our place, where my father had his house, his barn, his stable. I looked for all of it. Maybe I would find a stone, a piece of wood. Nothing (K24Am).

Usually, these forlorn and painful trips were made alone. If children or grandchildren did accompany the older people, they later openly admitted that, even if they sympathized with their parents or grandparents, they did not share their pain. Sometimes they even found it difficult to comprehend, let alone empathize: especially among the youngest respondents, there were speakers who shrugged their shoulders and stated that they could not understand why their grandparents continued to cultivate memories of the "old homeland" that they had lost so long ago.

Granny still dwells on it, and before it was even worse. [...] She still knows those Ukrainian songs and prayers. I don't really get it, but they really care about it. [...] I ask why, why do you need it? You're Polish. I understand that you want to remember it, I mean, why not remember it, sure. But it's like... It's as if she didn't fully grasp that she's Polish and she doesn't need that now. [I want to ask her:] "Why didn't you get used to it, it's been so long" (K20Df1).

Against the background of an absence of sympathy or understanding, or even, as in the statement above, actual disapproval from loved ones, the loneliness of the resettled and deported becomes even more suffocating. An even tougher situation was perhaps encountered by those would have very much liked to undertake a return journey, but never managed to see their old homes. Even the most painful confrontation with one's former homeland could have provided a sense of some form of activity, of trying to take control of one's own life; the people who did not undertake such an attempt were consigned to futile remembrance of the past and to dwelling on their losses. The most common reasons for not making the trip included old age, bad health, and lack of financial resources; sometimes, people were afraid of the emotional and physical consequences of the encounter. A sense of lost life predominates in these testimonies, as well as 
incompleteness of one's biography - these people were lacking an experience that would give closure and coherence to their lives.

A person is always attached to their homeland. I would have liked to have at least seen it before I die, but now I definitely won't. I can't travel far now. Maybe if my husband was from the East, he would come with me, but he's from here and he's not attracted to the idea. Our children have also become used to being here. [...] I just gather things, whatever I can, so that we have something to remember it by, so that the children know what it was like, and the grandchildren too. They are tough memories. It's difficult to forget, because I was big enough, I remember everything. If I had been younger, I would have remembered less now, and it wouldn't have been so painful. But now I go out, and I am on the streets of Ch.; quite often, I feel like I am at home, over there, in the East (K2Af).

The only respondents who felt they had lost, who continued to yearn for their old homes and never truly came to terms with their fate, were Poles resettled to Krzyż from the former eastern territories. No other groups of migrants expressed such emotions. This is strong evidence of the exceptional status of the so-called Eastern Borderlands, the lost eastern lands, in the construction of Polish identity - both on the collective and individual levels. ${ }^{211}$

\section{No Need for Homeland: "Why would we go there?"}

The fourth type of narrative is, in fact, the absence of a return narrative. One section of interviewees never went to their native territories because they never felt a need to do so. These individuals were not reluctant to travel for any specific reason; rather, they generally had no desire to undertake the journey, even if circumstances were conducive. They asked with a tone of surprise: why would we go there? After all, the past was the past, and nothing connected them to that place any more. There were not many respondents who made such arguments only a few individuals in the entire sample. Moreover, they were all Ukrainians resettled from Poland. As a rule, they were the same people who declared that they never felt nostalgic about their former homes, and who also assessed the overall balance of gains and losses resulting from resettlement to have worked in their favor. ${ }^{212} \mathrm{~A}$ weak bond with the old homeland also corresponded in these instances with a lack of any real symbolic connection with the new place of residence. It follows that this disposition is rather a general absence of a particular

211 There is a vast literature on the significance of the so-called Eastern Borderlands for Polish identity and collective memory. In English, see: Robert Traba, "The Kresy as a Realm of Memory: The Long History of Persistence," Herito, Vol. 8 (2012), pp. 58-91.

212 Halyna Bodnar has written about the frequent occurrence of such statements among Ukrainian resettlers, in: Bodnar, “Tam bulo dobre.” 
sensitivity and reflexivity, or what Maria Lewicka, in her study of the relationship between people and places, describes as individual, psychological factors. ${ }^{213}$

\section{The Old Homeland in the Consciousness of the Younger Generations}

In both towns, members of the younger generations were much less likely to express a desire to visit territories connected to their family history. ${ }^{214}$ A clear majority of younger speakers in Zhovkva and a significant number of their counterparts in Krzyż stated that the idea of a journey to their parents' or grandparents' former homes had little appeal. Sometimes they declared outright that they saw no point or necessity in undertaking such a journey, because those lands had no meaning to them: "I was born here, in this house. Why would I want to go over there? It has nothing to do with me. [Do you have any sentiment for those lands, or none at all?] No, none at all" (K9Bm). Others were less categorical in their unwillingness to take the journey, even declaring that if their elders wanted to go, they would happily accompany them. But this readiness to travel often came across as a general desire to see the world, with little or no connection to the history and identity of the family. It would appear that these respondents would invest a similar amount of emotions into a willingness to go on any other tourist trip. The last sentence of the following statement captures the speaker's strong indifference to the older generation's nostalgia:

My mother wanted to take a trip, to have a look. You know, to visit, take a trip down memory lane, that sort of thing. [...] Who knows? Maybe I would go, to keep her company, to find out what it looked like, why not? [But you don't feel any bond with that place?] No, absolutely none. None at all (K26Cf).

Such declarations are important because the speaker's attitude to the potentiality of a visit gives a strong indication of how they see their "old homeland." To put it simply, for a large majority of younger people, the former family territory is at best an illusion onto which their elders still cling. Also, it is no

213 Maria Lewicka, Psychologia miejsca (Warszawa: Wydawnictwo Naukowe Scholar, 2012).

214 For an interesting case study on the identity of Ukrainians deported to North-West of Poland within the "Vistula Operation" in 1947, see: Wangler, Rethinking History. This study shows much deeper attachment of the second generation to the "lost homeland" in comparison to my sample. The difference might have originated from Wangler's interviewees being much better educated and involved in the activities of deportees' associations. 
coincidence that both of the above quotes came from Krzyż: the topic is totally absent in Zhovkva, where respondents were surprised to even be asked. The following statement, by a woman whose parents were both resettled from Poland, conveys this fact: "I was born in Zhovkva, I'm a pure, born-and-bred Zhovkvan" (Z6Cf).

There was a small number of interviewees in Krzyż whose attitudes to family history, and therefore their own identities, were more complex. These people spoke of an indirect bond with the regions from which their parents came, and said that family roots were important to them. Again, only people whose families were resettled from the pre-war eastern provinces made such statements; moreover, in cases where only one parent came from the eastern borderlands, the home territory of the other parent (e.g. in the case of the speaker cited below Wielkopolska) had no such significance. This shows the enormous role played by forced migration in the creation of an intergenerational myth of lost homeland. It is also extremely significant that this was a large-scale, collective trajectory: the loss of these territories was felt not just by individuals, but also by a greater collective.

The Eastern Borderlands are close to me for a variety of reasons. I collect stories, you know, about hunting and different aspects of life connected to the region, I've heard lots of different things, very interesting things. I'll always have a sentiment, for sure, because I am a part of it. It's inside me somewhere, maybe even more than it seems. [...] When, one day, my mother's generation will be gone, I'll be thinking about the Borderlands, but not in a way that I'll want, say, to go there $(\mathrm{K} 43 \mathrm{Cm})$.

The speaker's bond with the former eastern regions ${ }^{215}$ is founded on a feeling of symbolic linkage with the cultural heritage of that place; it is neither a personal connection nor a desire for restitution. It is nostalgia, but not yearning. All of the respondents in Krzyż who stated that the pre-war eastern lands retained significance for them displayed an attitude of this kind. It is pertinent that whilst the above speaker was sentimental about the region, he had no intention of going there, and was not making any claims on the territory - it was not, after all, his home. There were only two interviewees of the younger generations in the entire

215 It is interesting to note that younger people use the term Eastern Borderlands much more frequently than the oldest respondents. This is an indication of how the broader, national community of memory about this formerly Polish territory is constructed, for the second generation and onwards, in mediatized discourse and not only through family transmission of memory. A similar observation has been made in: GłowackaGrajper, "Społeczna i indywidualna kontynuacja pamięci." 
sample who declared that they felt a stronger connection to the native land of their parents than to the place in which they themselves were born. Interestingly, one was from Zhovkva and the other from Krzyż.

Oh God, she [my mother] used to say: "We were still young then," she would say that it wasn't her decision, it was her father's. You know, if someone told her now that she could go, that there was nothing holding her here, Granny would go. And S. [the speaker's son] and I would also link up our hands and go to Poland. We probably wouldn't even bother to pack our bags (Z16Bf).

My father taught me that this is not our land, that our family home is over there, in the East. [And do the Eastern Borderlands mean something to you now?] Well definitely, just like to everyone. You know, it's a bit like... Now there are no barriers, I mean at the border, but I know for sure and I feel that my roots are over there, because that's what my father told me. That no matter what happened, we would know that we were not in our own place here (K8Bm).

Both statements are exceptional in comparison to other interviewees of the same generation, and are better explained by individual biographical factors than broader social conditions. Both individuals spent their entire adult lives away from Krzyż and Zhovkva, only returning there after early retirement. They both felt alienated from their surroundings after their return, and were disappointed in the towns where they had grown up: both Krzyż and Zhovkva had changed substantially in the intermittent decades. The speaker from Zhovkva, who was from a mixed Russian-Ukrainian family, was additionally uneasy with locals whom she considered "chauvinistic" nationalists. In these circumstances, the construction of a personal myth of a lost homeland comes across as an individual mechanism of rebuilding one's own identity, rather than a consequence of social phenomena.

A final interesting phenomenon concerning the relationship between migration and identity building among the younger generations is that respondents reflected on their sense of rootedness despite the lack of a macro-historical or family continuity. For a significant group of Krzyż residents, the fact that their family did not originate from the town that they themselves considered their own was an issue they reflected on in some detail. They did not perceive this fact as a barrier to their own sense of being at home; rather, it was an additional element of what connected them to Krzyż. Their statements often featured a gradual development of a bond between the town and its new residents. They observed an intensification of this bond from generation to generation, with further descendants treating the fact of being at home in Krzyż as something obvious and taken for granted. 
My mother always said, all her life, that [the pre-war eastern provinces] was where she grew up. That is how I see Krzyż. My mother didn't really understand that for a long time. But this is where I grew up, where I became an adult. This land is what I know, it's normal to me. Everything that has happened to me in life was connected to Krzyż. Even if I left for somewhere else, I always came back here, to this Krzyż (K43Cm).

Importantly, such reflections feature only in interviews with people from Krzyż. When respondents in Zhovkva were asked questions in a similar vein, they normally responded with surprise: why would they not feel at home in Zhovkva? What significance did it have that their parents weren't born here? Clearly, this reaction is a consequence of the specific status of resettlement in both family and broader collective memory - it had a weak presence, if any at all. Moreover, communist-era propaganda had a different function in Krzyż, preserving a sense of temporariness, whilst in Zhovkva it had an opposite effect. On the one hand, this sense of assuredness gave residents of Zhovkva a certain carte blanche in the construction of a bond with their place of residence, releasing them from apparently unnecessary burdens. On the other hand, it is possible that these identity formulations are somewhat superficial, with their complete absence of doubt; perhaps, this taken-for-grantedness is too simple, and some form of reckoning still awaits.

\section{Gains and Losses - Who Came Through Migration Successfully?}

Studying the identities of resettled people naturally leads to asking to what extent those people have become integrated into the new community; in other words, whether or not their migration was a success. The last stretch of the narrative interview took the form of a weighing up of the personal gains and losses that resulted from the fact of migration, the outcomes of which could be seen as a personal assessment of the speaker's level of integration. Some of these gains and losses pertained to the emotional costs of resettlement and the challenges associated with building a new identity in the new place of residence. Other parts of the evaluation concerned the economic, social and political aspects of migration.

The observations presented in this and the previous two chapters yield a temptation to make some overall generalizations. It appears that the most important factor affecting the success of a person's migration - other than individual circumstances specific to the situation of the interviewee - is the group of migrants to which they belong. Looking at the objective variables that could facilitate or obstruct the adaptation process, it is clear that there were huge differences from the very outset in terms of resettlers' chances of reconstructing 
their identities and regaining a similar social and economic position to that which they had previously occupied. Factors that were conducive to successful integration in Krzyż and Zhovkva include: the voluntariness of migration; a high degree of physical and cultural similarity between the old and new home town; a confidence and certainty that the resettlement was long-term; the presence of locals who were born in the town; and the possibility of contributing to social life in the new place of residence. Factors that correlate negatively with social integration include: migration as a large collective, leading to a shared loss of a former homeland; social and economic marginalization associated with the fact of being a migrant; and the degree of oppressiveness of the non-democratic system. ${ }^{216}$

Some of these factors played a role in only one of the towns, whereas others were important in both towns and for all residents, but to varying degrees. Both communities were located in non-democratic countries after the war, but the tangible level of threat from state repression was incomparably higher in Zhovkva. Krzyż was relatively privileged, because despite the totalitarian nature of the political system, residents had a genuine influence on the organization of local social life, strengthening the emerging social bonds. At the same time, the integration of new residents in Zhovkva was made comparatively easier by the presence of locals, who - at least in theory - could act as "guides" for the new arrivals. A similar role was played in Krzyż by "neighbors from the other side of the river," but ultimately their presence had a minor significance for the integration of settlers. The final variable that had an effect in just one town was the fact that in Krzyż, many migrants - those from the East - had lost their homeland together, as a collective. Migrants in Zhovkva were at least spared this difficulty.

People who arrived from the shortest distances were the ones who faced the fewest challenges: that is, migrants from nearby Polish or Ukrainian villages. Their resettlement was voluntary, and they had not fundamentally changed their physical and cultural environment; and even if they were not certain that they would stay in the long run, their potential return journey home was much simpler than for others in a similar position. Moreover, as "nearly locals," they did not have to deal with the threat of migrant marginalization or the trauma of losing their homes. The second most likely to have a successful migration were the Soviet pioneers in Zhovkva and settlers who arrived in Krzyż from Polish

216 My list of factors that facilitate integration among migrants partially overlaps with the variables proposed by Zdzisław Mach in his book Niechciane miasta. 
regions that remained inside the state's borders after 1945. Whilst the Soviet pioneers did travel to western Ukraine under duress (usually, they had been assigned to work there), they did not usually perceive migration from Russia or eastern Ukraine as a form of repression, as they could count on a privileged social position at the point of arrival. They treated the possible temporariness of their stay in Zhovkva as a natural component of their lives as Soviet citizens, not as a threat. They were also the only group for whom the difference of the new cultural environment was more a benefit than a drawback. Their integration was, however, made difficult by the negative disposition of other Zhovkva residents towards them. For migrants from central Poland, adaptation to life in Krzyż was facilitated by the fact that they had chosen to move there; even if there was an element of economic duress, they had migrated in order to improve their own living conditions, not to escape starvation. Their former homelands were distant, but not irrevocably lost to another state. The difference between their old and new places of residence was larger than for the "neighbors," but incomparably smaller than for the Poles from the pre-war eastern provinces. Their social position upon arriving in Krzyż was generally high, and other residents tended to treat them well.

The groups that undoubtedly had the hardest experience were the Polish and Ukrainian "repatriates." Whilst the majority of Ukrainians resettled from Poland did not lose a part of their ideological homeland, ${ }^{217}$ they were encumbered with the ordeal of deportation, and their social and economic status in the new place of residence remained low. ${ }^{218}$ Moreover, others were negatively disposed towards them, and their feeling that the new situation would only be temporary - and the hope that they would return home - acted as barriers to adaptation. The only positive influence on their integration was the fact that Zhovkva differed little

217 For a definition of an "ideological homeland" (as opposed to the private one), see: Stanisław Ossowski, “Analiza socjologiczna pojęcia ojczyzna," in: Dzieła, Vol. III (Warszawa: PWN, 1967), pp. 201-226.

218 It appears that the symbolic inclusion of so-called Zakerzonnia (i.e. Trans-Curzonia, or the now-Polish regions that previously had significant Ukrainian populations) into the Ukrainian ideological homeland, and especially the construction of a Ukrainian myth of "lost homelands," happened much later than in Poland, where the myth of Eastern Borderlands became very powerful very quickly. Andrew Wilson argues that these processes took place after 1991, when new national myths were being formed, see: Andrew Wilson, "National history and national identity in Ukraine and Belarus," in: Nation-building in the Post-Soviet Borderlands, ed. Graham Smith, Vivien Law, Andrew Wilson, Annette Bohr and Edward Allworth (Cambridge: Cambridge University Press, 1998), pp. 23-47. 
from their previous home territory. The eastern Poles had it even worse: in addition to the burden of forced migration, the sense of impermanence, the threat of marginalization in the new place, and the prejudices of other residents, they had to come to terms with major differences between the cultural landscape of Krzyż and their former homes, as well as - and perhaps above all - the trauma of irreversibly losing lands that they considered a part of their ideological homeland (and not just their private native realm).

The narrative biographies of the oldest residents of Krzyż and Zhovkva confirm this model of a relationship between a speaker's level of integration and the starting conditions of their resettlement. Integration - which at the level of the individual means, above all, a maintained coherence of personal identity - was easiest for the local "neighbors" and was relatively untroubled for migrants from western and central regions of Poland. It also posed few problems for easterners in Zhovkva, although in this case the level of social (rather than individual) integration can be somewhat questioned, given that this group was and remains ghettoized. Polish and Ukrainian "repatriates" experienced the most serious difficulties, although it would appear that the former faced greater problems in their individual rather than social integration, and vice versa for the latter group. In many cases, the deciding factor that tilted the personal evaluation of migration was a subjective assessment of whether or not the respondent had advanced socially, irrespective of their migrant group or even sometimes going against the grain of the rest of their group. A good example is provided by a dialogue between a Ukrainian married couple who were resettled to Zhovkva from Poland, in which the wife explained to the husband that the economic benefits had made their resettlement a success - despite the fact that the majority of migrants from a similar background saw their life in Zhovkva as materially poorer than before.

It wasn't right, it was no good. They should have made a commission of some sort, seeing as... they had driven people out, just to... Oh shut your mouth, it was good in some ways that people were separated. Some lived poorly, others were rich. Those who lived in poverty came here, they went to work, and they had a job. They had food on their plate, and everything they needed. And if we had stayed over there, in Poland, what would have happened? You'd have your land, you'd have got married, and what? Kids and all that what would you have lived on? (Z18Am/Z18Af)

Younger respondents, who did not experience resettlement themselves, sometimes reproduced the evaluations made by the oldest interviewees. In the second and third generations, this topic was raised principally by people who believed their families had lost out as a result of migration. Usually, these speakers came from families that had been most socially and economically marginalized in the 
new place of residence; they had genuinely felt the effects of this marginalization, especially in their childhood. Sometimes their assessment of resettlement was only a constative statement of how unfavorable circumstances were, but at other times it took the form of accusations leveled against the older members of the family, with little basis in reality ("When Granny was alive, we asked her so many times: 'why did you go to Ukraine? Why didn't you stay in Poland?' " [Z15Cf]).

So the whole family stayed in Zhovkva. And we're still here, unfortunately. [Why "unfortunately"?] Oh, who knows... Well... to a certain extent the atmosphere of the provinces is specific. Lviv was our home. [...] Different issues came up, including housing issues. Having your own house is having your own house. [...] You keep a certain sentiment. [...] And the fact that it was ours. What's your own is your own (Z41Bf).

An individual sense of social regress could also determine that someone whose family belonged to a group that was theoretically at an advantage could see migration as a negative experience. The parents of the man cited below, for example, moved to Krzyż from Poznań; he did not view resettlement in Krzyż as an act of regression, but he did feel that his family would have benefitted more from staying in the regional capital of Wielkopolska.

It seems to me that they even regretted it a bit, coming here [to Krzyż], because even years later, after all, it has to be said, it's a different level of life, right? Krzyż, and Poznań. My father's colleagues were normal bakers, my father was a chef, and these normal bakers, every one of them built themselves a nice house, in those nice [areas] around Poznań. Such pretty houses. We went to visit them a few times, but here? We had nothing, that's the truth $(\mathrm{K} 10 \mathrm{Bm})$.

Evaluations carried out by the youngest interviewees were usually neither positive nor negative (and in the entire sample, there were many more such statements in Krzyż than in Zhovkva). Even people from families that suffered the most after migrating were so well settled in the new place that they felt no desire or need to regret the move their grandparents made, or to remember old wrongs. An important circumstance that explains the attitude of these youngest speakers is that in both towns, they were the first generation that did not feel the consequences of the post-war divisions or suffer the effects of marginalization resulting from migration. They were the first since their grandparents' generation to have similar opportunities for a decent start in life to anyone else of their age cohort. Sometimes their statements contained a somewhat arrogant and self-absorbed conviction that, with the benefit of hindsight, they were in a better position to evaluate the experience of resettlement than their own grandparents - they apparently believed to be more rational and objective then 
the older generation. In reality, it appears that these speakers saw the experience of migration as not that bad.

Would they have had it better or worse? If they had stayed there, I don't think they would have had it better than here, because of the pressure of Ukrainian society. I think there would have been a lot of pressure and as Poles they wouldn't have had a good life. They always wanted a free Ukraine, and the relations [between Poles and Ukrainians] were not always that great. [...] I think that every person is best off where he is among his own kind. That's why they are happy here, because they built their own house, their own family. [...] I think they have had a good life here (K9Df).

The distribution of positive and negative factors affecting resettlement among different groups also explains why migration itself occupies such divergent places in the narrative autobiographies. Forced resettlers, the Polish and Ukrainian "repatriates," spoke at most length about the journey itself and the effects of the move. Theirs are the principal voices in the sections of this book that focus on longing, the sense of impermanence, and an inability or unwillingness to adapt to the new place of residence. Essentially, all of the dimensions of social integration made greater demands on these settlers than on all the other migrants. Only once we grasp this key difference between the starting positions of voluntary migrants and deported persons can we see what a monumental achievement it was for these individuals to maintain any wholeness of their personal identity - and how easy it would have been to admit defeat. Migrants from the "intermediate" groups - easterners in Zhovkva and new arrivals from central and western Poland in Krzyż - dedicated the largest part of their narratives to post-war insecurity and the problems of adapting to new social and political conditions. Because their social positions in the new town were privileged or at least moderately advantageous, the challenges upon their personal identities were less substantial. The local migrants, the "neighbors," are the least prominent group in the sections of this book devoted to migration and social integration because they suffered minimal losses as a result of their change in environment. The privilege of these two groups is shown by the fact their voices become most audible when the analysis turns to ways in which the influx of new arrivals made their lives and social relationships more difficult. 


\section{Remembering the Absent: Germans and German Heritage in Krzy: $\dot{\mathbf{z}}^{219}$}

\section{Settlers vs. Germans: Memories of the Oldest Generation}

The first encounters between Poles and Germans in Krzyż were above all emotional, because the experience of the war was still fresh and painful for both sides. A man who arrived in Krzyż in one of the first transports of "repatriates" (K17Am) remembered that, when he came out of the station and walked into the town's main street, a German woman leaned out of a nearby window and started to shout obscenities at him: "polnische Schweinerei" ["Polish scum."] $\mathrm{He}$ still remembered the anger he felt at that moment, although for the most part his recollections of relations with local Germans were positive and filled with empathy. Closer contact with Germans occurred primarily at the moment when Poles moved into houses inhabited by Germans. For obvious reasons, these were difficult meetings:

I remember this sad, but at the same time kind of reconciliatory meeting with a German farmer, a Bauer. He came to us and proposed of his own accord that we take over his homestead. I remember the Bauer was called I., a nice man, elderly. [...] But it was sad. I know he was suffering, he put on a brave face, but it was tough for him. We went into his house, and there was a group of women sitting there. Women are more emotional about things, they suffer more, and they didn't want to talk to us. [...] There was an old lady and a younger woman sitting there, the young woman's husband was at the front and she was waiting for him to return. Somehow I got talking to these German ladies and they somehow warmed up to me, and they started to show me where they had stored their supplies of summer fruits preserves, they even gave me some, told me how they made them, and I showed them that I was interested in everything... (K18Af).

The encounter with the Germans of Krzyż was remembered as a disheartening event because it had been oppressive for both sides. Gestures like the one discussed above could alleviate the discomfort, but they could not significantly alter the overall situation, in which both Poles and Germans were deprived of subjectivity. Accounts of other first encounters that took place in more neutral settings were less emotionally burdened. Among those likely to meet Germans

219 An earlier version of this chapter was published as a stand-alone article as: "Obraz Niemca we wspomnieniach nowych mieszkańców niemieckiego miasta," Kultura $i$ Społeczeństwo, Vol. 3 (2009), pp. 45-66. 
were Poles living in the vicinity of the barracks where Germans were stationed whilst they awaited resettlement, as well as railway workers. Polish railway workers remembered having friendly relations with their German colleagues, whilst their wives recalled trying to enter into dialogue with German women and offering them assistance.

[A German woman] came for milk, and... Well, she plucked up the courage, after all I wasn't the type who would refuse to give it to her, but I didn't know what she wanted. She said something, I shrugged to show that I didn't understand. Then she took out a baby's dummy from her pocket, put in her mouth, and went "yum, yum" and then I finally understood that she wanted some milk. I didn't speak any German, and she didn't speak Polish, but we managed to understand each other (K36Af).

Positive experiences predominated in the memories of the Poles, but their contact with Germans was not always disinterested; moreover, it was usually the Poles who benefitted from these exchanges. German machinists were de facto forced laborers, who were forbidden from leaving for Germany because their skills were required by the new (first Soviet, then Polish) authorities in order to get the railways up and running. ${ }^{220}$ Many of the oldest respondents in Krzyż talked about the unpaid, often forced labor undertaken by the Germans for the Poles and Soviets, but none of them called this phenomenon by its name. Not once were the phrases "forced labor" or "forced laborer" use; rather, Germans were said to have worked with the Poles, to have helped, to have been captives, but never anything more than that, as if even a verbal comparison of their status with the wartime experience of Poles was impossible. ${ }^{221}$ The testimonies of a mother and daughter who had a German housekeeper for some months after the war are very illustrative.

She [a German woman] came at first to do our laundry. [...] And then she told us that she could come and clean the house. Then she noticed that I was sitting at the sewing machine, and she offered to [help]. She was a very kind woman, very polite. We gave her bread and everything else, and she was very happy. Whether she had kids or someone else at home, I don't know. I never asked her. [...] She even asked us whether we could give her more jobs, yes. She was very insistent, saying she had nothing to do at home... The Russians were still around, they were, I'm telling you, a nasty bunch. If you were

220 On Germans working in Poland after the war, see: Service, Germans to Poles, p. 115; Halicka, Polski Dziki Zachód, pp. 303-317.

221 Specifically for post-war attitudes among Poles towards German PoWs working as forced laborers in Poland in the years 1945-1950 (including differences among regions), see: Jerzy Kochanowski, "Nienawiść ograniczona. Niemieccy jeńcy wojenni a społeczeństwo polskie 1945-50," Przeglad Socjologiczny, Vol. 49 (2000), pp. 115-140. 
a German, you had to [endure rape], you had no choice. She wasn't so keen, and she always asked my father to walk her home (K23Af).

We had a German maid. [...] She looked after me and my sister a lot. And the things she had to live through because of the war! Her whole family had died and she didn't really want to go to Germany. In the end she was forced to leave. [...] She never cried, she was always happy. She would always talk to my mum, and to my dad a lot too. We treated her like our aunt, we didn't call her by her name, maybe that's why I don't even remember what she was called. It was just Auntie. Auntie this, Auntie that (K23Bf).

The situation of the German woman, who carries out heavy labor for the Polish family for mere subsistence, and whose private life does not even interest that same family, undergoes a surprising metamorphosis in the daughter's testimony. From a poorly compensated housemaid with only the most superficial personal freedom, she becomes nothing short of a member of the family, but nonetheless, she is forced to leave for Germany. We need not doubt the authenticity of the speaker's childhood memory; the woman surely did indeed look after the daughters with genuine affection. At the same time, it is more likely that she was only working for the family because of a fear of violence by Soviet soldiers, rather than because she had nothing to do at home; likewise, she probably felt some relief at the opportunity to depart for Germany. This situation shows the extent to which the post-war forced labor of Germans in Poland remains taboo in the collective memory of Poles.

Besides Germans who worked on the railways, in industry and in Polish homes, agrarian families also remained in the nearby villages, comprised mainly of women, children and elderly people. These Germans were obliged to allow Polish resettlers from the pre-war eastern provinces into their homes: this was the beginning of a period of communal living, often within a very limited area. After initial moments of mutual anger and regret, the Poles and Germans tried somehow to work out a modus vivendi. They worked together, because the Poles had arrived just before or during the harvesting season. Cooperation was not without its difficulties: the Polish settlers were accustomed to different ways of working the land and did not know how to use German machinery. The Germans, meanwhile, were often unwilling to supply the necessary hints. Accounts of this short period of coexistence contained traces of the distrust from that time: the behavior of the Germans was remembered as having been purposefully spiteful, intended to cause problems. For example, interviewees recalled that Germans sold off their property behind the backs of the Poles, so as not to leave things for the new owners of their homes.

More often, however, pictures of communal life with Germans were very emotive and positive; they showed a harmonious coexistence, as far as possible 
in the circumstances, as well as above all, a sense of empathy for people who were about to lose their homes, as the Poles themselves had done. Such sentiments appeared almost exclusively in interviews with eastern Poles, rarely with people form Wielkopolska, and never in the testimonies of settlers from nearby villages. There were memories of holidays and feast days celebrated together, as well as accounts of how these former cohabitants maintained epistolary contact long after the Germans had gone. Against the background of a perceived commonality of experience, the mutual foreignness, both linguistic and cultural, was often relegated to the shadows. ${ }^{22}$

The German woman was with us because she wanted, as anyone else would, to stay on her own property. They must have hoped that things would change, that we would be forced out, and that they would stay. [...] Those Germans were with us for around a year. They were nice people, very nice. When they were leaving, their son came [...], and we said such an emotional goodbye, they cried with us, because we had grown so used to each other. We helped those Germans, in the garden for instance. The men would dig up the garden, we would do the planting, she thought she would collect [the vegetables] herself, but later they were taken away, and we were left with the produce (K21Af).

There were also respondents who described the injuries the Germans had suffered, although such voices were definitely in the minority. Most of all, the perpetrators of hurt were the Soviets, who raped German women and treated German laborers with disdain. If Poles featured as wrongdoers in these stories, they were, as a rule, treated by the interviewee as alien elements that did not belong in Polish society; speakers made efforts to separate themselves from these villains. Polish perpetrators came from elsewhere ("The ones from Belarus or wherever, they were nasty to the Germans, shouting 'You bloody Hitlerites!' at every turn" [K21Af]), were social degenerates, or were simply "not real Poles." Brutality against Germans emerges in these cases as yet another method for expelling guilty parties from the confines of "our" world. ${ }^{223}$

222 Andrew Demshuk writes about the mutual understanding that was achieved between autochthonous Germans and eastern Poles in Lower Silesia, in: Andrew Demshuk, The Lost German East. Forced Migration and the Politics of Memory, 1945-1970 (Cambridge: Cambridge University Press, 2012), p. 106.

223 Aleida Assmann calls this type of phenomenon "externalization:" the guilt that an individual feels, either directly or indirectly (e.g. through belonging to the same national group), is projected onto someone else by a process of delineation, whereby the other is rhetorically expelled from the community, see: Aleida Assmann, "Fünf Strategien der Verdrängung," in: Der lange Schatten der Vergangenheit. Erinnerungskultur und Geschichtspolitik (CH Beck: München, 2006), pp. 169-182. 
In this context the following accounts of (what appears to be) the same event, by Poles from different regions who lived in neighboring streets, are very interesting.

"Get out of here!" And this elderly couple came out of the house, so as not to make things worse, they sat down under the wall, as long as they had the strength to sit there. Later, once the cold night had set in, they lay down on the ground. As for the Poles, the Polish family [who had forced the Germans out], the residents of the house, they were completely unmoved, they just didn't care. They still live in Krzyż, I know their names... My parents knew about it, and after lunch they would tell me to go and take some food out to them [the Germans]. And I would bring them their lunch, but in the end it became so cold that they died - without any medicines and living only on that lunch. The people who lived in the house [...] for them it was like water off a duck's back, they just buried them in the garden (K25Bm).

I remember this event; I was walking into town with my mum, it was just after we had arrived. [...] There was an old German woman, poor, who was lying on a feather blanket. I still remember this like it was yesterday. She had a feather blanket and she was just lying on it. Who kicked her out, what that was all about, I don't know... Later she was taken in, someone came to look after her and took her in (K2Af).

The first respondent, a Pole who returned from emigration in Germany, sharply criticized the behavior of Poles towards the Germans and directly accused them of killing the elderly couple. This speaker's family had suffered a significant amount of abuse in post-war Krzyż, because they were considered by other Poles to be "camouflaged" Germans. The second speaker, a woman from former eastern Poland, also expressed concern for the German woman, but saw the story's ending very differently - she was convinced that someone must have taken the evicted woman into their care; she did not even consider the possibility that her compatriots could have been so heartless towards a fellow human being.

The second most emotionally intense memory, after cohabitation with Germans, was the deportation of the Germans. Again, the eastern Poles were the group who remembered this event most strongly, irrespective of whether they were talking about Germans with whom they had shared a house or others whom they may have never met.

They may be our enemies, but you have to treat them humanely, they are also people! Just like we came here as expellees, they were also forced out. When we arrived in Łokacz [a village near Krzyż] and wanted to move into this house, a German woman put all of the crockery into a basket and, out of spite, took it all outside and threw it on the ground so it would break, right in front of our eyes. The path was made of stone, so everything smashed into small pieces. Then the policeman who had accompanied us here to the house, a Pole, took his rifle and started to beat her, the German, on the back. We're 
standing there, crying our eyes out, because how can you beat a woman like that? [Voice breaking] But she was in the wrong too. Who was the guilty party here? The policeman, the woman, or us? Whose fault was it? I don't know (K8Af).

I also endured a tough, sad moment. One day, my father and I went with the horses to Przesieki [a village near Krzyż]. And in P., we enter a house because my father wants to meet someone there, and we look up: the doors are open, a pot is on the stove with potatoes cooking, and everything is open. There are plates on the table, as if the table has just been set for us all to sit down for lunch. It was the moment when they had come to get the Germans, to deport them. Today we protest when those German expellees gather somewhere and complain, claiming this and that. But they really were expelled like that. I know it was an international treaty and all that... But they were also deported. I understood that they were expelled the same way that we were (K17Am).

These two quotations illustrate a sentiment that was shared across a range of social divides. Other than the fact of being resettlers from the East, these two speakers had very little in common - the first interviewee is a woman, born in a village and possessing no educational qualifications, who spent her whole life working as an agricultural laborer. The second is a man who grew up in a town in a well-to-do, educated family, with a university qualification, who worked as a teacher and was an important figure in local public life. These differences are visible in the ways in which the two respondents narrate their stories; at the same time, it is striking that the content of their speech is almost identical. Both speakers sympathize with the Germans, seeing in their experiences a reflection of their own post-war past. Neither denies that the Germans were deported in accordance with a set of legal norms, or that they were collectively responsible for the atrocities of the war. At the same time, it is clear to both speakers that in some cases, that collective responsibility was very heavy indeed, and they both felt vulnerable as a result.

In the testimonies of these eastern Poles, expelled Germans gain a status similar that of the Poles themselves: the status of people who were at the mercy of the whims of political change and caught up in a trajectory over which they had no control; this is precisely why, for these Poles, the Germans deserved their empathy. ${ }^{224}$ Meanwhile, almost none of the eastern Poles, let alone other settlers from Wielkopolska or neighboring villages, stated outright that Poles had been guilty of over-zealousness in their attempts to expel the Germans. One of the

224 MarekCzyżewskireaches similar conclusionsinhis: "Repatrianciiwypędzeni:wzajemne uprzedzenia w relacjach biograficznych," in: Biografia a tożsamość narodowa, ed. Marek Czyżewski, Andrzej Piotrowski and Alicja Rokuszewska-Pawełek (Łódź: Wydawnictwo Uniwersytetu Łódzkiego, 1996), pp. 159-172. 
very few who did state something to this effect was a man from near Lublin, who reported with sadness and a degree of remorse that: "When I hear today that Germans have been saying that the Poles treated them so badly during the expulsions, I remember that this really was how it was then (K16Am)." On the whole, in the testimonies, the Germans are expelled by faceless perpetrators, who are labeled simply as "they," the "police," "soldiers," or, occasionally, Poles from a different social group or place of origin than that of the speaker.

Not even the most sympathizing interviewees suggested that the Germans could have stayed in Krzyż. All of the older respondents were convinced that Poles and Germans could not have peacefully coexisted in the formerly German territories after the war. Settlers from the East and from nearby villages reasoned that the Germans would be under threat from other Poles, although they personally had no issues with them. Respondents from central Poland and Wielkopolska saw the deportations of the town's Germans as an act of justice and, to a certain extent, as a form of reparation for the harm they themselves had suffered. Nonetheless, they also hesitated when asked directly whether the expulsions were fair - they constructed their responses using equivocations, saying that deportation was perhaps an undeserved punishment for some individual families: "How should I know whether it was fair? It's tough luck, those Germans might not have done anything wrong, but we were also kicked out from our homes" (K36Af). The speaker quoted here, who was herself expelled from her home and forced into labor for Germans in a distant locality, spoke with bitterness about her own past hurt, but then immediately began to talk at length about the "good Germans" who had helped her to survive the occupation - as if she wanted to offset and justify her preceding critical evaluation.

Settlers from central Poland and Wielkopolska also voiced the very few testimonies that featured unconcealed joy at the expulsion of the Germans. The dialogue quoted below loses some of its expressivity in transcription, but when listened to, its tone of vengeful satisfaction is striking. The speaker's wartime biography is fairly standard among people from Wielkopolska; he was not persecuted by the Germans noticeably more than other interviewees. His unforgiving views can probably be better understood in the light of his post-war political career in the Polish United Workers' Party and a very strong faith in the socialist state's propaganda. ${ }^{225}$

225 For a brief summary of post-war propaganda in the "Recovered Territories," see: Tyszkiewicz, "Communist Propaganda." 
The Russian NKVD came along. They ordered them [the Germans] to pack their bags and get to the station to board a train, and they passed the buildings to us, Poles. [Did the Germans leave obediently, or did they protest, or cry?] How could they protest? [Well if they couldn't, did they just carry out the orders?] If they tried to resist, they'd get a bullet in the head and that was the end of it. Those Germans knew after all what they'd done in the East, so they acted like meek sheep (K28Am).

It was also amongst this group of respondents that the German narrative of expulsion was most frequently contested. Settlers from central Poland and Wielkopolska claimed fairly often that no one had been deported from Krzyz; the Germans had left of their own accord. As a rule, it was people who had arrived in Krzyż later, after 1946, or people who had no direct contact with Germans who made such claims. Their convictions about the fate of the Krzyż Germans was often based on their own experiences; they did not even consider that the situation in Krzyż could have been different from what they themselves had been through. One interviewee (K30Af), who had worked as a forced laborer on a German estate during the war and was forced to evacuate with her hosts, said of the Krzyż Germans: "They ran away by themselves, no one kicked them out." Thereafter she spoke at length about her own journey to the Third Reich. A somewhat similar statement, made with recourse to other narrative devices, was the claim that the deportation of the Germans took place in less drastic circumstances than the resettlement of Poles from the pre-war eastern provinces. Interestingly, it was not the eastern Poles who argued in this way, but people from other regions who were closely connected with them, such as spouses or close neighbors. The expulsion of the Germans is not negated in this logic, but the validity of the word "expulsion" is questioned - since the Germans were not transported in "cattle cars," they cannot have experienced what the resettled Poles did. "I wouldn't say they went in those cattle cars. [...] For example there was a couple that lived in that house opposite, their son came to get them from Germany in a car" (K2Am).

There were a few exceptional examples of eastern Poles who argued that the Germans had never been deported. These were isolated instances of people who had endured exceptionally difficult experiences during the war, or were generally indisposed to Others. The individual quoted below - who came from Volhynia and was a forced laborer in Austria during the war - had suffered greatly in difficult circumstances during his time as a laborer, including the death of his brother. His wounds were still raw, and because he had been forced to leave Volhynia, he was convinced his life had been wasted. His own biography was clearly visible both in his account of his own resettlement and of that of the Germans, with his identity as a victim acting as the axis around which 
his narrative revolved. To recognize the Germans as victims of expulsion would have been to share this status with the people he considered unequivocally to have been perpetrators. ${ }^{226}$

It was fine, they were told to leave, and they signed up for trains and left for Germany. Now that woman, you know that one from the television, that leader... [Erika Steinbach] Yes. The way she describes it all, that we kicked them out, it's a lie. No one kicked anyone out. They left by themselves. Actually it was the opposite - they tried to get rid of us. They peppered us with bombs. Who? The Germans. And now they are trying to claim something from us (K24Am).

It is instructive to compare the Krzyz interviews with the results of quantitative research. ${ }^{227}$ A survey conducted in 2010 by the Museum of the Second World War showed that $83 \%$ of respondents considered the post-war expulsion of Germans to have been justified; $10.7 \%$ thought they had not been justified. Just $4.5 \%$ were convinced that it would certainly have been possible for Poles and Germans to live peacefully side by side in the "Recovered Territories" after the war; $20.7 \%$ considered this to have been probably possible, whereas $30.4 \%$ thought it probably impossible. $32 \%$ of respondents thought it was definitely impossible. These answers were matched against respondents' age and area of residence - the possibility of peaceful coexistence was supported above all by older people and people who lived in Wielkopolska. This survey had a nationwide scope, but my local sample from Krzyż supports these observations strongly; it can explain why some answers were common and others less so.

226 The psychological concept of "competitive victimhood" can help to understand this type of reaction. According to this idea, members of groups that are affected by brutal conflict often create a special narrative, according to which the enemy collective did not suffer at all, see: Masie Noor, Nurit Shnabel, Samer Halabi and Arie Nadler, "When Suffering Begets Suffering: The Psychology of Competitive Victimhood Between Adversarial Groups in Violent Conflicts," Personality and Social Psychology Review, Vol. 16(4) (2012), pp 352-374; Katie N. Rotella and Jennifer A. Richeson, "Motivated to "Forget:" The Effects of In-Group Wrongdoing on Memory and Collective Guilt," Social Psychological and Personality Science, Vol. 4(6) (2013), pp. 730-737.

227 Cf. Lech M. Nijakowski, "Pamięć o II wojnie światowej a relacje Polaków z innymi narodami," in: Między codziennością a wielką historią. Druga wojna światowa w pamięci zbiorowej społeczeństwa polskiego, ed. Piotr T. Kwiatkowski, Lech M. Nijakowski, Barbara Szacka and Andrzej Szpociński (Warszawa: Scholar, Muzeum II Wojny Światowej, 2010), pp. 239-286. 


\section{Before our Grandparents: Memory Among the Younger Generations}

Memories about the Germans were less abundant in conversations with younger respondents, for obvious reasons. Encounters with the Krzyż Germans were not a part of their own biographical experience; thus, social memory, constructed through family transmission and socialization outside of the home environment, was the only medium through which narratives concerning the German presence could be passed on. Just a brief glimpse at the interviews with younger residents of Krzyż shows, however, that both of these modes of transmission were fairly ineffective. Asked about family stories about the Germans, respondents usually told tales from the occupation period, only thereafter (if at all) turning to the period after their family arrived in Krzyż. The wartime stories are worth consideration because images of the Germans during the war closely affected stereotypes about Germans in the early post-war period - as they did for the oldest interviewees. Descendants of Poles from Wielkopolska spoke of decent conditions during forced labor, while people whose families had moved from the eastern territories remembered that their grandparents were surprised that the Germans turned out to be less evil than expected, especially in comparison to the Soviets. Personalized accounts from the early years in Krzyż, with specific events and personalities, were few and far between. Although the oldest Poles remembered their relations with local Germans very well, these memories were not passed down to successive generations. The son of one of the women quoted in the preceding section of this chapter $(\mathrm{K} 21 \mathrm{Cm})$ did not know that his mother had lived for a significant time in a house shared with Germans. Perhaps this is a result of the specific character of family memory in that household: the father's memories played a greater role in the son's identity formation. Nonetheless, extended narratives about contacts with local Germans were rare among other families as well. Occasionally, there were general and depersonalized exchanges about living with Germans. There was only one detailed account, in an interview with a woman whose grandmother had migrated from today's Ukraine:

The other house ${ }^{228}$ was inhabited by Germans, there were still Germans in this area then. They lived together well enough for that short while. There weren't any conflicts or quarrels or anything else like that... I know from what my grandparents had told me that they treated each other as fellow humans, not as invaders. That was the state

228 The speaker lived in a large farmhouse with two separate entrances; the "other house" is therefore the neighboring apartment within the same building. 
of things: they were leaving this land, and Poles from the East, from the Kresy, were arriving here (K9Df).

Interestingly, the granddaughter described the Germans as sympathetic, even ideal, and she also recounted a later visit by the former German homeowners in similar tones; the grandmother, meanwhile, spoke of her time of cohabitation with the Germans with a slight resentment, and the later visit with a mixture of indifference and anxiety. This difference recalls the mechanism, described by Harald Welzer, Sabine Moller and Karoline Tschuggnall, by which family memory is transformed in younger generations so as to preserve an image of the moral rectitude of the family. 229 In the instance described by Welzer et al., a granddaughter claims that her anti-Semitic grandmother helped to conceal a Jew who had escaped from the camps; the interviewee in Krzyż inscribes a harmonious coexistence with Germans into the family narrative, although the period of cohabitation was in fact far from ideal. This will to re-write memories can be ascribed above all to a universal desire to idealize one's own family. In this particular case, the respondent's positive personal attitude to the German past of her home town is also a significant factor: the young woman maps her vision of her grandmother's erstwhile relations with Germans to her own present-day picture of Polish-German relations.

One theme that practically never appeared in these testimonies was the Soviets' brutal treatment of the Germans, and Polish mistreatment of the Germans even less so (with the exception of a few individuals with a special interest in local history). Respondents had clearly not heard such stories at home, because their grandparents were not inclined to discuss the harm suffered by people they had recently considered to be enemies. Polish collective memory, in turn, continued to have little room for an image of a German victim, as shown by the controversies that arose in Poland when plans for the construction of a Centre Against Expulsions in Germany were announced. ${ }^{230}$ Considering that the question of whether to recognize the Germans as victims as well as perpetrators of the war is a difficult topic for Polish intellectual elites, we cannot expect memories of injury suffered by Krzyż Germans to enter the history curricula of local schools.

229 Cf. Welzer, Moller and Tschuggnall, “Opa war kein Nazi,” pp. 81-104, 134-161.

230 For a discussion of the debates surrounding this project, see: Basil Kerski, "Historia i pamięć w aktualnych debatach politycznych między Niemcami a Polakami," Borussia, Vol. 30 (2003), pp. 33-46; Maren Röger, Flucht, Vertreibung und Umsiedlung. Mediale Erinnerungen und Debatten in Deutschland und Polen seit 1989 (Marburg: Verlag Herder-Institut, 2011). See also: "Introduction," footnote 5. 
Narratives about the deportation of local Germans were also significantly simplified in the family transmission of memory. Like in the case of the expulsion of Poles from Zhovkva (see: Chapter 7), the family memories of Krzyż's new residents did not leave any room for dwelling on others' traumas. Memories of people's own difficult experiences were predominant. All of the residents with whom I spoke in Krzyż knew that the town had been a German community before the war and that Germans had lived and worked in its buildings. Nonetheless, the question of what happened to those Germans faded against the fog of war in the minds of the younger generation. When asked what had happened to the Germans, one interviewee (accompanied by her father) answered that:

I think that you know, it was wartime, so it was, there were lots of those... I can't remember what the place is called... [turns to her father] Dad, what's that place with [the monument of] Hans Pasche, you know, we went there, to the monument, what's it called? Zacisze. Zacisze, exactly. So we went there, and there are lots of little cemeteries near the houses. It looks as if the residents died and then the houses were empty, and the cemeteries remained by the [houses] $(\mathrm{K} 25 \mathrm{Df} / \mathrm{K} 25 \mathrm{Cm})$.

In this account, the Germans disappeared from their houses in some mysterious way, leaving behind empty houses and cemeteries, but it is unclear what happened to the residents of the village that the Poles called Zacisze after 1945. A different respondent gave a similar response; here, it is particularly striking that the speaker was convinced that the Germans could not have been deported because the Poles would never have allowed such a thing to happen.

[When your grandparents came here, were there no Germans here, did they say anything about that?] They didn't say anything about any Germans. I can't remember them saying anything about any Germans here. It was just empty. I think no one lived here, I mean, there can't have been anyone living here, because they wouldn't have kicked them out, right? (K5Df).

Conversations with the youngest residents were sometimes reminiscent of a guessing game - speakers would begin to think out loud about what had happened to the Germans, and it was clear that they were considering this question for the first time. Today's residents of Zhovkva asked themselves about the history of local Jews in an identical fashion; the key difference, however, was that in Krzyż there were just a few individuals from the youngest generation who were unsure, whereas in Zhovkva, memory of the absent Others was largely speculative among a much greater range of interviewees, also including members of the oldest generation. Among people in their forties and fifties in Krzyz (at the time of the interviews) there were no individuals who did not 
know what had happened to the Germans. The clear tendency was for them to believe that the majority had left of their own accord, before the Red Army arrived: "They packed up and left. [...] They knew the threat they were facing, the Red Army was advancing after all, and they didn't deal in half-measures. Here, in our territories, they had permission to do whatever they wanted - and they did" (K2Bm).

The expulsions that did actually occur were relegated to the background, but - in comparison to the state of memory about Jews in Zhovkva - this relativization was of a much smaller scale than the belief that the Jews had simply "left" Zhovkva. After all, some of the Germans had indeed escaped from Krzyz themselves, without the "help" of the Poles or Soviets, and the others were deported, not murdered. In statements made by people who did mention the expulsion of the Germans, a similar tone was discernible to that of the testimonies of the older generation: the Germans had certainly been deported, but it was a nondescript group of "others" who had carried out the operation - other Poles and the Soviets, but no one connected to respondents' own families and friends.

There were probably situations where Poles just kicked them out, after all, Poles aren't all necessarily good people. I reckon those looters came from various places [...] and they took everything they could when the Germans left. [...] My father used to tell me that there was a guy who lived with him for a short while, and then he wanted to leave, but he had to wait a bit for that transport. And my father helped him out (K2Cf).

Only a few young people in Krzyż had any substantial knowledge of the deportations - as a rule, it was only those individuals with an above-average interest in local history. It always became apparent in the course of an interview that this knowledge came not from family transmission of memory, but from other sources, such as books or the Internet. For some of these interviewees, the discovery that the previous residents had been violently expelled was a shock. One respondent, an avid collector of German postcards (K42Dm), said that reading oral history interviews published online had changed his way of thinking about his own family's history. Only direct contact with testimonies of concrete individuals had led him to see the real hurt and drama of the expulsions, for which Poles had also been responsible. Another interviewee, a young history teacher who wrote his Masters thesis on post-war expulsions in the Krzyż region, commented as follows on the archival research he had carried out:

That kind of expulsion operation, there's nothing nice about it, nothing good. I will never forget searching through those records of things that were confiscated from the Germans who left: a bag of some rags, some soap, a pair of long johns, underwear, that kind of thing. In other words, these were things that clearly showed that people were unequivocally evicted from here (K44Dm). 
The way in which current residents of the town who were born after the war remembered the Krzyz Germans is a reflection of the older generation's representations, filtered further through individual experiences and emotions. Neither family transmission of memory nor school education could fill this gap; informal channels of social memory have started to make small inroads in recent times. Families do not talk about the Germans who lived in Krzyż, because for the older generations, encounters with the town's pre-war residents were not essentially important events. The community does not construct its identity on the German past, so it has no interest in preserving narratives about it, and schools are silent on this matter. In principle the younger residents of Krzyż know that Germans lived here before the war, and that they disappeared as a result of the same political transformations that compelled their own parents or grandparents to come to Krzyż. What is lost with the passage of time is memory about concrete individuals and their stories, as well as a sensitivity about questions of guilt and responsibility. Memories of the past make occasional returns through new media, converting anonymous traumas into the troubles of real people made of flesh and blood, and activating this sensitivity in moments of heated public debates about the past. Nonetheless, these flashes in the pan affect a small number of individuals at best, passing by the social collective as a whole.

\section{The Germans Today: Castaways, Tourists, Litigants?}

Whilst they are no longer physically present, the vanished others continue to remind the new residents of Krzyż that this was once their town. One German family remained in Krzyż after the war, while several elderly individuals and a few people who entered marital relations with Poles also stayed. When I asked about these autochthonous Krzyż residents during interviews with Poles, it was usually the family, who lived on the outskirts of the town, that was mentioned. The male head of the family was perceived by the local community as a wealthy landowner, who maintained excellent relations with the authorities as well as with Poles, many of whom had been employed by him. He was an assimilated German, who had "even" learned to speak some Polish.

I remember him as a nice man, he spoke some Polish, he really tried to speak Polish, whereas his sister wasn't so good at speaking Polish. [...] I went there a few times with my father, because they had a very big farm and my father had a few chickens. He would go there from time to time and buy grain. That was my contact with that family. I don't remember anything bad (K32Cf).

Practically every respondent who remembered this individual seemed to feel obliged to add some kind of commentary. The speaker cited above noted that 
the man was harmless despite being a German - such statements clearly show the effects of post-war propaganda, whereby the image of a "bad German" was instilled in the subconscious of this woman raised in socialist Poland. Older interviewees tried to explain why the Z. family had remained in Krzyż. There was a huge variety of explanations, from the simple statement that "they clearly hadn't done anybody any harm" to the hypothesis that Z. had collaborated with the communist secret police after the war, informing on local Germans. Another possibility was that $\mathrm{Z}$. had been an ally of the Poles during the war and that he had been granted special permission to stay in light of his contribution to the resistance. No matter the truth, it is noteworthy that the residents of Krzyż were convinced that he could not have stayed for no particular reason at all - he had to have some underlying motive. This shows once again that the post-war expulsion of the Germans from Krzyż was generally considered to have been an act beyond questioning.

Older interviewees sometimes remembered other Germans who had remained in Krzyż; however, these were accounts that invariably ended in their disappearance, a fact that was treated as a natural outcome of events: the German population either blended into Polish society through marriage and assimilation, or gradually died out.

Here [in Kuźnica, a village near Krzyż] one German woman stayed behind, but she married a Pole and became like a Pole, she crossed over. [And who was that?] Well, her father was a miller [...] She owned a farm. They had a Polish farmhand. And those young ones had fallen in love and when the parents were deported, he came and took her from the train. She knew about it, she helped to arrange the escape. [...] She was a very nice woman, small in build, but very kind and full of generosity (K19Af).

In this and other similar statements, a glaring feature is the ostentatious emphasis that the Germans who remained in Krzyż were good people - they were good despite their Germanness, and they could be accepted because they had "crossed over." Nevertheless, it was only the oldest generation of respondents who expressed such views. For younger people, there were simply no more Germans in the town - as is indeed the case in today's Krzyż.

The Germans who do appear in today's Krzyż are most often tourists. Practically every interviewee had had direct contact with German tourists, seen them, or heard of such visits. Visitors from Germany started to arrive in the 1970s when the border between Poland and East Germany was opened. Almost all of those tourists had a family connection with Krzyż. A similar situation prevailed in the 1990s, when a second wave of German tourists arrived; this time, it was West Germans with roots in the now-Polish town, who came. Only recently 
have Germans started to arrive who treat Krzyż simply as a holiday destination, although they are still in the minority. Both kinds of visitor are received well by the town's Poles. Interviewees from all backgrounds and generations stated that they harbored no ill feelings towards the former residents of Krzyż, and that they accepted and understood their desire to visit the town. Such assertions were often accompanied by a more or less explicitly articulated conviction that their openness was possible because the Poles themselves bore no guilt for the tragedy that the Germans had lived through; indeed, they felt the opposite was true, i.e. that they themselves (or their families) had suffered at the hands of the Germans during the war, and that they now had every right to treat the Germans badly if they so wished. These statements are therefore mixed at some level with a sense of the speakers" own self-righteousness: between the lines it is implied that "we don't have any duty to be nice to them, they are our old enemies, but we do so because we pity them."

They came here, they didn't want us to feed them, no. But they had lunch, and then when they were leaving, I had a duck, I gave them this duck, a live one, they took it. Fancy that! [with emphasis] Then she came again, just the daughter this time, she said that her mother had died, and she came just with her husband. I have a photo, they took more pictures. They left their address, they said we should come, but... [...] I mean, what do I owe her and what does she owe me? (K9Af).

A large number of interviewees did however recall the German visits without hidden subtexts and with genuine emotion. The most empathetic accounts were those of eastern Poles of the oldest generation, especially those who had shared a house with Germans after their arrival in Krzyż. A striking example is that of a woman who met the family she had lived with in Krzyż, almost half a century after the departure of the Germans. The evicted former homeowners, with whom the interviewee had grown very close during their period of cohabitation in her childhood and with whom she continued to correspond for many years, had left a photograph of themselves as a souvenir. The speaker had kept the image for nearly five decades, enabling the Polish woman and her former German friends to recognize each other long after they had played together in the streets of Krzyż.

I kept this photograph between other pictures. I never threw it away. [...] It was 1992. [...] And what do I see, a [German car] pulling up outside. [...], three men and a woman come out. They walk towards the house, but they seem so unsure, but they come in, they clearly want to come into the courtyard. The woman comes up to me, and she grabs of me like this, and asks "J.?" [the speaker's name,] and she's in tears. At first I didn't know what it was all about, but she's standing there crying. She says "S.," and I know that name, S., it's her surname. I know it because I wrote it down on that photograph, because 
I thought that after my mum dies, as time goes by, I would forget, so I wrote it down in pencil. [...] And so we met in that same courtyard where we had said goodbye. It's amazing! There's that saying [in Polish] that mountains never meet, but people always find each other somewhere down the line... [...] We were so happy, we were literally holding hands. It was a bit like lost siblings finding each other. You could say we understood them better than anyone, but we ourselves had had to pack our bags and travel in those cattle cars, just like they did. Who cares about politics, borders being here and there, and all that? We have no influence over that stuff, none at all. But we're all humans and we spent time together, that was our destiny. And we understood that they also had to leave, they were born here but had to move out, just like we had been born over there and had to leave (K26Bf).

Not all the interviewees in Krzyż were so emotional about the visits of the Germans - only a few individuals had personal histories that would predispose them to such moving encounters. Nonetheless I would claim that the most common feeling with which the Poles met the German visitors was sympathy, as well as, even more so perhaps, understanding. ${ }^{231}$ This attitude is shown in the following statement by a younger respondent, who never met any local Germans, but declared that he understood their feelings.

They came here, and I was the headmaster of the school in 1991, and I sometimes looked out of my window to see older people standing around and pointing with their fingers. I would go out, have a talk with them, and invite them inside. They cried, they were really in tears, as they came in. "This was the boarding house, this was where we slept, this was where we met, that was the church where we got married - can we go inside the church?", that kind of thing. [...] These people were shocked to see someone coming out towards them, that I was trying to speak their language, however badly. That this could happen in communist Poland, as they still saw it then... I know it meant a lot to them then $(\mathrm{K} 40 \mathrm{Cm})$.

Such visits as described in the above two quotations could not infrequently result in long-term friendly relationships between the old and present-day residents of Krzyż. Many interviewees recalled receiving help from Germans during the Martial War period in Poland (1981-83) (in the form of aid packages sent through the post) and exchanging gifts during visits; nonetheless, such accounts are more frequent in the testimonies of older residents. Younger people who

231 Another study carried out in a locality near Krzyż reached similar conclusions about residents' attitudes to German tourists, see: Cezary Trosiak, "Kaława a 'bunkry.' Z badań nad stosunkiem społeczności lokalnej do poniemieckiego zabytku," in: Wspólne dziedzictwo? Ze studiów nad stosunkiem do spuścizny kulturowej na Ziemiach Zachodnich i Pótnocnych, ed. Zbigniew Mazur (Poznań: Instytut Zachodni, 2000), pp. 355-388. 
spoke about the German visitors concentrated more on the symbolic dimension of the contact with the town's former residents, considering these encounters as a means of building bridges between the Polish and German parts of their town's history.

We were all standing in front of the house, we invited them inside and we were just talking and laughing. It was pleasant. They were so grateful that we had invited them in and talked to them, that we had accepted them as guests. There used to be a huge pear tree that grew in our garden. This pear tree had been there since before the war. When they came, they went into the garden and saw that tree. They were so moved, they started crying. I also cried with them. A couple years later my dad had to chop the tree down, it had dried up and was attracting lightning, so we had to remove it. So that last symbol of our shared life on this land is now gone (K9Df).

A similar tone was struck by people who appreciated the visits of the Germans as an opportunity to deepen their knowledge of the history of Krzyż. This was especially true of individuals who were particularly interested in local history, who wanted to obtain information from the Germans about the history of their town; for such individuals there was also a symbolic aspect to these meetings, whereby they gained a moral right to access the German heritage of Krzyż. ${ }^{232}$

I am in contact with two gentlemen who used to live in this area. [...] The way I perceive it, they want to share these things with me. [...], to show, remind, bring to my awareness, that this happened here and that was there. But I never get the feeling that they have any kind of revisionist intentions, that this is their place and that they are planning to come back some time $(\mathrm{K} 37 \mathrm{Bm})$.

The above quote raises a different issue connected to the German visitors: distrust. When I embarked on this research, I expected respondents to be distrustful of German tourists, perhaps more than any other sentiment they might hold; however, this only turned out to be the case for a marginal few. Not a single interviewee admitted to not letting Germans into their house. I heard of only instance of such an event, from a young man who claimed that his grandmother had refused to invite a German family into her home, although the grandmother herself did not say a word about such an incident in her own interview. Of course

232 Zbigniew Czarnuch has analyzed the phenomenon whereby second-generation settlers in the "Recovered Territories" explore local German heritage and seek contact with Germans, including with members of unions of expellees [Vertriebenenverbände], see: his "Oswajanie krajobrazu." On Poles who see visiting Germans as potential links between the new and old histories of the "Recovered Territories," see also: Demshuk, "Reinscribing Schlesien as Śląsk," p. 68. 
it cannot be said for certain that no one else had acted in this way. Nonetheless, it appears more probable that, although for the majority of people the visits of the town's pre-war residents may have initially caused anxiety and negative emotions, they really were able to accept the tourists once it became clear that the Germans had no intention of claiming back their families' former homes.

On the first visit, the Germans arrived, and they didn't come into the courtyard or the house, they just stood around and took photographs. Then my mum and dad were a little anxious. Who were these people and what were they doing here? Then someone said they were Germans, and mum said: "That's a bit sick isn't it? Do you think they want to come here?" But once we had talked to them, once they came to visit specifically, it was OK... They're not interested in living here, they just wanted to come and see their own haunts. Where their mother was born, or where their father was born, where they lived before, they just wanted to see if things had changed or not. So my parents calmed down a bit after that (K15Cf).

The Poles' initial reluctance is easy to understand. There was still a grain of uncertainty about the extent to which they could feel safe in their formerly German homes. Contemporaneous political debates also affected their attitudes towards Germans coming to Krzyż. The fear of a mass return of Germans, whose echoes were heard especially in interviews with older people, was stoked by campaigning before the referendum on Poland's accession to the European Union. In this period of tension, in which Eurosceptics whipped up a supposed threat, even neutral behavior by Germans could be interpreted as somehow suspicious. ${ }^{233}$

We had a period when Germans were coming in droves. I guess it lasted for about two years. There's a lake nearby, and they would gather there, they had some sort of conference there or something, I don't know... So they were here, or their children were here, and I thought they were here to try and reclaim their property. [...] We always lived with a hope that we wouldn't be left to live on the street, that it would go through the government, and if the government gives them the houses, then they'd put us somewhere else too. But later it became calmer (K19Af).

Almost all of the interviewees spoke of their doubts and distrust towards the Germans as a thing of the past. They perceived their feelings of that period as an individual weakness, often admitting with expressions of shame that they had let themselves be deceived by political manipulation. Younger speakers who

233 Andrzej Sakson has analyzed the effect of the pre-referendum campaigning on perceptions of Polish-German relations, in: Andrzej Sakson, Przeszłość i teraźniejszość stosunków polsko-niemieckich w świadomości społecznej Polaków (Poznań: Instytut Zachodni, 2002). 
confessed their fear of Germans immediately turned it into a joke, trying to convince me - and also themselves - that no one was "seriously" afraid: "We had a laugh! [After a visit by Germans] my son-in-law said 'Mum, are we packing our bags then, are you packing your bags?' " (K16Cf).

The respondents who had definitely lost no sleep at all over the prospect of German revanchism belonged to the youngest generation. They were the least empathetic towards the Germans, but they also felt no anxiety at all. This is the first generation of residents of the former "Recovered Territories" who consider the Germans' visits as simply irrational - similarly to their perception of their own grandparents' desire to travel to their distant places of birth. The key to understanding this attitude is pragmatism: they were convinced that these trips have no purpose. As one of the youngest interviewees put it, laconically but poignantly: "They won't stay here, what would they be looking for? Their life in Germany is better. What is there for them here? Practically nothing" (K16Dm).

Another related question is that of reparations that might in theory be paid to Germans as compensation for property left in Krzyż. All of the respondents, irrespective of age and background, were unanimous in their opinion that no financial reparations were owed to the Germans. The most common argument to support this view was that the loss of their property was a just punishment for the fact that it was Germany that started the war; some interviewees added that the Germans had received compensation from their own government. ${ }^{234}$

Here is my opinion: it wasn't us who decided what would happen to this land, and we shouldn't be compensating anyone for what happened, neither should they compensate us for anything. Because it wasn't our decision. We need to accept this as a pre-existing fact. [...] What should our state pay them reparations for? We didn't do them any harm. We didn't invade them. How did they treat our parents? How was my mother treated when she was evicted from her home and sent to labor? They treated us like dogs (K1Bf).

It is surprising, meanwhile, that a clear majority of respondents who did not experience resettlement argued that no reparations in any form should be paid to Poles who were resettled from the pre-war eastern territories. The most common reasoning behind this belief was that it was not worth digging up past injuries after so many years, no matter who the victims were. A range of different ideas lies behind this view. One is fear of a chain reaction: one set of reparations could mean that another group would have to be compensated, and at the end of the chain might be the expelled Germans coming to reclaim their old homes from

234 This is partially true, similarly to the case of Polish resettlers from the East, see: Ther, "The Integration of Expellees." 
the Poles. Looking at the broader situation in Krzyż, however, another explanation looks more justified: the town's new residents see Krzyż as their only possible home and they see no need to make claims on any other homeland, including in the financial realm.

The most surprising thing about memory of the Germans in Krzyż was that the first Polish settlers remembered the short period of cohabitation in the town in mostly positive tones. People only rarely spoke in a disparaging way about the former enemy, and never with condescension or contempt. The overall absence of strongly negative attitudes is striking especially when compared to how the same speakers talked about the Soviets. Even the vocabulary used was markedly different: when discussing the Soviets, pejorative terms such as "Russkies" [Ruscy, Rusoki] and "Katsaps" [Kacapy] would predominate; the Germans, meanwhile, were rarely referred to as "Krauts" [Szwaby] or similar. The existing scholarship on the attitudes of Polish society towards the Germans in the immediate post-war period shows unequivocally that people at this time were ill-disposed towards the old foe. ${ }^{235}$ This was at least partly a consequence of the strong anti-German rhetoric of the Polish state propaganda, which would soon become the rhetoric of the Cold War; nonetheless, these were also genuine social attitudes. ${ }^{236}$ It would therefore be reasonable to expect that interviewees would recall their feelings and thoughts from those times when returning to that era in the act of retelling; however, this was usually not the case. Whilst there were examples of negative attitudes towards the Germans being reported, in most accounts these were attributed to other people, such as neighbors, acquaintances and randomly encountered individuals - people rarely remembered themselves in this role. Narratives of encounters with Germans were organized according to a symbolic division of the remembered world into two camps: "us, who were good" and "them, who were bad." "We" were not only the speaker's in-group, variously defined, such as family, neighbors and relatives, but also, for example, "our" Germans. "We" and our close neighbors didn't hate and didn't expel any Germans, and "our” Germans were not actually too bad. "They" were the "bad" Germans who had killed all those Jews, as well as "bad" Poles who could not forgive the Germans after the war, humiliated them and evicted them from their homes.

235 See: Sakson, "Niemcy w świadomości społecznej Polaków;” Mach, Niechciane miasta. 236 Cf. Edmund Dmitrów, Niemcy i okupacja hitlerowska w oczach Polaków. Poglądy i opinie z lat 1945-1948 (Warszawa: Czytelnik, 1987). 
There were two principle reasons behind this unexpectedly positive image of the Germans in respondent's memories. First, the speaker's own real-life relations with Germans, both before and after the war. The pre-war encounters were important for the group of "neighbors" in particular; they spoke in very positive tones of their relations with local Germans before 1939. Whilst it is difficult to speak of any positive reminiscences from the occupation period, it is interesting that memories of Germans from this period are much less negative than those of contact with the Soviets, despite the enormous damage caused by the Nazis during the war. ${ }^{237}$ There is a clear division between the occupier, an impersonal representative of German power, and the individual German, an ordinary human being with whom one could have surprisingly good and "human" relations. ${ }^{238}$

In the case of people who came to Krzyz from the pre-war eastern provinces, their own experiences of losing their homes played a key role in forming their memories of contacts with local Germans. Someone who had very recently been forced to leave their homeland was in a better position than anyone to empathize with another deportee, irrespective of the reasons behind the latter's deportation. The earlier experience of Soviet occupation (1939-41) also influenced the emergence among "repatriates" of a strikingly empathetic memory in relation to the Germans: for these Poles, the greatest trauma of the wartime period, which also had a major effect on their individual destinies, was the annexation of Poland's then-eastern provinces by the USSR - it was as a consequence of this event that they had to depart from their homes forever. The German occupation was also tough, but this group of respondents remembered it as relatively moderate in comparison to the Soviet period. The perpetrators of the most severe suffering (from a Polish point of view) - arrests, deportations, mass executions

237 Barbara Szacka has noted a similar phenomenon in her research. She explains that Polish-German relations have been worked through in the last two decades and, to a certain extent, "unblocked;" a new, positive image of a German has also been constructed. In relation to Russians, however, negative emotions that have been suppressed for 50 years are still being released, leading to a rise in the temperature of every discussion, see: Barbara Szacka, "II wojna światowa w pamięci rodzinnej", in: Między codziennościa a wielka historią. Druga wojna światowa w pamięci zbiorowej społeczeństwa polskiego, ed. Piotr T. Kwiatkowski, Lech M. Nijakowski, Barbara Szacka and Andrzej Szpociński (Warszawa: Scholar, Muzeum II Wojny Światowej, 2010), pp. $81-132$.

238 Tomasz Szarota, among others, has drawn attention to the existence of a trope of a "good German" in Polish memory (e.g. farmers at places of forced labor, merciful soldiers of the Wehrmacht, etc.), see his: Niemcy i Polacy. Wzajemne postrzeganie $i$ stereotypy (Warszawa: Wydawnictwo Naukowe PWN, 1996). 
and murders - were the Soviets and, in some respects, the Ukrainians. Thus, the most important wartime enemy and object of hatred were the Soviets, who were responsible for the deportation of both the Poles and Germans; meanwhile, wounded memory of the German occupation was somewhat mellowed, and negative attitudes towards the German occupier were not transferred to the local Germans in Krzyż. For the eastern Poles, the Soviet occupiers were the embodiment of barbarism. Even if the Germans had not actually behaved much better, they were perceived by this group as representatives of a common, western civilization, whereas the Soviets were seen as the greatest threat to this civilization, a symbol of eastern chaos and barbarism. Thus, when after the war, the Soviets supervised the expulsion of the Germans, they came across at the symbolic level as barbarians deporting unarmed people from "our" civilizational group. The Germans deserved sympathy at this moment, despite their civilizational degradation resulting from the atrocities they had carried out during the war.

How, then, to explain the fact that settlers who came to Krzyż from Wielkopolska and central Poland also remembered the local Germans as "good people?" They did not experience the Soviet occupation, which had the effect of dividing Poland's two wartime occupiers into a "better" one and a "worse" one. Germans should therefore represent the entire spectrum of evil and cruelty that they would associate with the war, especially if the experience of forced labor is taken into account. Nonetheless, it again transpires that individual experiences played a crucial role in the formation of a present-day image of the Germans. Most of the Poles from Wielkopolska had German neighbors before the war. With the exception of two individuals, every respondent from Wielkopolska and central Poland had worked in a German family-owned farm or a small workshop during the war, where they had contact with civilians above all. All of them were treated well - in some cases, they were even treated as part of the family. Fortuitously, very few of their pre-war hometowns and villages were subjected to the violent reprisals that were often carried out by the Germans in regions annexed to the Third Reich (the exceptions were two interviewees who were deported). All interviewees emphasized that, if they had not been sent to work in the houses of "local" Germans (i.e. those who came as occupiers, or those who were already living there), the Arbeitsamt [employment office in Nazi Germany] would have sent them to Germany proper, which would have been a significantly worse fate. Their lives during the war were filled with difficult manual labor, but working for German civilians also de facto meant being cordoned off from the crimes being carried out by German soldiers in the occupied territories. The terror that the "repatriates" had lived through during the entire war period only really struck the settlers from Wielkopolska when their German hosts started 
to flee from the advancing frontline and the Red Army began to "liberate" the eastern parts of the Reich. Edmund Dmitrów has reached a similar conclusion in his analysis of how the Poles perceived the German occupation: for the Polish villages in the General Government that were not subjected to mass repressions by the Germans, the occupation was a relatively benign time in economic terms, a period of relative "order," especially in comparison to what followed when the Red Army arrived. ${ }^{239}$

There was, however, a difference in attitudes between Poles from the East and those from Wielkopolska and central Poland. A phenomenally strong empathy for the evicted Germans and an emotional approach to the deportations were characteristic only of the Poles from the pre-war eastern territories. Other accounts contained understanding and were devoid of hatred, but did not feature feelings of regret and compassion. The coldness of these statements is easy to understand: setters from Wielkopolska and central regions did not experience the forced loss of their homes, and if they did, it was the Germans who were responsible for that loss. For people whose main wartime experience was the occupation, there was no question of sympathizing with the German expellees.

Another, no less important trope are the meetings between today's Krzyż residents and the German visitors. This experience is the missing element of the puzzle. The oldest respondents remembered the brief period of cohabitation with Germans as a happy time. Only when we see this period as an experience that is overlaid on top of the relatively neutral wartime years and the almost exclusively positive post-war encounters do we begin to see why the memory of the time between 1945 and 1946 takes this particular form. The German visits that started in the 1970s gradually facilitated the loosening of tensions in Polish-German relations at the level of relationships between individuals. The new residents of the "Recovered Territories" gradually came to the conviction that the Germans had no intention of returning to their old houses, and during successive encounters they began to perceive the tourists as human beings no different to themselves, not the monsters portrayed by anti-German propaganda. As a consequence, they remembered the post-war period of cohabitation with the Germans with much more empathy.

Scholars of individual memory have long been convinced that memory does not operate like a tape recording, which remains the same irrespective of the circumstances; rather, it is formed continuously through the entire life of the individual and is influenced by events that occur much later than the thing or

239 Cf. Dmitrów, Niemcy i okupacja. 
event being remembered. ${ }^{240}$ The oldest Poles' memories of the Krzyż Germans confirm this thesis emphatically. Constructed on a base of specific experiences, they were later modified by subsequent events in the lives of the speakers. The final layer is added by contemporary Polish memory culture and the general state of Polish-German relations: the stability of the Polish state on the international stage, the common presence of Poland and Germany in the European Union, and various forms of economic and cultural cooperation, especially in western Poland. The Germans, as a nation, are seen by the Poles in an ever better light, with survey results showing that Poles associate the Germans with the Nazi occupiers ever more rarely; rather, they increasingly associate Germany with cultured, western "Europeanness."241 Only with all of these factors in mind is it possible to fully understand the testimonies of the residents of Krzyż.

\section{Around Material Heritage}

Although, objectively speaking, fewer traces of German culture survived in Krzyż in comparison to the Polish relics in Zhovkva. The overall consciousness of the "Germanness" of the town's past is much more widespread than awareness of Polish heritage in the Ukrainian town. Asked when and how they found out that Krzyż used to be German, many respondents struggled to formulate an answer: the town's Germanness was so obvious that they could not name a specific moment of discovery. One speaker put it as follows: "I don't know, it just sort of came gradually. [...] I don't remember when I learned it" (K9Df). Many interviewees pointed to their family as a source of the knowledge that Krzyż used to be called Kreuz; most often this fact was conveyed in stories about the former place of residence of the speaker's grandparents or parents. In such instances the Germanness of Krzyż would appear as an aside or as a matter of context.

I learned from my parents, my mother used to tell me stories about how she came from the East, what her life was like there, and that we are now living on German territory,

240 See: Tomasz Maruszewski, Pamięć autobiograficzna (Gdańsk: Gdańskie Wydawnictwo Psychologiczne, 2005).

241 The fullest quantitative analyses are the opinion polls conducted by the Public Opinion Research Centre (Centrum Badań Opinii Społecznej, CBOS), see: Komunikat z badań CBOS “Jak Polacy postrzegają swoich sąsiadów," Sygnatura: 5241, Numer publikacji: Nr 124/2015, https://www.cbos.pl/SPISKOM.POL/2015/K_124_15.PDF, last accessed 7.05.2018, according to which only $3 \%$ of respondents used historical associations in their descriptions of Germans, whereas positive images of diligence and honesty were dominant ( $27 \%$ of respondents). 
formerly German that is. [...] When I started school, I knew that this area used to be German (K2Cf).

Often, the space itself caused people to talk about the town's German past - for example, roadside posts remaining from pre-war check-points could prompt passers-by to point out former places where the border between Germany and Poland used to run. The middle generation of interviewees most often discovered the Germanness of Krzyz through its material traces - the same signs that the socialist authorities had tried so hard to erase in the early post-war years. These included German inscriptions and shop signs that gleamed though the layers of paint applied by Poles. Ironically, even the old name of the town, the most prominent symbol of Krzyżs German heritage, was not effectively masked from its new residents: "We knew as kids that it was called Kreuz. Even at the train station, when I was small, it said 'Kreuz', I think. The sign was painted over but you could see the letters through the paint" (K25Bf). It was not only the urban fabric that contained reminders of the German past. The natural landscape also contained German traces - there were German bunkers under the forests, and everyday objects from the pre-war period are still occasionally dug up from the ground. Even members of the youngest generation still notice signs of German heritage, although this was limited to people with an active interest in the town's history. The "German patina," as communist propaganda called it, must have covered Kreuz in a very thick layer indeed, if it can still be seen today.

I've been interested in history practically since I was a small child. History has always interested me, but there were also always lots of signs of the German past here when I was small, you just had to be able to spot them. [...] Bunkers, when I went out mushroom picking with my dad, or German cemeteries, which were out there somewhere with their strange letters. So I don't really know when exactly I grew aware of this. It was always obvious to me that this was a German town (K44Dm).

For respondents from the middle generation, who were born in Krzyż or arrived as infants and toddlers, the material layers of German culture were part of the environment in which they grew up; they were part of the magical world of childhood. In their recollections the debris of German houses turned into lost Atlantises, in which the rosy-cheeked children of Krzyż's new residents hunted for German treasures, while the town as a whole emerged as a space filled with buildings of unknown purpose - and the more time divided today's retirees from those intrepid young explorers, the more mysterious those places became.

There was something very interesting here as well. In the park [...] was a kind of mound, and I remember it like it was yesterday, it had these small doors. [...] Then there were 
some old wooden doors and a kind of storage space, which we were afraid to go into. We didn't want to get locked in or fall into a hole. We would look in, but never climb inside. [...] They say it used to be some storage area or a passage of some sort, but no one knows for sure (K26Bf).

Stories about searches for German treasures sometimes took on a somewhat macabre hue, when instead of hidden valuables, people dug up human remains. In such moments, the tangible, eerie mementos of the past would act as a sobering reminder that searches were not necessarily all fun and adventure: "We went digging umpteen times, and hit upon a tin bathtub. Under that, we heard some wooden boards, like we were hitting a coffin. Granddad decided to stop digging, he didn't want to see or hear any more" (K23Bf). On another occasion, the romantic fervor of a child aiming to find some German treasures turned into pragmatic calculation on the part of the adult rememberer, who secretly regretted that he had not been able to dig up the riches before the Germans - as well as sadness that it is increasingly unlikely today that such valuable discoveries can be made.

I remember in Huta [a village near Krzyż], near my uncle’s house, there was a demolished house, and some Germans had asked about it, and every night the dogs were barking and there was a lot of noise. They [the speaker's uncle and parents] went to check it out one morning, and the basement had been dug up. No one knew that there was a basement under the ground there, and it had been dug up and cleaned out. [The Germans] must have known that there was something there, they had their own supplies of something there, maybe gold, who knows. Anyway they took it all. [...] There must be other unexplored places like that here, whole generations died here after all $(\mathrm{K} 21 \mathrm{Cm})$.

Thus, the material traces of Krzyż's German past accompany the town's residents at all times, up to this day, including at the most everyday level - many respondents continue to live in formerly German buildings. Interestingly, the fact of living in a German house did not necessarily prompt people to reflect on the town's Germanness. Especially among younger respondents, the term "formerly German" [poniemiecki] seemed to have lost its original meaning, now denoting nothing more than an old, well-constructed building that probably required refurbishment. This is shown by the statement of a young woman who only began to consciously think about her experience of living in a formerly German house after the previous owners paid a visit:

I was born here, I've lived here all my life, it had never even occurred to me that it wasn't my granddad who built this house, that the house was already here and used to belong to Germans. [...] It was only later, when the Germans came, that it somehow came out that they [the speaker's grandparents] had traveled here [to Krzyż, after the war]. Granddad told me that he came here with M. and started to live here (K5Df). 
Right after the war, German homes and German architecture were unattractive to the new residents of Krzyż because of their foreignness - this was especially true for settlers from the East. This aversion is illustrated above all by the example of a church in one of the villages, a historic wattle and daub structure from the eighteenth century, which was completely rebuilt by the "repatriates" in order to remove all traces of its Germanness. One of the participants of the refurbishment project described this endeavor as follows:

It was such a big crowd of people and everyone was against those German fittings, German relics, even though it was historic architecture - that didn't bother anyone. [...] Everyone wanted to bring a piece of the church that they had left behind, in the place where they came from, here. Whatever they remembered from their church over there, they wanted to fit here (K13Am).

Nonetheless, such sentiments appeared only in accounts of the first post-war years. 65 years later, people's attitudes to the German heritage were diametrically opposite. The pre-war buildings left by the Germans were now perceived as attractive and valuable. Respondents from the youngest generation in particular spoke of their fascination with the architecture of vanished Kreuz, which many were discovering anew thanks to the Internet. Some speakers regretted that the Polish administration had allowed German technical solutions to fall into disuse, such as the irrigation system. Respondents, especially younger ones, also questioned the insufficient maintenance of historic buildings, which they believed were losing their unique character; some were on their way to outright ruination, such as the former neo-Gothic abattoir. These statements very clearly express the self-criticizing Polish auto-stereotype of polnische Wirtschaft [serious mismanagement], according to which careless and unprofessional Poles allow German technology to go to waste. Such opinions were also voiced by older interviewees who had had personal experience of the German times, as well as younger people who had heard of them through storytelling.

Krzyż is completely irrigated, there are pipes all over the place. Some of them are as thick as my arm, so that the excess water we get around here goes into the river. But it's all buried [and disused]. Maybe it'll happen in my lifetime, but if not, it should happen in yours, that they'd pull it all out. You'll remember me telling you this when they do. [...] Take our river flowing from the lake, the Germans left it all done up, with drains everywhere, but that's all gone. Finished. Today there's no trace of it. It flows because it flows. They should have looked after it (K12Am).

Among the interviewees who expressed an admiration for German heritage, the ones who turn words into action deserve special mention. One respondent, an employee of the town hall, had long been active in the preservation and 
commemoration of the pre-war heritage - it was on his initiative, among others, that the town council published an album of old German postcards, and that the oldest village in the district, Huta Szklana, held tercentenary celebrations. His courtyard was filled with objects destined for the rubbish dump, such as an old German memorial to the soldiers who had died in the First World War, which after years of neglect had simply fallen over and was earmarked for removal. During our conversation, he enthusiastically described some of his latest ideas:

Among other things, I have an idea like this: we apply for funds from the EU, from the rural development fund, and open a nature-historical park in the area around Żelichowo [a village near Krzyż]. Using the old Sapieha ${ }^{242}$ estate as a foundation [...] The point is to turn this area into a memorial, to showcase it. Not necessarily for locals, it's not at all about that. Our aim is to provide a place where school groups and other visitors can come and learn about the history $(\mathrm{K} 37 \mathrm{Bm})$.

It is thanks to such enthusiasts that the affair concerning the leveling of the old German cemetery in Krzyż came to the broader public consciousness. Located next to the Polish cemetery and separated from the town by a forest, the German graveyard was for most residents of Krzyż an integral element of the local landscape. ${ }^{243}$ People walked along footpaths and collected wild lilies-of-the-valley in thick, picturesque shrubbery amidst gravestones that were increasingly grown over by nature. Perhaps it is precisely because of the "idyllic" nature of the cemetery, a result of long-term neglect, that for most of the town's residents the burial place of the pre-war residents had begun to lose its sacral significance, becoming nothing more than a part of the natural landscape. This attitude can be seen, for example, in the following statement, in which an echo of anti-German prejudice is also discernible - "their" cemetery is of a different, inferior, order, unlike the Polish one, which is a "proper" cemetery: "There was a German cemetery, yes, but they dug it up, now it's a Polish cemetery. Our proper cemetery is round the back" $(\mathrm{K} 21 \mathrm{Cm})$. The gradual defacing of the old cemetery was not only an effect

242 The Sapieha family, a house of Polish magnates, were in the eighteenth century the owners of most of the land on which Kreuz and the surrounding villages developed.

243 Andrzej Brencz has argued that placing a town's new Polish cemetery next to the former German one, and allowing the German one to go to ruin, was a typical practice in villages and small towns in the "Recovered Territories", see: his "Niemieckie wiejskie cmentarze jako element krajobrazu kulturowego środkowego Nadodrza," in: Wspólne dziedzictwo? Ze studiów nad stosunkiem do spuścizny kulturowej na Ziemiach Zachodnich i Północnych, ed. Zbigniew Mazur (Poznań: Instytut Zachodni, 2000), pp. 287-308. 
of natural forces, it was also hastened by new residents of Krzyż, who reused the expensive granite slabs to turn them into headstones for their own deceased.

On the one hand, that cemetery could have been preserved the way it was, but Poles removed headstones and crosses from there straight after the war. [...] The headstones, those were all converted from old German ones. I don't know how old I was then, but I know I would cycle past, so it was after my first communion, and there were still lots of tombs there. The names, everything was intact, and now there is nothing left $(\mathrm{K} 31 \mathrm{Bm})$.

Such behavior was universally condemned by today's residents, who were critical of the "graveyard hyenas," especially in cases where the clergy participated in the procedure. One respondent (K19Af), who told me about the sale of German gravestones by the local priest, seemed both angry and ashamed that such a thing had taken place ("But it was the priests and the town authorities who arranged it, it was all legal. It was a little ugly. When they [German visitors in the 1990s] arrived, they recorded it on film, because some of the tombstones had been placed upside down, and you could see it.") For this speaker, it was as if the heinous act put the whole community to shame, especially in the context of Germans visiting the cemetery.

In 2009 a large portion of the main cemetery in Krzyż, which was directly adjacent to the Polish graveyard, was razed to the ground and made available for new Polish burials. When asked about the reasons behind this procedure, the mayor explained as follows: the idea had been consulted with the leaders of the Evangelical Church of the Augsburg Confession, exhumations had been carried out in line with all existing regulations, and only then were new burials carried out. At the same time, she noted that the decision to convert the old cemetery had been taken by the previous administration, and she as mayor was only putting it into practice; she had, meanwhile - after protests by local residents made sure a commemorative plaque to the exhumed Germans was installed. All residents interviewed were unequivocally critical of the leveling of the cemetery. A few exceptional voices argued that this solution was preferable to allowing natural decay and the "graveyard hyenas" to carry out the full course of destruction. Nonetheless, a huge majority of respondents, irrespective of age and background, considered the authorities' decision to have been misguided, many of them arguing that all human remains deserved proper respect, "even Germans" (and even, as one interviewee added, "Russians.")

It's good that they at least set up that burial and chapel. I am against all vandalizing of graves, it doesn't matter whether they're the graves of former Soviet soldiers who liberated this territory or those of local residents. A cemetery is a cemetery and you have to respect a place like that. [...] You have to transfer the remains, exhume them, put them 
in one place, commemorate them properly, showing that here lie the remains of former residents of this land, may they rest in peace $(\mathrm{K} 25 \mathrm{Cm})$.

Another oft-cited argument in favor of respecting the German cemetery was a comparison with Polish burial sites in the East ("There are so many of our graves in the East and we Poles would be sad if our graves were being destroyed" [K27Bm]). Interestingly, it was not only people whose families had come from the East who raised this point - interviewees with no personal relation to the pre-war eastern territories also saw the analogy, although they usually felt a need to explain that "not all Germans were bad" ("Why not let the cemetery be, those Germans lived and worked here and they weren't all Hitlerites" [K27Bm]); in other words, to their minds, respect for the German cemetery needed to be specifically justified with argument.

The state of repair of the German cemeteries that still exist in the Krzyż region (besides the main parish graveyard, there are also village cemeteries and numerous private ones) is for many of today's residents a source of discomfort and shame, especially before people from outside. I encountered several instances of people trying to justify the collective passivity. Many respondents turned out to be keen observers of their social environment, who gave convincing answers to why the given situation had come to pass: they spoke of prejudices against the Germans that resulted from the war, propaganda in socialist times, and lack of rootedness among the new residents.

A guest is not going to look after anything that they still associate with people who were, in one way or another, the cause of hurt, who caused such pain. So you need to understand these people too. When I was a child I also protested against the vandalizing of graves, for example. That is, it was for me, something sacred. For example people took fences and things from German cemeteries, saying those cemeteries were all overgrown. And that was when $[\ldots]$ my father said that a few more generations would need to pass before people started to treat these places as the resting place of innocent individuals (K41Cf).

At the same time, it is striking that these statements of regret about the state of the cemeteries are never accompanied by a desire to actively do something to fix the situation. Respondents typically believed that "someone" should take care of the cemeteries - perhaps the authorities, perhaps an as yet undefined organization..$^{24}$

244 Passive acceptance of commemoration of German former residents, with little active engagement, is not a specific trait of Krzyż. Similar attitudes are described, for example, by Tomas Sniegon in his article on memorial plaques commemorating violence against Germans in post-war Czechoslovakia: Tomas Sniegon, "Between Old Animosity and 
There should be an institution that fences off the land and looks after it, at least to make sure that no one can go in there, and cuts the shrubs to make it obvious that this is a cemetery. I've never seen children running around in there or anything, but I know that the metal gates and all that, all that is gone. It was all stolen (K5Df).

This relinquishing of individual responsibility overlaid on a declared goodwill may be connected to universal processes of social atomization and the fading of collective bonds, especially among the youth. But it is not without reason that people become passive when the matter at hand is in some way "foreign." The Krzyż residents expressed sufficient empathy with the Germans to accept hypothetical action by others, but not enough to take up action themselves. It is interesting in this context to compare the attitudes voiced in Krzyż with the results of nationwide quantitative research, analyzed by Lech M. Nijakowski. ${ }^{245}$ The sociologist argues that a declared readiness to preserve the graves of members of other national groups is a useful indicator of a person's inner disposition towards those national collectives. The data he analyses show that $58 \%$ of Poles were prepared to look after German graves (in comparison, $81 \%$ would work to preserve Jewish graves, $63 \%$ would look after Soviet burial sites, and $53 \%$ would respect the graves of Ukrainian nationalists). In Krzyż the proportion of people concerned about the German cemetery was much higher than $58 \%$, but when one considers the actual condition of the cemetery, it becomes clear that these declarations of intent are no more than verbal declarations. It remains an open question how many of the $58 \%$ of Poles identified in the research carried out by the Museum of the Second World War would turn their intent into concrete action.

\section{German Heritage and Identity}

Finally, it is worth considering whether and to what extent the erstwhile Germanness of Krzyż bears significance for the social identities of today's residents and their lives in the present-day town. Age, education and the place of origin of individual respondents or their families were all significant factors in this regard. In the oldest generation, the former "neighbors," i.e. settlers from nearby villages who witnessed the end of the German presence, had no issues with coming to terms with the German past. Their testimonies did not

New Mourning. Meanings of Czech Post-Communist Memorials of Mass Killings of the Sudeten Germans," in: Whose Memory? Which Future? Remembering Ethnic Cleansing and Lost Cultural Diversity in Eastern, Central and Southeastern Europe, ed. Barbara Törnquist-Plewa (New York-Oxford: Berghahn Books, 2016), pp. 49-72. 245 Nijakowski, "Pamięć o II wojnie światowej." 
contain propaganda staples from socialist times that justified the Polishness of the "Recovered Territories." Such phrases did, however, appear fairly regularly in statements by people who settled from the East, Wielkopolska and central Poland, especially less educated people and those who were less interested in history.

I put a figure of Mary here at the corner, that was me, from my own pocket. And it says, "Holy Mother, Bless us in these Recovered Polish Lands." Because this was Poland before, probably. The Germans took it from us. Who knows if that is actually true? It's what I've heard in any case from older and more serious people, I doubt they were lying. [...] I wasn't there, I didn't see or hear it, so I can't say for sure, but that's what I have in my memory and that is what I think. That's why it says "in these Recovered Polish Lands" (K27Af).

This statement is striking for its uncertainty about facts: Krzyż was "probably" Polish at some point, but it is unclear how or when exactly it became German. At the same time, it is apparent that this uncertainty was not an issue for the respondent; it did not stir up any unease on her part. History remained the realm of other, "more serious" people, and that was for her a good thing. The topos of the "Recovered Territories" also featured in statements by children of resettlers. As a rule, they were aware of the great extent to which this idea had been politicized as it was inculcated in them when they were growing up, yet they nonetheless sometimes repeated key arguments concerning the Polish presence in the "Recovered Territories."

We know that this was Kreuz before the war, not Krzyż. But if we, in turn, go back a few centuries more, wouldn't we reach the conclusion that, with the time of Mieszko I, and, you know, Bolesław Chrobry, ${ }^{246}$ that these were Polish territories right up to the river Oder? (K2Bm).

Full recognition of the former Germanness of Krzyż, without any equivocation, was voiced very rarely in conversations with people from the second generation. The first cohort to have no issues with admitting that the town was once German was the third generation, now middle-aged people who entered adulthood around the time when Poland transitioned to independence. For the fourth and youngest generation, the myth of the "Recovered Territories" belonged to a reality that had passed long ago. Residents in their twenties and thirties felt no need to justify their presence in the town. Even if Krzyż had been German at

246 Mieszko I and Bolesław Chrobry were Polish rulers of the Piast dynasty $\left(10^{\text {th }}-11^{\text {th }}\right.$ centuries), under whose rule the area of the latter-day "Recovered Territories" first became part of a Polish state. 
one point, as they admitted with few scruples, this fact had no bearing on the present; the German heritage of Krzyż was so distant for them, like most other historical events, that it aroused few emotions. As one interviewee put it: "[The Germanness of Krzyż] has no significance, because you know... I only know from learning history that Germans used to live here. But on the whole [...] I don't really feel it" (K25Df).

This brief summary of different generations' attitudes to the town's German past, combined with the analysis provided so far, shows that the myth of the "Recovered Territories" has been irrevocably abandoned. It was partly internalized by the oldest settlers and laid deep roots in the minds of the middle generation who grew up and were educated in socialist times, but was only reflected in linguistic mimicry among the youngest interviewees who went to school after 1989. These words and phrases will surely remain present in Polish language usage for some time, but their original meanings have been lost irreversibly. The myth of the timeless Polishness of the lands transferred from Germany in 1945 may have been a necessary tool for creating social cohesion, but it never stood a chance of being fully successful because it was a flawed myth. It lacked an element that would complement the idea of the regained land, namely an abandoned homeland or lost paradise; ${ }^{247}$ the settlers had supposedly come from nowhere, the tension caused by unmourned lost homelands steadily increased, and the myth was destroyed from within and rejected at the first possible moment.

Acceptance of the town's Germanness corresponded with an increasing recognition of the pre-war residents' contribution to its development. Asked straightforwardly whether today's residents of Krzyż should remember the Germans and whether the town should be thankful to them for anything, interviewees replied nearly unanimously in the affirmative. The Germans were an unquestioned source of the town's heritage.

Well of course we should [remember the Germans], because in any case, no one would have come to this place called Krzyż if it hadn't existed. No matter what, they also spent some time educating, building and creating culture here, didn't they? They built and maintained the railway. Krzyż probably wouldn't have existed if it weren't for the railway. They also had their own plans, their own dreams, just like everyone here now (K31Bm).

The oldest residents of Krzyż also agreed that knowledge about old German Kreuz should be spread, although they made it very clear that questions of guilt and responsibility should be foregrounded in such a way as to prevent dangerous

247 Cf. Marcin Kowalewski, “Ziemie Odzyskane. Co dalej?”, Przeglad Polityczny, Vol. 67/68 (2004), pp. 64-65. 
relativism. As one interviewee put it: "It should be taught, but within the limits of, as they say... So that they don't come back or anything like that, so that they don't think that this place is still theirs" (K15Bf). In the first and second generations the acceptance of remembrance of the town's German heritage was less conditional among people who had migrated from the East, whereas it was more conditional among the group of "neighbors." This fact provides further support to the hypothesis that a sense of commonality arose between the eastern Polish resettlers and the Germans expelled from Krzyż.

Attempts to include the German past in the history of Polish Krzyż can be seen in conversations with local teachers, people who - at least in theory - have both greater knowledge of history and a direct responsibility to transmit knowledge. A respondent who taught history stated that students in her classes always learn that "[Krzyż] owed its history to the Germans. And that its history was related to the development of the German state, not the Polish one" (K41Cf). The vision of history teaching advanced by this woman was very open to talking about the German past, and it also made a point of avoiding interpretations typical of communist education; at the same time, she was convinced that there was no space in school history for relativization. It was important that the Germans were seen to have been responsible for the outbreak of war, and therefore for their own post-war fate, no matter how cruel. It is interesting to compare the attitudes of Krzyż teachers with available qualitative survey data. Research conducted among teachers from the cities of Zielona Góra, Gorzów Wielkopolski and Olsztyn in the mid-1990s showed a similar level of openness to the German past, but a significantly greater adherence to ideas from socialist-era propaganda and, consequently, a greater fear of the Germans returning. ${ }^{248}$ The changes in attitudes can be explained by the passing of time and the deepening of the conviction that life had become no less secure in the Polish-German borderlands after Poland joined the EU, the borders were opened and free movement of people and goods began. Teachers, like other residents of Krzyż, today feel secure in the

248 Over $70 \%$ of the teachers surveyed stated that the "Recovered Territories" returned to Poland in 1945, and $53 \%$ believed that they belonged to Poland because they were inherently Polish. $43 \%$ of people believed that the Germans were trying to return to the "Recovered Territories." Interestingly, of the three cities studied, it was Olsztyn located furthest from the Polish-German border - that showed a significantly lower level of fear of German revanchism and the greatest level of openness, see: Zbigniew Mazur and Krzysztof Wawruch, Nauczyciele wobec przeszłości Ziem Zachodnich i Północnych (Poznań: Instytut Zachodni, 1998). 
"Recovered Territories" - and the way they teach history is a consequence of that sense of security.

Krzyżs German past rarely had any significance for people with little interest in history and for those whose daily lives provided few reasons to reflect on this past. Only very rarely did respondents note that they consciously considered it an element that affected their experience of living in the town. Much more commonly, people stated outright that the pre-war heritage had no influence whatsoever on their lives today. Sometimes interviewees were even surprised at the question. The quintessence of this outlook can be seen in the following answer concerning the German past's significance for life in Krzyż today: "What kind of meaning could it possibly have? I feel fine here, I have no strange dreams that some German guy used to live here, I sleep fine. It has no meaning for me, none at all" (K2Bm).

This last quote illustrates the greater point of this chapter. Memory of the absent Germans in Krzyż may not be devoid of the complications typical for this type of memory, but is relatively unproblematic. Memories were abundant and detailed among the oldest generation, fading and losing their sharpness as they were passed down to successive generations; this is, however, a typical process for collective memory in general. In terms of Jan Assmann's typology, the Krzyż Germans stopped being characters of living, communicative memory, increasingly becoming impersonal and distant elements of cultural memory; ${ }^{249}$ this process cannot be assessed using categories of good and bad or healthy and pathological. The process of moving forward is one in which certain things are lost: emotions, which comprised an integral part of the biographical memory of interviewees, are lost forever. Children and grandchildren can try to reconstruct them, but this requires a lot of effort - and this effort is not always undertaken.

One of the dangers of the intergenerational transformation of memory is the relativization of responsibility, but it seems that in Krzyż this has not taken place to such an extent that falsification and secondary traumatization of memory would result. The most important elements are suppressed to a similar extent: it is not the case that violence exerted by Poles against Germans has been completely forgotten while harmonious coexistence is celebrated as a formative experience. Younger residents know little about both phenomena. It is a result of this particular equilibrium that today's residents of Krzyż do not experience any

249 Assmann, Cultural Memory, p. 6. 
real difficulties regarding the town's German past. They neither build their identity on it, nor do they strive to forget or negate that heritage; they neither build new myths nor believe in the old ones; they do not fight for any causes and do not attempt to impose their views on others, because they feel there is no need to do so. This collective self-confidence is conducive to the ever-diminishing strength of historical prejudices held against the Germans today. The younger a resident of Krzyż (and the more educated, although this is not a hard and fast rule), the more likely they are to look at Germans visiting their town through a lens of ordinary curiosity and economic interest, and the less they see in them the former owners of local buildings and a potential threat. ${ }^{250}$ This calmness is captured in a phrase uttered by an interviewee of the oldest generation, a woman living in a nearby village. An older German had recently built a summerhouse near her home and was spending the warmer months there: "[How did people here react when a German built himself a house? Was there no fear? That the Germans would come and start claiming property?] No, no. You know, no one even noticed" (K19Af).

We may ask whether this specific tranquility of memory is not a step too far, whether it isn't threatening to turn into passive forgetting, and whether it can really be a benefit to the local community in the long term. I will resist the temptation to hazard predictions and recommendations, in part also because of my personal ties to Krzyż. At the same time, I can say with complete certainty that the overall state of memory in Krzyz is the absolute opposite of the feverish condition of memory in Zhovkva, to which the next two chapters are dedicated.

250 This rule was noted in the "Recovered Territories" in the early 1990s, and since then, the observed tendencies have only become stronger, see: Sakson, "Niemcy w świadomości społecznej Polaków." 



\section{Remembering the Absent: Jews and Jewish Heritage in Zhovkva ${ }^{251}$}

\section{Life and Death Among Neighbors}

Memories of the Jews who lived in Zhovkva before the war are clearly differentiated. The oldest generation born in the town remembers the Jews differently to the resettlers, whose memories are different again from the younger residents of various backgrounds. It is not surprising that the pre-war residents of Zhovkva remembered the Jews most often and in most detail - they were the only group for whom contacts with the town's Jews had been part of their personal experience. These memories appeared fairly frequently in the first, free-speaking part of the interviews. In her study of memory in the previously multiethnic village of Jaśliska near Sanok in south-eastern Poland, Rosa Lehmann identifies three types of narratives about Jews before the Holocaust: "political" (dividing the speaker's own group from the ethnic and religious other, marking borders, highlighting inter-group rivalries and the statuses of specific groups); "mythical" (prejudices and misunderstandings resulting from lack of knowledge, such as the myth of Christian children being kidnapped for matzo); and "positive" (describing concrete examples of positive relations with Jews). ${ }^{252}$ The testimonies of autochthonous residents of Zhovkva contained all three types of narrative, with minor modifications. Similarly to Lehmann's study, "political" accounts appeared most frequently, i.e. those in which the speaker delineated the Jewish community from their own (Polish or Ukrainian) group whilst describing its size and status.

We went to the same [school], and there were many Jews [Zhydivochky] there then. There were more Jews than us, Ukrainians or Poles. I once had a small calendar, and you know what? Zhovkva used to have a population of about 10,000, and of those 10,000 more than half were Jews, that's more than Poles or Ukrainians. [And did you have any Jewish friends?] I did, you know. Across the road [...] there was a Jewish centre. But we all lived together in peace! (Z30Af).

251 A shorter version of this chapter was previously published as a stand-alone article: “(Nie)pamięć na gruzach. Zagłada Żydów żółkiewskich w świadomości nowych mieszkańców miasta," Zagłada Żydów. Studia i Materiały, Vol. 7 (2011), pp. 144-169.

252 Rosa Lehmann, Symbiosis and Ambivalence. Poles and Jews in a Small Galician Town (Oxford-New York: Berghahn Books, 2001), pp. 103-105. 
In this fragment, the third type of narrative elucidated by Lehmann also makes an appearance, i.e. the "positive," according to which harmonious pre-war coexistence is emphasized. Statements of this type usually supported their claims with a concrete example and appeared to have an offsetting effect: they allowed speakers to distance themselves from negative stereotypes. An image of mutual contact between the Christian and Jewish communities was observable in the memories of autochthonous residents of Zhovkva; respondents primarily remembered relations from the professional sphere, such as shopping in Jewish stores or working for Jewish employers. These narratives were articulated in a warm tone, but Jews were presented more as members of a specific social or professional group than as distinct individuals with personal names.

They [the Jews] had their own kind of farms, land on which they gathered people [to work]. My mum went to one, to get a jug of milk, so that she had something to bring us. [...] Sometimes she didn't have any money, and we would come to the farm where he [the Jewish owner of the farm] sold us milk, and he would give it to us on credit, writing down how much we had taken. Then, when mum got some money somewhere or whatever, we would settle up. They gave us everything we needed, no questions asked. [...] The Jews were good people. No doubt about that, better than the Ukrainians (Z14Af).

The interviews contain no traces of deeper, closer relationships between members of the two ethnicities. Respondents stated that their parents had had no Jewish friends, or they admitted that they struggled to recall the names of Jewish schoolmates. A similar picture of Christian-Jewish relations emerges from the analysis conducted by Anna Landau-Czajka, who argues that even in partially or fully assimilated families, Jewish residents rarely interacted with local Christians other than in the professional realm. ${ }^{253}$ One interviewee, a Pole (Z8Af), stated hesitantly that there had probably been some Jewish children in her school, but she remained unsure, because Jews had had their own faith-based education. She finished her statement with the sentence: "they wore their sidelocks and had their own rabbis," explaining why she had no memory of Jewish schoolmates: they were not part of her world because they were not full members of her group, they belonged to the world of Others. Another interviewee blamed the Jews themselves for the creation and maintenance of inter-ethnic boundaries, arguing that, for example, Jewish residents were not in favor of mixed marriages (although in reality, such marriages were frowned upon by both groups).

253 Anna Landau-Czajka, Syn będzie Lech... Asymilacja Żydów w Polsce międzywojennej (Warszawa: IH PAN, 2006). 
There were no expressions of blatant prejudice or "jokes" about children being kidnapped for matzo. At the same time, some interviewees expressed a mixture of curiosity and fear at the different culture of the Jews, which was a world unknown to them. From the words and phrases they repeated (sometimes incorrectly) and rarely understood - both at the time and, even less so, in the present day - it is possible to discern how inviolable and even magical the boundary between "us" and "them" had been.

There were Jews, yes... There were Jews who spoke Polish, and Jews who spoke Yiddish [po zhydivsky]. And there were Hussite Jews [sic - husyty - the speaker means Hasidic, khasidy ] - the ones with those sidelocks, the Old Believers ${ }^{254}$ of the Jews, and they spoke only in... I think it was called something like hybrid language [po hibrydsky; she obviously means Hebrew, ivryt]. They only spoke their own language. And they were very kusher [sic - kusherni, a mispronunciation of Ukrainian kosherni, i.e. they observed kashrut]. For example, there was a Jewish woman who bought milk from us, and my mother always had to milk the cow into her pan, not into ours, because our pan or cup was already treif [trefny, i.e. non-kosher] (Z1Af).

The Holocaust overshadowed the memories related to the Jews of most of the pre-war residents of Zhovkva. Whilst relations between Christians and Jews in the pre-war period received sporadic treatment in the interviews (which could also be a consequence of the age of the respondents), the Shoah was discussed by every member of this group. Many speakers talked about their memories of Jews from before the war in broad brushstrokes, then immediately moved on to the wartime catastrophe. These statements were also divisible into distinct types, based on structure, content and emotional saturation. Many accounts were "comprehensive" narratives, which tried to describe the entire Holocaust in a few sentences as a single, closed statement.

Then they started to exterminate them. At first they told them how much gold they would have to give up, then how much of everything else, and they had to carry out all the instructions. Once they had taken everything away, they built a ghetto. [...] It was possible to go inside, people did go in, but if you were to go in there, you wouldn't come

254 The Old Believers were a group of Orthodox Christians that appeared after a schism resulting from a section of the Russian Orthodox Church refusing to recognize the liturgical reforms of Patriarch Nikon in 1652-1656. The Old Believers were officially classed as heretics by the Russian Orthodox Church and were persecuted, firstly by the Tsarist authorities and later by the Soviet regime. In order to preserve their distinct confessional identity, they gathered in distant and less accessible areas. For this respondent, the reference to Old Believers appears to mean religious orthodoxy, but also backwardness. 
back out. People went in with their own fears and at their own risk. Later, they started to shoot them [...] and that was so horrible, it affected everyone else despite everything. Of course, with such mass murders happening, who could remain impartial? (Z31Am).

The above fragment is exceptional - no other interviewee born in Zhovkva spoke about the Holocaust so laconically and without emotion. Many other accounts contained traces of personal prejudices that unconsciously seeped between the lines, but nonetheless, respondents tended to discuss the deaths of their Jewish neighbors with a degree of emotional involvement. They also always included in their accounts a set of concrete, personal reminiscences - say, of a Jewish acquaintance whom the speaker had seen being transported to her place of execution, or of neighbors who were expelled to the ghetto. Besides hints of anti-Semitism and expressions of sincere regret, these descriptions of the Holocaust also sometimes contained hints of detachment from the events, both at the time and in the present. At a certain point, people stopped registering what was happening to their Jewish neighbors - through horror, repulsion, or fear for their own survival. Fear often lay at the root of the striking indifference these residents showed, an indifference that appeared in condensed form in the interviews as a recurrent statement to the effect that "we didn't get involved in that."

They sorted those Jews, and then they chose a committee, which decided that the healthy ones would dig graves. So they dug graves, and they took the ones who had been chosen by the sorting, but I don't know how, because I didn't really poke my nose around, it was terrifying to look at. Later, there were these men who stood above the holes and carried the women to their deaths, and threw them in the hole. And there was a German... [...] And there was a kind of mound, we would climb onto the mound and look. Those people just went "bang!" - and they were in the hole (Z36Af).

In his absorbing travel report from Ukraine following the history of the "Holocaust by bullets," the French scholar and clergyman Patrick Desbois argues that there are three kinds of Holocaust witnesses: those who did not know anything themselves but who heard from witnesses; those who saw the events first hand; and those who were coerced into participating in the process of murder. ${ }^{255}$ A clear majority of autochthonous Zhovkva residents belonged to the second type: they saw the Holocaust unfold with their own eyes. Their testimonies contained descriptions, details and a variety of emotions, but rarely followed a chronology of any kind, usually being closer to a mosaic, or to a process of

255 Cf. Patrick Desbois, The Holocaust by Bullets. A Priest's Journey to Uncover the Truth behind the Murder of 1.5 Million Jews (New York: Palgrave Macmillan, 2008). 
wandering from one point at which Christian and Jewish fates overlapped to the next such point.

He would transport them to the forest himself, that German; it was terrible, the way he killed people. I saw it myself. The car was parked, there was a closed off ghetto here, and there was a mother walking along with an infant in her arms. He grabbed her by the legs and stood her against the wall...! Later they threw the infant into the car (Z8Af).

Encounters between Christians and Jews sometimes also revolved around interests. Interviewees very rarely said so outright, more often stating that their parents had helped Jews with no ulterior motive by sending food packages into the ghetto. But many people did make material gains from providing help. Only one respondent talked about trade across the ghetto walls, although her interview did not become part of the main analytical corpus. Many more people discussed ways in which Poles and Ukrainians helped to conceal Jews from the Germans. These were, however, mostly vague constatations of fact that "many people hid Jews;" when I asked for specific details, I rarely received a response. The only story that appeared in a number of accounts was that of a Pole of ethnic German origin, Józef Beck, who sheltered 17 Jews in the cellar of a house on Lvivska [ulica Lwowska] Street that is still standing to this day. The story appeared in significantly transformed forms, having been filtered through various retold and overheard versions; nonetheless, it is significant that it was the only individualized narrative that was told.

There were no individuals among the interviewees of this group who claimed to have directly helped in concealing Jews. Two respondents, however, recalled other forms of help that their families had provided. One woman (Z7Af) remembered how her mother carried water to a Jewish family who were hiding in their barn. A second woman told a story about how her mother had smuggled a Jewish girl out of Zhovkva using her own daughter's identity papers.

When the Germans made the Jewish ghetto here, there was one Jewish girl, she was very beautiful and she looked like my sister. So this Jewish guy asked us, asked mum to take his wife to Poland. So mum took my sister's papers, because they were similar. [...] Mum left all her children at home and took that Jewish girl to Poland on my sister's papers. [...] I'm telling you, she could have gotten in touch by now, right? I think she lives in Poland now, she must be old by now, it's OK, but nonetheless, she should have remembered. It was lucky that, thank God, we weren't all killed and mum came home. She didn't gain anything from it, but she saved that Jewish woman and her child (Z14Ak).

Interestingly, in both cases these stories featured as if as an aside to the main narration of the Holocaust. Both speakers were ethnic Poles, who strongly emphasized that their families had had no ulterior motive in helping the Jews. 
In addition to help afforded to Jews, interviewees also recalled instances where Christians refused assistance to Jews or handed them over to the Nazis. Only in one case, however, was the speaker referring to her own personal circumstances. The respondent, whose father did not agree to conceal her Jewish friend (nota bene this was also the only instance in which a respondent mentioned having a Jewish friend), was still mournful, but she did not condemn her father's actions at all. Rather, she ascribed his attitude to the broader framework of ChristianJewish relations during the war - and in this way, seemed to justify it.

That girl was so pretty, with her curly hair, like... I can still see her before my eyes. She was five years old. She said: "You can say that I'm part of the family, or something." My parents got scared. They were scared, and... the girl was taken away and killed. Her father was a doctor, a really good one, a great dentist. No one hid them, no. Essentially, no one hid them (ZAlf).

The same speaker also spoke disapprovingly of the neighbors who had given up a Jewish family they were hiding to the Germans, once the Jews had run out of money for their upkeep. "What they did was bad, it was bad," she repeated. Another interviewee spoke in similar tones of pre-war neighbors who had concealed three Jewish doctors, extracting all of their money, before handing them over to the Germans. One of the Jews, however, escaped to the forest before the tragic day, perhaps guided by a presentiment; he returned after the war and filed a lawsuit against his "benefactor." The Ukrainian was sent to prison and died whilst serving his sentence. The interviewee spoke about the incident in a stern voice, showing no sympathy for him.

Accounts of the Holocaust were without exception stories about fear and a sense of being constantly under threat - both for the Jews and the present-day Ukrainian respondents. Interviewees remembered the singular instances in which members of their own groups became "collateral victims" of the Shoah with a similar intensity to the mass murder of the Jews: ethnic Ukrainians and Poles who tried to help Jews and were caught in the process, or those who were mistaken for Jews and lost their lives as a result. In both cases, sympathy for the suffering of Jews appeared mixed with a dose of resentment that Christians had died "because of them."

For example, I was going into town in the morning, or to the church, and there was a woman lying on the road. She lived here, on this road. They killed her because they thought she was a Jew, but it was a Pole going to church. They killed her. She was walking along, and then she was gone! [with resentment in her voice] (Z36Af).

It also happened on several occasions that speakers followed their memories of the Holocaust with a seamless transition to the dangers that they themselves 
had faced; sometimes, this was connected to the reality of the Shoah (such as the possibility of being mistaken for a Jew), but on other occasions memories of the speaker's own suffering were evoked through a process of analogy: using the same context to describe a completely different situation. A similar narrative divide - the usage of descriptive frames from someone else's suffering to describe one's own - is labeled by Harald Welzer and Karoline Tschuggnall as a phenomenon of "changing frames" [Wechselrahmung]..$^{256}$

There was a raid, I saw it through the window, and we all had an Ausweis, some papers for school or whatever, to show that I wasn't a Jew. We were all very dark-skinned and very similar [to Jews], so I had to carry this document with me wherever I went. I opened the blinds on the window, and there was a German standing there on the asphalt, aiming his gun at a Jew. He shot at her, and I hid straight away. [Did such raids happen often?] Yes, they carried out raids and took people away! They took people to Germany [for forced labor], they took our people to Germany! (Z30Af).

A similar statement featured a conviction that wartime suffering was universal first the Jews suffered, then the Ukrainians: "they did the same [to the Jews] as the Moskals later did to us! The Germans started it, then bloody Stalin finished the job!" (Z35Af).

Witnessing the Holocaust also sometimes meant making gains from it. Memory of such profiteering is very much a taboo, and if interviewees spoke about it at all, they described "hyenas" who were somehow Other - whether situationally or permanently - such as people who were excluded from society. In the following fragment, for example, a Pole describes the behavior of Ukrainians from a village outside Zhovkva.

There was a Jew running away, the Germans had shot him in the leg and injured him. The villagers ran up to him and they saw that he was dying, and they took the boots from off his feet. I was out grazing the cows, I was still small, but I remember it very well. I even told my husband about it. I can't stand that kind of thing. You should try and save people, try your best, and if it doesn't work out, then... But don't steal his boots... (Z14Af).

Interestingly, this is the same mechanism that appeared in the accounts of Krzyż residents in relations to the post-war violence against local Germans what Aleida Assmann calls externalization of guilt. ${ }^{257}$ Yet, while statements that condemned Holocaust-related profiteering appeared in a few interviews, actual collaboration in the murder of Jews was mentioned only in clipped phrases.

256 Tschuggnall and Welzer, "Rewriting Memories."

257 Assmann, "Fünf Strategien." 
The last speaker quoted (an ethnic Pole) briefly recalled a Ukrainian auxiliary policeman who participated directly in the shooting of Jews: "he stood guard, stood there and drove [the car]." Two other respondents (a Ukrainian woman and a woman with mixed Polish-Ukrainian identity) spoke very critically of the Ukrainian police, but it was nonetheless difficult to obtain from them any more exact information about its role, or a broader comment on the fact that a Ukrainian auxiliary police existed and participated in the Holocaust.

I went to town, and there was a Jew lying in the gutter, injured, and all he needed to do was just lie there and stay still, the silly Jew. At that moment a policeman came along and, well, killed him. [Was the policeman a German or one of ours (i.e. Ukrainian)?] Ours. They worked for the Germans. [Our people were in the police as well?] I was thinking: "What did you do that for?" Idiot, he would have lived, if only he had waited till the evening (Z35Af).

The police was, well... What do I know...? Err, they were pretty nasty people, who went out looking for Jews, here and there... So, kind of, those types... (Z1Af).

This topic had clearly been relegated to oblivion - my attempts to extract it from there were met with huge difficulties. These difficulties were exacerbated by the fact that it was not only individuals who had forgotten; broader social frames of memory also obscured this theme. This conclusion is reached fairly quickly when one looks at trends in contemporary Ukrainian historiography or Ukrainian reactions to attempts by western scholars to raise related questions. ${ }^{258}$

A related issue that has been even more thoroughly erased from memory is the theft of Jewish property. Whilst there were a few individuals who spoke about collaboration in the Holocaust, looting was a strict taboo - not a single interviewee who had lived in the town before the war was willing to discuss it on record, and in informal conversations they all denied that such a thing could have taken place in Zhovkva. Meanwhile the resettlers who arrived after 1945 said that looting was a fairly common act:

Oh yes, there were empty Jewish houses in the town centre. Yes, everything in the centre was empty. We were supposed to live in a house [like that]. Everything was ready. But people went in there and took apart the stoves, looking for gold in the stoves. [In the

258 On the relationship between individual and collective forgetting, see: Maria Hirszowicz and Elżbieta Neymann, "Społeczne ramy niepamięci," Kultura i Społeczeństwo, Vol. 3/4 (2001), pp. 23-48. One of the best analyses of Ukrainian discussions on collaboration in the Holocaust is: John-Paul Himka, "Debates in Ukraine over Nationalist Involvement in the Holocaust, 2004-2008," Nationalities Papers, Vol. 39 (2011), pp. 357-370. 
Jewish houses?] Yes, our people, Ukrainians, went into them. They took apart the stoves, some even took doors. Some would piss, others would shit in there... You see what it was like? (Z5Am).

One account, which contained a long and detailed description of what happened to the Jews in Zhovkva, featured a fragment that essentially justified, if not quite praised, the Holocaust - such attitudes are well known from existing studies of folk anti-Semitism in Poland. ${ }^{259}$ According to this argument, the Jews had deserved their treatment because they had killed Christ; but the scale and brutality of Nazi murder had made it more difficult to accept. If only the Germans had killed only the Jews, it would have quite alright: "If only they had killed the Jews because they saw how much harm they cause, and treated the other nationalities differently. But they treated the Ukrainians, the Poles and everyone else in their German way" (Z2Am).

This was the only example of such outright and extreme anti-Semitism among all of the interviews with the oldest generation in Zhovkva. Other statements contained attitudes that can be cumulatively summed up with the phrase "we may not like the Jews, but they are also people" ("I wouldn't have been able to do anything like that. Sure, they were Jews, but why shoot them straight away?" [Z35Af]). Only one respondent, however, gave the Holocaust his explicit approval.

\section{Hearsay: What do the Resettlers Know about Zhovkva's Jews?}

With a very small number of exceptions, there were no respondents of the oldest generation who moved to Zhovkva after 1945 who did not know that Jews had lived in the town before the war. Nonetheless the manner in which they talked about the vanished Jewish population was very different from the autochthonous residents. The resettlers arrived in Zhovkva to find only traces of the Jewish community's previous existence. The statements they made during the interviews were based entirely on what they had been told by others, not their own personal experiences. The resettlers rarely composed long, closed narratives about the Jews; I usually had to prompt them with many probing questions. Sometimes, answers were restricted to a single, weighty sentence: "What people around here

259 For a definition and discussion of folk anti-Semitism, see: Alina Cała, Wizerunek Żyda $w$ polskiej kulturze ludowej (Warszawa: Wydawnictwo Uniwersytetu Warszawskiego, 1992). 
say is that the Jews here were also dealt with in that way; they were murdered and buried" (Z9Af).

People who lived in the vicinity of Zhovkva before 1945 displayed the most detailed knowledge about the town's pre-war Jewish population. This is, of course, a result of the fact that they visited the town from time to time before settling in it, for example to do some shopping with their parents. These accounts also contained the most anti-Semitic remarks, closer in nature to modern political anti-Semitism than the traditional religious variety. ${ }^{260}$

I remember [the Jews] a little. When they lived here, when we used to buy things from them. I was still small, but I used to come to Zhovkva with my dad quite a bit. [And were there lots of Jews here?] Loads! Let me put it this way: Zhovkva was practically a Jewish town. And let me tell you, I don't have too much respect for the Jews. I told you that the Germans beat them, and they didn't beat them enough. They're still in power. You don't hear much about Jews who work their own land. They only like it when others work for them, when they exploit others. It was tough to watch how they were killed. But I, for one, deep down... I see how they rule the world now (Z19Af).

If a respondent's nearest town before the war was a place other than Zhovkva, they would often make comparisons with that nearby town, drawing analogies to "reconstruct" what must have happened in Zhovkva.

[Where there Jews here in Zhovkva?] Oh yes, lots, there were lots of Jews. And in Zolochiv [another town in Lviv Oblast] too, my goodness... If it wasn't for... you know, who knows how many of those Jews there would be now, what a nightmare. Basically everything, all of the trade, everything like that was in Jewish hands. Or in the Poles' hands, but the Poles were more interested in politics, you know, but everything to do with money, that was the Jews. The doctors were all Jews, the lawyers were all Jews, and all of that. It's the same now (Z20Am).

Meanwhile, anti-Semitism did not feature at all in interviews with educated people. ${ }^{261}$ This correlation may be a result of a certain "political correctness" to which these respondents adhered, a certain cultural code among educated people that limits the readiness with which one voices attitudes considered inappropriate; it may equally be that these interviewees were more self-aware or

260 Cf. Ireneusz Krzemiński, ed., Antysemityzm w Polsce i na Ukrainie. Raport z badań (Warszawa: Scholar, 2004).

261 That is, people with at least a high school education. There were no interviewees from the oldest generation in Zhovkva who possessed a university degree. For comparison, two respondents of the oldest generation in Krzyż were university graduates. The relatively low level of education among the resettlers in Zhovkva is another indicator of their low social status in the new post-war reality. 
sensitive. These individuals rarely made sweeping generalizations about "typical Jews," more often referring to specific individuals of whom they knew.

There were Jews here, and there were some after [the war] too; there was a guy called Liainer, for example. ${ }^{262}[\ldots]$ He was caught, he told me the story - it really is quite a story. He was caught, but he escaped, somehow he managed to get out of here. And then he was the director of a bakery here. [In Zhovkva?] Yes, he was a good man. He also wrote poetry, stories, memoirs. We were already living here, we've been here for 22 years, and he came and asked me to edit his writings, in Ukrainian (Z23Af).

The fragment cited here shows a fundamentally important tendency pertaining to post-war contacts with "locals." The more often and intensively the newly arrived residents spoke with people who had lived in Zhovkva during the war, the more they knew about both the interwar period and the Holocaust. Respondents, who answered questions about Zhovkva's Jews with perfunctory responses or casually slid into observations on Jews in their own pre-war hometowns, did not, as a rule, remember having close contacts with autochthonous residents of Zhovkva. Speakers were able to give much more coherent responses on matters they had learned about "at first hand." The respondent cited below, for example, obtained her information from neighbors, local Ukrainians, whereas another interviewee had spoken to a Jewish family who used to live in her house and paid a visit in the 1990s.

The people here [residents of Zhovkva] said that they left for Poland. They were in Poland, those people from our house, they escaped to Poland. And from Poland they went to Israel. The ones who were still alive, they left just like we did. And then there were those who couldn't escape, and... [And you were told of this by locals, about the Jews who lived here?] Yes, yes! The people who lived here before, the ones from Zhovkva, who were born here, they told us about it (Z16Af).

The narratives being analyzed here reveal another correlation: people who remembered the Holocaust in detail and had experienced it as an emotional event in their places of birth were generally more interested in its history in Zhovkva, showing more sensitivity when discussing the subject. In other words, someone who had witnessed the Shoah in another place was more likely to

262 Zygmunt Lajner (after 1944 Zygmunt or Zigmunt Liainer) was one of the two Holocaust survivors who stayed in Zhovkva after the war. He took part as a witness in criminal trials against Nazi perpetrators, wrote a set of memoirs, and also recorded a video testimony (Visual History Archive, Zigmunt Liainer, cat. nr. 40403). Due to the fact that he can be considered a public figure, in his case I deviate from my principle of anonymity. 
acquire knowledge about it in the new place of residence. The structure of such statements was usually similar: asked about the Jews in Zhovkva, the speaker would discuss the topic for a short time, then quickly transition to a story about the Jews in their own native area, sometimes completing their account with a coda in which the story line returned to Zhovkva.

The level of emotionality (or rather, the lack thereof) in some accounts of Zhovkva's Jews as told by Ukrainians deported from Poland allows us to distinguish yet another type of memory. A complete lack of emotional engagement in the murder of the town's Jews was characteristic for some respondents in this group. These people were aware that a Jewish community had lived in Zhovkva before the war, and they also knew what had happened to it, but did not consider this matter to be of any importance. Very often, they would quickly and unobtrusively move on to other topics about the wartime in Zhovkva when asked about the town's Jews - usually, questions related to their own ethnic group's experiences. In essence, the attitude being expressed was: "we weren't here then so we don't know about it, and moreover, that was not our people, so it has nothing to do with us."

[Were there a lot of Jews here in Zhovkva?] In Zhovkva? Yes, there were, the whole town was Jewish, that's what they say. The shops, everything was Jewish. There is some temple of theirs still standing there as well... Next to it is our beautiful church, the Basilians serve Mass there. [And were there any Jews who remained in Zhovkva after the war?] Oh I don't know. Well, you know, they were all... Whoever escaped, whoever didn't escape, they all got killed all the same. And when the Germans came and the Moskals were escaping, on the spot where the town hall is, there are those walls going around... How many people they killed there... They've even put a small chapel and memorial plaque there. How many children, even children, 15-year old girls, boys... (Z3Af).

In this fragment, it is striking that the speaker adorns her description of the murder of prison inmates by the Soviets in 1941 with so much detail and retells the story with such passion. Although this undoubtedly tragic event (though considerably less so than the Holocaust) also happened before the speaker arrived in Zhovkva, she internalized it much more readily than the fate of the Jews, considering it part of the local history of her own group. Jews, meanwhile, were definitively excluded from this group.

A similar resonance was audible in statements made by Zhovkva's Easterners, both Ukrainians and Russians, about the town's Jews. The following response to the question whether there were any Jewish families left in Zhovkva when the speaker arrived in the town was fairly typical: "I don't know exactly. I know those Jews were taken away somewhere around here, or maybe they left by themselves. They were persecuted, those Jews. But I can't 
tell you exactly what happened" (Z26Af). What is striking in practically all of the interviews with migrants from the East is not so much the lack of sensitivity, but the complete absence of interest in what had happened in the town before and during the war, whether to Ukrainians, Poles, or Jews. This did not mean that respondents had had no previous contact with Jews or with the Holocaust. One interviewee, a Ukrainian woman from near Poltava [eastern Ukraine], had sheltered a Jew during the war. Yet the way in which she described this act was very different to equivalent fragments in interviews with Ukrainians deported from Poland, who also talked about Zhovkva's Jews by drawing analogies with their "own."

[Did you say there were not so many Jews when you arrived here?] No, there weren't many. I only knew one, Liainer, he was a Jew. [And were there Jews here earlier?] Yes, there were. They say there were a lot of Jews here before. [And what happened to them?] They left. They left for Israel. God only knows where they went. Probably most of them to Israel. [Did the Germans kill Jews here?] Yes they did. But people helped them to hide as well. Where I am from, in the Donbas [region in eastern Ukraine], there were Jews too. There was even a doctor who stayed with us, we helped her to hide. She was called Valentyna, she was a doctor, a therapist. The Germans were there for two years, and she lived with us for two years. Despite the Germans being there! (Z11Af).

The speaker described the way in which her family sheltered the Jewish doctor in minute detail, but her account did not return to the question of Jews in Zhovkva. Remembering the rescued Jewish woman did not act as a prompt to make comparisons, serving rather as a pivot for communicating that she knew nothing more about Zhovkva because she had not been there then; it was not her history and she did not find it interesting, but she was more than happy to tell a story about similar and more interesting matters from personal experience. The fate of Zhovkva's Jews was confined in her statement to just a few words: "yes, they did kill them." She treated it as the fate of people she did not know, about whom nobody had told her anything. They were, thus, anonymous.

It was from this group of settlers from the East that the two people who had no knowledge of the town's Jewish past came - they knew neither that Jews had lived in Zhovkva, nor that they had died there. Asked about the composition of the pre-war population, one speaker responded as follows: "Local people lived here most of all, Ukrainians and Poles. And there were lots of barracks as well, lots of soldiers. I remember that. Then, later, Ukrainians most of all, Poles, and a few Russians and Jews" (Z24Af). According to this respondent, Jews only appeared in Zhovkva after the war, alongside the representatives of all other nationalities who arrived in the town during the Soviet colonization of western Ukraine. There were, indeed, "colonizers" of Jewish ethnicity, but the fact that it was only 
interviewees from among the "Sovietizers" who did not know about the pre-war Jewish community is no accident.

One reason is the greater social distance between the Easterners and the locals, relative to migrants from Poland and settlers from nearby villages. Whilst the locals sometimes treated the resettlers with contempt, they were genuinely afraid and hateful of the Easterners, who personified a repressive and imposed system. The settlers from the East were, in turn, suspicious of the locals and ill-disposed towards them, considering them to be "Banderites" and "nationalists." Such a situation was hardly conducive to mutual contact, let alone discussions of the war, which required a high degree of trust. Once the situation had normalized to an extent that members of different groups began to intermingle, the Holocaust was already a distant event - especially because it was not "relevant" to the community and was not kept alive through direct recollection, the "living memory" of survivors. ${ }^{263} \mathrm{~A}$ second reason could be the general attitude of Easterners to the questions of ethnicity. Educated in the spirit of Soviet internationalism, they sometimes did not perceive that Zhovkva was comprised of residents from different ethnic backgrounds. For the same reason, they were less interested in the multicultural history of the town. The post-war memory policy of the USSR also facilitated blindness to ethnicity: it subsumed the Soviet Jews who died in the Holocaust into the general number of casualties of war. ${ }^{264}$ The Ukrainian historian Yaroslav Hrytsak calls this marginalization of the memory of the Holocaust in the USSR an "intentional social amnesia." 265 In such an ideological climate, remaining ignorant of Jewish history was not a difficult task.

\section{Family (Non-)Memory: The Next Generations}

Members of the younger generations in Zhovkva could only have known about the Holocaust through hearsay. The question is whether they did indeed

263 The concept of "living memory" is used by Robert Traba in relation to memories of relatively recent events that continue to exert an influence on social reality, see: Traba, Kraina tysiaca granic, pp. 179-198.

264 For Holocaust memory in the Soviet Union, see: Zvi Gitelman, "Soviet Reactions to the Holocaust, 1945-1991," in: The Holocaust in the Soviet Union. Studies and Sources on the Destruction of the Jews in the Nazi-Occupied Territories of the USSR, 1941-1945, ed. Lucjan Dobroszycki and Jeffrey S. Gurock (Armonk, New York: M.E. Sharpe, 1993), pp. 3-28. See also: Amar, "A Disturbed Silence."

265 Yaroslav Hrytsak, "Istoriia i pamiat: Amneziia, Ambivalentsia, Aktyvizatsia," in: Ukraina. Protsesy natsiotvorennia, ed. Andreas Kappeler (Kyiv: K.I.S, 2011), pp. 365-380. 
hear about it. The majority of interviewees in this cohort were aware that a Jewish population had lived in the town, but their knowledge of this history was fragmentary and vague. Sometimes it could be condensed to a single sentence: "before the war half of Zhovkva was Jewish, maybe even more" (Z17Bm). More extensive responses about the pre-war presence of Jews appeared in two types: "bookish" narratives and "anecdotes." The former contained general information including numerical statistics and broad historical facts about Zhovkva's Jews. This knowledge had been gained not from family storytelling, but from reading books, local guides, etc. Respondents often deflated the number of Jews relative to the town's overall population before the war, treating them as a significant presence that were nonetheless a minority in the Ukrainian-Polish town.

There were a lot of them. Sobieski [the seventeenth-century Polish king] invited them to settle here back in the day, so that they would engage in commerce. Maybe there were some earlier as well, judging by the synagogue, but in any case there were a lot of them. At that time it was Jews who mainly engaged in trade, and that's why we have a synagogue, because Jews won't go and trade in a town if it doesn't have a synagogue. [...] You know, it seems to me that as many as one in five residents of the town before the war were Jews (Z39Cf).

"Bookish" responses were given mostly by people who were more educated or who had to be more closely acquainted with the town's history for professional reasons - the respondent cited above, for instance, was a local tour guide. People whose parents or grandparents had not lived in the vicinity of Zhovkva were also more likely to give such accounts. Meanwhile "anecdotes" were told by people from local families and those whose parents had lived near Zhovkva. These narratives concentrated above all on the distinguishing features that made Jews different to the Christian population, thereby emphasizing the boundaries between the groups.

[My grandmother] used to say that there were no real negative relations with the Jews. Well, sometimes our people complain that there was a tavern in the village. [Well, there was, wasn't there?] Sure, there was a tavern, but no one forced you to go to there and drink the vodka that the Jews were selling. On the other hand, you could always borrow money from a Jew (Z45Dm).

However, the "anecdotes" never touched upon the Holocaust - there were no stories of, say, a grandmother's acquaintances who were taken to Bełżec extermination camp and murdered. This state of affairs is illustrated well by a statement by a woman who gave an extensive account of a Jewish family who used to buy milk from her grandmother, who spoke in very general terms about the wartime 
fate of Zhovkva's Jews. She used a lot of "hedging" phrases that showed her lack of authority as a narrator (such as "somewhere," "some kind of:")

[And did your grandmother tell you anything about the murder of the Jews? If there were Jews here, and they're not here any more...] Erm, nooo, I remember just one story, that somewhere, somewhere around here, near Kamianka Buzka [a small town ca. $30 \mathrm{~km}$ east of Zhovkva], there was a day when they killed a lot of Jews. They were rounded up as whole families and evicted, there was some kind of ghetto, and the Germans forced them into there later. Otherwise I don't [know anything]. [And the Jews from Zhovkva? What happened to them?] I don't know. The Germans killed them for sure. They murdered people after all, shooting on sight, it didn't matter whether you were Jewish or not Jewish (Z19Cf).

The fragment cited here shows not only absence of knowledge, but also lack of interest and unwillingness to raise the given topic. For these respondents, talking about the Holocaust was more problematic than simply stating "there were Jews here before the war." Another interviewee, a young, educated woman active in a local NGO that promotes regional development, gave a long and detailed account of the historical contribution of the Jewish community to the cultural life and architecture of Zhovkva. Asked about the Holocaust, however, she said: "Hmm, do I know about anything about the Holocaust in Zhovkva? No, I don't know that history, I can't tell you exactly what happened" (Z41Df). This state of affairs may in part result from the way in which the Holocaust is treated by education curriculums. Compared to Soviet times, it is significant that the Holocaust appears in textbooks at all; nonetheless, it is clear that it still receives little attention during the course of school education. Ukrainian history textbooks make declarative statements about respect for the multi-ethnic social landscape of Ukraine in both the past and present, but otherwise ethnic minorities are given fairly short shrift; information about the Holocaust is mostly presented in contexts outside Ukraine (such as anti-Semitism in Germany being a cause of the Holocaust, or concentration camps being a means of its realization). References to the Ukrainian context are usually restricted to the massacre at Babyn Yar, near Kyiv, where tens of thousands of Jews were killed during the Nazi occupation. ${ }^{266}$

266 Cf. Nancy Popson, "The Ukrainian History Textbook: Introducing Children to the Ukrainian Nation,” Nationalities Papers, Vol. 29, No. 2 (2001), pp. 325-350; Stefan Rohdewald, "Post-Soviet Remembrance of the Holocaust and National Memories of the Second World War in Russia, Ukraine and Lithuania," Forum for Modern Language Studies, Vol. 44, No. 2 (2008), pp. 173-184; Podolskyi, "Ukrainske suspilstvo." 
Only two respondents from the younger generation discussed the Holocaust with reference to specific individuals of Jewish descent. These were not extensive accounts, but they were exceptional in that they treated Jews as subjects rather than objects of history. Both stories were connected to the rescuing of Jews by Christians. The first was told by a woman whose grandmother had sheltered a Jewish family during the occupation: the speaker did not know many details, but could show where the Jews had hidden and knew that they left Zhovkva after the war. She was also undoubtedly proud of her grandmother's actions, although it appeared that she had little conception of the scale of the Holocaust; her knowledge of this one Jewish family's fate had not prompted her to reflect more deeply on the broader history.

My late grandfather put them on a train and in this way helped them to escape from here, from Ukraine. Where they went from here, I can't tell you. But I know for a fact that they didn't end up in the hands of the fascists [i.e. the Nazis] or the Russians. So, they somehow got out, but what happened later... I don't know (Z27Df).

The second story about the Shoah was told by an interviewee who was living in the house where 17 Jews had been sheltered during the war. Whilst the first speaker was telling a story from her family history, the second had been, in a way, personally implicated in the trajectory of the Holocaust. It was not until a group of American Jews - two of the town's survivors and their families - visited Zhovkva in the 1990s that the respondent learned that the derelict cellar under his house had served as a hiding place during the war. The guests' reaction as they entered the house made no less an impression on him than the story itself.

I was surprised, of course. [...] They fainted, they cried. There was such drama... The first time they came here, that time, it was truly amazing. I had no idea they would react like that. One of them had to be taken away in an ambulance... [...] They had some memories flooding back or something... That's how I learned that something like that is right here. For them it's a special place, but for us, it's a cellar like any other $(\mathrm{Z} 38 \mathrm{Cm})$.

The survivors' visit was a very important event for the interviewee. An ethnic Russian whose parents came to Zhovkva in the 1950s, he had previously not shown any particular interest in the history of the town. The personal encounter with Holocaust survivors, however, gave this element of the past a meaningful significance for him; it made the past more real.

Sometimes the generalizations made by interviewees about the Holocaust in Zhovkva resembled a process of guessing out loud in order to attempt a "satisfactory" answer for the interviewer.

The Jewish community, yes, maybe there were Jews here, that would follow from what my parents said. There's a synagogue in Zhovkva, a Jewish synagogue, so that must mean 
that there are Jews. But I don't really know anyone especially, any Jews... [So were there more Jews here before?] Well of course, since we have such a big synagogue, that must mean that there were more. But as I said, my parents came here later, but maybe before the war there were a lot of them, since there is such a big synagogue ... [And what happened to them?] I think that during the war, when the Germans were persecuting the Jews, they started to leave. They probably hid wherever they could. That's how it seems to me, because I was never particularly interested in that. [...] Probably some of them were murdered, and the rest, whoever managed, escaped (Z6Cf).

This fragment contains a very characteristic and oft-voiced belief that the Jews left Zhovkva of their own accord (an element of the negative stereotype that Jews were resourceful and cunning, and therefore able to get out of any situation). Statements that a significant number of Jews left Zhovkva before the war also featured in accounts by respondents who possessed fairly detailed knowledge of the Holocaust from family storytelling. The tendency to mix up facts and to alter the scale or significance of events appeared not only in relation to the supposed emigration of Jews, thanks to which they had purportedly avoided death during the war. Respondents also wrongly identified the perpetrators of the Shoah or did not consider the Holocaust to have been a unique event, being no different in essence to the ocean of other terrible events. For example, one of the women cited earlier said when commenting on her grandmother who concealed Jews during the war: "[Grandma] hid Jews, yes... But I'm not sure if she was protecting them from the Germans or the Soviets. I think it was both, because the Soviet authorities were also against the Jews (Z27Df)."

Sometimes it transpired that respondents thought they were discussing the Holocaust but were in fact describing a completely different event. One person, for example, answered a question whether Jews had died during the war in Zhovkva by referring to the aforementioned massacre by the Soviet NKVD of prisoners: "Yes, lots [of Jews died]. There is a memorial by the town hall, commemorating how people were buried alive, and even when people were walking home from church, the ground was still moving" (Z18Bf). This respondent remembered the Holocaust in a transformed and factually incorrect framework, yet in the moral dimension this was still a form of Holocaust memory, not memory of the NKVD massacre - as if two pictures had become unconsciously overlapped in the memory of the speaker. There were however instances where memory of one event acted as a pretext for talking about a different history in a way that the contours of the former event were appropriated by the latter. The following fragment illustrates this mechanism:

[Did your grandmother talk about the murder of Jews here? Or did you maybe hear about this at school?] They told us in school about the murder of the Jews, yes. Always. 
And I saw some historical films where the Jews are killed. They were treated really badly, I saw it, I've seen those historical films where they are really tortured. Actually everyone suffered cruelty, really, the Ukrainians as well. There was the Holodomor... [But the Holodomor was carried out by the communists, whereas...] Yes I know. But I mean that it was the same, whether you were Jewish or Ukrainian, it was largely similar (Z4Dm).

Here, talking about the Holocaust becomes an opportunity to draw an analogy and discuss the suffering of the speaker's own group. The respondent does not negate the Holocaust, but he does try to emphasize that suffering is universal and that his own people, the Ukrainians, suffered just as much as the Jews.

Among the respondents of the younger generations, there were many instances of simple lack of knowledge. Of 44 people interviewed, ten individuals did not know that Jews had lived in Zhovkva or that they had somehow disappeared. Sometimes this was the result of a general lack of interest in the town's history, not only in the Jewish component of the past - the speakers were ignorant of history related to Jews, Poles and Ukrainians alike. I asked one interviewee whether Zhovkva before and after the war were demographically similar, i.e. whether it was mainly populated by Ukrainians, to which she replied: "I can't answer that, I don't know. We never really looked into that" (Z9Bf). It was clear from her interview as a whole that whatever had happened in Zhovkva before her family's arrival was immaterial to her: these were not only events that had passed long ago, but were not her "own;" in this case, it was not only Jews and Poles who were Other, but local Ukrainians as well. In other cases, however, the absence of memory only pertained to ethnic Others, the Jews and Poles, whilst Ukrainian history was of greater interest to the respondent. As Yaroslav Hrytsak writes, Galicia's Ukrainians built a robust national identity through selective memory, forgetting not only that their national heroes, the Cossacks in Lviv, were feted above all for their brutality against the Ukrainian and Polish bourgeoisie, but also that Galicia had been inhabited by numerous Others (and how those Others' presence there came to an end) - Jews, Poles and Germans. Eradicating these groups from memory was made easier by the fact that after the war they were no longer physically present. ${ }^{267}$ Such erasure of memory is most disturbing when voiced by educated individuals who, with the exception of the Holocaust, knew the multicultural history of Zhovkva very well:

267 Yaroslav Hrytsak, "Historical Memory and Regional Identity among Galicia's Ukrainians," in: The Roots of Ukrainian Nationalism: Galicia as Ukrainian's Piemont, ed. Paul Robert Magocsi (Toronto: Toronto University Press, 2002), pp. 185-209. 
[What about the murder of the Jews? Was this discussed at all?] I don't know. I can't tell you anything about that. What do you mean? Which murder, in which period? [During the Second World War almost of the Jews of Zhovkva were murdered by the Germans.] I heard about that fairly recently, in the last few years. Or maybe not, sorry, we're talking about different things. What I am thinking of is the murder by the NKVD, the victims' remains were exhumed. As for murdered Jews, to be honest, I don't know, I can't even... So is there, in Zhovkva, say, a grave of some sort in the cemetery? [Yes, there is a grave in the main cemetery]. So, my bad (Z33Bm).

The interviewees who did remember explicitly noted the absence of memory about pre-war Jewish community, especially the silence on this matter in the public realm. This was especially the case for individuals who had been personally touched by the Holocaust for various reasons, whether through personal encounters with survivors who had lived in their house before the war (the woman cited in the first fragment below) or through the discovery that Jews had been sheltered in their house during the war (the speaker in the second fragment below). Interviewees' reactions to the public silence could be very passionate.

In all the time I've lived here, to my memory, no one, not a single swine has blurted a single word that this is a Jewish town, built by Jews [...] Not a breath about the Jews. If the Jews had never been here, what would we even have now? [...] No one has ever said anything to me about the Jews, and I find this so strange. I don't think I've even heard the word "Jew" here (Z16Bf).

We didn't know anything, absolutely nothing, no one ever went around talking about that [...] Well, the fact that there were Jews, there was some talk about that... There was a period when that was a thing. People didn't talk a lot about it, but I knew a thing or two. That Liainer told me, he was a good colleague of mine, and a good man, he would talk about those things sometimes... (Z38Cm).

The second speaker's statement points to the reasons behind the predominant silence, also explaining the source of his own knowledge about the Holocaust. It follows from his words that in Soviet times, the only available channel for the transmission of knowledge about the past was informal contact. The new residents of Zhovkva learned about the previous existence of Jews in Zhovkva through private conversations with the few individuals who had lived in the town before the war, or, as in this particular case, through hearing the personal testimonies of survivors. If such communication did not take place, then memory was not passed on. It could in theory have been supplanted by official memory, but in the USSR there was no official memory of the Holocaust. Over several decades, the victims of the Holocaust were consigned to the margins of the larger statistics on Soviet war victims; both 
official discourse and public space were methodically "cleansed" of references to the Holocaust. ${ }^{268}$

The Holocaust was and still is largely absent from family memory as well: the interviewees who stated that their parents or grandparents had spoken at home about the Holocaust in Zhovkva were distinctly in the minority. The Holocaust is still not a topic of conversation in most households in Ukrainian Galicia: research carried out by psychologist Elena Ivanova among Ukrainian students has shown that young people acquire all of their knowledge about the Holocaust through school education (if they gain any knowledge at all); only those with Jewish roots learned about it in their family home. ${ }^{269}$ Given the quality and quantity of knowledge about the Holocaust that is gained in schools, it is unlikely that young people in Zhovkva would act as "indirect witnesses" of the Holocaust that Patrick Debois sought on his journey.

The few individuals who are actively interested in the town's Jewish past, and who carry out their own research into the Holocaust in Zhovkva, form a counterweight to the overwhelming silence on this heritage. It was in a conversation with a member of this small group that I heard the only expression of outright condemnation of Ukrainian collaboration in the Holocaust. This was also one of only a few people who voiced a deeper contemplation of the causes and nature of the Holocaust.

This infection called Nazism, it didn't only affect Germany, it also infected all of Europe. You know very well that it was in the Slavic countries, and the Balkans and so on, everywhere, including Ukraine. [...] Later, when the time came for the Nazis to realize their policies, people sucked up to them, they were afraid of resisting official power, of course. And the defenceless, persecuted [Jews], they were in for it... The Ukrainian police helped the Germans to set up the ghetto, and with the liquidation of the ghetto. Those are known facts. Some caught them and turned them in, other people gave them shelter and saved their lives, that's how it was. [Pause] All nations have brighter pages in their history, as well as undoubtedly shameful pages (Z40Bm).

268 Cf. Hrynevych, "Mit viiny."

269 Elena Ivanova, "Regionalnyie osobennosti kolektivnoi pamiati studentov o holokoste v sovremennoi Ukraine," Holokost i suchasnist. Studii v Ukraini i sviti, Vol. 2(4) (2008), pp. 9-28. Wilfried Jilge has written about the formation of Holocaust memory among young people in Ukraine through school education, in his: "Competing Victimhoods - Post-Soviet Ukrainian Narratives on World War II," in: Shared History, Divided Memory. Jews and Others in Soviet-Occupied Poland, 1939-1941, ed. Elazar Barkan, Elizabeth A. Cole, and Kai Struve (Leipzig: Leipziger Universitätsverlag, 2007), pp. 103-132. 
Interest in Jewish themes was usually related to education or professional engagement in the past; respondents who fit into this category were historians (an employee of the tourist information center and an NGO), an art historian (the director of a museum) and an ethnologist (an employee of a museum complex). Such individuals are an exception rather than the norm in Zhovkva; this is confirmed by the fact that I recorded interviews with each of these people outside the family sets that made up the majority of interviews - I met them because I was already aware of their interest in the Jewish themes. Significantly, all of these respondents expressed a sense of ostracization in the local community; they all claimed that their efforts to raise awareness about the Jewish community in Zhovkva were usually met with disinterest or lack of understanding, including from local authorities.

\section{Foreign Heritage}

Attitudes to material heritage reveal a great deal about the nature of social memory. Although the Jewish population of Zhovkva has ceased to exist, its material heritage remains and, arguably, is impossible not to notice. A large walled synagogue from the seventeenth century stands in the town center, in ruins since post-war times and currently undergoing a gradual process of renovation (at the moment of writing of this book, funded by an American foundation.) By the market on the site of the former Jewish cemetery it is still possible, if one knows where to look, to see remnants of matzevot (headstones over Jewish graves) protruding from the ground; the doors of some houses also feature traces of mezuzot (parchment inscribed with texts from the Torah, attached in a case to the doorpost of a home). After 1991, three monuments were erected that publicly commemorated the town's Jews. Do these points in public space have a meaning or significance for the residents of Zhovkva? How do people relate to the material heritage?

The synagogue is still the most recognizable element of Jewish heritage in Zhovkva. There was not a single interviewee who did not know that it existed although not every respondent made the connection between the building and the existence of a Jewish community in Zhovkva before the war. It did happen that people struggled to name the building with the correct terminology, and many were puzzled by the efforts to restore it:

They have that, what's it called... syna... synagogue. They've started to do something with it, and they keep coming over here, those bearded guys with the sidelocks. They keep coming here, they're plastering it now, they're going to refurbish it. They're going to make it all spick and spam, but who's going to go there? No idea. [...] [Is it the Jews who 
are renovating it, or the municipality, or the state?] No, it's the Jews themselves. They must be employing workers, paying for it and doing it up. Why would the state need it? It's been there for so many years with the state doing nothing, so why would they do something now? (Z8Cf).

Sometimes my questions aroused consternation, especially in cases of educated respondents who did not want to make a bad impression on me through their ignorance. The speaker cited below, for instance, tried to justify and "compensate" for her lack of knowledge with a desire to discuss other artefacts and with openness to general discussions on historical themes.

[When was it destroyed?] I don't know... [Embarrassment in her voice]. But it would definitely be a good thing to renovate it, despite everything... Yes, I would go there myself, I would have a look with pleasure, if there was also a guide that told you something about the history. We didn't have guidebooks for a long time here, we didn't have them in Zhovkva, and it was only recently that the museum opened. We take the children there, we show them the model of Zhovkva, the kids even get interested, they say: "wow, was it really like that?" I tell them about the Glinska Gate, the Armenian Gate [historical entry gates to Zhovkva]. As for the synagogue, I don't really know... We don't have any Jews here in Zhovkva (Z15Cf).

The oldest autochthonous residents of Zhovkva remember the times when the synagogue was still an active institution - and this is the picture they envision every time they pass it nowadays. Many of them talked about it with a sense of pride: "Our synagogue was famous throughout nearly all Europe, I don't remember exactly what place it took, whether it was the third or second largest... That's how special our synagogue was" (Z1Af). Most respondents were aware that the Germans had burned down the synagogue; a few people whose parents or grandparents were originally from Zhovkva had been told about this at home. Others had learned about the destruction of the synagogue from reading. "I for one know from my history classes that the synagogue was blown up with a bomb, I mean, not a bomb, they put some explosives under it and wanted to destroy it" (Z41Df). Every interviewee who discussed the synagogue noted its poor state of repair. They drew a connection to the absence of a Jewish community, and also with deliberate neglect by the Soviet authorities in the post-war period. The latter was strongly condemned; an interviewee who sang the praises of the synagogue in its pre-war state, ended her statement with the words "The bastards, it wasn't enough that they destroyed the churches, they even got to such a beautiful synagogue!" (Z1Af).

Another important consideration in perceptions of Jewish material heritage was the conviction that Jewish people should be responsible for maintenance 
and repairs. One respondent openly declared that the synagogue was in such a bad state because the Jews had shown no interest in it:

I'll tell you honestly, that of all the monuments the synagogue is in the worst state. That's right. This is easy to explain - there are no Jews. [...] They [Jewish people] haven't shown any interest in it. They could have done something, anything, you know? But maybe they don't feel the need (Z39Cf).

The speaker argued that other religious monuments in Zhovkva (Orthodox and Catholic Churches) were maintained by resources collected from the faithful. She also complained and regretted that the situation in the nearby town of Belz was different: there, thanks to financial support from Israel, the synagogue had been restored and a museum opened. ${ }^{270}$ It is clear from her statement that she believes the municipality should bear no responsibility for the building's upkeep, even though the synagogue is considered a valuable landmark that attracts tourists to the town. This interviewee's opinion is also noteworthy in that she was professionally involved in local tourism (she ran an agritourism farm and conducted tours of Zhovkva). A stronger statement of a similar attitude can be seen in the following fragment:

There are various tour groups who come here very often from Israel or wherever it is, you know, those... What are they called... Jews. They come here very often for excursions of some sort, or some other things... And they even carry out refurbishments, the Jews pay for it themselves. It just so happened that in Zhovkva, in our Ukraine, there is a synagogue like that. [...] The way I understand it, the synagogue belonged to Ukraine, and Ukrainians were in charge of it. And now the Jews have learned that this synagogue exists, and that it's their monument, it's theirs, their church or mosque if you can put it that way, so they learned about it and made it theirs. Now it is theirs, a component that belongs to them, but which is in Ukraine (Z6Df).

The status of the synagogue is clear to this interviewee: it is a "Jewish object" that is extraterritorial in some magical way, and it is excluded from the overall town landscape. The young woman not only did not recognize the synagogue as part of the cultural heritage of her own group, she also explained its provenance in Zhovkva in a fairly oblique manner, making no connection with the local Jewish population. Understood in this way, the state of the synagogue perhaps does not inspire enthusiasm, but it is also unsurprising; evidently, the Jews do not want to pay for its upkeep. Perhaps they would be more willing to shell out if they were to make some additional, undefined gains, another respondent claimed: "Maybe

270 Belz was historically an important center of Hasidic worship and has regained this status since the 1990s. This is why its synagogue has been restored. 
[the Jews] want to set some conditions for these things. Say, we renovate a church [i.e. the synagogue] ${ }^{271}$ in your place, and you give us, say, five hectares of land. [Laughter]" (Z33Bm).

A much smaller group of respondents (mostly younger and better educated people) expressed a view that the Ukrainian state should pay for the maintenance of the building.

[What do you think should happen with the synagogue in Zhovkva?] It should be restored. [At whose expense?] With the same money that is used to renovate other buildings. This is history. This synagogue is, for one, a UNESCO protected site, ${ }^{272}$ and it is also a beautiful building. If the Greek Catholic and Roman Catholic Churches have a right to exist... (Z45Dm).

Such statements were usually accompanied by expressions of regret and shame that the synagogue was in such a bad state, as well as sometimes a sense that the synagogue's disrepair reflected badly on local Ukrainians. Such feelings were intensified by visits by Others who commented on the matter (mostly Jewish tourist groups) as well as a conviction that the local authorities were embezzling funds received for this purpose or were simply incompetent.

I couldn't take it any more, the place was constantly full of rubbish. So I went to the chairman of the town council, and I said to him: "Please, you could at least remove the rubbish, there are tour groups who come here, they stand there and tell the history, and people laugh. How can you not be ashamed?" [The Jews were laughing?] Yes. I said to him: "How can you not be ashamed? I for one, I'm not even from here, and I am ashamed, but you are the chairman, and you're not ashamed?" And since then people have stopped littering around there (Z10Af).

Although many interviewees argued that the synagogue should be converted into a museum, only a few had any deeper thoughts on this issue. Not many saw a potential museum as a way of replenishing the broken identity of the town. The speaker cited below was an exception in this regard, but this is understandable given her education and professional activity (she has a degree in Cultural Studies and was working in the tourist office of Lviv city council):

It seems to me that creating a museum of Jewish culture like that would be much more effective, both for the local community and for many others. This would increase tolerance above all, and that is something that we Ukrainians, I would say, don't have enough of; I would argue the same for the people who live here. That's one thing. And the second

271 Older Ukrainians often refer to synagogues as a Jewish church [zhydivska tserkva.]

272 There are seven UNESCO World Heritage Sites in Ukraine. The synagogue in Zhovkva is not amongst them. 
reason is that it would simply go well with the history, which unfortunately we... That memory, that history was taken away from people at one point and they couldn't even tell anybody, because, first, of ignorance; second, of a lack of interest, and third - who knows - indifference? (Z41Df).

It should be noted that, formally speaking, the Zhovkva synagogue is already a museum - it belongs to the town's museum complex. Among the interviewees, three museum employees were the only people who possessed specific knowledge on the actual status of the landmark; others merely repeated various rumours. The museum staff members, with whom I conducted expert interviews, spoke of the synagogue with anxiety and a feeling of helplessness. They had no complaints about a lack of funding from Jewish circles, but did point a finger at the Ukrainian state; at the time of the interviews, no funds had been set aside for the renovation of the synagogue.

The second important site for gauging attitudes towards Jewish material heritage is the cemetery - or rather, what is left of the cemetery after the site was turned into a marketplace in the 1960s. Unlike the synagogue, the former Jewish cemetery is easy to overlook; it has disappeared from sight, much like the community it used to serve. Opinions about the cemetery intertwine with broader trends in memory and forgetting of the Jewish community. The youngest cohort of respondents, born in the 1960s or later, were most likely not to know of its existence. Older people who were attuned to the changes in urban space in their immediate surroundings tended to remember the Soviet-era demolition of the cemetery. Consciousness of this fact, however, did not always coincide with a negative assessment; people sometimes described the event with no emotional involvement, or openly declared that they were simply uninterested.

This wasn't the market to begin with, this was a Jewish cemetery, it was called the okopysko [a folk term for a Jewish cemetery]. During the German occupation Jews were buried here. Then it was all built over. Over there, where the pigs are, on the north side, that was all Jewish graves. [...] Then they took it all apart to use the stones. I'm not sure where, I was never really interested in that. [Was it destroyed during the German occupation?] Yes. And then the Soviet authorities turned it into a market. This whole history is impossible to describe. And I was never really interested anyway, I didn't have the time (Z36Af).

Paradoxically, deep-seated negative stereotypes about Jews sometimes surfaced when people criticized the move to put the marketplace on the site of the former cemetery. Characteristic phrases such as "Jews are human too, after all" and "no matter what they were like, this is a cemetery and those are people in the ground" $(\mathrm{Z} 27 \mathrm{Bm})$ revealed speakers' prejudices when they were purportedly speaking in defense of the Jewish dead. 
Among the younger respondents, knowledge about the previous function of the market square was displayed mainly by people who had heard something in conversations at home, and those had learned of the site's history as a result of other personal experiences. For instance, one interviewee, who lived near the square, had played there as a child and had by chance discovered the remains of a matzevah, which prompted her to make enquiries. Another speaker's curiosity had been drawn by the fact that a Jewish acquaintance pointedly avoided the site:

We would go to the market with my grandmother, and she would say, "P. never comes here." And I always asked why not. "Because it used to be a cemetery, that's why P. never comes here to the market on Saturdays." [...] It was a kind of landmark, this cemetery. And on the whole... They did have some plans to move the market somewhere else. But they were only plans. The town council was talking about it. But that was as far as it got. [...] I don't know, it must be really tough for the Jews. Because a cemetery for them is like, they call it a "house of life" (Z44Df).

This statement contains a clear indictment of the fact that the marketplace was built on the site of the cemetery; the transcription does not adequately convey the emotion with which the respondent spoke, but her strong disapproval is clearly audible in the recording. Another speaker was yet more passionate in her disapproval:

You know that our marketplace is built on the bones of the Jewish population? This cemetery was enormous, even the biggest graveyard in Zhovkva. And then there are the burial vaults and headstones. I still remember the inscriptions, and how in Soviet times pigs used to walk all over them. I know that Liainer's wife, R., never went to the market. Her parents are lying under those stones. [And how did people respond to the market being built on the cemetery?] I can tell you what I thought about it. It's terrible, it's an offence against humanity. And against God, and against mankind as His creation. [How did people respond?] Well they went to the market. I also went (Z1Bf).

Respondents rarely (with the exception of experts) connected the building of the marketplace on the Jewish cemetery with the broader political outlook of the USSR. Although it was the Soviets who demolished the already ruined cemetery, the opprobrium of residents did not single them out as villains, instead hovering indeterminately between "Russkies," "the Germans" and an undefined "them." Several interviewees riled against people's indifference and cynicism, both at the time of the leveling of the cemetery and in the present, in which there is no will to change the situation.

Cattle were sold in the midst of Jewish tombstones, but who cares? People just didn't think about what it was they were walking on... [And were there any attempts to move the market?] No. There are rumours, but they are based on the fact that this is a convenient location, in the town centre, and that that was a long time ago, it's difficult to 
move people around. It is difficult. This is business we are talking about, after all [with irony] (Z42Cf).

How can we summarize the attitudes of respondents to Jewish material heritage in Zhovkva? Undoubtedly, it is the synagogue, a monument impossible to ignore, that they noticed above all. Not many knew about the cemetery, one person was aware that a ritual slaughterhouse was still extant, and no one mentioned the mezuzot, let alone remembering objects that had ceased to exist. With a few exceptions, respondents did not consider the synagogue or the cemetery to be their "own" - they did not feel connected to these sites or feel in any way responsible for them, rarely seeing any potential benefit in restoring them from their current ruinous state. The deputy director of the Zhovkva museum summarized this situation very well:

No one has engaged themselves with this. No one has researched it or popularized it, and besides, the town suffered another huge tragedy in 1941 - a rupture in its historical and cultural continuity. These are very important matters, because if you don't have continuity in these things, then knowledge disappears, traditions and so on disappear, and you have to start from scratch. [...] People came here from the villages, from the East, having no idea what these ruins were, and so on. These ruins caused great difficulties and lots of negative emotions, and they were unsafe for children, and alcoholics would gather to drink around them, and there were thefts and acts of vandalism and looting, and so on. All of these things were a concern to the authorities, so they got rid of the ruins. They didn't have any money to do anything else... There were even nice buildings in a fairly decent state, just without a roof or something like that. They demolished them, took them apart, bulldozed them, or cleaned them up in some other way. Then they made town squares, bringing a bit of order, in whatever way they could at that time. No one had any idea what this or that place was. There was no talk of it having been an ideal town in the past (Z40Bm).

Until the 1990s, the condition of the Jewish material heritage in Zhovkva continued to deteriorate; moreover, not a single memorial to the victims of the Holocaust or the pre-war Jewish community was erected. This is the broader context in which the above examples of fragmentary and incomplete memory - or even total absence of memory - should be interpreted. The people who grew up in this symbolic space were cut off from both potential sources of social memory transmission: their physical uprooting nullified, or at least limited, family-based memory, and the totalitarian state did nothing to substitute this source of knowledge about the past. After 1991, Ukrainian memory policy started to change; however, the changes have been gradual and often hardly noticeable at the local level. Besides the gaps in school education already noted, which are not at all compensated for by teachers in Zhovkva, grassroots activity to commemorate 
the Holocaust remains marginal. If one agrees with historian Stefan Rohdewald that the Holocaust of Eastern European Jewry took place at the peripheries - both physically and symbolically - then it has also been at the peripheries that it has been remembered since 1991. ${ }^{273}$ The Holocaust memorials that have appeared in Zhovkva since the fall of communism are socially invisible; they are physically marginal, because the largest of them stands several kilometers outside the town, neglected and vandalized, in an empty field where several thousand Jews were murdered in 1943; and they are symbolically marginal because a clear majority of residents are unaware of the existence of the other two memorials (a symbolic grave in the communal cemetery, and the ohel [grave] of Tzadik Aleksander Sender Schor in the marketplace on the site of the former Jewish cemetery).

The local authorities have not undertaken any commemorative initiatives related to the town's Jewish heritage, nor do they give support to the efforts of local organizations, which have limited resources and opportunities. It can be tentatively concluded, therefore, that memory policy in relation to the Holocaust has not actually changed significantly since 1991, despite a superficial opening up to the Jewish past. Neither in Zhovkva specifically, nor in Ukraine as whole is there a cultural fascination with historical Jewish culture. In many circles in Poland - especially among young people - broad movements to rediscover Jewish heritage - at least in the "ethnographic" dimension of music and cuisine, and also through deepening knowledge of the histories of local communities - have provided a means of constructing regional identities. ${ }^{274}$ In contrast, in Ukraine no equivalent phenomenon is visible on a larger scale. Given this situation, it is hardly surprising that the majority of residents of Zhovkva are unaware of and uninterested in the town's Jewish past, and that initiatives launched by the minority of local residents who are cognizant of the problem receive neither social support nor recognition. ${ }^{275}$

273 Rohdewald, "Post-Soviet Rememberance."

274 On the building of local identities on the basis of past multiculturalism, see: Erica Lehrer, ed., Jewish Space in Contemporary Poland (Bloomington: Indiana University Press, 2015). For a wider discussion of the phenomenon of Jewish heritage without Jews, see: Ruth Ellen Gruber, Virtually Jewish: Reinventing Jewish Culture in Europe (Berkeley: University of California Press, 2002).

275 It was thanks to the efforts of the Svitlo kultury [Light of Culture] organization and the town's last remaining Holocaust survivors that the memorials mentioned above were erected. The organization has also tried to launch initiatives to restore the synagogue, for example by winning a grant from American sources to carry out partial renovation works; however, the effort was ultimately unsuccessful - the materials purchased were stolen in as yet unexplained circumstances, and the funding was withdrawn. 


\section{Survivors, Ghosts, Visitors}

In my conversations with the residents of Zhovkva, I was also interested in their attitudes towards Jewish people today. There were around 70 individuals who survived the Holocaust in Zhovkva, all of whom, bar two, left the town after the war; in the present day, however, not a single person claimed to be of Jewish origin. The reasons behind this state of affairs are the mass emigration to Israel in the 1980s and 1990s of the descendants of Holocaust survivors and also of "Soviet" Jews (i.e. those who came to Zhovkva from other parts of the Soviet Union after 1944). My interviewees were generally aware of this fact, although there were some who gave inflated estimates of the present-day local Jewish population ("If you were to count them, I would say there are around thirty people, not more" [Z1Bf]) or who hedged their bets with vague claims that "there are probably some Jewish people around here somewhere." Characteristically, many statements clung to stereotypical images of the pre-war Eastern European Jews who had disappeared from the landscape as a result of the Holocaust: "there are some Jews in Zhovkva, but not, you know, officially, with sidelocks like in Israel, none like that" (Z27Df).

When I asked about the Jews who had remained in Zhovkva after the war, older respondents spoke only of one of the survivors, Zygmunt Liainer. "He was my friend, a bit. He was a good person. [Did he tell stories about the wartime, about how he survived?] I don't know how he survived, but I wouldn't want to talk about him, he was a cultured Jew" (Z33Am). Zygmunt Liainer was - both in Soviet times and after 1991 - the practical and symbolic representative of Zhovkva's Jewish community; in a way, he was a kind of a "Jew on duty." ${ }^{276}$ When he died, it was the end of an era: the town no longer had a single Jewish Holocaust survivor, no more representatives of the vanished world. Interviewees also made this observation - noting, for example, that much fewer Jewish visitors were making excursions to Zhovkva since Liainer's death. Now that there are no Jews left in the town, these visitors provide the only opportunity for real-life interaction with Jewish people, as well the only frame in which stereotypes, and knowledge gained from books and domestic discussions, can be tested against reality. However, my interviews showed that no such interaction takes place. The Jewish excursions take place in such a way that the residents of Zhovkva and Jewish tourists continue to live in separate worlds, with no overlap whatsoever. ${ }^{277}$ The

276 Polish residents of Krzyż spoke about one of the town's few remaining Germans in a strikingly similar manner.

277 A separate question altogether is the nature of the Jewish tour groups that come to Zhovkva and other former shtetls. On Jewish visits to Polish towns, see: Jackie 
town's residents treat the tourists as exotic and non-threatening curiosities - in fact, they notice this attitude themselves:

[What do people in Zhovkva think of these Jewish tour groups?] How can I put it... "The Jews are here! The Jews are here!" They talk about it for half a day: "Did you see? A whole bus of Jews!" They'll tell a couple of jokes about Jews and then, a couple of days later, they'll have forgotten that they were here. They notice the skullcaps and sidelocks. But that's it, and half a day later, they will have forgotten. I suppose it's no different to other tourist groups (Z45Dm).

Despite this speaker's assertion that Jewish visitors to Zhovkva were perceived no differently to other tourists, other conversations showed that this was not the case, especially among the oldest respondents - people who were witnesses of the Holocaust in Zhovkva or in their places of birth. When I asked them about attitudes to Jewish tourists, I usually received replies to the effect that: "We have nothing against them, no one is hostile to them" (Z16Af). One interviewee (Z8Af) argued that today's Jewish visitors try not to advertise their Jewish identity, due to fear of locals; a respondent cited above stated that he didn't wish to discuss Liainer because he was a "cultured Jew" - seemingly implying that talking about someone as a Jew necessarily put them in a bad light. One respondent asked me to turn off the tape recorder during a story about how her son lent his car to a group of Jews who wanted to travel to the Holocaust monument outside the town. All of these examples show that for the oldest generation, it is not only memory of the Jews that poses a problem, but also the present-day instances in which real-life Jewish people enter their lives. As Michael Bernard-Donals argues, memory consists of anamnesis (memories that return to the remembering agent without their volition) and mneme (rational, constructed narratives about events, or in other words, cultural memory); furthermore, the former individual memories or facts that a society as a whole has erased from the sphere of mneme - constantly interfere with the latter. The Holocaust is always a part of anamnesis - an obstinate and unwanted return of the repressed; Jewish people who appear in Zhovkva today are in a way representative of that branch of (non-) memory. Between the lines of their statements, interviewees conveyed a sense of insecurity, a defensive fear, and a readiness to fend off potential accusations. These complex emotions, meanwhile, where not observed among younger people who did not live through the war. For them, Jewish tour groups really were no different to "any other visitors;" at most, respondents simply did not understand

Feldman, Above the Death Pits, Beneath the Flag: Youth Voyages to Poland and the Performance of Israeli National Identity (New York: Berghahn Books, 2008). 
why Jewish people would come to Zhovkva. Thus, while for the oldest generation the Holocaust and the Jewish tour groups who served as a reminder of this past were linked to memories that had been suppressed, for the younger respondents, they simply fell within the social frames of forgetting:

If there are Jews here, it's only people who have come from outside. Not a long ago there was a really large delegation of those Jews here, they were going around the sites, counting things, something like that... Well, maybe there is some history here that is somehow connected to them, sure... But I'm telling you, that has no connection to us. With us, with Zhovkva... It's their business (Z6Df).

Real interaction between Jews visiting Zhovkva and local residents only took place under one set of circumstances: when a Holocaust survivor or their descendants came into contact with locals. There were only two such individuals among the interviewees. One has been quoted above: the man who was living in the house where Klara Schwarz, her family and neighbors (together 17 people) hid during the war. The second was an older woman who was living in a house previously owned by Jews; a Jewish woman who had been born in that house visited her in the 1990s.

For me it was like this. Some Jewish people came from Israel. [...] They approached the window and [one of them] said "I was born here. I came to have a look at how things are here..." I told them to come inside, I invited them in. They were recording everything on a camcorder, everything... They were so happy. I have a photo somewhere... Later they wrote me a letter, those same Jews. They had photographed every corner here and they wrote to say that the whole family had been touched that I welcomed them like that, that I invited them in... She remembered everything, she was born in this house (Z16Af).

The warm welcome offered to the Jewish family by the interviewee, as well as the emotional tone of voice in which she recalled this episode, show that deep compassion and emotional memory are possible in the Polish-Ukrainian-Jewish triangle (with the Russians in the background) in Zhovkva - but only when people's trajectories directly meet. However, such meetings happen rarely in today's Zhovkva.

Two quotes from an interview with the same respondent - the man who rediscovered the town's past after being visited by Holocaust survivors - effectively summarize the state of memory about Jews in Zhovkva.

I saw how moved they were, that it was very important to them... [...] I said to them, I see how significant this is to you, so why don't you put up some sort of memorial here...? [A memorial?] Yes... They could put up some kind of memorial or something. 
That's what I thought, and that was the end of it. If it's so important to you... if you want, go for it. [You would have no objections?] Why would I? Absolutely not (Z38Cm).

They made a memorial, that Liainer guy, you know. In that spot where the Zhovkva Jews were shot, they made a monument. There is a forest there, and that's where he put the monument, in my opinion a nice little monument, and he did it at his own expense and all. [...] There was a monument and that, what do you call it. That iron bow, you know? [Menorah?] Yes, menorah. But then it started to get horribly destroyed, first on one side, then the other. There were bronze letters on there, saying "in memory of the Jews," or something like that, and people started taking them. [...] The menorah was taken away by his [Liainer's] son, he said it was the most important part of the monument, that's how I understood it. And now there is nothing there $(\mathrm{Z} 38 \mathrm{Cm})$.

Both fragments illustrate the extent to which memory about Jews is "not ours" for the residents who arrived in Zhovkva after 1945. There would be no objection to a Jewish initiative to place a Holocaust memorial in the town; however, the homeowner felt no drive to do so himself. ${ }^{278} \mathrm{~A}$ monument to commemorate the victims of the Shoah was built on the initiative of the town's last Holocaust survivor and with funds from the Jewish diaspora, but local hooligans vandalized it and the now-deceased Holocaust survivor's son removed the remaining parts. In these hypothetical and real deeds, the locals are absent (with the exception of the anonymous vandals, who probably acted with material gain in mind, rather than because they were anti-Semites). Social memory of an event can be more or less personal, i.e., it can be seen as "our own" to greater or lesser extents. Among today's residents of Zhovkva, memory of the town's Jews, and above all memory of the Holocaust, is very distant and often unwanted; in some instances, there is no memory at all. Rosa Lehmann's typology of three distinct varieties of Holocaust narrative can be useful to understanding this situation: according to this scholar, remembrance can be classified into memories of the victims, the witnesses, and the others (with the children of victims and witnesses also falling under "others.") ${ }^{279}$ Except for the respondents who were born in Zhovkva, all of the interviewees remembered them as "others;" they had heard little or nothing at all, and could not bear witness to the Shoah. This otherness has different degrees and is manifested in various dimensions: spatial (the first generation of migrants, who were in a different place when the Holocaust happened), temporal (the second generation of migrants, who were born after the Holocaust), and

278 Analogous attitudes were observed in Krzyż in discussions of the German village cemeteries that were going to ruin. Here, similarly, respondents were prepared for "someone" to do "something," but remained entirely passive themselves.

279 Lehmann, Symbiosis and Ambivalence. 
moral - when the victims of the Shoah are excluded from the community seen to be "our own."

The reasons behind this widespread lack of knowledge are to be interpreted with reference to the ways in which social memory is formed: through the interaction of various modes of transmission, including official (state) memory, private memory (especially family transmission) and public memory outside the realm of state policy (social transmission). I have discussed above the reasons behind the absence of family frames of memory about the Jews in Zhovkva. We might consider, therefore, why official memory about Jewish life and death in Zhovkva is so limited, and why social transmission remains insignificant. The answer to the first question may go somewhat beyond the scope of this book, but the essential fact is fairly easy to pin down: memory about Jews, and especially about the Holocaust, did not become a priority of Ukrainian memory policy after 1991. Although this topic is not off-limits as it was in Soviet times, official historiography, the narrative with the greatest influence on educational policy, generally ignores it. ${ }^{280}$ As Anatolii Podolskyi, the director of the Ukrainian Centre for Holocaust Studies, argues, the Soviet heritage can no longer be blamed for the current state of memory in Ukraine, despite the fact that, in a certain sense, Ukrainian memory policy is a continuation of Soviet practices: it suppresses the Holocaust in order not to diminish the status of "our own" victims - the Ukrainians who died during the war and Holodomor. ${ }^{281}$ This strategy does not only apply to the Holocaust: other inconvenient topics include the anti-Polish operations of the UPA during the war and the later deportations of Poles. Both in the official memory policy of the Ukrainian state and in Ukrainian public discourse, there is no room for discussion of the Shoah because both of these realms are dominated by memory of ethnic Ukrainian victims and heroes, much as in Soviet times when the Holocaust was downplayed.

However, the fact that the state does not initiate or support efforts to commemorate the Holocaust does not a priori negate the possibility of social activism

280 Of course, there are important discussions of the Holocaust in Ukraine (such as the debate between Yaroslav Hrytsak and Sofiia Hrachova on Ukrainian collaboration in the Holocaust, or recent polemics surrounding Omer Bartov's book Erased: Vanishing Traces of Jewish Galicia in Present-day Ukraine (Princeton and Oxford: Princeton University, 2007)). However, unlike in Poland where debates about the work of historian Jan T. Gross have had widespread social resonance, the Ukrainian discussions do not reach beyond a narrow circle of specialists.

281 Podolskyi, “Ukrainske suspilstvo." See also: Yaroslav Hrytsak, "Holokost i Holodomor: vyklyky kolektyvnoii pamiati," Krytyka, Vol. 1-2 (2011), pp. 14-16. 
in this sphere - this is shown by the example of the informal, bottom-up efforts to return the Ukrainian nationalist underground to public memory, which emerged before the Ukrainian authorities had recognized this as a suitable topic for commemoration. Social remembrance of the Shoah is scarce because private and social memories about this event were effectively marginalized during the Soviet period, much like the local communities of Galicia that were destroyed. This is clearly visible in Zhovkva, where the pre-war populations of Jews, Poles and Ukrainians disappeared, followed closely by memories about those vanished peoples. As a result, what is possible and necessary today is not just a return of memory, but a painstaking rebuilding, almost from scratch. Importantly, at least some of the local elites in Zhovkva were perfectly aware of this state of affairs:

Well, the old generation, the ones who are in their eighties now, it's like they know everything. They all know about the Holocaust. Well, I say they know the Holocaust - they might not know this word, but they know what it was. As for younger people, maybe the older ones told them... That monument of ours is so far out of town. There aren't any tours to go and see it, nothing. If it was a bit closer, and... I don't know, maybe we should apply for a grant or something to start some additional teaching in schools, do some excursions to that monument to the mass murders (Z44Df).

I would surmise that any real breakthrough in social memory of the Jewish presence and the Holocaust in Zhovkva - and other former shtetls in Ukraine can only happen if the activities tentatively suggested by the above interviewee become official state policy. For now, however, there are no signs of such a development. 



\section{Remembering the Absent: Poles and Polish Heritage in Zhovkva}

I begin the analysis of memory about Poles and Polish heritage in Zhovkva with some preliminary comments in order to signal from the outset the main differences from memory about Jews. First, unlike the Jewish community, the Poles were the politically dominant group in pre-war Zhovkva and had their own titular state. Thus, the analysis considers not only memories about a social group and individual residents, but also memories about the authority ascribed to this group and the political and cultural Polishness of the town. Second, whilst the Jewish community exists in today's Zhovkva in the social imaginary only, local Poles survived the war and remained in the town, although their numbers diminished to the rank of an insignificant minority. The third point follows on directly from the second: as well as people with Polish roots, there were respondents who considered themselves to be Poles. For methodological reasons, responses of individuals from the oldest generation who unequivocally identified themselves as Polish are not considered in this chapter.

\section{Once upon a Time in Poland}

Like in Krzyż, there was a widespread consciousness in Zhovkva that the town had once been part of a different country. Only a small minority of respondents from the youngest age group were unaware that "this used to be Poland." Interestingly, this ignorance was not dependent on family background. Among the respondents who did not know about the town's former Polishness were people of various backgrounds, including Polish backgrounds. One of them (Z8Dm) reacted to the question of whether his grandmother had told stories of life in pre-war eastern Poland with puzzlement: "What do you mean, in Polish times? What do you mean? [This used to be Poland.] Ohhh... [Before the war.] Well I didn't know that." As a rule, these were the same individuals who did not know that a Jewish community existed in Zhovkva before the war; it appears therefore that this absence of knowledge is a result not of prejudice or specific gaps in cultural transmission, but of those individuals' general lack of interest in the past. A major difference between the interviewees in Zhovkva and Krzyż was that the former were noticeably less well versed in concrete historical events that determined which state their town was part of. Whereas people in Krzyż clearly 
pointed to the year 1945 as the moment when the town joined Poland, residents of Zhovkva - especially younger ones - frequently confused basic facts.

There was a struggle between the Poles and... as far as I know, the Germans. And they divided the land, as they had before. And this part of the land went to the Polish side, and the Poles were here. And when Ukraine became independent, then... Then they set the borders again and Zhovkva became a part of Ukraine again, not Poland. And that's it. That is why there are a lot of people with Polish roots here (Z10Df).

In comparison to the respondents in Krzyż, it is also striking that in Zhovkva, people from the middle generation were sometimes unaware that the town had belonged to Poland in the interwar period; such a state of affairs was unthinkable among the quinquagenarians and sexagenarians I spoke to in Krzyż, who had played among the rubble of German buildings in their childhood and who considered the German origins of those debris to be obvious. The explanation for this difference can be found in the modes of post-war socialization. Both Polish and Soviet propaganda used worn-out clichés to describe the former residents of these towns, such as "old enemies," "invaders" and "occupiers." However, in the political propaganda of socialist Poland, the key figure was that of a German who had been "justly" driven out of the inherently Polish lands thanks to the heroic victory of the Red Army in 1945, whereas the Soviet master narrative focused on more distant periods in which the Poles oppressed the Ukrainians, such as the Cossack Uprisings of the seventeenth century. Recent history, such as the PolishUkrainian conflicts of the early twentieth century and the post-war expulsions of the Polish population, was politically inconvenient because it contradicted the official vision of fraternal relations between the common folk of Poland and Ukraine. Periods in which the two populations were at each other's throats were therefore hushed up or marginalized. ${ }^{282}$ This could be why the year 1945 was so obvious as a caesura to residents of Krzyż, whilst people in Zhovkva attached less significance to it.

Narratives about Zhovkva's former Polishness were usually non-conflictual only insofar as the speaker was simply stating that the town had previously been on Polish territory. More elaborate points were typically accompanied by arguments about the town's Ukrainian identity. This is very strongly visible in statements where speakers discussed the early history of Zhovkva, connected to

282 Cf. Oksana Ruda, "Do dzherel mifolohizatsii ukrainsko-polskykh vidnosyn," in: Istorychni mify i stereotypy ta mizhnatsionalni vidnosyny v suchasnii Ukraini, ed. Leonid Zashkilniak (Lviv: Instytut Ukrainoznavstva im. Krypiakevycha NAN Ukrainy, 2009), pp. 289-333. 
Poland and Poles. Respondents mentioned Żółkiewski and sometimes Sobieski, yet the statement that it was a Polish hetman who had founded the town was always qualified with the additional detail that Żółkiewski had built his settlement around a Ukrainian village.

Some people believe that Zhovkva belongs to Ukraine, that it's a purely Ukrainian town. Others will tell you that it was Prince Żółkiewski who founded the town, and that it's a Polish town. [...] As a Ukrainian, I will obviously tell you that it's our Ukrainian town [laughter]. [So it's not at all Polish...?] No, not at all. Although it has a shared history, it's like a joint venture. Yes, that's right. It's more like both [...] Other sources show that Zhovkva was founded as the village of Vynnyky, actually before Prince Żółkiewski arrived (Z27Df).

Respondents with a deeper knowledge of local history often emphasized the Ukrainian elements of the past; in the meantime, they did not so much negate the Polish historical presence as delicately skim over it, thereby making it clear that it was less important. A respondent who worked in the tourist center (Z43Dm) was sincerely disappointed that there was no monument of Źółkiewski in the town, because, he claimed, the Hetman had been Ruthenian, not Polish. Asked what she knew about the distant past in Zhovkva, another speaker (Z1Bf) raised the supposed fact that Bohdan Khmelnytsky hailed from the town, as well as the activity of the Basilians. There were also instances of respondents radically downplaying or even denying the historical role of the Polish presence although these were a small minority of mostly older people who to this day retained a negative attitude towards Poland: ${ }^{283}$

They still look at us as if from above. [Who?] The Poles. [Here...?] Here, they want [to claim] Zhovkva. Supposedly Żółkiewski lived here. OK, maybe he did. And they named it after him, but this was the village of Vynnyky before he came. But they never stop banging on about their bloody Żółkiewski (Z13Am).

On the whole, however, the era of the Polish-Lithuanian Commonwealth was presented in a positive light, as a time of well-being in which Zhovkva flourished. Żółkiewski and Sobieski, whilst remembered unequivocally as "Polish lords," were not evil, foreign invaders; rather, they were part of the history of Zhovkva. Perhaps the acceptance of Żółkiewski and Sobieski as "our own" is partly a result of the large separation in time, which reduces the emotionality of memory. The

283 In her research on the attitudes of local populations to their places of residence, Maria Lewicka shows that residents overestimated the pre-war proportion of their own ethnic group in every town she studied in which the population had been largely changed (Lviv, Szczecin, Wrocław, Vilnius), see: Lewicka, Psychologia miejsca, p. 466. 
town's historical Polishness was treated by respondents somewhat like a fairytale past, as something distant, unreal and exotic, and therefore completely harmless. ${ }^{284}$

Whilst the memory of the Polish-Lithuanian Commonwealth was positive, the nineteenth and twentieth centuries (thus, the periods in which Galician Ukrainians harbored national ambitions to rival the Polish ones) were remembered as times of occupation. The powers-that-be were "occupiers" because they were not "ours," i.e. Ukrainian. A respondent from a mixed Polish-Ukrainian family summarized this thought very concisely: "From what people close to me say, they had it best under Austria. That was the most loyal occupation. I call everything that was foreign, not Ukrainian, occupation, if you don't mind" (Z1Bf).

How, then, is the "less loyal" period of occupation, the interwar era, remembered by residents of Zhovkva? Two themes dominated these narratives: first, pressure from the Polish authorities; and second, the oppressive nature of Polish culture and material wealth. The difficult life under Polish rule was remembered almost exclusively by interviewees who had experienced it themselves, whereas younger respondents spoke with more sentiment about the interwar years. Negative memories revolved around individual experience, such as childhood suffering or being treated unequally at school. One interviewee who was born in Zhovkva (Z30Af) recalled the hurt she felt when, as a pupil at a Polish school, she received a mediocre grade in her own language, whereas Polish classmates who did not speak any Ukrainian were awarded with top marks. She also had clear memories of being bullied by other children: "As soon as they heard someone speaking Ukrainian, they would start saying things like 'Oh, she's grunting like a pig!'” (Z30Af).

284 Nonetheless, despite these generally positive memories, the Polish-Lithuanian Commonwealth never became part of a founding myth about Ukraine's place in Europe among Galician Ukrainians - neither in Soviet times, nor at any point thereafter. Whilst the Europeanness of Ukrainian (or Galician) culture was beyond dispute in intellectual debates, the Polish contribution to civilization and culture was not recognized - unlike, for example, the Austrian one. For a dicussion of this issue, see: Ola Hnatiuk, Pożegnanie $z$ Imperium. Ukraińskie dyskusje o tożsamości (Lublin: Wydawnictwo UMCS, 2003); and Natalia Yakovenko, Paralelnyi svit. Doslidzhennia z istorii uiavlen ta idei v Ukraiini XVI-XVII st. (Kyiv: Krytyka, 2003), pp. 333-365. This is not to say that there was no interest in the Polish influences on Ukrainian culture, rather that intellectual discussions did not form a broader paradigm of thought. 
Besides details of childhood unpleasantries and humiliations, interviewees also spoke of difficulties experienced by adults: for example, trouble finding work, or discrimination faced by people involved in Ukrainian cultural and political life. Some also added with bitterness that it may be normal for a nation state to favor its "own," but the Polish case went too far in its drive to assimilate minorities. Interestingly, practically no one from the younger generation spoke of the suffering of Ukrainians under the Polish yoke, and only one person who had migrated from the East did so. This interviewee, who came from a Polish family in the Zhytomyr region (central Ukraine), and who resettled to work in Zhovkva in the 1950s and married a local Pole, gave an extensive and very critical account of the "Polish ways:"

I asked, for example, my mother-in-law: "When this was part of Poland, you lived better than now, didn't you? If it was better, why did you have such an impoverished house and why did so many of you live in it?" [...] "Because there was no work. Life was tough." And I told her: "So, now [in Soviet times] there is work for everyone, and you are still not happy." $[\ldots]$ And now look at what we have: my mother's brother's kids have finished university, my mother has her own house, even though her brother spent 15 years in Vorkuta [i.e. in a labor camp]. He brought money from Vorkuta and built a very nice house (Z10Af).

I have outlined previously the reasons why migrants from the East did not discuss the wartime too willingly with neighbors who had roots in Galicia. In relation to their memories of life in interwar Poland, however, there may be another explanation available: perhaps the locals did not want to complain about life in bourgeois Poland because in doing so, they would put the Soviet regime in a favorable light - something they were reluctant to do in the company of the Easterners.

Another recurrent theme in the interviews was the idea of Poland as a cultured, civilized and relatively powerful country, to which speakers willingly returned in their thoughts and feelings. This attitude was expressed almost exclusively by younger respondents with local family roots. The most prominent idea they voiced was that their families lived better in Polish times than under the Soviet regime.

They had their own field, they worked, they had their own bread, you understand? My family had plenty of land, we weren't poor. Then all of that was taken away from us, just like that. What is there to remember? We had a lot of land, a big house, and then all those horrors. I don't even know how we survived all that, I just don't know (Z32Cf).

Even when such views did appear fleetingly in the account of older respondents, they were quickly drowned out by the predominant memory of injury at the 
hands of the Poles. The only wholly positive image of Poland among the oldest generation, a sentimental and even mythological picture of the interwar years, was articulated by a woman from a mixed Polish-Ukrainian family:

In Polish times this was a fabulous town. [...] The cafés were wonderful, such amazing cafés. [...] Here on the corner there was a wonderful shop - I always used to go there and buy a kajzerka bun [this word pronounced in Polish] with ham. How perfectly evenly they sliced the ham! Everything was so fresh, it smelled so good, I can't even tell you... People say we have culture now. What kind of culture do we have... [with irritation]? My father, in Polish times, if someone came through the door of our house, would immediately say: "Marusen'ka - to my mum - give me my marynarka [jacket]!" He would never sit at the table in a jumper with a shirt sticking out, like people do nowadays. [...] I only have the most beautiful memories from those times. You know, if this was still Poland, we would have a villa on the high street by now. We would be rich and powerful, and not old nobodies like we are now, thanks to Soviet rule. I'm sorry to get so emotional, but you know... These are memories from my childhood, from my youth, memories of all that was good in my life (Z1Af).

Like the younger woman cited above, this speaker remembers interwar Poland as a time and place in which her family were well off, and even - according to her own words - as the best days of her life. In her account, Poland of the 1920s and 1930s is elevated to the rank of a lost childhood realm, an ideal time, when even the slicing of ham was superior to today. There is a striking resemblance to how Poles from the East in Krzyż spoke of their lost homelands; the key similarity is the sense of having lost an opportunity to enjoy a more comfortable life. ${ }^{285}$ This respondent's family belonged to the intelligentsia that was relatively wealthy and had a high social status before the war. The wartime troubles and post-war transformations hit her family hard, and as a child she must have been particularly sensitive to the changes in status.

Younger respondents struck a somewhat similar tone on occasion, although with a lesser emotional input. These accounts were not related to personal experiences or family history, but rather to general ideas about interwar Poland having been a better country for a range of reasons.

There was a lady who lived near us, she owned this huge house with a garden, right next to the printing house. She lived her whole life, her whole life, in Zhovkva - I'm not sure what happened to her children, maybe they went somewhere else. She was always so clean you know, like a real Polish lady, well presented, well-dressed, all neat and tidy.

285 Kaja Kaźmierska discusses a similar trope of memory among people recalling the places of their childhood, see: Kaźmierska, Doświadczenia wojenne Polaków. 
When kids would go into her garden in summer, to pick apples or whatever, she never even complained. They could just come and take what they wanted (Z37Cf).

The status of Polishness in this statement is very clear: the Polish lady was a relic of a past that had disappeared long ago, and her passing was a sign of a certain chapter in the town's history coming to a close. The next part of this chapter discusses the end of this shared period of history.

\section{Times of Threat}

The Polish presence in Zhovkva began to disappear in September 1939. If we accept that this month brought two significant events to the pre-war Polish provinces, the second of which was the direct consequence of the first - the Soviet invasion and the loss of Polish statehood - it can be clearly stated that today's residents of Zhovkva remember only the former. The fall of the Polish state was, in their eyes, nothing more than the exchange of one foreign power for another; this is probably why it has no place of its own in local memory. The minority who did speak of this event were - once again - respondents of the oldest generation who were natives of Zhovkva or who settled there from villages in the vicinity; for younger interviewees, 1939 did not comprise a caesura of any kind. One of the few statements that touched upon the collapse of the Polish state went as follows: "when the Polish war broke out, it was the landlords [pany] who escaped to Poland, not the [ordinary] Poles" (Z34Af). Two things stand out in this sentence. First, the defensive campaign of 1939 is labeled as "Polish," which immediately sets it off as "not ours" - the struggle against the Nazi invasion was carried out in defense of the Polish state, not in the Ukrainian interest and without Ukrainian support (although in reality many Ukrainian soldiers fought in the 1939 campaign). Second, a side effect of the invasion was the flight of local Polish landowners - the pany - who are distinctly separated from the ordinary Poles who remained in the area and continued to share their fate with the Ukrainian population. There was no emotion or judgement in this statement - because no one among the Galician Ukrainians mourned the loss of the Polish state.

The Polish-Ukrainian conflicts during the war, meanwhile, had a much more marked presence in the testimonies from Zhovkva. Like the persecutions from the interwar period, these were remembered most of all by respondents from the oldest generation who were born in Zhovkva or the vicinity. Many of these speakers were convinced that, although it was the Poles who suffered more in these confrontations, it was ultimately their own fault because they had provoked the Ukrainians with their brutal treatment before the war: 
It all started after... After those pacifications. ${ }^{286}$ I mean, it's my opinion, and the opinion of many historians, that every action is followed by a reaction. With the Polish state there was a time when, instead of showing its Europeanness, it started to carry out polonization. Forced polonization. Well, there are two sides to a coin, and every action is met with a reaction. State terror always provokes a response in the form of terrorism (Z42Cf).

There were also opinions voiced that the victims of Ukrainian violence did not include Poles who had done no harm to Ukrainians, but only those who genuinely "deserved it" through their actions in the interwar period; one respondent said of a Polish acquaintance from that time: "There was a guy called R., for instance, he was a nice, gentle Pole, no one touched him" (Z6Am). Another argument aimed at diminishing the guilt of the Ukrainians was the claim that the Soviets were at fault for the outbreak of conflict - they had donned UPA uniforms and murdered Poles so that the Poles would carry out revenge operations against the Ukrainian nationalists. One woman, who had witnessed such a murder, made this argument with great passion:

The Poles are always saying that we started to murder them, and that they started to kill Ukrainians in Poland in response. [...] But it wasn't Ukrainian partisans that murdered Poles, it was the Moskals, the Russian partisans, they went about massacring Poles, even at Christmas, in order to stir up hatred, here, over there across the border; I mean there wasn't a border here, it was all Galicia. They [killed] Poles, so that they would kill Ukrainians (Z29Af).

Such arguments are united by a desire to rid Ukrainians of the reputation of "killers" [rezuny,] which the respondents believed the Poles held them to be. The strategies of argumentation took various forms. The first woman believed that the Poles had started the conflict before the war; the wartime events were a response to pacification operations, and so the guilt lay with the Poles. A related justification was that the killing of Poles was a simple tit for tat at the individual level - people who had done no harm to Ukrainians in the interwar period had no reason to fear, in this speaker's view. The last interviewee deflected the guilt onto the Soviets, who were interested in stoking up conflict between Poles and Ukrainians. It is worth noting that none of these speakers attempted to completely absolve the Ukrainian militias of any responsibility or to undermine the fact that

286 The speaker has in mind the pacification of Ukrainian villages in eastern Galicia that was carried out by the Polish state in 1930, in response to acts of sabotage by the Ukrainian Military Organization. The pacification operations were conducted on the principle of collective responsibility, and they featured arrests, destruction of property, and physical violence. 
they had carried out mass murders against the Polish population; rather, they attempted to justify and rationalize this history. Likewise, none of these speakers denied that Poles had been the main victims of this conflict in Galicia.

The following statement is somewhat similar in style, and represents certainly the most common view (both among the sample of interviewees, and in Ukraine generally $)^{287}$ of the Polish-Ukrainian conflict:

Poles and Ukrainians lived side by side - and we lived well together. Then, during the war, the shenanigans started, someone was deliberately provoking it. Ukrainians started to shoot Poles, and Poles shot Ukrainians, and lots of people got killed. Later most of the Poles left, because it wasn't quite like the Jewish pogroms, but still, lots of people died. Basically, everyone was killing each other. [...] Such foolishness, but it happened on purpose, it was political. To turn people against each other (Z31Am).

Whereas the previously cited respondents aimed to justify the murder of Poles, this statement contains a significant change of emphasis: here, there is no question of Ukrainian nationalists having carried out a planned operation to kill Poles en masse; rather the conflict was fratricidal and provoked by external forces. Seen through such a lens, the issues of guilt and responsibility vanish entirely, and only common injury remains. If such statements by older respondents can be read as a reflection of their own wartime experience, assessments of wartime events by younger people often evolved in the direction of an increasing blurring of the question of responsibility; murders of Poles were thrown into the mixer with all the other tragedies of the war, as terrible events that are so distant that it is now difficult to pass judgement on who killed whom and why.

Were there conflicts at some point, long ago? Yes, there were. So were we at war, or were there conflicts, how am I supposed to know? My grandmother used to tell me that during the war, Poles killed Ukrainians and Ukrainians killed Poles, they would shoot at each other, yes. But that is all in the past now (Z19Cf).

Meanwhile, an opposing opinion posited that it was the Ukrainians, rather than the Poles, who were the main victims of the fratricidal conflict. Interestingly, respondents who remembered events in this way - mostly older respondents employed concrete examples in their accounts, unlike the speakers cited above. Yet more interesting is the way in which these examples were used. Among the various stories of Polish terror, the recurring theme of the Polish village of Stanyslivka (Pl. Stanisłówka) near Zhovkva is exemplary. This village served for

287 For the results of the recent all-Ukraine opinion poll, see: http://hvylya.net/analytics/ politics/kak-ukraintsyi-smotryat-na-otnosheniya-mezhdu-ukrainoy-i-polshey.html, last accessed 28.12.2018. 
some time during the war as a base for a large division of the Polish Home Army. In 1944, during a period when the Polish underground soldiers were absent from the village, nationalists attacked Stanyslivka. Several dozen residents were killed, and most of the buildings and farming equipment were incinerated. After the attack, most of the local Poles escaped to Zhovkva. ${ }^{288}$ Nonetheless, in the interviews, Stanyslivka appeared primarily as a site of Ukrainian suffering, whilst the village's later fate was mentioned only in passing, or not at all. One respondent spoke of neighbors from her native village that had been murdered by the Home Army in the vicinity of Stanyslivka: "They were killed in the forest and buried in the forest. What did people do about this? Nothing. But that was the politics of that time" (Z19Af). Two other interviewees made statements in a similar tone:

The Poles who were in the towns, they were afraid to go into the countryside. They stayed in their towns. True, but there were the ones who stayed in the villages. The worst were around Stanyslivka, in the villages there. The whole of Stanyslivka... It was completely burned down! If a Ukrainian went in there, that was it, he wouldn't get out of there alive. They didn't tolerate it, didn't let us in, terrible things happened there... The partisans... They burned it all down... It was the partisans who burned it down. Ukrainians had no right to even set one foot in there. Yes, they were pretty cruel around there too. It was blood for blood, an eye for an eye. And then they [Poles from Stanyslivka] escaped to the town in droves (Z6Am/Z27Bm).

In both interviews, the incinerated Polish village features primarily as a source of threat for the Ukrainians. ${ }^{289}$ The first respondent did not mention at all that the village had been destroyed, and in the dialogue between two residents, the exchange of views effectively sanctions this deed and transforms its moral status - practically into a necessary act of self-defense. Thanks to such rhetorical devices, the mass murder of a group of Poles becomes lost in a haze of other

288 Information concerning the Stanyslivka events is taken from: Szczepan Siekierka, Henryk Komański and Krzysztof Bulzacki, Ludobójstwo dokonane przez nacjonalistów ukraińskich na Polakach w województwie lwowskim 1939-1947 (Wrocław: Wydawnictwo Stowarzyszenie Upamiętnienia Ofiar Zbrodni Ukraińskich Nacjonalistów, 2006). I accept and understand that the source is potentially biased towards the Polish point of view; however, unfortunately I could not find any information on Stanyslivka in Ukrainian works of history.

289 In her study of cities that experienced war and then population exchange, Maria Lewicka notes that residents generally only remember the hurt suffered by members of their own national group, completely passing over the atrocities carried out against other groups, see: Lewicka, Psychologia miejsca, p. 503. 
details. The only interviewee who did speak of Stanyslivka primarily as a Polish village burned down by Ukrainians was a man who had resettled in Zhovkva from Poland - thus, not a local who could have genuinely remembered the event. Nonetheless, even he claimed that the impetus for the massacre was violence from the Polish side:

There was a terrible massacre here, including in Zhovkva. People here used to say that the Poles killed this or that person, that they carried out murders. And the Ukrainians also carried out terrible killings of Poles after the war. Not far from here [...] there was a village called Stanyslivka. There were about 20-30 Polish families who remained there. Ukrainians surrounded this village and they burned everyone alive - everyone! A few managed to escape, naked and barefoot. It was spring, or so they say. That was that! This village, you know, it also used to dish it out to the Ukrainians who lived there. The Poles killed more than half of the Ukrainians. It was a mass mutual massacre (Z15Am).

It is just a small step from deflecting the guilt onto the Poles and claiming the Ukrainians as the main victims to arguing that there was no brutal conflict or genocide of the Poles. It is worth pausing for a moment to consider statements made by educated people who cultivated an interest in history, and who, furthermore, had a favorable view of Poles and Poland; their conviction that there was no conflict is especially striking. One woman from a mixed PolishUkrainian family stated briefly that: "I don't know anything about any ethnic conflict between the Poles and the Ukrainians... I just don't know anything about that" (Z1Bf). Another respondent was equally convinced that there had never been a Polish-Ukrainian conflict in Zhovkva: "Even during the war in Zhovkva, not a single Pole was killed" (Z40Bm), and attempted to outline the broader context of a historical tradition of peaceful coexistence between ethnicities in the town (including tolerance and multiculturalism during the interwar period).

For both of these interviewees, personal biography explains why they remember Polish-Ukrainian relations in this way. The first speaker came from a mixed Polish-Ukrainian family in which the Polish component of identity was deliberately suppressed from the wartime onwards, in order to protect the children from possible persecution. At the same time, a hero myth of the Ukrainian nationalist underground was cultivated, as the Ukrainian side of the family had been actively involved in this movement. In this context, the partial "unblocking" of family memory in the 1990s and the re-emergence of the fact of having Polish roots would naturally lead one to believe that no conflict could have taken place. The second speaker, a museum employee, was deeply convinced of the integrity of the town's history and its cultural heritage. It appears 
that he was unable to admit a historical conflict between ethnicities because this would directly contradict his prized vision of Zhovkva as an ideal multicultural town - in the same way that a bloody Polish-Ukrainian conflict would have destroyed the newly discovered family memory of Polish-Ukrainian coexistence for the first interviewee.

Harsh condemnations of Ukrainian violence were heard very rarely in the interviews. One respondent with Polish roots from Zhytomyr region [Central Ukraine] (Z10Af) complained to me after the tape recorder had been turned off that her grandson considered the UPA to have been heroes, even though they had been nothing more than common criminals who were responsible for the destruction of many Polish villages. Another person who made no effort to justify the Ukrainian side in the Polish-Ukrainian conflict was an elderly woman originally from a village near Zhovkva. It is possible that she said the things she said because the interview was carried out by a fellow Ukrainian; significantly, this speaker was genuinely afraid that her views could still expose her to trouble.

You understand, after the war there was... that fighting. I still remember, you know, how can I miss this out? The fact that there were two or three Polish families [in the speaker's native village]. One of our distant cousins married a Pole, and it was during this fighting, you know, the OUN-UPA, they were against them, against them... They burned... I remember, my father woke up and he said: "there's a fire." I mean, they wanted the Poles to... [goes quiet] [Leave?] Leave, yes. You don't need to record this, no, it's not necessary, but it's what happened (Z23Af).

The question is unavoidable: why was it almost exclusively older residents who remembered the Polish-Ukrainian conflict? Or in other words, why did only autobiographical memories of that period remain, but no social memory? The majority of the youngest cohort of respondents simply had no idea that there had been any trouble between Poles and Ukrainians in Zhovkva during wartime. In the middle generations, a vague consciousness of "some difficulties" was predominant, with a prevailing narrative of fratricidal conflict in which both sides suffered equally. It was only interviewees who harbored nostalgic sentiments towards the USSR who mentioned that the Ukrainian nationalist underground had planned an operation to clear Galicia of Poles - and they normally did so in passing, whilst condemning the UPA for their anti-Soviet activity. The massacre of Poles was, for these people, an additional argument against the UPA, not a fact with its own independent standing in their appraisal of the past.

Two issues contain the key to understanding this non-memory: people's direct experiences of the conflict, and the social memory of post-war and contemporary times. As Aleida Assmann writes (citing Freud), that which is never properly 
noticed can neither be committed to memory nor properly forgotten. ${ }^{290}$ Assmann cites the case of the Holocaust in Germany as an example of such an "unnoticed" event, and the tragedy of the Poles in Galicia can be understood in similar terms. Ukrainians who lived in towns might well have never personally encountered any hostilities. Others did not notice because they did not want to, for various reasons - fear, shame, being blinded by emotion, or a desire for their own national heroes to remain unscathed. ${ }^{291}$ The settlers who came from elsewhere did not hear about the killings of Poles from locals for obvious reasons; nor did they hear from Poles who remained in the area, as they lived in fear and concealed their nationality. Furthermore, it was in the interests of the Soviet authorities to blacken the reputation of the UPA, but not necessarily by remembering the Polish presence in Galicia. In Soviet historiography the Polish-Ukrainian conflict could only have a social dimension: Poles were described using clichéd terms such as "Polish lords [pany]" or "invaders," whilst inconvenient themes were omitted from discussion. At the same time, informal, local memories in Galicia spread the notion that Poles had murdered Ukrainians in wartime and collaborated with the Nazis, while Ukrainians had only killed Poles in revenge. ${ }^{292}$ The unnoticed massacre could not be narrated to children and grandchildren - and even if it had been noticed, it was hardly a topic suitable for recollection during family gatherings.

For the youngest generation who grew up in independent Ukraine, school education also played a role in their non-memory of Polish victims. The metanarrative of Ukrainian national identity, which is founded on the myth of a heroic underground resistance, contains no room for consideration of the victims of the UPA (whether Polish or Ukrainian); despite the absence of a nationwide consensus on the UPA, this is the narrative that has dominated since 1991 in school textbooks and curricula. As the Lviv-based historian Leonid Zashkilnyak has argued,

290 Assmann, "Fünf Strategien." Social psychology provides the basis for an interesting reflection on this issue. As Martin A. Conway writes, facts that do not fit with the prevailing structures of autobiographical memory may not be recorded; in other words, we do not commit to memory that which we find inconvenient, or we remember it differently because the principal function of autobiographical memory is to maintain the coherence of the self, see: Martin A. Conway, "Autobiographical knowledge and autobiographical memories," in: Remembering our past. Studies in autobiographical memory, ed. David Rubin (New York: Cambridge University Press, 1996), pp. 67-93.

291 Jacek Nowak has written about Ukrainians not remembering the killing of Poles in neighboring villages, see: Jacek Nowak, Społeczne reguły pamiętania. Antropologia pamięci zbiorowej (Kraków: Nomos, 2011), p. 238.

292 Ruda, "Do dzherel." 
the image of past Polish-Ukrainian relations in Ukrainian textbooks may have become more faithful to the truth, but troublesome issues are nonetheless glossed over, especially those that cast the Ukrainians in a bad light; at the same time, double standards are rife when it comes to the portrayal of others (e.g. Operation Vistula is depicted as an event organized by the Poles, whereas the deportations of the Polish population are blamed on the Soviets). ${ }^{293}$ Ukrainian historian Andrii Portnov bitterly notes that a 2011 Ukrainian history textbook makes no mention of the Polish-Ukrainian conflict (Portnov writes about the ethnic cleansing in Volhynia, but his remarks de facto concern the entirety of the wartime PolishUkrainian conflict). ${ }^{294}$ The previous textbook reduced the mass murders of Poles to a tragedy "of the civilian population on both sides of the conflict."

The Ukrainian Institute of National Remembrance perceives the wartime fate of Poles in a similar way. In a documentary film recommended by this institution, entitled A Chronical of the Ukrainian Insurgent Army 1941-1954 [Khronika Ukrainskoi Povstanskoi Armii 1941-1954], two and a half minutes are dedicated to the role of the UPA in the orchestration of the purge of Poles in Volhynia, while the commentary of the narrator (set against a picture of a burning village) states: "The situation in the region was made more difficult by the conflict between Poles and Ukrainians. [...] The provocative policy [of the Germans] was the reason for the bloody conflict which spread throughout Volhynia and Eastern Galicia. Tens of thousands of innocent people died on both sides."295 Based on this narrative, it is difficult to understand why these tens of thousands of people died. At the same time, independent institutions that work towards Polish-Ukrainian reconciliation tend to choose the path of compromise, rather than open discussion (which is painful and initially antagonizing) on the question of responsibility. ${ }^{296}$ Given this overall situation, it would be asking too much

293 Leonid Zashkilniak, "Istoriia 'svoia' i istoriia 'chuzha," Krytyka, Vol. 9/10(143/144) (2009), pp. 24-26.

294 Andrii Portnov, “Ukraińska (nie)pamięć o Wołyniu 1943,” http://www.pk.org. pl/publikacje/pojednanie_przez_trudna_pamiec_wolyn1943.pdf, last accessed 15.08.2018.

295 “Khronika Ukrainskoi Povstanskoi Armii 1941-1954", video, part one: https:// www.youtube.com/watch?v=c1bX6em5PRs, part two: https://www.youtube.com/ watch?v=LxGbJ-RyuTU, last accessed 28.12.2018.

296 One example of such activity is a project conducted by the Brama Grodzka and Panorama Kultur foundations in Lublin and the Lesya Ukrainka Eastern European National University in Lutsk. The project aims to commemorate the "righteous" Ukrainians who rescued Poles and Poles who rescued Ukrainians during the Second World War. The results of the project are available in an online publication: http:// 
to expect the residents of Zhovkva - especially the youngest ones - to remember the Polish victims of the UPA. ${ }^{297}$

\section{Emigration, Expulsion, Marginalization}

Although the Polish-Ukrainian conflict did not exist in the consciousnesses of most respondents, those same people usually spoke at length about the postwar expulsions of the Poles. This fact can be explained by a simple generalization: most of these speakers believed that the Poles had left the town voluntarily. There was a prevalent conviction that the Poles simply did not want to live in the Soviet Union because they did not see it as their homeland. In the words of one interviewee, who came to Zhovkva from eastern Ukraine (Z11Af): "[The Poles] left by themselves. [...] They left freely, there was no violence of any kind. If you wanted to, you left. Most of them went to Poland. [...] They didn't want to live under the Soviet state."

Both older and younger respondents cited a desire to "return" as a reason for the departure of the Poles. Interestingly, many of them used propaganda clichés such as "return to the motherland" to describe the events of that era:

The Poles just went back, because, as I far as I understand, there were a lot of them at that time... There was an opportunity because the Germans had left Poland, so there was that land, and they went back there. You know, even the house where my grandparents and their parents live, that was a Polish house. They also went back (Z15Df).

The ubiquity of such statements in accounts of the departure of the Poles shows, especially for the second and third generations, the strength of communist propaganda. It also demonstrates how easy it can be to turn a group of domestic Others, who had lived in the same territory for centuries, into foreigners and exogenous invaders who had settled there through some error of history.

The Poles were resettled in Poland, and the Ukrainians came here. Poles with Poles, Ukrainians with Ukrainians. Sure, there was a bit of that... Some stayed, they also didn't

www.pk.org.pl/publikacje/pojednanie_przez_trudna_pamiec_wolyn1943.pdf, last accessed 28.12.2018.

297 For an overview of Ukrainian public debates and memory politics around the ethnic cleansing in Volhynia (also presenting a wider picture of Polish-Ukrainian relations) in the period slightly before my interviews were conducted, see: Georgii Kasianov, "The Burden of the Past. The Ukrainian-Polish Conflict of 1943-44 in Contemporary Public, Academic and Political Debates in Ukraine and Poland," Innovations: The European Journal of Social Science Research, Vol. 3-4 (2006), pp. 247-259. 
want to go to Poland. It wasn't forced. [...] But if you're a Pole, go to Poland - and live your life there (Z13Am).

The impersonal and emotionally cold tone with which the above statement was made was fairly typical of the way in which people in Zhovkva talked about the town's population exchanges. This process was treated without greater consideration as something that had simply taken place. Such statements did not contain any sentiment that the Poles had suffered as a result of resettlement; the phrase "Poles with Poles, Ukrainians with Ukrainians" is more reminiscent of the sorting of vegetables than of people. Among the older respondents there were also several individuals who believed that the Poles had actually benefitted, rather than suffered, as a result of Poland having gained the "Recovered Territories" in exchange for Galicia: "Well, the Poles aren't complaining, they got those German lands, and ours too, and so their Poland is a little richer now. [...] It all worked out well for them" (Z3Af).

Claims concerning the supposed benefits of resettlement were frequently accompanied by comments, usually expressed with bitterness, that the Poles had left because they no longer wanted to live with the Ukrainians: "They didn't want to live with Ukrainians, oh no. They wanted to go to Poland, to their own place" (Z16Af). However, it was only older respondents who gave such explanations perhaps a reflection of their own negative experiences of living side by side with Poles in Zhovkva or a previous place of residence (in cases of Ukrainians resettled from Poland). Sometimes, their argument included an element of belittling the scale of resettlement; interviewees said that Poles had certainly been expelled, but that there had not been very many in the first place and so it was not possible to talk of any mass operation. Such memories were, in a sense, a continuation of earlier disputes about the nature of local identity; accounts of the post-war expulsions were imbued with a sense that Poles had never been in the majority in the town, and so there was no reason to make a fuss about their disappearance.

There were only two interviewees who clearly stated that the Poles had left because they were simply afraid of the Ukrainians, and that coexistence had become impossible in the light of the brutal conflict. It is worth noting that one of these two speakers was one of the few interviewees who gave a full account of the burned village of Stanyslivka; he was not selective in his courage to speak of difficult legacies.

[Why didn't the Poles want to stay in Zhovkva?] Well, you know, those were difficult times when they suffered terrible killings. [Here, in Zhovkva?] Sure, why not? When we arrived here, there were already very few Poles. But the killings were big. Big. We were told that they burned someone here, killed another there, then a third... (Z15Am). 
If we compare the ways in which people in Zhovkva spoke of the expulsion of the Poles with statements about the expulsion of the Germans in Krzyż, there is a striking difference in the nature and intensity of emotions. Whereas the present-day residents of Krzyż recognized the suffering and loss experienced by the Germans, respondents in Zhovkva were much more matter-of-fact about the resettlement of the Poles: they spoke of population exchanges and "going back" to Poland. Only rarely did speakers - mostly educated individuals from the younger generation - expressed awareness that the Poles had lost their homeland (often also losing their loved ones) and experienced great suffering.

They were kicked out, really. [...] And I don't think that this was the right thing to do. You know, there was this and that, sure... Casimir III [the Great] took over Galicia, Ukrainian land, that is true, yes. But on the other hand, entire generations [of Poles] grew up here during the course of all those years. You can't just say it never happened, that this wasn't their homeland. Take, say, the Turks or Tatars - they came here from outside, stirred up trouble, and left. It was different with the Poles (Z39Cf).

The comparison here between Poles and "Turks or Tatars" is important, emphasizing that the Poles should not be treated as outsiders after so many centuries of coexistence; they were, for this speaker, people with roots in Galicia, just like the local Ukrainians. Such opinions were very rarely expressed in the interviews conducted in Zhovkva. Expressions of regret at the departure of the Poles were equally rare - of the many interviewees who had been to school with Poles before the war, worked alongside them, and shared many aspects of daily life, only one person said that it was a shame that they were now gone.

Then they brought our people [Ukrainians] here from Poland, even that W., she came from Poland. The people from this house, they were [expelled.] And they were such nice people, the Poles. Great girls, just like us, we went to school together (Z35Af).

Why is it that memories of Poles in Zhovkva, which were fairly abundant in relation to other aspects of the historical Polish presence, were so lacking in empathy, especially when compared to the compassion that the eastern Poles in Krzyż continued to feel for the deported Germans? The most important factor affecting the earlier biographical experiences of the oldest interviewees was the difficult state of Polish-Ukrainian relations in the interwar period, followed by their dramatic worsening in the course of the war. Whereas the Poles who arrived in Krzyż from the pre-war eastern provinces had never had any negative experiences of German civilians, the Ukrainians in Zhovkva (and those resettled from Poland) had accumulated bad memories both of Polish government and of Polish neighbors. Whereas the Germans had been one of the warring sides, the occupiers (and so it was possible to symbolically divide the 
occupation authorities from the "ordinary Germans,") from the Ukrainian point of view, Poles remained part of a neighborly conflict, one that was therefore much more painful. ${ }^{298}$ Furthermore, for Ukrainians resettled from Poland, the Poles also represented the people who had deprived them of their homes. All of these factors made Poles an inconvenient group for memory in Zhovkva: they reminded one of bygone troubles, including of past injuries or an unsettled conscience. Given this context, their disappearance could be a cause for relief or an object of indifference, but not a source of regret.

Another significant issue is that most Poles left Zhovkva at the beginning of the repatriations, shortly after the end of the war; most new settlers in Zhovkva from the East and those resettled from Poland, meanwhile, arrived the following year, once the largest wave of Polish "repatriation" had already departed. Thus, the newly arrived residents did not usually witness the expulsion of the Poles, and there were very few instances of people who had just lost of their home cohabiting with people who were about to meet the same fate - an occurrence that made a strong impression on Polish settlers from the East in Krzyż. Ukrainians resettled from Poland did describe their impressions of moving into a Polish house and having regular contact with Poles who were preparing to leave; no one, however, told a story about living with a Polish family or celebrating holidays together.

And while my father was here on his own, they [the Polish former owners of the building] were still here for two more weeks. They were given decent conditions, they were put onto a train and they left for Polish territory. [...] [And that Polish family didn't treat your father in any untoward way?] No, they were fine. My father told me, he went to see them a few times, because he was living over at H.'s place, and he would check if they were still there, and they would always receive him with something at the table. But they were already packed and ready to go (Z15Am).

This fragment suggests that contacts between Polish and Ukrainian resettlers were superficial, and that the two groups essentially passed each other by. Both in Krzyż and in Zhovkva, resettlers usually crossed paths with former residents at the point where they took over the houses of those who were leaving. Whilst the eastern Poles in Krzyż perceived a certain commonality between their own experiences and those of the Germans, the resettlers in Zhovkva appear to have

298 This conflict had a deeply internalized class dimension - although the objective differences in economic status between the Polish and Ukrainian populations of Galicia were in fact often minimal, many Ukrainians still thought in class-based categories of "Polish lords" and "Ukrainian peasants." 
treated their encounters with Poles in a more pragmatic manner, as little more than an opportunity to secure a roof over their heads. Importantly, moreover, narratives about the expulsion of the Poles appeared very rarely in interviews with the younger generations - this seems to have been an insignificant event that was not considered worthy of preservation in family memory. The few who did mention it did so in the context of their family's obtaining of a Polish house. Strikingly, the majority of younger respondents - irrespective of their family backgrounds - were indifferent to the origins of their own homes, whether those homes were formerly Jewish or formerly Polish; most simply knew nothing about the past of the building they lived in. Perhaps this history was considered so insignificant that the grandparents never mentioned it; another possible reason is that for the Ukrainians resettled from Poland, the architecture in Zhovkva was essentially similar to that which they had left behind in Tomaszów or Lubaczów, so they gave it little thought - in contradistinction to the cultural shock that the eastern Poles experienced when they were transplanted into the urban fabric of Krzyż.

The Poles disappeared from view after the war, becoming socially invisible as a group. On the occasions when interviewees mentioned Poles in Soviet Zhovkva, they talked about specific individuals, never an entire community. There were no stereotypical constructions of the kind that were common for the interwar period, such as "those nasty Poles" or "we lived well with the Poles;" on the contrary, some people claimed that the nationality of their neighbors or co-workers was of no consequence. Settlers from the East were especially likely to deny that nationality played any role. Undoubtedly, the Poles' invisibility in memory is a consequence not only of their physical disappearance from Zhovkva, but also of the social marginalization of those who remained in the town. Whilst the Soviet authorities acted to remove all traces of Polish culture, the remaining Poles were afraid to demonstrate - or even publicly admit - their identity:

[When you came here, were there many Poles left?] Do you think they admitted that they were Poles? Unlikely! Maybe there were two or three people who I knew were Poles, because they spoke Polish. [...] Here, people hid the fact that they were Poles (Z10Af).

The process of assimilation also affected the decimated Polish population, partly in conjunction with the fear of revealing one's Polish identity and with the social ostracizing that Poles experienced on many levels. Interestingly, it was bettereducated respondents from the younger generations who noticed this assimilation most often, perhaps because they were more sensitive to the changes in identity that were taking place before their eyes. As one interviewee put it: 
If there was anything like that in the family, it was hidden far away and you couldn't tell anyone, because God forbid, if you played with someone and they went home and said something. Then your parents might be paid a visit, for a talk, and then who knows what kind of corrective education they might get told to do... (Z37Cf).

The situation of the Poles in post-war Zhovkva can be easily summarized: those who didn't die, left; those who didn't leave were forgotten. Only the systemic change of the 1990s changed the status of the Polish community - both in the new socio-political reality of independent Ukraine and in the consciousnesses of the residents of Zhovkva.

\section{"Now it is OK"}

After Ukraine gained independence, Zhovkva's Poles, like other groups that had been directly or indirectly persecuted, figuratively emerged from the underground: they regained a church, created an association, and started traveling to Poland and receiving guests from across the border. Nonetheless, the Polish presence in Zhovkva appears as a kind of phantom. Non-Polish respondents stated with complete assertiveness that there was a Polish community in the town today, pointing to the large, working Roman Catholic Church as evidence; however, they hesitated when I asked about specific individuals, say, neighbors or colleagues from work or school. The oldest interviewees named people their own age, many of whom, it turned out, had already passed away. Younger people cautioned that they couldn't be sure whether the Poles in Zhovkva were "proper" Poles. Many observed that it was not only Poles who attended the "Polish" church, and they were often unsure where these Poles could have come from in the first place - perhaps some had migrated from Poland? It was striking that questions about Poles in Zhovkva today were often answered with an immediate claim that there were no conflicts at the local level, although the questions never implied such an issue: "You can see it is calmer today, than, say, in Soviet times... [...] I would say that here in Zhovkva there is no problem between Ukrainians and Poles; here it is like in any other town" (Z15Df).

The first (and sometimes only) thing with which the Polish community in Zhovkva was associated was the collegiate church. Poles were perceived as a church-going group that cultivated Roman Catholic religious traditions. This distinctiveness was generally considered in positive terms; it was even the subject of a certain local pride. Zhovkva was deemed to gain a distinct character from its small but "ethnographically" colorful minority, making it more interesting for people from outside. All of the respondents without exception emphasized the harmonious coexistence of the Roman and Greek Catholic churches 
in Zhovkva, citing examples of the two congregations paying mutual visits on holidays or the friendships between the two sets of clergy; often, this relationship was cast in contradiction to the tense relations with the Moscow patriarchy of the Russian Orthodox Church:

We [Ukrainians] go there [to the Roman Catholic church] on Christmas Eve, we sing, we do everything. There is friendship, also between the priests... To begin with, everything was in Polish, so not many people went - because everything was in Polish. Later they started doing everything half in Ukrainian, half in Polish. [...] Lots of people go to the [Roman] Catholic church, pure Ukrainians. So the Poles are completely... People here like them, we think well of them ( $\mathrm{Z} 5 \mathrm{Cm})$.

Interviewees were also positively inclined towards the charitable and cultural activities of the Roman Catholic Church. These were mostly associated with the Polish nuns who cared for children in Zhovkva, including non-RomanCatholics. Residents of Zhovkva spoke of these activities approvingly, although at times - especially among the older respondents - there was a hint of surprise and envy, laced with a mild suspicion: did these activities not have a hidden motive of polonizing the Ukrainian children?

The Poles now, after the war, they've done lots of work here. There are three nuns here [...] They speak excellent Ukrainian, but they teach Polish history, all the kings, do you understand what I am getting at? They keep the discipline, they give food and other things - and all the families are satisfied, and it's clear that the children have got the hang of all that (Z29Af).

Despite these incompletely verbalized anxieties, today's relations between Ukrainians and Poles were seen by interviewees as very good, both at the local level between the town's communities, and also in terms of relations with tourists visiting from Poland. This is seen very clearly in the following statements by two siblings, both middle-aged, who were from a family of resettlers; interestingly, both underlined that now - in the era of independent Ukraine - Poles no longer faced any threats.

The Poles now are fine, sure! No one has anything bad to say to them. Once we [Ukrainians] started going over there [to Poland], my God, there are such contacts with them over there! The young people have great relations - guests visit, they load up cars full of meat... [Do you mean direct contact?] Yes, loads! They come here for every opening and town festival and what have you, lots of Poles. They drink, they talk, no hatred from anyone, and the young people are completely at ease with them - they are friends. They've won us over completely. People think well of them, everything is forgiven, let's get on with our lives! And, well, it is their town after all. We built it, the Poles traded, it's their town... [When they come, do they say that it is their town?] They used to, a lot, but not any more. [Not any more?] They used to say: it's our town, our 
town [said in Polish: To nasze miasto, nasze miasto]. But now, after everything. [...] I didn't think it could ever be so calm, they don't dig up the past, they just walk around... (Z5Cm).

Don't you think that people get violent and murder straight away around here. Everyone lives in harmony. We have bandits, and you have bandits. But people say such silly things (sister of $\mathrm{Z} 5 \mathrm{Cm}$ ).

Thus, the interviewees were convinced that there was no longer any conflict, and that business and social ties were flourishing among the youth. It would appear that the Poles have irreversibly lost their traditional status as the important Other in the eyes of the Galician Ukrainians - and the younger the respondents, the more ingrained this new status becomes. Whilst before the Second World War, as well as in the first post-war years, Ukrainians in Galicia defined their national and cultural identity in opposition to the Poles, the Poles have now become less significant - including both the few who remained in Zhovkva and the ones who left the town. ${ }^{299}$ As Yaroslav Hrytsak argues, this diminishment in the hierarchy of animosity is a result both of the Poles' physical absence, and of the fact that they have lost their previous socio-political status. ${ }^{300}$ Absent and/ or harmless, the Poles no longer matter in Galicia; their place as the significant Other has been taken by the Russians/Soviets.

I did nonetheless expect to hear of the symbolic importance of the Poles in response to questions about present-day Polish tourists in Zhovkva. However, these visitors were generally received with a polite indifference, and they clearly conjured no ghosts of the past. The majority of residents related to the tourists with empathy and understanding; the town has links to Polish history, and so it is natural that Poles visit it.

[How are Poles received in Zhovkva today?] Well, I think [that] Poles come to Zhovkva very often on the whole. Firstly, it's close, secondly, Żółkiewski, a Pole, founded Zhovkva, so many Poles come here to see the town. Even my mother often does guided tours. So in my opinion there is no big deal in the Poles visiting (Z10Df).

Resettlers from the oldest generation often perceived an obvious analogy: the Poles visit Zhovkva in the same way that they visited their own places of birth in Poland after 1991. Such statements usually took the form of simply "giving permission" to the Polish tourists to visit, such as in the case of this woman,

299 Interestingly, in the Polish national imaginary- according to Ireneusz Krzemiński - the role of the principal Other is played by the Jews, despite their absence, see: Krzemiński, Antysemityzm w Polsce i na Ukrainie.

300 Hrytsak, "Historical Memory." 
who when asked whether Poles come to Zhovkva, said: "Why shouldn't they? They come here, both tourists and those Poles [former residents]. [...] At the beginning everyone wanted to travel. I also went to see my home" (Z3Af). More extensive reflections were articulated less frequently. The following speaker, for instance, went from describing his own experiences of visiting his native land to commenting on the Polish visitors in Zhovkva:

It's the same here. The historical heritage has been preserved and the people who used to live here, the Poles, who worked here, who built and refurbished the houses, they are happy that it is still there. They feel something special here. [...] When they come here, and many of them do, they say: "we used to live here and work here." It's not even the parents, but the children and grandchildren (Z15Am).

To the question of whether the Polish tour groups cluttering the streets of Zhovkva were an annoyance, interviewees rushed to vehemently deny such a claim; some were even offended that anyone could suspect the community of such a lack of hospitality. Many people did not understand the context of my question - they asked in complete seriousness why anyone would have anything against the Poles. When I explained that people in Krzyż were often anxious about the Germans returning, they were genuinely surprised. Many speakers joked that only a fool would bite off the hand that fed them - in other words, the Polish tourists were perceived above all as sources of income: [How do people receive these tour groups?] "Fine. Firstly, the good thing is that the shops receive them very well [laughter]. It's very good for the shops. Because you Poles lap up everything - vodka, cigarettes, sweets" (Z20Cm). One possible reason why some respondents did not understand why people might be negatively disposed towards the Polish tourists is that they were unaware of the motivations that drive some Poles to visit Zhovkva. Asked why so many Poles traveled to the town, one resident claimed to have no idea. She perceived the Polish visitors positively, with no reference to the historical context: "It's great that they have the opportunity to come here and visit the town, I would also like it if someone took me on a tour to Poland and showed me round, why not? People are wealthier, they can afford it, so why shouldn't they come?" (Z17Cf).

Negative opinions about Poles were expressed very rarely indeed, and usually in a mediated form - i.e. speakers claimed that there were some other people who did not like the Poles. They pointed unequivocally to "nationalists," or in other words, to the section of Zhovkva society that they deemed to be right-wing and/or radically anti-Russian or anti-communist.

[Did people receive the Poles well?] Yes, even... You know who doesn't receive them well? The nationalists, you know... [whispering]. They don't treat the Poles well, they 
have some issues with the Russians and with... [the Poles]. I'm not even sure why, what they are trying to say with their attitudes, what they are actually thinking inside? I asked a colleague once, I said: "What have they done to you?" And she said [scornfully]: "Ha, the Polish army was on bicycles!"301 (Z16Bf).

Although I spoke to many "nationalists," none of the people whom one could label as such expressed any dissatisfaction with the Polish groups visiting Zhovkva. Perhaps the outcome would have been different if I, the interviewer, were not a Pole; however, no such opinions were expressed in interviews conducted by my Ukrainian collaborators. The only statement that contained any dissatisfaction with the number of Polish tourists was made by a man of the oldest generation, who had arrived in Zhovkva from a Galician village, and showed his dislike of Poles at several other points in the interview. When asked to clarify his views, however, even he retracted his previous comments, turned them into a joke, and claimed he had no real enmity against the Poles. The tone of his statement was mildly deprecating and ironic, but not hostile. Interestingly, his account was in a way a mirror image of the question that had been asked. The speaker commented not on his attitude towards Poles or other people, but about the attitude of Poles to Ukrainians:

Poles don't like Ukrainians, no they don't! I see, for example, how they come here, and it is almost like we are all friends, we are good and kind, but I can see perfectly well that that is not what they are thinking. [...] [And you said that Polish tourist groups come here, and that they... That it is visible that they don't really like Ukrainians. How can you tell? Do they behave badly in some way?] No, why would they, Poles are intelligent people, you can't say that they would... But a Pole can always say "this is all ours" [laughter] (Z20Am).

Whilst the interviews contained no clear expressions of dislike for Poles or their visits to Zhovkva, for some speakers their relations with Poles did have some difficult moments. This is true above all of situations in which the postcolonial dimension of Polish-Ukrainian relations made itself known. In such situations, the Poles appeared as a group belonging to a higher civilizational, cultural and material level, whilst the Ukrainians in contrast acted as a subordinate group (today - economically, in the past - both economically and politically). Sometimes this context emerged accidentally, without any intention on other side, such as in a story about Polish tourists giving out sweets to Ukrainian

301 This is a reference to the Ukrainian minority's negative attitude towards the Polish army during the defensive war of 1939 (the Polish military was less well equipped than the German Wehrmacht). 
children. The Poles here appeared as visitors from another, better world, and they unconsciously played the role of "wealthy relatives." They had no intention of displaying their superiority over the children of Zhovkva, but the respondent perceived the incident as a humiliation, and it was clear from the tone of her voice that she considered this story as the tip of an iceberg - rather than being an isolated incident, it symbolized an entire gamut of problematic relations between Ukrainians and Poles.

Personally I didn't enjoy looking at that at all, seeing our children, from here, from Zhovkva, running up to those buses and trying to speak Polish, managing a couple of words... I don't remember what exactly they were saying, but you know... But they aren't beggars, they're not poor (Z41Df).

Stronger negative emotions were aroused in situations where Poles intentionally positioned themselves as representatives of a superior group - culturally, civilizationally and economically. Their haughty behavior was understably met with anger and distaste. It did happen that such behavior was reported in Zhovkva; the most illustrative incident, however, was said to have taken place during an encounter with Poles in Poland.

I have some very good friends in Poland. I've visited them, we get on very well, and they have been here many times. [...] They treated me like family, saying "if someone visits a brother, they should be received well;" everything was great. But then once some relative from the mother's side comes to visit the parents, and she starts questioning me about why I am there and then tells me off because of all those Ukrainians who sell cigarettes. Now you can see how upset I was... First, you don't know me, but I definitely do not sell cigarettes, and I am a guest in your house, and I've welcomed your children into my house, and everything was great. Why would you say such things to me? You know, I'm also not thrilled that Ukrainians go and trade like that, but I know that some of them have no choice. But there's nothing I can do about it. So don't judge the entire nation from them (Z39Cf).

This fragment clearly shows the mechanism by which the speaker rejects collective responsibility and collective judgement. The humiliation caused by a feeling a sudden solidarity with fellow Ukrainians mixes with a desire to draw a boundary to separate them from herself. Nonetheless, the negative emotions are directly above all at the Polish woman, and negative Polish-Ukrainian stereotypes become activated.

\section{Material and Symbolic Heritage}

For most residents of Zhovkva, especially the younger ones, Poland and the Poles were associated above all with contemporary times - if any talk of problems 
arose, it concerned the present-day economic and political situation, rather than the past. Perhaps this was a consequence of the fact that - unlike people in Krzyz - in Zhovkva, even the first generation of resettlers did not fear that Poles might return to claim their old homes, even when those former owners came to visit.

[How did those Poles treat you when they came to visit?] Fine, fine. They were even pleased. And dad made lunch for them. They were here, yes, for about three days. They looked around at everything. [...] [And you weren't afraid that the Poles would want to take their house back? Since they came to see... their own home.] I'm not sure about that... This house was given to us by the town council after all. It's legally ours (Z12Bf).

Most statements, by both older and younger respondents, contained a clear conviction that the decisions of the authorities from over six decades ago to remove the Poles from Zhovkva were irreversible. The eastern Poles in Krzyż felt no such security, living "with packed bags" for many years and receiving the returning Germans with suspicion and fear. How may I explain this difference? On the one hand, the differences in the political regimes of Krzyż and Zhovkva shed some light on this problem. Whilst for the residents of socialist Krzyż, life was difficult in Stalinist times and afterwards, the communist regime in Zhovkva was undoubtedly more repressive and totalitarian in nature; its activities were not to be undermined by ordinary individuals. The phrase "this house was given to us by the town council after all," spoken with a degree of incredulity, shows that it was essentially unthinkable to the resettlers that anyone - here, the long-expelled Poles - could question the status quo. Another factor is the content of post-war propaganda. Whilst the new residents of Zhovkva were told repeatedly that there had never really been any Poles in Galicia (and that the ones who had lived there had left voluntarily), the resettlers in Krzyż were kept alert to the threat of the evil Germans. The Soviet regime had the more effective means of keeping the new communities in check. Paradoxically, the present-day visits of Poles who had previously lived in Zhovkva worked to deepen people's (especially younger residents') conviction that the material and political status quo had been settled once and for all. The guests appeared to interviewees to be completely rooted in their new homes in Poland, and for this reason, they were deemed unlikely to advance any claims of any kind:

A Polish woman came here once. "It's nothing," she said. "It's nothing, we have a place to live over there." That was it. [She used to live here?] Yes, that's right. She came to visit. It was fine. She said: "we have everything we need over there, everything." So you see, weve been here for 64 years now, not a year or two! (Z4Af). 
Respondents' reactions to visits from the former owners were calm, with no trace of insecurity; rather, they showed understanding, a certain empathy, and sometimes a degree of surprise that someone would want to travel so far just to see the house in which a grandparent had been born. At the same time unlike in Krzyż - no one spoke of maintaining close, warm relations with the Poles who had previously lived in Zhovkva; there were no repeat visits, no holiday greeting cards were exchanged, and no parcels were sent. If any contact did take place, it was usually superficial and a one-time affair. This could be a result of memories of past conflicts, conflicts that were much more intense than on the Polish-German axis, continuing to reverberate in contemporary relations. Another possible reason is that the majority of residents in Zhovkva did not see any common ground between their own post-war experiences of resettlement and those of the Poles.

Because of the belief in the irrefutability of the decisions taken by the Soviet authorities, conversations with residents of Zhovkva never featured any discussion of reparations being potentially demanded by the Polish side. Only one person commented on this topic - a lawyer by education who clearly perceived my question to be a "professional" matter and therefore felt obliged to answer in some detail.

It wasn't their fault and they didn't know whose houses they were moving into. [...] In my opinion such matters should not be subject to claims, because it would create a complete precedent. Then everywhere all over the world, if people started giving everything back to everyone else, say, Germany was also half in one country and half in another, just like Poland, for example. People would start digging in archives - it would be complete chaos (Z15Df).

Other, shorter responses on this subject were similar in tone: that there was no point in digging up personal matters after so many years, especially in regions affected by the post-war border shifts; and furthermore, that older people lacked the strength to get involved in such things, whilst the younger people were simply indifferent.

Did this feeling of legal and political security also entail a sense of symbolic security, i.e. an assuredness not only that one's house could not be repossessed, but also that there were no cultural or moral grounds on which to even make a claim? Have Zhovkva's post-war residents incorporated the town's Polish heritage into their own culture - do they consider it their own? The interviews showed that the Polish heritage could be roughly divided into two categories: the church, and everything else. For the vast majority of interviewees, the Roman Catholic Church in Zhovkva remained "the Polish church." They associated its history - its 
former renown, the post-war neglect, and the current renovation - with the history of the Polish community in Zhovkva; the restoration work was linked in the present day to Poles from Poland. This does not mean they were indifferent: religious residents of Zhovkva perceived the church as a sacred building, and were negatively disposed towards its decline. The blame for the building's ruination is put firmly at the door of the Soviets - as with the synagogue, although in this case the condemnation was much stronger. The dichotomy between "Polish culture" and "Soviet barbarism" appears again in this context, and as a result, the church becomes less foreign; it is "ours" because it is "not Soviet," and it was destroyed by the Soviets in the same manner as "our" Greek Catholic and Orthodox churches.

Do you know what they did there? They turned it into a grain store! And now the priest is here, since a couple of years ago, when there was that announcement that the Catholic church would be re-opened, and then it was opened. They took everything out then, the priest took care of it... Poland helped a lot. Those Poles are very good people. Did they ever do anything bad to us? What is there to talk about? (Z34Af).

Respondents treated the Polish state's involvement in the renovation of the Roman Catholic Church as something natural and positive. Some commented critically on the Ukrainian state's inactivity in this regard, but such criticisms were usually general indictments of the dysfunctional Ukrainian state, rather than a specific claim that it should not neglect the Polish church.

The Polish church - yes it was the Poles who came here and refurbished it themselves, after Ukraine became independent. [...] Our government did nothing towards this, nothing. And in the same way, the Jews come here, it was Jews who gave money for the renovation of that synagogue (Z35Af).

It was also considered natural for abandoned Polish churches to be transferred to other religious communities in need of a building, although most speakers felt it necessary to justify this opinion - they pointed to the buildings' bad state of repair or the absence of a Catholic congregation that would use the premises: "They surely took it [the church] with the agreement of the Poles. It's not as if... It's not as if they commandeered it" (Z1Af).

Importantly, respondents emphasized not the destruction of architectural heritage, but the fact that sacral space would go to waste; in the absence of the Roman Catholics, it could still serve other religious groups. The exclusion to this trend was a very emotional and critical statement by a museum employee, who trained as an art historian. Whilst she did not disagree in principle with the transfer of Roman Catholic churches to the Greek Catholic and Orthodox communities, she was incensed by the way in which their refurbishment was being carried out. Her response was characterized not only by the indignation of a 
professional, but also a protest against the destruction of the common heritage of Zhovkva. Commenting on the renovation of a former Dominican church, which included the painting over of some valuable frescoes, she said:

What is happening here now, that's not refurbishment. That is devastation in my view. [...] It's not ignorance, it's sheer human stupidity, it's just a waste. [...] Why would they restore some old paintings if they might not even suit the Greek Catholic church of today? (Z42Cf).

The rest of the architectural heritage is treated very differently - the castle, town gates, and old town houses: these buildings are not considered foreign because for most residents, Polishness is directly associated with Roman Catholicism; since the buildings are not religious in nature, they are not "marked" as culturally Polish. Interestingly, the opposite is true in Krzyż: the town houses in the center are still considered to be (post-)German - especially by the oldest generation whilst both churches were completely polonized from the very beginning. Only a few interviewees revealed a belief that the historical space of Zhovkva was created primarily by Poles, mostly individuals with a deeper interest in history, who were prone to reflect on their own identity. These speakers were convinced that it was thanks to the historial presence of the Poles that the town took on its current appearance, which Ukrainians today can continue to enjoy - "It's thanks to Poland that we have so many buildings. So many architectural relics, and that's thanks to Poland" (Z11Dm).

Very few people considered the Polish material and cultural heritage to be an integral part of Ukrainian culture, understood in a civic or political sense as the sum total of traditions of the different ethnic groups that have lived in the present-day and historical territory of Ukraine. ${ }^{302}$ For these individuals, the local Polish heritage was of course valuable: they argued that it enriches today's Zhovkva whilst posing no threat to the ethnic identities of today's Ukrainian residents.

I'm talking about the maintenance of cultural heritage. This is very important, very important. Because we Ukrainians are not only "pure" Ukrainians; our history is everything that came before in this territory - the Poles, the Jews, they all assimilated here. All of this is assimilated in our present-day consciousness. And we have no right to say

302 This tendency is not only true for Zhovkva. In Galicia more broadly, Polish heritage remains a difficult issue for intellectuals, see: Eleonora Narvselius, "Tragic Past, Agreeable Heritage: Post-Soviet Intellectual Discussions on the Polish Legacy in Western Ukraine," The Carl Beck Papers in Russian and East European Studies, Vol. 2401 (2015), pp. 1-75. 
that we are only "pure" Ukrainians, because the Poles lived here and still live here; that is us, everyone who lived here before - the Jews, the Poles. It was all passed down to us somehow, like a smell, the way the wind carries a smell, all of that was carried into our consciousness, it is what we are made of $(\mathrm{Z} 40 \mathrm{Bm})$.

Importantly, exclusively people who were professionally involved in architecture, the arts, and cultural activities, or who were otherwise closely connected to Polish culture made such statements. Again, it is possible to see the parallels with local identity in Krzyż - there, likewise, the town's German past, its architecture and material inheritance were important primarily to those individuals who were personally involved in the study of the pre-war history of the town.

Memory of the Poles in Zhovkva is strongly differentiated, above all between generations, but also between the backgrounds of individual respondents and their families. For older people born in the town or its vicinity and for those who were resettled from Poland, this memory was dominated by past injuries - with pre-war disagreements and wartime conflicts at the forefront. Migrants from the East knew little about the Polish presence in Zhovkva - as was the case with the Jewish presence. The lack of mutual trust between different kinds of migrants and locals in the post-war period blocked the creation of a local memory. If the Easterners had anything to say about the Poles, they were most likely to talk about their departure (because at least some of them had been witnesses to the deportation operations), but not about Polish-Ukrainian conflicts from the wartime.

A similar state of affairs held true among interviewees of the middle generation: they spoke mostly in generalities, with a naïve conviction that the post-war "repatriation" had been voluntary. Only very rarely did people give vague accounts of the interwar period - and as a rule, these were people from local families; with few exceptions, these accounts gave no inkling that relations had been conflictual. Memory was undoubtedly thinnest among the youngest generation many respondents of this category did not even know that Zhovkva had previously been under Polish rule. This particular ahistorical thinking of the younger groups was often equally forgetful of the Poles and the Jews. Interestingly, young people made no distinctions in their non-remembrance, being equally ignorant of both wartime conflicts and Polish persecutions of the interwar period; in other words, Ukrainian victims and perpetrators were on a level setting. I have analyzed some of the reasons why Zhovkva families maintained no memory of the wartime Polish-Ukrainian conflicts mentioned above. Why, however, did they not discuss the era of Polish-Ukrainian coexistence in Zhovkva, a time when Poles were the "bad guys" in mutual relations, i.e. the interwar period and 
the Polish persecutions against the Ukrainian movement for national self-determination? It would appear that in relation to memory of the Poles, both in the post-war period and after Ukrainian independence, the "interests" of the local community and state memory policy converged. The fact that a significant Polish community had existed in Galicia in the past, one that was culturally and politically dominant, was of little value both to the propagandists of the Ukrainian SSR and to the architects of the official memory narrative in independent Ukraine. Meanwhile, family memory (unlike the autobiographical memory of the oldest respondents) was reluctant to preserve any recollection of interwar persecutions, because that would raise difficult questions about what had later happened to those oppressors.

Besides silence in people's homes, (non-)memory of the Poles has also been created by official narratives. The changes that affected state memory production after 1991 were significant, yet Poles continue to be portrayed mainly as a side in a conflict, with much less attention paid to Polish-Ukrainian cultural ties and social coexistence. ${ }^{303}$ Meanwhile, as Natalia Yakovenko has rightly noted, stereotypes about one's own nation and neighboring societies, including ideas of Self/Other and Friend/Enemy, are formed above all at school age, through popular literature and cinema, and primarily through history education..$^{304}$ One can hardly expect that the youngest generation of residents of Zhovkva - who have been presented in school with a panoramic vision of Poland and Ukraine as mutually hostile and absolutely distinct cultural entities - would have a vivid interest in the history of the town's Polish community. This situation is made more problematic by the fact that, in the new version of the town's history promoted at the local level since 1991, the Poles are not completely absent, but they only appear when it is convenient and safe. A glimpse at the display of the town museum or local guidebooks, albums and tourist maps shows that figures such as Żółkiewski and Sobieski have become part of the town's past, but no social or political actors from the nineteenth century have made the cut. After the times of these sixteenth and seventeenth century luminaries, the town's Polish history seems to enter a phase of mysterious silence, until at last, like deus ex machina, there appear a series of well-kept and refurbished Polish churches. The calendars

303 See: Zashkilniak, “Istoriia svoia," pp. 24-26; Viktoria Sereda, "Vplyv polskykh ta ukraiinskykh pidruchnykiv $\mathrm{z}$ istorii na formuvannia polsko-ukraiinskykh etnichnykh stereotypiv." Visnyk Lvivskoho universytetu. Seriia istorychna, Vol. 35-36 (2000), pp. 387-397.

304 Yakovenko, Paralelnyi svit, pp. 366-382. 
with images of interwar Polish postcards issued by the town museum contain no information about why there are no more Poles in Zhovkva. ${ }^{305}$

Today, people in Zhovkva associate Poles with the contemporary Polish state Poland is a wealthy neighbor and a model of successful transformation, and as an additional factor in its positive image, the Poles offered significant support to Ukraine during the Orange Revolution of 2004. Outside the oldest generation, there are very few historical associations or stereotypes - and Zhovkva is far from an isolated case in western Ukraine. ${ }^{306}$ This diagnosis is supported by recent research conducted among history students in Lviv; most of them had positive associations of Poles and Poland, because those associations were from the present day. ${ }^{307}$ One of my respondents, a poet and translator and someone with close connections to Polish culture, made a similar comment:

There are some people who really don't like the Poles, and there are other people for whom the Poles are... well, how would I put it, they are a civilizational ideal. A very important factor here is the economic factor, by which I mean that Poland today is associated much less with ideology. It's a question of standard of living. Some things happen just because people go to Poland to earn money, and they bring back from Poland a picture of what it's like to live well, $[\ldots]$ and that begins to have an effect (Z1Cf).

Poland and Poles, in other words, signify a European standard for people in Zhovkva, in terms of both economics and culture; it is no surprise that they arouse positive associations, especially among younger people with pro-Western and pro-European sympathies. The attitude towards Poles in Zhovkva today could be described as a role model relationship, but it is questionable whether this situation has any longer-term stability. This image of a role model has its roots in the incompleteness and superficiality of collective memory, including

305 There is a clear parallel with local history materials published by the town council in Krzyż, including a similar book of German postcards that contains no hint as to what happened to the town's German population.

306 Yaroslav Hrytsak has written about the vanishing of past stereotypes in the PolishUkrainian borderlands, see: Jarosław Hrycak, "Stereotypy o stereotypach: pogranicze ukraińsko-polskie i problemy jego prezentacji," in: Akulturacja/asymilacja na pograniczach kulturowych Europy Środkowo-Wschodniej w XIX $i$ XX w., Vol. 1: Stereotypy i pamięć, ed. Robert Traba (Warszawa: ISP PAN, 2009), pp. 53-77.

307 Olena Arkusha, "Polskyi i rosiiskyi chynnyky u formuvanii suchasnoi natsionalnoi svidomosti halytskykh ukraintsiv: istorychnyi dosvid i suchasni paraleli," in: Istorychni mify $i$ stereotypy ta mizhnatsionalni vidnosyny $v$ suchasnii Ukraini, ed. Leonid Zashkilniak (Lviv: Instytut Ukrainoznavstva im. Krypiakevycha NAN Ukrainy, 2009), pp. 144-209. 
the sweeping under the carpet of practically all of the difficult questions related to the past. It is easy to declare warm sentiments towards someone whom one only sees in a good light; it is also easy to remember an Other who has vanished from a territory, together with the entire baggage of difficult legacies connected to its historical presence there. Memory of the Poles in Zhovkva is selective in a dangerous way. It is easy to imagine that, once the generation of witnesses who remember Poles as part of their own biographies has passed away, young residents of Zhovkva might irreversibly lose all awareness of this part of the town's history, because the memories of the elders were not passed down. After such a blockage in the transmission of memory, it is only a small step to further forgetting and the instrumental mythologization of the memories that remain. I would argue that in the context of Polish-Ukrainian relations, the precarious situation of memory threatens to be explosive: at some point it could transpire that the people of Zhovkva - Ukrainians, Russians and even Poles - are unable to understand what Poles from Poland are talking about when they begin conversations on their shared history and future reconciliation. ${ }^{308}$

Of course, forgetting is also a part of remembering - as Aleida Assmann argues, the inseparability of memory and forgetting at the individual and collective levels creates the cultural memory of any given group. ${ }^{309}$ According to Assmann, forgetting can be active - in which case the element of memory is lost forever - or it can be passive, a result of a lack of attention rather than an intentional act of erasure, and then the forgotten thing can be restored to memory; Assmann uses the metaphors of a museum display and its storage (active and passive memory, the canon and archive). I believe that memory of the Poles in Zhovkva is not yet lost - it is still possible to reach into the memory storage and transfer it to one of the exhibition rooms, even if not the main hall. The painful, antagonistic memory of the Polish presence does still filter through the layers of forgetting, for example when respondents unreflectingly note that "now there are no problems with the Poles." Its further destiny depends above all on whether the new generation recognizes it as a potentially important part of its identity.

308 The extremely negative reaction to the film Wolyń (dir. by Wojciech Smarzowski, 2016) and the general worsening of Polish-Ukrainian relations in the context of mutual settling of historical accounts in 2017 and later, show that this moment has already arrived at a pan-Ukrainian level. For a short overview of the discussion that followed in Ukraine, see: Wojciech Konończuk, "Ukraińcy patrzą na 'Wołyń,"” Tygodnik Powszechny, Vol. 47 (2016), pp. 44-45.

309 Assmann, "Canon and Archive." 



\section{Between Heroes and Traitors: The UPA and the Soviets in Zhovkva ${ }^{310}$}

\section{Bandits or Heroes? Troubled Autobiographical Memories}

The Ukrainian Insurgent Army is undoubtedly the most controversial candidate for the status of collective hero in Zhovkva. One section of interviewees considered the fighters of the UPA to be national heroes, whereas others deemed them unquestionable villains. ${ }^{311}$ This polarization was most visible among the oldest generation, whose members had been witnesses or even participants of hotly disputed events. Ukrainians born in or near Zhovkva were most likely to praise the UPA, alongside some of the Ukrainians resettled from Poland. For people from these groups, giving a positive appraisal of the UPA was so ingrained that there was no need to verbalize it fully; it was signalized by the tone of voice or in the use of prepositions - the insurgents were "our boys." At the same time, these respondents were determined to help spread a positive reputation of the UPA: this is why even before any confrontational questions had been posed, many of them began to justify and defend "their boys." One important element of this mode of argumentation was the theme of Soviet soldiers dressing up as UPA members and carrying out atrocities in disguise:

People said it was the Banderites... One day they [a family of acquaintances] were all killed, absolutely all of them, just one child survived by hiding under the wardrobe. [...] And [after the war] he [Zygmunt Lajner] revealed that it really was true that this R. [a Jewish woman who married a Ukrainian man] and her family were killed not by the Banderites, but by the Moskals. In a great many cases, they disguised themselves as Banderites and killed people. They killed both Poles and Ukrainians to show how

310 The first part of this chapter was published as a stand-alone article: "Bohaterowie czy kolaboranci? Pamięć o UPA na Ukrainie Zachodniej," in: Małgorzata GłowackaGrajper, ed., 20 lat rzeczywistości poradzieckiej (Warszawa: Wydawnictwa UW, 2012), pp. 134-154.

311 This is not a phenomenon specific to Zhovkva: many studies have shown that Ukrainian memory is deeply divided in this field, see: Yulia Yurchuk, Reordering of Meaningful Worlds: Memory of the Organization of Ukrainian Nationalists and the Ukrainian Insurgent Army in Post-Soviet Ukraine (Stockholm: Stockholm University, 2014); Oxana Shevel, "The Politics of Memory in a Divided Society: A Comparison of Post-Franco Spain and Post-Soviet Ukraine," Slavic Review, Vol. 70, No. 1 (2011), pp. 157-163. 
evil those Banderites were. [...] But the Banderites were people who fought against the Moskals. Just like in Poland, where there was a resistance movement (Z1Af).

There were, of course, exceptions: the apologists of the UPA included a woman from eastern Ukraine. The fact that her statement - which was replete with equivocation - both praised Bandera (as a broader symbol of Ukrainian nationalism) and explicitly justified her own views shows the extent to which her attitude is untypical for her group (in this case, the Easterners in Zhovkva). The statement also displays clear traces of Soviet propaganda, for which the UPA were Nazi collaborators and "bourgeois nationalists" and were therefore anathema to good taste.

It's only now that people talk about fascism, nationalism, and Banderites. But I for example, maybe I am wrong here, I've had unpleasant conversations even with my relatives about this... I, for one, believe that the Bandera faction, just like the first Cossacks, they just wanted the freedom of Ukraine. What did Bandera do that was bad? Is giving your life for the freedom of your people a crime? (Z25Af).

As always with cases of "non-standard" or surprising memory, this statement should be understood in the broader context of the interview as a whole. One of the speaker's key experiences was the Holodomor, the Great Famine of 19321933, in which her grandmother died. Thus, it appears that the respondent had trouble reconciling the contradictions between her personal negative experiences of the USSR and the propaganda in which she had been immersed her whole life. In her narrative, staples of Soviet ideology are mixed with patriotic (Ukrainian) phrases, and Bandera is glorified on a similar level with Lenin. Talking about any one side always provoked a defensive, safe counternarrative.

The second type of memory of the UPA among the oldest generation was a stance of passive objectivity, as embodied in a phrase that recurred in the majority of interviews with Ukrainians resettled from Poland - "we didn't get involved."

There were gangs roaming, yes... Who knew who they were? [...] I never got involved in anything. I was terrified even to ask, is it this or that. I was deaf, dumb and blind, and so was my whole family. [...] [Now there is a lot of talk about rehabilitating and honoring the soldiers of the UPA...] I don't care about that. People fought, that is well known. I never poke my nose into things, I don't protest and I don't support (Z16Af).

The resettled Ukrainians usually said less about the UPA than they were able. Despite the passage of time, they still believed that it was safer to claim no knowledge and to have no opinion (especially if one was married to a Russian retired soldier, as in the case of the respondent cited here). This passive stance also appears in some statements by Ukrainians who migrated to Zhovkva from 
the East. Again, these attitudes are better explained with reference to broader circumstances of their biographies: as a rule, these interviewees endured difficulties under Soviet rule and life taught them that it is better not to stand out. One such respondent lost both her parents in the Terror of the 1930s and 1940s and grew up in an orphanage. After the war her husband was a director of a factory in Zhovkva, but as she put it, "he knew nothing, he kept his silence." She herself avoided walking home from work in the evenings by herself, usually being accompanied by male acquaintances, but she was reluctant to remember whom exactly she was afraid of: "There were men roaming the streets, but who were they... No one bothered us and we didn't bother anyone. Who were they? They didn't bother us..." (Z11Af).

Sometimes, an apparent indifference slipped unnoticed (also for the speaker) into condemnation of the UPA - as a military formation, of the methods they used, or more generally of the entire episode of senseless fighting over lofty ideas that had no real significance for "ordinary people" - "There were young boys fighting, they fought and they died. Now they are all gone" (Z4Af). Such words are only a few steps from open condemnation of the UPA. Other than the exceptions already noted, migrants from the East were unanimous in their negative assessment of the UPA - many of them had been fed scare stories of murderous Banderite gangs before they left for western Ukraine. In their view, the UPA soldiers were Nazi collaborators and, above all, criminals responsible for the murder of innocent people - Russians, Poles and Ukrainians. For these respondents there could be no question of equating the importance of the Red Army with the UPA, whether in moral terms or in the realm of veterans' rights and privileges. They often buttressed their criticisms of the UPA with stories they had heard from locals in the period immediately following the war.

Now people are supposedly saying that the Ukrainians liberated Ukraine themselves, that it was the UPA and all that lot... Well my relatives told me that it was horrific, what happened here. The Banderites murdered people from the East. [...] Those were terrible times. I organized meetings with people fairly often, it was a form of educational work, and people would cry and tell stories about Poles being hideously murdered. There was a Polish village not far from here, where they drove people into a barn, and threw kids into a well, and they burned the whole thing down. And now they claim that it was the Moskals. That's not true! (Z10Af).

Yet Zhovkva's ethnic Poles offered more emotional assessments of the UPA. The main difference between their statements and those of the Easterners was that the Poles still recalled the nationalist militias with fear and dread: they hushed their voices, some requested to speak off the record, and others garnished their stories with sparse detail so that I was unable to identify any individuals therein. 
Unlike the Easterners, the Poles usually spoke of their own, often very traumatic, experiences:

If our people [i.e. Poles] hadn't gone to Poland, if they hadn't been moved over there, they'd have all been killed. My dad's side of the family is almost all in Poland! [cries] Because, just between us, we were living over there at the factory where my dad worked, and the Banderites came and wanted to kill us. [cries] [...] Yes! And now they want to elevate the UPA. The people who were in the UPA, they were in the UPA, but a lot of them [Ukrainians] fought for the Germans! $!^{312}$ They served the Germans, and they murdered us, Poles, you know! [cries] It's true! I remember, and my sister remembers, the day they came to get us. They didn't get us, and we escaped to the second floor, and there was such a solid door that they couldn't do it in. We screamed and screamed, we were still kids. What could we do? Dad wasn't there, it was just our mum and us... [cries] (Z14Af).

Importantly, local Ukrainians from western Ukraine also voiced some negative assessments of the UPA. However, these respondents were even more afraid to voice their opinions than the Poles, and if they did make the decision to open up, they were visibly uncomfortable; for example, the respondent already cited in the previous chapter on Poles (Z23Af) described the murder of a Polish family by a Ukrainian nationalist militia, then concluded that "you don't need to record this, no, it's not necessary." A completely isolated instance is that of a respondent from a Galician village whose views on the past were fully compatible with the memory of the Easterners. A retired police officer is a typical example of a person who benefitted from Soviet social mobility, his desire to discredit the UPA was mixed with a clear dislike of Poles; he was reluctant to speak badly of the Ukrainians in front of a Pole. Asked about his opinion of the UPA, he initially started to passionately declare that it was the Poles who had stoked the flames of conflict during the war, and that the UPA - like the Home Army in Poland - had primarily defended innocent civilians. However, after a short while the tone of his response changed:

God knows what they wanted, I don't know, I never spoke to them. But just consider the fact that I was educated by the Soviet system. Since I was this small, I was a member of the communist party. I was a police detective, I was a major, now I am retired, but I have this thing inside me, this... I believe that no one has right to deprive anyone else of life! Do you agree or not?! [raising his voice] [...] So I am telling you, now they are trying

312 The speaker has in mind the Ukrainians who fought in the "SS Halychyna/Galizien," the $14^{\text {th }}$ Waffen Grenadier Division of the SS, which was created by the Nazis with the participation of volunteers from western Ukraine in April 1943. For the memory of SS Galizien in contemporary Ukraine, see: Khromeychuk, "Undetermined" Ukrainians. 
to make heroes out of all the people who died at the hands of the KGB, they're rehabilitating them, saying they were all repressed. [...] But the people who were killed by the Banderites - no one talks about them, but there were a great many people who died at their hands, tens of thousands! (Z20Am).

The respondent concluded his narration, after a brief pause, with a story about his brother-in-law's Polish relatives who were murdered by the UPA because they refused to leave for Poland. It was nonetheless visible that airing this negative assessment of the UPA in this specific situation - talking to a Pole - was not a simple matter for him, and that it required a certain amount of self-censorship and negation of his own identity. ${ }^{313}$

\section{Pride and Prejudice: Ukrainian Nationalists in Collective Memory}

The younger the respondents, the more positively they spoke of the UPA. With ideas and narratives being sourced not from autobiographical, but from collective memory, responses had diverse shades and hues and used different strategies of argumentation; nonetheless, the common thread was the heroization of the nationalist underground. The majority of members of the middle and youngest generations considered the UPA fighters to have been national heroes. Above all they emphasized their dedication:

I, for one, couldn't imagine being able to leave everything behind, my whole life essentially, and take up arms $[\ldots]$ in those horrific circumstances, under a totalitarian regime. [...] And nevertheless, in those horrific circumstances putting up such serious resistance, and resistance that was completely conscious and directed towards defending your native land against people trying to conquer it, not for the sake of conquering others. That's both the fascists and the Bolsheviks. And they didn't get the better of us neither the Germans, nor the Russians (Z33Bm).

Defenses of the UPA were the more passionate, the more positively the given individual could associate the history of the nationalist underground with their own family history. As David Lowenthal argues, the very function of memory is to transform great historical events into personal experience. ${ }^{314}$ Sometimes this link is almost entirely imagined, as in the case of a respondent who post factum interpreted the evening noises from his grandfather's story as the voices

313 On the modification of narrations because of the nationality of the interviewer, see: Rosenthal and Bar-On, "A biographical case study;" Wylegała, "Badacz z Polski na Ukrainie."

314 Lowenthal, The Past is a Foreign Country. 
of UPA partisans: "Granddad used to tell me about people coming to visit. Under the stairs at our house, there were these noises, they must have been from the insurgents. I think that it could have been the insurgents" (Z4Dm). At other times, the link has a doubly inclusive character - one interviewee from the middle generation seemingly "participated" in the heroic history of the UPA through family remembrances, also simultaneously including all other Ukrainians and creating clear divisions between "us," the supporters of the nationalist militia, and "them" - all enemies.

We had our underground Banderite organizations, and there was the Russian army. At that time they were fighting against each other. He [the respondent's father] used to tell stories about that period all the time, those were tough experiences, and often our Ukrainians had to shelter the insurgents, they risked their lives but they sheltered them anyway, because everyone felt sorry for them. That's what he talked about, all the time (Z6Cf).

Two particular threads of this statement stand out: the speaker's conviction that the nationalist insurrection was universal, and her belief that the UPA soldiers were above all victims. For the creation of national heroes, mere heroism and virtue are insufficient; heroes must also suffer as victims of the highest order, sacrificing their lives and standing out as the heroes of all Ukrainians. Interestingly, vernacular, informal memory mainly reflected the principal tendencies that characterized Ukrainian history after 1991, as noted by the existing scholarly literature. Andrew Wilson, a historian and political scientist researching Ukrainian politics of memory, identifies the myths of resistance and of national rebirth as embodied by the UPA as being among the most important foundational myths of independent Ukrainian historiography. This was combined with its heroization and presentation as a nationwide movement, for example through inflation of the number of participants. ${ }^{315}$ Historian David R. Marples, in turn, notes that victimhood and glorification worked in tandem as inseparable elements of Ukrainian historiography on the nationalist movement. Ukrainian scholar Vasyl Rasevych, meanwhile, draws attention to the centrality of victimhood as an organizing metaphor of national history as a broader characteristic of post-imperial, postcolonial and post-Soviet memory policy in Ukraine. ${ }^{316}$ Although the work of academic historians rarely has a direct, observable effect

315 Wilson, "National history and national identity."

316 Marples, Heroes and Villains; Vasyl Rasevych, "Polityka pamiati i podolannia mizhnatsionalnykh stereotypiv v suchasnii Ukraini," in: Istorychni mify ta stereotypy, ed. Leonid Zashkilniak (Lviv: Instytut Ukrainoznavstva im. Krypiakevycha NAN Ukrainy, 2009), pp. 53-71. 
on the means by which ordinary people remember the past, in this case there is a clear influence. ${ }^{317}$ This is especially visible among the youngest generation, i.e. people who were schooled in post-independence Ukraine, who learned history using textbooks that were conceived in a patriotic vein. It was indeed the youngest residents of Zhovkva who most idealized the UPA, sometimes taking their passion to absurd lengths - like the respondent who stated that there were many Poles in the Ukrainian underground because it was, above all, an antitotalitarian movement: ${ }^{318}$

Poles, for example, a lot of Poles, well, half-Poles, were in the UPA, Jews too... Because they were just defending this specific land... They had this regional way of thinking, they didn't accept that someone would want to deport them somewhere else, expel them, throw them into other living conditions or another way of life. I mean, the point is not that this was an army with a purely national aim. Its aims were more against than for... I mean, the basic idea was that it was anti-totalitarian (Z41Dm).

The people who idealized the UPA protested much more than others against the pressuring of Ukraine by neighboring countries unsatisfied with its memory policies, namely Poland and Russia. In particular, they were critical of the negative comments that arose in Poland in September 2010, after outgoing president Viktor Yushchenko posthumously awarded Stepan Bandera the title of Hero of Ukraine (the highest honor bestowed on citizens for exceptional service to the country). ${ }^{319}$ According to these respondents, Ukraine had a right to honor its own heroes, especially after foreign value systems and foreign heroes had been forced on the country for so long by those very same neighbors that were now expressing criticism.

317 On academic history in this period, see: Stryjek, Jakiej przeszłości potrzebuje przyszłość?; Georgiy Kasianov, “'Nationalized' History: Past Continuous, Present Perfect, Future...," in: A Laboratory of Transnational History. Ukraine and Recent Ukrainian Historiography, ed. Georgiy Kasianov and Philipp Ther (Budapest - New York: Central University Press, 2009), pp. 7-22.

318 This form of argumentation overlaps with the strategy adopted by the Ukrainian Institute of National Memory after 2014, see: Jared McBride, "Ukraine’s Invented a 'Jewish-Ukrainian Nationalist' to Whitewash Its Nazi-era Past," https://www.haaretz. com/opinion/ukraine-nationalists-are-using-a-jew-to-whitewash-their-nazi-erapast-1.5464194, last accessed 8.10.2018.

319 Both official memory in Ukraine and the polarization of collective memory in the country have become more radical since 2014. For one of the most perceptive analyses of Ukrainian memory disputes after 2014, see: Olszański, Wielka dekomunizacja. 
And now they are condemning Bandera because Yushchenko gave him the [title of the] Hero of Ukraine. I would also condemn it, because Bandera doesn't need that Hero of Ukraine at all - better to give it to someone who's still alive. It was completely unnecessary. But I also condemn the fact that Poland and Russia protested. We don't protest when the Russians canonize Tsar Nicholas [II, in 2000]. We don't protest when the Home Army is showered with awards in Poland. We don't protest when the Vlasovites ${ }^{320}$ have all kinds of monuments to them all over the world. That's the historical memory of a certain nation. For our nation, [Bandera] was a hero. And the UPA for us was an army that wanted the independence of Ukraine, that fought for this independence (Z42Cf).

Respondents in Zhovkva who considered the UPA to have been heroes very often felt a need to defend it from supposed accusations. The fact that they were speaking to a Pole almost certainly played a role. Whereas broader nationwide debates treat the collaboration of the UPA (and the auxiliary Ukrainian police during the German occupation, whose members deserted en masse to join the UPA) in the Holocaust as the thorniest question, ${ }^{321}$ my interviewees were fastest to shield the insurgents from accusations of murdering Poles and Ukrainians. ${ }^{322}$ The most frequently offered justification, cited at the beginning of this chapter as a quote from a respondent of the oldest generation, had been filtered through family memory, school education and social norms, and now appeared in the statements of younger people. As one such interviewee put it:

I know that none if it is true, all of what people say about the UPA, that they carried out atrocities, that they were Banderite gangs, all those negative opinions. I know with complete certainty from my grandmother, N., my mother's mother, that it's not true, that they really had a true Ukrainian spirit (Z27Df).

Other voices tried to justify the UPA's actions, rather than to completely dismiss the accusations. A recurring theme was that the wrongdoings of the insurgents

320 The respondent has in mind the Russian Liberation Army, a Russian military formation led by General Andrei Vlasov that collaborated with the Nazis. Informally known as the Vlasovites, this term is often used in the former USSR as well as Poland to denote all Russian, Ukrainian and Belarusian collaborationist militias.

321 Cf. Gabriel N. Finder and Alexander V. Prusin, "Collaboration in Eastern Galicia: The Ukrainian Police and the Holocaust," East European Jewish Affairs, Vol. 34, No. 2 (2004), pp. 95-118; Grzegorz Rossiliński-Liebe, "Ukraińska policja, nacjonalizm i zagłada Żydów w Galicji Wschodniej i na Wołyniu," Zagłada Żydów. Studia i materiały, Vol. 13 (2017), pp. 57-79.

322 David R. Marples discusses at length the Ukrainian debates from the 1990s of the darker sides of the UPA's activities in his aforementioned book Heroes and Villains. As a result of these self-critical debates among Ukrainian intellectuals, the volume Strasti za Banderoiu, edited by Amar, Balynski and Hrytsak was published in 2010. 
should be seen "in the context of wartime," in which different rules applied than in peacetime. In other words, perhaps the UPA was not entirely free of sin, but it fought for Ukraine, its fighters suffered, and so there was plenty of room for forgiveness. "It was wartime. And when there is a war on, negative human characteristics come to the surface, things that are kept in check by the state in times of peace" (Z44Df).

The trope of the Soviet NKVD carrying out crimes disguised as UPA insurgents also appeared in the form of a specific story from the 1940s, involving a group of children who died in consequence of a fire in a village club. Whilst officially the UPA were held responsible, the unofficial version blamed Soviet functionaries working under cover of UPA uniforms. The following statements by a grandmother and her grandson demonstrate the intergenerational interplay of memory:

The fair was in town, there was a film showing. There were lots of children, lots of horseplay... The building was drenched in petrol, and it had a porch... They covered it in petrol, and the children ran away and some got burned. I think one even died. [But who? Who did it?] How should I know? [But you said that they covered it in petrol, right?] It was at night, in the evening. Who did it, we didn't know. How could we know? [Was it the NKVD, or someone else...?] No, no, I think it was our own people, more likely, that's what I think. There were those young lads around, local boys, you know... But what do I know? (Z4Af).

My grandmother told me that one child was killed there. If I understood correctly, there was dancing and other fun. People were dancing, maybe someone took offence or something... And it happened. [But was it the UPA that burned the building down, or was it the NKVD who then said that it was the UPA?] I'm sure that is what happened. There were situations when the Russians disguised themselves as insurgents and pretended to be Ukrainian partisans (Z4Dm).

Neither of these respondents - neither the grandmother nor the grandson knew what had actually happened, but the older woman admitted with some difficulty that "our own people" had probably been settling accounts, whereas the grandson was inclined to believe that it was the NKVD that had carried out the killing - because he had heard of other similar instances. It is not surprising that the two interpretations diverged: the grandmother was a Ukrainian resettled from Poland, whose father was killed by UPA fighters for joining a collective farm; the grandson believed, on the other hand, that there would be no Ukrainian nation today without the activities of the UPA. The woman was still living in fear, afraid to talk about the first post-war years: in her interview with me she mentioned neither the death of her father nor the children who died in the fire (this interview was coincidentally carried out twice, once by myself and 
once by my Ukrainian colleague). She had also never mentioned the incident concerning her father to her grandson. These examples demonstrate the malleability of memory and how often the picture of the past is created ad hoc, as an effect of interaction, depending on whom one is talking to and why.

While accusations of killing "one's own" for the sake of the "greater good" caused difficulties for the interviewees - as evidenced by numerous attempts to justify such events even before a related question had been asked - the collaboration of Ukrainian nationalists with the Germans (in the Ukrainian auxiliary police, and above all, in the SS Galizien division) was much less controversial. People often answered that allies can only be chosen in accordance with the circumstances of a given time. Sometimes this question was dismissed altogether as unimportant, and was raised only later in the course of deflecting other accusations. This is easy to understand given the extremely strong anti-Soviet attitudes that are prevalent in Ukrainian Galicia - both in reality and in memory, the enemy of one's enemy becomes a friend, and collaboration with that friend appears as a lesser evil that is easily justifiable by claiming the national interest.

They had a common goal, to defeat the Soviet Union and the whole of that communist cabal [...] They were fighting for Ukraine, for the independence of Ukraine using all available means, doing whatever it took, doing the inevitable and necessary. [...] And you can only choose your method from those that are available. And you can only look for allies where it might bring some benefit (Z37Cf).

The extreme position taken by interviewees was to argue that the UPA had done nothing other than defending Ukrainians against the Soviets and Germans. This is easy enough to comprehend if the respondent claims that they have simply never really given the question any deeper consideration. It becomes more problematic when people who declare an interest in history cleanse their memories of the darker sides of the UPA's activities. A specific form of ethnocentric memory was observable especially among the middle generation of Zhovkva residents, a form of remembrance that focused above all on the suffering of Ukrainians whilst more or less consciously rejecting information about other groups - especially when those other groups competed with the martyrdom of the Ukrainians. Their perception of the UPA was clearly shaped by "social frames of forgetting."323 The respondents who remembered the past in this selective manner did not only ignore the crimes of the UPA; as a rule, the Polish-Ukrainian conflict and the Holocaust had also never taken place.

323 Hirszowicz and Neymann, "Społeczne ramy niepamięci." 
At least from what I have read in the archives and from what I have heard from eye witnesses - I have not heard even once that, say, the insurgents attacked Ukrainians in some village here or their own village. I don't know anything about that. [And what about the Poles and the Jews?] What do you mean, the Poles and the Jews? (Z33Bm).

Analogous statements act as evidence of the strength of Ukrainian nationalism in its heroic-martyrological vein, an ideology that has dominated the social space of Galicia since 1991 and whose basic fundament is the memory of the UPA. The unfettering of memories that had previously been banned caused a plethora of commemorative activity: plaques and monuments were erected, articles were printed, memoirs were published. Needless to say, most space was given to positive narratives of the UPA, which explains why the respondent cited above may really have never read about the more controversial aspects of the militia's activities in the generally patriotic press. The underpinning of this "fever" of memory is easy to understand. On the one hand, the memory actors who have worked to restore "defrosted" memory after half a century of communist restrictions have tried simply to compensate for previous losses, i.e. to obtain that which was unjustly lost. On the other hand, the two decades of independent Ukraine's existence have been a time during which the actual participants of those historical events have been gradually passing away; they, in turn, are aware that there will soon be no more witnesses and that there will be no more living (autobiographical) memory, or communicative memory, to borrow Jan Assmann's term - and for this reason they are interested in the preservation of the past and its conversion into social memory. There is a clear analogy with what several commentators have called a "memory boom," an era of memorialization in which the elder generation is slowly passing; Jan Assmann has drawn attention to the fact that there was a real interest in the Holocaust in the 1980s, when the youngest survivors who experienced the Holocaust as conscious adults began to enter pension age and pass away. ${ }^{324} \mathrm{~A}$ similar phenomenon was observable in Poland after 1989, when the gradual passing of Home Army veterans and the last residents of the Eastern Borderlands created equivalent explosions of memory. ${ }^{325}$

The fact that a huge majority of the youngest respondents had a positive view of the UPA shows the attractiveness of the memory of the nationalist underground to the younger generations, especially for those born in the 1980s and 1990s. Unlike for the middle generation, family background and biographical

324 Assmann, Cultural memory.

325 See: Lewicka, Psychologia miejsca; Głowacka-Grajper, Transmisja pamięci. 
experience played no role here: there were fierce supporters of the UPA even among the descendants of elders who believed the insurgents had been bandits. This was also true of families with Polish roots: one interviewee (Z9Af) spoke with unconcealed disgust about her son's participation in nationalist rallies in the 1990s; he even brought home a portrait of Stepan Bandera from one of them, and the mother burned the image in secret using the kitchen stove. Neither her son nor her grandson agreed to be interviewed by me, and the woman herself requested that I turn off the recording device when she recounted the story of the burned portrait. Another Polish woman (Z10Af) complained that her grandson had hung a red-and-black UPA battle flag on his wall and was more willing to listen to the stories of his Ukrainian grandfather, who had fought in the UPA, than those of his Polish grandmother. The results are thus unequivocal: the positive image of the nationalist underground is dominant because it can be used to build an attractive identity at both group and individual levels, and that is precisely what young people in Galicia are yearning for. ${ }^{326}$

The few members of the youngest generation who equated the UPA with banditry formed an exception that proved the rule. They were all from Easterner families or from families with Polish backgrounds. Interestingly, they all emphasized that their negative assessment of the nationalist militia was not connected to their own ethnic background, but was the product of a general disagreement with the kind of nationalism represented by the OUN and UPA.

They weren't soldiers, they were just bandits in every way. The UPA was something totally specific, it's another topic. [...] It's as clear as day. Just go to the cemetery, have a look what's going on there, how many soldiers are buried there. That all happened under

326 The results presented here are from the period before 2014, but more recent quantitative studies carried out after the Russian invasion of Crimea show that the demand for a heroic identity are on the rise in Ukraine, see: Anna Wylegała, "Managing the difficult past: Ukrainian collective memory and public debates on history," Nationalities Papers, Vol. 45(5) (2017), pp. 780-797. The broader scholarly literature contains many studies that confirm the importance of positive identity narratives to societies that are in period of crisis or rebuilding - as well as the unimportance of how "objectively" true those narratives are. The case of Israel, for example, shows the importance of "invented tradition" in the process of building a sense of belonging to the "imagined community;" hero myths of the first settlers from the 1920s have been constructed and re-deployed in numerous ways since the war of independence, see: Yael Zerubavel, "The Historic, the Legendary and the Incredible: Invented Tradition and Collective Memory in Israel," in: Commemorations. The Politics of National Identity, ed. John R. Gillis (Princeton: Princeton University Press, 2004), pp. 105-128. 
the sign of the UPA. What is there to say...? I personally have a negative opinion... And I am not ashamed to say so $(\mathrm{Z} 38 \mathrm{Cm})$.

Whilst those who expressed positive assessments of the nationalists were more light-minded in their opinions, the interviewees who were critical were uncompromising and had clearly defined views, often also stating that they were unashamed of their attitudes. Their isolation and even - to a certain extent - sense of being under threat among the UPA-supporting majority was clearly observable in the following statements by a mother and son, who were descended from the family of a Ukrainian resettled from Poland and a Russian soldier.

If only it had been a peaceful struggle... But the way it was, a teacher who came from eastern Ukraine or, say, a young Polish woman who married one of them, they would come the very next day, burn her alive, cut her head off and drown all the family's children in a well. You call those people soldiers? And then they're all like, "it's the Russians' fault, the Russians." Not all Russians did that kind of thing and not all Ukrainians either. And now many of those people, those Ukrainian nationalists, the one who sat in the forest... They're proud of their insurgent past. You know, I can't say the idea they fought for was a bad one, but... (Z16Bf).

When I was small, they called me a Moskal too, the same people who had fought... [...] The people who are now being held up as Ukrainian national heroes, with Stepan Bandera at their head, they were just bandits and murderers. They killed civilians Ukrainians, Poles, Russians - it didn't matter who you were, if you didn't want to fight on their side, against the Soviet army, you were shot on the spot - children, women, old people. My grandmother told me that, she saw it all herself $(\mathrm{Z} 16 \mathrm{Dm})$.

The memories of the children and grandchildren of UPA members, as well as the descendants of their victims, form a separate topic for analysis: in each case, memory is more alive and painful than in the case of people with no such family history. The children and grandchildren of UPA insurgents spoke above all about the difficulties that they had endured, about the fear that dominated in their families and the enforced silence about the nationalist past that resulted from this fear. Testimonies were replete with references to the persecutions that had plagued the families. As one respondent put it: "You know, I've probably inherited it in my genes, that is how these things are passed on after all. And that's why it hurts so much. It's a painful topic for me [cries]" (Z19Cf).

The descendants of victims of the UPA that I managed to reach were mostly children and grandchildren of local Ukrainians and Ukrainians resettled from Poland. Their manner of speaking - as well their stated reasons for refusing to talk to me - still show traces of the post-war terror that was deeply inscribed into their family memories. Some respondents suppressed the deaths of their family members - I learned of these from third parties, for instance in the case of one 
interviewee (Z9Bf) whose uncle and his family, all of whom were Poles, were killed by the UPA during the war. Others said nothing about their murdered relatives because they simply knew nothing about them - such as the respondent from the youngest generation $(\mathrm{Z} 4 \mathrm{Dm})$ whose great-grandfather was killed by the UPA. Two people did agree to talk about this theme in their interviews; however, for diverse reasons they refrained from directly discussing the perpetrators. The first avoided categorical statements as if she was afraid of mentioning the guilty parties by name:

My grandfather was killed in 1947 on the steps of his own house. He went outside and... I don't know what to say, who did it... But then... [So you never found out who did it...?] There were Banderites then, so who knows whether it was the NKVD or the Banderites. They wore each other's uniforms as disguise. Then my grandfather was buried. Two months later, in 1947 as well... the children were called together, there was a free film screening for the children. [...] Then they blocked all the doors, closed it all with wire so that nobody could escape. And they set fire to it, they burned the children alive in front of everyone's eyes. [...] He [the speaker's uncle] was burned, but he made it home with his older brother, my older uncle. [...] The poor boy was in agony for three days before he died. [cries] And now they are being held up as heroes. Who knows what really happened? Heroes! [bitterly] (Z32Cf).

The second testimony was completely different in tone: it bears no similarities to the previous speaker's fragmentary statement, which was regularly interrupted by tears. This interviewee was torn between her belief, inculcated by her family, that the UPA had been responsible for the death of her grandfather and her own personal desire to exculpate the organization. Indeed, she said so herself, completely openly:

Some men came to our house in the evening, and they said: "Collect your things, you're coming with us." And he [the speaker's grandfather] said: "Guys, wait. Where am I going? Have mercy, I have a wife and three small children." They said nothing, just shot him in the head. [But who was it, insurgents or who...? That's a good question, we still don't know for sure. You have to understand, they used to say to us that it was the Banderites. But then it also turned out that the NKVD disguised themselves as Banderites, that is also true. We can't say any more who it really was, whether it was those Banderites after all... But why would they shoot one of their own, a simple peasant, who was neither a communist nor a rich man, nothing? I find that hard to believe. But, of course, we want to believe what we want to believe. We want to be able to say that it was the NKVD disguised as Banderites (Z39Cf).

Like with other historical issues, there were also people in Zhovkva who were indifferent to the issue of the UPA. One young woman argued that from today's perspective, the things that the UPA had fought for were now completely 
irrelevant, especially to younger people - only old people cared - "I don't really have an opinion. That was in the past, I don't see any reason to dig around in things that happened long ago" (Z10Df). However, the basis of this neutrality is only visible in the context of the interview as a whole: this interviewee was one of a substantial number of young people in Zhovkva who were generally indifferent to historical questions, irrespective of the era or specific event.

There were also some young people in Zhovkva who held the UPA to have been an important part of their nation's history but were able to subject it to objective assessment. On the one hand, they admitted that the insurgents had committed crimes, and that they had mistreated Poles; on the other hand, they contested that the UPA had grown above all out of a desire to fight for the nation and its territory, which had always previously been ruled by outsiders. One interviewee concluded her narration with the following statement:

Of course we wanted something for ourselves at last, something purely Ukrainian. And you see - it was precisely the UPA, and Bandera, they wanted something like that, something Ukrainian. I mean, they wanted to separate the Ukrainian nation from the Poles, from Austria, from Russia, from everyone else. [...] That is why it is a difficult truth for us (Z39Cf).

A small number of respondents were fully in favor of the rehabilitation of the UPA whilst also refusing to support the nationalist political movements that built their identities on positive memory of the wartime resistance movement. Many also spoke of a need to carry out objective research on the activities of the UPA - free of any ideology or political movement. As one interviewee put it: "If in the next fifteen years, we don't see a full re-evaluation of the truth of how the UPA is understood, we won't have anything left to study. Because the history of the UPA is so censored, distorted and doctored..." (Z1Cf). ${ }^{327}$

\section{"Liberators" and Liberators - or Two Types of Soviets}

Memories about Soviet power in Zhovkva form both a mirror image and a perfect complement to memories about the UPA. To greatly simplify this complicated picture: in the particular puzzles that comprise the past as seen by the residents of Zhovkva, the heroic UPA needs Soviet criminals, just as much as Soviet liberators would not exist without Ukrainian nationalist traitors.

327 In the context of the present-day (2018) state of research on the UPA in Ukraine, these words have turned out to be prophetic. 
The very description of the Soviet army as "liberators" has a strongly ironic tone when pronounced by the great majority of people in Zhovkva. Almost all of the pre-war locals and their families (both Poles and Ukrainians), as well as some people from families of Ukrainians resettled from Poland, spoke in this way. Respondents discussed the Red Army soldiers who appeared in Zhovkva in 1939 with a biting irony and a condescending pity, describing them as barbarians from a lower rung of civilization - often in a humorous manner. In the context of the narrations that subsequently ensued about the atrocities that the Soviets had committed in occupied Galicia, such statements played an important neutralizing role.

[Mother] remembers them in 1939, when they came to Lviv [...] The women would go out in their night gowns... Mother told me that it was a nightmare, they weren't those Russians who were good masters, who stayed on their land. These were complete vagabonds, such Ivan the Fools [a character from Russian folklore]. Supposedly lots of [people] here greeted them with flowers, they thought at really would give land, like in the slogans of the day... [...] Then, well, it all kicked off. We knew all about it, what it was like in Lviv, and what was going on here. They were occupiers (Z41Bf).

They were so uncultured. We still had a large garden back then, the Moskals hadn't confiscated it yet. We had a big garden, and we grew strawberries and flowers, and just outside our window there was a bakery. [...] And they wouldn't look around at all, they just went through like a battering ram, they just walked through... through the gardens, through the strawberries and wild strawberries, the flowers, that's what they were like... They were terrifying, really terrifying (Z1Af).

The two images here are connected by, on the one hand, a condescending attitude towards eastern barbarism: the characteristic theme of Russian women parading in their night gowns - worn as ordinary dresses - appeared in the testimonies of many people who had lived through the Soviet occupation of former eastern Poland, and can be considered a sort of canonical image, i.e. what Welzer, Moller and Tschuggnall call a "topos of memory,"328 a staple element of collective remembrance. On the other hand, this condescension is combined with fear. The older woman recalling the destruction of her garden spoke of this event with dissatisfaction and irritation, but also lowered her voice towards the end of the phrase and described the Soviets as "terrifying."

It should be noted, however, that a sense of superiority over the Soviets appeared only in statements by people originally from Zhovkva and other towns; it was less ethnic in character than cultural and class-based. This was the 
superiority of the urban middle class over the vulgarity of a peasant in uniform. Residents of Zhovkva who had moved from rural areas, whether from villages near Zhovkva or in today's Poland, often spoke about the Soviets with distaste, but never with condescension. Among interviewees originally from Galicia, a conviction that the arrival of the Red Army was a joyful event that brought positive change was completely exceptional. One woman, born in a village near Zhovkva, spoke very emotionally about the events of September 1939:

And then it was 1939, the liberation of 17 September. [...] And I have it etched into my memory, you know, those stables [that belonged to the Polish landowners] were all decorated in white, and people were so moved to start with. Some said that it was the liberation of Ukraine, that Ukraine would be Soviet now, independent and sovereign. People were so pleased that they set up a stage, and arranged a concert, I even recited a little verse, and there were artists from as far as Lviv (Z23Af).

This interviewee was the only member of the oldest generation from Galicia who used the term "liberation" [Ukr. zvilnennia] to describe the Soviet invasion. Everyone else preferred more down-to-earth words such as "arrived," "invaded," "entered," etc. The lofty idea of "liberation" was characteristic of people who migrated to Zhovkva from the East, who also frequently spoke of the "unification" of western Ukraine with the Ukrainian SSR (or with "Great" Ukraine, the motherland). Interestingly, the phrase "unification" often appeared in a completely unreflexive manner in statements by members of the middle generation, irrespective of their family background and their individual attitudes to the Soviet legacy. Like the expressions "return to Poland" and "Recovered Territories" in the Krzyż testimonies, such usage shows the astonishing extent to which propaganda clichés infiltrated the thinking of people who grew up in the communist era. The word "unification" had completely different connotations when spoken by the oldest Easterners in Zhovkva and their family members; they were convinced to this day that the Red Army had invaded the territory of Poland in order to protect it from the Germans. The respondent cited below was exceptional amongst the youngest generation, but similar statements were made by almost all of the Easterners and many of their children - they all justified the Soviet aggression.

No, they weren't invaders. They came here in 1939 in order to deploy troops in western Ukraine because it was 30 kilometres to the border, in case a war broke out. Although Stalin gave assurances that there would be no war, that the Germans wouldn't dare attack the Soviet Union. [...] And that is why Soviet power came here. It was a special strategic manoeuvre, to prevent the war (Z16Dm). 
One of the most important events in relation to memory about the Soviets is the massacre in the Zhovkva prison that was carried out shortly before the Soviet retreat from the town in 1941. Almost all of the respondents knew about it and remembered it (with the exception of a very few older people who migrated from the East and individuals from the youngest generation who declared no interest whatsoever in local history), and it was clear that this event had become a central pillar of the town's history thanks to commemorative acts in the 1990s; no one could remain indifferent. Among the most passionate statements were those by individuals who had witnessed the macabre discovery of human remains in Zhovkva castle and people who participated in the spontaneous demonstrations and commemorations that followed - these have now become important "memory events" in the local memoryscape: ${ }^{329}$

It happened when the Russians were leaving here. On their way out, they murdered those people, right at the end, and two days later the Germans arrived. It was, well, a real nightmare, seeing those things. Were they such activists, those people, that it was necessary to break their arms, cut off their heads and bore out their eyes? Because that is what they did, it was completely inhumane, do you get what I am saying? It was horrific [with voice raised] (Z31Am).

People who were resettled to Zhovkva were also aware of the NKVD killings; they mentioned repeatedly that locals had told them about the massacre after they had arrived. For understandable reasons, they discussed this topic in less detail, with the prison murders sometimes overlapping with other crimes committed by the NKVD that were discovered in the 1990s. They did, however, condemn the Soviet atrocities in similarly harsh terms to the autochthonous residents. The murders of the prisoners were also discussed by younger people, especially those who at the beginning of the 1990s, during the most heated period of the "memory boom," were young adults who actively became involved in the restoration of local memory.

There were meetings where we discussed the events and showed photographs, to see what it was like. Around 18 to 20 people were killed then - it was awful. One woman had her skin peeled off and was hanging upside down. My dad... My dad worked with

329 Uilleam Blacker and Alexander Etkind define "memory events" as "acts of revisiting the past that create ruptures with its established cultural meanings," see: Uilleam Blacker and Alexander Etkind, Memory and Theory in Eastern Europe, ed. Uilleam Blacker, Alexander Etkind and Julie Fedor (New York: Palgrave Macmillan, 2013), pp. 1-24. 
an electrician whose grandmother was killed there. Do you know how many were murdered...? They included women... ( $\mathrm{Z} 5 \mathrm{Cm})$.

This fragment is important not only because of the emotions contained therein: here, the man recalls conversations between his father and the grandson of one of the victims, which, in all probability, were his first source of information about the event. This shows once again how important direct contact between locals and new arrivals was in the first post-war years, as well as the extent to which such contacts created a divide between those who remained "deaf and blind" to the town's past and those who gained knowledge of key events. It is unlikely that the autochthonous residents would have discussed the NKVD massacre with the wives of party functionaries.

Interviewees with a positive opinion of the Red Army spoke in an especially compelling manner about the prison murders. None of them openly negated it, but most did make covert attempts to mask the event or to cast doubt on its authenticity, showing clear irritation.

[Have you heard about the massacre in the prison?] I don't know. To be honest, I can tell you that... Here we have a cemetery for people who were killed by the nationalists, it's a cemetery, they call it the military one. And there is a similar cemetery for soldiers of the UPA, so... [...] There was a home for invalids here [...], and there was a woman who worked there, I knew her pretty well, and she told me that there were some shootings here, and something was up... There was some kind of operation... [But what shootings...? Who did the shooting?] Well, it was... the NKVD that did the shooting. But how they did it, where... I never really asked about that, I don't find that [of any interest $] \ldots$ (Z38Cm).

The interviewees who made such statements had in common a hardly concealable unwillingness to talk about the crimes committed by the NKVD in Zhovkva. One woman from central Ukraine (Z10Af) expressed surprise that she had not heard about the massacre from her mother-in-law, who was from Zhovkva; and since she had not heard anything, perhaps it had not really happened after all? Considering her testimony as a whole, it seems entirely plausible that her Galician mother-in-law had indeed never discussed such matters with her - as the respondent herself noted, the mother-in-law considered her a Moskal and their relations were generally tense. The man cited above answered the question about the prison massacre in a very chaotic manner, intermixing stories about the victims of the UPA whose remains lay nearby the site of the prison - as if to compensate for the Soviet murders. He repeatedly equivocated with phrases such as "some kind of" or "somewhere," giving the whole affair an air of vagueness and unverifiability. The reasons for such a way of speaking are understandable enough: admitting that the Soviet authorities were guilty of crimes 
against the Ukrainian nationalists is difficult because it would mean that the UPA, whom they despise, would gain the status not only of heroes, but also of martyrs.

Another important moment in the memory of the Soviets is the end of the war, when the Germans retreated from Zhovkva and the Red Army took the town. Many respondents of Galician origin remembered their initial joy at the arrival of the Red Army. Unlike in their accounts of 1939, they described the return of the Soviet military as "liberation" in complete earnest, with no irony. Nonetheless, interviewees were also unanimous in their belief that this joy was short-lived, and they quickly transitioned to memories of the "old new order" that the Soviets began to reinstate: deportations and more mass murders, some of which were only uncovered in the 1990s.

Once they were done with the Jews, the Moskals arrived. And our people were so happy: "The Moskals are here!". [...] But then the Moskals started to oppress us! How many of our people were killed... [...] Even in the church, you know, how many of our church people were murdered? Awful! [...] Even the Germans took people to labor, and when people came back, they said that had even sent some money, the people whom they worked for, yes. And if they wanted, they were allowed to go abroad. Nothing like that with [the Russians]! (Z35Af).

This fragment demonstrates the high importance of comparison with the Germans as an element of memory of the Soviets in Zhovkva; and in this evaluation, it is the Germans who come out more favorably. This theme was also present in a large proportion of interviews with younger residents, some of whom even reduced the German occupation to a near-non-event.

Some people will tell you that when the Soviets came, they liberated us Ukrainians. That's not true, it's all lies. Quite on the contrary, they oppressed the Ukrainians and the local people had to hide and live in fear when the Soviets came, the Soviet army. But when the Germans came, it was the opposite. They were happy, because the Germans were polite and humane to our people (Z27Df).

This statement shows a specific characteristic of social memory in western Ukraine - similar statements would never be heard from someone who had lived through the German occupation in central or eastern Ukraine, where the Nazi occupation was incomparably more brutal. ${ }^{330}$ Individuals from mixed family backgrounds would also be unlikely to relativize the harshness of the

330 For the different realities of German occupation in western and eastern Ukraine, see: Karel C. Berkhoff, Harvest of Despair: Life and Death in Ukraine under Nazi Rule (Cambridge: Cambridge University Press, 2004). 
German occupation. This is only characteristic of a particular group of western Ukrainians with strong anti-Soviet attitudes, many of whom have relatives who fought in the UPA. They were most likely to express a belief that the reappearance of the Red Army in Zhovkva was no liberation, but simply an act of invasion and occupation.

\section{Stalinism, Stabilization, Veterans: Memories of Soviet Zhovkva}

Memory of the Soviet regime in the first post-war years was dominated by the terror that engulfed practically every aspect of everyday life. With very few exceptions - mostly the wives of Soviet officers, who enclosed themselves in a communist party ghetto and were untroubled by contacts with locals and their lowly world - and to similar extents, all of the oldest respondents remembered the post-war years as difficult times. The main differences were in emphasis, in terms of where the accents were placed in judgements of perpetrators and victims. For the Easterners who most ardently sympathized with Soviet power, the Soviet pioneers had been the victims of Ukrainian nationalist gangs; in contrast, for the locals, the Soviets had carried out massacres of the local population. Younger respondents from Easterner families gave more balanced replies, discussing the post-war terror with regret; nonetheless, they clearly tried to differentiate levels of responsibility, for example by arguing that it was the NKVD that had carried out the persecutions, not the rank-and-file of the Red Army. In other words, they were arguing along the lines: my father, who was a Red Army soldier, had nothing to do with it.

Well that is what happened. Both sides killed. What do you think happened to those young nationalist boys who were killed, eh...? Wasn't it the case that they were tied to trees by the police station, young twenty-year old boys and a young lady who carried food out to them? [...] Was that a humane way to do it? [...] The KGB did that, not soldiers, but the KGB - that was the punitive organ of the state, they were crazy when it came to politics, just kill, destroy, they're not people, so kill them, destroy them like the others... You see, the KGB men, they were fighting against the Banderites, and the Ukrainians were fighting against all the Russians and the KGB (Z16Bf).

It also happened that Easterners in Zhovkva found it hard to unequivocally identify perpetrators and victims, or "good" and "bad" people. On the one hand, they were able to understand the tragedy of the local population, whilst on the other, they were convinced that in the bigger picture the Soviet system had been generally beneficial. Moreover, they struggled to come to terms with the way migrants who had been sent to Galicia from the East had been treated. However, people from the families of locals and Ukrainians resettled from Poland did not have any 
difficulty giving a clear assessment of the Stalinist era in Zhovkva. They were all critical in their evaluations, although there was some variation in how strongly they condemned it. In some cases these accounts had humorous elements, which were strikingly similar to the description of the "barbarian invasions" in 1939. The difference was that, whilst the barbarians of 1939 had only stayed for two years, the post-war era of Soviet rule had lasted for most of the interviewees' adult lives.

We had nothing to do with the military. Although, once we had moved in here, it was quiet to begin with, but then the invasions started and people started stealing potatoes from the mounds. [Who did that?!] The Russian army. They put the wheelbarrow down, there was a little mound about 100 metres from the house, and... off they went to find potatoes! Once they came in the middle of the night, they stole some things, took some clothes, you know. Why would they... A great army [with anger]! (Z6Am).

The most strident criticisms were voiced by individuals whose families had suffered during the terror, regardless of their backgrounds (although most were locally born Ukrainians). The Soviet government in Stalinist times was, according to these speakers, responsible for crimes and killings not only against Ukrainians, but also against other ethnic groups. Indirectly, it was also responsible for the negative consequences that continue to affect independent Ukraine and its residents. The following statements of a mother and a daughter show the cultivation of such memories within a family:

The Soviet government destroyed all of the nationalists, the entire clergy, all of the priests, the doctors, all of the best people. Not only here; it also destroyed [them] in Russia. It destroyed [them] everywhere. What remained was common folk, you know, how to put this, well, common folk. They don't need to read books, or have any interests. They wake up, eat a piece of bread, have some soup, eat something - that is the kind of people who are left here. That's why Ukraine is in such a mess now (Z19Af).

I'm completely, what's the word... For example, I don't recognize the Soviet army. I grew up with that, it shaped my upbringing, but now I don't recognize it. It's nothing to do with me. [Why?] [...] They just destroyed the people, they decimated the people - that's why I have no respect for them. None at all (Z19Cf).

Whilst condemnation of the crimes of Stalinism was universal, almost all respondents clearly differentiated the Stalinist period from the later decades of Thaw and stabilization. People who lived relatively well in Soviet times spoke firstly, with great compassion, of the mass murders of Stalinist times, before smoothly moving on to a positive appraisal of the communist system per se. Many interviewees spared no effort to argue that the idea of communism had been a good one, although it had been abused. Older respondents originally from the 
East were most likely to praise communism; some locals who had moved up the social ladder also voiced approval. In many cases, the latter openly admitted that they owed all of their achievements in life to the Soviet regime. Their responses varied in their level of cynicism, but they all had a common thread: the crimes of communism were inexcusable, but the Soviet system itself was not at fault.

I don't know who I would be now if we had been in Poland. So I can't say that the Soviet Union was all that bad. [...] You see, under Soviet rule, I, a simple human being, a poor person with poor parents, I had an opportunity to study and to have a career. No one persecuted me, no one did anything bad... [...] We were all the same. And relations were normal. All local people could go to university, they could study and work, they received a pension, they lived and built their houses. To begin with it was difficult in the kolkhoz. It was tough, and there were some wild times after the war. But afterwards it became better with every passing year (Z20Am).

Two issues that appear in this quotation deserve commentary. First, the nostalgic assertion that "we were all the same." This phrase clearly demonstrates a yearning for a time when loyalty and moderation guaranteed social security, if not necessarily material abundance. This specific economic nostalgia for the USSR was equally present (if not, indeed, more so) in conversations with representatives of the middle generation, i.e. with people who did not personally experience the challenges of building a new world in the post-war years, but who had a very clear memory of the relative comfort of the Brezhnev era. Their testimonies frequently featured comparisons between the orderliness of those times and the chaos of post-independence Ukraine. The son of the man cited above $(\mathrm{Z} 20 \mathrm{Cm})$ remembered bitterly that in his own youth, the state had provided childcare, whereas his children were being forced to spend their afternoons on the streets. When he claimed that the Soviet regime had done no harm to local people in Zhovkva, I asked him about deportations to Siberia in the post-war years. His reply was that the Stalinist period was a different era to that in which he had lived.

Idealization of one's youth - even if that youth was spent in times of war and occupation - is easy to understand, and is encountered frequently in studies of individual autobiographies. In the case of Zhovkva's residents, this is a surprising phenomenon when a positive attitude to Soviet rule appears in people whose families were persecuted by the Soviets.

That's what those times were like, yes. But when people come to me and say the Moskals did this or that, I tell them: "I have nothing to say about that, they didn't do anything bad to me or my family." I mean, to me, my mother and her kids. [...] [But, in spite of everything, it was the Soviet regime that took away the men in your family, wasn't it?] Yes, yes, I already said that, that it was in the first period, when collectivization was underway. 
[But afterwards it was OK?] Later - yes. You see, I went to study, no one persecuted us. I came here, I was allocated an apartment, I educated my children, and no one charged me any money for it like they do today (Z10Af).

The roots of this attitude are very complex. On the one hand, part of this woman's family had died in the 1930s during collectivization (she hailed from central Ukraine) and she spoke about this past openly. On the other hand, she had been loyal to the ruling regime for all of her later life and was convinced of the correctness of this stance (working in the community library in Zhovkva, she conducted so-called educational work with the local population). At home her family never discussed the persecutions that had beset them the speaker's daughter only found out about the fate of her great grandparents after 1991, and her granddaughter was to this day unaware of those events. These contradictions are partly explained by a consideration of the respondent's broader biography. The main axis around which her testimony revolved was the war, especially the atrocities committed by the Germans - against this background, the persecution of her kulak grandparents and the post-war famine appeared to her as minor aberrations. In her account, the Germans appear as savage beasts, whereas the Red Army and the Soviet authorities emerge as the force that defeated Nazism - and, therefore, they deserve our gratitude. Such an entanglement of identity and autobiography is fairly typical for a particular group of residents who migrated from central and eastern Ukraine, and whose relatives were persecuted by the Soviet security forces. ${ }^{331}$ The autobiographical narratives of such individuals featured a dominant theme that they themselves had not been harmed by the Soviet regime; on the contrary, it was thanks to the victory of the Red Army over the Germans that they had escaped a terrible fate they owed their lives and livelihoods to the Soviets. For this reason, the fate of the persecuted relatives had to be erased from memory, or, as in this particular instance, it had to function in a parallel but less significant autobiographical space.

This separation of experiences also filters through, seemingly imperceptibly, to the younger generations; it was not only the daughter of the above respondent who voiced similar views, but also several other members of this cohort.

331 I analyze this problem in an article on autobiographical memories among Poles from central Ukraine, see: Anna Wylegała, "Negacja, separacja, marginalność. Represje i wojna w narracjach biograficznych najstarszego pokolenia Polaków z Żytomierszczyzny, Kijowszczyzny i Podola,' Studia Socjologiczne, Vol. 4(199) (2010), pp. 144-170. 
One such person, from a family of Russians who settled in Galicia after the war, spoke at length about the near-death of his grandmother as a result of famine and the persecution she had suffered at the hands of the Soviet security apparatus. However, he finished with the words "But we didn't suffer, no, not at the hands of the UPA, not anyone else. No one persecuted us, I completed my school education without any issues, that was in a Russian school..." (Z38Cm). In the middle generation of Zhovkva residents, it appears that internalization of gratitude towards the Soviet regime at the expense of a part of one's own identity has flourished, thanks in part to people becoming socialized in totalitarian conditions.

The opposite approach to Soviet rule was a clear disapproval of the communist regime as a whole: condemnation of the aggression of 1939 and the Stalinist terror, as well as criticism of the Soviet system per se. Such attitudes were encountered mainly among people from local families or among Ukrainians resettled from Poland, who had suffered as a result of the Soviet rule. The memories of Soviet-sanctioned injury that were cultivated at home - in the close family circle, among neighbors or in the larger neighborhood community - resulted in clear anti-Soviet and anti-communist attitudes being voiced by subsequent generations. As a young respondent from a family that had been deported to Siberia during the war put it: "On the whole, our attitude to Soviet rule was always, so to speak, negative. What I mean is, it was always clear that we were against all that" (Z45Dm). Sometimes respondents admitted that they had reached these attitudes gradually - especially people from the middle generation, who grew up in communist times.

At home we talked all the time [...], they [the speaker's parents] definitely remained as dissidents, they were against the regime. [...] I used to think that after all of those camps, they had simply got messed up, that they were prejudiced against the system, and that all those things they were saying could not be true. They told me one thing in school and something completely different at home. Later I came to understand that my parents were right. It was difficult to believe that those things had really happened. If you, as a child, had had all those things rammed into your head, to put it an unpleasant way... [...] But it really happened, I understood eventually. It just took a while to recognize that it was the truth (Z41Bf).

One of the most interesting and complex issues of memory is the evaluation of regular soldiers of the Red Army. Other than residents with the most ardent anti-Soviet views, most people expressed a certain respect for the rank-and-file soldiers, as people who had experienced a great deal and were not involved in the atrocities of the Stalinist era. According to Andrii Portnov, a tendency to emphasize the heroism and suffering of ordinary people whilst also accenting the errors 
and crimes of the Soviet system is a very characteristic feature of contemporary Ukrainian memory of the Second World War. ${ }^{332}$ To simplify, this interpretation can be summarized in a single phrase: condemn the system but sympathize with the people. Such an attitude also applied to those respondents who held the UPA to be heroes whilst generally being critical of the Soviet legacy: "Well veterans, veterans had their difficulties too. [...] So in my opinion, everyone who lived through that hell deserves respect" (Z6Cf).

Of course, it was older residents originally from the East and their families who expressed the most respect for Red Army veterans. In their eyes, the soldiers had defeated Nazism, the greatest evil. A reliable indicator of an individual's attitude to the Red Army is their participation in commemoration practices, especially Victory Day celebrations - both today and in the past. The oldest Easterners spoke with great emotion about the 9 May commemorations and their protagonists. Ukrainians with a more ethnocentric view of history were more likely to consider this holiday a foreign imposition. With all due respect for the Soviet soldiers, they treated this Soviet ritual with contempt and mild mockery. In accounts of their lives before 1991, many people described their attendence in marches and demonstrations as reluctant but necessary. Asked about the status of Victory Day in independent Ukraine, one interviewee replied: "9 May? Everyone sits on their allotment. They celebrate the Day of the Potato" (Z41Dm).

A large proportion of respondents argued that the veterans deserved respect above all because they had defeated the Germans, even if that victory had come at a cost. Interestingly, one of the most graphic and outspoken statements to this effect was voiced by one of the youngest interviewees, who reacted passionately against the recent re-evaluations of the role of the Red Army in the Second World War:

You need to understand that many people who fought on the side of the Soviet army weren't somehow evil or anything like that. They were just fighting for an idea. It's thanks to them that we are living here, because who knows what would have happened if the Germans had decided to wipe this town off the map and plant a forest here? They could have put two little huts here for two Germans to live in (Z11Dm).

People who clearly divided the Red Army soldiers from the functionaries of the Soviet security apparatus disagreed very strongly with the post-1991 tendency to devalue the contribution of ordinary soldiers, as well as to describe them alongside the NKVD, Komsomol and Party enthusiasts - using derogatory terms such as "Russkies" or the "Reds." Especially those residents whose fathers and

332 Portnow, “'Wielka Wojna Ojczyźniana.” 
grandfathers had fought on the front line (as in the example of the man cited above) spoke not so much with anger, but with disappointment.

\section{Heroes and Traitors: Summary}

In Zhovkva, local memories of the UPA and the Soviets as heroes/anti-heroes complement each other. Whenever the conversation turned to the Red Army, it was very often the case that the interview would come full circle and return to the UPA. For many respondents, a rational assessment of the two sides remained possible, when talking about one in isolation; when veterans of both military formations crossed unexpectedly in the course of a narration, the speaker often reacted with consternation or strongly negative emotions. This was especially true among older people, members of the post-Soviet community of memory, ${ }^{333}$ for whom the very thought of measuring the Red Army and the UPA with the same yardstick was an assault on the basic essence of their worldview. This issue is still very topical in Ukraine, to the extent that since the presidential term of Viktor Yushchenko, debates have raged on whether to endow veterans of the UPA with the same rights as Red Army veterans - not only in the symbolic realm, but also (and for some, above all) in the material realm. This discussion, which was still unresolved at the time of the interviews, ${ }^{334}$ aroused great passion among residents of Zhovkva. The material analyzed in this chapter shows a clear division of respondents into two memory groups, for whom the roles of heroes and villains are played differentially by the same actors. The borders of membership within these groups run across the generations. The larger memory group, which we can call "patriotic," comprised some of the oldest generation (those from Zhovkva and Galicia), most of the middle generation and almost all of the youngest generation. As a form of memory it is "on the attack," on the ideological offensive: having been suppressed throughout the Soviet period, it has now been rehabilitated and raised to the status of an official discourse. It was representatives of this group who formed the symbolic landscape of Zhovkva after 1991, and who defined the borders of the symbolic domains: ${ }^{335}$ they decided what monuments to erect,

333 In the aftermath of the Russian invasion of 2014, we could use the phrase: members of the imagined community of the "Russian world" [Russkii mir].

334 As of 2018, UPA veterans have still not received formal recognition as "war veterans" at the state level. The issue is delegated to regional [oblast] authorities, which especially in the west of the country have recognized a number of additional financial benefits to supplemment the basic pensions of former UPA fighters.

335 Nijakowski, Domeny symboliczne. 
whose names would adorn the town's streets, and - at the nationwide level - which version of history would be enshrined in school textbooks. This last factor is especially important because of its influence on socialization; it goes a long way towards explaining the near-total hold of positive memory of the UPA among the youngest respondents, as well as their distaste for the Soviet legacy.

The second group, which is much smaller but also has more clearly defined views, is the post-Soviet memory group, whose members retained the Soviet attitude to the UPA and Soviet rule, albeit with a somewhat different emphasis. This group consists of Zhovkva residents originally from the East and their descendants, the oldest Poles and Poles of the middle generation, as well as select individuals from different generations - whose life experiences were conducive to a negative assessment of the Ukrainian nationalist underground. This group has a marginal voice in the public sphere, where the new discourse of heroism and martyrdom is dominant. ${ }^{336}$ This form of memory is "in retreat," and full of bitterness because of its loss of the dominant position within Ukrainian society and a sense of unwarranted injury.

Interviewees who did not fit into either of these categories - who, in terms of sheer numbers, could have comprised a third group - did not have in common a vision of the past that differed from the two main narratives, but a specific attitude to the very past. They were generally indifferent to the debate on the UPA and the Soviets that divided the Ukrainian society, and careful in the views that they did articulate. This stance appears to have two sources. One section of interviewees - many of whom were Ukrainians resettled from Poland - avoided making clear evaluations out of fear: the same fear that they had previously felt when confronted with Ukrainian militias and/or the Soviet system, as well as a fear encountered today, as a result of being in opposition to the dominant vision of the past. For this group, none of the fighting factions had the status of a hero, thus it was preferable to stay on the sidelines of the current debates. The memory philosophy of this group might be summarized as follows: one side was bad, and the other was not good. The following summarizing statement describing the war demonstrates this attitude very well:

336 On memories of the Soviet past in Ukraine in the realm of memory policy (before 2014), see: Oxana Shevel, "Memories of the Past and Visions of the Future. Remembering the Soviet Era and Its End in Ukraine," in: Twenty Years After Communism. The Politics of Memory and Commemoration, ed. Michael Bernhard and Jan Kubik (OxfordNew York: Oxford University Press, 2014), pp. 146-167. 
The people who brought order [after the arrival of the Red Army in 1944], the KGB, the Red Army officers, had several names... They were terrifying. And so were the Ukrainian partisans. Those were tough times. But if you survived, you survived (Z15Am).

Meanwhile, other representatives of this group - mostly from the youngest cohort, simply claimed to have no interest in the past, irrespective of the particular aspect that was being discussed.

The memory groups of Zhovkva are quietly in a state of undeclared war: their members accuse each other of falsifying history and imposing a "single correct version" - both now and in the past. This war has periods in which hostilities are more heated and periods of relative calm, but it has been ongoing since 1991; as the Kyiv-based historian Vladyslav Hrynevych has noted, it is a merciless war over myths that is no less fierce than the armed confrontation between the Soviet army and the UPA. ${ }^{337}$ Paradoxically, the group that is more determined to advance its interests is the smaller one, the post-Soviet group. Perhaps a sense of living in a besieged fortress increases their energy and desire to go on the attack. The patriotic memory group is less vehement in its opposition to the other side, showing more understanding by making allowances for certain nuances. A sense of their currently favorable position is no doubt a factor, but this mildness in relation to the post-Soviet side is also a result of other factors. As much as Galician Ukrainians with anti-Soviet sympathies would like to believe otherwise, service in the Red Army was a much more common phenomenon in Galicia than participation in the UPA - not least because of conscription by the Soviet authorities. In a great many families that were far from being supporters of the new regime, men of conscription age joined the Soviet army. Even if this part of one's family history is now unlikely to be enthusiastically displayed, it can still significantly influence an individual's attitude to the Red Army as a collective of ordinary soldiers.

A different issue altogether is the permissive, and in some cases even nostalgic, attitude to the Soviet system as a whole that appears especially in interviews with the middle generation. As Vladimir Kravchenko, Ukrainian-Canadian scholar, argues, Soviet mentalities and official Soviet attitudes to questions of history were internalized by the residents of Ukraine to a much greater extent than anyone could suppose - such that after the collapse of the USSR, it was impossible to enact a state policy of complete separation from the Soviet heritage in Ukraine,

337 Hrynevych, "Mit viiny.;" Vladyslav Hrynevych, "Gespaltene Erinnerung. Der Zweite Weltkrieg im ukrainischen Gedenken,” Osteuropa, Vol. 4-5 (2005), pp. 88-102. 
in contrast for example to the Baltic states. ${ }^{338}$ Even though western Ukraine was under Soviet rule for a shorter period than the eastern half of the country, for a majority of the middle generation the formative years that they spent living under the communist system still play an important role in their evaluation of the Soviet legacy.

The generational distribution of memory in Zhovkva leads one to conclude that the patriotic memory group has the better chance of establishing its vision of the past as the dominant master narrative. Referring to Hrynevych again: it was this faction that won one of the key battles in the memory war, when it succeeded in having its version of events enshrined in school textbooks and the history curriculum. Whereas the post-Soviet memory group is comprised mainly of older people and members of the middle generation, young people in Zhovkva were nearly unanimous in their belief that the UPA were heroes; they spoke about the Red Army with understanding at best, even if the older members of their own families remembered the Soviet military in much rosier hues. Not a single young respondent used the phrase "Great Patriotic War," a staple term of the Soviet memory lexicon, although some of their parents and grandparents did. ${ }^{339}$ There were also practically no instances of Soviet nostalgia, a fact that harmonizes with the results of available quantitative survey work. ${ }^{340}$ This shows the ineffectuality of family transmission of memory, and also, above all, demonstrates how attractive and socially powerful a positive memory of the UPA is in today's western Ukraine - as a memory on which it is possible to build a strong group identity in opposition to the Soviet legacy.

338 Vladimir Kravchenko, "Boi s tieniu: sovietskoie proshloie w istoricheskoi pamiati sovremennogo ukrainskogo obshchestva," Ab Imperio, Vol. 2 (2004), pp. 329-368.

339 During the presidency of Viktor Yanukovych in 2010-2014, this term was again employed in school textbooks.

340 Olena Nikolayenko, "Contextual effects on historical memory: Soviet nostalgia among post-Soviet adolescents," Communist and Post-Communist Studies, No. 41 (2008), pp. 243-259. Only $8.2 \%$ of respondents in Lviv were dissatisfied with the collapse of the USSR, in contrast to a figure of more than $30 \%$ for Ukraine as a whole. 


\section{A Land Without Heroes: Problems of the Memory Canon in Krzyż}

\section{Good Russians and Bad Russians: Autobiographical Memory}

In contrast to the heated debates in Zhovkva about who should fill the role of the collective hero, Krzyz is rather a town with no heroes at all - there is no local conflict that complicates relations, but there is also no source of common pride that bonds residents together. The only shared memory that came across from the interviews was an anti-hero: the Soviets as they left the town in 1945. Of course, a number of specific nuances characterized the memories of today's residents. Two asymmetrical themes can be identified: one mocking and the other serious. Statements in the mocking vein were very similar to analogous statements about the barbarity of the Soviets in Zhovkva, as well as stories told by eastern Poles about the Soviet aggression of 1939. Often, narrations about the Soviet invasion of eastern Poland in 1939 flowed seamlessly into stories about the Soviet presence in Krzyż - the "repatriates" made obvious comparisons. In both cases, speakers mocked the Soviets mercilessly, for example in recurring anecdotes about Russkies buying watches or about the dress choices of the wives of Soviet officers. A similar intent is observable in the following description of Soviet soldiers looting a German homestead:

And the Russkies said: "we won you such nice houses" [quoted in broken Russian: $M y$ vam zavoiovali takie horoshie doma], in that way that they speak, "and we are going back to the kolkhoz." They said they envied us, that we would have it too good here [laughter]. You know, there were these feather blankets in the houses that the Germans had left, and they [the Russians] took those feathers, they emptied them out into a big pile, bundled them up and wanted to take them back to Russia. We just stood there watching! Then they decided to burn the feathers, but they didn't want to catch fire, the wind kept blowing it out, and they weren't sober I tell you, that was obvious (K20Af).

The function of such accounts appears to be similar in both Zhovkva and Krzyż. The mocking element of remembrance plays a supplementary role, mollifying the predominantly negative experience of contact with the Soviets - the same can be of said of the Zhovkva interviews. Nonetheless, the central axis around which most accounts revolved was a memory of fear and being threatened both for the eastern Poles and for other migrant groups. Paradoxically, it was Poles not from the pre-war eastern provinces who spoke of the Soviets with the greatest dread - people from Wielkopolska, central Poland and the neighboring 
areas "across the river." The migrants from the East sometimes gave the impression that, after the experience of two Soviet occupations in their eastern former homelands, the Red Army's actions in the "foreign" "Recovered Territories" had had little impact on them. It was also noticeable that memories of the Soviet presence in Krzyż were being arranged according to a scheme approximate to Polish and Ukrainian narratives of the Soviet invasion of interwar eastern Poland: recurring elements (a topoi of memory of a sort ${ }^{341}$ ) included the initial joy at liberation, perception of the Soviets as barbarians, accounts of a feeling of being personally threatened, and ubiquitous terror. In relation to the Soviets in Krzyż, however, all of these elements appeared less distinctly: they were weaker and represented on a smaller scale. No one remembered genuine joy at liberation, unlike in testimonies from the East; people from Wielkopolska and central Poland quickly became convinced that the Red Army heralded little good news. $^{342}$

They were welcomed as liberators [sneering]. A car came to this market square, and people greeted it with flowers. That's what it was like, a celebration. [...] They were greeted with flowers. But people only realized later who had really arrived. When they started to make arrests and rape people... (K11Am).

Memories of the post-war presence of the Soviets in Krzyż can be divided into several distinct sections. Perhaps the most drastic memories belonged to interviewees of the second generation who hailed from Wielkopolska and central Poland, and who had no autobiographical memories of the atrocities of war. For them, the encounter with the brutal behavior of the Red Army in the "liberated" Polish and German territories was often the first consciously experienced episode of violence, and it was heavily foregrounded in their testimonies. That is not to say that children from eastern families were less sensitive to Soviet violence; however, for these people the most formative childhood experience was resettlement, and events that took place after their arrival in the western territories were relegated to the background. For children whose parents came to Krzyż voluntarily, the chaos of the first post-war years was a significant shock.

I remember those experiences very well, they really shook me. There was a time when a

Russki threatened us. But when those transports were in motion, it was forbidden to sell

341 Welzer, Moller and Tschuggnall, "Opa war kein Nazi."

342 Marcin Zaremba has analyzed the "two-phased" reactions to the arrival of the Red Army. In his argument, in territories that were under German occupation for the entirety of the war, such as Wielkopolska, there was an initial joy that was replaced by a disappointment in the "liberators," see: Zaremba, Wielka Trwoga. 
vodka. Well my parents, my mum worked at the bar [operated by the speaker's family at the railway station], and she was serving people and holding me in her arms, when the soldiers came in. [...] Then came in, took their seats, I could even show you now which Russian sat where. They sat down, and they started to shout [...] and one of them went up to my mother and said he wanted vodka. He put a gun to her head, demanding vodka. She said she couldn't sell it to him, she didn't have any. So they grabbed her by the shoulders, she was still holding me in her hands, and they turned to the exchange office, there was an exchange office further down and my granddad worked there. And they said to granddad that if he didn't hand over some vodka, they would kill mum. And whether he wanted to or not, he had to give them some vodka (K25Bf).

Another issue that was strongly present in the memories of settlers in Krzyż was the rapes carried out by the Soviets against Polish and German women. This theme was equally present in the testimonies of eastern Poles and migrants from elsewhere. In most cases, people recounted episodes they had heard about; accounts of events witnessed first-hand were less frequent, and sometimes it had taken several years to fully understand what had happened.

There were three daughters, with the woman and her husband running the restaurant. A Russian guy came, a young man, a junior officer of some sort, and he counted on the holes of his belt, which one he wanted... I only understood later, when I was an adult, why he had shown his belt and the holes. He was after sex. He locked up the old woman and made her sit by the door and keep watch while he turned each one over and had his way with them (K23f).

Memories of rape by Soviet soldiers were very specific: they were strongly constrained by social norms of what can and cannot be said. ${ }^{343}$ Not a single person confessed to have personally witnessed a scene of post-war rape, and no one said that a member of their own family or their close circles had been a victim of rape - although I heard from other sources that some respondents' families had suffered. The identities of the victims - and therefore, also of children born as a result of rape - therefore disappeared into a protective local forgetting. The extent to which wartime rape remains to this day a taboo is shown by the example of a woman whose mother, a German, miraculously escaped

343 For the discussion/study of the unwillingness of men to discuss sexual violence against "their own" women, on the example of Poles deported to Siberia, see: Katherine R. Jolluck, Exile and Identity. Polish Women in the Soviet Union during World War II (Pittsburgh: University of Pittsburgh Press, 2002). More broadly on sexual violence during and after the Second World War, see: Maren Röger and Ruth Leiserowitz, eds., Women and Men at War. A Gender Perspective on World War II and its Aftermath in Central and Eastern Europe (Osnabrück: Fibre-Verlag, 2012). 
being raped by soldiers after the war. The respondent spoke of other women from villages who were raped, but in relation to her own mother she used the phrase "they wanted to kill her" - as if death was more socially acceptable than being raped. The taboo around rape is also visible in the following excerpt, in which the interviewee tried hard to avoid the word rape [ gwatt] - saying only that the Russians were "a little rapeful" [troche gwattowni].

$\mathrm{Oh}$, the Soviets were aggressive, there was no rest from them. There were loads of them roaming around in these streets with their rifle guns, and they were prepared to shoot. They were so, you know... [And they did they actually harm people here in the town, ordinary people?] No, no, no. No, I mean, no, but there were the ones who were forceful and, you know, a little violent. A little rapeful. If you were a woman, you had to give yourself to them, because if you didn't, they would shoot you dead, you know. So they were a little... When my husband went out, I stayed with B. [the speaker's younger daughter] and my older daughter, we shut ourselves in our room, quietly, we locked the door, whenever my husband went out to work to the railway depot, we stayed quiet, really quiet, so that, you know... Sometimes they came smashing on our door, Jesus, I tell you, I thought the door would crash down, but I never said anything, they kept smashing and smashing that door, but somehow it stood firm (K23Af).

This fragment is also a typical illustration of a specifically female perspective on life in a town with a Red Army presence; such experiences were shared by women from all geographical and social backgrounds. They all remembered fearing for their own lives and the lives of their loved ones, and there were several descriptions of soldiers trying to break down doors. Many respondents declared that the Soviets had not, in the end, caused any direct harm to their families, but they retained a clear image of the Red Army servicemen as violent rapists, remembering above all the fear they had felt in the first few months they spent living in new surroundings. A mirror image to these memories can be seen in the "male" descriptions of the Soviets' behavior in the broader context of the town as a whole. ${ }^{344}$ These related mainly to the situation on the railways, where the frequent movements of Soviet military transports through Krzyż caused difficulties, as well as the general insubordination of the Soviet soldiers stationed in the town.

It was still unsafe in Krzyż, because the Russian army, which was returning from the West, had its main loading station here, it was a junction station, so they stopped here

344 I describe these accounts as "male" in a cultural, gendered sense, rather than strictly in terms of the sex of the speakers - unlike in the female accounts cited earlier. A "male" narration, associated with a life outside of the house, also appeared in some women's accounts. 
frequently and they went into the town, drunk, and the shoot-ups would start - sometimes we had to hide. The Russian command did nothing - they were afraid of the soldiers themselves. They were all drunk, it was the end of the war and those troops were drunk as fiddlers, and it was terrifying! (K17Am).

At the same time, the undoubtedly negative assessment of the Soviets is accompanied by a certain detachment, as a result of a belief that the Soviet marauders mostly posed a danger only to themselves, as well as to individuals who had to come into contact with them because of their professions - railway workers and the police. Strong emotions - and an instinctive dislike of inimical Others who had crossed an arbitrary boundary of neutrality - appeared only when respondents remembered members of their local community suffering at the hands of the Soviets. The most frequently cited incident was the death of a local railway guard, who was shot by a drunk Soviet soldier when attempting to prevent the looting of a transport carriage. Accounts of this event appeared in the testimony of nearly every interviewee who had worked on the railways at that time - in a variety of versions that had each, in different ways, been modified by time and influenced by other narratives. A woman who had witnessed the entire incident first hand commented on it as follows: "People rebelled, because why, with what justification [did the soldier kill the Pole]? Supposedly an ally, supposedly, you know, a liberator as they said, 'we liberated you!', and then he kills?!' (K3Af). This statement contains negative emotions that had accumulated over time in relation to the stationing of the Soviets in Krzyż, but also - above all - the sense of impotence that accompanied this disapproval. The new residents of Krzyż could do nothing about the chaos that prevailed in the town, in which the Soviet military enjoyed impunity.

The problems that they were encountering may have been incomparable to the hardships being endured by residents of Zhovkva in the same period, but they nonetheless made it difficult to adapt to the new life conditions. The troubles were exacerbated by the physical destruction of the town itself, which was much more severe than in Zhovkva. Whilst Zhovkva had come through the war almost wholly intact, more than half of the buildings in Krzyż had been damaged or destroyed. When people arrived in Krzyż in 1945, it resembled somewhat the surface of the moon: the town center had been burned out, buildings were still smoldering, and ruins were everywhere. A huge majority of migrants to Krzyż understood fully well that this state of affairs had been brought about not by the Germans, but by the Soviets, who destroyed the town when they conquered it.

When the Russians were here they went about destroying the town, saying it was all German. My father remembers it. He once came to Krzyż and was walking along where 
the bank is now, and there is that window up above, and he was walking up to it, and suddenly, there was a loud crash. He looked around, and a Russian had thrown out a beautiful radio from up above. "Why did you do that?" my father asked him, [laughter]. "Because it's German." That's what they thought of those Germans [laughter] (K15Bf).

Despite the humorous note with which this respondent recounted this story (another example of mocking memory of the Soviets) the Soviet destruction of Krzyż was a very serious issue for the town's new residents. This was not only because the picturesque market square and townhouses had been destroyed. The damage caused to the town's infrastructure was much more significant. One respondent described in detail the pillaging activities of the Soviets, who had dismantled and exported to the USSR whole factories' worth of equipment, cattle, and even one of the railway lines. He summarized his account with the following laconic statement: "They left nothing" (K13Am). Many interviewees were outspoken in their critical assessments of the Red Army, bitterly noting the "allied" character of relations between Poland and the USSR: "There was no treaty that said that the Red Army had to leave it nice and tidy for us here, there was nothing like that, and if it was on paper, it went unnoticed. When we arrived here, we had to start from scratch" (K17Am).

As with any memory of a collective hero or a specific group, there were also some expressions of positive memory in relation to the Soviets. Similarly to stories of "good Germans" or of "our Jews", some respondents told anecdotes about "good Russians." One woman rented out a room to a Soviet soldier, who on one occasion protected her family from a group of aggressive Soviet marauders. The sense of her story is well conveyed by the final sentence, with its expression of surprise: "And look! We were protected by the guy, such a good one, he was. I've thought about him again and again, a Russki, but such a good guy" (K14Af). The Russkies turned out to be good in moments when they surprised people with their "civil" behavior, but also in instances whereby the new residents of Krzyż were able to gain from them in some way. There were some very interesting statements in which speakers admitted - sometimes explicitly, sometimes between the lines - that coexistence with the Soviets was bearable because they had been able to gain something from it for themselves.

They treated us well. As long as there was something to trade, that is. [...] Once, some Russkies came to us, wanting to get something to eat, and my dad was there and he said, "we haven't got anything for ourselves." So they got in the car and my oldest brother went with them over to Lubcz [a village near Krzyż], they shot a pig, and there were loads of those pigs. The owners of the place ran away and they opened the barn, letting out all the animals. [...]. I know it, wherever those [Soviets] went about doing their thing, there were so many cows, like, wow. People opened their doors to let them in. And once they were in, they closed it and had a cow (K7Am). 
As one can guess fairly easily, it was people from nearby Polish villages on the other bank of the Noteć river who most readily indulged in such activities, and they were the ones who were most likely to tell such stories. Of course, such accounts have their roots in the biographies of the speakers. Only interviewees whose families had not suffered directly at the hands of the Soviets were able to speak of the Red Army's presence in a light, sometimes even joking tone. Previous encounters with the Soviets were very important in this regard. People who had lost loved ones in the earlier Soviet occupation of the pre-war eastern provinces, such as the man cited below, described the drunk escapades of Soviet soldiers without a trace of a smile.

Later, it was 1944 or 1945 , the war was already over in 1944 . We came to Poland and that red horde was here, damn it, they were grinding grain... Those Russkies, they had stolen half your stuff already, and then they would go to another village or town and sell it to buy moonshine... It didn't last long, maybe two months, they were turning our grain into... They harvested the grain the Germans had sowed. And they ground it up and sold it for moonshine. [...] They weren't humans, they were, there were a horde, a, a... red horde (K5Am).

In this context, two statements by women cited earlier, a mother and daughter (K23Af and $\mathrm{K} 23 \mathrm{Bf}$ ) are of great interest. Both women had very negative memories of the Soviet order in Krzyż. Taking their wartime experiences into consideration, however, shows that their anti-Soviet attitudes were primarily rooted in that earlier period. The father of the older woman was shot dead by Soviet soldiers, in full view of his wife and daughter, during the liberation of Poznań. The older respondent completely omitted this event in the first part of the interview, in which she told her life story; it was only during the second part, during which the daughter was also present, that the younger woman "prompted" her mother to talk about the incident by asking me if she had already told the story. Forced in this way to talk about her father's death, the interviewee gave a fairly restrained and sparse account - it was clear that she would not have mentioned the event herself. That is not to say that she avoided talking about the Soviets in her testimony as a whole - her description of the Soviet entry into Poznań was extensive and rich in detail. Accounts of many different events were accompanied by clear statements containing value judgments, such as the one cited below. For this speaker, such descriptions appeared in a way to substitute for a direct retelling of the key trauma in her life, which she silenced for various reasons. Extremely negative feelings about the Soviets that had originated from that event were transferred to descriptions of other, less personal events.

[The Germans] were not good, as I already told you, but the Russkies were worse. The Russkies were worse, they were just inhuman. There was a water pump and the men 
always went there [during the Soviet attack on Poznan in 1945], they crawled on their bellies like this and they would reach out with their hand to the, what is it called, the handle that pumps the water, and they would pump. [...] People had to drink their own urine because there wasn't enough water. One person was going to fetch some water, but when a [Russian] shot from his rifle, he just stayed there laying down, he didn't stand up again, he didn't get that water. Later a neighbor went there too, with my husband, and Jesus, how I cried, my mother was on her knees praying to God to protect him, he was, you know, he was fetching that water, he was shaking, the water was splashing around, but he brought enough for everyone to have a gulp, he brought it. But the other guy, he stayed there, lying there. Because the Russkies weren't humans, they were monsters, the ones who just fought, they were so inhuman (K23Af).

The younger respondent had no difficulties talking about the death of her grandfather. Besides the obvious sadness at the loss of a close family member, her testimony was striking for its uncompromisingly accusatory tone against the perpetrators of the crime and the speaker's readiness to prove beyond doubt that the Soviets had indeed been responsible.

I could never forgive them, and I told myself that I would gain revenge for the death of my granddad, that I would tell everyone that's how it was, that they killed him. For a long time, my parents would hide me if we had visitors. I was a little loudmouth and they hid me in case I said something too much, because we weren't allowed to say anything because grandma would stop receiving her pension. There was a time during communism that we weren't allowed to say anything. The Germans had done all the killing, we had to say he died at the hands of the Germans (K23Bf).

\section{The Soviets in the Memories of the Younger Generations}

It is no accident that in all of the statements analyzed thus far, the respondents remembered the Soviets from their own lived experience. Younger interviewees (with the exception of people with a professional involvement in history) almost never discussed the Soviet presence in Krzyż on their own initiative. Asked whether, in their opinion, the Soviets had played any role in the history of the town, most answered in very general terms. The question of the town's destruction by the Soviets was raised relatively often. People from the middle generation repeated stories they had heard from their parents about the Russians warming themselves using bonfires kindled in abandoned buildings, voicing the same contempt for Soviet barbarism as their parents.

Yes, in Krzyż, my father told me often, many of the buildings on what is now Victory Square, on the quadrangle, they were standing, but a lot of it was demolished because when the Russians were here they warmed up using fires, but they didn't use the stoves, they lit them next to them. And then they left, and it kept smoldering, and smoldering, and burning (K1Bf). 
Younger people often imagined the charming German town of Kreuz that they had seen in postcards and images, and sincerely regretted that their town had not preserved its pre-war appearance.

It was always a source of sadness for me that Krzyż before the war looked a little nicer. Those townhouses, the town's entire architecture. It was really a pretty little town. Later it started to fall apart, when the Russians arrived. They destroyed it all, they robbed and burned it down (K9Df).

Whilst speakers identified the Soviets as the perpetrators who had ruined their nostalgic memory of the pre-war town, they did not, unlike in Zhovkva, mix this condemnation with hatred. Likewise, comparative statements by younger people on the roles of the Germans and the Soviets in the town's past - with the Germans as the founders of the beautiful town and the Soviets as its destroyers were different to analogous comparisons in Zhovkva. In Krzyż, respondents were not looking to demonize the Soviets at the expense of expiating the Germans; they were merely stating a fact, often with irony or sorrow, but not with vitriol. Genuinely negative emotions were expressed only in instances where the speaker's family had directly suffered at the hands of the Red Army; because such events had usually taken place not in Krzyż but in the previous place of residence, stories about contact with the Soviets in Krzyż almost always appeared as a "package" together with stories of previous encounters.

During the war my dad [...] ended up in Soviet captivity, he was there for a few days but was able to escape. But he got a taste of what it was like to be taken captive by the Soviets. [...] My mum didn't talk very much [about the Russians in Krzyż], just that they were brutal and unpleasant, that they treated the Polish people badly. But my dad, he talked a lot, because some of the family was deported to the East, into so-called exile, at the time of the uprising, one of the uprisings, before the war. So it was already in our blood, I don't have anything good to say about the Red Army, nothing that was told in our house about them, no, unfortunately. It was supposed to be a liberating force, but in the end it brought only terror and atrocity $(\mathrm{K} 8 \mathrm{Bm})$.

Many of the interviews showed that once a respondent was prompted to talk about the Russian presence in Krzyż, they fairly instinctively went on to discuss several misfortunes that had beset Poles (and specifically, the interviewee's family) during the war, or even, in the case of the speaker cited above, in the longer-term perspective of the nineteenth-century uprisings. This was however only true of those individuals who had heard not only about the family's past in the East, but also about the earliest period after arriving in Krzyż. It was clear that most younger respondents had not talked at home about Soviet actions in Krzyż in 1945. This cannot be explained only by a fear of the authorities during communist times, because people who had no knowledge of the 
Soviet presence in post-war Krzyż were able to reconstruct in great detail the migratory movements of their families from the East, and the Soviets usually appeared as the villains in such stories. Perhaps, for the eastern Poles this period was insufficiently dramatic - compared to the Soviet occupations of 1939-1941 and 1944-1945 - to pass it down to their children and grandchildren? Perhaps the extreme experience of being uprooted screened off the meetings with the Soviets in Krzyż to such an extent that there was no more room left for them in family memories?

The Soviet period of the history of Krzyż was also largely missing from the testimonies of people whose parents and grandparents had arrived from central Poland and Wielkopolska. The following statement by a respondent whose parents came from Drawsko [a Polish village on the other side of the Noteć river] illustrates this well:

As for the Russians, well the Russians didn't really have much to do with us here, I mean, there weren't a lot of negative opinions, because they came here and left straight away, they went on. Just from the few stories that I know, I know that my granddad, when he was a tailor, he had a large tailoring table, and they spread out some maps on it, and some of them were roaring drunk $(\mathrm{K} 22 \mathrm{Bm})$.

This fragment is best understood by focusing on its beginning. The Soviet presence in Krzyż was not an important element of memory about the town's history because for a clear majority of people, it had had no direct effect on their families; unlike in Zhovkva, the Soviets were in charge of Krzyż for a relatively short time. For Poles from the pre-war East, the biggest mark on their family history was left by the Soviet occupation of 1939-1941; for those from central Poland and Wielkopolska, it was the German occupation. As Lech M. Nijakowski argues in his analysis of memories of the Second World War among Poles, the hierarchy of enmity in the collective imagination depends on the occupation under which respondents (or their families) lived the longest. ${ }^{345}$ I would add that the degree of brutality of the occupation is also an important factor. The Soviet command in Krzyż was a burden on residents, but on the whole it did not threaten people's lives - unlike the other occupation regimes between 1939 and 1945. Family transmission of memory is selective, just like the material on which it is based, i.e. autobiographical memory; not everything that one's grandparents or parents experienced can be passed on. Dramatic or historic events tend to have the upper hand - these are also what children tend to ask their grandparents about most

345 Nijakowski, “Pamięć o II wojnie światowej”, pp. 239-286. 
readily. ${ }^{346}$ The period of Soviet rule in Krzyż was clearly not one of those events. Violence and drunken excess were not enough to ensure that the Soviet presence would become part of the family memory of the town's new residents - that is, as long as they had not been direct victims.

The absence of the Soviets from the memories of young people - as well as from local memory policies - can also be explained by a lack of a broader public debate on the role that the "liberators" Red Army played in domesticating the "Recovered Territories." For obvious reasons, this theme was not present before 1989. One could have supposed that after the fall of communism, this topic would likely be discussed in the public sphere and even enter the canon of official memory. Although it cannot be said that nothing has changed in this regard, it nonetheless remains difficult to compare the tentative attempts to reinterpret local history by individual communities in the former "Recovered Territories" (e.g. the initiatives by the Borussia group in Warmia) with the heated discussions that took place in Ukraine, especially in relation to the UPA and the Red Army, or even the many debates on recent Polish history. It appears that this topic is still waiting for its coverage in the Polish discussions of history. To borrow the phrase used by Marek Ziółkowski, it is still the "skeleton in the cupboard of Polish cultural memory." ${ }^{47}$

\section{Krzyż and Zhovkva: A Comparison of Heroic Canons}

Residents of Krzyż and a large section of people in Zhovkva therefore share the same anti-hero in local memory: the Soviets. However, these two memory regimes are undoubtedly different in that there is no dispute over the assessment of the Soviets in Krzyż. People agreed that the Red Army had brought nothing good to the town; some respondents were more critical, others were more indifferent, but no one considered the Soviet soldiers to have been heroes not even the few "builders of the new system," ardent communists who were still convinced of the rectitude of their support for the socialist state. A respondent from this group, who hotly defended the idea of socialism and social justice, was discussing life in the town in 1945 when he described the Soviet elite in Krzyż with the worst epithet he could muster: "I was in a good place for the time being, I could point a German gun at those Kraut NKVD bastards [ $c i$

346 My interviews confirm this observation. Nearly everyone who declared that they talk about history at home said that the war was the main theme of their discussions. Cf. Barbara Szacka, Czas przeszły, pamięć, mit (Warszawa: Scholar, 2006).

347 Ziółkowski, "Pamięć i zapominanie." 
enkawudziści szwabscy]" (K28Am). It is also clear that the propaganda of the socialist period was wholly unsuccessful in creating a cult of the Red Army as liberators in the "Recovered Territories." Rather, today's residents of all generations used the phrase "liberators" ironically: "[My uncle] later, after the war, also had various escapades, but they involved our 'liberators,' the 'Russian comrades'” $(\mathrm{K} 27 \mathrm{Bm})$. Moreover, respondents from the middle generation openly admitted that this particular aspect of memory policy was always taken with a pinch of salt: "Actually in school we didn't talk about these things at all, because it was obvious that the Germans had carried out all the evil. The Russians didn't do anything bad, they were our saviors [with irony], and of course they kept telling us this" (K15Cf).

Unlike in Zhovkva, in Krzyż the Soviets do not have an advocate, a group that identifies with their legacy. The dispute in Zhovkva over the local pantheon divides the city, and sometimes divides families. In Krzyż there is no disagreement; the potential local anti-hero drifts on the periphery of social memory, increasingly less able to arouse negative emotions that might result in a conflict. It is worth emphasizing once again that the lack of memory amongst younger generations in Krzyż concerns only the period of Soviet rule in the town, and not their role in respondents' family histories or in the broader history of the Polish state - such memory is strongly present (with a negative hue) in the family transmission of memory. ${ }^{348}$ It is as if an entire level was missing from the structure of memory: they remember (or know) that the Soviets persecuted their families (the level of family memory), and that they caused harm to Poles as a national collective (the level of collective memory) - but not that the Soviets destroyed the town in which they were born (the level of local memory).

The most important characteristic of local memory in Krzyz is therefore the fact that there are neither heroes nor anti-heroes with a direct connection to the town. In family memories, the important histories are those from previous lives, from the period before the oldest generation arrived in the town - stories about good Germans and bad, barbaric Soviets and murderous Ukrainians. With each successive generation, the urgency of these stories diminishes, details become effaced, such that in conversations with the youngest generation only broad generalizations remain, such as "Ukrainians murdered Poles." It can be stated that for the residents of Krzyż, migration led to a kind of "leveling" of the

348 In statements made by my interviewees, the Soviets were clearly a more important villain than the Germans. This aligns with nationwide trends as observed in quantitative studies, see: Szacka, "II wojna światowa w pamięci rodzinnej." 
heroic canon, which was not reconstructed anew. Subsequent generations are increasingly distancing themselves from the "old" heroes and anti-heroes, both spatially and emotionally: those historical figures arouse increasingly diminished emotions. This is easily observable on the example of people's memories of the Polish-Ukrainian conflict; whereas members of the middle generation spoke of this event with great passion, sometimes believing the Ukrainians to have been worse than the Soviets or the Germans, the youngest residents were more likely to give more moderate assessments or to refrain completely from negative evaluations. ${ }^{349}$

There is an essential difference between the local memory regimes of Krzyż and Zhovkva: the heroic canon of Zhovkva's new residents before they moved there seamlessly harmonized with events that took place after the war, including people's own lived experiences. The new residents of Krzyż, however, were cut off from their own canon and a new one either did not materialize, or was not fully internalized by them. Perhaps this was because the conflict between the UPA and the Soviets continued for several years after the war, in full view of the new residents of Zhovkva; given such a situation, it was easier to allow the image of the partisans and Red Army soldiers before and after the war to merge together. For the eastern Poles, the Soviets who occupied Krzyż were a completely different set of people to the Soviets who had driven them out of their old homes.

The reasons behind these differences should be sought in the divergent situations of the two towns in the early post-war period. Migrants in Zhovkva (with the exception of people who came from the East - although not necessarily their children and grandchildren) grew more or less smoothly into the canon of heroic and martyrological memory that was already in place, which was passed onto them by the few local residents who had remained from before the war. In Krzyż, however, such a process of adaptation was not possible - there was nothing to adapt to, because there were no native residents to act as carriers of an existing memory regime. If the experiences of the Polish neighbors from beyond the river were to be considered the "base," the local experience in Krzyż,

349 Survey-based research using a nationwide sample has shown that in the "Recovered Territories" a very high percentage of people identified the Ukrainians as the main enemy of the Poles during the war. This is a result of the significant number of residents whose families came from the pre-war eastern provinces, see: Lech M. Nijakowski, "Regionalne zróżnicowanie pamięci o II wojnie światowej," in: Między codziennościq a wielka historią. Druga wojna światowa w pamięci zbiorowej społeczeństwa polskiego, ed. Piotr T. Kwiatkowski, Lech M. Nijakowski, Barbara Szacka and Andrzej Szpociński (Warszawa: Wydawnictwo Naukowe Scholar, 2010), pp. 200-238. 
the experiences of migrants from the eastern and central regions would have been so cardinally different that it would have been impossible to combine their memory canons.

Yet more important is the fact that in present-day Krzyż, it is not only criminals and traitors who are absent from the memory canon; additionally, there are neither villains nor victims. If in Zhovkva there is disagreement on who fills these roles, in Krzyż there are no candidates. The potential heroes from the "previous life" are not sufficiently distinguished to cultivate their memory after the loss of the old homeland: the Home Army were remembered by only a few of the oldest respondents, while members of other underground resistance armies were not mentioned at all. The creation of new socialist heroes (e.g. the stoic unnamed settler of the "Recovered Territories" guarding the borders of the Piast legacy) was unsuccessful, whereas the symbolic potential of "dissident" heroes, such as the Polish railway guard killed by Red Army soldiers in w 1945, was too weak to form a collective image of heroism. The last example shows that in addition to a shortage of common heroes, Krzyz is also afflicted by lack of shared victims. Whereas Zhovkva with its division into two camps is characterized by its competitive commemorations of each camp's "own" dead, in Krzyż there is an unnatural silence and calmness. The people who were remembered and mourned by specific groups of new residents remained in the former homelands, separated by a thick symbolic boundary that divided the old life from the new. In Krzyż, there have never been any initiatives to commemorate the victims of Soviet persecutions or of Ukrainian nationalist murders. ${ }^{350}$ The only potential common victims are the women who were raped by the Soviets in 1945 and the Germans who were expelled or killed. However, social taboos make it impossible to commemorate the former, whereas the latter are only a little more important to today's people of Krzyż than the vanished Jews are to the residents of Zhovkva - for a long time there was no social need to remember them at all, let alone commemorate them. Today's residents of Krzyż have no one to commemorate, because their common history only began in 1945 . The new residents of Zhovkva entered unnoticed into a depleted existing community of memory, and the price was to be entangled into old memory wars.

350 There is a plaque commemorating the Poles murdered in the East in a church in Drezdenko, a small town $14 \mathrm{~km}$ from Krzyż. 


\section{Postscriptum: Symbolic Space}

In researching attitudes towards the past, it is important not only to analyze the statements made by interviewees, but also to take into close consideration the space in which they are living and how they relate to that space. A brief description of how the symbolic landscapes of Krzyż and Zhovkva have changed since the 1990s was provided in the first chapter of this book. The chapters devoted to the memory of the vanished communities - the Germans, Poles and Jews included examinations of respondents' attitudes towards the material heritage left by those groups, as well as issues related to their commemoration. Here, I would like to conclude this thread on symbolic space by considering respondents' attitudes to the changes that occurred as a result of shifts in the official canons of memory at the national and local levels. Above all, I am interested in attitudes to the removal of old monuments and the establishment of new ones, as well as changes in local toponyms. ${ }^{351}$

Despite the clear differences between local memories in the two towns, the two sets of residents had in common a fairly indifferent attitude to their symbolic spaces. Their statements in relation to this topic were rarely emotional. Especially in Zhovkva, it was possible to observe a significant contrast to the heated era of spontaneous transformation of the early 1990s. Then, the Lenin monument in the town center was enthusiastically dismantled. Today, respondents of all generations - except those with very patriotic views - were unconvinced that removing the statue had been the best thing to do. As expected, members of the post-Soviet memory group spoke in this way - for these people, the monument had been a symbol of a reality that they had fully accepted. More surprisingly, however, younger people, including people who did not express a pro-Soviet attitude at all, also held such an opinion. None of them defended Lenin as a symbol of the communist system; rather, most argued that the statue had been a part of the town's history, and that this history should be remembered, even if people were not necessarily positively inclined towards that past.

Here, all of those statues were destroyed, they knocked it all down... Maybe there really was no need to have so many Lenins here. [...] I think that, I don't know, but I for example would have collected all the monuments together and made some kind of

351 This chapter does not consider the period after 2014, i.e. the so-called Leninfall [Leninopad] in Ukraine - in which Soviet monuments were pulled down en masse and the decommunization laws being enacted since 2016 in Poland. 
culture park, or memory park, or something like that. Despite everything, they were ours... Despite everything, they were part of the history that we are learning, after all. We can't just run away from it (Z15Df).

In Krzyż, not a single monument was erected after the war that sought to legitimize the new post-war system, and so there was nothing to demolish after 1989. Nonetheless, echoes of similar attitudes can be heard in statements concerning the dismantling of German monuments in the 1950s and the removal of Red Army monuments in neighboring areas in the 1990s.

There, between the oaks, there was a German memorial. That was destroyed too. I didn't like that, they made an empty space. They were nice trees! [...] They made an ugly job of it. [But why did they do that? Because it was German?] Probably because German things have to be evil. [...] [You didn't have anything against a German memorial being there?] Nothing at all. [Why not?] For me, it's better if there is something there, rather than nothing. Let it be. In Trzcianka [a small town nearby] as well, a [Soviet] tank was taken down for no reason. They could have left it (K9Bm).

In many statements by members of the middle generations in both towns, a subconscious desire to prevent the time of their youth from being labeled as a lost or evil era became mixed with a prosaic indifference to the symbolic meanings contained in the monuments that were demolished. For the above speaker, the tank was nothing more than an object on which local children could climb, and the old trees that had surrounded the German memorial were what he missed most. Such statements can be interpreted as evidence of a successful absorption or pacification of the past symbolized by those monuments. Many respondents argued that one cannot run away from the past, but these words showed above all that they themselves had no need to run away from it; they felt sufficiently secure in relation to the previous "owners" of their towns whether the Soviets or Germans - that they could calmly agree to leave traces of their presence in public space. Undoubtedly, the large temporal distance here is an important factor - the fact that those monuments were demolished demonstrates that the attitudes to the Germans in the 1950s, and to the Soviets in the 1990s, were different. However, a similar indifference was noted in relation to new monuments erected in both towns after the transition. Other than people who were directly involved in their creation (then-representatives of the town authorities and social activists), the majority of interviewees did not know to whom those monuments were dedicated, only identifying them as sites where flowers are laid on national holidays. As one respondent in Krzyż put it, in relation to the memorial to the region's return to the Polish motherland that stands in front of the town hall: "Well, there are always some holidays 
or other, people always go there, right? With flowers. It's some kind of memorial to commemorate something like that, right?" (K3Bf). The great majority of interviewees declared that they had no interest whatsoever in the topic of monuments, suggesting that this was an issue for people who are directly involved. This division into "activists" and "ordinary people," who need not be concerned, is shown clearly in the following statement by a respondent in Zhovkva:

[When did the monument to the victims of the NKVD appear in front of the town hall? Also during that time, at the beginning of the 1990? Whose initiative was it?] That was recent. There are people who are involved in that kind of thing. But I was never curious about who those people are (Z32Af).

Besides the people who built them, also people who don't like them notice the new monuments for a variety of reasons. In Zhovkva, a typical example would be the residents who reject, more or less openly, the notion that the NKVD was responsible for mass murders. In Krzyż, the text written on the monument in front of the town hall was known almost exclusively by people who disagreed with the idea contained therein. Interestingly, these were above all interviewees from the middle generation - their parents had come to Krzyż from neighboring villages and had clearly never hidden from their children that the pre-war town could not be considered Polish.

For the liberation of Krzyż, its return to the motherland, it says something like that. But what is that all about? I read it and thought, what? The return of Krzyż to the motherland? Are you being serious? It wasn't Polish before, but OK, that is what they dedicated it to, that is what they wrote on it, and now we have to lay wreaths, simple (K31Bm).

The above statement is notable for its near-comical sense of fatalism, that "now we have to lay wreaths" - as if the ritual of laying flowers had become completely detached in its meaning from the actual reason for such commemoration. In such situations I always asked respondents whether in their opinion, there were any monuments still missing, i.e. whether there was anyone else to whom a memorial should be erected. Responses were usually negative; speakers tended to answer that no one came to mind. In Zhovkva, some people suggested a statue of the poet Taras Shevchenko, Ukrainian poet considered "a father of the Ukrainian nation," more often, however, I was told that there were no locally important figures who would be worth commemorating.

Who should we build a monument to? Hmm, well, who? I mean, we're not going to put up a memorial to any Poles, we're Ukrainian after all, right? A monument to that Konovalets [an activist for Ukrainian independence and leader of the OUN] is already standing. Can I think of anyone else? No idea, really (Z23Af). 
In the context of a town with a rich and colorful history, in which many iconic figures were born, this statement is symptomatic, showing lack of appreciation for local history as well as an elementary ignorance of the past. Everything the respondent had to say was that no monument to a Pole could be built. In addition to this specific indifference, another surprising fact was that many people were happy for monuments with mutually contradictory meanings to stand together in the urban space. A clear majority of residents - again, with the most radically inclined members of the patriotic and post-Soviet memory groups as the exceptions - had no problem with the Red Army and the UPA being commemorated simultaneously: "[If there was a plan to put up a monument to UPA soldiers, would you be for or against?] Why would I be against? Let them do it. Whoever fought here - they can all have a monument. Why would I have a problem with a monument?" (Z8Cf).

This statement captures in a nutshell the striking contradictions that, for the majority of residents in Zhovkva, pose no difficulty at all. Lack of coherence in the local symbolic landscape does not provoke any protest; rather, it is taken for granted. As Andrii Portnov argues, this situation is typical for Ukraine, where different memory discourses have coexisted since the fall of communism and each one has, to varying degrees, been represented through symbolic gestures in public space. ${ }^{352}$ Portnov rightly points out that in Ukraine after 1991, no acts of vandalism against, or full demolitions of, Red Army monuments took place; at most, they were adapted, with Christian symbolism supplanting Soviet signs (in Slavske in southwestern Ukraine, a Red Army monument had a figure of Mary added to it) or with the rituals being changed (in Zhovkva, the traditional ceremonies to commemorate Victory Day were enhanced with a religious element). Such forced coexistence of symbolic domains can, on the one hand, be considered a mechanism that enables localities to avoid conflict; on the other hand, it may be a consequence of the respect for the heroism of ordinary soldiers that was deeply ingrained into most people in Zhovkva. Whilst removing a Lenin statue may be an expression of disapproval of the despised old system, the destruction of the graves of Soviet soldiers would be simply unthinkable.

Interestingly, similar incongruence was also observable in Krzyż. In various ceremonies organized by the boulder memorial that was erected in 1995 with a plaque to commemorate the return of the Krzyz lands to the Polish motherland, one can note both typical rhetoric of the communist era (the anti-German

352 Portnow, “'Wielka Wojna Ojczyźniana.” 
song The Oath [Rota], the term "Recovered Territories") and an abundance of tributes to the "European idea" and the town's openness to the so-called West. The interviewees saw nothing unusual in this mixture. Asked about potential new monuments, most just shrugged their shoulders. Whilst in Zhovkva, such attitudes appeared more to be a consequence of ignorance, in Krzyż they seemed to have reasoned argument as their basis - respondents argued logically that there was no one connected to Krzyż to whom they would like to see a memorial built, whilst the memorialization of national Polish figures (other than the likes of Pope John Paul II) was not of great interest to them: "I don't think there is anyone from Krzyż who stands out, anyone who would deserve a statue or anything like that" (K33Df).

Sometimes, statements contained a tinge of regret that there was no pantheon of great figures connected to the town - some people believed that this was because the Germans had formed the town's cultural landscape for the last few centuries. Whereas most residents of Zhovkva did not want to commemorate Poles connected to the town's history, a small number of interviewees in Krzyż would happily commemorate German historical figures if only they had greater knowledge of them, reasoning that the town owed them its existence. One respondent, who was born after the war $(\mathrm{K} 22 \mathrm{Bm})$, admitted wholeheartedly that the Germans had built the town of his birth, but he proposed a monument to the Polish soldiers who died in the fight for the town's liberation. During an interview with a collector of German postcards from Krzyż (K42Dm), however, I was told that any new monument in Krzyz should honor the people who built the town, i.e. German architects and railway workers.

In the context of this symbolic void, i.e. the unavailability of a distinctive collective or individual hero, the surprising inscription on the boulder monument in front of the town hall in Krzyż is easier to understand. After the restrictions on public expressions of memory had been lifted and free construction of symbolic space had become possible, it suddenly transpired that the town was rather short of ideas about how to make use of this newfound freedom. There were no local heroes, because for today's residents of Krzyż the town's common history effectively began in 1945; German heroes were unfamiliar and above all, too foreign, whilst the bonds that connected people to their old homelands were by now too weak to reach back into that period of the past (not to mention the fact that there were too many of those old homelands). The desire to formally mark the town's integrity as a community was, however strong enough for an overture to be made to the only known and available discourse, the myth of the "Recovered Territories." The final text was a result of a compromise (in the original version, it was to commemorate 
the return of the town to the motherland, but after a councillor intervened, the term "town" was replaced by the "land;") the most important thing, however, is that the people behind the initiative continued to this day to emphasize the monument's role in the organization of space rather than its actual contents. To borrow a phrase from the respondent cited below, an employee of the town administration, the monument's role in Krzyż was to "honor state holidays:"

"In Krzyż there was no real place where we could honor the holidays, the state holidays, ceremonies and celebrations, you know? Now there is that place. There was no proper place, and now I think this is a good place, it's well displayed" (K36Bm).

The fact that many residents (especially young people) were indifferent to new monuments that, in both towns, had been put up only slightly more than a decade ago, suggests that the very function of the monument as a carrier of meaning is gradually in decline. ${ }^{353}$ This trend was captured poignantly by a respondent in Zhovkva, in response to my question about how young people engage with the past.

Young people aren't going to gather by the Konovalets [monument]. They're more likely to join some Google group on "Ukrainian nationalism" or something like that. But that is also a way of engaging in a mass phenomenon; just in this case it has a different nature... Not on the streets, not an outdoor meeting by a monument, but a form of integration in cyberspace or just through online communication (Z41Dm).

Observers of public space in Krzyż made statements in a similar vein. One education worker with a personal interest in the town history said: "I think, at the moment young people have no need or desire to celebrate things or to get involved in overt performances" (K39Cm). Meanwhile, a history teacher confirmed my observation that many people had no knowledge of the text on the monument by the town hall: "I think that if it was about the Trojan War, no one would notice" (K43Dm). These trends noted by the respondents themselves dovetail with conclusions reached by sociologists about contemporary attitudes to symbolic space. As Lech M. Nijakowski argues, monuments are undergoing a

353 Volodymyr Kulyk has drawn attention to the growing importance of the Internet in cultural memory, especially for young people, who see new media as a much more powerful carrier of meaning than material substances, see: Volodymyr Kulyk, "War of memories in the Ukrainian media: diversity of identities, political transformation and production technologies," in: Memory, Conflict and New Media. Web Wars in Post-socialist States, ed. Ellen Rutten, Julie Fedor and Vera Zvereva (London and New York: Routledge, 2013), pp. 63-81. 
process of desacralization and symbolic devaluation, as a result of the development of new technologies: as carriers of meaning, monuments and other physical manifestations of memory in space are losing their ability to affect people. ${ }^{354}$ As examples of this phenomenon, Nijakowski suggests acts of vandalism against monuments and the general "quotidienization" of sites of memory, such as statues being adorned with Santa Claus hats or parents allowing their children to climb on monuments. This decline of the monument as a carrier of memory and its ceding of its role to the Internet, as the interviewee in Zhovkva noted, can explain why the simultaneous existence of conflicting monuments is not perceived by residents as a problem.

A related and complementary issue to monuments and memorial plaques is the renaming of streets. The general situation here was similar: few responses on this topic were emotionally engaged. The only highly passionate statement came from an individual who had been actively involved in the renaming of streets in Zhovkva in the early 1990s (Z29Af), who spoke in a typically "militant" manner - the elderly woman remembered her activism fondly, finishing with a flourish: "And we changed Lenin to Bandera!" This woman was not the only one of my interviewees who had been involved in these activities. However, others showed less pride; rather, they were disenchanted and disappointed, as if their enthusiasm at the time had been irreversibly dispersed by the intervening two decades of life in independent Ukraine.

The streets? What was needed to make sure the economy was in order, that everything worked, and then think about the streets. What good came of it that we changed the street names? Those new signs were just a waste of money, nothing more. Nothing more! And now it's just gone with the wind $(\mathrm{Z} 27 \mathrm{Bm})$.

This pragmatic attitude appears to stem from a general disappointment in postSoviet reality, not a loss of conviction in the correctness of people's actions at the time. Asked if he would like to be living on Great October Revolution Street, the same respondent answered that there were of course limits - the people who destroyed the Ukrainian nation should not be commemorated. Most interviewees, however, spoke of the street name changes critically or with indifference - more so than in the case of the demolition of old monuments. Some were expressing their disapproval of the new master narrative of history and their disagreement with the sweeping assessment of everything connected to the old system as evil - both in Zhovkva and in Krzyż. Others - and this

354 Nijakowski, Domeny symboliczne. 
group was undoubtedly larger - were outwardly indifferent to the changes and stated that they simply didn't care about the name of the street they lived on. Two statements by young women from the two towns illustrate that these names genuinely do not carry significance; both were asked to identify the person after which their street is named. The Zhovkva resident lived on Oleksy Hasyn Street, named after a colonel in the UPA; it had previously been named after Illia Dovhanyk, a local communist activist who died in the 1940s (according to the official version of events, he was killed by the UPA). The interviewee in Krzyż lived on Julian Marchlewski Street, which had retained this name since the 1950s (Marchlewski was a prominent Polish communist; earlier the street was named after Adam Sapieha, a Polish cardinal active in the early post-war years).

Well, as for Hasyn I have absolutely no idea who he was [laughter]. And Dovhanyk... The name sounds familiar, but where I heard it... As for Hasyn, I remember when one of my classmates landed in hospital he told them he lived on Dovhanyk Street, and the hospital staff spent ages looking for it because there was no such street already. That was about the time they changed it (Z10Df).

I read it in school sometime, but now, if I had to answer, I don't remember [who Marchlewski was]. It doesn't really make a difference to me. I hear quite a few people want to change the name of their street, I hear about it in the town. But to me it makes no difference. It's been so many years, this street has had the same name for all my life and to have it changed now? And get used to a new name? No, I'd rather it stayed the same (K34Df).

These statements prompt two observations. First, it is clear that for young people in both towns, the names that exist in urban space, whether connected to the old master ideology or the new one, are essentially opaque. It can additionally be noted that a similar situation applies to the older generations as well. They recognize the best-known historical figures, such as Bandera, Lenin, Pushkin or Bierut; but not Hasyn, Dovhanyk and Marchlewski. It is therefore clearly visible that the residents of Krzyż and Zhovkva never properly internalized the minor details of the old memory narrative, whilst the new ideology still remains (or has already become?) insignificant. Second, neither interviewee was in any way embarrassed to admit that they did not know who the patron of their street was; they did not feel that they should know. In part at least, this is certainly specific to the individuals concerned - neither respondent was generally interested in history. Yet at the same time, these statements can be seen as symptomatic of a wider trend. In both fragments, the practical aspect of the speaker's opinion is noteworthy name changes (including potential future ones) are seen negatively because they bring inconvenience: people have to get used to new names, unexpected troubles 
result, and moreover, they are expensive. The question of cost was emphasized even by respondents who had sharply defined views on the past and who were far from ignorant of local history, unlike the two women cited above.

The one change from the last twenty years that all respondents identified with positively was the decision to restore Zhovkva's old, pre-Soviet name. Even the most ardent apologists of the old system were happy that the town had ceased to be called Nesterov. They also underlined that it was not a problem that the old/new name referred to the figure of the historical Polish hetman. Perhaps, deep down, they were also happy that the local authorities had not followed the general procedure for the renaming of streets and changed Nesterov to, say, "Banderov." "I'm all in favor of Zhovkva. It wouldn’t make a difference if Żółkiewski was a Turk or a Hindu. He founded this town and it should be named after its founder. [Even if he was a Polish lord?] So what? You didn't build Zhovkva, the Soviets didn't do it, he did" (Z20Cm).

Respondents whose views were more in line with the patriotic memory group spared no words of praise for the reinstatement of the pre-Soviet name; they considered the name Nesterov as a stain on the town and a symbol of difficult times. Statements by older people suggest that the Soviet name for the town was never treated completely seriously, that for most locals Zhovkva had always remained Zhovkva. In this context, the post-Soviet name change appears as a symbolic reinstatement of an order that had been unjustly violated by the Soviets.

"Why did they touch Zhovkva, which had its roots, even the name had its historical connections - Zhovkva castle, the name Żółkiewski, it all belonged to him. It was just the Soviet Union and its ideology. If you ask me, they should never have changed anything" (Z15Df).

The indifferent and disinterested relation of respondents to the symbolic space of their town leads one to a number of conclusions. This indifference is not a result of a lack of opinions about the past - the previous chapters showed clearly that most residents of Zhovkva and Krzyż had distinct views on their towns' collective heroes and villains. What emerges from these observations, however, is an overt divide between people's "theoretical" views (or even, in the case of older respondents, accounts of their own experiences) and practical action. In other words, opinions about the past do not necessarily translate into support for specific acts of commemoration. Second, as already argued, a process is under way whereby the equation of symbolic space with physical space is gradually being challenged, especially among young people. Representatives of the younger generation are not indifferent to history - but undoubtedly, once they do begin to make these decisions themselves, they choose to commemorate 
in ways other than those that have been hitherto dominant. ${ }^{355}$ The third conclusion is, in fact, rather a hypothesis. It appears that people's indifference to public space is also conditioned by the fact that an overwhelming majority of residents of both towns is comprised of migrants and their descendants. Despite respondents' claims that they felt completely at home in Krzyż and Zhovkva, there were few signs in both towns of a widely shared sense of responsibility for the common or social good - with very few exceptions. The residents of Krzyz and Zhovkva feel at ease in their towns, but their sense of home in any practical sense only stretches to the gate of their own front yard.

A key element of this attitude is one's relationship to the commemoration of ethnic others, analyzed in earlier chapters: people spoke with feeling that "the authorities should do something," but it did not even cross their mind that they themselves could take the initiative. In the case of Zhovkva it is difficult to test this hypothesis using concrete examples; for Krzyż, there are comparative studies available that show that localities in the "Recovered Territories" exhibit a lower level of social activity, and that the weaker embedment in local history correlates to a weaker connection to the space as well as weaker social ties on the local level. ${ }^{356}$ In both Krzyż and Zhovkva, only time will show whether young people's relationships to symbolic space - like their views on macro-scale history, local memory and family history - will continue to be determined by the fact that their grandparents were born elsewhere.

355 Uilleam Blacker and Alexander Etkind argue that public memory is still mostly analyzed through physical commemoration, but new technologies "have largely deterritorialized cultural memory," see: Blacker and Etkind, "Introduction," in: Memory and Theory in Eastern Europe, ed. Uilleam Blacker, Alexander Etkind and Julie Fedor (New York: Palgrave Macmillan, 2013), p. 5. In the case of local commemorations, physical manifestations still have a dominant position, but this is slowly changing.

356 Cf. Małgorzata Melchior, "Przeszłość jako czynnik zróżnicowań kulturowych dzisiaj - przypadek dwóch sąsiadujących wsi,” Kultura i Społeczeństwo, Vol. 4 (1996), pp. 109-118. 


\section{Conclusions}

In his article entitled "Living among the Ghosts of Others: Urban Postmemory in Eastern Europe," Uilleam Blacker observes that in most writing about places with resettled populations, the present-day residents are deprived of a voice by those who left that place or were expelled. Poles write about "their" Lwów, with little concern for the Ukrainians who live in today's Lviv, and Jews remember the shtetls they left behind, rarely considering that Poles and Ukrainians have settled in those places. Blacker, however, argues that postmemory is also necessarily connected to the present-day inhabitants of those places, who have access to the traumatic experiences of the vanished Others through various media; thus, any serious attempt to study the urban postmemory of East-Central Europe must "confront the memory of the other, and others' memories." ${ }^{57}$ This study of local memory in Krzyż and Zhovkva arose from similar foundations: the memories and experiences of the people who have disappeared from a given society Holocaust survivors, deportees and resettled persons - are important, but from the viewpoint of those specific communities, the memories and experiences of the people who took their place are more important. This book tries to give those people a voice and to accompany them in the reconstruction of the time when they made their new homes their own; this process was also often inseparable from the earlier loss of the old home and the associated trauma. It is for this reason that the greater part of the book is not overly theoretical, and the work as a whole does not offer any theoretical constructs. Now, in providing a concluding synthesis, I would like to attempt such a theorization by distinguishing the different types of social memory in places of mass population transfer.

I identify two axes along which memory can be understood: private/public memory on the one hand, and front- and back-stage memory on the other. Private memory is the sphere of remembrance that is cultivated exclusively in the family and in informal groups, having no influence on questions of public commemoration - not because such influence is impossible, but rather because no need is felt. Public memory, however, extends beyond the sphere of informal social contacts, demanding to be represented in the public sphere; it strives to

357 Uilleam Blacker, "Living among the Ghosts of Others: Urban Postmemory in Eastern Europe," in: Memory and Theory in Eastern Europe, ed. Uilleam Blacker, Alexander Etkind and Julie Fedor (New York: Palgrave Macmillan, 2013), p. 173-178, original emphasis. 
Tab. 1: Types of Memory

\begin{tabular}{lll}
\hline Sphere of Memory & Type of Memory & \\
\cline { 2 - 3 } & Krzyż & Zhovkva \\
\hline Resettlement & Private, Back-stage & Private, Back-stage \\
Absent Others & Public, Back-stage & Public, Back-stage \\
Heroic Canon & Semi-public, Back-stage & Public, Front-stage \\
\hline
\end{tabular}

be represented in public above all. Front-stage memories are aspects of memory that are essential to the construction of group identity - in this case, of the local community. Correspondingly, back-stage memory refers to aspects of social memory that are of secondary importance, which have no such group-forming function and do not aspire to front-stage status.

This typological scheme makes it possible to clearly present my overall findings, as summarized in the Tab. 1.

\section{Memories of Resettlement}

The biggest surprise in all of the analysis I carried out was that memories of the resettlement process and all related experiences - the process of adaptation to the new place and new surroundings, the drama of yearning for the old home, and the sense of being uprooted - remained in the realm of private, back-stage memory in both towns. These memories were cultivated only between specific groups of individuals who were resettled; these groups made little effort to share their recollections with other types of migrants. No claims have been made on public commemoration and the memory of resettlement is absent from public symbolic space. Furthermore, the resettled people themselves appeared to feel no negative emotions towards this status of their memory; they saw no reason to change matters. The testimonies of the oldest respondents often contained bitterness and resentment towards the erstwhile powers that were responsible for the act of resettlement, but never towards the present-day authorities who chose not to commemorate that history. Resettlement, then, does not make communities of memory, despite it appearing to have the potential to do so. Because memories of resettlement are confined to the private sphere, they are not a source of conflict and do not divide local communities - nor do they serve as building blocks for group identity.

Why is this the case? One of the most obvious explanations is that the experiences of resettlers were varied, and thus the different groups could not construct a single coherent narrative for "external" use by other members of the 
community. The experience of a settler from the overpopulated central region of Mazovia had little in common with that of someone from the pre-war eastern provinces, even if both had abandoned their old homes forever and were similarly forced to become accustomed to a "post-German" landscape. Considering that resettler memories were far from aligned, resettlement as a singular phenomenon was hardly communicable to those who did not experience it at all. Besides the divergence of memories between different resettled peoples, another issue is the inheritance of prejudices against specific groups of residents. These prejudices remain sufficiently strong to this day to effectively prevent mutual understanding and coordinated action. Despite the fact that both a Ukrainian deported from Poland and a Muscovite Russian sent to work in Galicia experienced a form of forced migration, they would hardly be expected to share a joint identity based on this common factor. Resettlement is thus too general a category to serve effectively as a foundation for a feeling of commonality. On the other hand, the very specific and concrete elements of resettlement that make it possible to distinguish groups such as the easterners in both Krzyż and Zhovkva are too particular and potentially antagonizing, because they contain the power to arouse the demons of mutual recrimination.

A second factor is the status of resettlement in communist times. Although it was not officially recognized and did not enter public memory, the symbolic legacy of resettlement was suppressed to an incomparably smaller extent than memories of the nationalist resistance in Ukraine. In Poland, commemoration and discussion in public space was possible (e.g. in churches or in cemeteries). In Ukraine, there was no threat of deportation to the camps if one revealed that one had been resettled, unlike if one had fought for the UPA. Likewise, being a resettler did not pose such obstacles to social advancement as belonging to other "undesirable" groups. Perhaps this memory was of a passive nature because the experience itself had been passive; being deported against one's will was hardly comparable to actively and consciously taking part in underground conspiracy. Thus, in comparison with other previously repressed memory groups, the resettlers rather lacked the motivation, decisiveness or determination to advance their memories to the front-stage, unlike the former UPA fighters in Zhovkva.

\section{Memories of Absent Others}

In both communities, memories of absent Others belong to public memory, but they are undoubtedly confined to the back-stage realm. Although both in Zhovkva and in Krzyż, the Poles, Jews and Germans have come to be commemorated in some form, and their historical presence is used as an element of the 
town's image, these memories do not in any way constitute the group identities of residents. The question, then, is: is this a particularity of these specific communities, or are memories of Others incapable of playing such a role in general? Perhaps they even ought not to, because the resulting identity would be a negative one? An arguably more important feature than the direct building of identities is for memories of Others not to be eradicated, for those memories not to fade imperceptibly into oblivion; this, however, is what is happening in both Krzyz and Zhovkva. The scale and character of this process, however, are different in the two towns. In both places, it is not the entirety of memory about Others that is disappearing, but only the most painful and difficult aspects - above all, the ways in which the absent Others disappeared from Krzyż and Zhovkva. This form of erasure is a typical instance of anamnesis: ${ }^{358}$ memory that is troublesome and buried, but which continues to return. The more painful it is, the more intensively it returns, along with a consciousness that today's residents and their predecessors did play a role in those people's disappearance - whether an indirect role as a passive observer, or a direct one as a perpetrator acting more or less voluntarily. Holocaust memory has a specific status, because unlike memories of the deportation of the Germans or the Poles, the residents of Zhovkva were not even witnesses - they could only have learned of it through hearsay. The absence of social memory in this particular case could perhaps be explained by the lack of an essential ingredient: autobiographical memory. However, this argument is weakened by the strength of memories about other victims whose fate was only spoken about, but not directly experienced - for example, the Ukrainian prisoners killed by the NKVD in 1941. Thus, besides first-hand experience, social memory is reliant on recognition of historical events as having happened to one's "own" people. The mechanisms of group memory are ruthless: Ukrainian victims of the NKVD are remembered because they are an extension of the Self, whereas the Holocaust of the Jews and the disappearance of Zhovkva's Poles are forgotten, because they remain Other.

The Others are also forgotten in Krzyż, but in a different way and in a different atmosphere to Zhovkva. The process of forgetting here seems to have more in common with natural features of memory in general, and less to do with a heritage of guilt that is yet to be worked through. Looking at the broader context: the Germanness of Krzyż is a much lesser problem for today's residents than the Polishness or Jewishness of Zhovkva. Everyone in Krzyż is aware that the town used to be a German one and that Poles did not live there in the past, but this

358 Bernard-Donals, Forgetful Memory. 
knowledge does not arouse any heated disputes or hasty justifications of one's right to live there or to belong to the locality. In Zhovkva, the memory of the Polishness of the town is still touched by unhealed injuries and lingering claims of guilt. The tone in which people in Krzyż spoke of Germans and German heritage was incomparably calmer than the manner in which people discussed the Poles in Zhovkva. Importantly, a greater acceptance of the historical presence of Others also seems to correlate with a greater readiness to commemorate the injuries with which they are associated - including injuries inflicted on them by members of one's own group.

\section{Memories of Heroes}

Only the heroic canon in Zhovkva showed features of both public and front-stage memory. Without a doubt, the town's identity after 1991 has been constructed on a recalibration of this canon, and this process has been carried out in public. There is no such memory in Krzyż - memories of the Soviets as anti-heroes are confined to the back-stage realm and are "semi-public" at best. In the terms employed by Charles Maier in relation to memories of communism and Nazism, memory in Krzyż is "cold," not "hot." 359 Perhaps in the near future these events will stop pertaining to the sphere of memory at all, becoming just history. Such a development would have significant consequences. In Zhovkva, there are two distinguishable memory groups that are very clearly defined and extremely antagonistic to each other, which are built on different approaches to the heroic canon; their boundaries cut across generations, and among young people they also cut across family backgrounds (which is evidence of their extraordinary power). There are no analogous divisions in Krzyż. One could perhaps posit that distinct groups exist in Krzyż in relation to the memories of resettlement, but such an observation would only apply to the first generation and they would be groups of people who shared similar experiences, rather than communities of memory per se. They would also be lacking an important constituent feature of memory groups: a desire to act as a group and to declare their interests in public.

The existence of memory groups directly affects the outbreak of conflicts of memory - or, to borrow Nijakowski's term, conflicts over symbolic domains. In Zhovkva there is a conflict of varying intensity between the post-Soviet memory

359 Charles S. Maier, "Hot Memory... Cold Memory: On the Political Half-Life of Fascist and Communist Memory," Transit: Europäische Revue, Vol. 22 (2002), http://www. iwm.at/transit/transit-online/hot-memory-cold-memory-on-the-political-half-lifeof-fascist-and-communist-memory/, last accessed 13.12.2018. 
group and the patriotic memory group. Importantly, Zhovkva's local authorities are an active participant in the dispute, working to further the cause of the patriotic group. The situation is very different in Krzyż: because there are no memory groups, there are no significant symbolic conflicts within the society. The only conflictual event in recent years was the issue of the destruction of the German cemetery; this, however, was a disagreement between active and more sensitive residents with an interest in history on the one hand, and the passive and rather indifferent town authorities on the other. Despite the small scale of this dispute, one consequence of the event was strengthening of social bonds and local identity: it served as a reminder of the Others who had previously lived in Krzyż in a milder way than the simmering anamnesis of Zhovkva, provoking discussions. It did not antagonize the community from within, because it was not an effect of internal divisions, but rather of misjudged actions by the authorities. The conflict raging in Zhovkva, in contrast, has no such bond-forming potential; whilst it does lead to discussions of local history and identity, these are largely futile because the distance between the mutually hostile camps makes it difficult to carry out an actual dialogue. The heroic canon in Zhovkva not only fails to build community, it even damages it, causing ever-deeper divisions.

\section{Between Memory and Forgetting}

In addition to the vanished Others, the experience of resettlement is also being relegated to the sphere of forgetting, although for completely different reasons. This memory has a private and back-stage character in both Krzyż and Zhovkva. This is a process that damages local identity, because it is a form of memory that is essentially free of the potential for conflict, and it is thus in a certain sense safe. Under different circumstances - perhaps even in another community nearby? it could possibly serve as the foundation for a shared local memory, which would be hugely significant for people who have been cut off from their roots. The private nature of this memory, the lack of consolidation in symbolic space, and the reluctance to commemorate resettlement in public have resulted in a blurring of these memories among the younger generations; they have become cut off from their specific historical context. This is especially visible in families of migrants from the pre-war eastern provinces in Krzyż. Many members of the youngest generation remember the Eastern Borderlands as a timeless mythological space, a vague "back then" with no connection to any specific time or place. In their memories, the political context of the loss of those lands - and therefore of their grandparents' old homelands - has become erased; only fragments of everyday life remain, such as the tough labor of the village or anecdotes told by former 
neighbors. In all certainty, their children, in turn, will not even remember these details, because the frames of autobiographical experience in which they functioned will have disappeared.

The weakening of memories of resettlement in subsequent generations is, in my interpretation, related to a broader change in the nature of how memory is passed on within the family. On the one hand, the existing literature points to a huge rise in interest in family history after the fall of communism, a democratization of such interests, and a higher value being attached to family histories. ${ }^{360}$ On the other hand, the increasing distance between generations - in particular, the substantial weakening of the authority that was once granted automatically to older people - and the decline in multi-generational families living under one roof have resulted in family pasts becoming less tangible and attractive for the youngest generation. The generation that grew up after the fall of communism in Poland and Ukraine is living faster and less calmly than the previous generation; its members are less likely to be brought up by their grandparents, and less frequently consider them to be personal authority figures to whom one would want to listen. This unwillingness to listen to elders also has deeper roots: children and grandchildren often hide away from family memory because of the sheer power of dramatic historical events - they do not wish to be touched by the trauma that affected their elders. One respondent in Krzyż was discussing how her family was drawn into the Polish-Ukrainian conflict, when she stated: "You know, the things we went through, I don't even want to... My children sometimes didn't even want to hear it when I tried to tell them about it. 'Mummy, don't say such awful things, we're scared' " (K35Af). On the other side of unhealed traumas are the silent parents and grandparents, who consciously cut themselves off from their wartime suffering, with scars too deep to speak about them openly. ${ }^{361}$ The blocking of memories in this instance is of a completely different nature to the forgetting of the Holocaust or of the deportation of the Germans, but it is much more complete.

A final reason why families were silent about resettlement is distrust and fear: in a totalitarian state, people were afraid to talk. In Krzyż this was not a factor,

360 Piotr T. Kwiatkowski, Pamięć zbiorowa społeczeństwa polskiego w okresie transformacji (Warszawa: Scholar, 2008).

361 Henry Greenspan has written about the complexity of family memory in relationship to traumatic experiences (his study concerns Holocaust survivors): people both want to share their traumatic pasts with their children and to protect them against these difficult memories, see: Henry Greenspan, On Listening to Holocaust Survivors: Recounting and Life History (Westport, CT-London: Praeger, 1998), p. 56. 
but in Zhovkva it often had a significant effect on family memory and broader family relations. Parents did not tell their children about resettlement because they were afraid of possible negative consequences; the children, in turn, did not believe their parents once they had eventually plucked up the courage to speak; on both sides, communication was paralyzed by fear. In such circumstances it was difficult to pass down family memories in a free and coherent manner; the consequences are still visible to this day, to a much greater extent in Zhovkva than in Krzyż.

Of course, it is not only memory of resettlement that is weakening in subsequent generations. This is also true of memories of Others and - perhaps to a lesser extent - of heroes and anti-heroes. The younger the respondents, the less detail they remember in, and the less emotion they adorn their accounts with thus, these memories are retreating further back-stage. With some exceptions, young people in Krzyż and Zhovkva remember the vanished Others with little vividness, depriving them of subjectivity; those Others are becoming more formulaic - i.e. little more than figures from history textbooks - as well as more distant. A similar process is underway in relation to the main anti-heroes in Krzyż, the Soviets; the younger the respondents, the more they find it difficult to harbor negative feelings against the former occupiers. The situation in Zhovkva is somewhat different because of the political potential inherent in the symbol conflict over the heroic canon; yet here as well, the younger generations' memories of heroes (and traitors) are weakening. However, it appears that the manner in which non-memory is advancing differs between the various subjects. Resettlement is forgotten in private, as a result of the faulty operation of family memory and its substitution by other, external forms of memory. Memories of Others and collective heroes, on the other hand, are on the wane for a range of reasons related to group identity, rather than individual concerns. Nonetheless, an overall pattern does hold for all of these processes of forgetting: the less experience people have of trauma, the fewer (painful) memories they have.

\section{Memories of the Past and Collective Identity}

What, then, is the relationship between the historical particularity of both towns and the local identities of their residents? How does the past affect the ways in which residents collectively define their ties to the locality, and how does it affect the town's image as it is presented to outsiders? Are history and social memory in Zhovkva and Krzyż constituent ingredients of a local identity, or do they hinder its construction? Or perhaps they play no role at all? Generally speaking, the building of identity - both individual and collective - is seemingly impossible 
without some invocation of tradition and a sense of continuity, because identity is precisely the consciousness of being contiguous with a previous self. This also applies to Krzyż and Zhovkva, although the status of history in the construction of a local identity is not immediately obvious.

In Krzyż, the two most important components of local identity are a regional allegiance to Wielkopolska and the railroad. The residents of Krzyż identify with Wielkopolska: the center in relation to which they situate themselves on the periphery is Poznań, the regional capital of Wielkopolska and a historically Polish city, and not Piła or Szczecin, towns that used to be German. Local folklore is replete with jokes and sayings about Poznań and Poznanians, and local culinary customs bear the hallmarks of the city's influence. Most young people move to Poznań to begin their university studies, and many who return to live in their native town after graduation commute to Poznan for work. Thus, on the one hand this allegiance is a pragmatic and practical regionalism that stems from ease of transportation and a need to be connected to a large city. On the other hand, Krzyżs link with Wielkopolska is to a great extent imagined, in the sense coined by Benedict Anderson, a classic in the nationalities studies, ${ }^{362}$ and despite appearances is intimately related to identity. Krzyż was in a way symbolically absorbed by the regional identity of Wielkopolska after the war; or rather, the town's identity seamlessly merged with the identity of Wielkopolska. The rich, abundant heritage of Wielkopolska was and continues to be much more attractive than the vague identity of the "Recovered Territories," which is associated with poverty, a landscape dotted with former collective farms, and uncertainty of people's fates. One respondent whose family was originally from Wielkopolska captured this idea poignantly: "The pull was always towards Wielkopolska, no doubt about that, we never identified as... I even remember that some people used to call Piła 'Karguland,'363 because it was almost exclusively resettlers who lived there" $(\mathrm{K} 40 \mathrm{Cm})$. The pre-war location of Krzyż on the German-Polish border made it easier for post-war residents to claim a Poznanian identity; since it was on the border, it was "almost" Polish, so it was not too big a step to treat it as if it had really been a Polish town. Krzyż's identification with Poznań was also facilitated by the presence of people from Wielkopolska, and especially Poznań,

362 Benedict Anderson, Imagined Communities: Reflections on the Origin and Spread of Nationalism (London: Verso, 1991).

363 Kargul is the name of one of the characters in the aforementioned film All Friends Here, a migrant from the pre-war East. In slang, "Kargul" is a synonym for a backward eastern resettler. 
among its new post-war residents; although they were not especially numerous, they tended to fill important roles within the community.

Interestingly, it appears there is no temptation to historicize the links between Krzyż and Wielkopolska; besides some activities that have been superficially internalized by the community, such as the singing of nineteenth-century patriotic anthems with an anti-Prussian bent during ceremonies, the town's self-identification with Wielkopolska primarily concerns the present day. Symptomatically, the most prominent articulation of the town's connection to Wielkopolska in recent years was not a monument or plaque, but a successful campaign to have Krzyż assigned to Wielkopolska Voivodeship, rather than Lubuskie Voivodeship, during the administrative boundary reforms of 1999.

The railroad, on the other hand, is a symbol that undoubtedly provides a sense of continuity. On the one hand, the town's identity as a rail junction has a practical dimension, determining its structures of work and family traditions (this influence is declining as a result of infrastructural dimensions, but it remains important nonetheless). In the words of one respondent: "Krzyż is like a family of rail workers. In Silesia, great grandfathers and grandfathers were all miners, and it's similar in Krzyż. In Krzyż granddads were railwaymen, and their sons and grandsons will be too... It's all about the railroad" (K16Am). On the other hand, the appeal to the railroad as a constitutive element of local identity since time immemorial naturally leads one to accept the town's German history. The Germans who founded the town and built the station become a positive force of development, expiated somewhat from their wartime crimes; they became "ours." At the same time, for the section of residents who would find it difficult to build their town's identity on its past Germanness, the railway can act as a safe, neutral and euphemistic substitute for this German heritage. A belief that Germanness is a partial or additional constituent of Krzyżs identity (but never the main one) was especially visible in interviews with the youngest generation. Many of them stated enthusiastically that they were from Kreuz, that they collected old German postcards, and that they were engaged in the rediscovery of the town's German past. This "thin" association with Germanness, devoid of any wartime trauma or guilt, is thus imperceptibly becoming part of the spectrum of local identity.

Zhovkva's identity also contains appeals to history, in a much more direct way than that of Krzyż. These appeals go in three directions. First, local identity is very visibly based on pre-modern times and the traditions of the age of the town's founders. The residents of Zhovkva are proud of the town's 300-year history, the architectural heritage and the historical figures associated with those traditions. The Ukrainians hold pride of place, but the earlier period of history 
is treated with a great tolerance for representatives of other nationalities, in part through a light Ukrainianization - Żółkiewski and Sobieski are "forgiven" their Polishness because of their connections to Zhovkva. ${ }^{364}$ A second element that anchors Zhovkva's identity in the past is the myth of multiculturalism, a "golden age" in its history, which presents the town as a place where various religious and ethnic groups lived in harmony. Many respondents held an idealistic image of Zhovkva and spoke of its pre-war past in these terms, even when they had personally experienced interethnic conflicts. The third direction is the activity of UPA and the post-war anti-communist resistance, understood as part of a tradition of Ukrainian martyrdom and anti-Soviet sentiment.

Unlike in Krzyż, the local identity of Zhovkva is based predominantly on the past, rather than the present. The neglected and run-down town is a typical postSoviet provincial landscape, so it is hardly surprising that people prefer to appeal to the bright past rather than exhibit the undistinguished present. Likewise, links with Lviv - to draw an analogy with the relationship between Krzyż and Poznan - are a source of frustration because of Zhovkva's dependent position, rather than a wellspring of security and pride. Thus, Zhovkva's local identity may even be overloaded with references to the past, especially considering that much of that memory is selective.

In both Krzyż and Zhovkva, the contemporary construction of identity is burdened with a similar bundle of negative inheritances: a post-war rupture in cultural continuity, indoctrination and the ideological dictates of the communist era, and the opening up of new possibilities after the fall of state socialism. In both cases, the reconstruction of the town's identity was a huge challenge both immediately after the war and following the fall of communism. Both the weight of the post-war abyss and the fear of the unknown after 1989/1991 made it necessary to seek new ways of laying roots. The identities of both towns therefore remain the expressions of a natural need for belonging, realized in different ways. The building of Krzyżs local identity is based on having access to the regional identity of Wielkopolska and through the accenting of the town's links to the railway, as well as also, after 1989, through a tentative appeal to the town's German heritage. In Zhovkva, continuity is established through a sense

364 This trend is characteristic of western Ukraine more generally. On the "Ukrainianization" or "multiculturalization" of the Polish past in Lviv, see: Eleonora Narvselius, "Polishness as Site of Memory and Arena for Construction of a Multicultural Heritage in L'viv," in: Whose Memory? Which Future? Remembering Ethnic Cleansing and Lost Cultural Diversity in Eastern, Central and Southeastern Europe, ed. Barbara Törnquist-Plewa (New York-Oxford: Berghahn Books, 2016), pp. 73-109. 
of being connected to Ukrainians who lived there in the past; the majority of today's residents identify with their "own" ethnic group while largely forgetting other ethnic groups who lived there previously.

Thus, what defines memory and local identity in Krzyż and Zhovkva is a state of suspension between two poles: on the one hand, a clear need to belong and inscribe oneself into a greater whole, and on the other hand, shallowness of these searches and superficiality of the imagined connections. This is why resettlement could not become a constitutive element of the two towns' new identities - an appeal to a past not shared would have been an unnecessary one, with no potential to build commonality. This balancing act is accompanied by a forgetting of the parts of the past that are inconvenient for the imagined bonds of community. I would even suggest that in Zhovkva, a forgetting of unhealed traumas is dominant, whereas in Krzyż the non-memory is less traumatized and has more in common with natural dampening of emotions linked to specific experiences. As a consequence, Zhovkva is mired in feverous self-justification through memory, while in Krzyż there is calmness and focus on the present, accompanied by openness to the town's historical heritage. I would surmise that it is easier to live with such memories in Krzyż than in Zhovkva. 


\section{Biographical Index of Respondents}

\section{Zhovkva}

Nationality and religious affiliation are given in accordance with respondents' own declarations. Unless stated otherwise, interviews were carried out in Ukrainian by the author.

Z1Af - born in 1930 in Rzeszów, Poland, to a wealthy Polish-Ukrainian household from Lwów (post-war Lviv). Greek Catholic. Before the war, she frequently visited Żółkiew on holiday. In summer 1939, her family was unsuccessful in an attempt to leave Żółkiew because of the outbreak of war, and she remained in the town. Her husband, a native of Źółkiew, was active in the UPA. Worked as a teacher.

Z1Bf - born in 1951 in Zhovkva. Ukrainian. Daughter of Z1Af. Higher education in a technical field. Retired at the time of the interview, though still working for a charity. During Soviet times, had several work contracts abroad, alongside her husband.

Z1Cf - born in 1973 in Zhovkva. Daughter of Z1Bf. Ukrainian. Higher education in humanities. Poet and translator (including from Polish). Living in Lviv.

Z2Am - born in 1922 in Żółkiew, to a peasant family. Ukrainian, Greek Catholic. Active in the UPA, was deported to Siberia in 1952. Returned to Zhovkva in 1957 after receiving an amnesty. Worked in a factory.

Z3Af - born in 1928 in a small town in Polish Subcarpathia. Ukrainian, Greek Catholic. Her parents died during the war. Her sister, who was active in the UPA, spent seven years in a Polish prison after 1945. In 1945, the respondent and her siblings were resettled to Zhovkva. Worked in a factory. Married a Ukrainian resettled from Poland, who had spent ten years in a Soviet labor camp in Siberia.

Z4Af - born in 1923 in a village in Polish Subcarpathia to a peasant family. Ukrainian, Greek Catholic. Was heavily injured in 1944 as a result of a German bombing. Was resettled to Zhovkva along with her family in 1945. Her father was murdered in Zhovkva by a Ukrainian nationalist militia, after he joined a Soviet collective farm. The respondent worked as a seamstress. Her husband was also resettled from Poland.

Z4Dm - born in 1978 in Zhovkva. Grandson of Z4Af. Ukrainian, Greek Catholic. Working as a teacher.

Z5Am - born in 1930 in a village in Polish Subcarpathia to a peasant family. Ukrainian, Greek Catholic. His family moved to Dnipropetrovsk (now Dnipro), eastern Ukraine, in 1944 as part of a resettlement operation. They attempted to 
return home in 1946, but settled in Zhovkva because the Polish border had been closed. Worked as a manual laborer.

Z5Cm - born in 1960 in Zhovkva. Ukrainian, Greek Catholic. Son of Z5Am. Secondary education, working in commerce.

Z6Am - born in 1929 in a village in Polish Subcarpathia. Ukrainian, Greek Catholic. His father's brothers fought in the UPA. His family applied for resettlement to Ukraine at the beginning of 1945 because they were afraid of the Poles. Worked in a collective farm. Married to a Ukrainian who was also resettled from Poland.

Z6Cf - born in 1963 in Zhovkva. Daughter of Z6Am. Ukrainian, Greek Catholic. Self-employed.

Z6Df - born in 1989 in Zhovkva. Daughter of Z6Cf. Ukrainian, Greek Catholic. Student of medicine in Lviv.

Z7Af - born in 1928 in Żółkiew. Polish, Roman Catholic. Married a local Ukrainian man. Worked in the town administration. Interview conducted in Polish.

Z8Af - born in 1930 in Żółkiew, to Polish-Ukrainian family. Polish, Roman Catholic. Married a Ukrainian from the vicinity of Zhovkva. Worked in a factory. Interview conducted in Polish.

Z8Cf - born in 1962 in Zhovkva. Daughter of Z8Af. Ukrainian, Roman Catholic. Trained as an accountant, working on an irregular basis in Poland. Married to a Ukrainian from near Zhovkva.

Z8Dm - born in 1985 in Zhovkva. Son of Z8Cf. Ukrainian, Roman Catholic. Basic vocational education. Working on an irregular basis in Poland.

Z9Af - born in 1929 in Łódź, Poland, to a Polish-Ukrainian family. Polish, Roman Catholic. Her father (a Ukrainian) decided in 1945 to move the family to Ukraine. After the war, she worked in a photography workshop and a factory. Married a Ukrainian from near Zhovkva. Interview conducted in Polish.

Z9Bf - born in 1954 in a village near Zolochiv, Ukraine. Daughter-in-law of Z9Af. Ukrainian, Roman Catholic. Working in a factory.

Z10Af - born in 1933 in a small town in central Ukraine (the Ukrainian SSR) to a peasant family. Polish, Roman Catholic. Several members of her family were killed during the Stalinist Terror of the 1930s. Graduated from a technical college in Lviv, and arrived in 1954 in Zhovkva to work in education. Married a local Pole.

Z10Cf - born in 1959 in Zhovkva. Daughter of Z10Af. Polish, Roman Catholic. Married to a Ukrainian from the vicinity of Zhovkva. Higher education, working as a teacher. Active promoter of Polish diasporic culture. Interview conducted in Polish. 
Z10Df - born in 1988 in Zhovkva. Daughter of Z10Cf. Ukrainian, Roman Catholic. Graduated from a teacher training college.

Z11 Af - born in 1927 in a village in Poltava oblast, Ukrainian SSR, to a family of well-to-do peasants. Ukrainian, Orthodox. Her parents were killed during the Stalinist Terror (her mother during the dekulakization of her family, her father in the camps); the respondent was transferred to an orphanage along with her siblings. Graduated from a teacher training college, married a Russian engineer in 1948; the husband was assigned to work in Zhovkva. The respondent worked as a teacher.

Z11Dm - born in 1984 in Lviv. Grandson of Z11Af. Ukrainian, Orthodox. His father was Russian. Graduated from Lviv Polytechnic National University, working in Zhovkva as an engineer.

Z12Bf - born in 1944 in a village in Polish Subcarpathia to a peasant family. Ukrainian, Greek Catholic. Her family was deported to Ternopil region, western Ukraine, in 1946. After a few months, they came to Zhovkva and settled in a nearby village. The respondent moved to Zhovkva in 1961. Worked in a factory. Her husband was from the vicinity of Zhovkva, from a Polish-Ukrainian family.

Z12Cm - born in 1973 in Zhovkva. Son of Z12Bf. Ukrainian, Greek Catholic. Secondary education. Working in commerce.

Z13Am - born in 1926 in a village in Polish Subcarpathia to a peasant family. Ukrainian, Greek Catholic. His home was burned down in 1944 during wartime hostilities. His family was moved in December 1944 to Odessa region (Ukrainian SSR). After one year, the family tried to go back home, but the Polish border was closed and they settled in a village near Zhovkva. The respondent moved to Zhovkva itself in 1964 . Worked in a collective farm.

Z14Af - born in 1926 in Żółkiew to a Polish-Ukrainian family. Roman Catholic. Her father (a Pole) passed away when she was a child. She married a Ukrainian from central Ukraine (the Ukrainian SSR), a police officer. Worked as a cook. Interview conducted in Polish.

Z15Am - born in 1934 in a village in Polish Subcarpathia to a peasant family. Ukrainian, Orthodox. His parents were resettled to Ukraine in 1946, initially to Ternopil Oblast, then to Zhovkva. Married to a Ukrainian from near Zhovkva. Worked in civil administration.

Z15Cf - born in 1960. Daughter of Z15Am. Ukrainian, Orthodox. Higher education, working as a teacher.

Z15Df - born in 1982. Daughter of Z15Cf. Ukrainian, Orthodox. Higher education in jurisprudence, working in a legal practice in Lviv.

Z16Af - born in 1928 in a village in Polish Subcarpathia to a peasant family. Ukrainian, Greek Catholic. Her family was resettled to Dnipropetrovsk Oblast 
(Ukrainian SSR) in 1944, and moved to Zhovkva a year later. Married to a Russian, a career soldier. Worked for a printing press.

Z16Bf - born in 1954. Daughter of Z16Af. Ukrainian, Orthodox. Higher education. Worked for the police. Married a Ukrainian from eastern Ukraine and lived there for 20 years.

Z16Dm - born in 1987. Son of Z16Bf. Ukrainian, Orthodox. Spent his childhood in eastern Ukraine. Studying medicine.

Z17Bm - born in 1942 in a village in Polish Subcarpathia to a peasant family. Ukrainian, Greek Catholic. His family was resettled to Dnipropetrovsk Oblast (Ukrainian SSR) in 1946, and moved to Zhovkva a year later. Worked as an electrician. Married to a Ukrainian from Zhovkva.

Z17Cf - born in 1971. Daughter of Z17Bm. Ukrainian, Greek Catholic. Secondary education. Working in commerce.

Z18Af - born in 1921 in a village in Polish Subcarpathia to a peasant family. Ukrainian, Greek Catholic. Was resettled to western Ukraine in 1944 along with her husband and daughter, initially to a village near Zhovkva, then to Zhovkva itself. Worked on a collective farm.

Z18Am - born in 1923 in a village in Polish Subcarpathia to a peasant family. Ukrainian, Greek Catholic. Was resettled to Ukraine in 1944. Worked on a stateowned forestry enterprise. Husband of Z18Af.

Z18Bf - born in 1944 in a village in Polish Subcarpathia to a peasant family. Daughter of Z18Af and Z18Am. Resettled to Ukraine with her parents in 1944. Secondary education, working in education.

Z19Af - born in 1927 in a village near Żółkiew to a well-to-do peasant family. Ukrainian, Greek Catholic. Active as local liaison in Zhovkva for the UPA from 1945. Exiled to Siberia with whole family in 1950. Married a Ukrainian (also a member of the UPA) whilst in exile. Returned to Zhovkva in 1962. Worked in a factory.

Z19Cf - born in 1963. Daughter of Z19Af. Ukrainian, Greek Catholic.

Z19Dm - born in 1991. Son of Z19Cf. Ukrainian, Greek Catholic. Studying in a technical college.

Z20Am - born in 1934 in a village near Złoczów (Lwów region, now Zolochiv), to an impoverished peasant family. Ukrainian, Orthodox. Graduated from police school, served in the police force from 1958 in a village near Zhovkva, and from 1961 in Zhovkva itself. Married to a Ukrainian from the east of the country.

Z20Af - born in 1931 in a village in Kyiv Oblast (Ukrainian SSR) to a peasant family. Ukrainian, Orthodox. Wife of Z20Am. Upon graduating from a teacher training college in Lviv, was assigned to work in western Ukraine. Worked in a school in Zhovkva from 1961. 
Z20Cm - born in 1963. Son of Z20Am and Z20Af. Ukrainian, Orthodox. Working as a taxi driver.

Z21Bm - born in 1938 in a village near Żółkiew. Ukrainian, Greek Catholic. His parents were killed by the NKVD shortly after the end of the war. Arrived in Zhovkva in the 1950s to study at a vocational school connected to a factory. Worked in the town until retirement. Interview conducted by Tetiana Rodnienkova.

Z22Af - born in 1918 in a village in Kursk Oblast, Russia, to a family of collective farm employees. Russian. Graduated from a teacher training college and married an employee of the regional party committee. Her husband died at the front during the war; she was evacuated to Kyrgyzstan, where her daughter died. Marched with the Red Army to Berlin as a volunteer. After demobilization, was assigned to work in the regional party committee in western Ukraine; transferred to Zhovkva soon after. Interview conducted in Russian by Tetiana Rodnienkova.

Z23Af - born in 1929 in a village near Żółkiew. Ukrainian, Greek Catholic. Graduated from a teacher training college in Lviv. Arrived in Zhovkva in 1951 to work in a school. Married to a Ukrainian man from the east of the country. Interview conducted by Tetiana Rodnienkova.

Z24Af - born in 1923 in a village in Kyiv Oblast (Ukrainian SSR). Ukrainian, Orthodox. Was sent into forced labor in Germany during the war. Graduated from teacher training college and worked in Ternopil Oblast in 1946-1948. Married a Soviet officer, a Ukrainian, in 1950; he was assigned to work in Zhovkva. Initially worked in a school in a village near Zhovkva, later in Zhovkva itself. Interview conducted by Tetiana Rodnienkova.

Z25Af - born in 1920 in Odesa Oblast. Ukrainian. Her father was a blacksmith and a teacher. Her grandmother died in the Great Famine of 1932-1933. Graduated from the Pedagogical Institute and arrived in Zhovkva in 1951, where her husband found work. Worked in education. Interview conducted by Tetiana Rodnienkova.

Z26Af - born in 1923 in a village in Krasnodar Krai, Russia. Russian. Her parents and siblings died during the Great Famine of 1932-1933. After graduating from a nursing college after the war, was assigned to work in a field hospital near Zhovkva. Met her husband there, a war invalid from near Zhytomyr (Ukrainian SSR). Moved to Zhovkva in 1947, where her husband found work. Worked in a hospital. Interview conducted by Tetiana Rodnienkova.

Z27Bm - born in 1938 in a village near Żółkiew to a peasant family. Ukrainian, Greek Catholic. Living in Zhovkva since the late 1950s. Worked as a driver.

Z27Df - born in 1978. Daughter of Z27Bm. Ukrainian, Greek Catholic. Studied economics at a university in Lviv. Living in a village near Zhovkva. 
Z28Bf - born in 1940 in a small town in Polish Subcarpathia to a PolishUkrainian family. Polish, Roman Catholic. Her parents - both teachers - arrived in Zhovkva voluntarily in 1944. Her father (a Ukrainian) spent several years in a labor camp in Kazakhstan. Higher education in a technical field. Married to a Ukrainian. Active member of Polish diaspora. Interview conducted in Polish.

Z28Dkf - born in 1993. Granddaughter of Z28Bf. Greek Catholic. Secondary school pupil. Interview conducted in Polish.

Z29Af - born in 1922 in Bydgoszcz, Poland. Ukrainian, Greek Catholic. Her father served in the Polish military. She spent the war in Rzeszów, Poland. Her parents left for Lviv in 1944. Graduated from teacher training college in Lviv, and was assigned to work in a village near Zhovkva in 1951. Later worked in a school in Zhovkva. Was an active participant of patriotic movements in the 1990s. Interview conducted by Myroslava Keryk.

Z30Af - born in 1928 in Żółkiew to a peasant family. Ukrainian, Greek Catholic. Graduated from a medical college, worked as a laboratory assistant. Interview conducted by Myroslava Keryk.

Z31Am - born in 1927 in Żółkiew. Ukrainian, Greek Catholic. His father worked on the railroads. During the war, was sent to Germany for forced labor. After the war, was sent first to the Donbas, then to the Ural Mountains. Returned to Zhovkva in 1947. Active in the patriotic movement, was an initiator of many public memorials, including to the victims of the NKVD. Interview conducted by Myroslava Keryk.

Z32Af - born in 1929 in Zaporizhia Oblast, Ukrainian SSR, to a RussianUkrainian family. Ukrainian, Orthodox. Graduated from a teacher training college and was assigned in 1951 to work in a library in Zhovkva. Her husband, a Ukrainian man from Poltava Oblast (Ukrainian SSR), was a functionary of the KGB. Interview conducted by Myroslava Keryk.

Z32Cf - born in 1960. Daughter-in-law of Z32Af. Ukrainian, Greek Catholic. Her parents came from Zhovkva. Secondary education.

Z33Am - born in 1917 in a village in Polish Subcarpathia to a peasant family. Ukrainian, Greek Catholic. Was sent for forced labor to Germany during the war. After returning, left for Ukraine and settled in Zhovkva. Worked as a carpenter. Married to a Ukrainian resettled from Poland. Interview conducted by Myroslava Keryk.

Z33Bm - born in 1949. Son of Z33Am. Ukrainian, Greek Catholic. Graduated from a university in Lviv with a degree in economics. Lives in Lviv.

Z34Af - born in 1932 in a village near Lwów. Ukrainian, Greek Catholic. Graduated from a medical vocational college, worked in a pre-school. Arrived 
in Zhovkva in 1952 to work. Married a local Ukrainian. Interview conducted by Myroslava Keryk.

Z35f - born in 1924 in Żółkiew. Ukrainian, Greek Catholic. Her brother joined the UPA after the war and was killed. In 1949 the whole family was deported to Siberia; she returned at the end of the 1950s. Worked as a cook. Interview conducted by Myroslava Keryk.

Z36Af - born in 1925 in Żółkiew. Ukrainian, Greek Catholic. Her mother died during the war. Her father worked for the town administration during the German occupation, and was deported to Siberia by the Soviets in 1945 together with her brother. The respondent joined them voluntarily. Returned to Zhovkva 35 years later. Interview conducted by Myroslava Keryk.

Z37Cf - born in 1972. Ukrainian. Her maternal grandparents came from Russia and her paternal grandparents from Zhovkva. A sociologist by training and an academic employee at a university in Lviv.

Z38Cm - born in 1956. Ukrainian. His parents were Russian; the father was assigned to work in western Ukraine after the war as a policeman, and the mother arrived from Krasnoyarsk Krai, fleeing from post-war famine. The respondent was working for the police and living in the so-called House of Clara, where Józef Beck hid 17 local Jews during the war.

Z39Cf - born in 1968 in a village in Lviv Oblast. Ukrainian, Greek Catholic. Her parents moved to Zhovkva when she was six years old. Married a local Ukrainian man whose parents had migrated from the vicinity of Zhovkva. Owner of an agritourism enterprise and working as a tour guide.

Z40Bm - born in 1952 in a village near Zhovkva. Graduate of Lviv Polytechnic National University, engineer. Arrived in Zhovkva in 1977 for work. Established the "Svitlo Kultury" ("Light of Culture") foundation in 1990, a social organization that initiated the renovation of many historical sites and monuments in Zhovkva, including the synagogue and memorials to local Jews. At the time of interview, deputy director of the museum in Zhovkva castle.

Z41Bf - born in 1955 in Siberia. Ukrainian, Greek Catholic. Her parents were members of the Lviv intelligentsia and were deported during the war. They returned to Ukraine in the late 1950s and settled in Zhovkva. Working as a teacher.

Z41Df - born in 1981. Daughter of Z41Bf. Ukrainian, Greek Catholic. Graduated from a university in Lviv with a degree in cultural studies, also studied in Canada. Working in the tourism department of the Lviv City Council. Together with her husband, founded an organization that promotes the cultural and touristic development of Zhovkva. 
Z41Dm - born in 1981 in Lviv. Husband of Z41Df. Ukrainian, Greek Catholic. Higher education, engaged in the development of cycling tourism.

Z42Cf - born in 1960 in Lviv. Ukrainian. Graduate of the Academy of Arts. Living in Zhovkva since 1992 (married a local Ukrainian). Director of the museum in Zhovkva castle since 2001.

Z43Dm - born in 1980 in Kamianske (then called Dniprodzerzhynsk) in eastern Ukraine. Ukrainian, Roman Catholic. Employee of the Tourist information center. Settled in Zhovkva because he had always wanted to live in western Ukraine.

Z44Cf - born in 1973. Ukrainian, Greek Catholic. One set of grandparents came from a village near Zhovkva, the others from Volhynia. Working in the museum, working on a doctoral dissertation on the Holocaust in Zhovkva.

Z45Dm - born in 1985. Ukrainian, Greek Catholic. Graduated with a history degree from Lviv University. One set of his grandparents came from Zhovkva, the other from villages in the vicinity. During the war, part of his family was deported to Siberia.

\section{Krzẏ̇}

Unless stated otherwise, interviews were conducted in Polish by the author.

K1Af - born in 1914 in a village in Wielkopolska to a peasant family. The Germans depopulated the village in 1940. After a short stay in a transit camp in Łódź, the respondent left for Poznań to join her fiancé. Lived in Poznań with her husband until 1945, working as a cleaner in a German shop. Her husband left for Krzyż in February 1945 to work on the railways, and the respondent and their daughters joined in 1946. Did not work professionally thereafter; looked after the house and the children.

K1Bf - born in 1941 in Poznań. Daughter of K1Af. Arrived in Krzyż with her mother in 1946. Secondary education, worked on the railways. Married a Polish "repatriate" from Belarus.

K2Am - born in 1927 in a village in Wielkopolska. Moved to Poznań in 1936 with his parents. During the German occupation, worked in the city abattoir and on a German farm near Poznań. Moved to Krzyż in April 1945, where he started to work on the railways. Husband of K2Af.

K2Af - born in 1930 in a small town near Tarnopol (now Ternopil, western Ukraine). Her father owned a large carpentry firm and her mother hailed from an impoverished landed gentry family. Her family decided to move to Poland in April 1945, after a stay in Tarnów; they settled in Krzyż in August of the same year. The respondent worked in a shop; after marriage she looked after the home and children. Wife of K2Am. 
K2Bm - born in 1954. Son of K2Af and K2Am. Secondary education, worked on the railways. Interview conducted by Teresa Wylegała.

K2Cf - born in 1959. Daughter of K2Af and K2Am. Higher vocational education, worked on the railways. Owner of a tailor shop.

K2Df - born in 1983. Daughter of K2Cf. Higher education with pedagogical specialization, working in a preschool.

K3Af - born in 1924 in a village in Wielkopolska. Her father was a railway worker and the family moved to a small town in 1926. In August 1939, the respondent, her mother and younger siblings were evacuated to the vicinity of Lwów. She returned home two months later. From 1940 she worked on a German estate in the vicinity. Started to work on the railways in Krzyż in 1945 and moved there permanently in 1948. Married to a "repatriate" from Ukraine.

K3Bf - born in 1951. Daughter of K3Af. Vocational education. Worked on the railways. Interview conducted by Teresa Wylegała.

K4Af - born in 1922 in a village in Wilno region (now Vilnius, Lithuania) to a peasant family. Began studies in a nursing college in 1944, then worked in a field hospital. Moved to Poland with her mother and siblings in 1946 and settled in a village near Krzyż. Worked as a dressmaker and cook, also ran a farmstead with her husband. Her husband was from Zamość region, Poland. Interview conducted by Jarosław Pałka.

K5Am - born in 1918 in a village in Lwów Voivodship (now Lviv, Ukraine) to a peasant family. Fought in the September 1939 defensive war. Was called up to the Red Army in 1944. Moved to Poland in 1945; settled in a village near Krzyż. Worked on a farm throughout his life. His wife was from the same village where he was born. Interview conducted by Dominik Czapigo.

K5Df - born in 1982. Granddaughter of K5Am and K16Am. Higher education in economics. Working in a commercial company.

K6Af - born in 1921 in a landowners' estate in Wielkopolska, where her father worked as a coachman. The family moved to the vicinity of Poznan in 1929, where they spent the war period. During the German occupation the respondent worked on an estate run by Germans. Arrived in Krzyż in January 1946, where her husband, a railway worker, found employment. Looked after the house thereafter. Interview conducted by Dominik Czapigo.

K6Bm - born in 1946. Son of K6Af. Vocational education, worked on the railways. Interview conducted by Teresa Wylegała.

K7Am - born in 1931. Spent his childhood in a Polish village near Kreuz. His father was a railway worker. His family fled from the German occupation to Lwów region in August 1939, but returned after a month due to fear of the Soviets. Worked as a forced laborer on a German farm near Kreuz between 1941 
and 1945. His family moved to Krzyż in 1948. Amongst other jobs, worked in a furniture factory and the state coach transport service.

K7Bm - born in 1954. Son of K7Am. Owner of a car repair workshop. Interview conducted by Teresa Wylegała.

K8Af - born in 1926 in a village in Nowogródek region (now Navahrudak, Belarus), to a peasant family. Emigrated to Poland in August 1945 together with her family, and settled in a village near Krzyż. Worked in agriculture throughout her life. Her husband was also a "repatriate."

K8Bm - born in 1954. Son of K8Af. An electro-mechanic technician by training. Lived in Gorzów Wielkopolski, western Poland, for 35 years; returned to Krzyż after retirement. Interview conducted by Teresa Wylegała.

K9Af - born in 1921 in a village in Stanisławów Voivodship (now IvanoFrankivsk region, Ukraine) to a peasant family. Her father was killed by Ukrainians in 1944. Her mother and siblings left for Poland in autumn 1944; the respondent and her husband made the journey in June 1945. Settled in a village near Krzyż, where her husband was a soltys [head of the village] for many years.

K9Bm - born in 1950. Son of K9Af. Vocational education, held several jobs including working for the forestry commission.

K9Df - born in 1978. Daughter of K9Bm. Higher education, working in administration.

K10Af - born in 1925 in Poznań. Her mother worked in a factory, her father in military storage units. Her father was arrested by the Germans during the war for illegal trading and was sentenced to prison, where he remained until the end of the war. The respondent worked in a factory in Poznan during the occupation. In January 1945, during the battle for Poznan, the building in which the family lived was burned down. The respondent married in May 1945 and moved to a Polish village near Krzyż, her husband's home. She moved to Krzyż in 1947 along with her family. Worked for the healthcare service. Interview conducted by Jarosław Pałka.

K10Bm - born in 1949. Son of K10Af. Vocational education, worked on the railways. Interview conducted by Teresa Wylegała.

K11 Am - born in 1929 in a village in Wielkopolska. His father was a forester. The respondent was brought up in a Polish town on the then Polish-German border. During the war underwent forced labor in a German abattoir in Kreuz. Moved to Krzyż in 1948. Graduated from a vocational training college, worked, amongst other jobs, as a driver and storage manager.

K12Am - born in 1926 in Lwów. Worked on the railways during the German occupation. His family moved to Kraków in 1944, afraid of Soviet persecution. After the Red Army took Kraków, he worked on the railways, and left for the "Recovered Territories" in March 1945 on a special transport for railway workers 
from Lviv. In Krzyż, was assigned to work on the development of a hydroelectric power station in the vicinity. Worked on the railways from 1947.

K13Am - born in 1931 in a village in Lwów Voivodship (now Lviv, Ukraine) to a peasant family. His father was a local social activist. His family's homestead was burned down by Ukrainians in June 1944 and the family moved to a nearby town; shortly afterwards, they were sent by the Germans to work in Hungary. The family emigrated to Poland in May 1945 and settled in a farmstead in a village near Krzyż. The respondent completed her secondary education on a part-time basis, then worked in agriculture.

K14Af - born in 1919 in a Polish village bordering on Kreuz. Worked in domestic service in Poznań in her youth. Married a communist activist in 1940. Worked in a German pharmacy during the occupation. Moved back to her native village in 1945 together with her husband, then left for Krzyż in search of a place to live. Worked as a cleaner.

K14Cf - born in 1974. Granddaughter of K14Af. Higher vocational education, working as a shop assistant.

K14Cm - born in 1972. Husband of K14Cf. Working on the railways.

K15Bf - born in 1936 in a Polish village bordering on Kreuz. Her parents owned a farm, and her father worked in a foundry during the German occupation. Due to the grandparents having a German-sounding surname, the family avoided persecution during the war. They moved to Krzyż in 1946, where the respondent's father gained employment on the railways. Graduated from a tailoring school and worked as a dressmaker from the age of 17. Interview conducted by Jarosław Pałka.

K15Cf - born in 1958. Daughter of K15Bf. Secondary education. Worked on the railways.

K16Am - born in 1926 in a village in Lublin region, Poland. His father was a forester. Was imprisoned by the Polish secret police twice, in 1945 and 1946, for assisting Home Army units during the war. The entire family left for the "Recovered Territories" in April 1946 out of fear of persecution by the communist state. They settled in a village near Krzyż. The respondent served in the military in Subcarpathia in the years 1947-1949, taking part in Operation Vistula. After returning, he studied at a technical vocational college and worked for a land amelioration company until 1989.

K16Cf - bon in 1957. Daughter of K16Am. Mother of K5Df. Secondary education with economic profile. Running a private farm together with her husband.

K16Dm - born in 1989. Granddaughter of K16Am and K5Am. Secondary education with technical profile, living in a village, proprietor of a construction company. 
K17Am - born in 1929 in Lwów (now Lviv, Ukraine). In 1933, after the death of the father, his family moved to a smaller town in Galicia, where his mother worked as a steward in a dormitory. Arrived in Krzyż in 1945 as part of the "repatriation" operation. Higher education, worked as a teacher, was a founder and active member of the scouting association in Krzyż and a regular representative of local self-government after 1989.

K18Af - born in 1915 in a village in Nowogródek region (now Navahrudak, Belarus) to a peasant family. Graduated from a teacher training college and was admitted to the Pedagogical Faculty of Lwów University in 1939, but did not begin her studies due to the outbreak of war. Married a teacher. Worked in a Belarusian school during the war. Migrated to Poland in 1945 with her husband and daughter. Ran a farmstead near Krzyż together with her husband until 1949; thereafter, worked for 30 years in a school. After the death of her son, a poet, looked after his literary estate.

K19Af - born in 1934 in a village in Lublin region, Poland. Sister of K16Am. Her father was a forester. Her family left for the "Recovered Territories" in 1946 out of fear of Ukrainian nationalist militias and persecution by the Polish communist secret police; they settled in a village near Krzyż. Worked in administration.

K20Af - born in 1925 in a village in Lwów Voivodship (now Lviv, Ukraine) to a peasant family. Left for Poland in May 1945 with her maternal aunt and her aunt's husband; her parents and siblings remained in the USSR and arrived in Krzyż in 1956. Lived in a village in the vicinity of Krzyż until 1948, then moved to a village near the Polish-German border with her husband. Returned to the Krzyż area after a decade, where she ran a farm enterprise with her husband. Her husband was also a "repatriate."

K20C $\mathbf{f}$ - born in 1959. Daughter of K20Af. Secondary education. Owner of a private farm together with her husband.

K20Df1 - born in 1982. Daughter of K20Cf. Higher vocational education. Looking after house and children.

K20Df2 - born in 1984. Daughter of K20Cf. Secondary vocational education. Looking after house and children.

K21Af - born in 1929 in a village in Volhynia, now Ukraine. Her father was a military settler and worked as a locksmith. Her mother worked as a dressmaker. After the Soviets invaded in 1939, her maternal aunt was deported to Siberia. The respondent's older sister and brother-in-law were murdered by a Ukrainian militia. The family fled to a nearby town in 1942, and were then sent into forced labor in Germany. The respondent and her family arrived in Poland's new western provinces in May 1945, settling in a rural homestead near Krzyż, 
then moved to the town itself in 1951. Worked in a canteen. Her husband was from Polish Subcarpathia.

K21Cm - born in 1958. Son of K21Af. Secondary education, worked on the railways; at the time of the interview, working as a security guard.

K22Af - born in 1928 in Poznań. Spent her childhood in a Polish village bordering on Kreuz. Her father was a tailor. Deported to Germany for forced labor in 1943. Returned home in 1944 and worked for the remainder of the occupation as a carer for children in a German family. Her family moved to Krzyż in October 1945. Worked in a variety of industrial companies.

K22Bm - born in 1950. Son of K22Af. Higher vocational technical education, worked in a number of jobs including in a foundry and the waterworks. One of his daughters married a German man and moved to Germany. Interview conducted by Teresa Wylegała.

K23Af - born in 1918 in a village in Wielkopolska. Her father was an administrator on a landowners' estate. After finishing school, the respondent lived and worked in Poznań. Worked in a German tailor shop during the war. Moved to Krzyż in May 1945, after her husband gained employment on the railways. Worked as a dressmaker.

K23Bf - born in 1938. Daughter of K23Af. Secondary education. Worked as a school secretary and in construction, among other jobs. Interview conducted by Piotr Filipkowski.

K23Cm - born in 1972. Grandson of K23Af, nephew of K23Bf. Secondary education, working on the railways in Poznań.

K24Am - born in 1930 in a village in Volhynia, now Ukraine, to a peasant family. His father was a Pole and his mother was Czech. During the German occupation his family concealed a group of Jews, who were later discovered and murdered by a Ukrainian man from the same village. In 1943 the respondent and his family were deported to Austria for forced labor, where one of his brothers died. After the end of the war the family was deported to Soviet Ukraine. Upon returning to Volhynia they lived on a collective farm for three months. They left for Poland in December 1945. The respondent graduated from a technical vocational college and worked in land amelioration. Married to another Pole from Volhynia (K24Af).

K24Af - born in 1935 in a village in Volhynia. Her father worked as a carriage driver on the estate of the Radziwiłł magnate family. The family hid from Ukrainian nationalists during the war. They were sent to Austria for forced labor in 1943. They left for Poland in May 1945 and settled in a village near Krzyż. The respondent moved to Krzyż in 1951. Worked in a canteen. 
K25Bm - born in 1938 in Germany. His parents, who were from central Poland, had migrated to Germany to work before 1918 and remained there. During the war they worked as agricultural workers on a German landowners' estate. The family left for Poland in April 1945 and settled in Krzyż. The respondent graduated from a polytechnic college and worked as an engineer. Was a town councilor after 1989. Writing a memoir and a history of his family.

K25Bf - born in 1944 in Kraków. Her parents and grandparents came to Krzyż in 1945, where her grandfather opened a restaurant in the railway station (it was confiscated after a few years during the state's fight against private business). Secondary education, worked in a bank. Wife of K25Bm.

K25Cm - born in 1965. Son of K25Bf and K25Bm. Secondary education, working on the railways.

K25Df - born in 1991. Daughter of K25Cm. Student of nutrition science.

K26Bk - born in 1942 in a village in Nowogródek region (now Navahrudak, Belarus) to a peasant family. Arrived in Krzyż in 1945 with her parents. Secondary education, worked as a drafting technician. Married a man from Gdańsk.

K26Cf - born in 1970. Daughter of K26Bf. Higher education, working in a care organization.

K27Af - born in 1919 in a village near Warsaw. Because the village became overpopulated after the fall of the Warsaw Uprising in 1944, moved to the "Recovered Territories" together with her husband. Settled in a village near Krzyż in 1945, where they ran a mill and farmstead. Interview conducted by Piotr Filipkowski.

K27Bm - born in 1940. Son of K27Af. His parents moved to a village near Krzyż in 1945. Higher education, worked as a teacher. Interview conducted by Teresa Wylegała.

K28Am - born in 1917 in Germany, where his parents worked as seasonal laborers. Spent his childhood in a village in Wielkopolska. His parents and siblings were deported to Germany for forced labor during the war, whilst he was employed in a factory in Poznań. Arrived in Krzyż in 1945, looking for work. Worked on the railways, was an active supporter of the communist party. Interview conducted by Piotr Filipkowski.

K29Bf - born in 1942 in a village in Polish Subcarpathia to a Lemko family of Greek Catholic faith. Her father was a postman. The family was resettled in 1947 as part of Operation Vistula. After a short stay in a formerly German estate near Piła, they settled in a village in Krzyż, where the respondent continues to live. Her husband comes from Wielkopolska.

K29Cf - born in 1969. Daughter of K29Bf. Higher vocational education, self-employed. 
K29Df - born in 1992. Daughter of K29Cf. Student of geography.

K30Af - born in 1926 in a village in Wielkopolska. Sister of K3Af. Her father was a railway worker. The respondent and her mother and siblings were evacuated to the vicinity of Lwów in 1939. Upon returning home, worked in a German dairy. Was sent to eastern Germany (part of the post-war "Recovered Territories") for forced labor in 1941. Was evacuated westwards in January 1945 together with the family to which she was assigned; she worked on their estate until April of that year. Began working on the railways in Krzyż in 1946. Her husband was from Wielkopolska. Interview conducted by Teresa Wylegała.

K30Cf - born in 1963. Daughter of K30Af. Higher education, working on the railways. Interview conducted by Teresa Wylegała.

K31Af - born in 1929 in a small town in Stanisławów Voivodship (now Ivano-Frankivsk region, Ukraine). Her father was a miner in a salt mine; he was arrested by the Germans during the occupation for illegal slaughter of animals and died in prison. Her brother died in a concentration camp in Germany. The family moved to Poland in July 1945. The respondent worked at the post office. Her husband was also from the pre-war East. Interview conducted by Teresa Wylegała.

K31 Bm - born in 1951. Son of K31Af. Vocational education. Worked on the railways in Lublin region for two decades and returned to Krzyż after retirement. Interview conducted by Teresa Wylegała.

K32Bf - born in 1940 in a village near Lwów. Her family fled to Lwów in 1944 out of fear of Ukrainian nationalists, and were subsequently deported to Austria for forced labor. They returned to Lviv in 1945, and then left for Poland. After trying to settle in a larger town, they found a home in Krzyż. The respondent graduated from a vocational school and worked in a shop and as a waitress. After becoming a mother, she looked after the household. Interview conducted by Teresa Wylegała.

K32Cf - born in 1962. Daughter of K32Bf. Higher education, worked as a teacher, retired at the time of the interview. Interview conducted by Teresa Wylegała.

K33Af - born in 1930 in a village now in Belarus to a peasant family. Her father was wounded in the 1939 defensive war and died. The family left for Poland in 1945 out of fear of Soviet collectivization. They settled in a village near Krzyż, where the respondent worked in a rettery. Moved to Krzyż after marriage, worked in a concrete plant. Interview conducted by Teresa Wylegała.

K33Df - born in 1986. Granddaughter of K33Af. Secondary education.

K34Bf - born in 1935 in Poznan. Her father worked on the railways. The family fled from Poznań in 1939 to escape from the Germans, and upon returning they 
were evicted from their home. Her father gained work on the railways in Krzyż in 1945 and moved the whole family there. The respondent worked as a teacher. Her husband was a "repatriate" from today's Belarus. Interview conducted by Teresa Wylegała.

K35Af - born in 1930 in a town in Stanisławów Voivodship (now IvanoFrankivsk region, Ukraine) to a military family. Her father was in hiding during the Soviet occupation. Her maternal cousins were murdered by Ukrainian nationalists. The family left for Poland in 1945 and settled in Krzyż. Her husband came from Poznań. Interview conducted by Teresa Wylegała.

K36Af - born in 1926 in a village in central Poland to a peasant family. Her mother had German roots. After the family refused to be included in the Volksliste after the outbreak of war, they were evicted from their homestead. The respondent came to Krzyż in November 1945, after her husband received work on the railways. Worked as a dressmaker and on the railways. Interview conducted by Teresa Wylegała.

K37Bm - born in 1946. Her parents were from a Polish village near the border with Kreuz; the family arrived in Krzyż in 1945. Working in administration, living in a village near Krzyż.

K38Bf - born in 1953. Mayor of Krzyż Wielkopolski. Higher education, previously worked as a teacher.

K39Bf - born in 1953. Her mother was a German who married a forced laborer from Poland, who was working on her parents' mill; after the war, the parents remained in Krzyż. Together with her husband, owns a farm enterprise in the vicinity of Krzyż.

K40Cm - born in 1955. His father was born in the USA to a family of emigrants from Polish Subcarpathia; the family moved back to Poland before the war. The respondent's father came to Krzyż in 1948 to work on the railways. The respondent himself worked in education.

K41Cf - born in 1959. A history teacher and head of an elementary school. Living in Krzyż since the 1970s.

K42Dm - born in 1978. His grandfather was from near Mława, central Poland, and was granted a farmstead near Krzyż for his service in the Polish military. His maternal grandparents were "repatriates" from today's Ukraine (his grandmother was Slovenian). Secondary education. A collector of German postcards.

K43Cm - born in 1971. His mother came from today's Belarus and his father from Kuyavia, north-central Poland. Completed a higher education degree in forestry, working as a forester. Interview conducted by Teresa Wylegała.

K44Dm - born in 1982. His grandparents came from today's Lithuania. A history teacher in an elementary school, he wrote his Masters thesis on the post-war deportations in Krzyż. 


\section{Bibliography}

Åberg, Martin. "Paradox of Change: Soviet Modernization and Ethno-Linguistic Differentiation in Lviv, 1945-1989." In: Harvard Ukrainian Studies, Vol. 24: Lviv. A City in the Crosscurrents of Cultures, ed. John Czaplicka, 2002, pp. 285-302.

Ahonen, Pertti, Gustavo Corni, Jan Kochanowski, Reiner Schulze, Tamar Stark and Barbara Stelzl-Marx. People on the Move. Forced Population Movements in Europe in the Second World War and its Aftermath. Oxford-New York: Berg Publishers, 2008.

Amar, Tarik Cyril. "A Disturbed Silence. Discourse on the Holocaust in the Soviet West as an Anti-Site of Memory." In: The Holocaust in the East. Local Perpetrators and Soviet Responses, ed. Michael David-Fox, Peter Holquist and Alexander M. Martin. Pitsburgh: University of Pitsburgh Press, 2014, pp. 158-184.

Amar, Tarik Cyril. The Paradox of Ukrainian Lviv. A Borderland City between Stalinists, Nazis, and Nationalists. Ithaca and London: Cornell University Press, 2015.

Amar, Tarik Cyril, Ihor Balynskyi and Yaroslav Hrytsak, eds. Strasti za Banderoju. Kyiv: Hrani-T, 2010.

Anderson, Benedict. Imagined Communities: Reflections on the Origin and Spread of Nationalism. London: Verso, 1991.

Arkusha, Olena. "Polskyi i rosiiskyi chynnyky u formuvanii suchasnoi natsionalnoi svidomosti halytskykh ukraintsiv: istorychnyi dosvid i suchasni paraleli." In: Istorychni mify ta stereotypy, ed. Leonid Zashkilniak. Lviv: Instytut Ukrainoznavstva im. Krypiakevycha NAN Ukrainy, 2009, pp. 144-209.

Assmann, Aleida. Der lange Schatten der Vergangenheit. Erinnerungskultur und Geschichtspolitik. München: CH Beck, 2006.

Assmann, Aleida. "Canon and Archive." In: Cultural Memory Studies: An International and Interdisciplinary Handbook, ed. Astrid Erll and Ansgar Nünning. Berlin/New York: de Gruyter, 2008, pp. 97-108.

Assmann, Jan. Cultural Memory and Early Civilization: Writing, Remembrance and Political Imagination. Cambridge: Cambridge University Press, 2011.

Assorodobraj, Nina. “'Żywa historia.' Świadomość historyczna: symptomy i propozycje badawcze." Studia Socjologiczne, Vol. 2(9), 1963, pp. 4-28.

Bartov, Omer. Erased: Vanishing Traces of Jewish Galicia in Present-Day Ukraine. Princeton and Oxford: Princeton University, 2007. 
Berkhoff, Karel. Motherland in Danger. Cambridge: Harvard University Press, 2013.

Bernard-Donals, Michael F. Forgetful Memory: representation and remembrance in the wake of the Holocaust. Albany: SUNY Press, 2009.

Bertaux, Daniel. "From the Life-History Approach to the Transformation of Sociological Practice." In: Biography and Society, ed. Daniel Bertaux. London-Beverly Hills: Sage Publications, 1981, pp. 19-28.

Bertaux, Daniel and Paul Thompson, eds. Between Generations. Family Models, Myths and Memories. Piscataway, New Jersey: Transaction Publishers, 2005.

Biess, Frank. "Feelings in the Aftermath. Towards a History of Postwar Emotions." In: Histories of the Aftermath. The Legacies of the Second World War in Europe, ed. Frank Biess and Robert G. Moeller. New York-Oxford: Bergham Books, 2010, pp. 30-48.

Bilaniuk, Lada. Contested Tongues: Language Politics and Cultural Correction in Ukraine. Itaca \& London: Cornell University Press, 2005.

Bilinsky, Yaroslav. The Second Soviet Republic: The Ukraine after World War II. New Brunswick: Rutgers University Press, 1964.

Blacker, Uilleam. "Living among the Ghosts of Others: Urban Postmemory in Eastern Europe." In: Memory and Theory in Eastern Europe, ed. Uilleam Blacker, Alexander Etkind and Julie Fedor. New York: Palgrave Macmillan, 2013, pp. 173-178.

Blacker, Uilleam and Alexander Etkind. Memory and Theory in Eastern Europe, ed. Uilleam Blacker, Alexander Etkind and Julie Fedor. New York: Palgrave Macmillan, 2013, pp. 1-24.

Bociurkiw, Roman. The Ukrainian Greek Catholic Church and the Soviet State (1939-1950). Edmonton-Toronto: Canadian Institute of Ukrainian Studies Press, 1996.

Bodnar, Halyna. “'Tam bulo dobre i tut ye nepokhano zhyty:’ osoblyvosti istorychnoi pamiati ukraintsiv, pereselenykh iz Polshchi." In: UkrainaPolshcha: istorychna spadshchyna i suspilna svidomist, Vol. 2: Deportatsii 1944-1951. Lviv: Instytut Ukrainoznavstva im. Krypiakevycha, 2007, pp. 20-36.

Borodziej, Włodzimierz and Hans Lemberg. Niemcy w Polsce 1945-1950. Wybór dokumentów, Vol. 1. Warszawa: Neriton, 2000.

Boski, Paweł, Maria Jarymowicz and Hanna Malewska-Peyre, eds. Tożsamość a odmienność kulturowa. Warszawa: Instytut Psychologii UW, 1992.

Brandon, Ray and Wendy Lower, eds. The Shoah in Ukraine. History, Testimony and Memorialization. Bloomington and Indianapolis: Indiana University Press, 2008. 
Bremmer, Ian. "The Politics of Ethnicity: Russians in the New Ukraine." EuropeAsia Studies, Vol. 46(2), 1994, pp. 261-283.

Brencz, Andrzej. "Oswajanie niemieckiego dziedzictwa kulturowego. Z badań etnologicznych na Środkowym Nadodrzu.” In: Wokót niemieckiego dziedzictwa kulturowego na Ziemiach Pólnocnych i Zachodnich, ed. Zbigniew Mazur. Poznań: Instytut Zachodni, 1997, pp. 191-216.

Brencz, Andrzej. "Niemieckie wiejskie cmentarze jako element krajobrazu kulturowego środkowego Nadodrza." In: Wspólne dziedzictwo? Ze studiów nad stosunkiem do spuścizny kulturowej na Ziemiach Zachodnich i Pótnocnych, ed. Zbigniew Mazur. Poznań: Instytut Zachodni, 2000, pp. 287-308.

Brodala, Marta. "Propaganda dla najmłodszych w latach 1948-1956. Instrument stalinowskiego wychowania." In: Przebudować człowieka. Komunistyczne wysitki zmiany mentalności, ed. Marta Brodala, Anna Lisiecka and Tadeusz Ruzikowski. Warszawa: Trio, 2001, pp. 123-179.

Browning, Christopher Robert. Collected Memories. Holocaust History and Postwar Testimony. Madison: University of Wisconsin Press, 2004.

Cała, Alina. Wizerunek Żyda w polskiej kulturze ludowej. Warszawa: Wydawnictwo Uniwersytetu Warszawskiego, 1992.

Chumiński, Janusz. "Czynniki destabilizujące proces osadnictwa we Wrocławiu (1945-1949).” In: Studia nad procesami integracji i dezintegracji społeczności Ślaska, ed. Władysław Misiak. Wrocław: Wydawnictwo Uniwersytetu Wrocławskiego, 1993, pp. 55-78.

Ciesielski, Stanisław, ed. Przesiedlenie ludności polskiej z Kresów Wschodnich do Polski: 1944-1947. Warszawa: Neriton, 1999.

Conway, Martin A. "Autobiographical Knowledge and Autobiographical Memories." In: Remembering our Past. Studies in Autobiographical Memory, ed. David Rubin. New York: Cambridge University Press, 1996, pp. 67-93.

Corbin, Juliet and Janice M. Morse. "The Unstructured Interactive Interview: Issues of Reciprocity and Risks when Dealing with Sensitive Topics." Qualitative Inquiry, Vol. 9(3), 2003, pp. 335-354.

Czarnuch, Zbigniew. "Oswajanie krajobrazu. Polscy osadnicy w dorzeczu dolnej Warty." In: Wokót niemieckiego dziedzictwa kulturowego na Ziemiach Pótnocnych i Zachodnich, ed. Zbigniew Mazur. Poznań: Instytut Zachodni, 1997, pp. 169-190.

Czyżewski, Marek. "Repatrianci i wypędzeni: wzajemne uprzedzenia w relacjach biograficznych.” In: Biografia a tożsamość narodowa, ed. Marek Czyżewski, Andrzej Piotrowski and Alicja Rokuszewska-Pawełek. Łódź: Wydawnictwo Uniwersytetu Łódzkiego, 1996, pp. 159-172.

Demshuk, Andrew. The Lost German East. Forced Migration and the Politics of Memory, 1945-1970. Cambridge: Cambridge University Press, 2012. 
Demshuk, Andriy. "Reinscribing Schlesien as Śląsk: Memory and Mythology in a Postwar German-Polish Borderland." History and Memory, Vol. 24(1), 2012, pp. 47-53.

Denzin, Norman. "Reinterpretacja metody biograficznej w socjologii: znaczenie a metoda w analizie biograficznej." In: Metoda biograficzna w socjologii, ed. Jan Włodarek and Marek Ziółkowski. Warszawa-Poznań: Państwowe Wydawnictwo Naukowe, 1990, pp. 55-69.

Desbois, Patrick. The Holocaust by Bullets. A Priest's Journey to Uncover the Truth behind the Murder of 1.5 Million Jews. New York: Palgrave Macmillan, 2008.

Dmitrów, Edmund. Niemcy i okupacja hitlerowska w oczach Polaków. Poglądy i opinie z lat 1945-1948. Warszawa: Czytelnik, 1987.

"Drugi powszechny spis ludności z dn. 9.XII.1931 r. Mieszkania i gospodarstwa domowe, ludność, stosunki zawodowe. Województwo lwowskie bez miasta Lwowa." Statystyka Polski - Główny Urząd Statystyczny, Series C, Vol. 68, Warszawa, 1938, pp. 32-38.

Dyczok, Marta. The Grand Alliance and Ukrainian Refugees. New York: Palgrave Macmillan, 2000.

Engelking, Barbara. Zagłada i pamięć. Doświadczenia Holocaustu i jego konsekwencje opisane na podstawie relacji autobiograficznych. Warszawa: IFiS PAN, 2001.

Erll, Astrid. "Cultural Memory Studies: An Introduction." In: Cultural Memory Studies. An International and Interdisciplinary Handbook, ed. Astrid Erll and Ansgar Niinning. Berlin-New York: De Gruyter, 2008, pp. 1-18.

Fehrenbach, Heide. "War Orphans and Postfascist Families: Kinsship and Belonging after 1945." In: Histories of the Aftermath. The Legacies of the Second World War in Europe, ed. Frank Biess and Robert G. Moeller. New York-Oxford: Berghahn Books, 2010, pp. 175-195.

Feldman, Jackie. Above the Death Pits, Beneath the Flag: Youth Voyages to Poland and the Performance of Israeli National Identity. New York: Berghahn Books, 2008.

Figes, Orlando. Whisperers: Private Life in Stalin's Russia. New York: Metropolitan Books, 2008.

Filipkowski, Piotr. "Historia mówiona i wojna." In: Wojna. Doświadczenie i zapis - nowe źródta, problemy, metody badawcze, ed. Sławomir Buryła and Paweł Rodak. Kraków: Universitas, 2006, pp. 13-35.

Finder, Gabriel N. and Alexander V. Prusin. "Collaboration in Eastern Galicia: The Ukrainian Police and the Holocaust." East European Jewish Affairs, Vol. 34(2), 2004, pp. 95-118. 
Gitelman, Zvi. “Soviet Reactions to the Holocaust, 1945-1991." In: The Holocaust in the Soviet Union. Studies and Sources on the Destruction of the Jews in the Nazi-Occupied Territories of the USSR, 1941-1945, ed. Lucjan Dobroszycki and Jeffrey S. Gurock. Armonk: M.E. Sharpe, 1993, pp. 3-28.

Głowacka-Grajper, Małgorzata. "Społeczna i indywidualna kontynuacja pamięci ojczyzn kresowych." In: Pamięć utraconych ojczyzn, ed. Ewa Nowicka and Aleksandra Bilewicz. Warszawa: Wydawnictwa Uniwersytetu Warszawskiego, 2012, pp. 155-182.

Głowacka-Grajper, Małgorzata. Transmisja pamięci. Działacze "sfery pamięci" i przekaz o Kresach Wschodnich we wspótczesnej Polsce. Warszawa: Wydawnictwa Uniwersytetu Warszawskiego, 2017.

Grabowska, Mirosława. "Wywiad w badaniu zjawisk 'trudnych.' Przypadek polskiej religijności." In: Poza granicami socjologii ankietowej, ed. Antoni Sułek, Kazimierz Nowak and Anna Wyka. Warszawa: UW, IS, PTS, 1989, pp. 141-166.

Greenspan, Henry. On Listening to Holocaust Survivors: Recounting and Life History. Westport, CT-London: Praeger, 1998.

Grinchenko, Gelinada. "The Ostarbeiter of Nazi Germany in Soviet and PostSoviet Ukrainian Historical Memory." Canadian Slavonic Papers, SeptemberDecember 2012, pp. 401-426.

Gross, Jan Tomasz. Revolution from Abroad. The Soviet Conquest of Poland's Western Ukraine and Western Belorussia. Princeton: Princeton University Press, 1998.

Gruber, Ruth Ellen. Virtually Jewish: Reinventing Jewish Culture in Europe. Berkeley: University of California Press, 2002.

Grzymała-Kazłowska, Aleksandra. “'Integracja' - próba rekonstrukcji pojęcia." In: Problemy integracji imigrantów. Koncepcje, badania, polityki, ed. Aleksandra Grzymała-Kazłowska and Sławomir Łodziński. Warszawa: Wydawnictwo Uniwersytetu Warszawskiego, 2008, pp. 29-50.

Halbwachs, Maurice. On Collective Memory. Chicago: The University of Chicago Press, 1992.

Halicka, Beata. Polski Dziki Zachód. Przymusowe migracje i kulturowe oswajanie Nadodrza 1945-1948. Kraków: Universitas, 2015.

Himka, John-Paul. "Debates in Ukraine over Nationalist Involvement in the Holocaust, 2004-2008." Nationalities Papers, Vol. 39, 2011, pp. 357-370.

Himka, John-Paul. "The Reception of the Holocaust in Postcommunist Ukraine." In: Bringing the Dark Past to Light: The Reception of the Holocaust in Postcommunist Europe, ed. Joanna Michlic and John-Paul Himka. Lincoln \& London: University of Nebraska Press, 2013, pp. 627-661. 
Himka, John-Paul. "Legislating Historical Truth: Ukraine’s Laws of 9 April 2015," https://www.academia.edu/12056628/Legislating_Historical_Truth_ Ukraines_Laws_of_9_April_2015 (15.02.2019)

Hirsch, Marianne. Family Frames. Photography, Narrative and Postmemory. Cambridge: Harvard University Press, 1997.

Hirszowicz, Maria and Elżbieta Neymann. "Społeczne ramy niepamięci." Kultura i Społeczeństwo, Vol. 3/4, 2001, pp. 23-48.

Hnatiuk, Ola. Pożegnanie z Imperium. Ukraińskie dyskusje o tożsamości. Lublin: Wydawnictwo UMCS, 2003.

Hollz, Werner. "Traces of German-Czech History in Biographical Interviews at the Border: Construction of Identities and the Year 1938 in BärensteinVejprty." In: Living (with) Borders. Identity discourses on East-West borders in Europe, ed. Ulrike H. Meinhof. Aldershot: Ashgate, 2002, pp. 95-118.

Hrycak, Jarosław. "Stereotypy o stereotypach: pogranicze ukraińsko-polskie i problemy jego prezentacji." In: Akulturacja/asymilacja na pograniczach kulturowych Europy Środkowo-Wschodniej w XIX i XX w., Vol. 1: Stereotypy $i$ pamięć, ed. Robert Traba. Warszawa: ISP PAN, 2009, pp. 53-77.

Hryciuk, Grzegorz, Małgorzata Ruchniewicz, Bożena Szaynok and Andrzej Żbikowski. Wysiedlenia, wypędzenia i ucieczki 1930-1959. Atlas ziem Polski. Warszawa: Demart, 2008.

Hrynevych, Vladyslav. "Mit viiny ta viina mitiv." Krytyka, Vol. 5(91), 2005, pp. 2-8.

Hrynevych, Vladyslav. "Gespaltene Erinnerung. Der Zweite Weltkrieg im ukrainischen Gedenken." Osteuropa, Vol. 4-5, 2005, pp. 88-102.

Hrytsak, Yaroslav. "Strasti po Lvovu." Krytyka, Vol. 7/8, 2002, pp. 2-7.

Hrytsak, Yaroslav. "Historical Memory and Regional Identity among Galicia's Ukrainians." In: The Roots of Ukrainian Nationalism: Galicia as Ukrainian's Piemont, ed. Paul Robert Magocsi. Toronto: Toronto University Press, 2002, pp. 185-209.

Hrytsak, Yaroslav. "Istoriia i pamiat: Amneziia, Ambivalentsia, Aktyvizatsia." In: Ukraina. Protsesy natsiotvorennia, ed. Andreas Kappeler. Kyiv: K.I.S, 2011, pp. 365-380.

Hrytsak, Yaroslav. "Holokost i Holodomor: vyklyky kolektyvnoii pamiati." Krytyka, Vol. 1-2, 2011, pp. 14-16.

Huta Szklana. Jubileuszowy biuletyn z okazji 300-lecia istnienia wsi. Krzyż: Urząd Miejski w Krzyż, August 2010.

Iliushyn, Ihor. Ukraiinska Povstanska Armiia i Armiia Kraiova. Protystoiania $v$ Zakhidnii Ukraiini (1939-1945 rr.). Kyiv: Vydavnychyi Dim "KyievoMohylians'ka Akademiia," 2009. 
Inowlocki, Lena. "Grandmothers, Mothers and Daughters. Intergenerational Transmission in Displaced Families in Three Jewish Communities." International Yearbook of Oral History and Life Stories, Vol. 2, 1993, pp. 139-154.

Ivanova, Elena. "Regionalnyie osobennosti kolektivnoi pamiati studentov o holokoste v sovremennoi Ukraine." Holokost i suchasnist. Studii v Ukraini $i$ sviti, Vol. 2(4), 2008, pp. 9-28.

Janowski, Maciej. Birth of the Intelligentsia 1750-1831, Vol. 1. Trans. Tristan Korecki. Frankfurt am Main: Peter Lang Edition, 2014.

Jasiak, Marek. "Overcoming Ukrainian Resistance: The Deportation of Ukrainians within Poland in 1947." In: Redrawing Nations: Ethnic Cleansing in East-Central Europe, 1944-1948, ed. Philipp Ther and Ana Siljak. Lanham: Rowman \& Littlefield, 2001, pp. 173-194.

Jilge, Wilfired. "Competing Victimhoods - Post-Soviet Ukrainian Narratives on World War II." In: Shared History, Divided Memory. Jews and Others in SovietOccupied Poland, 1939-1941, ed. Elazar Barkan, Elizabeth A. Cole and Kai Struve. Leipzig: Leipziger Universitätsverlag, 2007, pp. 103-132.

Jolluck, Katherine R. Exile and Identity. Polish Women in the Soviet Union during World War II. Pittsburgh: University of Pittsburgh Press, 2002.

Kasianov, Georgiy. "The Burden of the Past. The Ukrainian-Polish Conflict of 1943-44 in Contemporary Public, Academic and Political Debates in Ukraine and Poland." Innovations: The European Journal of Social Science Research, Vol. 3-4, 2006, pp. 247-259.

Kasianov, Georgiy. “'Nationalized' History: Past Continuous, Present Perfect, Future..." In: A Laboratory of Transnational History. Ukraine and Recent Ukrainian Historiography, ed. Georgiy Kasianov and Philipp Ther. Budapest New York: Central University Press, 2009, pp. 7-22.

Kasianov, Georgiy. "History, Politics and Memory (Ukraine 1990s-2000s)." In: Memory and Change in Europe. Eastern Perspectives, ed. Małgorzata Pakier and Joanna Wawrzyniak. New York-Oxford: Berhahn Books, 2016, pp. 193-211.

Kaźmierska, Kaja. "Wywiad narracyjny - technika i pojęcie analityczne." In: Biografia a tożsamość narodowa, ed. Marek Czyżewski, Andrzej Piotrowski and Alicja Rokuszewska-Pawełek. Łódź: Wydawnictwo Uniwersytetu Łódzkiego, 1996, pp. 35-45.

Kaźmierska, Kaja. Doświadczenia wojenne Polaków a ksztaltowanie tożsamości etnicznej. Analiza narracji kresowych. Warszawa: IFiS PAN, 1999.

Kaźmierska, Kaja. Biography and Memory. The Generational Experience of the Shoah Survivors. Boston: Academic Studies Press, 2012. 
Keleher, Serge. Passion and Resurrection - The Greek Catholic Church in Soviet Ukraine, 1939-1989. Lviv: Stauropegion, 1993.

Kerski, Basil. "Historia i pamięć w aktualnych debatach politycznych między

Niemcami a Polakami." Borussia, Vol. 30, 2003, pp. 33-46.

Khromeychuk, Olesya. "Undetermined" Ukrainians. Post-War Narratives of the Waffen SS "Galicia" Division. Oxford-Bern-Berlin-Bruxelles-Frankfurt am Main-New York, New York-Wien: Peter Lang, 2013.

Kitsak, Volodymyr. "Rozselennia ukraintsiv Polshchi v URSR (1944-47).

Pereselennia ikh iz pivdennykh ta skhidnykh oblastei v Zakhidnu Ukrainu." Moloda Natsia, Vol. 1, 2000, pp. 96-122.

Kochanowski, Jerzy. "Nienawiść ograniczona. Niemieccy jeńcy wojenni a społeczeństwo polskie 1945-50." Przeglad Socjologiczny, Vol. 49, 2000, pp. 115-140.

Konończuk, Wojciech. "Ukraińcy patrzą na 'Wołyń.” Tygodnik Powszechny, Vol. 47, 2016, pp. 44-45.

Kończal, Kornelia and Joanna Wawrzyniak. "Provincializing Memory Studies: Polish Approaches in the Past and Present." Memory Studies, first published 25.01.2017. https://doi.org/10.1177/1750698016688238 (15.02.2019)

Korzeniowski, Bartosz. "World War II in the Politics of Memory of the Polish People's Republic 1944-1970." In: World War II and Two Occupations.

Dilemmas of Polish Memory, ed. Anna Wolff-Powęska and Piotr Forecki. Frankfurt am Main: Peter Lang, 2016, pp. 61-80.

Kosiński, Krzysztof. O nowa mentalność. Życie codzienne w szkołach 1945-56. Warszawa: Trio, 2002.

Kowalewski, Marcin. “Ziemie Odzyskane. Co dalej?” Przegląd Polityczny, Vol. 67/68, 2004, pp. 64-65.

Kramer, Clara. Tyleśmy już przeszli. Dziennik pisany w bunkrze (Żółkiew 19421944), ed. Anna Wylegała. Warszawa: Stowarzyszenie Centrum Badań nad Zagładą, 2017.

Kravchenko, Vladimir. "Boi s tieniu: sovietskoie proshloie w istoricheskoi pamiati sovremennogo ukrainskogo obshchestva." Ab Imperio, Vol. 2, 2004, pp. 329-368.

Krzemiński, Ireneusz, ed. Antysemityzm w Polsce i na Ukrainie. Raport z badań. Warszawa: Scholar, 2004.

Kulyk, Volodymyr. "War of Memories in the Ukrainian Media: Diversity of Identities, Political Transformation and Production Technologies." In: Memory, Conflict and New Media. Web Wars in Post-socialist States, ed. Ellen Rutten, Julie Fedor and Vera Zvereva. London and New York: Routledge, 2013, pp. 63-81. 
Kura, Antoni. Aparat bezpieczeństwa i wymiar sprawiedliwości wobec kolektywizacji wsi polskiej 1948-1956, Warszawa: IPN, 2006.

Kurkowska-Budzan, Marta. Antykomunistyczne podziemie zbrojne na Białostocczyźnie. Analiza współczesnej symbolizacji przeszłości. Kraków: Tow. Wydawnicze "Historia Iagellonica," 2009.

Kuzio, Taras, Robert. S.Kravchuk and Paul D’ Amieri, eds. State and Institution Building in Ukraine. London: Palgrave Macmillan, 1999.

Kwiatkowski, Piotr T. Pamięć zbiorowa społeczeństwa polskiego w okresie transformacji. Warszawa: Scholar, 2008.

Kwiatkowski, Piotr T. "Wprowadzenie. Doświadczenie II wojny światowej w badaniach socjologicznych.” In: Między codziennością a wielką historią. Druga wojna światowa w pamięci zbiorowej społeczeństwa polskiego, ed. Piotr T. Kwiatkowski, Lech M. Nijakowski, Barbara Szacka and Andrzej Szpociński. Warszawa: Scholar, 2010, pp. 12-54.

Kwiatkowski, Piotr T. "The Second World War in the Memory of Contemporary Polish society." In: Memory and Change in Europe. Eastern Perspectives, ed. Małgorzata Pakier and Joanna Wawrzyniak. New York-Oxford: Berhahn Books, 2016, pp. 231-245.

Kysla, Iulia. "Konstruiuvaniia ukrainskoi istorychnoi pamiati w URSR vprodovzh stalinskoho periodu (1930-ti-1950-ti rr.)." Mizhkulturnyi dialog, Vol. 1: Identychnist, 2009, pp. 221-244.

LaCapra, Dominick. History and Memory after Auschwitz. Chicago: Cornell University Press, 1998.

Landau-Czajka, Anna. Syn będzie Lech... Asymilacja Żydów w Polsce międzywojennej. Warszawa: IH PAN, 2006.

Larossa, Ralph, Linda A. Bennett and Richard J. Gelles. "Ethical Dilemmas in Qualitative Family Research." Journal of Marriage and Family, Vol. 43(2), 1981, pp. 303-313.

Lehmann, Rosa. Symbiosis and Ambivalence. Poles and Jews in a Small Galician Town. Oxford-New York: Berghahn Books, 2001.

Lehrer, Erica, ed. Jewish Space in Contemporary Poland. Bloomington: Indiana University Press, 2015.

Lewicka, Maria. "Place Attachment, Place Identity, and Place Memory:

Restoring the Forgotten City Past." Journal of Environmental Psychology, Vol. 28(3), 2008, pp. 209-231.

Lewicka, Maria. Psychologia miejsca. Warszawa: Wydawnictwo Naukowe Scholar, 2012.

Lowenthal, David. The Past is a Foreign Country. London: Cambridge University Press, 1985. 
Lytvyn, Mykola, ed. Zhovkivshchyna. Istorychnyi narys, Vol. 1. Zhovkva-LvivBaltimore: Instytut Krypiakevycha NAN Ukrainy, 1994.

Łukowski, Wojciech. Społeczne tworzenie ojczyzn. Studium tożsamości mieszkańców Mazur. Warszawa: Scholar, 2002.

Mach, Zdzisław. Niechciane miasta. Migracja i tożsamość społeczna. Kraków: Universitas, 1998.

Maier, Charles S. "Hot Memory... Cold Memory: On the Political Half-Life of Fascist and Communist Memory." Transit: Europäische Revue, Vol. 22, 2002. http://www.iwm.at/transit/transit-online/hot-memory-cold-memory-on-thepolitical-half-life-of-fascist-and-communist-memory/ (13.12.2018)

Makaro, Julita. Gubin - miasto graniczne. Studium socjologiczne. Wrocław: Wydawnictwo Uniwersytetu Wrocławskiego, 2007.

Malewska-Peyre, Hanna. "Ja wśród swoich i obcych." In: Tożsamość a odmienność kulturowa, ed. Paweł Boski, Maria Jarymowicz and Hanna Malewska-Peyre. Warszawa: Instytut Psychologii PAN, 1992, pp. 15-70.

Marody, Mirosława and Anna Giza-Poleszczuk. Przemiany więzi społecznej. Warszawa: Scholar, 2004.

Marples, David Roger. Stalinism in Ukraine in the 1940s. New York: Palgrave Macmillan, 1993.

Marples, David Roger. Heroes and Villains. Creating National History in Contemporary Ukraine. Budapest-New York: CEU Press, 2008.

Maruszewski, Tomasz. Pamięć autobiograficzna. Gdańsk: Gdańskie Wydawnictwo Psychologiczne, 2005.

Mazur, Zbigniew and Krzysztof Wawruch. Nauczyciele wobec przeszłości Ziem Zachodnich i Pólnocnych. Poznań: Instytut Zachodni, 1998.

McBride, Jared. "Peasants into Perpetrators: The OUN-UPA and the Ethnic Cleansing of Volhynia, 1943-1944." Slavic Review, Vol. 75(3), Fall 2016, pp. 630-654.

McBride, Jared. “Ukraine's Invented a 'Jewish-Ukrainian Nationalist' to Whitewash Its Nazi-era Past." https://www.haaretz.com/opinion/ukrainenationalists-are-using-a-jew-to-whitewash-their-nazi-era-past-1.5464194 (8.10.2018)

Melchior, Małgorzata. "Przeszłość jako czynnik zróżnicowań kulturowych dzisiaj - przypadek dwóch sąsiadujących wsi." Kultura i Społeczeństwo, Vol. 4, 1996, pp. 109-118.

Melchior, Małgorzata. Zagłada a tożsamość. Polscy Żydzi ocaleni "na aryjskich papierach.” Analiza doświadczenia biograficznego. Warszawa: IFiS PAN, 2004.

Molenda, Tomasz. "Zmiany ludnościowe w Krzyżu Wielkopolskim i okolicy w latach 1945-1950." Unpublished MA dissertation. Poznań, 2008. 
Motyka, Grzegorz. Od rzezi wolyńskiej do akcji “Wisła." Konflikt polsko-ukraiński 1943-1947. Kraków: Wydawnictwo Literackie, 2011.

Mucha, Janusz. Stosunki etniczne we współczesnej myśli socjologicznej. Warszawa: PWN, 2006.

Münch, Richard. "Social integration.” In: International Encyclopedia of the Social and Behavioral Sciences, Vol. 11, ed. Neil Smelser and Paul Baltes. Amsterdam \& New York: Elsevier, 2001, p. 7591.

Narvselius, Eleonora. “Tragic Past, Agreeable Heritage: Post-Soviet Intellectual Discussions on the Polish Legacy in Western Ukraine." The Carl Beck Papers in Russian and East European Studies, Vol. 2401, 2015, pp. 1-75.

Narvselius, Eleonora. "Polishness as Site of Memory and Arena for Construction of a Multicultural Heritage in L'viv." In: Whose Memory? Which Future? Remembering Ethnic Cleansing and Lost Cultural Diversity in Eastern, Central and Southeastern Europe, ed. Barbara Törnquist-Plewa. New York-Oxford: Berghahn Books, 2016, pp. 73-109.

Nijakowski, Lech M. Domeny symboliczne. Konflikty narodowe i etniczne w wymiarze symbolicznym. Warszawa: Scholar, 2006.

Nijakowski, Lech M. "Pamięć o II wojnie światowej a relacje Polaków z innymi narodami." In: Między codziennościa a wielka historia. Druga wojna światowa w pamięci zbiorowej społeczeństwa polskiego, ed. Piotr T. Kwiatkowski, Lech M. Nijakowski, Barbara Szacka and Andrzej Szpociński. Warszawa: Scholar, Muzeum II Wojny Światowej, 2010, pp. 239-286.

Nijakowski, Lech M. "Regionalne zróżnicowanie pamięci o II wojnie światowej." In: Między codziennościa a wielka historia. Druga wojna światowa w pamięci zbiorowej społeczeństwa polskiego, ed. Piotr T. Kwiatkowski, Lech M. Nijakowski, Barbara Szacka and Andrzej Szpociński. Warszawa: Wydawnictwo Naukowe Scholar, 2010, pp. 200-238.

Nikolayenko, Olena. "Contextual Effects on Historical Memory: Soviet Nostalgia among Post-Soviet Adolescents." Communist and Post-Communist Studies, Vol. 41, 2008, pp. 243-259.

Nitschke, Bernadetta. "Repolonizacja czy polonizacja? Polityka władz polskich wobec byłych kresów wschodnich III Rzeszy." In: Polacy-Niemcy-Pogranicze, ed. Grzegorz Wyder and Tomasz Nodzyński. Zielona Góra: Oficyna Wyd. Uniwersytetu Zielonogórskiego, 2006, pp. 275-290.

Niżnik, Józef. Symbole a adaptacja kulturowa. Warszawa: Centralny Ośrodek Metodyki Upowszechniania Kultury, 1985.

Noor, Masie, Nurit Shnabel, Samer Halabi and Arie Nadler. "When Suffering Begets Suffering: The Psychology of Competitive Victimhood Between Adversarial Groups in Violent Conflicts." Personality and Social Psychology Review, Vol. 16(4), 2012, pp. 352-374. 
Nowicka, Ewa. "Wojna jako element opowieści biograficznej greckich repatriantów z Polski.” In: Pamięć zbiorowa jako czynnik integracji i źródło konfliktów, ed. Andrzej Szpociński. Warszawa: Scholar, 2009, pp. 73-124.

Olick, Jeffrey and Joyce Robbins. "Social Memory Studies: From 'Collective Memory' to the Historical Sociology of Mnemonic Practices." Annual Review of Sociology, Vol. 24(1), 1998, pp. 105-140.

Olszański, Tadeusz. Wielka dekomunizacja. Ukraińska polityka historyczna czasu wojny. Warszawa: Ośrodek Studiów Wschodnich, 2017.

Osękowski, Czesław. Społeczeństwo Polski Zachodniej i Północnej w latach 194556. Zielona Góra: Wyższa Szkoła Pedagogiczna im. Tadeusza Kotarbińskiego, 1994.

Ossowski, Stanisław. "Analiza socjologiczna pojęcia ojczyzna." In: Dzieła, Vol. III. Warszawa: PWN, 1967, pp. 201-226.

Platt, Jennifer. “On Interviewing One’s Peers.” The British Journal of Sociology, Vol. 32(1), 1981, pp. 75-91.

Podolskyi, Anataolii. "Ukraiinske suspilstvo i pamiat pro holokost: sproba analizu deiakykh aspektiv." Holokost i suchasnist. Studii w Ukriini i sviti, Vol. 1(5), 2009, pp. 47-59.

Pohl, Dieter. Nationalsozialistische Judenverfolgung in Ostgalizien 1941-1944: Organisation und Durchfihrung eines staatlichen Massenverbrechens. Munich: R. Oldenbourg Verlag, 1997.

Popson, Nancy. “The Ukrainian History Textbook: Introducing Children to the Ukrainian Nation." Nationality Papers, 2001, Vol. 29(2), pp. 325-350.

Portelli, Alessandro. "Philosophy and the Fact: Subjectivity and Narrative Form in Autobiography and Oral History." In: The Battle of Valle Giulia: Oral History and the Art of Dialogue. Madison: University of Wisconsin Press, 1997, pp. 79-90.

Porter-Szucs, Brian. Faith and Fatherland. Catholicism, Modernity, and Poland. Oxford: Oxford University Press, 2011.

Portnow, Andrij. “'Wielka Wojna Ojczyźniana’ w polityce pamięci Białorusi, Mołdawii i Ukrainy." Res Publica Nowa, Vol. 7, 2009, pp. 24-35.

Radziwiłł, Anna. “Model ideologii wychowawczej w latach 1948-1956.” In: Polacy wobec przemocy. 1944-1956, ed. Barbara Otwinowska and Jan Żaryn. Warszawa: Editions Spotkania, 1996, pp. 315-349.

Rasevych, Vasyl. "Polityka pamiati i podolannia mizhnatsionalnykh stereotypiv v suchasnii Ukraini." In: Istorychni mify ta stereotypy, ed. Leonid Zashkilniak. Lviv: Instytut Ukrainoznavstva im. Krypiakevycha NAN Ukrainy, 2009, pp. 53-71. 
Redlich, Shimon. Together and Apart in Brzezany: Poles, Jews, and Ukrainians, 1919-1945. Bloomington: Indiana University Press, 2002.

Renan, Ernest. "What is a Nation?" In: Nation and Narration, ed. Homi Bhabha. London: Routledge, 1990, pp. 8-22.

Ricœur, Paul. Memory, History, Forgetting. Trans. Kathleen Blamey and David Pellauer. Chicago: University of Chicago Press, 2004.

Risch, William Jay. The Ukrainian West. Culture and the Fate of Empire in Soviet Lviv. Cambridge-London: Harvard University Press, 2011, pp. 53-81.

Rohdewald, Stefan. "Post-Soviet Remembrance of the Holocaust and National Memories of the Second World War in Russia, Ukraine and Lithuania." Forum for Modern Language Studies, Vol. 44(2), 2008, pp. 173-184.

Röger, Maren. Flucht, Vertreibung und Umsiedlung. Mediale Erinnerungen und Debatten in Deutschland und Polen seit 1989. Marburg: Verlag HerderInstitut, 2011.

Röger, Maren and Ruth Leiserowitz, eds. Women and Men at War. A Gender Perspective on World War II and its Aftermath in Central and Eastern Europe. Osnabrück: Fibre-Verlag, 2012.

Rokuszewska-Pawełek, Alicja. Chaos i przymus. Trajektorie wojenne Polaków analiza biograficzna. Łódź: Wydawnictwo Uniwersytetu Łódzkiego, 2002.

Romaniv, Oleh and Inna Fedushchak, eds. Zakhidnioukrainska trahediia 1941. Lviv-New York: Naukove Tovarystvo im. Shevchenka, 2002.

Romanow, Zenon. "Pamięć historyczna mieszkańców Ziem Zachodnich i Północnych w latach 1945-89 na przykładzie Pomorza Zachodniego." In: Ziemie Odzyskane 1945-2005. 60 lat w granicach państwa polskiego, ed. Andrzej Sakson. Poznań: Instytut Zachodni, 2006, pp. 201-218.

Rosenthal, Gabriele. "Rekonstrukcja historii życia. Wybrane zasady generowania opowieści w wywiadach biograficzno-narracyjnych.” In: Metoda biograficzna w socjologii, ed. Jan Włodarek and Marek Ziółkowski. Warszawa-Poznań: Państwowe Wydawnictwo Naukowe, 1990, pp. 97-112.

Rosenthal, Gabriele. The Holocaust in Three Generations. Families of Victims and Perpetrators of the Nazi Regime. Opladen-Farmington Hills: Barbara Budrich Publishers, 2010.

Rosenthal, Gabriele and Dan Bar-On. "A Biographical Case Study of a Victimizer's Daughter." Journal of Narrative and Life History, Vol. 2(2), 1992, pp. 105-127.

Rossoliński-Liebe, Grzegorz. "Debating, Obfuscating and Disciplining the Holocaust: Post-Soviet Historical Discourses on the OUN-UPA and Other Nationalist Movements." East European Jewish Affairs, Vol. 3(42), 2012, pp. 199-241. 
Rossoliński-Liebe, Grzegorz. “Ukraińska policja, nacjonalizm i zagłada Żydów w Galicji Wschodniej i na Wołyniu." Zagłada Żydów. Studia i materiały, Vol. 13, 2017, pp. 57-79.

Rotella, Katie N. and Jennifer A. Richeson. "Motivated to 'Forget:' The Effects of In-Group Wrongdoing on Memory and Collective Guilt." Social Psychological and Personality Science, Vol. 4(6), 2013, pp. 730-737.

Ruda, Oksana. "Do dzherel mifolohizatsii ukrainsko-polskykh vidnosyn.” In: Istorychni mify i stereotypy ta mizhnatsionalni vidnosyny $v$ suchasnii Ukraini, ed. Leonid Zashkilniak. Lviv: Instytut Ukrainoznavstva im. Krypiakevycha NAN Ukrainy, 2009, pp. 289-333.

Rudling, Per Anders. 'Memories of 'Holodomor' and National Socialism in Ukrainian Political Culture." In: Rekonstruktion des Nationalmythos? Frankreich, Deutschland und die Ukraine im Vergleich, ed. Yves Bizeul. Göttingen: Vandenhoeck \& Ruprecht Unipress, 2013, pp. 227-258.

Sakson, Andrzej. "Niemcy w świadomości społecznej Polaków." In: Polacy wobec Niemców. Z dziejów kultury politycznej Polski 1945-1989, ed. Anna WolffPowęska. Poznań: Instytut Zachodni, 1993, pp. 408-429.

Sakson, Andrzej. "Procesy integracji i dezintegracji społecznej na Ziemiach Zachodnich i Północnych Polski po 1945 roku." In: Pomorze - trudna ojczyzna? Kształtowanie się nowej tożsamości 1945-1995, ed. Andrzej Sakson. Poznań: Instytut Zachodni, 1996, pp. 131-154.

Sakson, Andrzej. Przeszłość i teraźniejszość stosunków polsko-niemieckich w świadomości społecznej Polaków. Poznań: Instytut Zachodni, 2002.

Sakson, Andrzej and Robert Traba. Przeszłość zapamiętana. Narracje z pogranicza: materiały pomocnicze do analizy polsko-niemieckich stosunków narodowościowych na przykładzie warmińskiej wsi Purda Wielka. Olsztyn: Stowarzyszenie Wspólnota Kulturowa “Borussia," 2007.

Schulze, Rainer. "Growing Discontent: Relations between Native and Refugee Population in a Rural District in Western Germany after the Second World War." In: West Germany under Construction. Politics, Society and Culture in the Adenauer Era, ed. Robert G. Moeller. Ann Arbor: University of Michigan Press, 1997, pp. 53-72.

Schuman, Howard and Jacqueline Scott. "Generations and Collective Memories." American Sociological Review, Vol. 54(3), 1989, pp. 359-381.

Schütze, Fritz. Biography Analysis on the Empirical Base of the Autobiographical Narratives: How to Analyse Autobiographical Narrative Interviews, Part II, INVITE - Biographical Counselling in Rehabilitative Vocational Training. Further Educational Curriculum. EU Leonardo da Vinci Programme (14.05.2018) 
Sereda, Viktoria. "Vplyv polskykh ta ukraiinskykh pidruchnykiv z istorii na formuvannia polsko-ukraiinskykh etnichnykh stereotypiv." Visnyk Lvivskoho universytetu. Seriia istorychna, Vol. 35-36, 2000, pp. 387-297.

Service, Hugo. Germans to Poles. Communism, Nationalism and Ethnic Cleansing after the Second World War. Cambridge: Cambridge University Press, 2013.

Shevel, Oxana. "The Politics of Memory in a Divided Society: A Comparison of Post-Franco Spain and Post-Soviet Ukraine." Slavic Review, Vol. 70(1), 2011, pp. 157-163.

Shevel, Oxana. "Memories of the Past and Visions of the Future. Remembering the Soviet Era and Its End in Ukraine." In: Twenty Years After Communism. The Politics of Memory and Commemoration, ed. Michael Bernhard and Jan Kubik. Oxford-New York: Oxford University Press, 2014, pp. 146-167.

Siekierka, Szczepan, Henryk Komański and Krzysztof Bulzacki. Ludobójstwo dokonane przez nacjonalistów ukraińskich na Polakach $w$ województwie lwowskim 1939-1947. Wrocław: Wydawnictwo Stowarzyszenie Upamiętnienia Ofiar Zbrodni Ukraińskich Nacjonalistów, 2006.

Siudut, Grzegorz. "Pochodzenie wyznaniowo-narodowościowe ludności Małopolski Wschodniej i Lwowa wedle spisu ludności z 1931 r.” In: Lwów. Miasto - społeczeństwo - kultura, Vol. 2, ed. Henryk Żaliński and Kazimierz Karolczak. Kraków: Wydawnictwo Naukowe WSP, 1998, pp. 261-280.

Skonieczny, Tomasz. Postawy chłopów wobec koncepcji i poczynań PPR (PZPR) w początkowej fazie kolektywizacji polskiego rolnictwa (1948-1949). Słupsk: Akademia Pomorska w Słupsku, 2009.

Sniegon, Tomas. "Between Old Animosity and New Mourning. Meanings of Czech Post-Communist Memorials of Mass Killings of the Sudeten Germans." In: Whose Memory? Which Future? Remembering Ethnic Cleansing and Lost Cultural Diversity in Eastern, Central and Southeastern Europe, ed. Barbara Törnquist-Plewa. New York-Oxford: Berghahn Books, 2016, pp. 49-72.

Snyder, Timothy. The Reconstruction of Nations. Poland, Ukraine, Lithuania, Belarus, 1569-1999. Yale: Yale University Press, 2003.

Snyder, Timothy. "Holocaust: The Ignored Reality." The New York Review of Books, Vol. 56(12), 16 July 2009, http://www.nybooks.com/ articles/2009/07/16/holocaust-the-ignored-reality/ (15.02.2019)

Snyder, Timothy. Bloodlands: Europe between Hitler and Stalin. New York: Basic Books, 2010.

Solchanyk, Roman. "Russians in Ukraine: Problems and Prospects." In: Cultures and Nations of Central and Eastern Europe. Essays in Honor of Roman 
Szporluk, ed. Zvi Gitelman, Lubomyr Hajda, John-Paul Himka and Roman Solchanyk. Cambridge: Harvard University Press, 2001, pp. 539-554.

Sosnowska, Danuta. Inna Galicja. Warszawa: Elipsa, 2009.

Stryjek, Tomasz. Jakiej przeszłości potrzebuje przyszłość? Interpretacje dziejów narodowych w historiografii i debacie publicznej na Ukrainie 1991-2004. Warszawa: ISP PAN, Rytm 2007.

Subtelny, Orest. "Expulsion, Resettlement, Civil Strife: The Fate of Poland's Ukrainians, 1944-1947." In: Redrawing Nations. Ethnic Cleansing in EastCentral Europe, 1944-1948, ed. Philipp Ther and Ana Siljak. Lanham: Rowman \& Littlefield Publishers, 2008, pp. 155-172.

Sudnik, Bronisław, ed. Krzyż Wielkopolski - historia pocztówka pisana. Piła: Wydawnictwo Media, 2010.

Szacka, Barbara. Czas przeszły, pamięć, mit. Warszawa: Scholar, 2006.

Szacka, Barbara. "II wojna światowa w pamięci rodzinnej." In: Między codziennościa a wielka historią. Druga wojna światowa w pamięci zbiorowej społeczeństwa polskiego, ed. Piotr T. Kwiatkowski, Lech M. Nijakowski, Barbara Szacka and Andrzej Szpociński. Warszawa: Scholar, Muzeum II Wojny Światowej, 2010, pp. 81-132.

Szarota, Tomasz. Niemcy i Polacy. Wzajemne postrzeganie i stereotypy. Warszawa: Wydawnictwo Naukowe PWN, 1996.

Taffet, Gerszon. Zagłada Żydów żółkiewskich. Łódź: Centralna Żydowska Komisja Historyczna, 1946.

Tarkowska, Elżbieta. Czas w życiu Polaków. Warszawa: IFiS PAN, 2005.

Ther, Philipp. "The Integration of Expellees in Germany and Poland after World War II: A Historical Reassessment." Slavic Review, Vol. 55, 1996, pp. 779-805.

Thomas, William Isaac and Florian Znaniecki. The Polish Peasant in Europe and America. Chicago: Chicago University Press, 1918.

Thum, Gregor. Uprooted: How Breslau Became Wrocław during the Century of Expulsion. Princeton and Oxford: Princeton University Press, 2011.

Tomczak, Maria. "Obraz osadników w prasie i publicystyce polskiej." In: Ziemie Odzyskane 1945-2005. 60 lat w granicach państwa polskiego, ed. Andrzej Sakson. Poznań: Instytut Zachodni, 2006, pp. 45-58.

Traba, Robert. Kraina tysiąca granic. Szkice o historii i pamięci. Olsztyn: Borussia, 2003.

Traba, Robert. Historia - przestrzeń dialogu. Warszawa: ISP PAN, 2006.

Traba, Robert. "The Kresy as a Realm of Memory: The Long History of Persistence." Herito, Vol. 8, 2012, pp. 58-91. 
Trojański, Piotr. "Liczba, rozmieszczenie oraz struktura wewnętrzna ludności wyznania mojżeszowego." Lwów. Miasto - społeczeństwo - kultura, Vol. 2, 1998, pp. 243-260.

Trosiak, Cezary. "Kaława a 'bunkry’ Z badań nad stosunkiem społeczności lokalnej do poniemieckiego zabytku." In: Wspólne dziedzictwo? Ze studiów nad stosunkiem do spuścizny kulturowej na Ziemiach Zachodnich i Pótnocnych, ed. Zbigniew Mazur. Poznań: Instytut Zachodni, 2000, pp. 355-388.

Tschuggnall, Karoline and Harald Welzer. "Rewriting Memories: Family Recollections of the National Socialist Past in Germany." Culture Psychology, Vol. 8, 2002, pp. 130-145.

Turchyn, Andrii. "Administratyvno-statystychnyi ohliad 1880-1979." In: Zhovkivshchyna. Istoryko-memuarnyi zbirnyk, Vol. 2, ed. Yaroslav Kalika. Zhovkva-Lviv-Baltimore: Instytut Krypiakevycha NAN Ukrainy, 1995.

Tyszkiewicz, Jakub. "Communist Propaganda in the German Provinces Ceded to Poland." In: 1945: A Break with the Past. A History of Central European Countries at the End of World War Two, ed. Zdenko Cepic. Ljubljana: Institute of Contemporary History, 2008, pp. 91-100.

Urban, Thomas. Der Verlust. Die Vertreibung der Deutschen und Polen im 20. Jahrhundert. München: C.H. Beck Verlag, 2004.

Vronska, Tamara. Upokorennia strakhom: simeine zaruchnytstvo u karalnii praktytsi radianskoii vlady (1917-1953). Kyiv: Tempora, 2013.

Wangler, Alexandra. Rethinking History, Reframing Identity. Memory, Generations, and the Dynamics of National Identity in Poland. Wiesbaden: Springer VS, 2012.

Weiner, Amir. Making Sense of War. The Second World War and the Fate of the Bolshevik Revolution. Princeton: Princeton University Press, 2001.

Welzer, Harald. Das kommunikative Gedächtnis: Eine Theorie der Erinnerung. München: CH Beck, 2002.

Welzer, Harald. “Communicative Memory." In: Cultural Memory Studies. An International and Interdisciplinary Handbook, ed. Astrid Erll and Ansgar Niinning. Berlin-New York: Walter de Gruyter, 2008, pp. 285-300.

Welzer, Harald, Sabine Moller and Karoline Tschuggnall. "Opa war kein Nazi:" Nationalsozialismus und Holocaust im Familiengedächtnis. Frankfurt am Main: Taschenbuch Verlag, 2002.

Wierling, Dorothee. "Generations as Narrative Communities. Some Private Sources of Public Memory in Postwar Germany." In: Histories of the Aftermath. The Legacies of the Second World War in Europe, ed. Frank Biess and Robert G. Moeller. New York-Oxford: Berghahn Books, 2010, pp. 102-120. 
Wilson, Andrew. "National History and National Identity in Ukraine and Belarus." In: Nation-Building in the Post-Soviet Borderlands, ed. Graham Smith, Vivien Law, Andrew Wilson, Annette Bohr and Edward Allworth. Cambridge: Cambridge University Press, 1998, pp. 23-47.

Winter, Jay. Remembering War: The Great War between Memory and History in the Twentieth Century. New Haven: Yale University Press, 2006.

Winter, Jay. “The Performance of the Past: Memory, History, Identity." In: Performing the Past: Memory, History, and Identity in Modern Europe, ed. Karin Tilmans, Frank van Vree and Jay Murray Winter. Amsterdam: Amsterdam University Press, 2010, pp. 11-34.

Wojnowski, Zbigniew. The Near Abroad: Socialist Eastern Europe and Soviet Patriotism in Ukraine, 1956-1985. Toronto: Toronto University Press, 2017.

Wolfe, Thomas Clayton. "Past as Present, Myth or History? Discourses of Time and the Great Patriotic War." In: The Politics of Memory in Postwar Europe, ed. Richard Ned Lebow, Wulf Kansteiner and Claudio Fogu. Durham-London: Duke University Press, 2006, pp. 249-283.

Wylegała, Anna. "Negacja, separacja, marginalność. Represje i wojna w narracjach biograficznych najstarszego pokolenia Polaków z Żytomierszczyzny, Kijowszczyzny i Podola." Studia Socjologiczne, Vol. 4(199), 2010, pp. 144-170.

Wylegała, Anna. "Badacz z Polski na Ukrainie: problemy metodologiczne." Przegląd Socjologii Jakościowej, Vol. 9(4), 2013, pp. 140-151.

Wylegała, Anna. "Managing the Difficult Past: Ukrainian Collective Memory and Public Debates on History." Nationalities Papers, Vol. 45(5), 2017, pp. 780-797.

Yakovenko, Natalia. Paralelnyi svit. Doslidzhennia $z$ istorii uiavlen ta idei $v$ Ukraiini XVI-XVII st. Kyiv: Krytyka, 2003.

Yekelchyk, Serhy. Stalin's Empire of Memory. Russian-Ukrainian Relations in the Soviet Historical Imagination. Toronto-Buffalo-London: Toronto University Press, 2004.

Yurchuk, Yulia. Reordering of Meaningful Worlds: Memory of the Organization of Ukrainian Nationalists and the Ukrainian Insurgent Army in Post-Soviet Ukraine. Stockholm: Stockholm University, 2014.

Zaremba, Marcin. “Trauma wielkiej wojny. Psychospołeczne konsekwencje II wojny światowej." Kultura i Społeczeństwo, Vol. 2, 2008, pp. 3-42.

Zaremba, Marcin. “Gorączka szabru.” Zagłada Żydów, Vol. 5, 2009, pp. 193-220.

Zaremba, Marcin. Wielka Trwoga. Polska 1944-1947. Ludowa reakcja na kryzys. Warszawa: Znak, 2012. 
Zarycki, Tomasz. Ideologies of Eastness in Central and Eastern Europe. New York: Routledge, 2014.

Zashkilniak, Leonid. "Istoriia 'svoia' i istoriia 'chuzha." Krytyka, Vol. 9/10(143/144), 2009, pp. 24-26.

Zerubavel, Yael. "The Historic, the Legendary and the Incredible: Invented Tradition and Collective Memory in Israel." In: Commemorations. The Politics of National Identity, ed. John R. Gillis. Princeton: Princeton University Press, 2004, pp. 105-128.

Zinn, Maxine Baca. "Insider Field Research in Minority Communities." In: Contemporary Field Research: Perspectives and Formulations, ed. Robert M. Emerson. Long Grove: Waveland Pr Inc., 2001, pp. 159-166.

Ziółkowski, Marek. "Pamięć i zapominanie: trupy w szafie polskiej zbiorowej pamięci." Kultura i Społeczeństwo, Vol. 3/4, 2001, pp. 3-22. 



\section{Index}

A

Aberg, Martin 53, 353

Ahonen, Pertti 16, 353

Allworth, Edward 159, 370

Amar, Tarik Cyril 58, 73, 115, 214, 278, 353

Anders, Władysław 103

Anderson, Benedict 333, 353

Arkusha, Olena 268, 353

Assmann, Aleida 20, 24, 26, 95, 166, 207, 248, 249, 269, 353

Assmann, Jan 20, 26, 198, 281, 353

Assorodobraj, Nina 29, 353

B

Baltes, Paul 125, 363

Balynskyi, Ihor 73, 353

Bandera, Stepan 45, 73, 74, 98, 107, $140,143,272,277,278,282,283$, $285,321,322$

Barkan, Elazar 221, 359

Bar-On, Dan 33, 275, 365

Beck, Józef 205, 343

Bennett, Linda A. 34, 361

Berkhoff, Karel 57, 290, 354

Bernard-Donals, Michael 25, 231, 328,354

Bernhard, Michael 298, 367

Bertaux, Daniel 28, 31, 354

Bhabha, Homi 24, 365

Bierut, Bolesław 67, 322

Biess, Frank 29, 91, 93, 354, 356, 369

Bilaniuk, Lada 75, 354

Bilewicz, Aleksandra 49, 357

Bilinsky, Yaroslav 53, 354

Bizeul, Yves 73, 366

Blacker, Uilleam 288, 324, 325, 354
Bociurkiw, Bohdan R. 123, 354

Bodnar, Halyna 53, 83, 153, 354

Bohr, Annette 159, 370

Borodziej, Włodzimierz 16, 354

Boski, Paweł 91, 147, 354, 362

Brandon, Ray 46, 354

Bremmer, Ian 143, 355

Brencz, Andrzej 61, 103, 106, 191, 355

Brodala, Marta 63, 355

Browning, Christopher R. 82, 355

Budrich, Barbara 28, 365

Bulzacki, Krzysztof 246, 367

Buryła, Sławomir 35, 356

C

Cała, Alina 209, 355

Cepic, Zdenko 105, 369

Chęciński, Sylwester 64, 81

Chumiński, Janusz 97, 355

Ciesielski, Stanisław 16, 355

Cole, Elizabeth A. 221, 359

Conway, Martin A. 249, 355

Corbin, Juliet 31, 355

Corni, Gustavo 16, 353

Czapigo, Dominik 345

Czaplicka, John 53, 353

Czarnuch, Zbigniew 62, 107, 180, 355

Czyżewski, Marek 25, 168, 355, 359

D

D’Amieri, Paul 143, 361

David-Fox, Michael 58, 353

Demshuk, Andriy 61, 166, 180, 355, 356

Denzin, Norman 27, 356

Desbois, Patrick 204, 356 
Dmitrów, Edmund 183, 186, 356

Dobroszycki, Lucjan 214, 357

Domański, Emil 76

Dovhanyk, Ilia 54, 74, 322

Dyczok, Marta 33, 57, 356

E

Emerson, Robert M. 33, 371

Engelking, Barbara 27, 356

Erll, Astrid 18, 21, 24, 353, 356, 369

Etkind, Alexander 288, 324, 325,354

\section{F}

Fedor, Julie 288, 320, 324, 325, 354,360

Fedushchak, Inna 45, 365

Fehrenbach, Heide 93, 356

Feldman, Jackie 231, 356

Figes, Orlando 121, 356

Filipkowski, Piotr 35, 349, 350, 356

Finder, Gabriel N. 278, 356

Fogu, Claudio 28, 370

Forecki, Piotr 63, 360

Freud, Sigmund 24, 248

G

Gelles, Richard J. 34, 361

Gennep, Arnold van 100, 112

Gillis, John R. 282, 371

Gitelman, Zvi 143, 214, 357, 368

Giza-Poleszczuk, Anna 125, 362

Głowacka-Grajper, Małgorzata 16, $23,49,102,155,271,281,357$

Gomułka, Władysław 81

Gordon, Milton M. 147

Grabowska, Mirosława 29, 30, 357

Grass, Günter 82

Greenspan, Henry 331, 357

Gross, Jan T. 45, 234, 357

Gruber, Ruth Ellen 229, 357
Grzymała-Kazłowska, Aleksandra 79, 357

Gurock, Jeffrey S. 214, 357

$\mathbf{H}$

Hajda, Lubomyr 143, 368

Halabi, Samer 171, 363

Halbwachs, Maurice 17, 19, 20, 22, 26, 357

Halicka, Beata 60, 61, 92, 94, 103, 106, 164, 357

Hasyn, Oleksa 75, 322

Himka, John-Paul 58, 73, 143, 208, 357, 358, 368

Hirsch, Marianne 22, 358

Hirszowicz, Maria 208, 280, 358

Hnatiuk, Ola 240, 358

Hollz, Werner 139, 358

Holquist, Peter 58, 353

Hontar, Tamara 53

Hrachova, Sofiia 234

Hrycak, Jarosław (This is the same person as Hrytsak, Yaroslav, the spelling differs according to the language of publication) 40, $73,214,219,234,258,268,278$, 353,358

Hryciuk, Grzegorz 16, 358

Hrynevych, Vladyslav 57, 221, 299, 300, 358

Hrytsak, Yaroslav 40, 73, 214, 219 , 234, 258, 268, 278, 353, 358

\section{I}

Inowlocki, Lena 28, 359

Ivanova, Elena 221, 359

J

Janowski, Maciej 20, 46, 47, 359

Jarymowicz, Maria 91, 147, 354, 362 Jasiak, Marek 51, 359

Jedlicki, Jerzy 20 
Jilge, Wilfried 221, 359

Jolluck, Katherine R. 303, 359

K

Kansteiner, Wulf 28, 370

Kappeler, Andreas 214, 358

Karolczak, Kazimierz 40, 367

Kasianov, Georgii 72, 251, 277, 359

Kaźmierska, Kaja 21, 25, 27, 30, 149, 242, 359

Keleher, Serge 123, 360

Kerski, Basil 173, 360

Keryk, Myroslava 342, 343

Khmelnytsky, Bohdan 37, 56, 76, 239

Khromeychuk, Olesya 73, 274, 360

Kitsak, Volodymyr 53, 127, 360

Kochanowski, Jan 16, 353

Kochanowski, Jerzy 164, 360

Komański, Henryk 246, 367

Konończuk, Wojciech 269, 360

Konovalets, Yevhen 74, 75, 317,320

Kończal, Kornelia 19, 360

Korzeniowski, Bartosz 63, 360

Kosiński, Krzysztof 65, 106, 360

Kowalewski, Marcin 196, 360

Kramer, Clara 52, 360

Kravchenko, Vladimir 299, 300, 360

Kravchuk, Robert. S. 143, 361

Krzemiński, Ireneusz 210, 258, 360

Kubiiovych, Volodymyr 40

Kubik, Jan 298, 367

Kulyk, Volodymyr 39, 46, 320, 360

Kura, Antoni 66, 361

Kurkowska-Budzan, Marta 33, 361

Kuzio, Taras 143, 361

Kwiatkowski, Piotr T. 28, 85, 89,

$171,184,313,331,361,363,368$

Kysla, Iulia 56, 361
L

LaCapra, Dominick 22, 361

Lajner, Zygmunt 211, 271

Landau-Czajka, Anna 202, 361

Larossa, Ralph 34, 361

Lebow, Richard Ned 28, 370

Lehmann, Rosa 201, 202, 233, 261

Lehrer, Erica 229, 361

Leiserowitz, Ruth 303, 365

Lemberg, Hans 16, 38, 354

Lewicka, Maria 88, 89, 154, 239, 246, 281, 361

Lisiecka, Anna 63, 355

Lowenthal, David 18, 82, 275, 361

Lower, Wendy 46, 354

Lytvyn, Mykola 47, 362

Łodziński, Sławomir 79, 357

Łukowski, Wojciech 14, 103, 362

M

Mach, Zdzisław 14, 79, 97, 100, 103, $112,138,158,183,362$

Magocsi, Paul Robert 219, 358

Maier, Charles 329, 362

Makarchuk, Stepan 53

Makaro, Julita 95, 138, 362

Malewska-Peyre, Hanna 91, 147, 354,362

Marchlewski, Julian 67, 322

Marody, Mirosława 125, 362

Marples, David R. 46, 52, 55, 72, 276, 278, 362

Martin, Alexander M. 58, 353

Maruszewski, Tomasz 187, 362

Mazepa, Ivan 76

Mazur, Zbigniew 14, 61, 62, 179, 191, 197, 355, 362, 369

McBride, Jared 47, 277, 362

Meinhof, Ulrike H. 139, 358

Melchior, Małgorzata 27, 324, 362

Michlic, Joanna 58, 357

Misiak, Władysław 97, 355 
Moeller, Robert G. 29, 91, 93, 126, 354, 356, 366, 369

Molenda, Tomasz 42, 50, 117, 362

Moller, Sabine 82, 85, 173, 286, 302, 369

Morse, Janice M. 31, 169, 355

Motyka, Grzegorz 47, 51, 363

Mucha, Janusz 147, 363

Münch, Richard 125, 363

$\mathbf{N}$

Nadler, Arie 171, 363

Narvselius, Eleonora 265, 335, 363

Nesterov, Piotr 59, 66, 74, 77, 323

Neymann, Elżbieta 208, 280, 358

Nijakowski, Lech M. 23, 28, 74, 171, 184, 194, 297, 310, 313, 320, 321, $329,361,363,368$

Nikolayenko, Olena 300, 363

Nitschke, Bernadetta 60, 62, 119,363

Niżnik, Józef 107, 363

Nodzyński, Tomasz 60, 363

Noor, Masie 171, 363

Nowak, Jacek 249

Nowak, Kazimierz 30, 357

Nowicka, Ewa 30, 49, 114, 357, 364

Nünning, Ansgar 21, 24, 353

O

Olick, Jeffrey 19, 364

Olszański, Tadeusz 74, 277, 364

Osękowski, Czesław 96, 103, 125, 138, 364

Ossowski, Stanisław 159, 364

$\mathbf{P}$

Paasche, Hans 69

Pakier, Małgorzata 72, 85, 359, 361

Pałka, Jarosław 345-347

Park, Robert 147
Piłsudski, Józef 120

Piotrowski, Andrzej 25, 168, 355, 359

Platt, Jennifer 33, 364

Podolskyi, Anatolii 58, 216, 234, 364

Pohl, Dieter 46, 364

Popson, Nancy 72, 216, 364

Portelli, Alessandro 27, 364

Porter-Szucs, Brian 138, 364

Portnov, Andrii 250, 295, 318

Prusin, Alexander V. 278, 356

$\mathbf{R}$

Rasevych, Vasyl 276, 364

Redlich, Shimon 17, 365

Renan, Ernest 24, 365

Richeson, Jennifer A. 171, 366

Ricoeur, Paul 24-26, 365

Risch, William Jay 115, 365

Robbins, Joyce 19, 364

Rodak, Paweł 35, 356

Rodnienkova, Tetiana 341

Röger, Maren 173, 303, 362, 365

Rohdewald, Stefan 216, 229, 365

Rokuszewska-Pawełek, Alicja 25, $26,168,355,359,365$

Romaniv, Oleh 45, 365

Romanow, Zenon 60, 365

Rosenthal, Gabriele 28, 30, 33, 275, 365

Rossoliński-Liebe, Grzegorz 73, 365, 366

Rotella, Katie N. 171, 366

Różewicz, Tadeusz 81

Rubin, David 249, 355

Ruchniewicz, Małgorzata 16, 358

Ruda, Oksana 238, 249, 346, 348, 350, 366

Rudling, Per Anders 73, 366

Rutten, Ellen 320, 360

Ruzikowski, Tadeusz 63, 355 
S

Sakson, Andrzej 17, 60, 63, 64, 103, $108,181,183,199,365,366,368$

Sapieha, Adam 322

Sapieha, Jan Kazimierz 41, 69, 191

Schor, Aleksander Sender 77, 229

Schulze, Rainer 16, 126, 353, 366

Schuman, Howard 28, 366

Schütze, Fritz 25, 87, 366

Schwarz, Klara 52, 232

Scott, Jacqueline 28, 366

Sereda, Viktoria 72, 267

Service, Hugo 61, 164, 367

Shevchenko, Taras 317

Shevel, Oxana 271, 298, 367

Shnabel, Nurit 171, 363

Siekierka, Szczepan 246, 367

Siljak, Ana 16, 51, 359, 368

Siudut, Grzegorz 40, 367

Skonieczny, Tomasz 66, 367

Smarzowski, Wojciech 269

Smelser, Neil 125, 363

Sniegon, Tomas 193, 367

Snyder, Timothy 15,38 , 58,367

Solchanyk, Roman 143, 367, 368

Sosnowska, Danuta 38, 368

Stark, Tamar 16, 353

Steinbach, Erika 171

Stelzl-Marx, Barbara 16, 353

Struve, Kai 221, 359

Stryjek, Tomasz 72, 277, 368

Sudnik, Bronisław 71, 368

Sułek, Antoni 30, 357

Szacka, Barbara 28, 171, 184, 311-313, 361, 363, 368

Szarota, Tomasz 184, 368

Szaynok, Bożena 16, 358

Szczęśliwy, Paweł 37

Szpociński, Andrzej 28, 30, 171, $184,313,361,363,364,368$

Świerczewski, Karol 67
$\mathrm{T}$

Taffet, Gerszon 40, 46, 368

Tarkowska, Elżbieta 88, 368

Ther, Philipp 16, 51, 106, 117, 277, 359, 368

Thomas, William 27, 368

Thompson, Paul 28, 354

Thum, Gregor 61, 368

Tilmans, Karin 17, 370

Tomczak, Maria 63, 129, 368

Törnquist-Plewa, Barbara 194, 335, 363, 367

Traba, Robert 17, 69, 153, 214, 268, 358, 366, 368

Trojański, Piotr 40, 369

Trosiak, Cezary 179, 369

Tschuggnall, Karoline 28, 82, 85, 173, 207, 286, 302, 369

Turchyn, Andrii 40, 369

Tyszkiewicz, Jakub 105, 169, 369

U

Urban, Thomas 15, 369

V

Vree, Frank van 17, 370

Vronska, Tamara 55, 369

W

Wangler, Alexandra 104, 154, 369

Wawruch, Krzysztof 197, 362

Wawrzyniak, Joanna 19, 72, 85, 359, 360, 361

Weiner, Amir 54, 369

Welzer, Harald 20, 21, 28, 81, 82, 85, $173,207,286,302,369$

Wicki, Bernhard 82

Wierling, Dorothee 29, 369

Wilson, Andrew 159, 276, 370

Winter, Jay $17,18,22,24,370$

Włodarek, Jan 27, 30, 356, 365

Wojnowski, Zbigniew 56, 370 
Wolfe, Thomas C. 28,370

Wolff-Powęska, Anna 63, 64, 360, 366

Wybicki, Józef 67

Wyder, Grzegorz 60, 363

Wyka, Anna 30, 357

Wylegała, Anna 33, 275, 282, 294, 360, 370

Wylegała, Teresa 345, 346, 349-352

Y

Yakovenko, Natalia 240, 267, 370

Yanukovych, Viktor 73, 300

Yekelchyk, Serhy 56, 370

Yushchenko, Viktor 73, 277, 278, 297
$\mathrm{Z}$

Zaremba, Marcin 94, 98, 138, 302,370

Zarycki, Tomasz 16, 371

Zashkilniak, Leonid 72, 238, 250, 267, 268, 276, 353, 364, 366, 371

Zerubavel, Yael 282, 371

Zinn, Maxine Baca 33, 371

Ziółkowski, Marek 25, 27, 30, 311, 356, 365, 371

Znaniecki, Florian 27, 368

Zvereva, Vera 320, 360

Żaliński, Henryk 40, 367

Żbikowski, Andrzej 16, 358

Żółkiewski, Stanisław 37, 38, 58,

$239,258,267,323,335$ 